\title{
Biografías del Chacho
}

Génesis de una interacción polémica entre

\author{
José Hernández y Domingo F. Sarmiento
}

\section{TESIS DOCTORAL EN LETRAS}

Doctoranda: Lic. MARÍA CELINA ORTALE

Directora: Dra. ÉLIDA LOIS

La Plata, mayo de 2012 


\section{INTRODUCCIÓN}

\subsection{Estado de la cuestión}

Tratándose de dos autores tan significativos y tan ampliamente transitados por los lectores (tanto en el campo académico como fuera de sus límites precisos), llama la atención que ni Rasgos biográficos del General D. Angel V. Peñaloza (o su reformulación posterior, Vida del Chacho) de José Hernández, ${ }^{1}$ ni El Chacho, último caudillo de la montonera de los Llanos de Domingo F. Sarmiento, ${ }^{2}$ hayan merecido atención pormenorizada. ${ }^{3}$ En cuanto al establecimiento de vínculos entre ellos, constituye una excepción el historiador León Pomer, que editó las dos biografías con el título de Proceso al Chacho, precedidas de un breve "Estudio preliminar". ${ }^{4}$ Pero aunque su edición y sus breves palabras introductorias ponen el acento sobre la presencia de “dos miradas" sobre Peñaloza, su atención se centra en el personaje histórico y la injusticia de la que es víctima, no en los textos en sí mismos ni en la interacción polémica que entablan. Nuestra investigación se propuso en cambio rescatar dos procesos de textualización y hacerlos dialogar.

Ya en un trabajo anterior -predominantemente filológico, además de geneticista stricto sensu-, habíamos advertido que Rasgos biográficos del General D. Angel V.

\footnotetext{
${ }^{1}$ Antes de que se publicara nuestra edición crítico-genética de esta obra (J. Hernández, 2005), la Vida del Chacho de Hernández había merecido -en el marco de cuestionamientos de la "historia oficial" - algunas reediciones de muy escasa circulación que, a pesar de adoptar el título de la versión de 1875, se basan en el folleto de 1863 que se conserva en la Biblioteca Nacional; Horacio J. Becco las incluye en su "Bibliografía hernandiana" (1972a, asientos 303-307). Pero es probable que los pasajes seleccionados por Noé Jitrik (tan solo fragmentos, pero muy significativos) para el volumen 16 de la "Biblioteca argentina fundamental" (la colección que acompañaba los fascículos de la $1^{\mathrm{a}}$ edición de Capítulo. La historia de la literatura argentina) hayan constituido durante décadas el contacto más estrecho que tuvo esta obra con un público más amplio (J. Hernández, 1967, pp. 7-13).

${ }^{2}$ Aunque -al margen de las Obras de Sarmiento- a comienzos del siglo XX fue objeto de una edición y una reedición de La Cultura Argentina de Buenos Aires (Sarmiento, 1925) y existe una publicación relativamente reciente (Buenos Aires, Stockero, 2003), es una obra escasamente difundida. También puede leerse on line, por ejemplo, en:

http://constitucionweb.blogspot.com/2010/08/el-chacho-ultimo-caudillo-de-la.html

http://www.biblioteca.clarin.com/pbda/ensayo/elchacho/b-373303.htm

${ }^{3}$ En principio, no se ha ido más allá de menciones generales en la bibliografía que desplegó visiones panorámicas sobre la vida y la obra de sus autores.

${ }^{4}$ Pomer, 1968. Este libro tuvo muy escasa circulación, pero se conservan ejemplares en bibliotecas públicas. Pomer venía publicando, en Ediciones Caldén de Buenos Aires, una serie de volúmenes que confrontaban puntos de vista opuestos: Proceso a Sarmiento (1967), Proceso a Mitre (1967) y Proceso a la Guerra del Paraguay (1968).
} 
Peñaloza interactuaba polémicamente con el Facundo y con Campaña en el Ejército Grande, a la par que se situaba implícitamente en la línea político-ideológica abierta por las Quillotanas. ${ }^{5}$ Posteriormente, observamos que todas estas obras se interrelacionan en un complejo "hipertexto" en el que se integran otras piezas cuyo estudio nadie ha agotado (y que en algunos casos, nadie ha emprendido).

\subsection{Recorrido de la investigación}

Esta investigación se inició a partir de la formulación de cuatro hipótesis de trabajo:

1. El Chacho, último caudillo de la montonera de los Llanos de Domingo F. Sarmiento (1868) interactúa polémicamente con Rasgos biográficos del General D. Angel V. Peñaloza de José Hernández (1863), aunque su autor no haya avalado con su firma ningún testimonio acerca de lecturas de la obra periodística ni literaria de quien escribiría el Martín Fierro.

2. Esa interacción textual se enmarca en "la gran polémica nacional": la que inició Sarmiento con la publicación de Campaña en el Ejército Grande (1852), provocó la respuesta de Juan Bautista Alberdi en sus Cartas sobre la prensa y la política militante en la República Argentina (1853) y no concluyó con la publicación de Las ciento y una de su adversario ni con los otros intercambios polémicos textuales entre ambos autores en ese mismo año 1853.

3. La antinomia irreductible "civilización versus barbarie", como modelo de identidad nacional y como base para el diseño de una programática para la organización estable

\footnotetext{
${ }^{5}$ Nuestra tesis de licenciatura, dedicada a analizar el itinerario textual de la Vida del Chacho de Hernández, consistió en una edición genética anotada de esa obra, precedida de un "Estudio preliminar" (2002); luego, apuntando a un público más amplio que el de los especialistas del campo filológico, preparamos una edición crítico-genética (Ortale, 2005). Imaginamos después una tesis doctoral que retomara nuestra línea disciplinar: una edición genética de El Chacho, último caudillo de la montonera de los Llanos de Sarmiento unida a un aparato de lectura que reprodujera el diálogo polémico que su autor entabla con la primera versión de la biografía de Hernández. Pero nos obligó a desistir la comprobación de que la $2^{\mathrm{a}}$ edición de El Chacho, último caudillo de la montonera de los Llanos - publicada en París- había sido realizada con las mismas planchas tipográficas que la de Nueva York, y el convencimiento de que por su estado de salud y su escaso interés por las cuestiones específicamente editoriales, Sarmiento no había intervenido personalmente en la preparación de la $3^{\text {a }}$ (informaciones que debo a la generosidad de Javier Fernández, ex director de la Biblioteca de la Universidad Nacional de La Plata y reconocido coleccionista y conocedor de la obra de Sarmiento). Ver 3.2.4.
} 
del país, es el eje de esa interacción polémica (un bando pretende afianzarla y sus oponentes resquebrajarla).

4. Vida del Chacho (la reescritura de su primera biografía de Peñaloza emprendida por Hernández en 1875) se reinscribe en "la gran polémica nacional" en otra coyuntura política.

Con el fin de validar estas hipótesis, se profundizó el conocimiento del contexto histórico (1852-1875) y se reunió toda la documentación que fue posible rastrear (en particular, material inédito que en algunos casos no había sido estudiado antes o había sido considerado desde otros enfoques) para reconstruir los avatares y el intertexto de esa prolongada interacción polémica. Durante ese recorrido, se hicieron hallazgos documentales y se descubrieron problemáticas no entrevistas en el punto de partida. Finalmente, un último hallazgo permitió cerrar la secuencia de interacción polémica acotada con el análisis de un enfrentamiento público iniciado por un redactor anónimo que en 1875, desde La Tribuna de Buenos Aires, analiza la génesis de Vida del Chacho y por ese medio ataca a su autor. Hernández reconoce en el redactor anónimo "la voz de Sarmiento" y dirigiéndose a él responde con una serie de cartas abiertas.

La persistencia de la polémica entre Sarmiento y Alberdi en la política nacional no sólo enmarca las primeras biografías del Chacho, que se analizan en el primer apartado ("La gran polémica nacional del siglo XIX como intertexto de las biografías del Chacho"), sino también los temas de los restantes: "El alineamiento de los adversarios de Sarmiento" (apartado 2), la biografía del Chacho del propio Sarmiento ("Sarmiento contraataca con su biografía del Chacho", apartado 3), la reformulación de la primera versión de la suya que emprenderá Hernández en 1875 (“Vida del Chacho y El gaucho Martín Fierro: reescrituras de Hernández en 1875”, apartado 4) ${ }^{6}$ y la última manifestación de la polémica que estos dos autores entablaron a través de su práctica del género biográfico ("El último eslabón de una polémica: Sarmiento vs. Hernández", apartado 5).

\subsection{Marco teórico-metodológico}

\footnotetext{
${ }^{6}$ Sugestivamente, ese mismo año Hernández emprendió la reescritura del sociolecto de $E l$ gaucho Martín Fierro cuando preparó la 9a edición.
} 
El texto moderno, el que surge de las condiciones de impresión y circulación que se consolidan a fines del siglo XVIII en los países centrales, impone presupuestos metodológicos no siempre coincidentes con los que determinaban las fases críticas de la filología tradicional (la textología). En este caso, el tipo de corpus reunido requirió un enfoque específico: el de la crítica genética; pero esta corriente no excluye la aplicación de conceptualizaciones provenientes de otros abordajes consagrados al estudio de procesos de producción de sentido, como el análisis del discurso y la teoría de la intertextualidad. De todas maneras, se trata de actividades que sólo pueden encararse desde un paradigma de inferencias indiciales.

\subsubsection{Paradigma de inferencias indiciales}

Nuestro trabajo ha sido encarado a partir de "fenómenos observables" (documentos de génesis escritural, de procesos textuales, de conexión intertextual, de una interacción o de una evolución reflexiva, etc.), y cuando un investigador selecciona los indicios que le permiten construir un sistema de postulaciones con el objeto de adjudicar un sentido a los datos analizados, las operaciones semióticas desarrolladas se encuadran en el modelo epistemológico que Carlo Ginzburg ha denominado "paradigma de inferencias indiciales", 7

Cuando lo que se investiga no resulta inmediatamente accesible a la observación o se muestra inabarcable por su complejidad, cuando la "visión de conjunto" se define como un objetivo impracticable, la atención se vuelve hacia los detalles y se va desarrollando un método interpretativo basado en lo secundario, en datos marginales que son juzgados como "reveladores": es así como surge el concepto de "indicio" (por otra parte, cuando las causas son inalcanzables, sólo se las puede inferir a partir de sus efectos).

Frente a la multiplicidad de indicios, disciplinas diferentes desarrollan una actitud cognoscitiva similar, ya que las operaciones involucradas son idénticas: relevamiento, análisis, comparaciones, clasificaciones. Se trata de disciplinas eminentemente "cualitativas", orientadas hacia el examen de una casuística muy concreta: se consagran al análisis de "casos individuales" reconstruibles sólo por medio de las huellas que dejan. Este modo de conocimiento recorta sus objetos, los considera siempre en su singularidad: por consiguiente, al contrario de las ciencias fácticas (cuantitativas, experimentales y

${ }^{7}$ Ginzburg (1994, pp. 138-175). 
generalizadoras), los saberes "indiciales" constituyen conocimientos indirectos y conjeturales. Es precisamente por el peso de lo conjetural que sus resultados tienen siempre "un margen insuprimible de aleatoriedad". Adscribir a esta línea implica reconocer de entrada la limitación de las llamadas "ciencias sociales": las verdades que enuncian son probabilísticas, les está vedada la enunciación de "verdades universalmente válidas".

\subsubsection{La crítica-genética}

Un trabajo que estudia la "génesis de una interacción polémica" impone un marco teórico-metodológico: el de la crítica genética. ${ }^{9}$ Esta corriente surgió en el ámbito de los estudios literarios estableciendo un campo de análisis específico: el proceso de "producción” de los textos. Para enfocarlo, sus teóricos propusieron una categoría descriptiva para recortar un objeto de estudio privativo: el "pre-texto" (avant-texte), ${ }^{10}$ es decir, todos los testimonios de la arqueología de un proceso creativo. Pero pronto salieron del campo cerrado de los manuscritos de trabajo para considerar otros tipos de producción escritural y para enfocar textos sucesivos ya que, cuando se publica la reformulación de una obra ya editada, la primera versión se convierte en un "pre-texto": es lo que sucedió con Rasgos biográficos del General D. Angel V. Peñaloza (1863) cuando Hernández lo convirtió en Vida del Chacho en $1875 .^{11}$

El examen del itinerario textual de la biografía de Peñaloza escrita por Hernández impuso, entonces, una metodología geneticista stricto sensu: la reconstrucción de etapas escriturales, el inventario de las reescrituras, la descripción de la operatoria reformulativa y un análisis encaminado a proponer una interpretación de esa dinámica de producción de sentido.

En las últimas décadas, la crítica genética amplió aún más su campo: su óptica salio del ámbito del dossier de trabajo escritural de una obra singular para encarar no sólo la evolución de procesos de producción simbólica en series de textos de un mismo autor o de diferentes autores, sino también itinerarios de géneros textuales y de estrategias discursivas. ${ }^{12}$ De allí que hayamos analizado con un enfoque genético tanto

\footnotetext{
${ }^{8}$ Ibidem, p. 147.

${ }^{9}$ Barrenechea, 1983; Lebrave, 1992; Hay, 1993; Grésillon, 1994; de Biasi, 2000; Lois, 2001 a.

${ }^{10}$ Bellemin-Noël, 1972.

${ }^{11}$ Ortale, 2005.

${ }^{12}$ En 2010 -en el número 30 de la revista Genesis (órgano del Institut de Textes et Manuscrits Modernes del CNRS, sede de la escuela de crítica genética)- este grupo publicó una puesta al día
} 
la práctica de un género llevada a cabo por un mismo autor (el diarismo de Hernández) como una interacción polémica que va evolucionando a lo largo del tiempo y que se manifiesta en diversos géneros textuales (textos biográficos, polémicas periodísticas) abordados por distintos autores.

\subsubsection{El análisis del discurso y la perspectiva intertextual}

El análisis del discurso -una práctica en la que confluyeron las nuevas teorías acerca de la comunicación junto con el post-estructuralismo francés, la lingüística textual y la sociología del lenguaje- configuró un corpus doctrinario en la década del 70 (aunque posteriormente continuó enriqueciéndose). ${ }^{13} \mathrm{Su}$ objetivo es el estudio de la enunciación, es decir, los enunciados en su situación, lo que implica considerar las proyecciones del enunciador (su intencionalidad, las modalidades y las estrategias discursivas), las expectativas acerca del destinatario y el tipo de conexión que los vincula en su contexto histórico. Desde esta óptica, las marcas de la enunciación se suman a la construcción del sentido y toda práctica lingüística se asume como un acto social, por eso el investigador busca en ella todo tipo de inscripción que la relacione con la sociedad, la cultura, la política.

En el análisis del discurso de los textos analizados se buscó un "indicio" que pudiera vincularlos y se lo encontró en el campo semántico de la antinomia “civilización versus barbarie". El relevamiento y análisis de sus lexemas "en situación" (textual, intertextual y contextual) fue una metodología básica en el examen de cada texto y en la confrontación entre ellos, junto con el señalamiento de las marcas específicas del polemismo. ${ }^{14}$

Por otra parte, en un examen que consideró textos "en diálogo", estuvo siempre presente el concepto de "intertextualidad". ${ }^{15}$ En esta línea, los planteos teóricos de

de sus postulaciones teóricas y mostró a esta línea de estudios proyectándose más allá de la literatura para encarar otros lenguajes artísticos (la escritura musical, la ejecución de obras plásticas y arquitectónicas, las representaciones escénicas, las realizaciones cinematográficas), y más allá de los procesos creativos para analizar la gestación del discurso científico. Consecuentemente, hoy sus perspectivas de estudio ya se plantean a partir de una semiótica de la escritura, y en última instancia, a partir de una semiótica de la cultura (AAVV, 2010).

${ }^{13}$ Maingueneau, 1980; Mignolo, 1986; van Dijk, 1999; Kerbrat-Orecchioni, 1983, 2005 y 2009.

${ }^{14}$ Angenot, 1982.

${ }^{15}$ Gérard Genette define el concepto de "intertextualidad" en Palimpsestes (término acuñado por Julia Kristeva al cual Genette dota de un sentido propio) como una "relación de copresencia 
Gérard Genette se corresponden con los resultados de otro tipo de reflexiones producidas de modo independiente en otros dominios, como el concepto de "hipertexto" de la informática (un sistema que contiene documentos relacionados entre sí por hipervínculos); y en este sentido, los testimonios de la interacción polémica que hemos estudiado configuran un hipertexto.

entre dos o varios textos", y más específicamente, como la "presencia efectiva de un texto en otro" (Genette, 1982, p. 8). 


\section{LA GRAN POLÉMICA NACIONAL DEL SIGLO XIX COMO INTERTEXTO DE LAS BIOGRAFÍAS DEL CHACHO}

\subsection{La polémica entre Alberdi y Sarmiento}

En los comienzos del siglo XIX se funda la Nación Argentina, fruto de un proceso revolucionario fulminante que se integró al de otras repúblicas sudamericanas. Pero, la consecuente "argentinidad" que debió forjarse no se creó de la nada, sino que debió implicar el renacimiento y la reorganización de una estructura existente; complejos aspectos sociales y políticos que conformaban la sociedad criolla tuvieron que ponerse en tensión para lograr adaptarse y recrearse en una sociedad republicana moderna. Por consiguiente, el período de organización nacional fue no sólo arduo y delicado, sino más lento de lo que se esperaba.

En este mar de elementos que están recolocándose y resignificándose, se destaca la recreación de sujetos fundamentales para la modelización de la sociedad patria: el caudillo, los escritores-periodistas (los “publicistas"), el criollo, el gaucho, el indio y el inmigrante.

\subsubsection{Antecedentes: la problemática de la identidad nacional (los escritores de la "argentinidad")}

La literatura es un poderoso agentivo de identidades nacionales. Luego del período neoclásico que acompañó las primeras décadas de las celebraciones revolucionarias, se dio paso al movimiento romántico que en Europa estaba en su apogeo, y se consolidó en estas tierras al amparo de un ambiente propicio: primero, la impronta del historicismo romántico inició un proceso autorreflexivo fundacional; en una segunda etapa, el romanticismo tardío se abismó en la historiografía, en la conformación del idealismo heroico de los llamados "Padres de la Patria". Con este empeño, andado el siglo casi en su mitad, se fue definiendo el camino de búsqueda de la identidad regional, del color local, de la americanidad, de la argentinidad, liderada por los nuevos intelectuales que abrazaron con fervor la estética romántica. 
Los jóvenes escritores de esa primera etapa constituyen lo que se llamó la Generación del 37, que marcó el desarrollo de una reflexión política acerca del país y tomó partido en todos los hechos que lo convulsionaron. Esta elite letrada opina mediante la publicación de periódicos y panfletos y se reúne hasta en la clandestinidad para seguir con minuciosidad todos los avatares de la metamorfosis política, social y económica que comporta el abandono de las prácticas coloniales criollas. Cuando es inevitable en razón de la persecución ideológica, casi todos ellos se exilian y se expresan desde Chile y Uruguay, conformando así la generación de proscriptos, pues ninguno se resigna a guardar silencio; todos ellos siguen siendo escritores, políticos y periodistas y continúan viviendo como tales. El lugar público que ocupan es importante y, como herederos de la mentalidad iluminista, se sienten llamados a conducir la opinión, a ser los que eduquen al ciudadano.

Desde el Salón Literario de Marcos Sastre, Echeverría proponía a estos incipientes literatos dos cuestiones fundamentales ligadas al romanticismo social del período. Por un lado, la difusión popular de la cultura: publicar para el pueblo y servir de esta manera a la educación de la patria. Por otro lado pero en el mismo sentido, se planteaba el compromiso con la acción cívica. Proponían un arte al servicio de lo social y esta distinción definirá el alejamiento de los escritores "viejos", cultores del neoclasicismo.

Ese compromiso político será determinante cuando la persecución del gobierno de Rosas obligue al grupo a pasar a la clandestinidad y se convierta en la Asociación de Mayo. Las ideas fundamentales que se expresarán más tarde en la Declaración de Principios caracterizada como "la creencia social de la República Argentina", se concretan en la acción política opositora al régimen tiránico y se definen por luchar por la libertad de los oprimidos. Con este propósito editan periódicos y panfletos, y cuando son expresamente censurados y prohibidos, su voz se sigue escuchando desde la clandestinidad, legitimada por el valor de su participación personal en el sostenimiento coherente de sus principios; finalmente, la proscripción los convierte en los "héroes" de la causa.

1 "Código, o declaración de principios que constituyen la creencia social de la República Argentina", Montevideo, El Iniciador, $1^{\circ}$ de enero de 1839 (obra colectiva -redactada por Echeverría con el fin de dotarla de "unidad de estilo"- editada por Alberdi y conocida también como "Credo de la Joven Generación Argentina"). 
En este ambiente se conforma la primera elite literaria del país, entre la que se destacaron Echeverría, Alberdi, Mármol, J. M. Gutiérrez, V. F. López, etc., en Buenos Aires, y organizando actividades paralelas en San Juan, Domingo Faustino Sarmiento. Respecto de ello dice el sanjuanino que el socialismo romántico hacía:

[...] concurrir el arte, la ciencia y la política, o lo que es lo mismo, los sentimientos del corazón, las luces de la inteligencia y la actividad de la acción, al establecimiento de un gobierno democrático fundado en bases sólidas, en el triunfo de la libertad y de todas las doctrinas liberales, en la realización, en fin, de los santos fines de la revolución. ${ }^{2}$

Consecuentemente, estos escritores jóvenes, guiados por sus principios cívicos, irán dando forma al nuevo lector argentino y al nuevo objeto literario argentino: la geografía nacional, la política nacional, los caracteres nacionales, es decir, "la argentinidad". Es en este contexto que los nuevos sujetos sociales y sus ámbitos se transforman en objetos literarios: el caudillo y gaucho junto con la pampa, el indio, el desierto.

El pueblo debía ser ilustrado para sumarse a la lucha por la libertad, igualdad y fraternidad. Estos jóvenes se autoconsideran los "iluminadores" de la verdad, de la justicia y del camino del progreso social, y con estos fines describen la patria, su espacio, su gente y luchan contra la dictadura opresora. David Viñas, considerando la evolución literaria como una "historia de la voluntad nacional", afirma que "la literatura argentina empieza con Rosas", ${ }^{3}$ en la lucha contra la dictadura rosista que convierte al dictador en un "tópico literario" conformando un frente de ataque concreto a su figura y a todo lo que él representa. ${ }^{4}$ Una vez configurado el objeto de su literatura, el paso a seguir es la conquista de la opinión pública, del lector, del ciudadano al que deben ilustrar. Consecuentemente, se planean las obras con un sentido obviamente didáctico, pero además con un criterio clásico retórico que apunta a lograr la persuasión de la

\footnotetext{
${ }^{2}$ Así se expresa Sarmiento en "Segunda polémica literaria", cap. VI, (El Mercurio de 29 de julio de 1842). Ver Sarmiento, 1950, I, p. 316.

${ }^{3}$ Viñas, 1982, p. 14.

${ }^{4}$ Echeverría hace público su desagrado por los métodos del Restaurador y lo simboliza como la antítesis de los principios de Mayo, del crecimiento de la nación, la libertad y felicidad del pueblo. Aunados por estos criterios comienzan a escribir todos los jóvenes de su generación.
} 
opinión pública o, lo que es lo mismo, de la opinión política. Es dentro de este marco que Sarmiento literaturizará al "caudillo" haciendo de él un mito nacional, escribiendo las biografías de Aldao, de Quiroga, de Peñaloza, y eligiendo el género biográfico por considerarlo el más adecuado a sus fines ejemplificadores e ilustradores. En varias oportunidades hará los elogios de este género que es operativo tanto para reflejar al país como para atraer al público lector e imponerle la aceptación del mito del "caudillo bárbaro" que instalará con sus escritos.

\subsubsection{Sarmiento vs. Alberdi: el camino hacia la polémica}

Juan Bautista Alberdi participa activamente del grupo encabezado por Echeverría en Buenos Aires. Sarmiento manda su adhesión desde el interior del país, le escribe al joven tucumano, y aunque no pueda estar presente en las sesiones del salón porteño, desde San Juan asiste a reuniones análogas de un grupo de intelectuales destacados de su provincia. ${ }^{5}$ La pertenencia a estos círculos ponía de manifiesto un compromiso con sus ideales políticos y aseguraba la notoriedad pública necesaria para todo hombre interesado en formar parte de la elite intelectual emergente. ${ }^{6}$ Si bien las críticas contemporáneas señalaban muchas divergencias de pensamiento y posiciones políticas entre los concurrentes al salón de Marcos Sastre, las pautas de Echeverría sirvieron para dar en ese entonces un marco doctrinario suficientemente amplio como para albergar escritores que con los años se fueron distanciando. ${ }^{7}$ Es el caso de Sarmiento y Alberdi, protagonistas de una de las polémicas políticas más importantes del siglo. ${ }^{8}$

Sólo ocho años después de la constitución de la Asociación de Mayo, el sanjuanino publica su Facundo en Chile, ${ }^{9}$ y adquiere a través de esta obra una gran notoriedad. El Facundo es leído y comentado ampliamente, y el binomio "civilización y barbarie" se impone como la primera conceptualización sociológica de la Nación, hasta

\footnotetext{
${ }^{5}$ Años más tarde se declara congénere de todos ellos y se encuentra con Echeverría, ya exiliado en Montevideo, con el cual intercambia impresiones sobre la literatura y la política nacional.

${ }^{6}$ Ver "Dominante, residual y emergente" (Williams, 1980, cap. 8).

${ }^{7}$ Weinberg, 1958.

${ }^{8}$ Diana Sorensen (1998b) analizó esta polémica en forma pormenorizada.

${ }^{9}$ La obra que, en 1845, Sarmiento publicó completa con el título de Civilizacion i barbarie. Vida de Facundo Quiroga, i aspecto físico, costumbres i hábitos de la República Argentina había sido difundida de mayo a junio de ese año, como folletín y con el título Facundo, en el diario El Progreso de Santiago de Chile.
} 
de la América entera. Es la primera gran interpretación de la realidad nacional, ha sido lograda por un joven escritor de provincias y es aceptada por los porteños, y también fuera del país. Su repercusión se extiende por España, Francia y Norteamérica, donde se lo lee y se lo elogia.

De este modo, Sarmiento se consagra como escritor y descubre en la biografía un género muy apropiado tanto para fines didácticos como políticos. Valorado muy particularmente por él, es también muy bien recibido por el público argentino y logra que la figura del caudillo quede estampada en forma indeleble en el imaginario colectivo. Sarmiento, que ya había hecho una práctica del género (su biografía de Aldao, anticipada también por entregas) y años más tarde publicaría la del Chacho Peñaloza, expresa al respecto:

La biografía es, pues, el compendio de los hechos históricos más al alcance de un pueblo y de una instrucción más directa y clara. Mucho trabajo cuesta comprender el enlace de la multitud de acontecimientos que se desenvuelven a un mismo tiempo; pero nada es más fácil, ni hay cosa que excite mayor interés y mueva simpatías más ardientes, que la historia particular de un hombre a cuyo nacimiento asistimos, siguiéndole en seguida a sus juegos infantiles [...]. ${ }^{10}$

Luego de Caseros, Sarmiento ensaya una "giro biográfico" en una obra compleja desde la perspectiva de la teoría de los géneros: la Campaña en el Ejército Grande, donde describe la vida del general Urquiza con la clara intención de mostrarlo como un caudillo tan "bárbaro" como todos, heredero de Rosas y aún peor que él. ${ }^{11}$ El sanjuanino había actuado como boletinero oficial de la Campaña, y a un costado de Urquiza fue registrando dificultades y errores de la política del General en un diario sobre cuya base elaboró un texto en el que se va definiendo un evidente enfrentamiento personal con el entrerriano. Así, el binomio "civilización y barbarie" vuelve a aparecer en estas páginas, y como consecuencia de su publicación, esta suerte de taxonomía sarmientina tan extendida y aceptada pasará a ser cuestionada por Juan Bautista Alberdi, que se

10 "De las biografías" (Sarmiento, 2001a, I, p. 183).

${ }^{11}$ Se publicó con el título de Campaña en el Ejército Grande Aliado de Sud América (Sarmiento, 1852). Con el título de Campaña en el Ejército Grande fue publicada por la Universidad Nacional de Quilmes en 1997; en adelante, se citará por esta edición. 
transformará en su principal detractor a partir de la publicación de Campaña en el Ejército Grande. ${ }^{12}$

Movido por la irónica dedicatoria a su persona que Sarmiento incluye en este nuevo texto, y considerando que el sanjuanino se había excedido en las críticas al vencedor de Rosas, el tucumano publica sus Cartas sobre la prensa y la política militante en la República Argentina (pronto conocidas como las Cartas quillotanas). ${ }^{13}$ Así, dentro de una corriente crítica que ha enfocado a Sarmiento como adversario político, Alberdi inaugura una nueva perspectiva: cuestiona su modelo de interpretación de la realidad sudamericana. ${ }^{14}$ En su dedicatoria, Sarmiento denuncia a Alberdi de tener una posición de aquiescencia frente al poder $\mathrm{y}$, maniobrando paralelamente con estrategias típicas del discurso panfletario, desliza otras acusaciones: la de haber huido como un cobarde en el sitio de Montevideo después de haber inflamado los ánimos con sus escritos: "Háblole de prensa de guerra, porque las palabras que se lanzan en la primera, se hacen redondas al cruzar la atmósfera y las reciben en los campos de batalla otros que los que las dirigieron"; y continúa: "Y Ud. sabe, según consta de los registros de Montevideo, quién fue el primer desertor argentino de las murallas de defensa al acercarse Oribe". ${ }^{15}$

El proceso de esta polémica es complejo. Comprende la sucesión de varios hechos que se encadenan (además de la publicación de la Campaña) y van, paulatinamente, distanciando a los autores, e incluye además los mecanismos de “autofiguración" que ambos vuelcan en sus textos. ${ }^{16}$

El 16 de agosto de 1852, Alberdi funda el Club de Valparaíso, Club Constitucional Argentino destinado a apoyar a las Bases como programa. Allí se reprueba la revolución porteña del 11 de septiembre de ese año y se critica a Sarmiento

${ }^{12}$ Ver "Los ardides de la disputa. Alberdi lee el Facundo" (Sorensen, 1998b, pp. 91-108).

${ }^{13}$ Publicadas con el título de Cartas sobre la prensa y la política militante en la República Argentina (Alberdi, 1853), se las conoce como Cartas quillotanas por haber sido escritas en la localidad chilena de Quillota. Con ese título se publicó la edición por la cual se cita el texto en adelante (Alberdi, 1957). Refiriéndose al Facundo dice Alberdi: "Es la vida de un caudillo con pretensiones de ser explicación teórica del caudillaje argentino, teoría incompleta, pues deja en blanco los caudillos de la prensa y de la tribuna que tan bien calificó el padre Castañeda con el nombre de gauchi-políticos" (ed. cit., p. 104).

${ }^{14} \mathrm{La}$ famosa polémica ha sido analizada desde distintas perspectivas disciplinares (históricas, literarias, lingüísticas) y desde diferentes marcos teóricos. Entre las más recientes: Cobas Carral, 2003; Pagliai, 2005, pp. 9-32.

${ }^{15}$ Sarmiento, 1997, p. 119.

${ }^{16}$ Se toma este concepto de José Amícola (Amícola, 2007). 
por su carta de Yungay (13 de octubre) contra Urquiza. En respuesta, Sarmiento funda el Club de Santiago, que se declara en contra del Pacto de San Nicolás; y prosigue la discusión desde los diarios, con artículos a favor y en contra del Pacto. Es en este contexto que Sarmiento publica su Campaña el 12 de noviembre de 1852. En febrero del 53, el abogado tucumano le contesta con sus Cartas sobre la prensa y la política militante en la República Argentina, y en marzo del mismo año, le responde el sanjuanino con Las ciento y una. ${ }^{17}$

Luego de este fuego cruzado, la dura réplica de Alberdi no se hace esperar en su Complicidad de la prensa en las guerras civiles de la República Argentina. ${ }^{18}$ Sarmiento, a su vez, después de ser aprobada la Constitución que tiene como sustento las Bases de Alberdi, da a conocer sus Comentarios adversos, ${ }^{19}$ y a esta publicación, Alberdi responde con los Estudios de la Constitución Argentina de $1853 .^{20}$

\subsubsection{El intertexto sarmientino (Facundo en la Campaña en el Ejército Grande)}

La Campaña en el Ejército Grande de Sarmiento fue publicada con la irónica dedicatoria: "a mi querido Alberdi”, que actuará como un disparador de la polémica entre ambos:

Mi querido Alberdi: Conságrole a U. estas páginas, en que hallará detallado lo que en abstracto le dije a mi llegada de Río de Janeiro, en tres días de conferencias, cuyo resultado fue quedar $\mathrm{U}$. de acuerdo conmigo, en la conveniencia de no mezclarnos en este período de transición pasajera, en que el caudillaje iba a agotarse en esfuerzos inútiles por prolongar un orden de cosas de hoy más imposible en la Argentina. ${ }^{21}$

El texto servirá de este modo para reestructurar el sistema ideológico postCaseros, distinguiendo entre los que apoyan a Urquiza y los que nuevamente se

\footnotetext{
${ }^{17}$ Sarmiento, 1852.

${ }_{18}^{18}$ Alberdi, 1853b.

19 Sarmiento, D. F. Comentarios de la Constitucion de la Cofederacion Arjentina, con numerosos documentos ilustrativos del texto, Santiago de Chile, Imprenta de Julio Belin i Ca, 1853.

${ }^{20}$ Alberdi, J. B. Estudios de la Constitución de 1853 en que se restablece su mente alterada por comentarios hostiles y se designan los antecedentes nacionales que han sido base de su formación y deben serlo de su jurisprudencia, Valparaíso, Imprenta del diario El Mercurio, 1853.

${ }^{21}$ Ed. cit., p. 117.
} 
disponen a conformar la oposición. Sarmiento lo expresa con claridad desde las primeras líneas, en las que desliza la referencia irónica a la "posición semioficial" en la que se encontraría su antiguo camarada Juan Bautista Alberdi, responsable, de este modo, de la ruptura de un supuesto acuerdo de no intervención entre ambos escritores, que habría sido violado. ${ }^{22}$

Con esta excusa, Sarmiento justifica la divulgación de un documento íntimo ("Yo vi, yo oí, yo hice”), supuestamente impulsado por el deseo de rectificar la opinión equivocada que tendrían Alberdi y muchos otros más sobre la figura del general Urquiza, que como bien dice es "objeto del interés de todos, el hombre de la época", y se las ingeniará para llevar a un primer plano la vida íntima de Urquiza en Gauleguaychú (sus costumbres, su familia, sus amores y sus propiedades) y su posterior actuación, tanto durante la campaña militar (su relación con los soldados, los principios de autoridad, legalidad y humanidad) como durante su nueva vida en Palermo. ${ }^{23}$ Así, la irrupción del género biográfico en una sección de un texto híbrido que se presenta a su vez como una vivencia testimonial, autobiográfica, remite ex profeso al universo del discurso del Facundo y a su modelo de interpretación de la realidad nacional a partir de una historia de vida en la que se conjuga e intenta equilibrar la actuación del protagonista histórico del momento, Urquiza, con la del propio escritor del diario de campaña.

La reiteración de alusiones (y hasta de menciones explícitas) que remiten a Civilización y Barbarie acompaña el discurso de la Campaña en el Ejército Grande a la manera de un bajo continuo y reinstala una visión del país que el autor considera todavía vigente siete años después. ${ }^{24}$ Pero ahora, sobre la base del pacto de lectura que una obra exitosa ha establecido, la antinomia explicativa se vuelve más abarcadora y se subraya su presencia recalcitrante. Por otra parte, si bien desde el comienzo Sarmiento busca la complicidad de un lector con el que se reencuentra, en la sección titulada

${ }^{22}$ En la "Advertencia" Sarmiento se defiende atacando nuevamente a Alberdi: "A la distancia puede decirse de los hechos que refiero lo que sin referirlos me decía un amigo: U. ha reñido con Urquiza, y su juicio por tanto está preocupado. Yo no le contesté por cierto: $U$. ha recibido un nombramiento de Urquiza, y ha adquirido por tanto el don de lenguas" (ibidem, p. 119). Esta cita refuerza el sentido personal y polémico de la divulgación del diario.

${ }^{23}$ Ibidem, p. 142.

${ }^{24}$ T. H. Donghi, en su prólogo de la Campaña en el Ejército Grande (Sarmiento, 1997, p. 48), sostiene que "no utilizó Sarmiento esta antítesis que tan diestramente había manejado en el pasado". Sin embargo, el análisis pormenorizado del texto muestra lo contrario. 
"Campaña" -que adopta el molde genérico de un "diario"- se incrementa la interrelación con esa biografía de Facundo Quiroga que había sido identificado con una teoría de la barbarie, y el procedimiento va sacando a la luz una idea que había empezado a funcionar en el subtexto: también Urquiza se inserta en esa genealogía.

A pesar de que se lo encubra en un principio, a lo largo del diario Sarmiento vuelve a retomar el mismo tipo de planteo analítico que en su famosa biografía, pero volcando ahora una nueva temática en el molde ya probado. La novedad es el referente, que se repartirá entre Urquiza y su ejército, a pesar de que en un primer momento habían sido apoyados por Sarmiento como los únicos instrumentos capaces de derrocar la tiranía de Rosas. Ellos son, ahora, los "bárbaros" y "salvajes", y para lograr esta desviación referencial, Sarmiento se basa en una detallada y cuidada ilación de documentos y anécdotas orales de testigos presenciales sobre las actitudes del general, paso a paso, desde su estancia en San José hasta su establecimiento en Palermo.

Si Rosas fue siempre para el autor el símbolo de la "barbarie", Urquiza -su vencedor- tendría que haberse instalado como el símbolo de la "civilización". Sin embargo, Sarmiento descubre, supuestamente por haberse encontrado en su cercanía, que Urquiza también es la "barbarie" (con otros matices, pero con la misma sustancia). ${ }^{25}$

Contribuye a permitir el descubrimiento paulatino de esta nueva verdad la astuta organización del género textual del "diario", que permite que una desviación referencial tan significativa pueda ser asumida progresivamente por el lector. La estructura misma de la obra (sólo en apariencia inconexa) combina extractos de cartas, notas y párrafos de boletines alternando sus fechas con gran minuciosidad y con evidente intencionalidad. Sarmiento imita las idas y venidas de un razonamiento atribulado por el desarrollo de los sucesos, pero sus ideas se van trabando con perfecta claridad y unidad. Así enmascara el manejo de esa desviación referencial presentándola como un proceso que culmina en la metamorfosis que experimentaría el general Urquiza con su entrada a Buenos Aires. La nueva “imagen” de Urquiza surgirá de los ejemplos de involución en

${ }^{25}$ Con esta necesidad, la de rectificar el error de sus opiniones anteriores ante todo el pueblo argentino que sigue sus lecturas a la par del desarrollo de los hecho políticos del país, se supone que publica su obra. Retomando las ideas de la Generación del 37, en cuanto a la función social del escritor frente a la actualidad política, Sarmiento propone su texto como una herramienta para la comprensión del pueblo. También con esta finalidad didáctica incluye la carta del General Paz donde habla del escritor como orientador y modelador de la opinión pública. 
su carácter y en sus obras que nos muestra la Campaña, y a partir de ellos se lo asimilará a la raigambre rosista, a la "barbarie" por excelencia. El modelo -ya instalado- de la antinomia rige la escritura de Sarmiento, y conduce la interpretación del lector transportándolo al mundo del Facundo y a su sistema de valores.

\subsubsection{2. “Civilización”, primer término de la dicotomía}

Al observar la expresa mención de los dos polos de la antinomia conforme se van sucediendo en el texto de la Campaña se registran doce presencias, tanto del término "civilización” y sus derivados como de su alusión implícita. Las primeras pertenecen a un extracto del diario La Crónica de Santiago de Chile de 1849 en los que Sarmiento se describe a sí mismo, en relación con su labor como periodista, consagrado a una misión civilizadora y conocedor del mundo civilizado. Es el primer planteo sobre un tema que no quiere que se pierda de vista y en donde ya posiciona su "yo" en el campo de la civilización. ${ }^{26}$ Luego el término califica a Buenos Aires como la ciudad más avanzada de América antes de Rosas. También es un extracto de La Crónica pero del año 1850 y remite a tópicos del Facundo: el pasado culto de Buenos Aires, antes del gobierno del caudillo:

Hay más todavía: es opinión común en América y en Chile mismo, que en 1831, cuando principió a gobernar Rosas, Buenos Aires era la ciudad más culta de la América del Sur, y la más avanzada en instituciones europeas y civilizadas $[\ldots]^{27}$

El concepto reaparece metafóricamente en el contexto de los bocetos que hace Sarmiento de los pueblos que va conociendo en su viaje con el ejército. Describe con tono exaltado una presunta recepción calurosa que le hace el pueblo de Rosario por el

26 "Conspiraré, en fin, por los esfuerzos perseverantes de una vida sin tacha, consagrada a los intereses de la civilización, del engrandecimiento y prosperidad de la América, y muy particularmente, Exm. Sr., de la República Argentina, mi patria; pues que no he renunciado al título de argentino, y como a tal mi derecho imprescriptible de tomar parte en todos sus actos, como ciudadano que soy de ella [...]” (Sarmiento, 1997, p. 60); “¿Y es de extrañar Exm. Señor, que después de haber recorrido el mundo civilizado y atravesado veintiún Estados de los que forman la libre cuanto poderosa Federación Norte-Americana del Norte, no sienta sino el más profundo desprecio por el gobierno de Buenos Aires, que apoderado de la dirección suprema de la República, no ha sabido producir en veinte años sino guerras interminables en el exterior, ruina, despoblación y miseria en el interior?" (Ibidem, p. 64). En adelante los destacados en negrita son míos.

${ }^{27}$ Ibidem, p. 65. 
hecho de acercarles una imprenta, y aquí Sarmiento no pierde la oportunidad de destacar el poder de esta herramienta para una política de civilización y progreso como la que sueña. ${ }^{28}$ La asocia a la importancia de la educación, de su obra Educación Popular y de la nueva era que se inicia para el país. Y utiliza este episodio para confrontarlo luego con la actitud de Urquiza, que no sólo le ordena en determinado momento dejar de transportar la imprenta, sino que no le dará a sus boletines la relevancia que él considera necesaria.

Hay un trabajo literario intencional en el tratamiento de un tema tan vinculado con la figura del escritor-periodista del siglo XIX y con su afán educador y civilizador. ${ }^{29}$ La imagen de la imprenta se convierte en una metáfora de la "civilización”. Pensada como una ayuda fundamental para la difusión de la cultura en las masas populares, Sarmiento la presenta con esta connotación a lo largo del viaje que realiza el ejército hacia Buenos Aires. Los avatares que sufre la imprenta son las mismas dificultades que tiene la "civilización" para abrirse paso en la República. Los soldados que leen los boletines simbolizan al pueblo que quiere instruirse. El desinterés del general Urquiza por ella va en paralelo con la evolución que se describe en el personaje: primero encarga su compra pero no facilitará ninguna carreta para su transporte, luego no se interesa prácticamente por los boletines, y finalmente ordenará a Sarmiento que la abandone porque atrasa la marcha del ejército (pero permite, en cambio, que el padre de la Dolores sí lleve carretas con mercadería). El remate es el mismo que le da a su relación con el escritor: a Urquiza no le parece que la prensa haya logrado nada en su batalla contra Rosas.

En la reaparición siguiente se refiere a Pedro II. ${ }^{30}$ Sarmiento contrasta, frente al desinterés y la ignorancia del general que no lee nada de lo que Sarmiento le envía, el

28 "No pudiendo ahora ni más tarde expresar de otro modo mi gratitud a los habitantes del Rosario, lo hago por este medio para que mi nombre se asocie al recuerdo del día más feliz para un pueblo civilizado, y es aquel en que se erigió la PRIMERA IMPRENTA, y sus millares de lenguas llevaron a todas partes la fama del acto de heroísmo con que los habitantes se alzaban contra sus tiranos" (ibidem, p. 95).

${ }^{29}$ Aquí hay también un eco de las ideas de Echeverría, quien sostenía que había que publicar para el pueblo y acercar la literatura a las masas populares.

30 "Poetas, historiadores, publicistas, biógrafos argentinos que han sido en estos últimos años la materia predilecta del solaz y del estudio del Emperador, que empezó a ver desde un nuevo punto de vista a este pueblo joven como él, y como él luchando con las contrariedades de una naturaleza virgen donde las malezas amenazan sofocar a cada momento el árbol implantado de la civilización" (Sarmiento, 1997, p. 126). 
interés intelectual del joven emperador que "tanto se ha ocupado de examinar la carta geográfica" de nuestro país como de "conocer a los hombres que en ella figuraban". También emplea el término para aludir a la resistencia heroica al sitio impuesto por Rosas a Montevideo durante 9 años. ${ }^{31}$

Por otra parte, al referirse a su primera visión personal del ámbito geográfico pampeano, no puede dejar de retomar la conocida tesis del Facundo: las enormes extensiones desiertas de la pampa son las que engendran a los gauchos y sus hábitos contrarios a la civilización. La recuperación de la geografía implica también la recuperación concatenada de los hábitos de sus pobladores, de acuerdo con la lógica determinista que imperaba en la época; por lo tanto, al reencontrarse con el tópico de la pampa insiste una vez más en los "caracteres que engendra". ${ }^{32}$

El lexema se asocia también a su imagen del general Paz, a quien toma como paradigma del militar para oponerlo indirectamente a la figura de Urquiza, a quien designará más adelante como "provinciano educado por Ramírez y Artigas". Se trata de otra recuperación del Facundo, donde el general Paz ya había sido descripto como el militar a la europea con conocimientos estratégicos y científicos, es decir, como el modelo a imitar. ${ }^{33}$

Tampoco podía faltar la "civilización" como entidad personificada que puede servirse de sus escritos "indiscretos", en tanto no vacila en denunciar las ambiciones de Urquiza cuando ya la distancia entre ambos es insalvable y él se aleja de su lado para volver al exilio pasando por Brasil. Además, alude aquí irónicamente a Alberdi como “constitucionero" y como sostenedor de una política pragmática después de la batalla de Caseros. Tanto con la desvalorización implícita de una obra que él mismo había encomiado antes públicamente como con la alusión a diferencias políticas de peso,

31 "Esa administración tuvo que improvisar (Lamas era el jefe de policía) con materiales tomados donde los encontraba, por la ley del peligro supremo, las débiles murallas destinadas a guardar, en pocas cuadras de terreno, todas las esperanzas de la república, todas las de la civilización y de la humanidad en el Río de la Plata" (ibidem, p. 129).

32 "Paréme un rato a contemplarla, me hubiera quitado el quepí para hacerla el saludo de respeto, si no fuera necesario primero conquistarla, someterla a la punta de la espada, esta Pampa rebelde, que hace cuarenta años lanza jinetes a desmoronar, bajo el pie de sus caballos, las instituciones civilizadas de las ciudades" (ibidem, p. 167).

33 "Encontréme en el Montevideo con el viejo soldado de la Independencia, el General estratégico, el brazo que se ha alzado en veinte años a parar los golpes dirigidos a la libertad argentina, el salvador de Montevideo, el maestro, en fin, que enseñó a la parte civilizada de la República Argentina a pararse firme ante el caudillaje y dejar con eso sólo en descubierto su arrogante impotencia" (ibidem, p. 255). 
Sarmiento va preparando el camino hacia esa ruptura definitiva que se expresará en las Cartas quillotanas de Alberdi y la respuesta de Sarmiento en Las ciento y una. ${ }^{34}$

Interesa particularmente observar cómo, cuando Sarmiento define expresamente su posición política, actualiza y reformula el binomio para enmarcarla:

Para mí la guerra posible (¡y deseada! ¡si ese cáliz no puede apartarse de nuestra infeliz Patria!) es una guerra de libertad por un lado, y de caudillaje por otro, de estrategia y de ciencia militar de un lado, y de bandalaje [sic] y alzamiento compulsivo de campañas por otro; de ejército de línea regular por un lado y de milicias de chiripá colorado por otro; de civilización en los medios de un lado, y de barbarie en los fines por otro; de un pueblo que se defiende, y de un caudillaje que ataca; de la justicia en los motivos de uno, y de las preocupaciones del otro; y guerra tan premiosa, tan significativa, tan concluyente, vale la pena de desearla, aunque el patriotismo imponga el deber de estorbarla si es posible. ${ }^{35}$

Por último, en el final de la Campaña enuncia lo que considera una imposibilidad histórica para el futuro de Urquiza: "no será jefe de la República"; y discurre sobre la impureza y la falsedad del concepto de civilización que han utilizado quienes lo siguen para justificar su apoyo. Ésta es la segunda corrección que Sarmiento quiere instalar en la sociedad: por un lado, ha publicado una retractación (la rectificación del juicio sobre Urquiza que hasta él mismo había llegado a concebir por equivocación), y por otro, asegura que Urquiza y sus seguidores sostienen -de manera consciente y alevosa, según él- un concepto de civilización errado. ${ }^{36}$ Alude así a los que apoyaron lo que se definió como la "política práctica", con Alberdi a la cabeza, a quien Sarmiento execra explícitamente en esta obra.

\subsubsection{3. "Barbarie", segundo término de la dicotomía:}

\footnotetext{
34 "De paso la República, la moral, la civilización, y hasta los constitucioneros, como diría el general Urquiza, han de, lo espero, recoger algo de las indiscreciones del ambicioso, que no sabe jota de política práctica" (ibidem, p. 260).

${ }^{35}$ Ibidem, p. 302.

36 "Será Urquiza, en despecho de los que en número de quince o veinte, tránsfugas de la difícil pero gloriosa causa de la civilización, tratan de dar apariencias civilizadas y morales a aquel resto impuro de nuestros desaciertos pasados" (ibidem, p. 306).
} 
La reiteración de este lexema en el discurso recorre un camino que parte de un marco referencial histórico muy abarcativo y termina concentrándose en la figura de Urquiza y sus soldados.

En primer lugar, en el extracto de La Crónica (con fecha 1849) que incluye en el diario, habla de las "edades bárbaras" para referirse a la acción de las aduanas interiores que gravan el paso de mercaderías. ${ }^{37}$ Esta importante cuestión -analizada por Sarmiento tanto en el Facundo como en la Campaña- se asocia a una alusión a los "señores feudales" que apoyan la política del puerto único y se niegan a admitir la libre navegación de los ríos (Rosas y Urquiza, entre otros). En la Campaña se explayará sobre la relación de los caudillos con el poder económico y establecerá una nueva genealogía en la conformación de estos líderes: no importa ya tanto su fuerza física como en el Facundo, sino sus posesiones de tierras y vacas. Presenta a Urquiza como un terrateniente organizado más racionalmente, pero afirma que en su estancia de Entre Ríos sus prerrogativas son las de un señor feudal.

Después, en la carta a H. Southern, Sarmiento alude al Facundo e incorpora menciones de la barbarie que luego instrumentará como un reproche al accionar del general Urquiza en la provincia de Buenos Aires: "y no es necesario para mantenerla en paz, ni suma del poder público, ni cinta colorada, ni los epítetos de salvajes, infames en los actos oficiales". Se trata de un anticipo de lo que luego irá enumerando como rasgos negativos del vencedor de Caseros y con ese objetivo ha incorporado esa carta al corpus de la obra. ${ }^{38}$

La siguiente ocurrencia se vincula con la enfermedad endémica de la Confederación: el degüello, un mal que "queda latente en la atmósfera”. Sarmiento denuncia en el prólogo del "Complemento" de la Campaña -escrito en Río de Janeiro-, que Urquiza hace renacer este método tan repudiado y tan temido de la época de Rosas y anticipa inmediatamente, al referirse a la reposición de tres testimonios de barbarie, los pilares sobre los cuales estructurará su crítica al general: la pena del degüello, el

\footnotetext{
37 "En las edades más bárbaras de la Europa, los señores feudales que tenían establecidos sus castillos en las crestas de las montañas, en las gargantas de los valles, en las encrucijadas de los caminos, o en los vados de los ríos, tenían sus tropas de siervos armados para arrancar contribuciones a los pasantes, y quitarles parte de lo que llevaban" (ibidem, p. 61).

38 "Estos países, me diría, son demasiado bárbaros para ser gobernados de otro modo [...] Yo he habituado los oídos de los americanos a oírse llamar bárbaros y ya no lo extrañan. Pero aún admitiendo la barbarie de los argentinos, algunas explicaciones pueden atenuar en el ánimo de S. S. el rigor de las deducciones" (ibidem, p. 65).
} 
epíteto "salvajes unitarios" y la cinta colorada (prácticas y símbolos de una época abominable). ${ }^{39}$ La recuperación del epíteto paradigmático le permite caracterizar a Rosas como "bárbaro atrabiliario" y asociar el calificativo a quien lo resucita en el presente:

iy al gobierno de Buenos Aires y al redactor del Boletín mismo insinuóles el general Urquiza el nombre de salvajes unitarios! [...] ¿Quién a quién dice salvaje unitario, epíteto inventado para encubrir su rusticidad un bárbaro atrabiliario $?^{40}$

En la "Advertencia", satiriza la gestión de Urquiza luego de su victoria en Caseros describiéndola como la marcha de un carro triunfal que va demasiado rápido y no cuenta con todos los tornillos necesarios para avanzar con seguridad, y frente al riesgo de tumbarse dice:

¡Qué bárbaro! ¡Qué costalada va a darse! $!^{41}$

Luego asocia el lexema a la desprolijidad y a la vestimenta campesina de las tropas de Rosas y emblematiza así la barbarie en una marca cultural que le permite extender después una calificación despectiva implícita a las tropas entrerrianas y correntinas que visten de la misma manera. ${ }^{42}$ Después, por medio de una descripción de la infantería de Mansilla extiende su descalificación a todo ejército que desconoce las armas de fuego y se maneja fundamentalmente con el cuchillo. ${ }^{43}$

39 "Bastaba que el entrecejo de algún bárbaro se frunciese para hacer rodar la cabeza del que piensa, como no piensan los que no se tomaron nunca el trabajo de coordinar dos ideas" (ibidem, p. 104).

${ }^{40}$ Ibidem, p. 106.

${ }^{41}$ Observar que el uso del adjetivo "bárbaro" que hace Sarmiento corresponde a la acepción de 'arrojado', 'temerario'; no se trata del uso coloquial corriente en el español actual -no sólo en Argentina- (ibidem, p. 120).

42 “De cuántos actos de barbarie inaudita habrían sido ejecutores estos soldados que venían tendidos de medio lado, vestidos de rojo, chiripá, gorro y envueltos en sus largos ponchos de paño?" (ibidem, p. 37).

43 "Cuento estos detalles para mostrar la miseria de nuestros medios de guerra y la impericia de los bárbaros para el uso del cañón” (ibidem, p. 155). 
Más adelante también califica de "bárbaros" a la multitud rosarina que lo recibe exaltada y le pide unas palabras. ${ }^{44}$ Usa Sarmiento este pasaje para subrayar su "inocencia" en las derivaciones posteriores que luego tiene este episodio: asegura que no quiso responder a esta efusividad para no suscitar las envidias del general. Justamente, éste es el origen de sus problemas con Urquiza, pues a partir del incidente surge la irónica respuesta del general respecto de la influencia de la prensa en el ánimo de Rosas. Este disgusto profundiza las diferencias que impulsan la separación definitiva entre el militar y el escritor, y Sarmiento transcribe el parte que recibe de Urquiza en su "Ad memorandum" para darle más verosimilitud y agresividad a las palabras del general, quien manda comunicarle "que hace muchos años que las prensas chillan en Chile y en otras partes, y que hasta ahora D. Juan Manuel de Rosas no se ha asustado; que antes al contrario cada día estaba más fuerte". ${ }^{45}$ Este tema será retomado por Alberdi en la polémica posterior.

El término reaparece para acusar la desorganización del Ejército Grande (que no tiene "ni jefe de día, ronda, rondín, patrullas, ni avanzadas, que no había orden del día, ni Estado General, [...] ni oficial ninguno de Estado Mayor"). Con su inventario de detalles acerca de fallas y rusticidades, Sarmiento incrementa la efectividad literaria de su comparación con los otros dos ejércitos aliados, de organización europea. ${ }^{46}$ En esta línea, tampoco se olvida de registrar ningún detalle de primitivismo bélico ni de compararlo con los procedimientos análogos de Rosas. ${ }^{47}$

El concepto se asocia después al retomar tópicos del Facundo: el retraso de los métodos de explotación rural, el desinterés por la agricultura y la nefasta acción de Rosas en Buenos Aires como hacendado. ${ }^{48}$ El tópico de las campañas "pastoras" le

44 “Bárbaros! Me decía yo a estos gritos a que respondía la multitud con descargas cerradas de vivas, ¡me están asesinando! ¡me van a sofocar con sus abrazos!” (ibidem, p. 170).

${ }^{45}$ Ibidem, p. 97.

46 "Este lujo inaudito de barbarie y de desorden se hacía en presencia de brasileros y orientales, que en sus campos respectivos estaban en regla" (ibidem, p. 181).

47 "Rosas había agrandado el tamaño de las mochilas a punto de hacer de ellas un verdadero tercio, como había alargado la lanza de media vara, y aumentando la capacidad de la canana para añadirle un paquete; porque estos bárbaros presuntuosos a la par que ignorantes están creyendo que este arte de la guerra que desde los tiempos de Jenofonte, Alejandro, César, Federico y Napoleón se viene perfeccionando por el genio y la ciencia, lo inventaron ellos violando las leyes de la dinámica, o los resultados de la experiencia de siglos" (ibidem, p. 189).

48 “iQué barbarie en la explotación de la propiedad rural! Sin exageración ninguna la campaña de Buenos Aires es el país más atrasado de la tierra, si no se le compara con las otras provincias pastoras" (ibidem, p. 201). 
permite insistir en las cualidades que asocian a todos los caudillos: “QQue son Rosas, Quiroga y Urquiza? Apacentadores de vacas, nada más". ${ }^{49}$ En "Gualeguaychú” se había referido a otra faceta del problema: el escaso desarrollo agrícola de los campos de Urquiza, ${ }^{50}$ quien no vacilaba en obligar a todos los pobladores a abandonar los cultivos listos para la cosecha con el fin de incorporarse a las tropas.

Se demora luego en el degüello por la nuca de Santa Coloma, ordenado por Urquiza. Así, aunque reconoce que en su momento aprobó el castigo del mazorquero, insiste en destacar la persistencia de estas prácticas bárbaras; ${ }^{51}$ oportunidad que tampoco desperdicia cuando describe los ahorcamientos ordenados por Urquiza en la entrada de Palermo. ${ }^{52}$

Sarmiento ve en las deficientes comunicaciones entre las provincias la causa de la secesión de Buenos Aires (los gobernadores no reciben la convocatoria de Urquiza a las Juntas porque la invitación llega tarde) y utiliza otra manifestación de rusticidad para marcar la distancia entre sus proyectos civilizadores y el accionar de Urquiza. ${ }^{53}$ En otra ocurrencia del lexema, la eficacia retórica de Sarmiento crea un oxímoron irónico para referirse a una artimaña política del caudillo entrerriano: "porque hasta esta exquisita barbarie tenía el General; escamotear un diputado más a Buenos Aires, poniéndoles un provinciano". 54

${ }^{49}$ Ibidem, p. 248.

50 "La horticultura está muy desenvuelta, es decir relativamente a aquella barbarie inaudita de las campañas pastoras" (ibidem, p. 211).

51 "No abusaré de mi posición actual para afear este acto, de que gusté en ese momento cuán irregular era porque era una satisfacción dada a la vindicta pública, castigando a uno de los famosos mazorqueros, que habían espantado a la humanidad con refinamientos de barbarie inaudita" (ibidem, p. 219).

52 "Palermo es un monumento de nuestra barbarie y de la tiranía del tirano, tirano consigo mismo, tirano con la naturaleza, tirano con sus semejantes" (ibidem, p. 222).

53 "En conversación confidencial con Alsina le indiqué el deseo que tenía de ser administrador de correos, para secuestrarme de la política y empezar a desarrollar un sistema de comunicaciones con las provincias que, ligando el vapor de Europa con el correo de Chile, terminase con el establecimiento de la posta diaria por la aplicación del penny-postage, la de diligencias a Mendoza, y por fin la de casas de posta fuertes que atravesasen la Pampa, contuviesen a los bárbaros, fuesen hoteles, y posadas para emigrantes a pie, y un vínculo de eslabones de edificios y habitaciones, para estrechar las relaciones de la provincias entre sî" (ibidem, p. 249).

54 "Jerónimo Costa con la guardia ciudadana; los otros coroneles con milicias de campaña; Baldomero con una vacante in partibus; Anchorena en el consejo de Estado, que no era rueda necesaria; Lahite al Congreso, y Carril, un sanjuanino, de adlátere; porque hasta esta exquisita barbarie tenía el General; escamotear un diputado más a Buenos Aires, poniéndoles un provinciano" (ibidem, p. 288). 
Pero adquieren especial significación, en relación con la reinstalación del segundo término de su famosa antinomia, las conexiones intertextuales expresas que hace Sarmiento con su emblemático texto de 1845. La primera mención se lee en una carta dirigida a Mitre e incluida en el prólogo del "Complemento", en donde habla de cómo los intereses literarios del Emperador lo "introducen favorablemente" (según Sarmiento Pedro II había leído el Facundo y eso le había abierto las puertas en Brasil). ${ }^{55}$

También explicita con claridad el grado de conexión en el interior del intertexto sarmientino, apelando al lector para que interprete, en los términos del 45, el texto presente: "Quien haya leído en Civilización y Barbarie lo que sobre la cinta colorada he escrito, podrá formarse idea de la extrañeza, de la preocupación en que me echaba esta persistencia en seguir las prácticas de Rosas". ${ }^{56}$ De este modo busca la complicidad con el lector como cuando se comenta el paralelo que comienzan a establecer los pobladores de Buenos Aires entre Urquiza y Rosas. ${ }^{57}$

Por otra parte, Sarmiento se ha encontrado frente a frente por primera vez con la realidad geográfica que, no obstante, había descripto magistralmente en la obra que para muchos críticos es la auténtica pieza inaugural de una "literatura argentina":

A caballo, en la orilla del Paraná, viendo desplegarse ante mis ojos en ondulaciones suaves pero infinitas hasta perderse en el horizonte, la Pampa, que había descrito en el Facundo, sentida, por intuición, pues la veía por la primera vez en mi vida! $!^{58}$

Pero sobre todo, como se ha dicho, se busca reinstalar un modelo explicativo que se inscribe en el marco del determinismo filosófico de la época.

Finalmente, es el propio Sarmiento quien explicita su intencionalidad en el "Epílogo" destacando el carácter unitario del conjunto de sus obras:

55 “"...] y por lo que a mí respecta, habíame introducido favorablemente Civilización y Barbarie, hace tiempo, con la primera edición, habiéndose procurado después Sud América" (ibidem, p. 109).

${ }^{56}$ Ibidem, p. 123.

${ }^{57}$ Dice refiriéndose a los porteños: "Recuerdan que Rosas se tomaba estas libertades groseras [...] Y de estos incidentes insignificantes las analogías y las asociaciones de ideas empiezan a despertarse. La corte de Palermo como antes, el chaleco y la cinta como antes, los salvajes unitarios como antes, las matanzas de hombres en los alrededores como antes" (ibidem, p. 228). Los destacados son de Sarmiento.

${ }^{58}$ Ibidem, p. 167 
Si la libertad argentina sucumbe, es decir, si el caudillaje triunfa de nuevo, habré sucumbido yo también con los míos y el mismo polvo cubrirá Civilización y Barbarie, Crónica, Argirópolis, Sud América y Campaña del Ejército Grande, que son sólo capítulos de un mismo libro. ${ }^{59}$

\subsubsection{El general Urquiza, "Don yo" y los porteños ${ }^{60}$}

Si bien la evocación de Rosas retrotrae al lector al Facundo y a su sistema de interpretación de la realidad nacional, Sarmiento parecería querer probar al comienzo que esa figura emblemática remite a un grado de barbarie que no ha sido superado aún, y que Urquiza representa una "barbarie" de otro tipo, aunque de la misma especie del Restaurador, a quien sucede. Sin embargo, por obra del discurso de la Campaña, el general Urquiza va sufriendo un proceso de "barbarización", va asemejándose paulatinamente a Rosas hasta superarlo, y esta metamorfosis se va detallando en el texto. El proceso de "barbarización", pormenorizado hasta en sus más mínimos aspectos, pareciera ser la estrategia más clara y contundente de captación del público porteño. Sobre todo, las miras políticas de Sarmiento no pierden nunca de vista al sector político emergente y para estos espectadores se representa un juego teatral que, habiendo definido ya a un enemigo, da a conocer al antagonista por excelencia, que será él mismo; el pueblo porteño funcionará entonces como un tercer personaje espectador de este duelo, que en varias oportunidades opinará con voz propia coincidiendo con los juicios del autor.

De esta manera también apela al lector para que asuma la posición del pueblo porteño identificándose con su proceso de asociación de ideas, como cuando dice refiriéndose a los porteños:

Recuerdan que Rosas se tomaba estas libertades groseras [...] Y de estos incidentes insignificantes las analogías y las asociaciones de ideas empiezan a despertarse. La corte de Palermo como antes, el chaleco y la cinta como antes, los

\footnotetext{
${ }^{59}$ Ibidem, p. 306.

${ }^{60}$ Enrique Anderson Imbert discurre sobre el origen de este conocido apodo con que se referían a Sarmiento muchos de sus contemporáneos; entre ellos, Alberdi, Hernández y otros adversarios (Anderson Imbert, 1954).
} 
salvajes unitarios como antes, las matanzas de hombres en los alrededores como antes. $^{61}$

Como se ha dicho, la comparación con Rosas y sus métodos se va a sostener en adelante sobre la base de tres marcadores emblemáticos: el empleo del degüello, la imposición de la cinta colorada y la revitalización del epíteto "salvajes unitarios". Respecto del degüello dice Sarmiento que Urquiza es el último caudillo que usa el degüello como sistema. ${ }^{62}$ Los degüellos indiscriminados que tanto habían espantado a la sociedad porteña son vistos en este caso con un carácter más negativo: primero, porque no son coherentes, a algunos se los degüella mientras otros pasean tranquilamente por las calles de Buenos Aires, lo cual desorienta a los porteños, ${ }^{63}$ y segundo, por la exposición pública de los cadáveres que quedan en Palermo. ${ }^{64}$ Respecto de la cinta colorada, después de mencionarla como la causa de su nuevo exilio al Brasil, ${ }^{65}$ inserta este motivo en una extensa progresión que se remonta a su ya célebre Facundo, ${ }^{66}$ y culmina cuando el general reacciona contra la renuencia de los porteños a reinstalar su uso. ${ }^{67}$ Sobre la revitalización del calificativo "salvajes unitarios", uno de los capítulos del libro lleva este título y cuenta cómo Urquiza le pide que llame a Rosas con ese epíteto. Pero a partir de esta incitación, la aplicación del epíteto se va extendiendo y a su vez acotando a su blanco original. Urquiza llama "salvaje unitario" a Sarmiento

${ }^{61}$ Sarmiento, 1997, p. 228.

62 "El general Urquiza ha proscrito después su medio de compulsión" (ibidem, p. 163).

${ }^{63}$ Ibidem, p. 227.

${ }^{64}$ Urquiza manda colgar los cuerpos en el jardín de la casa de Rosas y las señoras de la ciudad exclaman: “¡En tiempos de Rosas no nos han colgado cadáveres en la vía pública!” (ibidem, p. 234).

65 "[...] siendo mi intención decidida no suscribir a la insinuación amenazante de llevar un "cintillo colorado" por repugnar a mis convicciones" (ibidem, p. 100). El destacado es de Sarmiento.

66 "Quien haya leído en Civilización y Barbarie lo que sobre la cinta colorada he escrito, podrá formarse idea de la extrañeza, de la preocupación en que me echaba esta persistencia en seguir las prácticas de Rosas" (ibidem, p. 123). Sarmiento detalla que después de las primeras entrevistas que ha tenido con Urquiza se le ha comentado que su falta de cinta colorada había sido notada, que después recibe una intimación para ponérsela y más adelante aparecen las quejas del propio general porque la gente de Buenos Aires no quiere llevarla puesta: "Aquí encuentro que nadie quiere ponerse la cinta colorada" (ibidem, p. 226). El destacado es de Sarmiento.

67 "[...] la insistencia sobre la cinta va haciéndose más exigente" (ibidem, p. 227) hasta que se llega a la amenaza violenta: "dando orden [...] de colgarlo de un pie en un árbol en el patio si volvía a presentarse sin cinta" dirigida a un comandante que no quiere obedecer a Urquiza (ibidem, p. 233). 
repetidas veces; por extensión, a todos los escritores del exilio; luego a Paunero, Aquino y Pacheco, que comienzan a sentir cierta discriminación (dice Sarmiento que no les dan caballos para marchar); a Ascasubi y finalmente a los porteños en general. La discriminación no corresponde a la nueva situación que sucede a la derrota de Rosas. Sarmiento se anticipa a los resultados señalando la supervivencia de las ideas de estos "antiguos caudillejos" como la semilla que continúa con el mal de la República, "lo que hacía más desastrosa esta recaída en las necedades ridículas y ya gastadas de Rosas". ${ }^{6}$

En el juego teatral en el que se ha instalado un antagonista (de la barbarie)protagonista (de la acción), la pintura del enemigo desliza un complejo sistema discursivo hacia el género biográfico. Hay un personaje protagónico que se impone en la práctica de una "escritura del yo", y aunque la Campaña no sea una autobiografía stricto sensu, Sarmiento incluye tantas referencias a su persona que por momentos su obra transcurre por las fronteras del género. Pero particularmente, esa estrategia discursiva pareciera intentar despertar un sentimiento de identificación personal con ese público porteño al que Sarmiento aspira a conquistar. Anderson Imbert ha propuesto un rescate de esa modalidad autobiográfica:

De Sarmiento sabemos, ante todo, lo que él mismo nos ha contado. Fue hombre de acción, pero tan locuaz que sus escritos, siendo siempre actos políticos, tienen un peculiar tono autobiográfico. Y en el modo con que nos cuenta su vida está la clave de su obra: le rebosa el sentimiento de ser algo más que un individuo, de ser nada menos que una fuerza histórica. Tanto insistió en el valor de su personalidad y en el sentido misional de su conducta que el vulgo lo llamaba Don Yo. Pero la egolatría de Sarmiento -tema favorito de coleccionistas de anécdotas- es sólo una vista exterior, superficial de esa íntima plenitud con que vivía. Es a su yo apasionado al que deberíamos asomarnos para comprender su mensaje. ${ }^{69}$

Sin duda, el personaje real es tan rico y complejo que no puede reducirse limitándolo a una sola mirada. Tampoco a la de Alberdi, que aportará la suya cuando descalifica la veracidad histórica del diario de campaña subrayando que no se trata de la

${ }^{68}$ Ibidem, p. 185.

${ }^{69}$ Anderson Imbert, 1967, p. 56. 
Campaña del Ejército Grande sino de la Campaña en el Ejército Grande (es decir, la “campaña” del propio Sarmiento):

Su campaña personal, en vez de ser un diario de las marchas del ejército, es la historia psicológica de sus impresiones de emulación contra su general en jefe; la historia de su desacuerdo con el general Urquiza, [...] que usted mismo revela ser fruto de sus decepciones de aspiración y de amor propio. $^{70}$

La primera aparición de Urquiza lleva su firma: es la carta que le envía a Sarmiento incluida dentro de la primera parte de la Campaña (en la sección denominada “Ad Memorandum”). Urquiza destaca allí la acción del sanjuanino como escritor y lo insta a continuar en ese camino. ${ }^{71}$ En carta de Albarracín, se analiza la oferta de acercarse al escenario de los sucesos que le manda el general. ${ }^{72}$ El distanciamiento progresivo de las dos figuras irá de la mano de la descripción del camino de "barbarización" de Urquiza y esa metamorfosis se presenta acompañada por el cambio de opinión que Urquiza va manifestando sobre el rol de Sarmiento como periodista en su ejército. Abre este proceso la escena en la que el general acoge con reticencias a Sarmiento, sin darle un lugar destacado en sus tropas (como él esperaba), y sigue más tarde con una invitación no demasiado entusiasta para trabajar como boletinero del ejército, a la que se sumará un serie de contratiempos: la orden de comprar una imprenta, encargada a último momento y en Montevideo (donde resulta muy difícil encontrar un instrumento de esas características luego de los largos años de sitio que sufrió la ciudad), y el accidentado viaje de la imprenta (es dificultoso conseguir un medio para transportarla porque es muy pesada), que culmina con la orden de Urquiza de abandonarla, desobedecida por Sarmiento. El escritor pasa entonces a analizar la influencia que este tipo de boletines ejercen en el ejército. Describe cómo los soldados se reúnen a leer sus escritos, y es en relación con este tema que se desarrolla el episodio de Rosario, donde Sarmiento es recibido con júbilo por las gentes del lugar, que le piden unas palabras. El resultado es el mensaje demoledor que Urquiza le envía por intermedio de su secretario, en donde desestima de manera categórica la influencia de

\footnotetext{
${ }^{70}$ Alberdi, 1957, p. 34.

${ }^{71}$ Sarmiento, 1997, p. 74.

${ }^{72}$ Ibidem, p.75.
} 
los periódicos en la vida política. ${ }^{73}$ Lo que define -como ya se analizó- la ruptura de la relación entre ambos. A partir de este episodio, sus encuentros se hacen más espaciados y las diferencias de criterio son ya sustanciales e insalvables. ${ }^{74}$

Todas las referencias a Urquiza, en las que Sarmiento asimila su punto de vista al de los porteños, subrayan la imposibilidad de un entendimiento entre Urquiza y la sociedad del Plata, destacando su primitivismo en relación con la modernidad y finura de la vida urbana- (se insiste incluso en detalles sobre su vestimenta, que alterna la usanza ordinaria y paisana-con un ropaje sobrecargado y ostentoso), y se muestra el contraste con la elegancia porteña y el inevitable rechazo que, frente al mal gusto del general, enfría los saludos cuando él pasea por la ciudad. Sus modos equívocos, que provocan que la gente lo apode "el loco Urquiza" (curiosamente, el calificativo coincide con el que le adjudicarán también a Sarmiento sus propios opositores), ocasionan, como consecuencia, la desconfianza de los pobladores de Buenos Aires. Así, se presenta el germen de un rechazo creciente que acarreará como resultado la revolución del 11 de septiembre de 1852.

En el universo de este discurso, la instalación de Urquiza en Palermo lo "barbariza" indefectiblemente, y operada la metamorfosis, la situación de Sarmiento se vuelve insostenible y sin otro recurso que "la fuga" (el texto alude a una supuesta

\footnotetext{
${ }^{73}$ Ibidem, p. 97.

${ }^{74}$ En el análisis que Sarmiento hace del carácter de Urquiza subraya episodios en que se muestra: la habilidad para engañar del general, sus deseos de ser adulado permanentemente, el desenfreno y la violencia de su trato (con la presencia de su perro Purvis). Respecto de su vida amorosa, muestra que Urquiza practica el concubinaje y dice que lo establece como sistema provincial y que tiene un harem con varias favoritas que lleva hasta Palermo y cuyos hijos naturales cumplen allí un papel muy importante. Sarmiento elegirá permanentemente, como figuras gravitantes, a la Dolores (una de las amantes más conocidas) y a su padre; cuenta que el padre de la Dolores goza de ciertos privilegios, como llevar carretas con barricas de harina, mientras que a él se le niega el transporte de la imprenta con la excusa de apurar la marcha. Otra falta de la que le acusa es la de utilizar el robo como hostilidad de guerra, sostener el desorden y propinar castigos exagerados que evidencian una "crueldad extrema" y se explican -según Sarmiento- por su calidad de acaudalado terrateniente (otra de las semejanzas con Rosas). También hablará Sarmiento del poder y de la autoridad que ejerce sobre los hombres en quienes infunde miedo, como se aprecia en el pasaje del cruce del río Paraná, cuando los soldados se retrasan como resultado de la fascinación mágica de la presencia del general. Más adelante describe su falta de educación al no saludar como corresponde según el rango, y su falta de estudios académicos (comenta que la gente confunde su formación con la de su hijo Diógenes). Hace hincapié en su embarazo al hablar en público y en su codicia de gloria personal, que lo lleva a conspirar para oscurecer a los aliados, grandes defectos para la puesta en marcha de un gobierno constitucional y ordenado. También subraya su pedido indiscriminado de fondos y sus impertinencias de aldeano cuando dice siempre lo que la gente educada sabe que no debe decir.
} 
amenaza de muerte sobre su persona). Los exabruptos reiterados de Urquiza lo han llevado a decir en momentos de exaltación: "dígale a su gobierno que fusile unos cuantos doctores", ${ }^{75}$ y Sarmiento imagina que en circunstancias semejantes le ha bromeado a Benavides: "dígale a Benavides que lo fusile si va... Me parece que oigo la voz, que veo la guiñada del ojo, y la risita con que acompaña estas bromas". 76

Se citan además las opiniones de la gente de Buenos Aires que tampoco deja de apreciar la semejanza de Urquiza con Rosas. Según Sarmiento, algunos lo llaman “segundo tomo de Rosas"; ${ }^{77}$ Hornos se pregunta, cuando ve desenvolverse la "política de cintajos y caudillejos” en Palermo: “¿Qué ha creído, que hemos venido a servirle de banco para sentarse en la silla de Rosas? ${ }^{78}$ Más adelante cita al vicealmirante Venancio López, que expresa: "yo creo que no ha hecho más que sustituir a Rosas". ${ }^{79}$ Y definitivamente, Sarmiento, despojando cualquier indicio de duda, lo nombra “omnipotente albacea testamentario de Rosas" en las últimas páginas del texto. ${ }^{80}$

Sarmiento sostiene que esta involución de Urquiza lo deja fuera de la nueva escena nacional cuando afirma: "recién el 11 de Septiembre caía verdaderamente Rosas con su cinta colorada, sus salvajes unitarios, sus campamentos de tropas en todas partes, su corte, familia y queridas en Palermo". ${ }^{81}$ Así culmina una absoluta identificación entre Rosas y Urquiza y se proclama una apasionada defensa del separatismo porteño. En este “diario" de la Campaña, Urquiza se exhibe como un nuevo azote para los porteños, un nuevo perjuicio para su cultura y su "civilización”. La situación se había agravado porque la ilusión del pueblo de Buenos Aires era otra y reclamaba un cambio profundo; sin embargo, Urquiza, a decir de Sarmiento, no resiste la tentación y elige resucitar la “corte” de Palermo y repetir un estilo ya conocido por todos: “¡Tan lindo aquello! ¡Tan poblado! ¡Ea provincianos, a Buenos Aires todos! ¡A castigar a la rica, a la orgullosa Buenos Aires!" ${ }^{82}$ El determinismo fulminante de Sarmiento no lo perdona al sintetizar en el Epílogo: “y mostró en seis meses de poder, que los vicios de conformación de esta

\footnotetext{
${ }^{75}$ Sarmiento, 1997, p. 255.

${ }^{76}$ Ibidem, p. 255.

${ }^{77}$ Ibidem, p. 234.

${ }^{78}$ Ibidem, p. 148.

${ }^{79}$ Ibidem, p. 263.

${ }^{80}$ Ibidem, p. 283.

${ }^{81}$ Ibidem, p. 291.

${ }^{82}$ Ibidem, p. 304.
} 
clase de espíritus son incurables. Han nacido así y así morirán" ${ }^{83}$ Por ello, ha presentado Sarmiento la clase de vida que se llevaba en Entre Ríos, en su Gauleguaychú, como el germen que luego de la victoria florece en el ámbito propicio de Palermo y justificará tanto el expreso apoyo de Sarmiento a la revolución de septiembre como su reposicionamiento político a favor de la separación de Buenos Aires.

\subsubsection{Refutación de Alberdi en las Cartas sobre la prensa y la política militante en la República Argentina (1853)}

Son cuatro las cartas abiertas conocidas popularmente como Cartas quillotanas, que Alberdi -“el verdadero interlocutor de Sarmiento"- ${ }^{84}$ fechó en su quinta de Quillota, en Chile, inmediatamente después de que el sanjuanino le dedicara irónicamente la sección del libro que presentó como su diario de campaña (diciembre de 1852). Alberdi no deja pasar la ofensa de Sarmiento y, apenas unos meses más tarde, utiliza su tiempo de descanso como abogado para componer estos cuatro opúsculos. ${ }^{85}$ La crítica fundamental que desarrollarán apunta a justificar la necesidad de reencauzar la labor del periodismo de los escritores del exilio, que ya pueden retornar al país, alentando una nueva actitud en toda la intelectualidad antes perseguida por Rosas, pero ahora ya en paz, frente al nuevo desafío de conformar la Nación bajo la dirección de Urquiza.

Puntualmente, Alberdi se concentra en defender de manera contundente la gestión de Urquiza frente a una nueva etapa histórica y en acumular pruebas que demuestren que la voz de Sarmiento se encuentra en una situación de "imposibilidad literaria" en la nueva realidad socio-política del país. Entre tanto, Alberdi ha sido nombrado Encargado de Negocios de la Confederación Argentina en Chile y habla desde el pedestal que le han construido las Bases (obra reconocida como el fundamento

\footnotetext{
${ }^{83}$ Ibidem, p. 305.

${ }^{84}$ Esta caracterización de Alberdi pertenece a José Amícola (Amícola, 2007, p. 162).

${ }^{85}$ Además, una pieza titulada "Carta Quillotana inédita. Noticia de los estudios que no ha hecho y de la educación que no ha recibido el escritor y pedagogo D. Domingo Faustino Sarmiento", que sólo se conoció en sus Escritos Póstumos (XII, pp. 13-36). Alberdi parodia allí pasajes de Recuerdos de Provincia y -lejos del brillo argumentativo de las cartas éditas- se burla de sus aspiraciones frustradas de "ser el Franklin" vernáculo y de sus anhelos de "dividir el poder a la mitad" con Urquiza en la batalla de Caseros (la cita se toma de la edición de Buenos Aires, Imprenta Juan B. Alberdi, 1900). De todas maneras, dada la compleja configuración del archivo privado de Alberdi, se ignora si verdaderamente tuvo, alguna vez, la intención de publicar estas páginas y muchas otras recogidas en los Escritos póstumos (Lois, 2007, pp. 14-16).
} 
jurídico de la Constitución del 53 que, antes de la revolución del 11 de septiembre de 1852, había sido encomiada por Sarmiento y por muchos otros que ahora han pasado a ser sus adversarios); al año siguiente de la publicación de las Quillotanas, aceptará la designación de Encargado de Negocios de la Confederación ante las Cortes de Europa.

Desde su nueva posición Alberdi sostiene que el discurso de Sarmiento ya no es adecuado frente a la nueva realidad de un país que necesita de otro lenguaje y otra literatura porque está en una nueva era, en una nueva etapa que la oratoria sarmientina ya no es capaz de interpretar ni comprender. Lo acusa de actuar como un caudillo que no quiere sujetarse a las reglas de la convivencia social (un "gaucho de la pluma").

Desde la Primera Carta $^{86}$ ya declara que la derrota definitiva de Rosas ha dejado a Sarmiento sin objeto literario. Sostiene que no puede escribir en la paz quien se ha acostumbrado durante años a hacer la guerra con la pluma, a luchar desde sus escritos, a pelear con publicaciones y artículos: "Los que han peleado durante diez o quince años, no saben hacer otra cosa más que pelear" ${ }^{87}$ Lo define como un escritor de combate, que usa su pluma como espada, y para demostrarlo le viene al dedillo la misma dedicatoria de la Campaña, que incluye en su "Advertencia” preliminar.

Describiendo los escritos del sanjuanino como fruto de la "prensa bárbara" (de la "prensa de vandalaje y de desquicio, a pesar de sus colores y sus nombres de civilización") $^{88}$ y caracterizándolo como el "caudillo de la prensa", Alberdi recuperará el binomio sarmientino para invertir la aplicación de los términos, y remedando la operación de Sarmiento en su diario sobre la batalla de Caseros, aplicará contra él la misma desviación referencial que conduce al discurso de la Campaña a la demostración de que Urquiza es un "bárbaro", pero de manera más cuidadosa y calculada, reprimiendo los desbordes pasionales propios de su oponente.

${ }^{86}$ En la Primera de las Cartas quillotanas, después de transcribir en una "Advertencia" la "Dedicatoria" burlesca de Sarmiento, Alberdi desarrolla el siguiente temario (anticipado en un listado inicial): Motivos y tendencias conservadoras de esta publicación. Prensa argentina. La nueva situación reclama nueva prensa. Caracteres de ambas. La prensa de guerra ha concluido su misión liberal. Conatos de restauración. El caudillaje en la prensa.

${ }^{87}$ Alberdi, 1957, p. 19. Más adelante, en la página 24, agrega: "La prensa sudamericana tiene sus caudillos, sus gauchos malos, como los tiene la vida pública en los otros ramos". Respecto de esta cuestión, es interesante destacar que Alberdi trabaja con las mismas ideas de su adversario y con su retórica; toma varias opiniones del propio Sarmiento, quien ha escrito que sus palabras se transforman en balas cuando se dirigen al campo enemigo y llegó a deslizar en Campaña la idea de que la época de Rosas le daba un sentido a su vida.

${ }^{88}$ Ibidem, p. 24. 
Alberdi reconoce la producción anterior de Sarmiento como una gran obra al servicio del progreso, como una acción "civilizada", pero considera que ahora el fragor de la lucha lo ha aturdido y que ya no es capaz de dar marcha atrás. Retomará también aquí al propio Sarmiento (que ha expresado que sin Rosas ya no tiene sentido su vida) para que sus palabras funcionen como un boomerang:

Para mí no hay más que una época histórica que me conmueva, afecte e interese, y es la de Rosas. Este será mi estudio único, en adelante, como fue combatirlo mi solo estimulante al trabajo, mi solo sostén en los días malos. Si alguna vez hubiera querido suicidarme, esta sola consideración me hubiera detenido, como a las madres, que se conservan para sus hijos. ${ }^{89}$

Lo acusa, así, de pretender repetir la historia, retrotrayendo la realidad del país a la época de Facundo Quiroga, y lo sitúa permanentemente en contraposición al "hoy", considerado como una nueva situación que desconoce quien se ancla en el pasado. Habla del nuevo rol de la prensa como emisora de paz y de orden constitucional para procurar el respetos de los nuevos intereses de la República. Sostiene que la acción del periodismo de combate es destructiva porque, sublevando al pueblo, lo conduce al caos, a la rebelión. Contrapone esta "vieja prensa de guerra", legado de Rosas, que está acostumbrada a batallar y cuyo terreno favorito es el ataque, con la "nueva prensa de paz" que reclama escritores nuevos e inteligentes.

Dice, además, que Sarmiento se inventa un nuevo Rosas para seguir la lucha y que a cualquiera llama "caudillo". Descalifica la acción de lo que llama "mala prensa", "prensa degenerada y bastarda". ${ }^{90}$ Parodiando las disquisiciones del Facundo, asevera:

En las edades y países de caudillaje, hay caudillos en todos los terrenos. Los tiene la prensa lo mismo que la política. La tiranía, es decir, la violencia está en todos, porque en todos falta el hábito de someterse a la regla. La prensa sudamericana tiene sus caudillos, sus gauchos malos, como los tiene la vida pública en los otros ramos. Y no por ser rivales de los caudillos de sable, dejan de serlo los de pluma. Los semejantes se

${ }^{89}$ Sarmiento, 1997, p. 115.

${ }^{90}$ Alberdi, 1957, p. 20. 
repelen muchas veces por el hecho de serlo. El caudillo de pluma es planta que da el suelo desierto y la ciudad pequeña: producto natural de la América despoblada. ${ }^{91}$

Además de disputar con Sarmiento, Alberdi defenderá en esta carta el rol social del gaucho (aspecto que debe haber incrementado la empatía de Hernández con estos escritos): "El día que creáis lícito destruir, suprimir al gaucho porque no piensa como vos, escribís vuestra propia sentencia de exterminio y renováis el sistema de Rosas". ${ }^{92}$ Más adelante reclama por la igualdad social: "Dad garantías al caudillo, respetad al gaucho, si queréis garantías para todos". ${ }^{93}$ Y concluye con un juego de analogías entre gauchos de la prensa y gauchos de los campos: "Si los gauchos en el gobierno son obstáculo para la organización de estos países, ¿los gauchos de la prensa podrán ser auxiliares y agentes de orden y de gobierno regular?" 94

En la Segunda Carta $^{95}$ se refiere en bloque a las últimas publicaciones de la prensa liberal, se centra en un análisis del discurso de la Campaña con el objeto de poner de relieve las estrategias de "autofiguración" puestas al servicio de evidentes objetivos políticos y concluye con un pantallazo crítico sobre los últimos artículos de Sarmiento. Afirma que todos sus escritos son mal intencionados y lo acusa de mantener una "actitud de agitador", que "perjudica la tranquilidad pública". 96 De esta manera Alberdi pretende institucionalizar una nueva función para el publicista: concentrarse en la organización institucional de la patria.

El tratadista que Alberdi es (fuera de toda duda) se esfuerza por mantener la compostura formal cuando se refiere a "la ignorancia" de Sarmiento como un obstáculo para que éste produzca otro tipo de obra que no sea la de un "conspirador de la paz", y la de un ególatra que sólo piensa en su puesto político perdido y en el lugar dentro de la esfera política que cree haber ganado con sus publicaciones. Pero esa descalificación

\footnotetext{
${ }^{91}$ Ibidem, p. 24. El destacado es del autor.

${ }^{92}$ Alberdi, 1957, p. 17.

${ }^{93}$ Ibidem, p. 19.

${ }^{94}$ Ibidem, p. 26.

${ }^{95}$ La Segunda Carta va precedida por este listado: Extravío de la prensa liberal después de la caída de Rosas. Campaña y escritos del señor Sarmiento. Son acusación, no historia; él es parte y no testigo ni juez. Motivos de su oposición personal acreditados por sus obras. Base de su crítica militar. Importación indiscreta de la ciencia francesa en guerra como en política. Esa obra sirve al desorden, distrae la opinión de los asuntos serios y compromete la gloria argentina. Caricatura de la batalla de Caseros. Propaganda de la resistencia anárquica.

${ }^{96}$ Ibidem, p. 30.
} 
intelectual, dirigida a un notable autodidacta que no ha podido disfrutar de formación académica, conlleva uno de esos "golpes bajos" que Sarmiento devolverá en Las ciento y una con un discurso desaforado.

También le interesa defender a Urquiza de los ataques sarmientinos, y en sus reproches reaparecen citas veladas del Facundo (como en el motivo del frac) y recriminaciones por su abandono de las posturas que venían sosteniendo juntos desde 1851:

Hoy que tiene la gloria de haber acabado con Rosas, reunido un Congreso Constituyente, dado a la República Argentina diez puertos accesibles a la Europa e internado en las soledades de nuestro desierto país el frac, las embarcaciones, las banderas, las lenguas vivas y los hombres de la Europa, que son símbolo de la civilización [...]. ${ }^{97}$

Pero particularmente, insiste en destacar en Sarmiento la condición de "agitador" profesional, y a través de un inteligente análisis del discurso de la Campaña, va demostrando que en realidad hay dos campañas ("una ostensible contra Rosas, otra latente contra Urquiza"), ${ }^{98}$ y sobre esa base lo denuncia como un especulador desleal que, al mismo tiempo que edita un boletín oficial de las operaciones militares, va redactando un diario personal que es una refutación de ese boletín.

En la Tercera Carta $^{99}$ le recrimina el tono brutal con que se refiere a antiguos compañeros, a quienes aplica los mismos calificativos que usaba antes contra asesinos probados:

${ }^{97}$ Ibidem, p. 29.

${ }^{98}$ Ibidem, p. 31.

${ }^{99}$ La Tercera Carta va precedida por este listado: Rol de la prensa en la caída de Rosas. Ambiciones impotentes surgidas de su seno. Escritos del señor Sarmiento anteriores al 3 de febrero. "Facundo" escrito conservador, y el proceso de las ideas exaltadas. Los caudillos son el desierto. La sociedad argentina, su gobierno y política, son expresiones del suelo extenso y despoblado. Fuentes normales de la autoridad. Desconocidas por los unitarios de otro tiempo y por sus imitadores de 1853. Errores de ambos. Rol de las campañas en el gobierno y civilización argentina. Por qué el diarismo no da hombres de estado. Biografías de caudillos. Por qué la prensa contra Rosas era superior a la actual. "Argirópolis", o el asiento y la posibilidad de un Congreso independiente. 
No es posible tolerar que Ud. siga empleando contra hombres iguales a Ud. en amor y en servicios a la civilización el tono y el lenguaje que en diez años se acostumbró a dirigir contra los asesinos de nuestros hermanos y de nuestras libertades. $^{100}$

Subraya también su egocentrismo y la intención política personal de sus escritos; y aunque prevalece la apariencia de objetividad, a veces se cuela la ironía, como en esta pregunta retórica: “ila gloria literaria es antecedente de gobierno en ninguna parte?”101

Valiéndose de una maniobra de desarticulación del oponente que también empleará Hernández en su momento, Alberdi cuestiona indirectamente la efectividad actual de los postulados básicos de Sarmiento:

El Facundo es más oportuno hoy, que en la época de su publicación. Ud. lo escribió contra Rosas, y viene a servir hoy contra Ud. por haberse puesto en oposición a su libro. ${ }^{102}$

Así se sintetiza la estrategia argumentativa de Alberdi, que viene aplicando los términos de la dicotomía sarmientina a su propio autor de manera invertida. Pero, rescata consideraciones del Facundo que, a su juicio, siguen teniendo vigencia (aunque plenamente consciente de que Sarmiento acaba de suprimirlas en un reciente reedición): "también [es] la historia y el proceso de los errores de la civilización argentina representada por el partido unitario". ${ }^{103}$ Tampoco se priva de citar los capítulos cercenados ni de agregar: "el estudio de Facundo se hace hoy del más vivo y palpitante interés", ${ }^{104}$ y se dedica a reproducir a continuación algunos pasajes del texto. ${ }^{105}$

${ }^{100}$ Ibidem, p. 74.

${ }^{101}$ Esa práctica inveterada de la escritura como "arma" por parte de Sarmiento se incrementará entre 1855 y 1858 durante su desempeño como redactor de El Nacional de Buenos Aires, encabezando desde allí una serie de exabruptos de violencia verbal que le valdrán innumerables y desgastantes polémicas que se analizarán más adelante.

${ }_{102}$ Ibidem, p. 79.

${ }^{103}$ Se retoma este tema en 2.2.2.

${ }^{104}$ Ibidem, p. 81.

${ }^{105}$ Sylvia Molloy destaca cómo Alberdi se esfuerza por señalar las falsedades históricas que introduce Sarmiento en su texto, no sólo sobre su propio enemigo -los gauchos y los caudillos-, sino también sobre sí mismo, vertidas en textos híbridos que encubren -como bien percibe Alberdi- procesos de autoconfiguración (Molloy, 1999, capítulo VIII "La autobiografía como historia: una estatua para la posteridad"). 
En su ya iniciada reconsideración de la imagen del gaucho y del caudillo, agrega:

[el Facundo] es la política del partido liberal exaltado, que desconociendo lo que había de normal en el hecho del caudillaje, quiso suprimirlo de un golpe, ya sancionando bruscamente las instituciones más adelantadas de la Europa del siglo XIX, ya fusilando o suprimiendo a los caudillos. Delante del poder irresponsable, se alzó la libertad omnímoda, y se quiso remediar el despotismo del atraso con el despotismo del progreso: la violencia con la violencia. ${ }^{106}$

Resulta evidente que Hernández retoma estos conceptos alberdianos en sus Rasgos biográficos del General D. Angel V. Peñaloza.

En la Cuarta Carta $^{107}$ vuelve a insistir en su ataque al egocentrismo de Sarmiento y se concentra en su autodefensa retornando a las acusaciones dirigidas a su persona en la dedicatoria de la Campaña en el Ejército Grande. Procurando mantener la apariencia de objetividad que se ha esmerado en construir a lo largo de estas páginas, emprende un análisis de su propia obra, en el que a la par que destaca los aportes conceptuales, opone su discurso sereno a la pasión desbordada de los últimos escritos sarmientinos, para concluir con una reflexión implacable:

La sensibilidad no resolverá el problema de nuestro atraso. El entusiasmo nos llevará a la muerte, nos dará la vanagloria, laureles fratricidas y odiosos, pero no nos sacará del desierto y de la barbarie. ${ }^{108}$

El folleto con las Quillotanas se publica en marzo de 1853 y entre abril y marzo Sarmiento ya está respondiendo con las cinco cartas de Las ciento y una, un arsenal

\footnotetext{
${ }^{106}$ Alberdi, 1857, p. 90.

${ }^{107}$ La Cuarta Carta va precedida por este listado: De la personalidad que interesa a las ideas. Del yo en política. Ataques contestados, sobre pacto de abstención, sobre cambios de propósitos. Pretendidas provocaciones. Posición semioficial. Comparación con Girardin. Empleo culpable del sentimiento en materias que exigen calma. Ganancias de los exaltados y pérdida de los calculadores. Los exaltados no tienen ideas fijas sobre forma de gobierno. Nuevos amigos de Buenos Aires y sus pruebas. Insultos contestados. Desacuerdos consigo, llamados desacuerdos con otros. Política atacada y después recogida. Si "Argirópolis" es copia o es original. Ideas viejas sobre libertad de los ríos, inmigración, ferrocarriles, abolición de aduanas interiores, política exterior, etc.

${ }^{108}$ Ibidem, p. 119.
} 
antológico de retórica de la injuria que no le resultará provechoso. Los golpes bajos disfrazados de análisis crítico y objetivo del Dr. Alberdi pegaron donde más dolía y su reacción es desenfrenada: se concentrará en defenderse de la impugnación intelectual por su falta de formación académica retomando con mayor virulencia las imputaciones de cobardía de su "Dedicatoria" (reitera que Alberdi dicta cátedra cuando hay que poner el cuerpo) y devolverá la acusación de lanzarse ostensiblemente en busca de cargos públicos sosteniendo que su adversario los consigue mediante maniobras solapadas.

Alberdi, cultivando la misma compostura discursiva de las Cartas quillotanas, responde con la publicación de Complicidad de la prensa en las guerras civiles de la República Argentina. Insiste en sus críticas a la prensa exaltada y belicosa, pero también exhibe conceptualizaciones: intenta extender lo que llama la "política práctica", que consiste en la aceptación de la realidad nacional tal cual se la había encontrado luego de Caseros. Propone como medida urgente el dictado de una constitución en términos de una política moderada que facilite la integración del caudillaje del interior como una verdad innegable del país.

Esta actitud de moderación que se reclama en relación con la realidad política propone un cambio radical en el enfoque literario, un giro conceptual respecto del lugar del letrado, ${ }^{109}$ que la Generación del 37 concebía expresamente en términos de impugnador de la tiranía. La lucha cívica planteada por la Asociación de Mayo había llegado, para Alberdi, a su fin. Rosas había sido depuesto y ahora correspondía a los escritores la conformación de la Nación, de sus instituciones, leyes y educación. Alberdi elogia los antiguos trabajos de Sarmiento que seguían esta línea, pero recrimina su nueva actitud hostil hacia Urquiza como un retroceso innecesario, sin fundamento, y como consecuencia de aspiraciones políticas frustradas. Y como se ha dicho, define a Sarmiento como "caudillo de la prensa bárbara", invirtiendo los términos de su ideologema dicotómico y demostrando el anacronismo de aplicar el discurso del Facundo a Urquiza.

Finalmente, no sólo la sociedad chilena consideró a Alberdi como el notorio vencedor de la polémica, las simpatías políticas de las provincias argentinas

${ }^{109}$ Había escrito en la Primera carta: "Por fin ha concluido la guerra por la caída del tirano Rosas, y la política ha dejado de pedir a la prensa una polémica que ya no tiene objeto. Hoy le pide la paz, la Constitución, la verdad práctica de lo que antes era una esperanza. Eso pide al publicista, al ciudadano, al escritor" (ibidem, p. 15). 
confederadas lo elegirán como su indiscutible mentor. Sin duda, esta polémica representa uno de las cumbres de la literatura política hispanoamericana del siglo XIX, pero tanto la recepción contemporánea como la posterior tendió a reducirla a dos piezas: las Cartas quillotanas y Las ciento y una; sin embargo, los momentos culminantes están representados por los intentos de dar cuenta de una coyuntura histórica precisa y por las propuestas programáticas consiguientes, y esos momentos están representados por la Campaña en el Ejército Grande y las Cartas quillotanas.

\subsubsection{Persistencia de la polémica en la política nacional}

La generación de proscriptos o exiliados constituye una de las primeras identificaciones conscientes de la intelectualidad nacional que busca distanciarse y deslegitimar la cultura y la política oficiales. Se sienten confortados en la creencia de integrar un grupo de pensadores: los que vigilan los sucesos patrios desde afuera, desde donde pretenden tener una mejor apreciación de los acontecimientos; así, se autoconsideran los "vates" de la República.

Echeverría, Alberdi, Mármol, Sarmiento, entre otros, pretenden instituirse como los únicos conocedores de la realidad nacional desde el extranjero, publicando desde afuera los escritos que se leerán clandestinamente en Buenos Aires, en los que procuran explicar y combatir la crisis institucional y cultural del país dominado por el poder del caudillo Rosas.

Sin embargo, bajo este rótulo de "proscriptos" se ampararon distintas corrientes que luego de Caseros comienzan a divergir. La mayor parte de los desterrados reconsideró los modelos de civilización después de Caseros, dando lugar a separaciones y enfrentamientos contundentes, como la disputa que se ha analizado. Pero la polémica continuó durante toda la vida de Sarmiento y Alberdi explícita e implícitamente, y también como subtexto de enfrentamientos entre terceros.

Alberdi se alejará de Sudamérica para cumplir misiones diplomáticas como representante de la Confederación Argentina ante las cortes europeas. Más tarde, una vez elegido Derqui presidente, Alberdi renuncia a su cargo, pero en lugar de regresar al país, se mantendrá autoexiliado por juzgar que no están dadas las condiciones necesarias para retornar a la patria. Con esta decisión, Alberdi define su vida de permanente proscripto, pues recién en 1879 volverá fugazmente a la Argentina. 
Se suceden las presidencias de Mitre (1862-1868) y Sarmiento (1868-1874), dos figuras y posiciones políticas que no congenian con el tucumano. Alberdi alega entonces que aún no hay garantías individuales para quien quiere expresarse con entera libertad. Considera que estar en el país es acallar la voz, es silenciar la palabra de sus escritos, que se manifestarán en contra de la guerra del Paraguay con numerosas disidencias. El exilio le permite no solo hablar, sino vaticinar sobre el futuro nacional, y con los escritos se asegura su presencia en la escena política.

Desde el exterior, Alberdi permanece atento a las cuestiones riojanas y considera particularmente los sucesos en los que se ve envuelto el Chacho Peñaloza, a quien se refiere en alguna oportunidad como "ese bravo patriota". Mientras Alberdi opinaba que "el mitrismo es el rosismo cambiado de traje", ${ }^{110}$ los Varela lo descalificaban como "defensor de los caudillos" y le cuestionaban sus amistades con antiguos rosistas. ${ }^{111}$ En La Nación Argentina y La Tribuna lo acusan de ser "representante nato del elemento bárbaro que [...] se muestra fiel a las tradiciones de la Confederación de Derqui y del Chacho", ${ }^{112}$ en tanto que los Varela lo catalogarán como representante de la reacción, del caudillismo. ${ }^{113} \mathrm{Y}$ es justamente el ataque sostenido que llevan adelante los principales diarios porteños lo que dificulta todas las gestiones emprendidas para que se le pagasen los sueldos adeudados por sus gestiones diplomáticas ${ }^{114}$ y para lograr que el ex funcionario autoexiliado regresase a Buenos Aires.

De todas maneras, el mayor conflicto entre Alberdi y el gobierno de Mitre se desata cuando éste declara la guerra al Paraguay. ${ }^{115}$ Además de la producción en contra de esta guerra que Alberdi va publicando durante los años en que se extiende el conflicto, también se debe considerar su obra, conocida póstumamente, El crimen de la guerra -aunque haya sido escrita con la intención de competir en un concurso

${ }^{110}$ Alberdi, 1895-1901, XI, p. 437, p. 490.

${ }^{111}$ La Tribuna, Buenos Aires, 6, 14 y 15 de marzo, 24 de abril de 1862.

${ }^{112}$ La Nación Argentina, Buenos Aires, 3 y 6 de octubre de 1865.

${ }^{113}$ La Tribuna, Buenos Aires 5 de octubre de 1865.

${ }^{114} \mathrm{Su}$ enemistad con el gobierno de Mitre se acentúa cuando éste decide por decreto la suspensión inmediata de su cargo como ministro argentino ante las Cortes de Europa (Mayer, 1963, pp. 646-650).

${ }^{115}$ En el "Estudio preliminar" de su edición de El crimen de la guerra, Lois enumera todos los textos de Alberdi vinculados con sus opiniones sobre la guerra, sobre los intereses de Argentina y del imperio brasileño, sobre el efecto de la guerra en las democracias americanas y otros temas conexos (Lois, 2007, p. 34). Entre otros: Las disensiones de las repúblicas del Plata y las maquinaciones del Brasil (1865), Los intereses argentinos en la guerra del Paraguay con el Brasil (1865), El imperio del Brasil ante las democracias de América (1866), etc. 
organizado por la Ligue internationale et permanente de la Paix- "también pesan en sus disquisiciones las experiencias bélicas sudamericanas (particularmente la contienda más cercana -la guerra de la Triple Alianza contra el Paraguay- en la que Alberdi se ha involucrado ampliamente con la pluma)". ${ }^{116}$ Hasta en ese comienzo (redactado en 1869) en el que Alberdi pretendía escribir para el mundo y consolidar una postura radical en la concepción del derecho internacional (la negativa a reconocer la existencia de un "derecho de la guerra" aunque estuviese encaminado a morigerar sus calamidades, por considerar que su sola enunciación era un oxímoron), la coincidencia con algunas secuencias de sus escritos recientes contra la Guerra del Paraguay permite percibir ecos anímicos de la contienda que desangra al Plata:

Estos actos [el derecho al homicidio, del robo, del incendio] son crímenes por las leyes de todas las naciones del mundo. La guerra los sanciona y convierte en actos honestos y legítimos, viniendo a ser, en realidad, la guerra el derecho del crimen, contrasentido espantoso y sacrílego, que es un sarcasmo contra la civilización. Esto se explica por la historia. El derecho de gentes que practicamos, es romano de origen como nuestra raza y nuestra civilización. El derecho de gentes romano, era el derecho del pueblo romano para el extranjero. Y como el extranjero para el romano, era sinónimo del bárbaro y del enemigo, todo su derecho externo era equivalente al derecho de la guerra. $^{117}$

Por eso no es casual que, unos parágrafos más abajo una asociación ocasional lo lleve a escribir "La guerra o el cesarismo en el Nuevo Mundo", ${ }^{118}$ si bien luego lo consideró un apartamiento del tema y eso lo obligó a escribir al margen que esa sección debería ser publicada como un folleto aparte. ${ }^{119}$ Tampoco es casual que la cuestión de la Guerra de la Triple Alianza lo conduzca a cuestionar una de las principales tesis de la obra (la constitución de una Asociación de Naciones) al detenerse en discurrir acerca de la tentación de los países poderosos a aliarse en contra de los más débiles. Y es

\footnotetext{
${ }^{116}$ Lois, 2007, p. 24.

${ }^{117}$ Alberdi, 2007, p. 73.

${ }^{118}$ Alberdi, 2007, pp. 121-141.

${ }^{119}$ Lois, 2007, pp. 35-41.
} 
sintomático que en este punto se interrumpan los borradores de un ensayo que su autor jamás consideró "listo para ser publicado". 120

El vínculo conflictivo con Sarmiento y Mitre no tendrá nunca solución y finalmente en sus autobiografías (redactadas entre 1869 y 1874) ${ }^{121}$ Alberdi se representará a sí mismo como la "cultura" y la "civilización” en permanente exilio, a su archienemigo Sarmiento como el "bárbaro" usurpador del gobierno y a ambos adversarios, por su permanencia en el manejo de los hilos del poder, como los principales impedimentos para su regreso al país.

\subsubsection{Otros ecos de la polémica: las autobiografías de Alberdi}

A lo largo del siglo XIX, en tanto la Argentina se independiza e intenta construir y afianzar una identidad nacional, las biografías se instalan como un género funcional al propósito de definir los prototipos del país. El Facundo fue el predecesor del modelo bárbaro. ${ }^{122}$ Luego circulan las vidas de los hombres que constituyen ejemplos para la sociedad -entre las que se inscriben las de Horace Mann y la de Abraham Lincoln escritas por el propio Sarmiento como "biografías de la civilización”-;i23 pero el género conoce un punto de inflexión en la historiografía que construye héroes (las de Belgrano y de San Martín que escribe Mitre son ejemplos paradigmáticos); las biografías de los próceres argentinos son las biografías de la Patria, pues hay que refundar la nación y es necesario imponer modelos que encarnen ideales aglutinantes.

Pero además de la práctica del género creador de los mitos fundantes de la identidad nacional, se ha venido registrando desde la época de las luchas por la Independencia la consecuente preocupación de muchos hombres públicos -tanto militares como políticos- por escribir sus memorias y sus autobiografías. ${ }^{124}$ Como la

${ }^{120}$ Lois, 2007, pp. 45-51.

${ }^{121}$ Se conservan en la Biblioteca Furt los manuscritos de dos textos autobiográficos inéditos fechados en 1869 (Lois, 2010, pp. 15-18).

${ }^{122}$ Ver Altamirano y Sarlo, 1982.

123 Aunque para escribir su contribución a este género Alberdi no haya elegido una vida ejemplar con el objeto de polemizar con los modelos de Sarmiento, es sintomático que su elección haya recaído en William Wheelwright (Alberdi, 1876), un businessman que jugó un papel esencial en el desarrollo del barco a vapor y en la construcción de ferrocarriles en varios países de Sudamérica.

${ }^{124}$ El discurso autobiográfico está ligado indisolublemente a su contexto de situación. Philippe Lejeune (1975) introdujo el concepto de "pacto autobiográfico" para definir el género de la autobiografía sobre la base de un "contrato de lectura" entre autor y lector (un pacto según el 
joven nación necesita de personalidades que funcionen como modelos para la sociedad, con ese desafío proliferan los relatos orientados hacia la "autolegitimación"; se trata tanto de exhibir el patriotismo individual o de registrar actos de arrojo o de contribución al bienestar general como de apuntar hacia objetivos específicos (como el de candidatearse para la presidencia de la nación), pero también emergen numerosos cultores de un subgénero autobiográfico que responde a la necesidad de justificar actuaciones públicas o defenderse de acusaciones: la "autodefensa". ${ }^{125}$

Entre 1869 y 1874 (más de quince años después de "la gran polémica nacional"), autoexiliado en Francia y acusado de "traición a la patria" en los más importantes diarios porteños por su oposición a la Guerra de la Triple Alianza contra el Paraguay, el discurso de Alberdi empezó a ser dominado por la práctica de ese tipo de escritura del yo que tanto había censurado en la producción de su enconado adversario (que había inaugurado brillantemente con $M i$ defensa un subgénero autobiográfico en Sudamérica). ${ }^{126}$ Ese proceso escritural arranca de la irrupción esporádica del yo en el análisis político y continúa en dos autodefensas inéditas (borradores de una respuesta a la acusación de "traidor a la Patria" que la prensa porteña reactiva en 1872). ${ }^{127} \mathrm{Se}$ demora luego en la elaboración de dos textos que constituyen canónicas autobiografías decimonónicas, es decir, una historia de la formación intelectual que fundamenta la idoneidad de un hombre de Estado (aunque en el caso de Alberdi haya un subtexto que las transforme en "autodefensas encubiertas"). ${ }^{128}$ En otra coyuntura política, esa

cual el lector decide aceptar la identidad real entre el autor, el narrador y el personaje, y por lo tanto, a considerar como verdadero lo que el texto expone). No obstante, desde entonces ha venido reformulando su teoría a medida que ensanchaba el corpus de análisis $(1996,2005)$. Finalmente, habiéndose dedicado desde los 90 al estudio de procesos escriturales autobiográficos (Lejeune, 1992, 1998; Lejeune y Viollet, 2001), los enfoque geneticistas se proyectaron en una diversificación y complejización de sus planteamientos teóricos.

${ }^{125}$ La extensa bibliografía sobre el género autobiográfico en Argentina conoce una línea reflexiva que tiene una pieza inaugural: Prieto, 1962. Particularmente en relación con los autores estudiados, citamos algunos trabajos de las dos últimas décadas: Rodríguez Pérsico, 1993; Molloy, 1996; Amícola, 2007; Lois, 2010.

${ }^{126}$ Entre otras manifestaciones del mismo tenor, Alberdi censura el gesto autopropagandístico de Recuerdos de Provincia en la tercera de sus Cartas quillotanas: “¿Cómo va a escribir un texto sobre su persona con la alevosa intención de utilizarlo como campaña política?" (Alberdi, 1957).

${ }^{127}$ Se trata de Para la Autobiografía y Simple carta en que su autor esplica a sus deudos y amigos los motivos que lo mantienen lejos de su país. Este itinerario escritural y su intertexto fueron documentados por Lois, 2010, pp. 15-19.

${ }^{128}$ Las dos piezas de este género que escribió Alberdi sólo se conocieron póstumamente: Memoria sobre mi vida y mis escritos (Alberdi, 1895-1901, XV, pp. 239-259) y Mi vida 
orientación escritural se proyectará en Palabras de un ausente en que explica a sus amigos del Plata los motivos de su alejamiento, ${ }^{129}$ un libelo autodefensivo donde los ecos de la polémica de 1853 son tan intensos que terminan asumiendo la forma de la "autocita". 130

En el final de de la gestión presidencial de Sarmiento, Alberdi reconsidera una vez más la posibilidad de regresar a la Argentina, ${ }^{131}$ pero debe repensar su lugar de hombre de Estado, pues - a pesar de haber vivido pendiente de la vida política y cultural sudamericana- han pasado más de treinta años desde que abandonara su suelo. Quiere hablar sobre su vida en una etapa de revisión de posiciones políticas; necesita explicar su situación para satisfacer tanto a un público que lo apoya desde hace muchos años como a quienes se han sumado al reclamo de su regreso. Después de que los tratados del barón de Cotegipe con el Paraguay humillaron a la Argentina, el cuestionamiento de la Guerra de la Triple Alianza, que durante la contienda había sido dominante en las provincias confederadas pero no en Buenos Aires, renace y se revitaliza, y con él, la adhesión a las tesis alberdianas. ${ }^{132}$ Pero muy particularmente, Alberdi debe responder a quienes lo acusan de "ajenidad" a causa de su larga ausencia.

Imbuido de la corriente romántica que marcó su juventud, Alberdi había salido del país como el peregrino Harold de Lord Byron, y cuando regresa de su primer viaje a Europa, se desgarra frente a las costas patrias. Pero al pasar los años, este sentimiento se transforma en relación con su desempeño en la función pública, y dejará a un lado la efusividad sentimental de cuño literario para preocuparse por legitimar su postura de

privada, que se pasa toda en la República Argentina (Alberdi, 1895-1901, VII, pp. 439-473). El título de la segunda está respondiendo implícitamente a las acusaciones de ajenidad que le dirigen algunos connacionales al cabo de su prolongada ausencia del país, pero el texto se centra en el proceso formativo de un estadista.

${ }^{129}$ Alberdi, 1874.

${ }^{130}$ Por otra parte, también enlaza las escrituras del yo de Alberdi con la tradición de las Quillotanas la presencia de marcadores formales del subgénero "carta abierta", lo que se observa desde el título del primer texto autobiográfico de Alberdi que ha podido ser documentado (Simple carta en que su autor esplica a sus deudos y amigos los motivos que lo mantienen lejos de su país) hasta el que parece ser el último, además de ser el único que publicó durante su vida (Palabras de un ausente en que explica a sus amigos del Plata los motivos de su alejamiento).

${ }^{131}$ A partir del momento en que cesan sus funciones diplomáticas (aunque había presentado su renuncia durante 1860, el decreto de cesación fue dictado por Mitre en 1862), el tema del regreso se vuelve recurrente en su correspondencia privada (Ricardo Rodríguez, 2004). Pero esa determinación se complica por la permanencia en el poder de sus principales adversarios políticos: Mitre y Sarmiento.

${ }^{132}$ Mayer, 1963, pp. 787-790. 
hombre político e intelectual. A diferencia de Sarmiento, que utiliza el discurso autobiográfico para defenderse de ataques públicos en los inicios de su carrera política, Alberdi los encara en sus últimos años, cuando a pesar de ser reconocido como un legislador e intérprete de la Nación ${ }^{133}$ se siente impelido a "rendir cuentas" ante sus compatriotas; por otra parte, a diferencia de su adversario (un autopropagandista inveterado), no se propone como actor político sino antes bien como mentor ideológico. En este contexto de situación, el "yo romántico" dará paso al "yo autodefensivo" y a la construcción de un personaje: "el gran pensador de la Nación”. Así, el concepto bajtiniano de encomion (forma de defensa que se manifiesta como un informe apologético público) guía la escritura de los textos autobiográficos alberdianos. ${ }^{134}$

\subsubsection{Palabras de un ausente en que explica a sus amigos del Plata los motivos de su alejamiento (1874)}

Las únicas páginas autobiográficas que Alberdi publicó en vida (Palabras de un ausente), como las que sólo se conocieron póstumamente y las que aún permanecen inéditas, pueden leerse como una sola obra: las escrituras del yo del último Alberdi (el que se autoexilia después de la batalla de Pavón y regresa fugazmente a Buenos Aires en 1879 para alejarse definitivamente dos años después).

Si se toma en cuenta que la "gran polémica nacional" estalla a partir de la elección política divergente que hace cada uno de los polemistas a partir del 11 de septiembre de 1852 (una opción entre la consolidación del predominio políticoeconómico de Buenos Aires y la defensa del federalismo que emprenden las provincias), siempre podrá percibirse en todo planteo que se asocie a esa "contradicción fundamental" un eco de la célebre confrontación textual. Así, las numerosas polémicas que se entablan entre las obras que Alberdi va publicando a partir de 1853 y otros textos de Sarmiento y de Mitre, ${ }^{135}$ más los debates en los que intervienen quienes acusan a Alberdi y quienes lo defienden (enfrentamientos que arreciaron durante la Guerra del Paraguay pero que ya se habían venido produciendo sobre temas puntuales y

\footnotetext{
${ }^{133}$ Terán (1996) lo llama "el redactor de la Ley".

${ }^{134}$ Mijaíl Bajtín analiza en esos términos la autobiografía clásica y deduce, a partir de esa condición, que las manifestaciones autobiográficas primigenias ostentan un carácter normativopedagógico (Bajtín, 1986, pp. 329-330).

${ }^{135}$ Estas críticas y ataques se canalizaron, particularmente, por medio del periodismo (y más aún en el de Mitre).
} 
continuaron una vez concluida la contienda) ${ }^{136}$ pueden considerarse como parte de una red de debates interconectados. En medio de esa interconexión -a veces arborescente, a veces rizomática- la polémica entre Sarmiento y Alberdi sobresale como la pieza más brillante; por consiguiente, siempre se podrá distinguir entre entroncamientos más estrechos (como el que establece Palabras de un ausente) o indirectamente ligados, como el de las otras manifestaciones de los discursos del yo de Alberdi.

En enero de 1874 concluyó el folleto titulado Palabras de un ausente en que explica a sus amigos del Plata los motivos de su alejamiento, que pocos meses después circula ampliamente entre sus compatriotas. ${ }^{137}$ Adriana Rodríguez Pérsico señala el propósito del texto:

[...] apunta a tres objetivos simultáneos: justificar la ausencia del país, consensuar el sistema de ideas y defenestrar al enemigo. El texto habla de ausencias y de presencias de cuerpos e ideas. En esta alternancia debate el concepto de patriota o su sinónimo argentino y busca delimitar los espacios que le pertenecen puesto que sólo el patriota puede realizar la civilización. Alberdi se coloca en el campo del adversario cuando redefine la civilización borrando el significado de educación que le había otorgado Sarmiento y sustituyéndolo por el de libertad o seguridad personal. ${ }^{138}$

Hace muchos años que no está en el país, y Alberdi debe reavivar la memoria de los porteños recordándoles que él perteneció a su sociedad y que se formó en ella (el texto subraya que a Buenos Aires le debe su formación intelectual, que allí vivió su juventud y comenzó a difundir su obra). Rememora que partió al exilio en busca de la libertad de opinión durante la dictadura de Rosas, pero destaca que su larga ausencia ha cambiado de motivos: además de haber estado representando al país ante las cortes europeas en misiones que destaca, una vez más considera que no están dadas las condiciones para el regreso: sabiéndose objeto de odios enconados, teme por su integridad personal e insiste en el concepto de que no hay libertad si no existen las condiciones de seguridad necesarias para la vida y para la expresión del pensamiento,

\footnotetext{
${ }^{136}$ Mayer, 1963, pp. 597-807.

${ }^{137}$ Ibidem, 1963, pp. 804-807. No obstante, Mayer no deja de destacar que -aunque se han mitigado las acusaciones de antiporteñismo que la sociedad de Buenos Aires enrostraba a Alberdi- el libro todavía despierta algunas polémicas allí.

${ }^{138}$ Rodríguez Pérsico, 1993, p. 149.
} 
que condensa en una cita de Montesquieu que incluye en una nota al pie en el primer apartado del folleto y luego reitera en el texto: "La liberté politique est cette tranquillité de l'esprit qui provient de l'opinion que chacun a de sa sûreté".

Así, además de resumir su programática para la situación actual (que se expresa en su propuesta de una real integración de las provincias bajo un auténtico "gobierno nacional" que no identifique los intereses del país con los de una sola provincia), ${ }^{139}$ por medio de la enumeración de su labor de constructor del Estado desarrollada a lo largo de una obra copiosa y significativa, aspira a demostrar que, verdaderamente, su vida privada "se pasa toda en la República Argentina". ${ }^{140}$ Pero esa temática no soslaya la mención de los ataques que ha recibido por sostener posiciones divergentes de las del gobierno de turno y le permite relacionar el poder de Rosas con el de quienes volvieron a ejercer dominio sobre el país entero defendiendo los intereses de la ciudad-puerto y postergando una definitiva organización de la nación.

Pero cuando se detiene en las causas que lo mantuvieron alejado de la patria, se remonta a su enfrentamiento con Sarmiento y retoma casi paso a paso la antigua polémica de las Quillotanas (casi la mitad del texto se conecta con este enfrentamiento). Alberdi intenta reponer un orden de cosas que remita al lector al periodo inmediatamente posterior a Caseros. En apartados como "Civilización y barbarie", "Barbarie letrada", "Lo que era Facundo Quiroga" o "Influjo de la biografía en el biógrafo", Alberdi vuelve a sostener la posición que esgrimió veinte años atrás para relacionarla con la situación del presente de la enunciación (el final de la presidencia de Sarmiento) y poder acusarlo ahora por haber llevado la barbarie al gobierno así como antes lo vituperaba por ejercerla en el periodismo.

Con esta vuelta atrás, Alberdi intenta explicar, justificar y acortar su larga ausencia, acusando nuevamente a Sarmiento de ser el "bárbaro" que lo hostiga por su independencia de juicio. Alberdi quiere establecer con sus lectores una comunicación más íntima que la que instalaba su obra de jurista y de pensador político, intenta captar las simpatías de un público receptor entre quienes se encuentran -como bien le señala Gregorio Benites en su correspondencia- muchos jóvenes que sólo han podido

\footnotetext{
${ }^{139}$ Esa programática política había sido anticipada por numerosos ensayos.

${ }^{140}$ Como se ha dicho, el título de uno de sus textos autobiográficos es Mi vida privada, que se pasa toda en la República Argentina, una caracterización en la que el adjetivo "toda" destaca que su país ha estado siempre en el centro de sus intereses.
} 
conocerlo leyendo sus escritos. No obstante, aunque la actitud defensiva que prevalece en Palabras de un ausente no puede soslayar la identificación de los impugnadores más poderosos y la búsqueda de complicidad con el lector, Alberdi retoma a veces esa apariencia de ecuanimidad (sin duda, esforzada) de las Cartas Quillotanas, que tanto contribuyó a convertirlo en el "vencedor intelectual" durante la famosa polémica con Sarmiento. Vuelve a comentar que no ataca la persona de Sarmiento sino sus escritos, o ubica a Mitre en la línea genealógica de Rosas sin nombrarlo. ${ }^{141}$

La observación de Patricio Fontana y Claudia Román acerca de cómo el confinamiento del exilio impulsa a los intelectuales a volcarse a la escritura como modo de acercarse al escenario nacional se aplica plenamente al caso de Alberdi, cuyo itinerario -que comienza en Montevideo, prosigue con su primer viaje a Europa, su instalación en Chile, su segundo viaje y su posterior establecimiento en Francia (quebrado por un fugaz regreso a la patria) - va siendo jalonado por una copiosa e ininterrumpida producción de textos que versan sobre una realidad nacional de la que no participa personalmente. ${ }^{142}$

\subsubsection{Palabras de un ausente en la correspondencia entre Alberdi y Gregorio Benites (1872-1877) $)^{143}$}

Hace años que los estudiosos se preguntan cómo pudo este estadista-escritor analizar con notable agudeza una problemática nacional observándola a la distancia durante más de 40 años (de los cuales, más de 25 transcurrieron en Francia). Nos acerca respuestas el archivo documental conservado en la Biblioteca Furt; ${ }^{144}$ este material ofrece pistas valiosísimas para penetrar en el acopio de documentación de una obra monumental. En el epistolario, Alberdi dialoga con voces diferentes y comenta o debate con ellas las informaciones periodísticas y documentales que recibe, ya que a menudo las cartas iban acompañadas de recortes periodísticos o escritos de terceros. Paralelamente, es miembro activo de la Sociedad de los Economistas de París, de la Academia de Historia de Madrid y de la Sociedad Geográfica de Berlín, y desde el

\footnotetext{
${ }^{141}$ Alberdi, 1874, pp. 22-23.

${ }^{142}$ Fontana y Román, pp. 53-96.

${ }^{143}$ Alberdi y Benites, 2007. Hasta ese año, ese valioso repositorio documental (que se extiende desde 1863 hasta 1883) había permanecido inédito.

${ }^{144}$ Se encuentra en la estancia histórica "Los Talas" (Luján, Provincia de Buenos Aires) y es patrocinado por la Universidad Nacional de San Martín.
} 
centro del poder político y cultural, mira incesantemente hacia la periferia y está pendiente de ella. Así, en el Archivo, se va delineando un laberinto de vasos comunicantes entre informaciones y perspectivas múltiples, y también una red de tensiones. $^{145}$

Cuando se encara la reconstrucción y análisis de procesos de textualización en el interior de un nutrido archivo documental, es posible enriquecer el conocimiento de la producción intelectual del autor aportando datos desconocidos, no sólo con respecto a cada una de las obras estudiadas sino con respecto a la red intertextual de la que esas obras forman parte y con respecto al contexto de situación con el que interactúan, tanto en el momento de su producción como durante su posterior circulación pública. En el Archivo Alberdi de la Biblioteca Furt, en el Archivo General de la Nación y en la Biblioteca Nacional de Asunción del Paraguay se conservan 830 piezas epistolares intercambiadas por Alberdi y el diplomático paraguayo Gregorio Benites a lo largo de dos décadas; aquí nos limitaremos al análisis del sector de ese corpus que se interconecta con el tema analizado: cartas enviadas a Alberdi por Benites entre 1872 y 1877.

El vínculo epistolar se había sido iniciado en vísperas del estallido de la Guerra del Paraguay por el entonces muy joven diplomático -admirador confeso del estadista argentino, que como él se encuentra en París-, se incrementa a lo largo de la contienda (durante la cual Alberdi se hace cargo de una auténtica paideia diplomática que Benites siempre agradecerá), recorre los avatares de la vida política posterior de ambos durante algo más de una década y concluye con una misiva de 1883 enviada a un Alberdi muy enfermo que ya no está en condiciones de responder.

A lo largo de 1872, Gregorio Benites -que había vuelto a su país al cabo de la contienda, pero ahora acaba de ser designado encargado de negocios del Paraguay ante las cortes europeas- se encuentra en Buenos Aires efectuando negociaciones previas a su retorno a Europa. Desde allí se sumará al conjunto de informantes epistolares acerca de la vida política y social del Plata con que cuenta Alberdi; ${ }^{146}$ pero son sus cartas las que más se conectan con el universo del discurso de las autobiografías del último Alberdi. Como los restantes corresponsales rioplatenses, le irá comunicando las

\footnotetext{
${ }^{145}$ Lois, $2011 \mathrm{~b}$.

${ }^{146}$ Ricardo Rodríguez, 2004.
} 
opiniones que despierta la mención de su nombre en el círculo porteño y las expectativas que genera su retorno.

Durante esa estadía en Buenos Aires, el paraguayo oficia de portavoz de las diferentes razones que se esgrimen para reclamar el inmediato retorno de Alberdi al país. Va tomando nota de todos los hombres que preguntan por él, de los diarios que sacan noticias suyas, de las ofertas políticas que se barajan, de la actitud de su provincia natal (los tucumanos desean que él los represente en el Congreso Nacional), y también de los comentarios críticos y de los rumores acerca de amenazas proferidas por el propio presidente Sarmiento. También se esmera en incluir a paraguayos y orientales en los reclamos del regreso de un autor que siempre habló de "la sociedad, los hombres y las cosas de Sudamérica". ${ }^{147}$ De este modo Benites le hace llegar voces (tanto de sus partidarios como de sus detractores) que Alberdi proyectará en la redacción de su folleto a medida que va autofigurándose como el "ausente" al que hay que hacer volver porque su presencia es necesaria para el bien de la patria. Alberdi puede rastrear en las noticias que le hace llegar Benites su propia imagen a través de la mirada de otros y volcarlas en su discurso autobiográfico del período 1872-1874, en donde intenta responder tanto a los requerimientos de quienes reclaman su presencia como a las críticas de sus adversarios. $^{148}$

Con su prolongada ausencia, Alberdi corría el riesgo de caer en el olvido o de ser visto como desafecto a su tierra o de conocerla mal, enturbiada su visión por la distancia (además no faltan comentarios en esa línea, que incluso volverán a repetirse después de la publicación de Palabras de un ausente). Pero las cartas de Benites parecen querer despejar esas tres amenazas que se ciernen sobre su figura política y literaria asegurándole la popularidad de su persona y la apreciación del patriotismo indiscutible de su proceder y de la idoneidad de sus escritos.

\footnotetext{
${ }^{147}$ Ese sintagma se lee en los títulos de varios ensayos incluidos en los Escritos póstumos.

${ }^{148}$ Analizando conceptos de Foucault acerca de las tecnologías del yo, dice Ángel G. Loureiro: "El sujeto <cuida de sí> al escribirse; se inscribe bajo la mirada del otro/destinatario de su escritura y como producto de relaciones de poder con <otros> a los que también inscribe en su texto. Si consideramos que el sujeto se constituye por medio de una doble sujección (de instituciones y disciplinas, a su autoconsciencia), podemos considerar a la autobiografía no como el acto de reproducción o de autoconstitución de un sujeto sino como el lugar privilegiado en que esa doble sujeción se manifiesta y por la cual, al mismo tiempo, al sujeto lo hacen y se hace" (Loureiro, 1993, p. 44).
} 
Respecto del reverdecimiento de su popularidad, Benites le hablará en dos de sus cartas sobre la recepción que la juventud porteña planea ofrecerle en el puerto de Buenos Aires. A su vez, el remitente subraya que sus galardones de patriota se sustentarán en el reconocimiento público a su obra escrita (en la que Benites señalará lo que considera una cualidad excepcional: su capacidad predictiva) y en el conocimiento íntimo de su gestión desinteresada por las cuestiones americanas; en este sentido, Benites proyecta una vez más el reconocimiento de sus compatriotas por la generosidad de Alberdi al defender la causa paraguaya.

Se puede conjeturar, entonces, que sobre la base de estas informaciones, las escrituras del yo de Alberdi -que habían arrancado de una indignada autodefensa ante la acusación de "traición a la patria" y se habían encauzado en la construcción de una figura de estadista ejemplar que siempre ha dado pruebas de capacidad y de patriotismo- hayan tomado a partir de 1872 un giro más intimista, que lo induce a contar su infancia en Tucumán -donde veía casi a diario al General Belgrano, amigo personal de su padre-, a recordar sus amistades del Colegio de Ciencias Morales y su intervención en el Salón Literario de Marcos Sastre. De su etapa formativa en Buenos Aires, detalla el itinerario de cómo pudo llegar a convertirse allí en un pensador de la construcción del Estado. Tampoco omite sus inicios como publicista ni la actuación política que lo legitima como patriota, acontecimientos que contribuyen a crear vínculos afectivos con sus destinatarios al inscribirlo en la historia porteña. Pero las páginas que contienen el giro más intimista, a pesar de presentar una textualización bastante elaborada, ${ }^{149}$ sólo fueron conocidas póstumamente.

Se puede observar cómo la correspondencia del año 72 anticipa algunos aspectos de sus textos autobiográficos ${ }^{150} \mathrm{y}$ debe de haber influido en la elaboración del único que decidió publicar en vida. Por otra parte, en el caso de Palabras de un ausente, el epistolario ofrecerá datos acerca de las estrategias usadas por Alberdi para crear expectativas sobre su circulación: envía a Benites lo que llama "el folletito"151 por

${ }^{149}$ Debe tenerse siempre presente que los textos editados en los Escritos póstumos (aunque asombren por su magnitud, ya que doblan en cantidad la extensión de sus Obras completas) son sólo borradores (Lois, 2007b, pp. 14-16).

${ }^{150}$ Algunos indicios textuales permiten conjeturar que los dos textos autobiográficos publicados en los Escritos póstumos fueron escritos entre 1872 y 1873.

${ }^{151}$ Aunque la inclusión de los destinatarios en el título ([...] en que explica a sus amigos del Plata los motivos de su alejamiento) evoca el formato de la "carta abierta", Alberdi le da a su 
correo y es Benites quien se encarga de repartir los primeros tres ejemplares entre conocidos de Alberdi.

Benites comienza a tocar el tema del ansiado regreso de Alberdi a su país en cartas de 1872: seis piezas de este año se refieren a esa posibilidad. Dice ya en la del 16 de marzo, escrita todavía desde Asunción antes de iniciar un viaje al Plata:

Me congratulo, mi querido amigo, de la grata noticia que U. me da de su resolución de regresar a su país, donde, le reitero la seguridad, Ud. será acogido por la mayoría de sus compatriotas y extraños del modo más digno y justo a que Ud. es acreedor por cien mil motivos poderosos. Quiera Ud. aceptar, de antemano, mis felicitaciones calurosas por su feliz arribo al Plata, y las simpatías y respeto de que será Ud. objeto. ${ }^{152}$

El convencimiento que tenía Alberdi sobre su capacidad de predecir los caminos de la Argentina también es confirmado por Benites, quien -ya desde Buenos Aires- le escribe:

Más de una vez me he permitido, decir a Ud., desde mi arribo al Plata, que Ud. tenía le bienvenu en estos países, donde todos lo desean y reclaman. Con varias personas respetables de aquí, he tenido ocasión de hablar de Ud. y todo el mundo lo tiene en la alta consideración y respeto de que es digno acreedor. Entiendo que Ud. será acogido calurosamente por la juventud argentina, que se propone recibirlo a Ud. en el muelle. Me permito pues reiterar a Ud. que no vacile en venirse a su país, o a lo menos al Plata. Ahora que las circunstancias son tan excepcionales, su presencia es de absoluta necesidad.

Y más adelante agrega:

No he cesado de oír a mi derredor, con el mayor placer, la cita de su nombre, como autoridad que ha previsto y vaticinado todo lo que ahora se pasa entre los dos

obra identidad de libro al imprimirlo en folleto, un formato comúnmente utilizado para asegurar una circulación más ágil de los impresos.

${ }^{152}$ Gregorio Benites a J. B. Alberdi, Asunción, 16 de marzo de 1872, BF 2390. Ver Alberdi y Benites, 2007, II, pp. 28-31 (las transcripciones publicadas en esa edición crítica que se citan fueron realizadas por María Celina Ortale). 
poderes aliados, o más bien ex aliados. Recién se aperciben de la rectitud y precisión de sus escritos. Mieux vaut tard que jamais.

Más abajo comenta: "ella ${ }^{153}$ como todos sus amigos y compatriotas anhela su regreso al Plata. Véngase pues, mi querido Amigo". Y agrega ya cerca del cierre de la carta: "Todos lo recuerdan a Ud. con perfecta amistad y respeto. Desean, como todo el mundo, su venida al Plata". ${ }^{154}$ Tampoco deja de referirse puntualmente a la imagen que se tiene de él entre los paraguayos donde se reconoce el apoyo que Alberdi ha hecho por su causa y la generosa actitud que tuvo para con el Paraguay y se le guarda mucha simpatía. ${ }^{155}$

En su visita a la capital porteña, Benites se relaciona con políticos y periodistas que conocen a Alberdi desde su juventud, y minuciosamente le transcribe sus impresiones acerca de la hipotética recepción del exiliado:

En la carta que le he escrito en mi arribo a esta ciudad, le he manifestado, como en todas las demás que le he dirigido de esta parte de América, el deseo y la conveniencia de que Ud. no retardase su venida a estos países. Hoy mejor informado de las cosas y hombres de su país de Ud. le vuelvo a decir que su presencia en el Río de la Plata es necesaria y de absoluta conveniencia en estos momentos excepcionales, que Ud. sabrá apreciar con mayor precisión que su humilde Amigo. Su nombre de Ud. es hoy una bandera y un modelo en el Río de la Plata. No hay hombres ni damas que no le hagan a Ud. la más completa y merecida justicia. No hay salón ni reuniones en que no se hable de Ud. ${ }^{156}$

Entre los periodistas porteños destaca a Manuel Bilbao: "El señor Bilbao es de opinión, como todo el mundo, que Ud. debe venir al Plata lo más pronto posible. Que no recele de nadie". ${ }^{157}$ Y respecto de un banquete al que asistió, invitado por amigos de

${ }^{153}$ Se refiere a Josefa Gómez de Cáneva.

${ }^{154}$ Gregorio Benites a J. B. Alberdi, Buenos Aires, 8 de mayo de 1872, BF 2393. Ver Alberdi y Benites, 2007, II, pp. 31-34.

${ }^{155}$ Gregorio Benites a J. B. Alberdi, Buenos Aires, 15 de mayo de 1872, BF 2391. Ver Alberdi y Benites, 2007, II, pp. 35-36.

${ }^{156}$ Gregorio Benites a J. B .Alberdi, Buenos Aires, 28 de mayo de 1872, BF 2394. Ver Alberdi y Benites, 2007, II, pp. 37-42.

${ }^{157}$ Sabiéndose objeto de odios enconados, Alberdi temía por su seguridad personal. Además de referirse repetidamente al tema en su epistolario, es muy reveladora una cita de Montesquieu 
la Banda Oriental, le observa que todos le profesan "afección y respeto": "Su nombre fue el tema de la conversación entre personajes de bastante importancia, como los Dres. Palacios, Sagastume, Navarro Viola, etc." Y vuelve a mencionar a los jóvenes: "Le confirmo que los estudiantes de esta Ciudad se preparan para recibirlo a Ud. en el muelle". 158

Finalmente, en carta del 11 de junio, penetra en un terreno más íntimo en relación con el tema del regreso:

Ayer tuve el gusto de estar con los Dres. Bilbao y Vicente López. ${ }^{159}$ Conversamos extensísimamente con ambos, que son personajes eminentes y de valor real. Ellos como todo el mundo, desean que Ud. se viniese. Que no hiciera caso de la locura de ciertas palabras del Sr. Sarmiento. Aseguré al Dr. Bilbao que Ud. no daba la menor importancia a las palabras a que aludía, que le había oído decir a Ud, que Ud. mismo, en persona, querría hacer su defensa contra sus calumniadores. ${ }^{160}$

Esta referencia extensa confirma la solidaridad ideológica de alguien que, como Bilbao, afrontó en momentos críticos - como durante la Guerra del Paraguay- la defensa de las posturas de Alberdi.

Así, las cartas de Benites no sólo exaltan la valoración intelectual que gran parte de la sociedad (incluidos los jóvenes que sólo conocieron sus escritos) hace de Alberdi, sino que además recuperan el antiguo conflicto, que esta vez encuentra a su oponente en la más alta magistratura del país. Alberdi nunca dejó de revivirlo y elegirá, entre muchos otros, a su viejo adversario como único responsable de su permanencia en el destierro: sostiene que Sarmiento es, fundamentalmente, quien le impide volver a su patria. Ése es el subtexto que se lee en Palabras de un ausente, una obra que empieza a circular en el último año del mandato de Sarmiento.

Benites parte para Europa en su calidad encargado de negocios el 23 de agosto de 1872. El 7 de octubre ya le escribe a Alberdi desde Londres, asegurándole que "no

que hace en el primer apartado de Palabras de un ausente: "La liberté politique est cette tranquillité de l'esprit qui provient de l'opinion que chacun a de sa sûreté".

${ }^{158}$ Gregorio Benites a J. B. Alberdi, Buenos Aires, 28 de mayo de 1872, BF 2394. Ver Alberdi y Benites, 2007, II, p. 38.

${ }^{159}$ Se refiere a Vicente Fidel López.

${ }^{160}$ Gregorio Benites a J. B. Alberdi, Buenos Aires, 11 de junio de 1872, BF 2396. Ver Alberdi y Benites, 2007, II, pp. 43-45. 
tenga el menor cuidado [...] no ha faltado quienes preguntan por Ud.[...] en nada he ilustrado a los curiosos y curiosas. Lo que saben por mí es que nada sé de Ud."161

A partir de su llegada a Europa, coordinarán varios encuentros y se seguirán carteando, pero la correspondencia ya no menciona el tema del regreso, aunque sí continúa registrando el afán de Alberdi por seguir las cuestiones sudamericanas. Durante el año 73 -en que Benites se ocupa primero de obligaciones diplomáticas en Roma y luego se dirige a Boulogne-sur-Mer, donde nacerá su hija Susana, ahijada de Alberdi-, se escribirán casi a diario.

Benites termina su gestión a fines del 73 y debe volver a Paraguay. El 12 de enero de 1874 se embarca en el Douro con destino a América y el 24 de marzo, ya desde Montevideo, le escribe dando cuenta de la recepción del folleto de Palabras de un ausente:

Estoy en posesión de su apreciable del 20 de febrero ppdo. con los 3 ejemplares del Palabras de un ausente, que lo devoré el en acto. ¿Qué le puedo decir, mi querido amigo, respecto a este chef d'oeuvre, si no que es toda una novedad, un acontecimiento? Es el estudio más acabado, más brillante, que se puede hacer de las cosas y de los hombres. En una palabra, y a mi humilde juicio, es un trabajo que va a producir un efecto considerable en América, bien entendido, favorable a su ilustre autor. Es imposible que sea de otro modo. Mañana sabré el efecto o impresión que haya hecho a dos lectores de importancia, a quienes presté este día mis dos ejemplares. El troisième salió hoy para Río de Janeiro. [...] Este día hablé extensamente con el Ministro de aquí sobre el autor de las Palabras, que con interés empezó su lectura esta tarde. Mañana me dirá su impresión. Al dejarle el ejemplar le hice yo mismo la lectura de la 2ª página de la Conclusión le agradó. Le hice una larga explicación de la actitud política y miras patrióticas de mi amigo desde su tierna edad, y en particular en la Alianza del 52. Le puedo asegurar que todo marcha viento en popa. ${ }^{162}$

${ }^{161}$ Gregorio Benites a J. B. Alberdi, Buenos Aires, 7 de octubre de 1872, BF 2404. Ver Alberdi y Benites, 2007, II, pp. 58-60.

${ }_{162}$ Gregorio Benites a J. B. Alberdi, Buenos Aires, 24 de marzo de 1874, BF 2525. Ver Alberdi y Benites, 2007, II, pp.324-327. 
Se observa así cómo Benites pone su grano de arena para asegurar la recepción y circulación del texto entre los partidarios de Alberdi, y entre quienes puedan interesarse por su regreso definitivo.

Benites debe volver al Paraguay, pero al llegar a Asunción es apresado por intrigas políticas internas. Logra huir y puede refugiarse en Montevideo, y es desde aquí, en el año 1877, que seguirá escribiendo a Alberdi, nuevamente, sobre la necesidad de su retorno a la Argentina. Benites volverá a la carga durante todo el año 77 para alentar la vuelta del expatriado sumándose a un coro de voces. De 27 cartas que le manda a Alberdi, 17 tocan este tema, donde pasa desde la euforia de creer en su inminente llegada ${ }^{163}$ y la alucinación de confundirlo con un paseante anónimo de Montevideo, ${ }^{164}$ al desengaño amargo de la última en la que expresa su opinión, siempre acompañada de la opinión de otros muchos: "Se me ha contagiado el escepticismo de los que no creen ni esperan en su regreso a América [...]". ${ }^{165}$

Pero anteriormente, en la pieza del 8 de abril de 1877 había vuelto a mencionar su autobiografía:

No dudo que le irán buenas palabras de su país en la actualidad, presidido por un hombre decente, ilustrado y bien intencionado, como lo es, en realidad, el Dr. Avellaneda. Pero Ud. tiene razón en vacilar, aun en presencia de esas animadoras palabras, no por desconfianza en la procedencia de ellas, si no porque comprende que las situaciones en nuestros países son más falibles que en otra parte. Además, en la administración de su país está mezclada una influencia adversa -según lo previó Ud. con una profundidad inmensa de vista en Las palabras de un ausente, que creo fue el título de su folletito de $1874 .^{166}$

\footnotetext{
163 "El entusiasmo con que he leído el anuncio de su disposición a venirse a residir a esta Capital" (Gregorio Benites a J. B. Alberdi, Montevideo, 8 de agosto de 1877 (ver Alberdi y Benites, 2007, III, pp. 83-89).

${ }^{164}$ Gregorio Benites a J. B. Alberdi, Montevideo, 25 de septiembre de 1877. Ver Alberdi y Benites, 2007, III, pp. 106-107.

165 "Se me ha contagiado el escepticismo de los que no creen ni esperan en su regreso a América" (Gregorio Benites a J. B. Alberdi, Montevideo, 18 de diciembre de 1877. Ver Alberdi y Benites, 2007, III, pp. 143-145).

${ }^{166}$ Gregorio Benites a J. B. Alberdi, Montevideo, 8 de abril de 1877, BF 2568. Ver Alberdi y Benites, 2007, III, pp. 42-45.
} 
De este modo, Benites vuelve a confirmar la identidad patria de Alberdi a la par que su admiración insiste en conferirle la facultad mágica de anticipar el futuro de su país. Pero finalmente, la correspondencia consultada aporta un testimonio más acerca del personalismo de todos estos debates, la confusión profunda entre los destinos de los hombres y el destino de la Nación, un rasgo que dejó una huella indeleble en la vida política así como en la historiografía y la literatura argentina del siglo XIX. ${ }^{167}$

\subsection{Alberdi y Sarmiento en Hernández: resemantización de la polémica}

Desde la etapa revolucionaria la literatura argentina abreva en las fuentes de la Nación, en su naturaleza y en su historia. El objeto literario se reparte entre la tierra americana y los elementos que constituyen la nueva sociedad en recomposición. Así se describirá por primera vez el desierto pampeano, sus plantas y animales, y las figuras del caudillo y el gaucho serán otros de los motivos predilectos para los hombres de letras que discuten el futuro del país, las leyes que los regirán y el tipo de composición social que se considera funcional para el desarrollo de esa programática. A lo largo del siglo XIX se acarician todos los sueños de la nueva República y se organizan sus bases constitucionales, educativas, productivas, financieras, y también culturales.

Como ya se ha dicho, Sarmiento propone en el Facundo un modelo interpretativo de la identidad nacional que divide tajantemente a los pobladores del país en dos categorías: "civilizados" (descendientes de europeos, de educación esmerada, de frac, ciudadanos trabajadores y respetuosos de las leyes) y "bárbaros" (gauchos que habitan en el campo, sin educación, ni casa propia, que visten poncho y chiripá, y no respetan las leyes ni las instituciones).

Como se dijo antes, el planteamiento de esa antinomia tajante tuvo gran repercusión -tanto en el país como en el exterior- y desde 1845 se venían reiterando las aceptaciones elogiosas de la elite de los proscriptos antirrosistas. Pero después de la escisión porteña, las opiniones se reconsideraron, y particularmente, la célebre polémica entre Sarmiento y Alberdi fue un punto de partida para los primeros cuestionamientos.

167 José Amícola trata este tema en "Voz individual y articulación nacional. Sarmiento en la generación de los románticos argentinos" (Amícola, 2007). Ver, también, Myers, 2003. 
Con esa polémica se entroncan los Rasgos biográficos del general D. Angel V. Peñaloza de José Hernández (1863), como otra refutación del modelo interpretativo de Sarmiento.

Si bien el folleto hace un recorrido histórico sobre la vida del caudillo riojano, el objetivo principal es claramente político, el texto ha sido pensado como "arma de combate y no página de historia". ${ }^{168}$ Con este propósito, se observa que Hernández emprende una estrategia narrativa coherente que le permite ir componiendo un subtexto que discute y resignifica las categorías conceptuales del texto de Sarmiento mediante la inversión irónica de su postulado principal: "civilización o barbarie". 169

Rasgos biográficos del General D. Angel $V$. Peñaloza ensaya, con esa orientación, una lectura opuesta a la tesis del Facundo, pero ese procedimiento estrecha, a la vez, la relación entre ambos textos, no sólo porque uno es un antecedente del otro (Diana Sorensen habla de "interdependencia" cuando confronta el Facundo con su recepción), ${ }^{170}$ sino porque el discurso panfletario que domina en el opúsculo de Hernández no está ausente en el libro que inaugura una propuesta de identidad nacional fundamentándola. En esa línea de percepción de encadenamientos intertextuales, la crítica de Hernández ha señalado que el Martín Fierro es, en realidad, la otra cara del Facundo. ${ }^{171}$

\subsubsection{Rasgos biográficos del General D. Angel V. Peñaloza}

En el año 63, José Hernández era un joven muy poco conocido, aunque había ido ganándose un lugar dentro del periodismo político de la Confederación; pertenecía a otra generación, mucho le faltaba todavía para escribir su Martín Fierro y para transformarse en un activo legislador.

\footnotetext{
${ }^{168}$ La caracterización es de Pagés Larraya (1987, p. 36).

${ }^{169}$ En un pormenorizado análisis del género ensayístico, Alberto Giordano deslinda distintos "modos del ensayo", uno de los cuales es definido como un juego dialógico de relectura de un texto anterior con el que el ensayo discute (Giordano, 1991).

${ }^{170}$ Diana Sorensen emprende la lectura de la recepción del Facundo desde su publicación en 1845 e imbrica al texto con su recepción enfocándolos como "un repertorio de interpretaciones en conflicto" que caracteriza -tomando una categoría descriptiva de Gérard Genette- como "una red de intertextualidades" (Sorensen, 1998).

${ }^{171}$ Halperín Donghi se refiere a esta cuestión en el prólogo de José Hernández y sus mundos, cuando comenta cómo se afanó la crítica en establecer a Hernández como alternativa o como paralelo de Sarmiento: "Martín Fierro es entonces el Facundo y Hernández el Sarmiento de ese hemisferio de luz que los servidores de las tinieblas, efímeramente victoriosos, buscaron, con éxito igualmente efímero, borrar de la memoria de la nación” (Halperín Donghi, 1985, p. 11).
} 
A comienzos de ese año, había fundado en Paraná el diario urquicista $E l$ Argentino, y en cuanto llegó allí la noticia de que Peñaloza había sido apresado y ejecutado por las fuerzas nacionales el 11 de noviembre, su indignación se proyectó inmediatamente en un alegato panfletario para el que eligió el molde genérico de la biografía, y lo fue publicando por entregas en su diario.

La veloz transmisión de la noticia a través de las provincias confederadas conlleva la adjudicación de la responsabilidad criminal a Sarmiento. Y es también veloz la escritura de una pieza en que una historia de vida va desarrollando, paralelamente, un ataque a la persona de Sarmiento -quien en ese momento era el gobernador de San Juan y había actuado como supervisor de la guerra contra las montoneras- y a la posición que ocupaba dentro del campo político y literario de la época. Aunque es una obra mucho más breve que el Facundo, Hernández se las ingenia para construir un subtexto que aporta una descripción de Quiroga antagónica de la de Sarmiento; revela así la intención cuestionadora del folleto. Por otra parte, en la insistencia en adjudicar la responsabilidad de la ejecución al "bárbaro Sarmiento", se hace muy evidente la expresa voluntad de retomar esa inversión de la antinomia trazada por el discurso de las Quillotanas. ${ }^{172}$

Esa serie de artículos (que además de una defensa de las luchas federales del interior incluye "advertencias" para Urquiza, que se ha venido mostrando más interesado en conciliar con Buenos Aires intereses personales que en defender causas políticas nacionales) se reunirá en un folleto publicado el $1^{\circ}$ de diciembre: Rasgos biográficos del general D. Angel V. Peñaloza; ese mes dejó de salir el diario.

El alegato panfletario a favor del Chacho muestra en progresión, un agresivo tratamiento de las categorías conceptuales del Facundo que practica la inversión de una mirada polarizada y subjetiva, y sienta las bases de un camino de reflexión constante que se verificará en todo el periodismo de Hernández; además, desencadenará un proceso de recepción que hasta puede rastrearse en la versión biográfica antagónica con la que Sarmiento ofrecerá una clara respuesta a esta manipulación de las categorías de "civilización” y "barbarie".

172 La escasa recepción que hasta hoy ha tenido esta pieza ha insistido en registrar esta insistencia. Es el caso de la biografía de Hernández escrita por Manuel Gálvez: "El folleto está precedido por dos artículos y algunas cartas. Trata allí duramente a Sarmiento, al que llama "bárbaro"” (Gálvez, 1945, p. 41). 
Marc Angenot subraya que existe un vínculo muy estrecho entre el género ensayístico y el discurso panfletario porque, en todo ensayo, el aparato de demostración está "chargé d’un puissant potenciel affectif" que lo aproxima al panfleto. ${ }^{173}$ Desde esta perspectiva, se puede observar que, a lo largo de los constantes comentarios de Hernández destinados a refutar la antinomia fundacional de Sarmiento, se va escribiendo un relato que lo tiene como protagonista; a la vez, se aprecia también un procedimiento sustitutivo de esta naturaleza en el texto que Sarmiento publicará en 1868, en donde se crea la ficción de "el último relato de la barbarie". Hernández se instituye con Rasgos biográficos del General D. Angel V. Peñaloza en un contrincante precoz de Sarmiento, ya que cuando casi nadie lo conoce aún, pergeña una pieza que operará como el antecedente del ataque más potente contra la política de Sarmiento: El gaucho Martín Fierro (1872). Por su parte, cuando Sarmiento le responda con su versión sobre la vida de Peñaloza, se autopropondrá como el "civilizador" que viene a superar el pasado caudillista bárbaro mediante la imposición de un programa de educación masiva.

En Rasgos biográficos del General D. Angel V. Peñaloza Hernández acusa a Sarmiento de "bárbaro" y presenta a un Chacho patriarcal y heroico, asesinado a manos de los que supuestamente representaban la "civilización", una dislocación que le permite echar mano del recurso que Angenot denomina "citación boomerang". ${ }^{174}$ Hernández denuncia la dislocación de los valores que lee en los trágicos sucesos recientes y reacciona desviando referencialmente la propuesta de Sarmiento; tanto en los editoriales como en las notas periodísticas sobre las campañas del Chacho, que precedieron la redacción de Rasgos biográficos del General ... (y que en retrospectiva adquieren el estatuto de pre-textos), como en la redacción del fervoroso alegato que Hernández emprende en cuanto llega la noticia de su muerte, llama la atención la concurrencia de lexemas del campo semántico de la devoción (civilización cristiana, reconciliación, mártires, apóstoles de la civilización, santa regeneración, sacrificio de víctimas inocentes, etc).

\footnotetext{
${ }^{173}$ Angenot, 1982, p. 58.

${ }^{174}$ Marc Angenot caracteriza lo que denomina "citación-boomerang" como un efecto dialógico del panfleto que confronta discursos opuestos en tensión: "De tous les usages "abusifs" qu'on peut faire de la parole adverse, le plus simple et le plus efficace consiste a lui renvoyer ses propres propos par un effet de boomerang, sans y changer une virgule" (Angenot, 1985, p. 293).
} 


\subsubsection{Primera y segunda edición}

La serie de artículos publicados en El Argentino de Paraná constituye una primera edición de esta biografía del Chacho; pero hoy ese diario -mencionado, sin embargo, por varios estudiosos de la obra del autor-, ${ }^{175}$ es inhallable. Sólo en la Biblioteca de la Universidad Nacional de La Plata se conservan algunos números de este periódico -aunque únicamente de los meses de febrero, marzo, abril y mayo-, pero en ellos hemos rastreado un material equivalente a la documentación pre-textual de un dossier genético.

El folleto que reunió esas entregas (que, desde el punto de vista genético, puede ser considerada como una $2^{\mathrm{a}}$ edición de esta obra) se tituló Rasgos biográficos del General D. Angel V. Peñaloza. Colección de artículos publicados en "El Argentino". ${ }^{176}$ Se presume, por el título, que consistió simplemente en la recopilación de esas entregas (el diario salía los martes, jueves y sábados de cada semana) organizadas en partes y capítulos para la publicación del folleto. Fue imposible emprender un cotejo de ambas etapas editoriales porque no se dispone de los ejemplares del diario a partir de mayo, pero tomando en cuenta el ritmo impuesto por la tarea periodística y por la inmediata reunión de los anticipos puede conjeturarse que, de haber existido hipotéticas reescrituras, no serían numerosas. ${ }^{177} \mathrm{La}$ inmediatez de las ediciones (la primera publicación se conoció durante el mes de noviembre de 1863 y la segunda el $1^{\circ}$ de diciembre del mismo año) no le daba mucho margen al autor ni para reformular opiniones, ni para detenerse en la reelaboración de un texto polémico nacido al ritmo de los acontecimientos políticos.

\subsubsection{Material pre-redaccional}

El material pre-redaccional analizado da pautas para conjeturar el proceso de producción de sentido del texto. Hernández se había exiliado en Paraná hacia 1858 en oposición a la política porteña; se definía así como un contrincante de Mitre y de

175 Horacio Jorge Becco, por ejemplo, aporta una somera descripción en su "Bibliografía Hernandiana" (incluida en la recopilación titulada Martín Fierro, un siglo (1972, pp. 261-396); muy difícil de hallar por su distribución restringida, fue reproducida en la edición del Martín Fierro de la Colección Archivos (pp. 1171-1326).

${ }^{176}$ Hernández, 1863.

${ }^{177}$ Por ese motivo, cuando cotejemos este texto con el de la edición de 1875, hablaremos de una $1^{\mathrm{a}}$ y una $2^{\mathrm{a}}$ versión. 
Sarmiento. Casi toda su obra periodística de esos años se consagró a combatirlos y para ello se había creado expresamente el diario urquicista El Argentino, que vería la luz sólo durante 1863. A lo largo de las páginas conservadas sobresale notoriamente la preocupación del editor por seguir los sucesos del interior del país, convulsionado por la intervención de un gobierno nacional identificado con los intereses porteños. Hernández se mostraba atento al movimiento de todos los caudillos - entre los que se destacaba el Chacho, viejo patriarca riojano- en oposición al sistema político imperante. Desde los primeros números seguiría su suerte, enhebrando datos que se proyectarán posteriormente en el texto de Rasgos biográficos del General D. Angel V. Peñaloza.

La tirada que se pudo consultar comprende las siguientes fechas: desde el número inaugural del martes 3 de febrero, los días 5, 7, 10, 12, 14, 17 y 19 del mismo mes; 7, 10, 12, 14, 17, 19, 21, 24 y 26 de marzo; 18, 21, 23, 25, 28 y 30 de abril; y 2, 5, 7 y 30 de mayo.

Desde el primer número del periódico se advierte el interés de Hernández por dar cuenta de las actividades del Chacho. La primera referencia a Peñaloza se hace el sábado 14 de febrero, en una sección apartada titulada "San Luis":

Se practicaban activas diligencias [...] hirió al Coronel Sandes, y caían sospechas en un chileno Salamanca, que ha sido ayudante del Gral. Peñaloza; y que había aparecido en San Luis, fugando después para pasar a los Llanos. El Coronel Sandes había hecho fusilar a un paisano Nazario Tisera acusado de espía de los indios [...]. El Gobierno de San Luis aprobó el proceder del Corones Sandes.

Luego, en el apartado "La Rioja", dice: "Hemos recibido una proclama del Gral. Peñaloza sin fecha y sin saberse a quién es dirigida: después la publicaremos". ${ }^{178}$

El martes 17 de marzo, en la sección "Interior", es claramente perceptible la simpatía por el caudillo:

Por cartas particulares venidas del Interior sabemos que el estado de varias provincias es bien poco lisonjero [...]. Infinidad de ciudadanos respetables [...] habían salido de ella, yendo a buscar a La Rioja al lado del Gral. Peñaloza la quietud y

178 Las transcripciones modernizan las grafías, pero mantienen la puntuación, el uso de mayúsculas y las abreviaturas. 
seguridad de que se ven privados en su provincia. En La Rioja se había establecido un gobierno provisorio, y el 14 de febrero se había retirado de la capital con dirección de los Llanos, el Gral. Peñaloza, acompañado de muchos individuos, que como hemos dicho, habían ido de otras provincias en su busca.

El jueves 26 de marzo, en "Última hora" se hace explícito el gesto de Hernández a favor del Chacho y en oposición a Sarmiento, y se anticipa el mismo tono del folleto:

[...] el Gral. Peñaloza había invadido la provincia de San Juan, [...] no nos sorprende el hecho, que no es más sino el resultado de las amenazas constantes de Sarmiento al Gral. Peñaloza y de sus trabajos bien conocidos para acabar de un golpe con la influencia de éste en La Rioja. El Gral. Peñaloza se arma en defensa propia, y a su lado deben hallarse todos cuantos han emigrado de San Luis y San Juan por las persecuciones tenaces de que han sido víctimas. La política de sangre da sus frutos. El Gral. Peñaloza amenazado siempre por el puñal de los asesinos no ha podido aguardar a que reprodujeran con él las escenas sangrientas de Benavides y Virasoro, y se arma en su defensa.

El sábado 18 de abril, bajo el título "Una medida anárquica", Hernández critica las decisiones del Gobierno Nacional al decretar la ocupación militar de La Rioja y habla de "luchas fratricidas" que conducen "al abismo". Y en "Última hora" informa: "Se afirma que el Gral. Peñaloza se hallaba en la provincia de Córdoba con una fuerte columna".

El martes 21 de abril, en la sección "Interior" transcribe una carta de Peñaloza dirigida al Coronel Iseas, donde el Chacho denuncia una "época de opresión” y de "terribles procedimientos", y Hernández agrega de su cosecha: "Esta carta es una revelación muy clara de los propósitos del Gral. Peñaloza, que no trepida en apoyar los pronunciamientos de los pueblos que se levantan clamando por la reacción. Esto es el resultado de rancias exclusiones [...] del Gobierno Nacional”.

El martes 5 de mayo vuelve a publicar una carta del riojano, bajo el título "Documento Importante", y ya describe así su personalidad:

Damos un lugar preferente en nuestras columnas a la importante nota que el Gral. Peñaloza ha dirigido al Coronel Sandes. En el documento que damos al público, 
como todos los que tienen al pie la firma del Gral. Peñaloza sólo se habla de la unión y de concordia, sólo se revelan sus sentimientos patrióticos y generosos [...]

Finalmente, en el último número que pudimos consultar -el del jueves 7 de mayo-, se observa la preocupación de Hernández por describir detalladamente la campaña del Chacho en la sección "Correspondencia" de El Argentino: "El Gral. Peñaloza marchaba sobre San Juan, y ya había notificado esta medida a S.E. el comisionado Sarmiento". Y en la sección "Interior": "La única noticia que tenemos es la de la ocupación de la capital de La Rioja por las fuerzas de Taboada. Peñaloza había reunido sus fuerzas concentrándolas en un solo punto y se espera que muy pronto tendría lugar un encuentro".

Puede verse entonces cómo en estos números Hernández anticipa el contenido y el tono de los Rasgos biográficos del Chacho. Habla ya de las amenazas de Sarmiento (a quien la inmediata repercusión popular le atribuirá después el asesinato), y de la buena intención y de los sentimientos "patrióticos y generosos" del caudillo riojano. Estas notas son un avance de los mismos conceptos y de la misma modalidad discursiva que irrumpirán en "La política del puñal”, uno de los apartados del folleto que se analizará a continuación.

\subsubsection{Características del folleto de $1863^{179}$}

La imposibilidad del cotejo con los números del periódico de noviembre determina que se ignore si las entregas de El Argentino fueron cinco o si, posteriormente, Hernández estructuró el folleto en cinco apartados (los cuatro primeros constituyen una especie de preámbulo del último): 1) "Asesinato atroz" (da la noticia del asesinato); 2) "El General Peñaloza ha sido degollado" (dos cartas recientes dirigidas a Hernández, que narran y comentan la "triste noticia"); 3) "La política del puñal" (denuncia de tono dramático y violento); 4) "Revelación de un crimen" (recopilación de los distintos partes oficiales con la noticia del asesinato); 5) "Rasgos

${ }^{179}$ El folleto consta de veinte páginas. Fue consultado en la sección "Tesoro" de la Biblioteca Nacional, TE 3 A 0556 13. De todos modos, se ha preferido citar nuestra edición (Hernández, 2005. Estudio filológico, edición crítico-genética y notas de María Celina Ortale). Para prepararla, se tomó ese folleto como texto-base; se modernizaron sus grafías, pero se conservó su puntuación así como las abreviaturas y el uso de mayúsculas y de destacados que hace el autor. El aparato genético (en este caso, las reformulaciones de la segunda versión) se registra en notas. 
biográficos del General D. Angel V. Peñaloza” (episodios de la vida del Chacho desde su niñez hasta su muerte distribuidos en diez capítulos). ${ }^{180}$

\section{"Asesinato atroz"}

Se comunica la noticia del asesinato, pero el "parte informativo" -con ecos de una veloz transmisión oral que se proyecta en el uso del estilo indirecto libre ("ha sido cosido a puñaladas en su lecho")- va siendo penetrado en forma creciente por la emoción, y la breve necrológica sentida (habla de la "grandeza de su alma" y de la "magnanimidad de sus rasgos") pasa de la celebración del caudillo y la evocación de una línea histórica abierta por Dorrego al estallido de indignación: "Que la maldición del cielo caiga sobre sus bárbaros matadores".

\section{"El General Peñaloza ha sido degollado"}

A continuación se publica la transcripción de dos cartas recibidas por Hernández (las caracteriza como "particulares", sin revelar el nombre de los remitentes) con pormenores acerca del prendimiento y de la ejecución (la primera, del 23 de noviembre, aparentemente completa; de la segunda sólo se toma un pasaje). El propósito claro de la inclusión de estos textos es remarcar el valor testimonial del relato de la muerte del caudillo exhibiendo apoyatura documental, destacar el consenso popular del que gozaba y adjudicar a Sarmiento la responsabilidad de su muerte.

\section{"La política del puñal”}

Es una defensa exaltada, de tono irónico y combativo, de la figura de Peñaloza como "mártir" de la causa federal. Se deplora la muerte de "uno de los caudillos más prestigiosos, más generoso y valiente" a manos del partido gobernante y se hace una denuncia explícita de la responsabilidad del "bárbaro Sarmiento" en la muerte del Chacho. Luego el texto vira hacia la admonición e incorpora un aviso a Urquiza que se reitera obsesivamente hasta el cierre del apartado: “Alerta Urquiza!”. ${ }^{181}$

\footnotetext{
${ }^{180}$ La numeración es nuestra.

${ }^{181}$ Sólo este apartado y el siguiente ("La política del puñal" y "La revelación de un crimen") que llevan su firma (las iniciales "J.H."), son justamente los textos en los que se proyecta, además de un apasionado partidismo, una violencia verbal desenfrenada. Estos excesos pasionales, que Hernández intentará moderar en la versión del 75 mediante la supresión de estos
} 


\section{"Revelación de un crimen"}

Mantiene el tono agresivo del alegato precedente, desplegando una retórica que compara a los opositores políticos del Chacho con tigres salvajes cebados con la sangre de Benavídez y de Virasoro. Además, se incorpora aquí documentación probatoria de las contradicciones oficiales en lo referente a la datación de la muerte del riojano. Hernández se vale de la confrontación de los distintos partes militares para sostener su idea de que Sarmiento es el responsable del hecho y aporta pruebas sobre la posterior manipulación de la noticia.

\section{“Rasgos biográficos del General D. Angel V. Peñaloza"}

En la sección nuclear del folleto se construye un relato épico de la vida de Peñaloza, pero caracterizándolo simultáneamente como un jefe humanitario y sensible (es un "héroe" y un "patriarca" a la vez). Hernández opta por un sesgo historiográfico para narrar parte de la niñez de Peñaloza y para describirlo como heredero natural de Facundo Quiroga; se pormenorizan sus campañas con ejemplos que resaltan la sencillez del caudillo y su figura venerable en la zona de los Llanos.

\subsubsection{Huellas alberdianas}

En el momento en que Hernández dirige estas fuertes críticas, ya han pasado diez años desde la polémica pública entre Sarmiento y Alberdi, y la propuesta de la antinomia "civilización versus barbarie" -presentada como la oposición de dos polos inconciliables- ya había sido refutada con maestría por Alberdi. A pesar del tiempo transcurrido, en las provincias confederadas sigue vigente la adhesión a la postura política alberdiana, y en el caso de Hernández, también la técnica confrontativa de revertir las propuestas del adversario contra su autor. En un sentido amplio, el contexto de los Rasgos biográficos de D. Angel Peñaloza incluye el de la gran polémica nacional (la nueva etapa histórica abierta por Caseros y la revolución del 11 de septiembre del mismo año como nuevo hito de la discordia), pero remite directamente a la situación

dos apartados -además de otras reformulaciones-, son lo que se le recriminan a Hernández en la polémica iniciada por el periódico La Tribuna (ver el apartado 5.2.). 
política que sigue a Pavón: la dura campaña presidencial de Mitre en el interior, donde Sarmiento actúa como supervisor de la guerra contra los caudillos.

De la posición adoptada contra Sarmiento en las Cartas quillotanas partirá la crítica de José Hernández, quien entronca así su texto con la célebre disputa y recupera los tópicos esgrimidos por Alberdi para refutar al sanjuanino, que en ese momento ejerce su mandato provincial. ${ }^{182}$

De todas maneras, al retomar tanto conceptualizaciones como técnicas argumentativas de las Quillotanas, Hernández las resemantiza. En sus disquisiciones acerca del caudillaje autóctono, Alberdi (que siempre distinguió entre "la República verdadera" y "la República posible"), aceptaba la presencia del líder natural de un tipo de sociedad que no era precisamente su meta y consideraba que la civilización terminaría por asimilarlo; en cambio, Hernández está identificado emocionalmente con el rol social del caudillo en el mundo rural y le preocupa la extinción de su figura como protagonista nacional. El caudillo, luego de la batalla de Pavón, está siendo perseguido desde los postulados dicotómicos del Facundo. Hernández se valdrá también del género biográfico, pero asume la tarea de ensalzar al término excluido por la oposición tajante modulando un tenor que a veces ensaya la oda pero que en otras es elegíaco. Las figuras de caudillos que construye en su texto son seres venerables: honestos, paternales, leales, sencillos y amantes de su pueblo. Frente a ellos, se anatemiza la "barbarie" de Sarmiento y los generales mitristas.

El conflicto se retoma, por un lado, con el cuestionamiento de la tesis del Facundo, y por otro, con la reutilización del término "bárbaro" aplicado a Sarmiento, pero ahora con un sentido "real" (aplicado a su conducta) no "figurado" (aplicado a su pluma). Alberdi lo había nombrado el "gaucho malo" de la prensa, como autor que no puede adaptarse a la nueva realidad socio-política, que no sabe escribir en momentos de paz porque se ha acostumbrado a la guerra, a destruir a un adversario. Esa falta de adecuación a la nueva situación argentina es traducida en un discurso que, aparentando mesura, va dando estocadas como una espada (como cuando lo acusa de deslealtad con Urquiza a quien había exaltado antes como el único poder capaz de derrocar la tiranía rosista).

${ }^{182}$ Es sabido que, como todos los partidarios de la Confederación, Hernández adhería a los postulados de Alberdi (Chávez, 1988, p. 50). 
Por su lado, Hernández da una vuelta de tuerca más y en su folleto describe la figura de Sarmiento como la de un caudillo auténticamente "bárbaro": violento, salvaje, asesino:

El general Peñaloza ha sido degollado. El hombre ennoblecido por su inagotable patriotismo, fuerte por la santidad de su causa, el Viriato Argentino, ante cuyo prestigio se estrellaban las huestes conquistadoras, acaba de ser cosido a puñaladas en su propio lecho, degollado, y su cabeza ha sido conducida como prueba del buen desempeño del asesino, al bárbaro Sarmiento. ${ }^{183}$

De esta manera adhiere al rechazo de la violencia de un temperamento que según Alberdi- perjudicaba la calidad de la vida institucional, pero también asimila notorios rasgos del político vilipendiado: no ha podido escapar de la influencia del Sarmiento-escritor, particularmente, de su retórica romántica desenfrenada. ${ }^{184}$ En Complicidad de la prensa en las guerras civiles de la República Argentina Alberdi expresaba con gran contundencia un pronóstico del paso de la violencia verbal a la violencia política.

No pueden ser amigos de la libertad, los que ejercen el libertinaje de la prensa. [...] ¿Podría respetar la vida como gobernante, el que descuartiza el honor como aspirante al gobierno? ¿Podrían servir a la causa y a los intereses del comercio y de la industria, los que fomentan revoluciones, campañas, guerras de desolación y de empobrecimiento? ¿Podrá sufrir la oposición como ministro, el que no puede soportarla como ciudadano? ¿El que insulta la justicia ajena estando desarmado, la respetaría teniendo bayonetas? ${ }^{185}$

La sutileza conceptual de Alberdi lo impulsaba a superar las antinomias simplificadoras y se negaba a identificar al campo y a la ciudad como una pareja de opuestos paralela a la de civilización versus barbarie: por eso valoraba la función de los pobladores rurales tanto en su medio como en relación con el conjunto de la sociedad y siempre propugnó la igualdad de sus derechos. Pero Hernández se atreve a dar un paso

${ }^{183}$ Hernández, 2005, p. 16.

${ }^{184}$ El tópico de la presencia de una "afinidad subterránea" se retoma en el apartado siguiente.

${ }^{185}$ Alberdi, 1957, p. 149. 
más, y en su biografía, el Chacho y Facundo Quiroga son ciudadanos ecuánimes que respetan las leyes, actúan con la mayor inocencia, acatan órdenes y conducen un ejército disciplinado. Como en las Quillotanas, se invierte el sistema interpretativo del Facundo, pero elevando el tono.

Finalmente, un pasaje significativo en el que aparece una alusión al concepto alberdiano del "despotismo del progreso" 186 puede ponerse en paralelo con la escena de la ruptura de relaciones entre Urquiza y Sarmiento en Campaña en el Ejército Grande, en el sentido de que se trata de dos quiebres (uno producido, el otro pronosticado):

Lea el general Urquiza la historia sangrienta de nuestros últimos días: recuerde a sus amigos Benavídez, Virasoro, Peñaloza, sacrificados bárbaramente por el puñal unitario; recuerde los asesinos del Progreso, que desde 1852 lo vienen acechando, y medite sobre el reguero de sangre que vamos surcando hace dos años, y sobre el luto y orfandad que forma la negra noche en que está sumida la República. ${ }^{187}$

Enlaza también los dos pasajes el tópico del "asesinato" y la estrategia discursiva de la inversión de roles: Sarmiento sugería que Urquiza elaboraba el plan de asesinarlo, mientras en los Rasgos biográficos de Hernández se le advierte al general entrerriano que se cuide de los designios políticos de Sarmiento y Mitre: "El puñal está levantado, el plan de asesinaros preconcebido". ${ }^{188}$

Alberdi y Hernández coinciden, además, en la crítica a la labor literaria de Sarmiento por estar encaminada hacia ambiciones políticas desmedidas y por ser remunerada. Escribía Alberdi:

No negaré su patriotismo, pero no me negará Ud. tampoco que siempre ha escrito periódicos por su sueldo, como medio honesto de ganarse el sustento de su vida. Ellos expresan pues, a la vez que patriotismo, necesidades satisfechas. ${ }^{189}$

\footnotetext{
186 "Delante del poder irresponsable se alzó la libertad omnímoda y se quiso remediar el despotismo del atraso con el despotismo del progreso: la violencia con la violencia" (ibidem, $\mathrm{p}$. 90).

${ }^{187}$ Hernández, 2005, p. 17.

${ }^{188}$ Ibidem, p. 18.

${ }^{189}$ Alberdi, 1957, p. 77.
} 
Pero antes había apuntado despreciativamente: "sus escritos no lo hacen a Ud. Presidente de la República". ${ }^{190}$ Y más adelante comentará sobre Recuerdos de provincia: "es el medio muy usado y muy conocido en política de formar la candidatura de su nombre. ${ }^{191}$ Por su parte, Hernández retoma esos juicios descalificantes en una sola frase contundente:

Con objeto menos loable, se han tomado otras tareas más arduas. Sarmiento escribió su Facundo sin más objeto que deprimir un partido que no podían vencer y haciéndose remunerar con largueza por los suyos ese trabajo. ${ }^{192}$

Ambos comparten, también, la valoración de la emblemática muerte de Dorrego, considerando su asesinato como el origen puntual de la violencia intolerante del partidismo político del país. Así opinaba Alberdi:

El día que este general [Lavalle] fusiló a Dorrego por su orden, quedó instalada la política que por veinte años ha fusilado discrecionalmente. ${ }^{193}$

Por su parte, Hernández expresa:

Este es el tronco genealógico de todas las desgracias que hasta ahora vienen afligiendo a nuestra patria. De allí parten nuestros males. La sangre del Coronel Dorrego fue la primera que se derramó alevosamente en nuestra guerra civil. Hasta hoy ha sido la última la del General Peñaloza. ${ }^{194}$

Sin lugar a dudas, Hernández coincidía con el tucumano en la necesidad de recuperar auténticamente los objetivos pedagógicos de la Generación del 37 (la búsqueda del perfeccionamiento del pueblo mediante la ilustración y el esclarecimiento) sin desvirtuarlos mediante conductas poco edificantes; por eso le interesa poner de relieve que los sujetos sociales estigmatizados son seres dignos de ese

${ }^{190}$ Ibidem, p. 76.

${ }^{191}$ Ibidem, p. 105.

${ }^{192}$ Hernández, 2005, p. 27.

${ }^{193}$ Alberdi, 1957, p. 19.

${ }^{194}$ Hernández, 2005, p. 30. 
perfeccionamiento. Alberdi destacaba que era más importante detenerse en el análisis de "civilización", como un buen ejemplo para la sociedad, y no en el de la "barbarie", que educa sólo en los vicios:

Educa mucho el ejemplo, es verdad, pero el ejemplo bueno y no el malo que es contagioso como todo ejemplo, bueno o malo. ${ }^{195}$

En esa línea, Hernández presenta la mejor cara del gaucho en la actitud inocente y la disposición generosa del caudillo del interior para defender su derecho a ser incorporado al mundo de la civilización al igual que todos los miembros de la sociedad post-Rosas. Cumple esa función la narración de una anécdota del Chacho que lo muestra más inclinado a educar que a castigar cuando debe sancionar a una partida de asesinos que ataca al coronel Yanzón, amigo suyo:

Véanlo los que lo han retratado animado de sentimientos sanguinarios. Su único castigo fue hacerlos marchar a pie, conduciendo en hombros el cadáver de su desgraciado compañero, hasta llegar a la Capilla de Gualfín, en el departamento de Belén, 12 leguas distante del teatro del suceso, y donde les hizo abrir la sepultura en que dejó enterrado a su antiguo amigo. ${ }^{196}$

Al final del folleto, otra anécdota confronta la humanidad del Chacho con la violencia de los oficiales mitristas:

El general Peñaloza devolvía todos los prisioneros que había tomado, no faltaba uno solo, y no había uno solo entre ellos que pudiera alzar su voz para quejarse de violencias o malos tratamientos.

Y, ¿dónde estaban los prisioneros que se le habían tomado a él?

Habían sido fusilados sin piedad, como se persiguen y matan las fieras de los bosques. $^{197}$

\footnotetext{
${ }^{195}$ Alberdi, 1957, p. 104.

${ }^{196}$ Hernández, 2005, p. 42.

${ }^{197}$ Ibidem, p. 46.
} 
Así, la generosidad del Chacho que le vale el "¡Viva!” de sus prisioneros de guerra se convierte en el ejemplo moral necesario para la educación del pueblo.

En suma, Hernández redefine en sus Rasgos biográficos del General D. Angel V. Peñaloza la identidad del caudillo, y por ello el texto conlleva una resemantización de los términos "caudillo", "bárbaro" y "civilizado" que circulan por el campo semántico sarmientino. Con notorias connotaciones épicas, el caudillo se convierte en un héroe, aunque no sea culto ni refinado. Tiene la sencillez del héroe épico y Hernández pretende instituir mediante su construcción biográfica el mito fundacional de una nueva literatura y de una nueva identidad nacional.

En cada circunstancia histórica se establece una pugna entre el imaginario impuesto por el poder, y un nuevo imaginario que intenta modificarlo. Hernández quiere construir aquí un nuevo relato de la vida de un caudillo: se retoman los ideales educativos que proclama el adversario, pero sobre esa base se busca establecer una identidad nacional diferente. El retrato de la vida del caudillo se propone por extensión como un paradigma funcional del país. Así, la idea de que la biografía de un caudillo puede emblematizar los componentes bárbaros de un país -desarrollada originalmente por Sarmiento en su Facundo- es retomada por Hernández para ser revertida: su biografiado es la expresión de una auténtica "civilización”.

En su intento de proponer un imaginario contrahegemónico, Hernández adhiere, otra vez, a posiciones formuladas en las Quillotanas de Alberdi, que serán retomadas en escritos conocidos póstumamente):

No es que yo menosprecie al gaucho. Sería desdeñar a la mitad de mi país, al pueblo de sus campañas, que en muchos respectos es mejor y más útil que el de sus ciudades, en el Plata como en todas partes. ${ }^{198}$

Hernández sostiene, como Alberdi, que el gaucho es funcional al progreso del país. En los Rasgos biográficos del General D. Angel V. Peñaloza, el Chacho simboliza todos los valores del gaucho argentino que están siendo perseguidos en nombre de la civilización, pero su biógrafo reclama por él con una iracundia que a veces, aunque recupere epítetos mazorqueros ("Los salvajes unitarios están de fiesta”), recuerda más a

${ }^{198}$ Alberdi, 1895-1901, XI, p. 38. 
la retórica desenfrenada de Las ciento y una que a la prosa reflexiva de su mentor ideológico. Y esas modalidades discursivas, justamente, serán objeto de una reformulación sostenida cuando Hernández republique su folleto en 1875. Pero también la exaltación del caudillismo será moderada en su reescritura, y en esta dirección habrá también un mayor acercamiento a su modelo original.

\subsubsection{Presencia del Facundo en Rasgos biográficos del General D. Angel $V$. Peñaloza}

Por más que sea innegable la filiación alberdiana del pensamiento político de Hernández, no puede decirse lo mismo de su práctica escritural; por otra parte, si bien bajo la apariencia de serena objetividad de las Quillotanas Alberdi refrena el discurso panfletario (que sólo esporádicamente se escurre del subtexto por alguna grieta), en la prosa combativa de Hernández brota con la misma espontaneidad que en la de Sarmiento.

Las biografías de Facundo Quiroga y la del Chacho comparten también los canales de manifestación y circulación. Se trata de artículos periodísticos por entregas que luego se compilan y se difunden como folletos, constituyen respuestas polémicas a un problema social que tiene imperiosa necesidad de resolverse. Vincula, también, a sus autores una modalidad de producción: ambos se dedican al periodismo batallador y su arma predilecta es el discurso panfletario (incluso, Sarmiento no renunciará totalmente a esta práctica en una obra tan enjundiosa como el Facundo, cuya adscripción genérica y su significación político-cultural es mucho más compleja que la de Rasgos biográficos). También es algo usual en la época que ambos recopilen una serie de entregas periodísticas en un folleto independiente (editado por la misma imprenta que compone el diario en el que escriben), y en este caso, lo hacen con el mismo propósito declarado: el de oponerse a la "barbarie de un tirano" que ostenta el poder. ${ }^{199}$

Por otro lado, se impone una influencia implícita de Sarmiento sobre Hernández desde el momento en que se ha visto compelido a adoptar un género en el que el adversario se ha consagrado, por más que lo haga para revertir el planteamiento nuclear.

${ }^{199}$ Sarmiento había sido nombrado Director de Guerra -cargo al que renunció dejándolo en manos de Paunero- ; de todas maneras, la imaginación popular le adjudicó el asesinato del Chacho aunque en esos meses ya no tuviera ninguna relación oficial en la lucha contra la montonera. 
Escribe una biografía de un caudillo, que además es oriundo de la misma provincia de Facundo Quiroga, estuvo bajo sus órdenes y se ha convertido en su sucesor. A través de su texto discute con el Facundo de Sarmiento. No lo acobarda combatir con su palabra a un escritor consagrado, pero no puede permanecer inmune a su potencia literaria. Lo ataca como político y como ensayista, pero en la dialogia discursiva que se entabla, al mismo tiempo que se rebate la propuesta central y se acusa a su autor de violento y "bárbaro", se desencadena un proceso de asimilación de su imponente arsenal retórico.

Por otra parte, además de utilizar la escritura como arma, Hernández también se inscribe -igual que Sarmiento- en la tradición iluminista reformulada filosófica y políticamente por la Generación del 37: también él está guiado por una vocación pedagógica: quiere "esclarecer" a la opinión pública. Escribe la biografía del Chacho para denunciar que el poder político está tratando de falsear la historia. En esta línea, Rasgos biográficos funciona como un texto bisagra entre dos obras literarias capitales del siglo XIX: el pasado Facundo y el futuro Martín Fierro (particularmente, la vocación pedagógica de Hernández culminará en La vuelta de Martín Fierro).

El Facundo está presente también como término de comparación. Hernández estructura, como Alberdi, un proyecto de refutación de la obra sarmientina que desestabiliza la famosa dicotomía "civilización o barbarie" al aplicarla, por inversión, al propio autor. Pero se atreve a utilizar el recurso de la inversión en una biografía -el mismo género discursivo que el adversario había practicado con maestría- para revertir el mito literario de Facundo con el retrato de otro caudillo riojano -su sucesor-, que es presentado como un patriarca venerable.

La versión popular le adjudicaba a Sarmiento la responsabilidad de ese crimen, y por ello, Hernández exalta e idealiza la personalidad de este caudillo para destacar la culpabilidad de Sarmiento y para socavar tanto su responsabilidad ideológica y política como su capacidad de gestión. Con ese objetivo va presentando distintas pruebas que incriminan al sanjuanino en la muerte del Chacho: "El documento con la misma firma anteriormente transcripto, no habla ni palabra de tales prisioneros, y la nota de Sarmiento dice que Vera iba con 5 hombres. O miente uno o miente el otro. La verdad es que mienten los dos". ${ }^{200}$ Luego: "El asesinato que se pretende encubrir está revelado.

\footnotetext{
${ }^{200}$ Hernández, 2005, p. 22.
} 
Los documentos que Sarmiento envía a Paunero son todos falsificados". ${ }^{201}$ Y por último:

Sarmiento, entre tanto, se ocupaba de confabular su plan de campaña, para dar la noticia de un modo que alejara la idea del asesinato, y al efecto, hace firmar con Irrazábal los partes y las notas transcriptas, comunicando la noticia del hecho como recientemente acaecido. ${ }^{202}$

Cuando Hernández elige el género predilecto de Sarmiento, al igual que él pretende reseñar la vida misma de la Nación, ya que los personajes elegidos son un símbolo de su época. Las peripecias del protagonista revisten un carácter ejemplificador porque sus avatares servirán para explicar los hechos del país. ${ }^{203}$ La vida del caudillo se entrelaza con la vida de la Nación y su retrato es casi una excusa para hablar de los acontecimientos con los que está relacionado. ${ }^{204}$ Como Sarmiento, Hernández busca en sus Rasgos biográficos definir una ejemplaridad histórica:

No es posible trazar el más ligero rasgo respecto a la vida de Peñaloza, sin encontrarse envuelto en las inmensas complicaciones de la guerra que desde hace cuatro décadas tiene lugar en nuestro país, y en todas las cuales ha tenido una parte a veces secundaria, a veces principal, pero siempre distinguida y honorable para él. ${ }^{205}$

Y más abajo, rubrica así el apartado: "Bosquejar, pues, la vida de Peñaloza es hacer una triste relación de nuestra luctuosa historia". ${ }^{206}$

${ }^{201}$ Ibidem, p. 25.
202 Ibidem, p. 25.

${ }^{203}$ Carlos Altamirano y Beatriz Sarlo destacan la eficacia con que se emplea en el Facundo un principio hermenéutico del historicismo romántico: la "ejemplaridad histórica" (Altamirano y Sarlo, 1982, p. 113).

${ }^{204}$ Así fundamenta Sarmiento su elección: "He creído explicar la Revolución argentina con la biografía de Juan Facundo Quiroga, porque creo que él explica suficientemente una de las tendencias, una de las dos fases diversas que luchan en el seno de aquella sociedad singular". Y continúa más adelante "porque en Facundo Quiroga no veo un caudillo simplemente, sino una manifestación de la vida argentina tal como la han hecho la colonización y las peculiaridades del terreno" (Sarmiento, 1963, p. 20).

${ }^{205}$ Hernández, 2005, p. 28.

206 Antes se había referido al caudillo como "una propiedad de la Patria y de sus amigos" (ibidem, p. 28). 
Con la misma operativa del Facundo, la base textual de los Rasgos biográficos se sustenta a partir de testimonios que avalan la verosimilitud de lo referido: se aportan algunos documentos escritos y se recurre a las tradiciones orales (cada anécdota funciona como una célula del relato); se trata de legitimar el texto enclavando su relato en la Historia. En tanto en el Facundo se aportan datos estadísticos, cuadros, ${ }^{207}$ partes oficiales, manuscritos, ${ }^{208}$ el texto de los Rasgos biográficos exhibe pruebas como si se tratara de organizar un expediente judicial. En la sección llamada "Revelación de un crimen”, Hernández transcribe todos los partes que refieren la muerte del Chacho; señala, además, que hay que precaverse de numerosa documentación falsa y analiza las fechas de las notas para probar la existencia de irregularidades. ${ }^{209}$

Por otro lado, y en franca contradicción con este afán, ambos autores se presentan como escritores superados por la urgencia de la publicación, lo que los lleva a cometer errores y a utilizar datos que no pudieron ser certificados. ${ }^{210}$ Hernández pide disculpas por las desprolijidades de redacción o la ausencia de documentación muchas veces: "No tenemos tiempo para detenernos más en hacer notar otras contradicciones de esos documentos fraguados para encubrir un crimen horroroso". ${ }^{211}$ Como periodista se declara superado por la vertiginosidad del medio de difusión, que impide corregir bosquejos veloces: "Vamos a describir a grandísimos rasgos la vida de este héroe sencillo y modesto, a bosquejarla con la brevedad con que nos lo permite el carácter y aun el objeto de esta publicación". ${ }^{212}$ Se sacrifica, entonces, la precisión histórica: "La premura del tiempo con que escribimos estos rasgos biográficos de la vida del general

207 "Creo oportuno hacer sensible por un cuadro la geografía política de la República desde 1822 adelante para que el lector comprenda mejor los movimientos que empiezan a operarse" (Sarmiento, 1963, p. 187).

208 "Me fatigo de leer infamias contestes en todos los manuscritos que consulto" (ibidem, p. 99).

209 Naturalmente, la artillería retórica pesa más que la tarea de reconstrucción histórica. Hernández señala que existe mucha documentación falsa, pero aunque no se detenga a fundamentar la autenticidad del documento sobre cuya base estima que queda revelado el engaño de los asesinos, utiliza las fechas de las notas sospechadas como prueba de la existencia de irregularidades. Por su parte, el mismo Sarmiento reconocerá que su ensayo contiene inexactitudes.

${ }^{210}$ Lo testimonia el pedido de Sarmiento a Valentín Alsina para corregir las imprecisiones del Facundo. Alsina le marca más de 50 errores, pero finalmente Sarmiento se excusa ante Alsina y no introduce los cambios porque privilegia mantener la unidad de estilo de la obra. Ver "Carta prólogo de la edición de 1851", edición en línea: www.stockcero.com , pp.12-14.

${ }^{211}$ Hernández, 2005, p. 22.

${ }^{212}$ Ibidem, p. 27. 
Peñaloza no nos permite recoger los datos que nos serían indispensables para hacer la historia de esos gloriosos 90 días". ${ }^{213}$ Finalmente confiesa:

No nos lisonjeamos de ofrecer al lector una obra acabada; esta obra sería el fruto de una consagración y de un tiempo del que no podemos disponer.

Pero hemos recorrido ligeramente el largo y complicado período de nuestra revolución, y aunque, no hemos trazado de él un cuadro completo, sino tocándolo apenas en sus más notables lineamientos, hemos hallado en todas partes el nombre del General Peñaloza [...] siempre de una manera distinguida y honorable para él.

Trazados estos rasgos al correr de la pluma, dejamos a la inteligencia de nuestros lectores el suplir con ella, la deficiencia de que han de adolecer naturalmente. $^{214}$

El carácter panfletario de ambas obras las exime de la obligación de presentar un texto rigurosamente fundamentado, pero su palpitación vital cumple la función de estrechar vínculos con el lector. También coinciden ambos autores cuando fundamentan la necesidad de difundir adelantos imperfectos: consideran imperioso rectificar los errores de la interpretación popular. Se pretende revelar al pueblo la "verdad" ocultada por el poder, y en Rasgos biográficos este propósito se metaforiza en el armado de una suerte de intriga policial en la que se van recolectando las pruebas de un delito. Así como Hernández anuncia que va a revelar un crimen, Facundo se ha levantado de la tumba para revelar un secreto. Los objetivos políticos son diferentes, pero la publicación es portadora de un sentido oculto, desenmascaradora de una mentira, y por eso puede aspirar a cumplir, de todos modos, la función de un documento histórico verídico. Con ese mismo fin se ha elegido biografiar a un caudillo, porque interrogando su figura se busca desentrañar un "enigma de la patria".

Por consiguiente, el texto debe desnudar secretos. Según Hernández, Peñaloza no fue asesinado el 12 de noviembre: "Lo vamos a probar evidentemente, y con los documentos de ellos mismos". ${ }^{215}$ Más adelante asevera:

${ }^{213}$ Ibidem, p. 38.

${ }^{214}$ Ibidem, p. 47. También Sarmiento había hecho declaraciones del mismo tenor: "Este estudio, que nosotros no estamos aún en estado de hacer, por nuestra falta de instrucción filosófica e histórica, hecho por observadores competentes habría revelado [...]" (Sarmiento, 1963, p. 15); “¡Cuántas páginas omito! ¡Cuántas iniquidades comprobadas y de todos sabidas callo!” (ibidem, p. 21); "ya es demasiado detenerme sobre este punto" (ibidem, p. 95). 
Sabemos muy bien que nuestra tarea de hacer conocer la historia de ese patriota infortunado nos valdría, cuando menos, de parte de sus encarnizados enemigos, la burla, los apóstrofes groseros, el insulto y la calumnia. Pero, por odiosa que esta tarea resulte a ciertos ojos, no puede semejante consideración influir más en nosotros que el sentimiento de justicia que coloca la pluma en nuestras manos. ${ }^{216}$

Luego reafirma: "Esa es la tarea que emprendemos con el sentimiento de la rectitud y justicia"; ${ }^{217}$ y concluye:

Queremos, al terminar nuestro trabajo, darle cima narrando un hecho histórico, de esa fecha, que al par que caracteriza bien al héroe que el partido unitario acaba de sacrificar a sus iras, daguerrotipa mejor la fisonomía que el coronel Peñaloza había alcanzado a reunir. ${ }^{218}$

Las apelaciones al lector abundan en estos textos apuntando a su convencimiento a favor de la causa expuesta; en los Rasgos biográficos, se busca establecer un diálogo intimista para convocar al lector como un testigo del juicio a Sarmiento. Por otra parte, la publicación periodística espaciada en entregas semanales impone este recurso para recuperar el nexo con el público. Se insiste en hacerlo partícipe de la investigación, ya que ve los documentos y comprueba la injusticia: "No tenemos tiempo para detenernos más en hacer notar otras contradicciones de esos documentos fraguados para encubrir un crimen horroroso. Nuestros lectores las descubrirán fácilmente". ${ }^{219}$

Este recurso es también una característica de los discursos agónicos; ${ }^{220}$ y en una ciudad como Paraná el círculo se achica: frecuentan el mismo club donde han

${ }^{215}$ Hernández, 2005, p. 19.

${ }^{216}$ Ibidem, p. 27.

${ }^{217}$ Ibidem, p. 28.

218 Ibidem, p. 45. Por su parte, aclaraba Sarmiento: "Es de otro personaje de quien debo ocuparme. Facundo Quiroga es el caudillo cuyos hechos quiero consignar en el papel [...]. ¿Quién lanzó la bala oficial que detuvo su carrera? [...] La historia explicará este arcano" (Sarmiento, 1963, p. 20).

${ }^{219}$ Hernández, 2005, p. 23.

220 "Referiremos ligeramente a nuestros lectores, un episodio [...] que servirá para que puedan apreciar mejor el temple generoso de ese esforzado caudillo" (ibidem, p. 41); "¿Queréis saber cuál fue el castigo? Véanlo, los que lo han retratado animado de sentimientos sanguinarios" (ibidem, p. 42); "Nuestros lectores no deben haber olvidado que el supuesto Gobierno Nacional 
contemplado el mismo escenario: "Este episodio lo conocerán, sin duda, muchos de nuestros lectores, pues es el que ha sido conmemorado en el cuadro trazado por el señor Rawson, que ha estado por mucho tiempo expuesto en los salones del Club Socialista". ${ }^{221}$ En la misma línea, también el Facundo ofrece numerosos ejemplos. ${ }^{222}$

Por otra parte, cabe destacar que aunque la utilización del género biográfico comparta modalidades discursivas no sólo con el Facundo sino también con la biografía de Aldao e incluso con la de Urquiza (insertada en la Campaña en el Ejército Grande), en la obra de Hernández se invierte -como se ha dicho- el objetivo perseguido. Esa desviación referencial asume evidente intención polémica cuando se le asignan al caudillo las más elevadas cualidades humanas, y a veces, casi sobrehumanas. El Chacho es aquí un patriarca venerable, un héroe a quien el atropello de la represión le conferirá la santidad del martirio: un caudillo "valiente, generoso y caballeresco", "una de aquellas almas inspiradas sólo en el bien de los demás, uno de aquellos corazones que no conocen jamás el odio, el rencor, la venganza ni el miedo", "un héroe sencillo y modesto", luego "prestigioso" y que hace "prodigios de actividad y de arrojo", "noble y desinteresado", que se preocupa solo por la "santidad de su objeto", de "temple generoso", que hace rezar a unos asesinos en la tumba de su víctima en lugar de degollarlos en venganza y con Benavídez "profesa una amistad franca y leal”. También cuando Quiroga irrumpe en el texto, un proceso de idealización polemiza con el Facundo de Sarmiento: se lo ve "haciendo las veces de padre" con el Chacho, como un "célebre y prestigioso caudillo", que aprecia "dignamente" al Chacho y que goza de “crédito y prestigio", y siempre en ejército regular y organizado según las órdenes de sus superiores.

En ambas obras, a su vez, los retratos de los caudillos parten de la infancia por medio de anécdotas recuperadas del registro oral. La pintura de esa niñez incluye la presencia de alguna señal que anticipa el futuro. El Chacho está a cargo de un sacerdote,

[...]" (ibidem, p. 41); "No nos lisonjeamos de ofrecer a nuestros lectores [...]" (ibidem, p. 47) ; "[...] dejamos a la inteligencia de nuestros lectores el suplir con ella, la deficiencia de que han de adolecer naturalmente" (ibidem, p. 47).

${ }^{221}$ Ibidem, p. 39.

222 "El que haya leído las páginas que preceden creerá que es mi ánimo trazar un cuadro apasionado de los actos de barbarie" (Sarmiento, 1963, p. 20); "Si el lector se fastidia con estos razonamientos contarele crímenes espantosos" (ibidem, p. 106); "Por la puerta que deja abierta el asesinato de Barranca Yaco entrará el lector conmigo en un teatro donde todavía no se ha terminado el drama sangriento" (ibidem, p. 202), passim. 
es criado en un ambiente de afecto y goza luego de la protección paternal de Quiroga. En la biografía de Sarmiento, en cambio, Facundo vive una infancia violenta y viciosa que lo prefigura como "gaucho malo"; él también, entonces, está signado por el determinismo.

Cuenta Hernández que Peñaloza perteneció a una familia notable, respetable y antigua de La Rioja y quedó a cargo de un anciano sacerdote que lo apodó "Chacho". Cuando Quiroga lo llevó a su lado, lo trató siempre con afecto (lo llamaba "Chachito") y así fue ascendiendo en el ejército, acompañado siempre por el cariño de la gente. Se insiste, sobre todo, en destacar sus rasgos de humanidad y su apego a la justicia. Hasta el apodo lo liga a un mundo impregnado de afectividad: el sobrenombre "Chacho" le es impuesto -según cuenta Hernández-por un "respetable anciano", el sacerdote que lo tiene a su cuidado, que "balbuciente ya por su avanzada edad" no puede pronunciar la palabra "muchacho" con dicción clara, y la reiteración impone la aféresis "Chacho" con la cual todos lo identificaron posteriormente. ${ }^{223}$ Esta tierna etimología actúa como una antítesis de la anécdota en la que Sarmiento narra cómo se gestó el epíteto épico de su personaje: el "Tigre de los Llanos".

La figura del tigre como metáfora del salvajismo y la fiereza aplicada al "bárbaro" también es recuperada por Hernández para revertirla sobre Sarmiento y los de su facción, cuyas "manos van siempre a cebarse a las entrañas de sus enemigos", engañan con "zalamerías de tigres" y actúan con alevosía dejando "la cola afuera". 224

También se revierte el símbolo del puñal (identificado por Sarmiento con la "barbarie") ${ }^{225}$ y la condena del ajusticiamiento por degüello al ser empleados por el partido que se autoidentifica con la "civilización". ${ }^{226}$ En este caso, la exhibición de contradicciones con el discurso civilizatorio del Facundo se extiende al universo

\footnotetext{
${ }^{223}$ Hernández, 2005, p. 28.

${ }^{224}$ Esta imaginería se concentra en el apartado "Revelación de un crimen" (ibidem, pp. 19-26).

${ }^{225}$ En el apartado "La política del puñal", Hernández insiste sobre esta contradicción: "clavar el puñal", "puñal de los asesinos", "caer bajo el puñal", "puñal unitario", "El puñal está levantado".

226 También corresponden al mismo apartado -"La política del puñal"- las referencias al degüello: "El general Peñaloza ha sido degollado", "para castigar a los degolladores", "al festín del degüello", "fue enseguida degollado".
} 
discursivo de la Campaña en el Ejército Grande, donde Sarmiento había consustanciado al puñal con la "barbarie" y había anatemizado de la práctica del degüello. ${ }^{227}$

En su empleo del lenguaje como arma, Hernández recupera el típico anatema rosista "salvajes unitarios". Y justamente, se trata de otro de los emblemas de la "barbarie" enumerados por Sarmiento en la Campaña; cuando registra que Urquiza ha vuelto a ponerlo en vigencia, lo denuncia como un anacronismo peligroso para la paz de la República y se detiene en el análisis de las connotaciones aterradoras de ese oxímoron. $^{228}$ Hernández es plenamente consciente de la fuerza irritativa que desencadena su adhesión a esta recuperación apelativa asumida por Urquiza, y después de presentar la noticia ("El asesinato del Gral. Peñaloza es la obra de los salvajes unitarios") $^{229}$ y de transcribir los primeros comunicados recibidos, inaugura su impetuoso alegato con esta aseveración rotunda: "Los salvajes unitarios están de fiesta". ${ }^{230}$ El uso de este epíteto se incrementa en los apartados que integran la introducción a la biografía propiamente dicha, ${ }^{231}$ donde se preferirá la reiteración de “partido de asesinos". Particularmente en el apartado "La política del puñal”, Hernández los asocia a una bestia feroz:

Y el partido unitario es insaciable.

Vuelve a todos lados su rostro sangriento, sus ojos inyectados de sangre, sus manos manchadas con sangre de hermanos; y sus ojos están siempre buscando una víctima, y sus manos van siempre a cebarse a las entrañas de sus enemigos. ${ }^{232}$

Y el apartado siguiente, "Revelación de un crimen", concluye con una terminante animalización: "Los salvajes unitarios han dejado también la cola afuera". 233

${ }^{227}$ Por otra parte, el degüello de Peñaloza fue aplaudido en el 63 por el contradictorio Sarmiento en una famosa carta ampliamente repudiada por la posterioridad. En el apartado 5 se retoma el análisis de esta contradicción que Hernández volverá a denunciar cuando polemice desde $L a$ Libertad a propósito de la publicación de una nueva versión de la biografía de Peñaloza, en 1875. Ver 5.3.

${ }^{228}$ Sarmiento, 1997, p. 183.

${ }^{229}$ Hernández, 2005, p. 13 (en el apartado inicial: “Asesinato atroz”).

${ }^{230}$ Ibidem, p. 15. Así comienza el apartado "La política del puñal".

${ }^{231}$ Como se verá más adelante, esa introducción -caracterizada por su discurso virulento- será suprimida en la $2^{\mathrm{a}}$ versión (1875).

${ }^{232}$ Hernández, 2005, p. 16.

${ }^{233}$ Ibidem, p. 26. 
Por otra parte, con la presencia tácita de la célebre antinomia se reafirma la inscripción de Rasgos biográficos en el marco de la gran polémica nacional, ya que aun sin utilizar más que una única vez el vocablo que designa explícitamente al polo negativo ("Cuánta barbarie"), ${ }^{234}$ se actualiza su contenido referencial por medio del empleo de lexemas de su campo semántico. En doce oportunidades se usa alguno de sus derivados: "bárbaros", "bárbaro", "bárbaramente", "bárbara”. 235

El lexema hace su aparición en el primer apartado (“Asesinato atroz”): "Que la maldición del cielo caiga sobre sus bárbaros matadores”; y se reitera a continuación en la transcripción de la nota de un lector de Rosario que le comunica a Hernández "la triste noticia" de que Peñaloza ha sido "bárbaramente degollado". 236

La tercera ocurrencia está dirigida a Sarmiento, el creador de su estatuto paradigmático:

El general Peñaloza ha sido degollado.

El hombre ennoblecido por su inagotable patriotismo, fuerte por la santidad de su causa, el Viriato Argentino, ante cuyo prestigio se estrellaban las huestes conquistadoras, acaba de ser cosido a puñaladas en su propio lecho, degollado, y su cabeza ha sido conducida como prueba del buen desempeño del asesino, al bárbaro Sarmiento. $^{237}$

La invectiva se extiende también al partido gobernante:

[...] recuerde a sus amigos Benavídez, Virasoro, Peñaloza, sacrificados bárbaramente por el puñal unitario; recuerde los asesinos del Progreso, que desde 1852 lo vienen acechando, y medite sobre el reguero de sangre que vamos surcando hace dos años, y sobre el luto y orfandad que forma la negra noche en que está sumida la República [...]. ${ }^{238}$

${ }^{234}$ Ibidem, p. 14.

${ }^{235} \mathrm{El}$ uso de este lexema se concentra fundamentalmente en los primeros apartados (del 1 al 4), que conforman la Introducción de la biografía propiamente dicha y que serán suprimidos en la republicación que hará Hernández en 1875. En esos primeros apartados se cuentan 9 empleos de los 13 totales; de los otros cuatro usos registrados en los capítulos que describen la vida de Peñaloza, Hernández conservará dos y suprimirá dos, como se señalará más adelante.

${ }^{236}$ Hernández, 2005, p. 13. Los destacados en negrita son nuestros.

${ }^{237}$ Ibidem, pp. 15-16.

${ }^{238}$ Hernández, 2005, p. 17. 
Debemos hacer notar que ésta es la única herida que el general Peñaloza ha recibido en su vida de combates; la segunda es la que le han abierto sus bárbaros asesinos. $^{239}$

Más adelante, cuando Hernández apunta contra la práctica del degüello, vuelve a revertir una propuesta contra su propio autor, ya que Sarmiento, después de haberlo inscripto entre los emblemas de la barbarie en el Facundo y en la Campaña, en la coyuntura política presente está, como se sostiene en los Rasgos biográficos, en connivencia con los responsables de "la bárbara degollación del general Peñaloza". 240 Además, Hernández inscribe la ejecución del Chacho en una tradición histórica de oprobio al asociarla a otros dos ejemplos de prácticas de la barbarie que considera paradigmáticos: el fusilamiento de Dorrego ${ }^{241}$ y el asesinato de Quiroga. ${ }^{242}$

Otra reiteración del lexema se refuerza asociada al emblemático puñal (que el biografiado no quiso usar contra sus adversarios):

Represéntese el cadáver del general Peñaloza degollado, revolcado en su propia sangre, en medio de su familia, después de haber encanecido en servicio de la patria, después de haber perdonado la vida a sus enemigos más encarnizados, después de haber librado de la muerte hasta al bárbaro instrumento que los unitarios han empleado para

${ }^{239}$ Ibidem, p. 28. Como se verá en el apartado 4.1., en la versión de 1875 Hernández se esmerará en sustituir el empleo de este lexema para moderar su prosa virulenta. En este caso puntual, reemplazará "bárbaros" por "crueles", un atributo más neutro.

${ }^{240}$ Ibidem, p. 19.

241 "La revolución encabezada por el general Lavalle, en Buenos Aires, el $1^{\circ}$ de diciembre de 1828, y que dio por resultado la caída del gobernador Dorrego y su bárbaro fusilamiento en los campos de Navarro por orden de Lavalle, alarmó justamente a los gobernadores de las provincias, a quienes Lavalle había desdeñado dirigirse para invitarlos a tomar parte en su movimiento" (Hernández, 2005, p. 30). El calificativo destacado será suprimido en la reedición de 1875.

242 “Quiroga, que a la sazón se hallaba en Buenos Aires, marchó en esa comisión con el carácter de mediador, en diciembre de aquel año, y a su regreso tuvo lugar en Barranca Yaco, el 16 de febrero de 1835, el bárbaro asesinato de este terrible y poderoso caudillo, muriendo también con él su secretario, el coronel Mayor José Santos Ortiz, los nueve individuos de su comitiva y el correísta Luegues, que dirigía la galera" (ibidem, p. 35). En este caso, Hernández conservará el lexema en la reedición de 1875. 
hundirlo en el cuello del caudillo más valiente y más humano que ha tenido el interior del país. ${ }^{243}$

Se registra también una prolongación internacional de la barbarie: "Estas hordas que con el bárbaro Flores abrazan la República Oriental, formadas y pagadas con el oro de la Nación Argentina". ${ }^{244}$ Y por último, se proyecta ese anatema en la apreciación sintética de la campaña mitrista: "Esta fue la situación de las provincias en aquel momento, aprestándose a una guerra sangrienta y, lo decimos con dolor, horrible y hasta bárbara". 245

Ya en el comienzo del vibrante alegato del apartado titulado "La política del puñal", se había descubierto otro objetivo manifiesto en la publicación de Hernández: reprochar a Urquiza su inacción política y sus negociaciones con el gobierno nacional. Las reiteradas advertencias a Urquiza para que se cuide de los designios del poder político de Buenos Aires se asocian siempre a esa actitud crítica):

¡Tiemble ya el General Urquiza: que el puñal de los asesinos se prepara para descargarlo sobre su cuello! Allí, en San José, en medio de los halagos de su familia, su sangre ha de enrojecer los salones tan frecuentados por el partido unitario. ${ }^{246}$

Este uso de "la palabra profética", ${ }^{247}$ característico del género panfletario, ${ }^{248}$ también había sido puesto en práctica por Sarmiento: a lo largo del Facundo se reiteran premoniciones sobre el futuro del país. Pero en la confrontación polémica que Hernández entabla con Sarmiento, se va revelando que hay una filiación subterránea

${ }^{243}$ Hernández, 2005, pp. 17-18 (apartado "La política del puñal”, que Hernández suprimirá en 1875).

${ }^{244}$ Hernández, 2005, p. 18.

${ }^{245}$ Ibidem, p. 31. En este pasaje, la reedición de 1875 conservará el lexema.

${ }^{246}$ Hernández, 2005, p. 17. La exhibición sin ambages de un tono recriminatorio no parece haber sido un gesto disociado del inmediato cierre de El Argentino, un órgano subsidiado por el urquicismo.

${ }^{247}$ La presunta profecía se cumplirá a medias, ya que serán los que le reprochan su traición política los que inscriban el asesinato de Urquiza en la cadena de la barbarie. Pero el predominio del tono crítico del texto de Hernández dará pie en 1875, cuando se publique una segunda versión de esta biografía, para que la reiterada técnica polemista de la reversión calificativa esta vez a cargo de sus adversarios- lea esas "advertencias" como "amenazas" que se han concretado.

${ }^{248}$ Angenot, 1982, p. 97. 
que vincula a dos adversarios (por más que, aparte de una posición política, los separe su aprendizaje vital: tienen un vínculo diferente con el ámbito rural). Ninguno de los dos ha tenido formación académica, ambos se han fogueado en la discusión política acalorada y utilizan con naturalidad el discurso panfletario porque ninguno de ellos siente la necesidad de enmascararlo; no tienen por qué guardar la formalidad de un prestigioso jurista como el Dr. Alberdi. Hernández ha leído el Facundo, la Campaña, muy probablemente también Las ciento y una, artículos periodísticos publicados en Buenos Aires, y no podrá evitar que la contundente prosa del "odiado Sarmiento" ejerza una influencia insospechada cuando decida incursionar en el género biográfico.

Aunque se trate de rasgos típicos de la retórica romántica, ese ritmo ternario que resuena en el Facundo desde su Introducción, parece proyectarse sobre el discurso de su impugnador. Hernández presenta a la víctima como el caudillo más "prestigioso, generoso y valiente"; se refiere irónicamente al partido del gobierno como el que invoca "la ilustración, la decencia, el progreso"; describe también con este ritmo la situación del "bárbaro", a quien "una sed de sangre lo mortifica, lo sofoca, lo embrutece", y lo opone a quien actúa con otros parámetros: "como lo exige la moral, la justicia y la humanidad"; luego se refiere a los que frente a Urquiza se proponen "adularlo, cortejarlo, complacerlo en cuanto desee, mostrarse con él solícitos, afables y cariñosos"; y también la apreciación sintética de un clima social que se está gestando palpita rítmicamente: "el descontento, el malestar y la agitación". ${ }^{249}$ Hasta la articulación del discurso se ajusta con naturalidad a la estructura triádica:

Así lo hicieron cuando asesinaron a Benavides. Así lo hicieron cuando asesinaron a los Virasoro. Así lo harán ahora que han asesinado a Peñaloza. [...] Peñaloza no ha sido perseguido. Ni hecho prisionero. Ni fusilado. Ni su muerte ha acaecido el 12 de noviembre. Lo vamos a probar evidentemente, y con los documentos de ellos mismos. ${ }^{250}$

Estos dos adversarios se hermanan tanto en las explosiones de indignación, en las apremiantes preguntas retóricas, en las advertencias imperativas, en las

\footnotetext{
${ }^{249}$ Todas las citas pertenecen al apartado "La política del puñal” (ibidem, pp. 15-18).

${ }^{250}$ Este ritmo ternario es particularmente pronunciado en los dos apartados: "La política del puñal" y "Revelación de un crimen".
} 
imprecaciones, en la capacidad espontánea para el insulto, como en la despreocupación por corregir desprolijidades formales: “¡Maldito sea! Maldito, mil veces maldito sea el partido envenenado con crímenes”, “¿En guardia, general Urquiza! El puñal está levantado [...] ¡En guardia, general Urquiza! [...] Es vuestra propia energía. ¡Alerta!, general Urquiza” [...], “QQué infames!”, “Cómo es entonces, que el día 13 de noviembre, es decir, al día siguiente, Echegaray dirige desde Pocitos, provincia de Córdoba, la siguiente nota al coronel Domínguez?" “Y su parte y nota de fecha 12 que dicen que lo sorprendió y fusiló esa madrugada?"251

En suma, es en el desprejuicio para liberar la pasión, que la prosa polémica de Hernández está más cerca de Las ciento y una que de las Quillotanas.

\subsection{Otras semblanzas del Chacho Peñaloza}

Además de José Hernández, hubo otros escritores que coincidieron en retratar la figura del caudillo de los Llanos. Por un lado, se registra un antecedente: Federico de la Barra publicó en 1862, en el periódico La Discusión de Montevideo, una nota biográfica que Evaristo Carriego republicó en El Litoral de Paraná ese mismo año. Por otro lado, al recibir la noticia del asesinato y desde una óptica poética, Olegario V. Andrade compuso un poema sobre el Chacho, aunque esta obra sólo se conocerá fugazmente en 1870.

\subsubsection{Federico de la Barra}

Federico de la Barra fue un periodista de extracción federal de amplia trayectoria. $^{252}$ Durante el gobierno rosista, había sido el redactor de El diario de la Tarde, periódico cuasi oficial, y esta condescendencia con el poder de turno le acarreará cierta desconfianza en su carrera periodística posterior. ${ }^{253}$ Sin embargo, su filiación

${ }^{251}$ Hernández, 2005, pp. 15-26.

${ }^{252}$ Néstor Tomás Auza lo menciona entre los hombres destacados de la Confederación "que fueron sólo periodistas, como Alejandro Pesce, Jorge Alzugaray, Federico de la Barra y Fermín de Irigoyen" (Auza, 1978, p. 129).

${ }^{253}$ Sus antagonistas porteños habían sacado a la luz un trabajo poco conocido en el que De la Barra atacaba al caudillo entrerriano, que titularon Federico de la Barra; autor de "La vida de un traidor: el general Justo José de Urquiza, datos para la historia”. Una reedición de 1915 con una introducción de José Arturo Scotto (Buenos Aires, Empresa Reimpresora y 
federal se tradujo en 1852 en un cerrado apoyo a Urquiza, y luego de la revolución de septiembre, secundó al general Lagos en su intento de someter por la fuerza a Buenos Aires mediante el sitio militar iniciado el $1^{\circ}$ de diciembre. Posteriormente continuó oponiéndose al círculo porteño. ${ }^{254}$

Con este objetivo, el 20 de febrero de 1853 De la Barra comenzó a publicar El Federal Argentino en San José de Flores, donde funcionaba el centro político de los sitiadores. ${ }^{255}$ Era un periódico oficial de reducida capacidad y escasa tirada, que se dedicó a ofrecer información sobre el sitio y a criticar a los hombres de Buenos Aires discutiendo, mediante la exposición de documentación pertinente, la legitimidad de la secesión. Se editó durante unos meses, hasta que Urquiza levantó el sitio el 13 de junio de 1853, aceptando pacíficamente la secesión de Buenos Aires y estableciendo en Paraná la capital de la Confederación. ${ }^{256}$

En 1854, distanciado definitivamente del estado separatista, se radica en Rosario donde funda, el 25 de mayo, el primer periódico de la ciudad: La Confederación. ${ }^{257}$ Desde este medio De la Barra difundirá la política de Urquiza, promoviendo las ideas de la Constitución Nacional y la organización del país sobre bases federales. ${ }^{258}$

Administradora de Obras Americanas)- puede consultarse en la Biblioteca Nacional de Maestros (SC 106-02/P SC 036-01-021; Ej. n 72609, donación de Alfredo Colmo).

${ }^{254}$ Dice Auza: "De la Barra figura en San José, junto con Marcos Paz, Vicente Fidel López, Ezequiel Ramos Mejía y Francisco Pico entre los colaboradores más inmediatos del general Lagos, siendo incluso De la Barra electo como representante ante la Convención que llegó a reunirse en San José de Flores, en el mes de junio, correspondiéndole integrar la Comisión encargada de expedirse sobre la Constitución de Mayo sancionada en Santa Fe" (Auza, 1978, p. 131).

${ }^{255}$ Según Galván Moreno, en este mismo período De la Barra está a cargo de la redacción de $L a$ Crónica, periódico "de alta doctrina” en el que lo sucederá luego Carlos Tejedor; pero al referirse a El Federal Argentino, no menciona a ningún otro redactor (Galván Moreno, 1944, p. 196).

${ }^{256}$ Con este periódico polemizaba El Progreso de Buenos Aires, bajo la redacción de José M. Saborido, pues los hombres del nuevo círculo porteño -en su mayoría integrado por los antirrosistas que vuelven del destierro- no pueden aceptar que dos ex rosistas como Federico de la Barra y el general Lagos, una vez vencido Rosas, se unan a Urquiza para actuar en contra de su provincia; en este contexto, el periódico que redacta es agredido sin ningún tipo de eufemismos.

${ }^{257}$ Su nombre aparece, como era costumbre, debajo del título del diario.

${ }^{258}$ Al promediar 1854, era notable el crecimiento de la ciudad de Rosario: su puerto concentró mucha actividad luego de la revolución de septiembre, pasó a contar con una aduana nacional y era además el asiento de la principal sucursal del Banco Nacional. En esta línea, también la vecina Paraná experimentaba un crecimiento paralelo al transformarse en capital de la Confederación. Pero así como ambas ciudades vivieron simultáneamente ese proceso ascendente también sufrieron desencanto y empobrecimiento cuando se disolvió la 
La Confederación fue ganándose un lugar destacado dentro del ámbito federal y bajo la tutela de Federico de la Barra se promocionaban desde Rosario todas las novedades de la política orquestada por Urquiza hasta 1858. Luego se orientó a favor de la candidatura presidencial de Santiago Derqui y apoyó su gestión durante su breve administración presidencial signada por el derrumbe del gobierno de Paraná. ${ }^{259}$

Mientras tanto, su raigambre federal lo mantendrá en las filas opuestas a los políticos porteños sobre todo al defender la gestión de Derqui, de quien era amigo personal. De la Barra acompañó a éste último aún sabiendo que el fin de la Confederación estaba cerca y como firme bastión de la política derquista, en 1860 es elegido diputado nacional en representación de San Juan.

Este hecho es cuestionado duramente por Sarmiento quien lo denuncia como un atropello autoritario en un panfleto publicado en El Nacional de Buenos Aires, en el que describe la vida del Dr. Antonio Aberastain, su íntimo amigo recientemente asesinado por el gobernador José Virasoro impuesto por Derqui. No obstante las quejas de Sarmiento desde Buenos Aires, Federico de la Barra asumirá la candidatura por San Juan debiendo alternar sus tareas de periodista en Rosario con las legislativas en Paraná hasta 1861, en que cae la Confederación y se dirige al destierro acompañando a Derqui. $^{260}$

\subsubsection{De la Barra y la provincia de San Juan}

En las postrimerías de la Confederación la provincia de San Juan fue castigada particularmente por el enfrentamiento enconado de los partidos en pugna. La zona de Cuyo, vecina de los Llanos riojanos, se convertiría así en una de las regiones más conflictivas de la Nación; allí se experimenta la mayor crisis política y militar del decaído gobierno confederal, y se sucede una serie de crímenes políticos que generaron el escándalo de todo el país y que fueron reflejados por la prensa de ambos bandos, pero sobre todo por El Nacional de Buenos Aires, donde Sarmiento se desempeñaba como

Confederación. Ese proceso de ascenso y caída fue acompañado por el nacimiento y muerte de numerosos órganos periodísticos. Ver De Marco, 1961.

${ }^{259}$ La Confederación de Rosario (1854) se imprimió en la casa de Tomás Peñaloza. Fue inicialmente bisemanal, luego trisemanal (salía martes, jueves y sábados) hasta 1861, año en que cayó la Confederación. La colección completa -donada en 1894 por Gabriel Carrasco- se encuentra en la Biblioteca Popular de Rosario.

${ }^{260}$ De la Barra cierra entonces el periódico La Confederación y se exilia a Montevideo. 
redactor. Del bando federal serán asesinados Benavídez (1857) y Virasoso (1860), y en el sector oponente, Aberastain (1861), el amigo de Sarmiento. ${ }^{261}$

La provincia de San Juan concentró de este modo una de las últimas reacciones del partido federal; el final anunciado de Benavídez en San Juan en $1857^{262}$ a manos de partidarios del liberalismo liderado por Antonino Aberastain profundiza el conflicto y el acercamiento de Urquiza a los porteños hace entrar en crisis la frágil estabilidad de las fuerzas políticas. ${ }^{263}$

La prensa reacciona ante la escalada de los sucesos; mientras Sarmiento en El Nacional celebra la muerte de Benavídez, desde Rosario La Confederación de Federico de la Barra pide venganza sobre sus asesinos y desde Paraná La Reforma Pacífica de Nicolás A. Calvo se alarma acusando al "loco Sarmiento" de cebarse en un cadáver.

A este caos político y social se agregan las invasiones de Peñaloza. Derqui, para recuperar el orden de la provincia nombra sucesor a José Virasoro. Virasoro, para vengar la muerte de Benavídez apresa a Aberastain, que había hecho pública una "Protesta de Aberastain y demás amigos a la tiranía de José Virasoro", también publicada por Sarmiento en El Nacional en 1860.

Pero la situación en San Juan continúa oscureciéndose. El 16 de noviembre de 1860 es asesinado Virasoro en una acción que comprometía la participación de Sarmiento -o al menos la instigación por intermedio de sus escritos en la prensa porteña- y de su amigo Aberastain como artífice. Los periódicos opositores lo acusan de haber anunciado con anticipación la muerte del gobernador y de haberla orquestado con dinero porteño. Por su parte, Sarmiento había publicado el 18 de noviembre, antes de conocer la noticia de su muerte, un folleto titulado El tirano José Virasoro, ${ }^{264}$ en donde

${ }^{261}$ En el apartado 3.1. se verá cómo Sarmiento sigue atentamente todos los conflictos de su provincia desde la redacción de El Nacional de Buenos Aires y cómo concentra sus denuncias en la figura del caudillo riojano Peñaloza. Junto con los artículos periodísticos, Sarmiento publica folletos biográficos en los que detalla el enfrentamiento entre los dos bandos facciosos.

${ }^{262}$ El 23 de octubre de 1857. Los historiadores coinciden en señalar esta relación explicando que su esposa y amigos habían advertido la amenaza y se la habían comunicado a Urquiza pero sin embargo no pudieron evitar el final anunciado; Virasoro fue ultimado mientras estaba preso esperando la protección del general Urquiza que llega un mes tarde.

${ }^{263}$ Más adelante, la claudicación de Urquiza ya se hará palpable en la correspondencia numerosa que le envía Peñaloza a Urquiza y que éste no responde, pidiendo y esperando órdenes de un jefe de partido que ya había dado vuelta la página de la historia del federalismo nacional.

${ }^{264}$ Sarmiento, 1860. Puede consultarse en la Biblioteca de la Universidad Nacional de La Plata (Salas Especiales, Arm. 7, caja 2 de Sarmiento, ${ }^{\circ}$ 37). 
lo calificaba de "torpe mandón" y de "intruso gobernante" incluyendo piezas justificativas (cartas de Aberastain a Sarmiento, de Amado Laprida a Aberastain y de los hermanos Cayetano y José Virasoro) sobre cuya base se esforzaba por fundamentar una opinión objetiva frente al conflicto. ${ }^{265}$

En esta nueva textualización sobre un "caudillo", Sarmiento desecha el empleo de su antinomia y se limita a hacer disquisiciones legales sobre la necesidad que tienen las provincias de garantizar su vida institucional por medio de un gobierno central fuerte. Con este criterio, el folleto se convierte en una demanda imperativa a Derqui para que intervenga con "enérjicas medidas" en San Juan para evitar la profundización del conflicto. Sarmiento se refiere a Virasoro como un "tiranuelo", y un "lunar odioso en el aspecto lisonjero que la República presenta" luego de la reunificación, pero se resiste a recuperar los términos dicotómicos del Facundo. ${ }^{266}$

A su vez, para resolver la crisis de San Juan, Derqui manda como interventor al coronel Juan Sáa, quien no logra dominar el caos político y social de la zona cuyana. Como consecuencia, apenas dos meses más tarde, es asesinado el amigo íntimo de Sarmiento, Antonio Aberastain. ${ }^{267}$

Ante este nuevo estallido de violencia Sarmiento responde componiendo una biografía sobre Aberastain en la que comienza a atisbarse la recuperación tímida de su tesis. $^{268}$ La biografía se organiza en cinco capítulos que van relatando la vida de Aberastain fundamentalmente en San Juan, con un tono lúgubre y elegíaco. Sin embargo, se combinan aquí reflexiones sobre el desarrollo político de los

265 Sobre el final del folleto, antes de las cartas que incluye, Sarmiento declara: "La circunstancia de ser ministro de gobierno de Buenos Aires no me impone el deber de acallar por más tiempo mis sentimientos y afecciones como argentino y como vecino de San Juan. He esperado tranquilamente a que la tiranía y usurpación de D. José Virasoro asumiesen formas evidentes por sí mismas, fuera del alcance de la tergiversación del espíritu de partido [...]. Lo que he hecho por toda la República treinta años sin descanso, lo que no he dejado de hacer nueve consecutivos por Buenos Aires, nadie hallará mal que lo haga un día por San Juan, mis deudos y mi familia" (ibidem, p. 20).

${ }^{266}$ Ibidem, p. 14.

${ }^{267}$ El 18 de enero de 1861. Este hecho, por otra parte, apura el desequilibrio del país, pues Mitre lo usa de excusa para quejarse ante Derqui, para intervenir en hechos que se suceden fuera de la jurisdicción de su provincia y afianzar así su hegemonía política en el interior.

${ }^{268}$ La pieza incluida en el tomo 45 de las Obras Completas, se titula "El Doctor Antonino Aberastain y la revolución de San Juan" y se compone del folleto "El tirano José Virasoro", la "Protesta del Doctor Aberastain y de más víctimas de la tiranía de Don José Antonio Virasoro en San Juan" y del folleto "El Doctor Antonino Aberastain". Para este análisis tomamos la edición de Universidad de La Matanza (Sarmiento, 2001, XLV, pp. 9-128). 
acontecimientos sanjuaninos en relación con la organización de la Convención Nacional Constituyente y Sarmiento usa el texto para condenar, desde su opinión facciosa, la imposición de la candidatura de Federico de la Barra, un ex rosista y urquicista, y actualmente su contrincante político:

No volvía, en efecto, la población del estupor de saber que ella elegía a Barra, su representante en la Convención, de que sólo había creído dignos a Carril, Aberastain, Oro, Sarmiento, Rawson. ${ }^{269}$

A lo largo de tres páginas se ocupa minuciosamente de cuestionar la legitimidad de este nombramiento y de alertar sobre el cambio de política que concluyó con el asesinato de su amigo. ${ }^{270}$

Sarmiento personaliza a San Juan convirtiéndolo en personaje inicial del texto: “el entenado del Gobierno Nacional” que está signado por una mala estrella. ${ }^{271}$ Luego, en este escenario dominado por la exaltación de las masas indígenas, de la chusma y el pueblo envilecido se destaca la virtud moral de Aberastain, que será perseguido por las "hordas de bárbaros que habían de matarlo" mientras se dedicaba a fomentar la minería y a garantizar el progreso de los sanjuaninos. ${ }^{272}$ El tópico de la barbarie se repondrá luego sólo en dos menciones: al referirse a las "bárbaras matanzas de mujeres y niños" que ha cometido Virasoro, ${ }^{273}$ y a "las depredaciones de los bárbaros" (llama así a los indios que asolaban la zona cuyana). ${ }^{274}$ Después de esta escueta introducción, hacia el cierre de este texto básicamente elegíaco se repone la tesis con todo su esplendor:

Del sentimiento íntimo de la provincia de San Juan, salió hace quince años esta frase, que dio la vuelta del mundo: Civilización o barbarie; el Alfa y la Omega de nuestras luchas. ${ }^{275}$

${ }^{269}$ Ibidem, p. 32.

270 "Barra, senador y convencional por San Juan, era la mácula visible que mostraba a los ojos de todos la burla que se hacía del Congreso; [...] ¿Podría llevarse la ceguera a mayor grado que tener por senadores por San Juan a Barra y Guido, por diputados a Virasoro y Álvarez Condarco [...]" (ibidem, pp. 36-38).

${ }^{271}$ Ibidem, p. 22.

${ }^{272}$ Sarmiento, 2001, XLV, p. 26.

${ }^{273}$ Ibidem, p. 44.

${ }^{274}$ Ibidem, p. 50.

${ }^{275}$ Ibidem, p. 57. 
Así Sarmiento insiste una vez más en su tesis; analiza los hechos con un ánimo pesimista y vuelve a fustigar a sus adversarios ubicándolos en el polo negativo de la antinomia irreductible, que readquiere vigencia cuando retoma personajes conocidos en textos anteriores. Sarmiento recuerda una escena con el emperador de Brasil, Pedro I, quién había sido destacado en la Campaña en el Ejército Grande como modelo de gobernante civilizado:

El joven emperador del Brasil que leyendo algunos apuntes sobre hombres y costumbres de San Juan, preguntaba con interés, como la figura que más había excitado su simpatía, y "ese doctor Aberastain tan virtuoso, ¿dónde esta ahora?” verá por estas páginas, si caen bajo sus ojos, que yace, no diremos asesinado que es palabra oficial, muerto, víctima de haber creído con su pueblo en el derecho y la justicia en su patria. El otro libro que lea le explicará los instrumentos y la causa. Siempre la barbarie. ${ }^{276}$

El texto también incluye menciones aisladas de Peñaloza, y de sus invasiones a San Juan, pero Sarmiento lo incorpora entre los elementos de desorden general en que se encuentra la zona de Cuyo, sin ensañarse en opiniones calificativas personales. ${ }^{277}$

\subsubsection{La “Organización Nacional” de Mitre y Sarmiento}

Una vez que la batalla de Pavón (1861) pone fin a la Confederación Argentina, Buenos Aires comienza a ejecutar una política de reunificación definitiva del país en función de sus intereses políticos y económicos; en este contexto, la actitud contemporizadora de Urquiza, que había optado por la convivencia pacífica aislándose en Entre Ríos, fue interpretada por la mayoría de sus antiguos partidarios como una traición. ${ }^{278}$

${ }^{276}$ Ibidem, p. 58.

277 "Virasoro para no anunciar la proclamación de la Constitución reformada, fingió, a la llegada del correo, que Peñaloza invadía a San Juan [...]" (ibidem, p. 38); "y como de propia experiencia sabía el Gobierno nacional qué estragos habían hecho en San Juan las bandas indisciplinadas del Chacho [...]" (ibidem, p. 44).

${ }^{278}$ En su opúsculo La guerra o el cesarismo en el Nuevo Mundo (incluido entre los borradores de El crimen de la guerra), Alberdi emite un juicio implacable acerca de las batallas de Caseros, Cepeda y Pavón: "Las tres han sido dadas por la libertad naturalmente. Sin perjuicio de esta mira, que no es un hecho todavía, las tres batallas han producido al autor estos servicios: la 
Buenos Aires, por su parte, inicia el proceso de imposición política sobre el interior del país; asegurado el Litoral, Mitre organiza sus fuerzas bajo el mando de Paunero y las dirige hacia la zona oeste. Sarmiento abandona su labor al frente de la redacción de El Nacional y se suma a la expedición con el cargo de auditor de guerra y, así como lo hizo en la campaña de Caseros (aunque esta vez con otra actitud), retrata esta marcha militar en una serie de escritos que al año siguiente serán publicados bajo el título de Itinerario del primer cuerpo de ejército de Buenos Aires a las órdenes del general D. Wenceslao Paunero, 1861. ${ }^{279}$ Acompañando el avance triunfal de este ejército Sarmiento llega a la caótica San Juan y el 9 de enero de 1862 es proclamado gobernador provisional "con una espontaneidad difícil de repetirse". 280

La situación de la ciudad Paraná, entre tanto, no es nada alentadora. Debe asumir el cierre de todas las instituciones nacionales que hasta entonces funcionaban en ella, junto con la desaparición de numerosos órganos periodísticos, clubes, teatros y demás aspectos de una vida cultural que se va apagando a medida que la gran mayoría de los emigrados porteños vuelve a su provincia natal para reinsertarse, en lo posible, en sus antiguas posiciones.

El caso es diferente para la facción federal dura que debe pasar al destierro en Montevideo, en donde algunos retoman allí el quehacer periodístico fundando nuevos órganos o incorporándose a la redacción de medios uruguayos. Los que continúan en el país son vigilados muy de cerca por el nuevo gobierno, que no da demasiadas opciones y ordena la clausura de muchos periódicos que continúan manifestándose en contra de la política gubernamental. ${ }^{281}$

Federico de la Barra se encuentra entre los que emigran nuevamente, exiliándose en Uruguay junto con Derqui, Juan Sáa y Nicolás A. Calvo. Allí comenzará a colaborar para el periódico La Discusión de Montevideo en el que publica el 30 de abril de 1862 una nota biográfica sobre Peñaloza. Esta nota, bastante extensa, pretende redimir a

primera le ha dado la Presidencia de la República, la segunda una fortuna colosal, y la tercera la seguridad de esa fortuna" (Alberdi, 2007, p. 133).

${ }^{279}$ Sarmiento, 1862. Este texto puede interpretarse como un antecedente de su versión sobre la muerte del Chacho -que se analizará en el apartado 3.1.5 y 3.2.3-, particularmente en el tratamiento literario del coronel Sandes. Aquí se lo presenta como un héroe épico (como un Cid Campeador) y en Vida del Chacho como un héroe homérico (se dedica un apartado para exaltar sus hazañas bélicas).

${ }^{280}$ La apreciación es de Campobassi (1975, p. 507).

${ }^{281}$ Ésa fue la suerte del periódico de Olegario V. Andrade, El Porvenir, del que se hablará más adelante. 
Peñaloza de las "infamias" que lo califican como un caudillo "bárbaro". Evaristo Carriego, redactor de El Litoral de Paraná, levanta esta noticia y la incluye en su periódico en el mismo momento en que colaboran con él los hermanos José y Rafael Hernández.

De la Barra, haciendo lo posible por apoyar su desfalleciente credo político, sigue con lealtad desde Uruguay los sucesos de la provincia de La Rioja, donde el Chacho Peñaloza se manifiesta con una nueva rebelión a la autoridad porteña. Es por ello que redacta una nota elogiosa sobre el caudillo riojano que pretende mantener su oposición al centralismo porteño. De este modo De la Barra inicia el camino de un ciclo épico que comprometerá la participación de los hombres más destacados del país en arduas polémicas periodísticas, legislativas y hasta literarias, pues ya se ha visto cómo Hernández hace eco de los sucesos del Chacho y que también lo hará Olegario V. Andrade y más tarde, el propio Sarmiento.

Varios años más tarde -entre 1882 y 1884-, De la Barra coincidirá también con José Hernández en la legislatura de la provincia de Buenos Aires; se verificará allí la línea de simpatía que mantiene vinculados a los dos senadores. ${ }^{282}$

\subsubsection{Una biografía de Peñaloza como antecedente de la de Hernández}

Esta biografía se tituló, escuetamente, "El Chacho" y fue difundida por $E l$ Litoral de Paraná (el diario de Evaristo Carriego) en 1862. Aunque más breve que la que vio la luz en El Argentino, y sin estar signada todavía por el destino funesto del protagonista, operó como un claro antecedente de la biografía de Hernández y del poema de Andrade. Escrita con el objeto de resaltar la benignidad y las calidades humanas de un caudillo difamado por la prensa liberal, el autor mismo explicita el objetivo de hacerle justicia ante la propaganda porteña que lo presentaba como un caudillo feroz y sanguinario.

${ }^{282}$ En la $49^{a}$ sesión ordinaria del 28 de octubre de de 1882 del Senado de la provincia de Buenos Aires, dirá Hernández: "Empezaré por agradecer a mi honorable colega el señor Barra sus conceptos altamente favorables hacia mí, y realmente tengo el sentimiento de que las palabras que voy a decir pueden ser interpretadas también como una retribución, aunque justa, de los elogios que me ha discernido y que no merezco. Puedo decir que casi me ha convencido el señor senador, aunque no pasa de esto. Conozco que sus ideas son elevadas, su dicción fácil, su palabra persuasiva, su convicción bien manifiesta [...]” (Hernández, J. s/f, II, p. 139). 
Con una mirada intuitiva, De la Barra se anticipa en el análisis del dilema político que plantea el Chacho -incluso mientras vive-, dilema que se profundizará luego de un asesinato que representará un baldón para la gestión liberal de Mitre. Esta problemática que encarna el Chacho en un nivel político y social lo convertirá en leyenda popular: determinará su ingreso en la tradición oral al proyectarse en coplas populares que cantan no sólo sus hazañas -y las de su mujer, Victoria Romero (que solía acompañarlo en las batallas)-, sino también su captura y su asesinato.

La serie de De la Barra principia encauzando su rechazo de las críticas en el molde retórico de la paradoja: que un general de la Nación sea difamado por sus adversarios políticos, cuando antes se le habían consagrado rimas y alabanzas. ${ }^{283}$ Esta "noble figura", "notable personaje", contradice la construcción de su imagen emprendida por el periodismo porteño:

El mismo Chacho a quien hoy llaman sus ingratos detractores, gaucho oscuro, bárbaro de las pampas, jefe de tribu y hasta vil mazorquero, porque no se apresta a seguirlos en la carrera de excesos en que están empeñados; y porque no acepta el hacha traidora que le brindan, para ayudarles a demoler el edificio de la nacionalidad Argentina. ${ }^{284}$

Empeñado en resaltar la flagrante manipulación periodística y política de un personaje respetable (sobre todo para el interior del país), De la Barra continúa contraponiendo los modos en que se ha definido a Peñaloza: "Ídolo de ayer. Maldecido de la actualidad. Alternativamente bravo y cobarde, patriota o insurgente, claro $\mathrm{u}$ oscuro, prestigioso o impopular”. Y luego se pregunta “; ¿qué es el Chacho?” para seguir inquiriendo párrafo tras párrafo: ¿Qué es ese hombre errante [...]? ¿Quién es ese hombre oscuro, que defiende los principios del preclaro Mitre?"

Acto seguido ensaya una respuesta definiendo al Chacho como "el Cadoudal de la organización Argentina”, 285 "el Espoz y Mina de la independencia federal de las

283 "El Chacho", El Litoral, Paraná, 1862, año 1, n 50, p. 1, cols. 2, 3, 4 y 5; p. 2, col. 1.

${ }^{284}$ El destacado es de Federico de la Barra. Para la transcripción se modernizaron las grafías.

${ }^{285}$ Georges Cadoudal, político francés contrarrevolucionario. Figura emblemática de la Guerra de los Chuanes, su nombre es sinónimo de la resistencia hasta el martirio frente al jacobinismo parisino. 
provincias", ${ }^{286}$ y suma a un Masanielo, ${ }^{287}$ un Murat, ${ }^{288}$ un Ney, ${ }^{289}$ un Masena ${ }^{290}$ y un Kléber $^{291}$ en una enumeración que agrupa a personajes de diverso tenor político que tienen en común su origen modesto y, a veces, el ascenso social (como en el caso de mariscales del ejército de Napoleón); destaca así que la extracción humilde del Chacho no puede ser un impedimento para percibir su grandeza y sostiene que "El genio de una gran nación sabe derramar sobre sus héroes la aristocracia de la gloria”.

La definición de Peñaloza se perfila en oposición a la figura de Mitre. Este enfoque será tomado por Hernández y por todos los defensores de la causa federal que se manifiestan horrorizados al percibir que el autoproclamado liberalismo gubernamental contradice los principios civilizadores que proclamara esa doctrina. En este sentido, De la Barra se ocupa de contraponer la intuición honesta de Peñaloza a la traición racional de Mitre:

El general Peñaloza que no ha escrito la Historia de Belgrano, que no ha bebido en las fuentes de la ciencia las nociones del derecho soberano de los pueblos, que no ha hecho alarde de purismo federal en las asambleas y en la prensa, que no ha vocingleado sin cesar la cháchara de las libertades del hombre. El modesto ciudadano, el soldado moral realiza todo eso cuando llega una ocasión suprema; hace prácticas esas teorías que conoce por intuición, se sacrifica por ellas, combate y combate sin desaliento en su defensa, mientras el general Mitre, el hombre culto, el hombre de escuela, el hombre de principios, el tribuno, el escritor, traiciona la fe jurada sobre el puño de la espada, derriba una organización creada, pisotea el derecho del hombre y del pueblo, quiebra los vínculos de unión y lanza al país de nuevo en los brazos de la guerra civil y la anarquía $\left[\ldots . .{ }^{292}\right.$

${ }^{286}$ Francisco Espoz y Mina, militar español que practicó la técnica de la guerrilla frente al ejército francés, que pese a su superioridad no pudo vencerlo.

${ }^{287}$ Tommaso Aniello d'Amalfi, pescador y revolucionario napolitano que según De la Barra "colgó sus redes en trono de reyes". Quedó en la historia como símbolo del pueblo napolitano.

${ }^{288}$ Joachim Murat, hijo de un posadero, llegó a ser mariscal del Imperio de Francia, Duque de Berg y soberano de Nápoles.

${ }^{289}$ Michel Ney, hijo de un pobre tonelero de Saarlouis, Lorena, Napoleón lo nombró mariscal del ejército francés y Duque de Elchinguen.

${ }^{290}$ André Masséna, hijo de un tabernero de Niza, llegó a mariscal del Imperio de Francia, Duque de Rivoli y Príncipe de Essling.

${ }^{291}$ Jean Baptiste Kléber, hijo de un constructor jornalero se dedicó a la vida militar llegando al cargo de general y comandante en jefe del ejército revolucionario francés.

${ }^{292}$ El Litoral, Paraná, 1862, año $1, n^{\circ} 50$, p. 1, cols. 2, 3, 4 y 5; p. 2, col. 1. El destacado es del autor. 
Luego pasa a confrontar las actitudes de piedad y respeto del Chacho con la dureza de "Sarmiento [que] desde San Juan ordena en una nota publicada, que se pase por las armas a todos los que se tomen". ${ }^{293} \mathrm{Y}$ se dirige al lector en tres párrafos sucesivos con un exhortativo "Comparemos" para poner de relieve, por un lado, "el patriotismo puro y desinteresado" del "humilde guerrero que lucha con la miseria", y por otro, la "sórdida ambición" de la "entidad usurpadora llena de medios y recursos". El mismo tipo de contraposiciones marcará Hernández al año siguiente para denunciar la contradicción interna del liberalismo porteño.

Después, la narración opta por un tono más ameno, menos crispado, para hacer una semblanza afectuosa del caudillo:

Chacho es el amigo y el padre de los habitantes de las campañas de La Rioja y es muy especialmente querido en las fronteras de San Luis y en la sierra del Norte de la provincia de Córdoba. Vive entre esas poblaciones, participa de sus costumbres, parte de los peligros con ellas y saborea con ellas las victorias. ${ }^{294}$

Para exaltarlo, lo llama "el patriarca de las campañas", de instintos "tan buenos y generosos que lo inclinan al orden y a la subordinación"; afirma que "su distintivo es la honradez y la lealtad" y pone de relieve las cualidades forjadas en la vida rural: "Todas las sutilezas del gaucho se manifiestan en su vida, toda la agilidad, toda la destreza de sus usos". Más adelante, al hablar de "esa sencillez y reserva que es peculiar a nuestros hombres de campo", asume una defensa explícita de la causa del gaucho:

Quizás lo despreciáis porque es gaucho con esa invencible repugnancia que propaláis contra los gauchos. Pero mal que os pese esa es la Repúbica Argentina; y no es culpa del Chacho que las masas del país no jueguen l'écarte [sic] en vez del pato $[\ldots] .{ }^{295}$

\footnotetext{
${ }^{293}$ El destacado es del autor.

${ }^{294}$ El Litoral, Paraná, 1862, año 1, n 50, p. 1, cols. 2, 3, 4 y 5; p. 2, col. 1.

${ }^{295}$ Nuevamente, el destacado es del autor, lo mismo que en la cita siguiente.
} 
Hacia el final del artículo -de más de tres columnas- enhebra una serie de epítetos elogiosos de Peñaloza, presentándolo como el "campeón de los Llanos, firme y leal", "sereno y firme", como un "guerrero invencible", un "genio fantástico de las guerras del desierto" y un "noble paladín" que sostiene el credo de "la nacionalidad en ruina", "perseguido ahora por los perjuros y los traidores".

Finalmente, sobre el cierre y al igual que Hernández y Andrade, De la Barra exalta una condición heroica que conlleva el rasgo de la santidad:

El general Peñaloza no es un bárbaro; es un patriota. El general Peñaloza no ostenta una bandera de caudillo; defiende el país [...], llena un santo deber [... $]^{296}$

De este modo, esta publicación de 1862 anticipa la serie artículos sobre Peñaloza que Hernández publicará en El Argentino al conocer la muerte del caudillo en noviembre de 1863, y que republicará a fines del mismo año en formato de folleto. Por su parte, cuando Carriego conozca la noticia del asesinato del Chacho, El Litoral se publicará enlutado, mientras que en Montevideo, Federico de la Barra, Santiago Derqui, Juan Sáa y Nicolás A. Calvo ofician un servicio de honras fúnebres en honor de Peñaloza.

\subsubsection{Un poema de Olegario $V$. Andrade}

Olegario Víctor Andrade -que quedó huérfano de padre y madre de muy niñopasó su infancia en Gualeguaychú. El coronel Rosendo Fraga, delegado de Urquiza, descubrió su talento precoz en una visita a los establecimientos educativos de Gualeguaychú y Urquiza lo becó para continuar sus estudios en el célebre colegio que fundó en Concepción del Uruguay. En esta escuela trabará amistad con futuros dirigentes de la vida política del país: Julio A. Roca -que lo asistirá hasta el día de su muerte-, Eduardo Wilde, Salvador María del Carril, Victorino de la Plaza, Onésimo Leguizamón y otros.

La asistencia del caudillo entrerriano nunca fue olvidada por Andrade, que inició su carrera literaria escribiendo un poema dedicado al vencedor de Caseros. De este modo, acompañará sus inclinaciones literarias con una dedicación apasionada al

${ }^{296}$ El Litoral, Paraná, 1862, año 1, nº 50, p. 1, cols. 2, 3, 4 y 5; p. 2, col. 1. 
periodismo de fuerte orientación federal. Con esta intención se acerca en 1857 a Buenos Aires para participar de la redacción de La Reforma Pacífica de Nicolás A. Calvo, por lo que podemos suponer que conoció aquí al futuro autor de Martín Fierro, pero pronto regresó al litoral y allí colaboró con su protector Rosendo Fraga en la redacción de numerosos periódicos a favor de la Confederación. En 1859 es redactor, junto con Evaristo Carriego, de El Comercio de Rosario.

En 1860 se desempeña en Paraná como secretario privado de Derqui, lo que indica que debió conocer aquí a Federico de la Barra, que -como ya se dijo- era amigo íntimo del presidente, y se movió en el círculo paranaense en el que habían venido participando, entre otros, los hermanos José y Rafael Hernández, Andrés y Melitón González del Solar, Manuel Martínez Fontes y Benjamín Victorica. De aquí proviene su amistad con Lucio V. Mansilla, y conocerá también a Carlos Guido y Spano, Miguel Cané, Victorino de la Plaza, Salvador María del Carril, Juan F. Monguillot, Vicente G. Quesada, Juan María Gutiérrez y Mariano Fragueiro. El año siguiente, cuando la Confederación se encamina hacia su disolución, redacta en esta ciudad un periódico fugaz, El Paraná, que acompaña la caída definitiva del gobierno de Derqui.

En 1863, ya en plena presidencia de Mitre, se hace cargo de la redacción de $E l$ Pueblo Entrerriano, periódico urquicista de Eugenio Gómez en el que permaneció hasta 1864. Luego, ese mismo año, fundó El Porvenir y en este medio polemizó incansablemente contra los hombres de Buenos Aires acusándolos de descuidar la situación del interior. Tan duras eran sus críticas, que Rawson -en su calidad de ministro del interior- solicitó por orden de Mitre al gobernador de Entre Ríos -José María Domínguez- que dispusiera la clausura del periódico de Andrade por considerar que, al igual que muchos otros medios federales, fomentaba la rebelión abierta contra las instituciones nacionales. ${ }^{297}$

En esta etapa de enconados enfrentamientos Andrade compone un poema sobre el caudillo riojano al conocer la noticia de su muerte: "Al General Angel V. Peñaloza". ${ }^{298}$ Esta pieza siguió un recorrido editorial complejo y confuso: además de

${ }^{297}$ En el prólogo de Eleuterio Tiscornia a las Obras Poéticas de Andrade se trascribe el texto de la comunicación ministerial que ordena el cese de El Porvenir (Tiscornia, 1953, p. XXXIII, nota $1)$.

${ }^{298}$ Horacio J. Becco incluyó en su "Bibliografía hernandiana" la edición de Vida del Chacho de 1947 que incorpora el Canto al general Ángel Vicente Peñaloza de Olegario V. Andrade (Becco, 1972a, asiento 305). 
permanecer en el olvido, sufrió una manipulación alevosa descubierta décadas después. ${ }^{299}$ El homenaje de Andrade, compuesto en 1863 no se republicará hasta 1870 , en El Entrerriano de Gualeguaychú. En ese medio lo leyó Héctor Varela durante el viaje en el que acompañó a esa ciudad al ahora presidente Sarmiento; ese mismo año lo republicó en su periódico, La Tribuna, tergiversándolo: después de suprimir las dos primeras estrofas, lo tituló “Al general Lavalle” sin omitir la firma de Olegario V. Andrade. ${ }^{300}$ Esta superchería será la causa de que el poema circule de modo equívoco durante muchos años y en varias ediciones que se lo atribuyeron a Olegario V. Andrade sin controlar un rasgo tan llamativo, tomando en cuenta la conocida extracción federal de Andrade. El filólogo Eleuterio Tiscornia denuncia el fraude citando al historiador Martín Ruiz Moreno, ${ }^{301}$ que poseía un ejemplar del periódico de Gualeguaychú en el que se publicó el poema y tenía noticia de que Andrade lo había compuesto "al saberse en Entre Ríos el asesinato". 302

Como señala Tiscornia, Andrade comparte con Hernández la valoración política del asesinato: "Para Andrade como para Hernández, el mártir fue el caudillo riojano Ángel Peñaloza, el Chacho". ${ }^{303}$ Y esta opinión se modaliza en el tono elegíaco de la composición. Sus versos describen a un "mártir del pueblo" de "gigante talla" como una "víctima expiatoria", como un "apóstol del derecho", "un héroe" y una "gloria" a quien "los proscriptos, los hermanos" deberán reverenciar. También es explícita la posición partidaria, ya que Andrade denuncia la muerte de Peñaloza por obra de "el cuchillo del

\footnotetext{
${ }^{299}$ Pedro Luis Barcia relata ese itinerario: "El caudillo fue asesinado el 8 de noviembre de 1863. Ese año Andrade compuso el poema. En 1870 se publica en El Entrerriano de Gualeguaychú. Héctor Varela lleva el poema, a propósito de una visita que hace a la ciudad entrerriana, y lo publica en Buenos Aires en La Tribuna el 2 de octubre de 1870 cambiándole el nombre por el de Al General Juan Lavalle. La infamia de Varela generó el error de los editores que repetían la falsa titulación del poema" (Barcia, 1998, p. 75, nota 2).

${ }^{300}$ Tiscornia reproduce las líneas de La Tribuna en las que Varela presenta su engaño: "Dicen que los domingos son los días en que más se lee. En ese supuesto ofrezco a mis lectores una preciosa composición de Olegario Andrade, que nadie conoce aquî" (Tiscornia, 1953, p. LXVI, tomado de La Tribuna, Cosas de Orión, 2/X/1870)

${ }^{301}$ Ruiz Moreno, 1913, II, p. 310.

${ }^{302}$ Registra Tiscornia: "Dice el ilustre historiador entrerriano: 'Al saberse en Entre Ríos el asesinato del general Peñaloza, Olegario Andrade, que había sido secretario privado del presidente Derqui, le dedicó un canto a Peñaloza, recordando en él su prestigio y patriotismo"" (Tiscornia, 1953, p. LXV, nota 2).

${ }^{303}$ Ibidem, p. LXV.
} 
déspota porteño". ${ }^{304}$ Con diferente modalidad discursiva (polemismo violento y doliente elegía) Hernández y Andrade coinciden en sus juicios históricos y en la percepción de la dimensión mítica del caudillo de los Llanos. Ambos autores ubican al personaje en un linaje heroico de sustrato romántico (el héroe es una encarnación magnificada de su tierra y de su gente) y coinciden en el giro religioso de su óptica épica: el Chacho es presentado como el mártir del programa liberal y sus matadores se convierten en cultores del puñal.

\subsubsection{La memoria oral}

La capacidad del personaje para generar adhesión popular se proyectó en una épica oral. Coplas y relatos protagonizados por el Chacho -y también por Victoria Romero- se transmitieron verbalmente de generación en generación. Los cantares populares recopilados por Juan Alfonso Carrizo ${ }^{305}$ a partir de la década del 30 y las leyendas rescatadas por Berta Vidal de Battini $^{306}$ a partir de la del 40 permitieron justipreciar su magnitud simbólica y acceder a los valores que encarnó Peñaloza para el pueblo riojano. Carrizo transcribió sobre el terreno las recitaciones de antiguos pobladores de la zona que todavía recordaban coplas de memoria ${ }^{307}$ para compilar sus cancioneros populares de La Rioja, Catamarca y de Tucumán. ${ }^{308}$ Vidal de Battini se

304 “¡Mártir del pueblo! Tu gigante talla / más grande y majestuosa se levanta / que entre el solemne horror de la batalla, / cuando de fierro la sangrienta valla / servía de pedestal para tu planta. // ¡Mártir del pueblo! Víctima expiatoria / inmolada en el ara de una idea, / te has dormido en los brazos de la historia / con la inmortal diadema de la gloria / que del genio un relámpago clarea. // ¡Mártir del pueblo! Apóstol del derecho, / tu sangre es lluvia de fecundo riego, / y el postrimer aliento de tu pecho, / que era a la fe de tu creencia estrecho, / será más tarde un vendaval de fuego. // ¡Mártir del pueblo! Tu cadáver yerto; / como el ombú que el huracán desgaja, / tiene su tumba digna en el desierto, / sus grandes armonías por concierto / y el cielo de la patria por mortaja [...]" (Andrade, 1998, pp. 75-77)

${ }^{305}$ Carrizo, 1937, 1941, 1942.

${ }^{306}$ Vidal de Battini, 1980-1995.

307 Durante el transcurso del seminario "La poesía tradicional argentina: los archivos documentales y la memoria oral" -dictado por la Dra. Gloria Chicote en la UNLP durante 2008-, pudo apreciarse cómo la figura del Chacho aún permanece vigente en la tradición oral de La Rioja. En ese marco se llevó a cabo un estudio de campo -emprendido por investigadoras del Departamento de Letras de la Facultad de Humanidades y Ciencias de la Educación (a quienes debo el anticipo de un "Informe final" actualmente en prensa)-, que verificó la vigencia de algunas de estas antiguas tradiciones y leyendas sobre el Chacho que aún circulan por la zona de Chilecito.

${ }^{308}$ Carrizo recopiló numerosas piezas: "Tengo un barquito de loza / pa'embarcar a Peñaloza [...]" (Cancionero Popular de La Rioja, $\mathrm{n}^{\circ}$ 93, p. 74); "El general Peñaloza / confiado en su bienestar / no se quiso retirar / de una casa peligrosa [...]" (ibidem, $\mathrm{n}^{\circ}$ 96, p. 77); "El general 
valió a menudo de recopilación indirecta (recogida por intermediarios, particularmente maestros de escuela), pero también recopiló personalmente leyendas locales, como las que hablaban de los refugios en los que se escondía Peñaloza ("La cueva del Chacho") y que aún hoy se conservan en la tradición oral. ${ }^{309}$

En un aporte más reciente de Ariel de la Fuente, ${ }^{310}$ se recupera la dimensión mítica del Chacho en la tradición oral de los llanos riojanos y el modo en que esta memoria colectiva incidió también en la formación de una idea de nación, particularmente entre los defensores del federalismo. Se analiza allí la relación entre los alzamientos del caudillo y los cantos que reproducían y aumentaban su prestigio y consolidaban su liderazgo entre las montoneras riojanas y se muestra cómo las creencias populares y la cultura oral operan como otro ámbito político, como otro espacio donde se seguía librando "la lucha entre unitarios y federales". Toda la documentación reunida en coplas y relatos que hoy forman parte del folklore riojano pone de relieve el valor emblemático que la figura de Peñaloza adquirió durante las últimas guerras civiles, así como las razones por las cuales su vida concitó un amplio interés en el horizonte literario de la época.

Peñaloza / sevido muy combatido / Responde doña Victoria /-Peñaloza está rendido" (Coplas Históricas, Hechos de Armas, n 894); "El general Peñaloza / vino porque le ofrecían / El darle cinco mil pesos, / Y el saqueo libre tres días [...]" (Cancionero Popular de Tucumán, n ${ }^{\circ}$ 174, p. 454).

${ }^{309}$ En una de las leyendas recopiladas por Vidal de Battini, se habla de la existencia de un refugio en donde el Chacho se escondía con su mujer para defenderse de las tentativas de captura. Así, la tradición lugareña aporta datos acerca de una de las estrategias utilizadas por un personaje consustanciado con su área regional para burlar la enconada persecución de las tropas nacionales (Vidal de Battini, 1980-1995, VII, leyenda ${ }^{\circ}{ }^{1258,}$ p. 24).

${ }^{310}$ De la Fuente, 2007. 


\section{EL ALINEAMIENTO DE LA OPOSICIÓN A SARMIENTO}

\subsection{La "barbarie" como figura sociopolítica de la oposición a Sarmiento}

Dentro de una tradición del análisis del discurso que, asociando la reflexión sobre los textos y la historia para esclarecer procesos ideológicos, busca poner en evidencia particularidades de las formaciones discursivas a partir de su vocabulario, consideramos que el término "barbarie" constituye una "figura sociopolítica", ya que se trata de una condición que determinado grupo atribuye a ciertos actores sociales así como a sus prácticas culturales y políticas; es la imagen que se tiene de "el otro" y de "lo otro".

El imaginario social argentino quedó definitivamente signado por la publicación del Facundo de 1845 y -como ya se ha visto-su propuesta sociológica se constituyó en una matriz interpretativa de la identidad nacional sobre la que confluyeron las diferentes pulsiones que intentaban configurar la esencia patria.

En ese entonces, Sarmiento tomó el término "barbarie", empleado ya para hacer referencia a la exuberancia natural de América, y lo aplicó a la Argentina dirigiendo el enfoque a su aspecto sociopolítico. De esta manera, convirtió a la Argentina en un país poblado por "bárbaros" que era necesario "civilizar" desde un nuevo modelo político, literario y lingüístico. En este marco, la tesis se integra en un extensísimo proceso de discusión ulterior que va desde los cuestionamientos más íntimos posteriores a Caseros (su polémica con Alberdi los emblematiza) ${ }^{1}$ hasta su continentalización. ${ }^{2}$

De este modo, el éxito abrumador que obtuvo el Facundo lo posicionó de manera indiscutida como faro interpretativo de lo nacional y su ficción orientadora, “civilización y barbarie", regirá posteriormente el rumbo de la organización nacional. ${ }^{3}$ En contrapartida con esta imposición, luego de la batalla de Caseros los rivales políticos de Sarmiento intentarán refutar esta tesis afiliándose al esquema planteado por Alberdi en las Cartas quillotanas, en donde sustenta la paradoja de una "barbarie ilustrada".

\footnotetext{
${ }^{1}$ Como se ha dicho, consideramos que "la gran polémica nacional" está representada por la dupla Campaña en el Ejército Grande versus las Quillotanas (no por esta obra y Las ciento y una).

${ }^{2}$ Gabriel Matelo ha analizado la continentalización de la tesis (Matelo, 2008, pp. 45-61).

${ }^{3}$ Shumway, 2005.
} 
Después del 11 de septiembre de 1852, la nueva situación política e ideológica desencadenada por la secesión de Buenos Aires había impulsado a Alberdi a producir una revolución semántica que amplió el campo designativo del vocablo incluyendo esa subclase: la barbarie ilustrada. En forma concomitante, su discurso revolucionará el campo enunciativo del modelo de identidad nacional propuesto en el Facundo: su tesis se volverá contra su enunciador y trastornará el subtexto que convertía a Sarmiento en "el civilizador" por excelencia para instalar un nuevo actor social: "el bárbaro de la pluma". Por añadidura, esa operación alberdiana desencadenará nuevas reacciones: se multiplicarán intervenciones públicas en las que distintas figuras literarias y políticas se apropiarán del discurso modelizador para desarticular su propuesta desviándola referencialmente contra su propio creador.

Sin dejar de compartir el ideario fundante de Mayo y de la Generación del 37 y sin dejar de reconocer el diseño de un plan de combate contra la tiranía rosista que representó la $1^{\text {a }}$ edición del Facundo, una serie de nuevas intervenciones públicas recontextualizarán la polémica originaria e intentarán resemantizar y resignificar la célebre antinomia. En cuanto a Sarmiento y Alberdi, pasarán a contender en veredas opuestas, y sin renovar sustancialmente sus propuestas, se enfrentarán nuevamente más de una vez, de modo directo o indirecto. ${ }^{4}$

\subsubsection{La "organización nacional" y su discurso}

Recién llegado a Buenos Aires, Sarmiento ocupará el puesto que le deja Mitre como redactor de El Nacional desde 1855 a 1861. Desde aquí protagoniza furiosas reyertas defendiendo la posición de Buenos Aires en contra de la Confederación, y fundamentalmente, contra Urquiza y el caudillismo. En este período se inscriben sus principales polémicas con otros destacados periodistas que coinciden en la ciudad portuaria: Nicolás A. Calvo y Francisco Bilbao.

Sarmiento necesita justificar su decisión de apoyar a Buenos Aires y seguirá esgrimiendo infatigablemente su interpretación de la realidad nacional sobre la base de su antinomia irreductible, actualizada después de la publicación de su Campaña con la

\footnotetext{
${ }^{4}$ No obstante, muchas de las piezas de Alberdi que continúan engarzadas en la polémica originaria sólo se conocerán póstumamente.
} 
inclusión del urquicismo en el campo de la "barbarie", un tema en el que insiste con la clara intención de atraer la aprobación de los porteños.

Más tarde, una vez lograda la unificación nacional con la batalla de Pavón y en pleno gobierno de Mitre, Sarmiento ve la posibilidad de concretar sus aspiraciones políticas y comienza a gravitar con fuerza en los cargos públicos que lo irán convirtiendo en uno de los protagonistas de la época. Bajo su guía intelectual, el lema "civilización y barbarie" se instala como el slogan de la administración mitrista que aspira a regir la tarea de reorganizar el país sobre bases liberales. ${ }^{5}$

El dominio discursivo de la tesis del Facundo en el partido gobernante halaga a Sarmiento que, como dijimos, actúa como director de la guerra y luego como gobernador de San Juan, y frente al objetivo de poner en práctica un "programa civilizador" obstaculizado por los alzamientos de los caudillos del interior, no vacila en poner en práctica un antiguo principio del pragmatismo político: “el fin justifica los medios". Así, no hesita en poner en marcha ese ataque decisivo, que no repara en excesos ni en apartamientos de las leyes vigentes y que culmina con el asesinato del Chacho Peñaloza. ${ }^{6}$

Este proceder se transformará en el blanco de la oposición que sigue fiel al ideario de las provincias confederadas, que comprueban, con alarma, que la tesis se ha impuesto y que la república reunificada se ve dominada por presupuestos maniqueos y excluyentes. Esta hegemonía de la palabra del poder es la que seguirá siendo enfrentada por medio de la operación discursiva que elabora una inversión del campo designativo original o una parodia irónica del texto de Sarmiento. Así, la polémica se sustenta sobre la base de la subversión de los postulados: lo que en el Facundo es bárbaro será civilizado y a la inversa.

Los periódicos de la época se convierten en los canales de una verdadera batalla discursiva que permite sucesivas apropiaciones y reformulaciones a partir de las cuales

\footnotetext{
${ }^{5}$ De todas maneras - como lo señala Matelo en el artículo citado-, Sarmiento no habla de "organización nacional" como la gran mayoría de los liberales sino de un proceso de "reconstrucción", en analogía con el modo en que se nominalizó el proceso histórico que se desarrolló en EEUU luego de la guerra de secesión.

${ }^{6}$ La comunión de las ideas de Mitre con las de Sarmiento respecto de la figura de los caudillos ha quedado documentada en la difundida carta del ex presidente a Marcos Paz, escrita en que inicia su gestión: "aprovechemos de la oportunidad de los caudillos que quieren suicidarse, para ayudarlos a bien morir" (carta de Mitre a Marcos Paz, 10 de enero de 1862, Archivo Paz, II, p. 175). No obstante, frente a los acontecimientos irán surgiendo matices que provocarán el distanciamiento progresivo de estos dos políticos.
} 
se intenta persuadir y convencer al lector de lo contrario que ha venido leyendo hasta entonces. Los opositores de Sarmiento necesitan hacer salir de la apatía a lectores determinados por la matriz interpretativa del Facundo, hacerlos reaccionar y rebelarse contra estas opiniones impuestas. Por otro lado, los textos se cargan de contenido en razón de vínculos intertextuales que los densifican y en este contexto se legitiman sus voces. Apelan, además, a las ventajas del género panfletario, discurso de ruptura, escándalo y desesperación que busca desestabilizar un sistema de valores establecido, ${ }^{7}$ y le suman un soporte editorial en procura de garantizar la distribución masiva.

\subsubsection{Búsqueda de lo "argentino" a través del lenguaje}

La organización nacional confronta también códigos lingüísticos. La necesidad de "nombrar" objetos y sujetos políticos (al país, a su gente, al enemigo y al correligionario, los ideales perseguidos y las realidades execradas) se proyecta ineludiblemente en el lenguaje. El proceso independentista de las colonias americanas trajo aparejado un cuestionamiento análogo sobre la independencia lingüística de la norma metropolitana.

En el comienzo del período postindependentista, los filólogos que reflexionaron sobre la cuestión del español utilizado en América (al igual que los poetas neoclásicos que celebraron la liberación con lenguaje y retórica castiza) fueron "americanistas" como los libertadores pero no "independentistas" como ellos; ${ }^{8}$ sin embargo, desechado el temor de la fragmentación, ${ }^{9}$ se da un segundo momento en el que los intelectuales influidos por las teorías acerca del nacionalismo que impone el movimiento romántico (que consideran que la lengua y la nación son entidades inseparables) se plantean la cuestión de la "lengua nacional". Esta preocupación está indefectiblemente marcada por los diferentes presupuestos ideológicos, políticos y sociales que interactúan en la caracterización de las nuevas sociedades independientes y democráticas, por lo que la configuración de esta "lengua nacional" comporta todo un mundo de polémicas sobre ideas de lo social, lo político y lo económico que se discuten en las ciudades más importantes de los nuevos países latinoamericanos.

\footnotetext{
${ }^{7}$ Angenot, 1982, p. 42.

${ }^{8}$ Moure, 2004.

${ }^{9}$ Graciela Salto ha analizado los planteamientos acerca de la importancia de sostener "el bien inapreciable de un idioma común" que tuvieron lugar inmediatamente después de los procesos independentistas latinoamericanos (Salto, 2007).
} 
En la Argentina, La Gaceta Mercantil se había hecho eco de la preocupación por la unidad de la lengua en 1826 (manifestada originariamente por los colombianos) y había manifestado el interés por la creación de una institución que asegurara la comunicación de todo el territorio americano emancipado de la norma castiza. Sin embargo, una vez que esta amenaza es olvidada, en el interior de cada una de las jóvenes repúblicas se reflexiona sobre el poder del lenguaje como fuerza colonizadora y pasa a primer plano el intento de acentuar la independencia lingüística.

Entre los intelectuales más destacados de nuestro país, Sarmiento y Alberdi discurren acerca de esto; en época temprana ya escribe Alberdi en su periódico La Moda con ánimo americanista, sobre estas cuestiones.

La revolución americana de la lengua española comenzó el día que los españoles por la primera vez pisaron las playas de América. Desde aquel instante ya nuestro suelo les puso acentos nuevos a su boca, y sensaciones nuevas en su alma. La revolución americana la envolvió en su curso: y una juventud llena de talento y de fuego acabó de comunicarla. ${ }^{10}$

Nombrar la realidad con un lenguaje nuevo se consideró una condición ineludible para recrearla durante el proceso de reconfiguración de América como continente independiente. Los jóvenes intelectuales se propusieron bautizar esencias nuevas y hacer renacer lo existente imprimiendo en el lenguaje sellos que pusieran distancia de la norma lingüística del poder colonial, incluso incorporando vocabulario francés -y más esporádicamente inglés- que se imponía a través de las doctrinas filosóficas, políticas y económicas.

A partir de las lecturas de bibliografía francesa ${ }^{11}$ por parte de la Generación del 37 (con la que Sarmiento se identifica a la distancia), circula un concepto muy preciso del vocablo "civilización". El Diccionario de la Real Academia Española no registra hasta 1817 el verbo "civilizar" y su derivado "civilización" ("La accion y efecto de civilizar"); lo define como "Hacer culto y sociable" y avala su incorporación con formulaciones en latín que confirman la pureza lingüística resaltando su vinculación

\footnotetext{
10 "Emancipación de la lengua", El Iniciador (Montevideo), $1^{\circ}$ de septiembre de 1838. Se toma la cita de Alberdi, 1986.

${ }^{11}$ Conceptualizaciones fundamentales en la historia del pensamiento escritas en otras lenguas (es el caso del historicismo alemán) se difunden en el Plata en su traducción francesa.
} 
semántica con el sustantivo civilitas: Ad civilem vitae cultum mitemque reddere, ad civilem vitae cultum revocare. Habrá que esperar a la edición de 1899 para leer estas dos acepciones: "Sacar del estado salvaje á pueblos ó personas. / Educar, ilustrar". ${ }^{12}$

En contraposición, el diccionario Robert informa que ya en 1568 se registraba en francés el empleo de civiliser ("Faire passer une collectivité à un état social plus évolué"), y durante el siglo XVIII, las primeras acepciones de civilisation: "Acte de justice (1732)", "Le fait de se civiliser" (1756); pero se documenta una nueva acepción, más precisa, en 1828 -cuando del Siglo de las Luces se ha pasado al apogeo del movimiento romántico-: "Ensemble des caractères communs aux vastes sociétés les plus évoluées; ensemble des acquisitions des sociétés humaines (opposé à 'nature', 'barbarie')". ${ }^{13}$ Los jóvenes de la Asociación de Mayo y Sarmiento se anticiparán de hecho a la certificación académica de su entrada en la lengua española.

\subsubsection{2. "Civilización versus Barbarie"}

En este orden de cosas, consciente de que una formulación lingüística conlleva legitimación social y política, Sarmiento fue el primero en "nominar" una tesis exitosa con la que separó las aguas del pensamiento postcolonial. Dictaminó que no todo en América era valioso porque parte de ella estaba constituida por la pobre realidad de la "barbarie", que había que "civilizar" desde la riqueza de la cultura, y con esta premisa dio forma a una concepción antinómica de la sociedad argentina. ${ }^{14}$

Sin embargo, la necesidad de nombrar al oponente, de darle una entidad que le otorgara homogeneidad y lo acotara fue un objetivo político que no le permitió a Sarmiento distinguir los matices existentes entre figuras como Quiroga, Aldao y Urquiza, generalización objetable que aprovecharon rápidamente sus adversarios para

\footnotetext{
${ }^{12}$ Nuevo Tesoro Lexicográfico de la Lengua Española (NTLLE), www.rae.es

${ }^{13}$ Se cita la "Nouvelle édition revue, corrigée et mise à jour" (Montréal, Les dictionnaires ROBERT, 1991) de Le petit Robert.

${ }^{14}$ En su prólogo del Facundo, observa Noé Jitrik: "la relación entre realidad pobre y escritura rica establece los límites de lo que modernamente se conoce como 'antropología de la pobreza', que viene a ser exactamente lo mismo; abundancia de observaciones que, a su vez, permiten abstracciones y generalizaciones, realizadas sobre un material escaso y socialmente poco valorado; por otro lado, y para no caer víctima de la tendencia a reconocer en el Facundo un nuevo género del que sería 'precursor', diría más bien que manifestaría y habría captado la 'cultura de la pobreza', concepto que podemos también advertir en el Martín Fierro, en donde la elaboración de esta posibilidad reviste otros pero también sutiles caracteres" (Jitrik, 1977, pp. XXVI-XXXVIII).
} 
retribuir, a su propio creador, el mote de "bárbaro". Pero ellos, a su vez, operan de modo análogo cuando comparan a Sarmiento con Juan Manuel de Rosas.

Además de la presencia del lexema positivo en la bibliografía francesa, "Civilización y barbarie" era una fórmula ya probada en América del Norte por Fenimore Cooper, y Sarmiento la relocaliza en el sur del continente aprovechándose del potencial interpretativo de la "barbarie" americana y volviendo a comprobar su efectividad en casi todos sus textos.

Con el Facundo se verifica que la conformación de la identidad nacional trajo aparejada la constitución de una lengua que identificara lo argentino. Pero la "nominación" del otro conlleva un conflicto subyacente: en términos conceptuales, se identifica al "bárbaro" (un sujeto pasivo al que hay que "civilizar"), en tanto que en términos políticos se encarna al enemigo (un sujeto activo que se opone a una programática civilizatoria). Como casi dos décadas después de Caseros la sociedad argentina -reunificada después de la batalla de Pavón- continuaba ideológicamente dividida, el poder gubernamental puede retomar la antinomia sarmientina de 1845 para diseñar la imagen de un enemigo que enfrenta a una sociedad y le impide que se organice establemente.

Para Sarmiento, el "otro" es el caudillo que amenaza con impedir el cumplimiento de sus planes y lo denomina "bárbaro" porque él se instala como el modelo de "civilizador". Por el contrario, la resistencia se organiza como un grupo de intelectuales que denuncia la presencia de la "barbarie" en Sarmiento, que interpreta la ficción orientadora desde la subversión de sus postulados, en un giro que desvía definitivamente su referencia: encuentran la "otredad" en el propio Sarmiento.

En De pronto, el campo, escribe Graciela Montaldo:

Las leyes, los programas políticos, los proyectos culturales, si bien tenían canales de circulación divergentes con lo real, poseían una energía real que se despliega a lo largo del siglo XIX. Desde una formación europea relativamente al día, los letrados comenzarán a representar las formas de un desajuste que en la mayoría de los casos se establece como una ruptura con un otro en el que se quieren magnetizar las diferentes 
formas de "lo bárbaro" (el indio, el caudillo criollo pero también el letrado, el hombre urbano que tiene la ley, en el caso particular de la gauchesca). ${ }^{15}$

Frente al proceso de denigración de lo rural que instaura el Facundo, y que parece dominar el proyecto de organización nacional, los cuestionadores de Sarmiento sostienen la paradoja de una "barbarie ilustrada" y, luego de 1863, eligen como modelo paradigmático de esa presencia en el poder el asesinato del anciano patriarca riojano Ángel V. Peñaloza. Esa muerte -descripta y analizada inicialmente en el folleto que Hernández publica en Paraná al calor de los acontecimientos- fue instituida como un emblema del horror y del exceso político de la administración mitrista y cumplió con el objetivo de estigmatizar a Sarmiento, tal como se analizó, como "el bárbaro Sarmiento"; a partir de esa instalación, sus enemigos no cesaron de recuperar el conflicto con Peñaloza en numerosas oportunidades, durante la presidencia del sanjuanino y después de su finalización. Los adversarios se dedicaron simplemente a encarnar en el personaje del "civilizador" las cualidades distintivas del gaucho malo, outlaw o caudillo, desde su misma lengua fundadora de lo nacional.

El análisis emprendido permite observar que los lexemas se repiten y se retoman con diferentes connotaciones de acuerdo con el contexto de producción de los textos, pero que de todos modos el campo semántico que configuran no descarta el sentido lato dado por el propio Sarmiento cuando instaura a la barbarie como una figura sociopolítica clásica en la estética nacional. Se trata entonces de reapropiaciones, desviaciones y resemantizaciones de un discurso ajeno empeñándose en reconocer en él la condición de "autorreferencial"; cuando ese procedimiento termina por configurar un campo semántico que se carga de proyección autobiográfica, se abren otros caminos a la interpretación.

\subsubsection{Biografías de caudillos}

Como se ha dicho, el género biográfico fue el molde literario elegido por Sarmiento para instaurar su modelo antinómico y José Hernández lo mantuvo para proponer un antimodelo. Pero esa matriz genérica, fue matizada a su vez por el propio Sarmiento: el paradigma semántico que sostenía y promovía la "barbarie" en la

\footnotetext{
${ }^{15}$ Montaldo, 1993, p. 33.
} 
construcción de personajes como Facundo Quiroga o el Fraile Aldao fue reformulado para encasillar en él personalidades más complejas, como la de Urquiza. ${ }^{16}$

Por otra parte, Sarmiento no había optado, en este último caso, por el aséptico encadenamiento de hechos de un cronista para componer su biografía, y en medio de sus agudos análisis de la idiosincrasia sudamericana, suele vibrar el discurso panfletario. En contraposición, cuando Alberdi había resemantizado los lexemas de la antinomia para caracterizar a una "barbarie ilustrada" emblematizada en la persona de Sarmiento (a quien llama "gaucho de la pluma") -aunque incluyó en ella a todos los actores políticos que no aceptaban el orden constitucional propuesto por Urquiza-, se empeñó en degradarla implícitamente empleando un discurso analítico riguroso y esforzándose por conferirle apariencia de objetividad. No obstante, en los continuadores de esa línea polémica se observará una escalada de agresividad que se cierra volviendo a sus orígenes: Hernández usará la retórica sarmientina para configurar al "bárbaro Sarmiento" en sus Rasgos biográficos del general D. Angel V. Peñaloza (1863).

La participación ideológica y política de Sarmiento en la muerte del caudillo riojano abre todo un abanico de polémicas: desde la acusación inicial de ese folleto hasta la autodefensa del propio Sarmiento cuando decide responder escribiendo otra biografía del Chacho, a quien -sugerentemente- caracteriza desde el título como el "último caudillo". ${ }^{17}$ En torno de esta cuestión brota un orbe de textos, panfletos, cartas y notas en los diarios, con citas y contraejemplos, que replantean un análisis discursivo de los postulados del 45 propuestos como base de una interpretación de la identidad nacional.

La reposición del anatema "salvajes unitarios", en la que estalla la indignación de Hernández ante un acto de barbarie ejecutado en nombre de la civilización, también fue percibida por parte de la sociedad como una amenaza. Pero esa recuperación del epíteto rosista por parte de Hernández es un indicador de hasta qué punto los viejos

\footnotetext{
${ }^{16}$ Luego se verá que Sarmiento repone su antinomia en la respuesta que da a Hernández con su versión de la historia de Peñaloza al publicar El Chacho, último caudillo de la montonera de los Llanos en 1868. Sin embargo, se observa con claridad que Sarmiento es consciente de que una recuperación acrítica de los términos de su tesis y retacea el empleo de una oposición tajante que solo adquiere plenitud cuando ha sido introducida en un ajustado enfoque educativo.

${ }^{17}$ Sarmiento compone El Chacho, último caudillo de la montonera de los llanos en 1866, mientras pergeña su campaña presidencial desde los E.E. U.U. Así, si bien el texto se estructura sobre la base del conflicto que inicia Hernández y carga con este debate, desea también dar respuesta -en un momento crucial para su carrera política- a las denuncias que pesan sobre su participación en los hechos.
} 
enconos aún no han sido superados. Sin embargo, si bien la revitalización de los presupuestos rosistas resultó "cuestionable" para muchos y a pesar de que la tesis del Facundo perduraba, el contradiscurso de sus impugnadores tuvo ecos impensados. En esta línea se entronca la implacable oratoria de Guillermo Rawson en 1875-un correligionario político de Sarmiento- en el senado de la Nación. En su revisión del proyecto de ley amnistía (en la que se buscaba el perdón de la reciente rebeldía mitrista) que Sarmiento acaba de presentar, Rawson inserta dentro de un meduloso análisis jurídico el cuestionamiento ad hominem: sacando a relucir las tropelías cometidas durante la guerra contra el caudillismo, equipara a Sarmiento con Rosas y compara su metodología de poder con la del Restaurador.

Si las Quillotanas contribuyeron a instalar a Alberdi como el mentor ideológico de los federales confederados, la reapertura de la polémica por medio de la biografía de un caudillo por parte de Hernández contribuyó a generar debates acerca del caudillismo.

\subsubsection{Algunas polémicas emblemáticas}

En su desesperado esfuerzo por contener el poderío porteño mediante el levantamiento de las montoneras llanistas, el Chacho fue visto como el símbolo de un último bastión de resistencia de las provincias ante el dominio centralista de Mitre. El bando crítico del partido gobernante identificó su muerte con el deseo frustrado de recuperar la ideología de Mayo para lograr, por fin, una organización nacional estable. En esta línea, fue visto como un mártir de la patria por los simpatizantes de la causa federal, como un ícono del defensor de la libertad victimizado por el poder central.

Como Sarmiento - entonces el gobernador de San Juan- había dado gran impulso a la represión de las resistencias regionales y había tenido a su cargo -aunque por un breve período- la dirección de la guerra contra el caudillo, alrededor de su figura se conformó un escenario de fuerzas ideológico-políticas que prolongó las discusiones acerca de cómo verter en un molde explicativo la realidad nacional. Sus adversarios, a la par que vieron en el sanjuanino la encarnación del poder central, retomaron la imagenshock de su creador para revertirla contra él. ${ }^{18}$

De este modo se conforma un tramado intertextual muy productivo que se articula en reapropiaciones y desviaciones, combinadas con la confrontación de la

\footnotetext{
${ }^{18}$ Svampa, 1994, p. 54.
} 
amenaza del resurgimiento del discurso rosista. Los polemistas se valen del mismo lenguaje; los mismos adversarios parecen robarse unos a otros los tópicos, las imágenes, las modalidades enunciativas: la barbarie y la civilización, el sacrificio de las víctimas y la sangre, las fieras salvajes, los mártires. Se conforma un coro de voces que llevan y traen la lengua del otro, la cuestionan pero también la reponen.

Los rivales a la política liberal que participaron de los distintos acontecimientos civiles, políticos y militares durante el período de la Confederación apoyando a Urquiza, se refugian ahora en la prensa para capitalizar allí su rol de opositores, esforzándose en plasmar en sus artículos una retórica persuasiva. Construyeron con este fin un discurso coherente y cohesionado que circuló por los canales del periodismo para volcar allí una opinión contundente.

Desde el exilio, Juan Bautista Alberdi continúa siendo una guía por medio de sus sucesivas publicaciones. Entre las nuevas generaciones, el joven periodista José Hernández lo sigue a la distancia instituyéndose como un protagonista que acompaña las pulsiones nacionales con su participación incansable en la escritura y prosiguiendo el ataque al "bárbaro Sarmiento". A su vez, al recorrer el coro opositor (Nicolás A. Calvo, Juan José Soto, Francisco y Manuel Bilbao, Federico de la Barra, Olegario V. Andrade, Evaristo Carriego) se advierten las marcas de adscripción a una misma formación discursiva: el cuestionamiento de la antinomia implacable implícito en las imputaciones a Sarmiento y al poder porteño que hizo Alberdi (figura frente a la cual todos se manifiestan atentos, de cuya producción y de cuyo regreso estarán siempre pendientes).

La interrelación entre los miembros del grupo opositor fue estrecha y no ha sido rescatada aún toda la correspondencia que se sabe que intercambiaron. ${ }^{19}$ También se conservan cartas que Nicolás Calvo envió a Alberdi entre 1860 y 1873, que confirman los lazos que los ligaban al "ausente". ${ }^{20}$

Particularmente, a partir de un análisis de los lexemas que tienen como principal objetivo revisitar la nominación sociológica que Sarmiento impone en el Facundo, se observa cómo se conforma un complejo sistema de colisión, que va siendo configurado por polemistas que comparten un vocabulario que, contextualizado, va diseñando una

\footnotetext{
${ }^{19}$ Una "Carta de Nicolás A. Calvo a Don Francisco Bilbao, Redactor de El Nacional Argentino. Hotel du Brasil, 19 de junio de 1859, Paraná" puede leerse en la Biblioteca de la Universidad Nacional de La Plata (Folletos Históricos, tomo 54).

${ }^{20}$ Mayer, 1963, pp. 675-764.
} 
imagen que se opone a la del Sarmiento "civilizador", ya que construye la figura sociopolítica de la "barbarie".

En Sarmiento, el empleo de los mismos lexemas se relaciona con la construcción de una mirada peyorativa sobre el interior rural, mientras que el arco opositor invierte esa valoración: por un lado, sostiene que la barbarie puede encontrarse en los centros culturales del país, en hombres ilustrados; por otro, se empeñan en demostrar que la barbarie es inherente a la persona de Sarmiento: el gaucho malo de la pluma, el que apalea a periodistas por las calles de Buenos Aires, el matador del Chacho, el que aplaude la forma en que fue ejecutado, el que pone precio a las cabezas de revolucionarios, el que administra despreciando la ley igual que Rosas; irrumpen incluso en su vida privada aludiendo a aquel a quien las malas lenguas acusan de haber envenenado al primer marido de su esposa.

En el proceso discursivo que va construyendo esta imagen de Sarmientobárbaro, se distinguen claramente diferentes etapas relacionadas con su recorrido político.

Una primera etapa transcurre entre 1853 y 1861, cuando Sarmiento -luego de su estruendoso rompimiento con Urquiza y Alberdi- se instala en Buenos Aires y comienza a construir su carrera pública allí estableciendo vínculos cada vez más estrechos con los hombres influyentes de la provincia escindida de la Confederación. Polemizará violentamente con los que desde la ciudad-puerto abogan por la unidad nacional y defienden la posición de Urquiza; sus antagonistas más visibles en la prensa porteña serán Nicolás Antonio Calvo y Francisco Bilbao. Por su parte, la circulación del poema "Sarmienticidio" (1853) - escrito por el periodista español Juan Martínez Villergas en otro contexto de situación- contribuirá a convocar a estos contrincantes ofreciéndoles una mirada satírica a la que más de una vez recurrirán para reforzar sus embestidas contra Sarmiento.

Cuando a partir de 1862 Sarmiento empiece a actuar directamente en la guerra contra los insurgentes, y sobre todo, cuando en 1863 se produce el levantamiento de Peñaloza -que culminará con su asesinato y la vejación pública-, la ofensiva será liderada por Federico de la Barra, Evaristo Carriego, José Hernández y Olegario V. Andrade, quienes habían seguido con especial interés la trayectoria del caudillo riojano. Los demás adversarios acompañarán este nuevo embate. 
Las críticas recrudecen durante la presidencia de Sarmiento y se incrementan entre 1874 y 1875, al finalizar su administración. Se retoma entonces el conflicto con Peñaloza, y en una etapa histórica proclive a la superación de los viejos enconos, esa recuperación adquiere gran repercusión política y social. Por otra parte, los desgraciados episodios que culminaron con la trágica muerte del Chacho se ligan intencionadamente con la revolución de López Jordán, y finalmente, con la sedición encabezada por el propio Mitre para impedir la asunción de Avellaneda: es entonces cuando la embestida contra un estilo del ejercicio del poder alcanzará su clímax, ${ }^{21}$ muy particularmente, cuando un correligionario político y coprovinciano de Sarmiento, Guillermo Rawson, asuma la misma estrategia discursiva de la oposición y sume un jalón que imprime nueva fuerza al embate.

\subsubsection{Polémica con Nicolás A. Calvo}

El porteño Nicolás Antonio Calvo es uno de los más destacados antagonistas de Sarmiento durante sus primeros años en Buenos Aires. Figura de activa participación política y periodística después de Caseros, toma distancia del círculo exclusivo que ejerce el poder y, con el propósito de promover el acercamiento de su provincia a la Confederación (ya que, a pesar de haber sido inicialmente crítico de algunas medidas de Urquiza, rechaza ante todo la secesión) crea el Partido Federal Reformista. A las filas de los reformistas (llamados despectivamente "chupandinos" por los "pandilleros", denominación popular de los militantes del nuevo Partido Liberal) se incorporarán posteriormente los hermanos Hernández.

Para defender la propuesta política de su partido, Calvo funda junto con Juan José Soto el periódico La Reforma Pacífica, donde combatirá apasionadamente contra el separatismo porteño. ${ }^{22}$

Por su parte, Sarmiento encabeza la campaña contra los reformistas criticándolos enconadamente desde las columnas de El Nacional; y en la dinámica de un encendido

${ }^{21}$ En el final de la presidencia de Sarmiento, Mitre encabeza una revolución. Desde Montevideo, Hernández analiza en "De presidente a revolucionario. De revolucionario a pirata" (La Patria, 25 de octubre de 1874) este nuevo ejemplo de contradicción ideológica que brindan los autotitulados "liberales" (Rela, 1967).

${ }^{22}$ Galván Moreno, 1944, p. 205. 
polemismo, se forjará entre él y Calvo una arraigada enemistad. ${ }^{23}$ Por otra parte, las discusiones periodísticas se reanudarán después de Pavón, cuando La Reforma Pacífica, en su segundo período, se publique en Montevideo.

El enfrentamiento político de Calvo sube sus decibeles y en un viraje lleva la vida privada a la escena pública cuando en 1857 acusa a Sarmiento de hacer envenenar al primer marido de su mujer, Benita Paunero de Castro y Calvo. Sarmiento, además de iniciar una querella judicial, responde desde El Nacional el 23 de junio de 1857, en un texto que se que se publica en la sección "Correspondencia" con fecha del día anterior. Además de avalar su honorabilidad incorporando cartas en las que el presidente chileno Manuel Montt le manifiesta "estimación y aprecio", no pierde la ocasión de describir las actividades que le dieron relevancia pública en el país vecino. Pasa luego a atacar la persona de Calvo calificándolo como “un perdido y un hombre manchado". Recuerda, además, otros casos en los que se intentó imputarle otros asesinatos y enumera acusaciones de 1842, y 1845 y el caso de un tal Espejo. Todas las circunstancias fueron aclaradas, a decir de Sarmiento, por lo que interpela a Calvo: "Ha tomado Ud. las colas de varias calumnias distintas, y ha hecho una que ha agarrado la mano del calumniador para presentarla adherida a la obra". ${ }^{24}$

Sarmiento aprovecha su incidente con Calvo para aludir a dos hermanos con los que polemizó en Chile -en lo que parece ser una referencia a los hermanos Bilbao-, y retomando una de las acusaciones que le hicieron en 1842, comenta al respecto:

El que inventó en Chile la calumnia que Ud. transporta a 1847, cambiando nombres y lugares, estaba nombrado Intendente de una provincia entonces [...] Su nombre y el de su hermano cómplice han sido borrados de la lista de los hombres públicos de Chile. ${ }^{25}$

\footnotetext{
${ }^{23}$ Sin embargo, como se verá más abajo, con el correr de los años Nicolás se mostrará más contemporizador con su contrincante.

24 "Correspondencia", El Nacional, Buenos Aires, 23 de junio de 1857. Este periódico puede consultarse en la Biblioteca de la Universidad Nacional de La Plata (Sección Hemeroteca, periódico $\mathrm{n}^{\circ} 303$ ).

25 "Correspondencia", El Nacional, Buenos Aires, 23 de junio de 1857.
} 
En el afán por defenderse, Sarmiento hace extensivos sus ataque a otros opositores, y también menciona aquí a $\operatorname{Alberdi}^{26}$ (a quien atribuye la creación de uno de sus más célebres apodos descalificativos, el de "Don Yo"), y a Juan Martínez Villergas como "detractores mucho más altos", y dice refiriéndose a sus antagonistas en Chile: “allá eran leones, aquí son sabandijas". Para cerrar esta jugosa nota concluye: "Es Ud. un perdido desesperado, y yo soy siempre D. F. Sarmiento". ${ }^{27}$

Estos combates periodísticos constituyen una muestra de la virulencia que se proyecta en el polemismo de la época, contextualizado por la violencia que domina la vida política. En las elecciones para gobernador de Buenos Aires convocadas en marzo de 1857, el Partido Federal Reformista había sido derrotado en comicios fraudulentos cuya belicosidad está testimoniada por una célebre carta de Sarmiento a Domingo de Oro. ${ }^{28}$ Los enconos entre pandilleros y chupandinos irán en aumento y Nicolás Calvo tomará en 1859 la decisión de mudarse a Paraná, donde se acercará definitivamente a Urquiza y estrechará sus vínculos con los hombres del Partido Federal del interior.

En 1862, en los comienzos de la presidencia de Mitre, Calvo se traslada a Montevideo junto con muchos otros periodistas de la disidencia federal. Allí iniciará la segunda época de La Reforma Pacífica, que acompañará con especial atención la suerte de los caudillos del interior en consonancia con la tarea que realizan en Paraná Evaristo Carriego en El Litoral y Hernández en El Argentino. Estos dos publicistas colaborarán en la difusión de La Reforma Pacífica transcribiendo sus artículos y haciendo de puente para sus suscriptores.

Cuando se produce el trágico final del levantamiento de los Llanos, Nicolás Calvo repudia la política del partido gubernamental de su país, publicará enlutadas sus

\footnotetext{
26 "Hallará Ud. en todo esto un poco de don yo (creación de Alberdi) la más alta ofensa que me han hecho aquellos a quienes llamo malvados o explotadores. Es que de cuando en cuando tengo, como ahora, necesidad de sacudir el todo de mis vestidos y mostrarme como soy, sin mancha desdorosa" (El Nacional, Buenos Aires, 23 de junio de 1857). El destacado es de Sarmiento.

${ }^{27}$ Sarmiento alude al poema "Sarmienticidio o, a mal sarmiento, buena podadera" de Juan Martín Villergas, que se analizará más adelante.

${ }^{28}$ Fermín Chávez da detalles acerca de la votación de 1857, "tristemente célebre" por el fraude que se ejerció con apoyo de la policía. Es muy conocida, también, la narración que hace Sarmiento de esa misma elección, en carta a Domingo de Oro del 17 de junio de 1857, en la que le cuenta que los gauchos que no votaban por los pandilleros eran llevados al cepo o a la frontera, perdían el rancho, todas sus pertenencias "y hasta su mujer". Chávez no puede evitar relacionar esta carta con los versos correspondientes del Martín Fierro (Chávez, 1959, p. 32).
} 
columnas y participará personalmente de un homenaje fúnebre al Chacho juntamente con Santiago Derqui, Juan Sáa y Federico de la Barra.

Ya durante la gestión presidencial de Sarmiento, la prolongación de la Guerra con Paraguay y el último alzamiento de López Jordán continúa estrechando la alianza entre los opositores de Sarmiento. Nicolás Calvo vuelve a coincidir aquí con la posición de Alberdi, de quien hasta se rumorea en 1869 que volverá a la patria juntamente con él (que en ese momento reside en Londres), para escribir en La República (de Manuel Bilbao) o El Río de La Plata, posibilidad que no se concreta. ${ }^{29}$

Pero Nicolás Calvo publicó en El Siglo de Buenos Aires, entre 1878 y 1879, una serie de cartas en las que -aunque con la moderación de las pasiones impuesta por el tiempo transcurrido difuminó su fervor polemista-, mantiene un tono crítico cuando reconsidera la antinomia sarmientina. ${ }^{30}$ Se trata de 29 cartas enviadas desde Londres en las que se propone pasar revista de los principales acontecimientos históricos sudamericanos que se sucedieron desde 1870 hasta 1879 . Como en ellas se tratan varias cuestiones, el tema que analizamos no se desarrolla orgánicamente, pero las intervenciones públicas de Sarmiento, Alberdi y Hernández no sólo forman parte de su intertexto, sino que además reaparecen puntualmente.

En primer lugar, la colección arranca con una mención que parece retomar el tono de la polémica:

Sarmiento no me hizo huir de Buenos Aires como cree. Me retiré a Europa con intención de regresar [...] y suprimida La Reforma Pacífica, acusando 150 artículos míos, casi arruinándome, por defender la nacionalidad argentina; me convencí de que no era bastante rico para poder decir la verdad en el Río de la Plata ni bastante humilde para callar $\left[\ldots . .{ }^{31}\right.$

\footnotetext{
${ }^{29}$ Al respecto se expresa el biógrafo más destacado de Alberdi, Jorge m. Mayer: "Se anunció que volvía con Nicolás Calvo y escribiría en La República o en El Río de La Plata [...]" (Mayer, 1963, p. 755).

${ }^{30}$ Interesantes cartas publicadas en El Siglo (1878-1879). Córdoba, Biblioteca Mayor, 1879, pp. 236. Se pueden consultar en la Biblioteca de la UNLP (Salas Especiales, bajo la asignación Sd-89).

${ }^{31}$ Ibidem, p. 3.
} 
Sin embargo, este ánimo se diluye cuando se avanza en la lectura, descubriendo que a menudo parecen superados los violentos enfrentamientos con Sarmiento. ${ }^{32}$ Calvo volverá a referirse a él de modo explícito sólo dos veces, aunque es interesante que en ambas oportunidades retoma conocidos planteamientos de la Generación del 37, lo que remite a los postulados que los dos bandos en pugna han compartido: el aislamiento de las provincias, la necesidad de dotarlas de caminos, la importancia del desarrollo de empresas e industrias que permitan el crecimiento económico de esas vastas regiones.

En este contexto menciona el efecto perjudicial del desierto para las provincias del interior, para las que actúa como "la mortaja que las envuelve separándolas de la civilización", y en una nueva referencia a Sarmiento opina:

Cuando el señor Sarmiento fue elegido presidente, creí que se atreviera él a tocar la cuestión de territorios nacionales y de límites provinciales, [...] pero al bajar del poder, quedó como estaba. ${ }^{33}$

Aunque el último comentario sobre Sarmiento señala fracasos en su gestión presidencial, va seguido de un elogio a la obra educativa del sanjuanino. ${ }^{34}$

Respecto del empleo de los lexemas de la tesis del Facundo son varias las oportunidades en las que se constata su uso. En parte se relacionan con la problemática del atraso en que están sumidas las provincias, para las que el gobierno nacional debe consolidar la estabilidad con el fin de asegurar su marcha hacia la "civilización”. En ese mismo contexto señala la lejanía del universo del discurso sarmientino del 45 (y también la de su resemantización del 52), que evoca mediante la mención de sus actantes con el refuerzo de un destacado: "Ya no necesita nuestro país gobiernos politiqueros: ya no hay caudillos que combatir; ya Rosas se murió y a Urquiza lo mataron". Y agrega:

\footnotetext{
${ }^{32}$ Ibidem, p. 5.

${ }^{33}$ Ibidem, p. 13.

${ }^{34}$ Después de comparar las inversiones en el sistema educativo que está encarando el gobierno argentino con las que se llevan a cabo en Chile, concluye: "entre nosotros se está destruyendo por economía la obra de Sarmiento" (ibidem, p. 21).
} 
Si los pueblos cultos no tuvieran otros medios a su disposición para hacer triunfar el buen derecho, la razón y la justicia, que la fuerza bruta, la civilización sería una palabra sin sentido práctico. ${ }^{35}$

Más adelante habla de la conveniencia de la relación entre la educación popular de las masas y el trabajo que servirá para cimentar una política sudamericana de fraternidad y "de civilización", 36 y al detenerse a analizar "nuestra civilización", distingue dos fases: juzga que el país se encuentra avanzado en literatura y moral, pero atrasado materialmente en administración pública, justicia civil, criminal y política. Pero en su concepto de "civilización" también pesan las ideas alberdianas: define al medio diplomático como el único conocido para "explicarse y entenderse, entre los hombres y los pueblos cultos y civilizados" 37 y sostiene que "el trabajo civiliza las masas". 38

Pero cuando acuda al segundo lexema de la dicotomía sarmientina, lo someterá a una reflexión crítica atribuyendo las rémoras de las sociedades sudamericanas a la "barbarie de una y otra parte". ${ }^{39}$ Sin embargo, no omite un reproche a la montonera cuando se refiere al estilo desorganizado de la guerra sudamericana ("conducida de la manera semi-bárbara") por considerarla un obstáculo perjudicial para las inversiones económicas y para el desarrollo del comercio y fatal para el empleo del capital, lo que conspira contra la inclusión de Sudamérica "entre los pueblos civilizados". 40

Como se vio, Nicolás Calvo no podía dejar de mostrar su adscripción a las propuestas alberdianas. A la manera de un bajo continuo insiste en la inutilidad de las guerras en estos territorios que deben ocuparse en tareas más productivas. ${ }^{41}$ Como Alberdi, Calvo se lamenta permanentemente del gasto enorme e infructuoso que las guerras civiles o exteriores representan para las repúblicas sudamericanas e insiste en la necesidad de que esas inversiones sean destinadas a las empresas que promuevan la

\footnotetext{
${ }^{35}$ Ibidem, p. 32.

${ }^{36}$ Ibidem, p. 185.

${ }^{37}$ Ibidem, p. 223.

${ }^{38}$ Ibidem, p. 229.

${ }^{39}$ Ibidem, p. 229.

${ }^{40}$ Ibidem, p. 239.

${ }^{41}$ Si bien El crimen de la guerra (escrito en 1869) sólo se conoció póstumamente, Alberdi venía insistiendo en esta idea ya desde los artículos periodísticos escritos en Montevideo entre 1839 y 1843.
} 
civilización y el progreso de la sociedad. Como él, insiste en que esas prácticas condicionan la persistencia de las tiranías y se lamenta por la falta de idoneidad para emplear los medios diplomáticos para negociar y mantener la paz. Además, repudiará enfáticamente la sedición de Mitre de 1874 en consonancia con el espíritu antimitrista de Alberdi y Hernández.

Pero también, al igual que Alberdi en Peregrinación de Luz del Día, no dejará de reconocer que la barbarie sobrevive en las prácticas de los países civilizados. En alusión al conflicto entre Chile y Bolivia, escribe: "El diario The Standard nos califica a todos los sudamericanos de semi-bárbaros y filibusteros"; pero añade que la prensa europea también censura las campañas colonialistas de Inglaterra en Afganistán y en África:

Se califican de bárbaras en sus medios. No de semi-bárbaras, sino simplemente de BÁRBARAS. Y así son. ${ }^{42}$

Y el lexema reaparece a continuación para rechazar procedimientos del gobierno de Bolivia (confiscar propiedades y otras irregularidades): "ES UN GOBIERNO SEMIBÁRBARO". ${ }^{43}$

También resuenan ecos del discurso de Hernández en dos cartas (VII y VIII), dedicadas exclusivamente a denunciar los problemas de la frontera y la situación del gaucho en Argentina. Aunque se trata de un tema reiterado por todo el periodismo crítico de la política gubernamental instaurado a partir del 11 de septiembre de 1852, cuando se refiere a la desorganización de los fortines y la injusticia social que padecen los trabajadores del campo, resuenan versos del Martín Fierro: "El gaucho argentino mismo no tiene carrera; o es peón, o vago, o soldado sin sueldo". ${ }^{4}$

Además, también mencionará en varias ocasiones a los hermanos Bilbao, como cuando rescata sus opiniones como las mejores guías para analizar los conflictos con Chile.

En suma, con el tono más moderado que también comparten sus compañeros de ruta, una perspectiva más objetiva permite a Nicolás Calvo conjugar aportes de

\footnotetext{
${ }^{42}$ Ibidem, p. 243. El destacado y las mayúsculas son de Calvo.

${ }^{43}$ Ibidem, p. 243. Las mayúsculas son de Calvo.

${ }^{44}$ Ibidem, p. 72.
} 
Sarmiento con los de Alberdi y de Hernández. Pero persiste en la denuncia que mantuvieron los federales críticos: ve "barbarie de una y otra parte".

\subsubsection{Polémica con los hermanos Francisco y Manuel Bilbao ${ }^{45}$}

Sarmiento había polemizado inicialmente con el publicista socialista y liberal Francisco Bilbao durante su segundo exilio en Chile, a pesar de que en ese momento compartían la misma línea ideológica; luego volvieron a enfrentarse cuando el chileno se radicó en Buenos Aires.

Francisco colaboró en El Orden -dirigido por Féliz Frías y Luis Domínguezentre 1855 y 1856 , donde atacó enconadamente a Sarmiento, quien lo llevó ante los tribunales en medio de una ruidosa acusación ganada finalmente por el sanjuanino. ${ }^{46}$

En 1857 fundó la Revista del Nuevo Mundo, donde mantuvo una agria polémica con Sarmiento, quien respondía desde El Nacional. La revista alcanzó 24 números en total, hasta su despedida el 29 de diciembre de $1857{ }^{47}$

En la edición del 17 y 18 de octubre se refiere a la frontera y a los indios "bárbaros" y dirige críticas a Sarmiento y a Mitre en el apartado titulado "NacionalidadPolémica a El Nacional y Los Debates", con argumentos que se reiteran y amplifican en números siguientes. En una nota del 20 de octubre titulada "Contestación a El Nacional", Bilbao cuestiona que se pretenda exigir la renuncia de Urquiza a la gobernación de Entre Ríos como garantía para que Buenos Aires se una a la Confederación. Analiza la animosidad de Sarmiento contra Urquiza y la cuestión del caudillaje en la línea argumentativa de Alberdi, pero con el tono apasionado de la polémica paralela que sostiene Nicolás Calvo, denuncia el costado "bárbaro" del liberalismo porteño con acidez e ironía:

El Sr. Sarmiento nos dice que no olvidemos "que bajo la cuestión nacional está la cuestión caudillaje”. Está bien pero deseo que se me ilustre a este respecto [...] Y si se habla de caudillaje unipersonal, no se podría también hablar del caudillaje

\footnotetext{
${ }^{45}$ Los hermanos Bilbao nacieron en Santiago de Chile y murieron en Buenos Aires. Francisco nació en 1823 y murió en 1865; Manuel nació en 1827 y murió en 1895.

${ }^{46}$ Galván Moreno, 1944, p. 205.

${ }^{47}$ Revista del Nuevo Mundo, Buenos Aires, Imp. y Lit. J. A. Bernheim, Calle Representante, 113, 1857. Consultada en la Biblioteca de la Universidad Nacional de La Plata, Sección hemeroteca, revista ${ }^{\circ} 2904$.
} 
oligárquico, que jamás quiere someter al pueblo la decisión de una cuestión sobre los hechos? $?^{48}$

Pero como tantos otros, Bilbao debió cerrar su publicación, y ante una invitación personal de Urquiza, se traslada a Paraná para tener bajo su responsabilidad la redacción de El Nacional Argentino; así ocupa el cargo que acaba de dejar Lucio V. Mansilla y en el que en un futuro inmediato se desempeñará Hernández. Desde este órgano se dispone a defender la unidad nacional con un espíritu exaltado que condice con las preparaciones bélicas que se realizan en la Confederación y en Buenos Aires.

En este breve período (pues Bilbao renuncia a la redacción en 1859, luego de la batalla de Cepeda), se publican en su diario dos poemas gauchescos firmados con el seudónimo Juan Barriales, que se componen en respuesta a los que en El Nacional de Buenos Aires (que dirige Sarmiento) había venido publicando Hilario Ascasubi bajo la firma de Aniceto el Gallo. Se trata de "Un cielito ateruterao dirigido a Aniceto el Gallipavo" (publicado el 20 de abril de 1859) y de "El cielito de la luz dedicado al Ejército que va a invadir Güenos Aires" (que sale el 28 de abril de 1859). Después de establecer la filiación de Hernández con el seudónimo "Juan Barriales”, Fermín Chávez le atribuye la autoría de estas dos composiciones. ${ }^{49}$

Por su parte, Néstor Tomás Auza -al igual que Chávez- señala que Bilbao difunde dos poemas que ya han sido publicados en el periódico El Uruguay -de Concepción del Uruguay-, donde meses antes Bilbao se había desempeñado como colaborador a pedido de su redactor político, Benjamín Victorica. Pero además, Auza consigna que Bilbao difunde artículos de Olegario V. Andrade, que habían visto la luz en El Patriota de Santa Fe; destaca, también, la coincidencia temática entre El Nacional Argentino de Paraná y la prédica de Federico de la Barra en La Confederación de Rosario (que dirigió desde 1854 a 1861). Tanto estas coincidencias como la circulación de artículos y poemas por diferentes medios ponen de relieve la estrecha vinculación entre los publicistas que responden a los intereses de las provincias argentinas confederadas; por otra parte, el mismo tipo de circulación incluye a medios uruguayos

\footnotetext{
${ }^{48}$ Ed. cit., p. 215. El énfasis es de F. Bilbao.

${ }^{49}$ Chávez, 1859, pp. 27-56. Cabe consignar que, en caso de ser verdadera la autoría de Hernández, sus versos están lejos todavía de la maestría que se proyectará en el Martín Fierro más de una década después.
} 
ideológicamente afines de Concepción y Montevideo (los que responden al Partido Blanco). ${ }^{50}$

En 1875 (durante el primer año de la presidencia de Avellaneda), ya en una nueva etapa política y diez años después de la muerte de su hermano Francisco, es Manuel Bilbao quien mantiene una sonada polémica con Sarmiento. Manuel se desempeña en este momento como redactor de La Libertad, y cuando se conocen las opiniones vertidas por Sarmiento en una carta dirigida a Mariano Varela, donde se objeta la actuación de Francisco Bilbao, articula su respuesta en una serie de cartas que, según declara, están destinadas a defender la honra de su hermano. Fueron publicadas con el título de Cartas de Bilbao a Sarmiento, recopiladas por unos amigos de la verdad ${ }^{51}$ en las que, retrocediendo -al igual que Sarmiento en la carta cuestionadaquince años en el tiempo, recupera el conflicto que se ha venido desarrollando.

Por otra parte, desde la elección del género epistolar para componer una respuesta polémica, Manuel Bilbao está enfatizando su inclusión en un sector del intertexto de la gran polémica nacional; y justamente, él y Eduardo Wilde, mientras actuaban en apoyo de la candidatura de Avellaneda en 1873, habían anunciado la reedición de las Cartas quillotanas. Por otra parte, copiosa correspondencia atestigua su vínculo con Alberdi así como su colaboración en los intentos por lograr su definitivo retorno al país. 52

El folleto se compone de ocho cartas y, supuestamente, la recopilación habría sido realizada por terceros aunque no figure ningún nombre responsable en la edición. Con el declarado propósito de refutar "infamias", Manuel se dedicará a poner de relieve las conocidas contradicciones políticas de Sarmiento y su desmedida vocación por el polemismo concentrándose en su campaña contra los caudillos del interior del país.

Comienza con la transcripción de la carta que origina su reacción, y la publicación del "disparador" de la polémica funciona como un eco lejano del comienzo de las Quillotanas, donde la reproducción de la Dedicatoria de la Campaña en el Ejército Grande precede la secuencia de cartas con las que Alberdi responde. En su

\footnotetext{
${ }^{50}$ Auza, 1978, pp. 97-105.

${ }^{51}$ Se ha consultado este folleto (Buenos Aires, Imprenta Rural, calle de Belgrano números 133 y 135, 1875) en la Biblioteca de la Universidad Nacional de La Plata (Salas especiales, Armario 2, tomo $2,2^{\circ}$ fila, $n^{\circ} 2$ ).

${ }^{52}$ Años después, ya fallecido Alberdi, el Congreso de la Nación designó a Manuel Bilbao para recopilar, junto con Arturo Reynal O’Connor, las Obras Completas de Alberdi (1886-1887).
} 
carta a Mariano Varela, Sarmiento describe sus diferencias con los dos hermanos Bilbao que defienden tiranos y son partidarios de Urquiza. Después de recapitular las principales discrepancias con Francisco en Chile, pasa a atacar fuertemente a Manuel, a quien acusa de perseguirlo sin tregua en una "guerra de injurias y reproches" desde la redacción de La Libertad, y para establecer la diferencia que lo contrapone a los Bilbao, elige como marcador la posición adoptada frente a los caudillos, lo que equivale a restaurar la antinomia irreductible. Los Bilbao están en el polo de la Barbarie (son “defensores de caudillos”) y él encarna la Civilización:

Entre mi primer escrito contra Rosas, y mi imputada redacción de La Tribuna median veinticinco años, consagrados a destruir despotismos, gobiernos arbitrarios; pues Urquiza mientras lo fue; Rosas, los Aldao, Quiroga, el Chacho, Benavides, los Taboada, no me contaron en el número de sus adherentes y llevan mi marca. ${ }^{53}$

Paralelamente, no pierde la ocasión de denigrar las condiciones de escritor de Manuel:

Esta es la querella con el finado Bilbao, pero no con D. Manuel, que ni en Chile, ni aquí tenía vela en el entierro. Muerto Bilbao, el escritor, éste heredó su nombre, y escritor me fecil [sic], y lo tengo à mes trousses, hace diez años, y diarista de profesión y al servicio de la libertad. ${ }^{54}$

La respuesta de Manuel no se hizo esperar y eligió como vehículo un discurso polémico contundente que, a la vez que dialoga una vez más con la tesis del Facundo, permite una minuciosa descripción del antagonista. Las cartas están fechadas en Buenos Aires los días 26, 27, 28, 29 y 30 de abril y el 1, 3 y 5 de mayo de 1875 .

En una suerte de prólogo, la primera nota pasa revista a las polémicas que han acompañada la vida agitada de Sarmiento, y entre sus contrincantes, menciona a Alberdi y a su hermano Francisco. Luego lo apostrofa:

¿Cuál ha sido el rol político de Ud. Sr. Sarmiento, en su país y en Chile? En Chile y en la República Argentina no ha desempeñado otro rol que el siguiente: vivir del

\footnotetext{
53 "Carta de Sarmiento", op. cit., p. 4.

${ }^{54}$ Los destacados son de Sarmiento.
} 
tesoro público, defendiendo allá el patíbulo para causas políticas, y acá sosteniendo el patíbulo como sistema administrativo. ${ }^{55}$

Retoma después la conocida estrategia de los polemistas que enfrentaron a Sarmiento: la puesta en discusión de su autoposicionamiento como civilizador. Defiende su participación y la de su fallecido hermano en la historia política de Chile y Argentina: "Este bárbaro, como lo llama Ud., respetó siempre la independencia del Poder Judicial". 56

En la segunda carta, después de retomar otro lugar común de este subgénero, una anécdota que termina "con trompadas" (uno de los tantos estallidos violentos del sanjuanino), recupera la antinomia en un uso irónico:

Se hizo el tipo del educacionista. La cuestión era civilización y barbarie. Ud. era lo primero. Lo segundo el pueblo argentino. ${ }^{57}$

Pero cuando Bilbao trae a colación el conflicto con Peñaloza, retoma tácitamente la antinomia con el tono incriminatorio del folleto de Hernández aunque con una dosis mayor de ironía burlesca:

Pero en su rol político era donde debía Ud. inmortalizarse. El asesinato de Benavides fue en ese entonces una acción santa. El asesinato de Virasoro otra acción santa. ¿Recuerda Ud. quién aplaudía esos asesinatos en El Nacional? De un momento a otro cambia la pluma por la espada y se va en la expedición pacificadora contra Peñaloza. ${ }^{58}$

Y una y otra vez amplía el anecdotario emblemático acerca de la agresividad descontrolada de Sarmiento, tal como lo hacían su hermano Nicolás y también Juan José Soto:

\footnotetext{
${ }_{55}^{55}$ M. Bilbao, 1875, p. 14.

${ }^{56}$ Ibidem, p. 18.

${ }^{57}$ Ibidem, p. 24.

${ }^{58}$ Ibidem, p. 25
} 
Montado en el periodismo, libraba Ud. combates contra Calvo, contra Mur, contra el género humano, convirtiendo la prensa en un fangal tan inmundo de personalidades que difícilmente recordará Buenos Aires una época semejante. Esto no le bastaba, necesitaba más escándalos. La ocasión es calva. Encuentra al Sr. Soto en la calle, y porque lo miraba, le acomete como un changador a mojicones. Recoje allí unos bastonazos y corre a quejarse a la policía, de donde sale reprendido. Era el mismo de siempre; no escarmentaba. Ya se había hecho revolcar en Chile acometiendo a Espejo.

De este modo se pueden continuar entretejiendo piezas del polemismo contra Sarmiento en una red intertextual que fija la composición de la imagen de una personalidad intolerante, violenta, agresiva, en definitiva, "bárbara".

Por otra parte, Manuel Bilbao relaciona el asesinato de Peñaloza con la participación de Rawson como una traba legal, una oposición intrapartidaria que se reiterará en el mes de julio de ese año 1875, como se verá más adelante:

Llegó a San Juan. Fue el director de guerra. Fue el gobernador de San Juan. Como director de la guerra ordenó al coronel Sandes fusilar a los prisioneros y fueron fusilados. Como gobernador sostuvo que podía declarar el estado de sitio, lo cual impidió el Dr. Rawson. ${ }^{59}$

Se anticipa además, en el empleo irónico del término "civilización" al tenor de las cartas que Hernández publicará hacia fin de año en el diario de Manuel Bilbao, La Libertad, desde donde polemizará con la "voz de Sarmiento" que resuena en La Tribuna a propósito de la reformulación de su biografía de Peñaloza, recientemente publicada. ${ }^{60}$ Finalmente, como el transcurso histórico ha permitido incluir nuevas piezas en este hipertexto, Manuel Bilbao puede sumar otros ejemplos de la barbarie del civilizador: la tan controvertida orden de poner precio a las cabezas de los revolucionarios durante el alzamiento de López Jordán:

A más de esos actos ¿quién se atrevió a dar el escándalo en este país sino Ud., de pasar un mensaje al Congreso para poner a precio la cabeza de López Jordán y sus

\footnotetext{
${ }^{59}$ M. Bilbao, 1875, p. 25.

${ }^{60}$ Es conflicto se analizará en el apartado 5.
} 
jefes? Y extrañaba la represalia por mano de los Guerra? No, señor Don Domingo, Ud. no puede decir que se basó en la ley para gobernar, cuando están para desmentirle sus órdenes de matar bárbaras, en las cuales se deleitaba describiendo hasta el modo como debían despresar al hombre. ${ }^{61}$

\subsubsection{Polémica con Guillermo Rawson ${ }^{62}$}

Guillermo Rawson -un sanjuanino que será correligionario político de Sarmiento- se había educado en el Real Colegio de San Carlos, completó su formación en la Facultad de Medicina de la Universidad de Buenos Aires, donde se graduó con honores en 1844. Tras concluir sus estudios universitarios, regresó a su provincia natal. Como diputado y como senador enfrentó al caudillo y gobernador de la provincia, Nazario Benavides, que lo encarceló. Después de Caseros, fue electo diputado del Congreso Nacional, donde se opuso a Urquiza. Finalmente, después de Pavón fue elegido senador nacional por San Juan y más tarde se incorporó al gabinete de Mitre, quien lo designó Ministro del Interior.

En el desempeño de esta gestión se enfrentó duramente con muchas de las decisiones gubernamentales de Sarmiento, a la sazón encargado del gobierno de su provincia. El enfrentamiento fundamental se desató durante el levantamiento de Peñaloza, pues fue Rawson quien impidió la promulgación del estado de sitio que Sarmiento pretendía para facilitar la persecución del Chacho, o por lo menos, quien la sancionó como ilegítima desde una postura autorizada. Era la voz de un estado ajustado a la ley lo que se escuchaba a través de las palabras de Rawson.

Esta nueva circunstancia, que una voz legitimada por las marcas de la Civilización y perteneciente a su mismo partido se opusiera a Sarmiento, densifica el conflicto. Rawson, de raigambre unitaria, "doctor", ministro de Mitre, cuenta con todos los atributos suficientes como para desestabilizar la posición asumida por el Sarmiento civilizador. $^{63}$

El 13 de marzo de 1863, cuando se produce el levantamiento del Chacho, Rawson envía una circular a Sarmiento con las recomendaciones sobre las medidas que

\footnotetext{
${ }^{61}$ Ibidem, p. 47. El destacado es nuestro.

${ }^{62}$ Guillermo Rawson nació en San Juan en 1821 y murió en París en 1890.

${ }^{63}$ Con posterioridad, Rawson se destacará además en su labor como médico higienista realizando una tarea pionera en el país.
} 
deben adoptarse frente a la montonera en La Rioja y sus alrededores. Como no son observadas por Sarmiento, que le responde a su vez con otra circular, desde el gobierno de Mitre se ven en la necesidad de publicar un trabajo titulado El estado de sitio según la Constitución Argentina, que comprende los documentos producidos por una y otra parte a fin de que el conflicto con Peñaloza no se transforme en una amenaza para la unidad y paz de la República, o que por lo menos, no dañase la figura presidencial. ${ }^{64}$ Rawson transcribe las circulares dirigidas a Sarmiento en la que le recomienda en nombre de Mitre que se ajuste a la prescriptiva constitucional y se demuestra sorprendido de que Sarmiento no entienda cabalmente los conceptos de "estado de sitio" y habeas corpus y de que "quiera alzar hoy su opinión como doctrina".

Como respuesta, Sarmiento publicó el mismo año, una serie de notas en $E l$ Nacional Argentino desde el 8 hasta el 13 de julio, que más tarde compilará en un folleto titulado El estado de sitio según el Dr. Rawson, publicado cuando prepara su campaña presidencial desde EE.UU en $1866 .{ }^{65}$ Aquí Sarmiento defiende su posición y agrega más información sobre la cuestión de Peñaloza, pero ya empieza a cultivar la estrategia discursiva que dominará su escritura de la biografía del Chacho: procura desterrar el uso del yo y se refiere a sí mismo en $3^{\mathrm{a}}$ persona del singular, y alternativamente, en $1^{a}$ del plural. Por otra parte, desde las líneas iniciales se concentra en desautorizar la voz de su oponente:

Muy a designio ponemos este encabezamiento al examinar un panfleto que con el nombre de Documentos oficiales publicó en Gobierno Nacional en 1863 [...] el lector cándido cree que es una autoridad competente pero [...] es simplemente la manera de ver del Ejecutivo Nacional. ${ }^{66}$

\footnotetext{
${ }^{64}$ En la Biblioteca de la UNLP, puede consultarse El estado de sitio según la Constitución Argentina. Documentos oficiales (Buenos Aires, Imprenta de la sociedad tipográfica bonaerense, 1863). Esta acompañado por un estudio de Ramón Ferreira, Fiscal de Estado y Ministro del Interior (Salas especiales, Colección Joaquín V. González, Armario 7, caja 8, folleto $n^{\circ} 170$ ).

${ }^{65}$ El estado de sitio según el Dr. Rawson (Buenos Aires, Imprenta Argentina de El Nacional, 1866) puede consultarse en la Biblioteca de la Universidad Nacional de La Plata (Salas especiales, Colección Joaquín V. González, Armario 7, caja 8, folleto ${ }^{\circ}{ }^{169}$ ). A modo de introducción y firmado por El Editor, se explica el origen de la publicación. Como se verá en el apartado 3, durante ese año Sarmiento se dedica a preparar su biografía de Peñaloza: El Chacho, último caudillo de la montonera de los llanos.

${ }^{66}$ Ed. cit, p. 2.
} 
Busca demostrar, trazando un sucinto panorama político de la región cuyana, que el gobierno nacional, asentado en Buenos Aires, no tiene una perspectiva real de los hechos. Sostiene que reina la anarquía y se vive una permanente situación de desborde. De todas maneras, las referencias a los caudillos del interior no se suceden con saña. Ahora su encono se vuelca sobre Rawson, de quien se burla por haber firmado tratados "aludiendo al Chacho a quien reputaba amigo de la administración", y contrasta su actitud de mantenerse "en la sombra", mientras "Sarmiento, entre tanto", se ocupaba de "sofocar el conflicto". 67

Por otra parte, la sagacidad de Sarmiento no puede pasar por alto las huellas de una animosidad encubierta en el "lenguaje de admonición paternal" que Rawson emplea con un gobernador de provincias (o sea, él), y no pierde la oportunidad de denunciar que, una vez que se han suprimido las explicaciones dogmáticas sobre el estado de sitio y el habeas corpus, "queda un esqueleto de resortes de polémica, impropios del despacho oficial". 68

La excepcional capacidad retórica de Sarmiento y su habilidad política lo ayudarán a sortear obstáculos mediante una manipulación y readaptación de su definición de lo "civilizado" adecuada para cada situación. Durante su administración como gobernador, había soslayado el conflicto legal con el apoyo de la autoridad mitrista. Pero en otra coyuntura política (que le impone enfrentar graves acusaciones), Sarmiento despliega un arsenal conceptual para argumentar que el fenómeno concreto de la revolución montonera no puede ajustarse a la "razón teórica". No obstante, esa justificación no resultaba contundente para quien aspiraba a la presidencia de la República, y la reconvención de Rawson será analizada explícitamente por Sarmiento en la autodefensa que encarará en 1868 cuando publique El Chacho, ultimo caudillo de la montonera de los Llanos (también buscará un refuerzo adicional para la legitimación moral de su actuación en el prefacio que escribe Mary Mann para esa edición). ${ }^{69}$

Pero en 1875 Sarmiento volverá a enfrentarse con su coprovinciano Rawson en el recinto de la cámara alta, cuando ya ha dejado la presidencia para convertirse en

\footnotetext{
${ }^{67}$ Ibidem, p. 10.

${ }^{68}$ Ibidem, p. 22.

${ }^{69}$ Ver 3.2.4.
} 
senador nacional por San Juan. ${ }^{70}$ Frente a la necesidad de resolver la situación procesal de los sediciosos de 1874 (entre los que se encuentra Mitre) ${ }^{71}$ se retomará una vez más el antiguo conflicto. Sarmiento había redactado un proyecto de ley de amnistía que condonaba la rebeldía mitrista, pero Rawson propuso una revisión cuidadosa de los términos en que estaba escrita esa ley. Su oratoria parlamentaria fue cuidadosamente planeada con el fin de relacionar este proyecto con una línea política de excesos arbitrarios que podían rastrearse hasta el rosismo. ${ }^{72}$

Sarmiento había presentado su proyecto mediante un discurso juzgado por Rawson como "personalísimo", que relativizaba los hechos empleando el término “irregularidades" para referirse a la sedición de Mitre. ${ }^{73}$ Por su parte, en su intervención, Rawson se desvía de la fundamentación legal empleando argumentos ad hominem en una cuidadosa progresión. Así, por ejemplo, la circunstancia política de que el senador que presentó y expuso el proyecto de ley haya sido el presidente de la República durante la época en que se produjo la sedición es presentada como una prueba de la existencia de un pacto de amistad que justificaba manipular las leyes en beneficio de quienes lo habrían suscripto.

El camino que toma el discurso de Rawson alarma a Sarmiento que, luego de algunas demostraciones de incomodidad desde su banca, paraliza la sesión abandonando el recinto. ${ }^{74}$ Rawson se niega a continuar hasta que no regrese a su puesto, y una vez restablecida la asistencia, retoma su discurso en estos términos:

Yo me preguntaba luego, al estudiar la cuestión del punto de vista de los acontecimientos nacionales argentinos, lo que podía entenderse por irregularidades y empezaba a decir lo que ellas fueron en tiempos de Rosas. El señor senador por San Juan encontró que era inadecuada la comparación; creyó que me proponía encontrar

\footnotetext{
${ }^{70}$ Sarmiento asume la banca por San Juan que quedó libre luego de la muerte de J. M. del Carril, el 9 de marzo de 1875. La otra senaduría nacional ya la desempeñaba su rival Rawson.

${ }^{71}$ En noviembre de 1874 , después de que Avellaneda fuera elegido presidente por amplia mayoría, Mitre -su contrincante- encabezó una revolución alegando fraude en las elecciones de diputados nacionales por Buenos Aires. Pero fue derrotado y encarcelado.

${ }^{72}$ La trascripción de pasajes del debate parlamentario se toma de la edición de Polémicas con Sarmiento hecha por Jackson Editores de Buenos Aires, Colección Grandes Escritores Argentinos (Rawson, s/f).

${ }_{74}^{73}$ El debate se extendió del 6 al 15 de julio de 1875.

${ }^{74}$ José Campobassi describe con detalle los incidentes que se desarrollaron en el recinto (Campobassi, 1975, pp. 308-316).
} 
afinidades y analogías entre el gobierno de Rosas y el que acababa de ejercer y tuvo a bien interrumpirme. ${ }^{75}$

A continuación hace un repaso histórico del ejercicio de la violencia política que se viene reprochando a una política de integración nacional basada en el exterminio de los caudillos del interior. Se refiere al asesinato de Benavides y de Virasoro como otros casos de "irregularidades" que se deben denunciar y como el obligado antecedente para considerar el caso del Chacho.

Pasa a denunciar con minuciosadad la manipulación de los hechos y de las leyes en el caso de Peñaloza como otro ejemplo más de las peligrosas "irregularidades" que dificultan el camino institucional de la República, y acusa directamente a Sarmiento de haber apoyado procedimientos ilegales. Aquí se detiene con especial cuidado para describir los acontecimientos que concluyeron en el asesinato del caudillo durante la campaña dirigida por Sarmiento y hace denuncias concretas:

Hubieron fusilamientos de oficiales, verificados por el Director de Guerra, escrita y terminante. Viene el hecho bien conocido de que el Chacho mismo, vencido en todas partes y perseguido, se guarece en su casa o en la de algún pariente en el sitio que se llamaba Olta y que ahora se llama Belgrano. El jefe que mandaba inmediatamente la fuerza va en su persecución, llega a Olta, lo sorprende allí indefenso, porque no tenía fuerza, sino alguna escolta quizás, lo toma, lo mata, y pone sobre un palo la cabeza del viejo Chacho, con su barba blanca, encanecida; y como era conocido por todos, hasta por las plantas que le rodeaban, lo pusieron para terror y espanto de los demás montoneros. Señor aquí me parece que hay también una irregularidad [...]. ${ }^{76}$

Y luego, en una narración que coincide con la del folleto de Hernández, reproduce también algunas de sus modalidades discursivas en la descripción del estado de indefensión en que se encontraba el caudillo, con su larga edad atestiguada por una "barba blanca, encanecida" (que le agrega dignidad patriarcal a la figura), su popularidad (como personaje de los llanos que "era conocido por todos hasta por las plantas que le rodeaban”). Retoma entonces el tono irónico del enjuiciamiento con que

\footnotetext{
${ }^{75}$ Rawson, s/f, p. 104.

${ }^{76}$ Ibidem, pp. 112-113.
} 
había comenzado su exposición: "Esto de cortar la cabeza a un hombre que se toma prisionero, indefenso, es un irregularidad". ${ }^{77}$

Por último, desde la parcialidad política opuesta, Rawson asevera -en la línea abierta por Alberdi- que existe la Barbarie en el campo de lo que se identifica con la Civilización:

Por lo menos requería este hecho cierta reticencia decorosa, ya que no se quería hacer efectiva la responsabilidad contra esos bárbaros que a título de liberales, han contribuido tanto al descrédito del país, y al ensañamiento de las pasiones públicas. ${ }^{78}$

El germen de la desestabilización del modelo antinómico, así como su fundamentación teórica, arranca de las Cartas quillotanas de Alberdi y será cultivado por el periodismo de las provincias confederadas. En ese proceso, la Vida del Chacho de Hernández ahonda el proceso de descalificación de Sarmiento (el "gaucho de la pluma" se convierte en el "bárbaro de la política") en tanto que los polemistas subsiguientes irán sumando a lo largo de la historia política nuevos ejemplos de descolocación de la Barbarie.

De este modo, el discurso de Alberdi, es continuado y matizado por Hernández, a quien acompañan, como hemos visto, personalidades como Nicolás A. Calvo, los hermanos Francisco y Manuel Bilbao, Federico de la Barra, Evaristo Carriego, Olegario V. Andrade. A lo largo de ese proceso, se verifica no sólo la reconsideración de las figuras de la Barbarie. El periodismo de las provincias federales asume la exaltación de Urquiza. Hernández y otros publicistas no sólo encarnarán la Civilización en un caudillo, el Chacho, sino que lo convertirán en un mártir de la lucha por la libertad. Benavides, Virasoro, y más tarde López Jordán, también serán revisitados durante un largo proceso. Sin embargo, el mismo Hernández que se ha atrevido a recuperar a Facundo Quiroga siembra ya en su biografía de Peñaloza semillas de la denuncia de la defección de Urquiza.

\footnotetext{
${ }^{77}$ Sugestivamente, desde comienzos de 1874 está circulando con éxito por Buenos Aires Palabras de un ausente, donde Alberdi identifica el poderío político de Buenos Aires con el que ejerció Rosas durante su dictadura. Lo había hecho, también, en De la anarquía y sus dos causas principales (Alberdi, 1862).

${ }^{78}$ El destacado es nuestro.
} 
A su vez, el antagonismo se plantea con los mismos códigos lingüísticos y estéticos con que se había escrito el Facundo en 1845, o sea sobre la tesis modelizadora de "civilización o barbarie". En consecuencia, el corpus de las polémicas alrededor de la figura del caudillo se complejiza mediante reapropiaciones y resignificaciones discursivas permanentes de la palabra del otro al que se intenta cuestionar y reconstruir. Este esquema de polaridades habilita todo un orbe de asociaciones que se establece inicialmente sobre la base del oxímoron "barbarie ilustrada" introducido por Alberdi en 1853 y que desemboca en la configuración de los "nuevos caudillos" de Buenos Aires, Sarmiento y Mitre.

Así se ve que tanto la exaltación de los caudillos del interior presentados como mártires del progreso, como la estigmatización de los protagonistas políticos del poder de Buenos Aires (los "gauchos de la pluma" que se convierten en "bárbaros de la política") se relacionan con un mismo tipo de ejercicio del poder: como señala Montaldo, la figura sociopolítica del caudillo "magnetiza” sobre sí la descalificación. Por eso los opositores de Mitre y Sarmiento podrán retribuirles los mismos calificativos con los que ellos descalificaron a sus enemigos: "exaltados", "violentos", "revolucionarios", "piratas", en definitiva, "bárbaros". 79

Pero el debate parlamentario en el que interviene Guillermo Rawson marca un importante punto de inflexión en el antiguo polemismo acerca de la organización nacional, ya que la línea crítica inaugurada por Alberdi y continuada por los "federales" críticos de la hegemonía de Buenos Aires termina siendo asumida por un típico representante del Partido Liberal.

Así, quienes contienden con Sarmiento, tanto fuera de su partido como en el interior de él, coinciden en una estrategia discursiva: ubicarlo en el polo negativo de su antinomia irreductible para descalificarlo y, consecuentemente, desestabilizar su propuesta de identidad nacional y su "receta" política. Pero en prospectiva, las objeciones de Rawson son un síntoma de un momento de efervescencia política. En 1876, tanto conspicuos miembros del Partido Liberal como activos opositores -entre ellos, Hernández- confluirán en el Partido Autonomista, que conformando una alianza

\footnotetext{
${ }^{79}$ Hernández, que desde Uruguay ha seguido atentamente todas las polémicas contemporáneas, denuncia en las colaboraciones que hace para La Patria de Montevideo los desplazamientos políticos de Mitre en su nota titulada "De Presidente a revolucionario. De revolucionario a pirata" (La Patria, Montevideo, 25 de octubre de 1874, año II, n 276 , p. 1, cols. 1 y 2 -citado por la edición de Rela-1967, pp. 71-73-).
} 
más vasta se transformará en el Partido Autonomista Nacional en 1880, un año que parte aguas: termina una etapa histórica y comienza otra.

\subsubsection{4. "Sarmienticidio o a mal sarmiento buena podadera"}

Existe una pieza cuestionadora de las posturas de Sarmiento que, aunque constituye una anécdota marginal, está vinculada por un hilo subterráneo con el corpus analizado. Se trata de un texto que el periodista español Juan Martínez Villergas escribió en 1853 reaccionando ante la poca amabilidad y simpatía por la Madre Patria exhibida en los Viajes de Sarmiento. ${ }^{80}$

Es revelador de la capacidad para generar el rechazo público que tenían ciertas posturas y actitudes de Sarmiento el hecho de que Villergas reedite el texto en 1868 (el año de la llegada a la presidencia) en Buenos Aires y en 1874 (el del fin del mandato), esta vez en Montevideo. En el artículo titulado "El escritor como mito político", Adolfo Prieto aporta datos sobre las motivaciones del autor y registra la repercusión que tuvo este folleto en la opinión pública:

Hortelano, librero e impresor español establecido en la ciudad desde antes de la caída de Rosas, envió un ejemplar de los Viajes de Sarmiento a los oficiales de una nave española surta en el puerto. Fue tal el escándalo que la lectura de los pasajes dedicados a la Península provocó entre los oficiales, que Hortelano, entre burlas y veras, imaginó una digna compensación a tantas impertinencias, encargando una réplica a Martínez Villergas, el versátil periodista residente entonces en París. En agosto de 1853, Martínez Villergas concluyó su Sarmienticidio o A mal sarmiento buena podadera, y semanas después llegó a Buenos Aires la edición completa del mismo. -En pocos días vendí los 500 ejemplares -dice Hortelano-, y en breve fue reproducido en varios diarios de Buenos Aires y las Provincias de la Confederación. Varias ediciones se han hecho del Sarmienticidio, habiendo logrado los honores de ser leído por todos los habitantes del Río de la Plata y del Pacífico, en donde Sarmiento es muy conocido. Lo sustantivo de la anécdota no reside, desde luego, en la sátira de Martínez Villergas ni en el dudoso ingenio de su artefacto en prosa y verso. Reside en la comprobación de que el nombre

\footnotetext{
${ }^{80}$ Martínez Villergas, 1853. El texto llevaba un largo título: Sarmienticido o a mal sarmiento buena podadera. Refutación, comentario, réplica, folleto o como quiera llamarse esta quisicosa que, en respuesta a los Viajes publicados sin ton ni son por un tal Sarmiento ha escrito a ratos perdidos un tal J. M. Villergas.
} 
de un escritor local, vivo, fuera suficiente para urdir un proyecto editorial preciso cualquiera fuera la dimensión del mismo-y la comprobación de que ese proyecto estuviera fundado en la existencia de un círculo de lectores para los cuales el nombre, la imagen de un escritor actuaba como determinante de apelación autónomo. ${ }^{81}$

El texto de Villergas combina algunos versos satíricos con capítulos en prosa en los que se dedica a desautorizar los escritos de Sarmiento sobre España. La referencia a su desempeño político en Argentina está ausente porque el folleto fue pensado únicamente como una reivindicación de lo español, sin embargo, su tono polémico y su ironía juguetona despertó una aquiescencia que impulsó su circulación tanto por el Buenos Aires de entonces como en las provincias del Litoral, así como en Uruguay, y hasta llegó a manos de residentes en el exterior. José Campobassi describe en estos términos la difusión de esta obra de Villergas durante su gestión presidencial de Sarmiento: "Uno de los ataques que más se empleó en esos años fue hacer circular profusamente un escrito antisarmientista del andariego periodista español Juan Martínez Villergas". 82

Hernández hace una primera referencia a Villergas en una de sus colaboraciones para La Reforma Pacífica en $1860^{83}$ y luego vuelve a citarlo en 1868 , en uno de los artículos de El Eco de Corrientes. Quizás esta última mención signifique que Hernández ha visto ya la segunda edición de la sátira de Villergas o que sepa que se está preparando la reedición en la ciudad. ${ }^{84}$ Carriego demuestra conocer, al menos, la primera edición del urticante opúsculo. ${ }^{85}$

También Alberdi registra su recepción en los escritos dedicados a examinar la obra de Juan María Gutiérrez y la circulación de la lengua castellana en América. Alberdi ha emprendido este trabajo como un homenaje post mortem para su querido amigo; sin embargo, cuando se refiere al rechazo del diploma de la Real Academia Española por parte de Gutiérrez, la ridiculización que hace Villergas de ese gesto se

\footnotetext{
${ }^{81}$ Prieto, 1988, pp. 482-483.

${ }^{82}$ Campobassi, 1975 , p. 232

83 "No fue Villergas más feliz en la pintura de su D. Pascual Fandango que andaba con dos maletas" (La Reforma Pacífica, Buenos Aires, 29 de febrero de 1860).

84 "Razón tenía Villergas al decir que Sarmiento no sabía el castellano, pero sin duda que debe ser fuerte en geografía" (El Eco, Corrientes, 10 de marzo de 1868).

${ }^{85}$ En una nota titulada "Apuros de Sarmiento", Carriego cita al periodista español: "Con razón Villergas escribió un libro para inmortalizar el tipo especialísimo del exboletinero del Grande Ejército" (El Litoral, Paraná, 27 de mayo de 1862).
} 
cruza inevitablemente con su escritura y no puede reprimir su simpatía por el folleto: "Yo nunca fui desafecto al Sr. Villergas, a quien, lejos de eso, tenía motivo de mirar con el aprecio de un compañero de armas en cierta campaña contra un común adversario". ${ }^{86}$

Es indudable que -como señala Campobassi- es el "antisarmientismo" la causa de esa profusa circulación textual; pero en este caso particular $-\mathrm{y}$ por más que el tono sea de broma irónica-, es la reacción de quienes se autoconsideran "amos de la lengua" y portadores de superioridad cultural lo que impulsa a ubicar a Sarmiento en el polo de la barbarie.

\subsection{Alberdi y el Chacho}

Como ya se ha dicho, el 11 de septiembre de 1852 divide el campo político en el que habían participado mancomunadamente quienes se habían exiliado durante el rosismo. Sarmiento ve en el vencedor de Caseros la persistencia del caudillismo bárbaro y defiende la posición de Buenos Aires - la ciudad que identifica con la Civilización- en tanto Alberdi apoya el proyecto de organización nacional de Urquiza y valora su intención de darle el marco legal imprescindible: una Constitución. Por eso, la polémica entre ambos es un emblema del tipo de confrontación que inaugura una nueva etapa histórica.

Durante el período de la escisión se ahondará aún más ese antagonismo. Cada uno de ellos se consagrará a fortalecer la opción elegida: Alberdi con su labor de tratadista (ya que las Bases fueron complementadas por escritos jurídicos y económicos publicados en Chile) antes de hacerse cargo de las funciones de Ministro Plenipotenciario de la Confederación Argentina ante las Cortes Europeas; Sarmiento, con sus comentarios sobre la Constitución del $53^{87}$ y una prolífica actividad periodística en la que predominará ese discurso panfletario que supo cultivar con maestría.

En 1861, el derrumbe de la Confederación tras la batalla de Pavón los hallará en la misma brecha ideológica en que se habían situado pero en distintos lugares de acción: uno como protagonista de hechos políticos significativos; el otro, como un atento

\footnotetext{
${ }^{86}$ Alberdi, 1895-1901, VI, p. 95.

${ }^{87}$ Ver 1.1.2.1.
} 
observador a la distancia consagrado a fijar en la escritura su reflexión sobre los acontecimientos que no puede presenciar. $^{88}$

Mitre, como gobernador de la provincia hegemónica, pasa a ejercer la representación de todo el país ante el exterior, y en las elecciones de 1862 será elegido presidente de la República. Paralelamente -como ya se ha dicho-Sarmiento impulsará un emprendimiento político-militar en diversas provincias y se desempeñará como gobernador de San Juan.

La resistencia del interior encarnada en el levantamiento de Peñaloza que culmina con su trágica muerte no escapó al análisis de Alberdi, que rechaza la desmesura de la represión. Sus comentarios -vertidos en correspondencia privada que ha trascendido- más alguna que otra indiscreción que ha llegado a oídos porteños le valieron el mote despectivo de "chachista", "amigo de los caudillos". ${ }^{89}$

\subsubsection{El Chacho en los Escritos Póstumos}

Sin embargo, a la luz de la obra póstuma de Alberdi puede observarse que su preocupación por el suceso superó las meras contingencias, y que el tucumano sopesó el significado político y social que este acontecimiento generó en su época y que incluso leyó en el desenlace fatal del episodio una advertencia más acerca de las frágiles condiciones de seguridad personal que ofrecía la patria para su anhelado y siempre pospuesto retorno. En este sentido, la muerte del Chacho deja de ser simbólica en Alberdi para patentizar la cruda realidad que las inestables sociedades latinoamericanas ofrecían a la instalación de la libertad y del libre pensamiento, aun luego de unificado el país. $^{90}$

Alberdi deduce de este ejemplo trágico que, a pesar de que la Argentina se ha reunificado, no están dadas las mínimas garantías para habitar su suelo. Sentencia el hecho, a su vez, con la mayor contundencia posible, calificándolo de "asesinato

\footnotetext{
${ }^{88}$ Además de publicar numerosos ensayos enjundiosos, Alberdi frecuentará cada vez más el género panfletario y hasta incursionará en esas escrituras del yo que tanto había censurado en su adversario. Pero sobre todo, debe tomarse en cuenta que la mayor parte de los borradores publicados en los llamados Escritos póstumos (que ocupan 16 volúmenes, doblando la cantidad de tomos de sus Obras completas) fueron escritos después de Pavón.

${ }^{89}$ Mayer, 1963, pp. 666-667.

${ }^{90}$ Alberdi mismo lo explica: "No intentamos defender al Chacho ni rehabilitar su personalidad. Nos importa solo ver la humanidad respetada, y la vida pública de nuestro país asegurada hasta en sus excesos y desvíos, contra sofismas, más terribles que todas las lanzas de los salvajes" (Alberdi, 1895-1901, V, p. 327).
} 
político" y parangonando al Chacho con grandes figuras de la historia universal que han sufrido muertes violentas. Lo considera una muestra de lo que acontece cuando no pueden superarse las coyunturas facciosas que adormecen los juicios y no se remiten los conflictos hacia un modelo superior de conducta civil y republicana que ofrezca garantías a la sociedad, más allá de los colores partidarios.

Los Escritos Póstumos revelan también que el enfrentamiento con Sarmiento es una obsesión para Alberdi (así como los artículos periodísticos del Sarmiento que se radica en Buenos Aires en 1855 revelaban que Alberdi cumplía la misma función para él), quien dedica mucha tinta a criticar la labor política y literaria del sanjuanino en el final de su primera magistratura. ${ }^{91}$ De los 16 tomos que compendian su labor póstuma, los que rescatan sus "Ensayos sobre la sociedad, los hombres y las cosas de Sudamérica" -que ocupan 4 tomos (del 9 al 12)- tratan temas que lo tienen a Sarmiento como protagonista; en todos ellos hay extensas menciones hacia su persona, su tarea presidencial, sus escritos literarios sobre los caudillos, su "ridícula teoría de civilización y barbarie", sus promesas como educador, sus teorías económicas, y varias menciones sobre su responsabilidad en el asesinato de Peñaloza.

En el tomo V, antes del ensayo titulado Facundo y su biógrafo, se lee una disquisición histórica sobre el origen del caudillaje en América, que se gesta en la revolución contra España y pone a Peñaloza a la par de Artigas, López, Güemes, Quiroga y Rosas, que -como jefes- "son obra del pueblo, su personificación más espontánea y genuina". ${ }^{92}$ Según registra Alberdi, el título de "caudillo" fue otorgado por los propios españoles a los que encabezaron las sublevaciones contra la corona peninsular $\mathrm{y}$, con el poder obtenido, se mantuvieron en las repúblicas que se conformaron; de este modo, constituyen el producto americano del sistema democrático. Aunque Alberdi les reconoce los defectos (sus “arbitrariedades y sus violencias"), subraya que representan "La democracia del pueblo más numeroso y menos instruido y rico" y los contrapone con la "democracia del ejército de línea", que es la democracia que les interesa a Mitre, a Sarmiento y al nuevo partido liberal que busca imponerse

\footnotetext{
${ }^{91}$ Se estima que estos textos han sido compuestos por Alberdi entre 1870 y 1876.

92 Ibidem, pp. 192-211 (apartados XXVIII, "El caudillaje es la democracia mal organizada. Cómo suprimirla según la idea de Belgrano"; XXIX "El caudillaje es la democracia en forma republicana"; XXX, "Si el caudillaje es producto de la democracia bárbara, el despotismo es producto de la democracia inteligente").
} 
desde el poder de Buenos Aires. ${ }^{93}$ Después de traer a colación el deseo de Belgrano de implantar una monarquía para evitar el caudillaje futuro ("a los Quiroga, a los Chachos, y a toda esa larga dinastía de reyes de poncho"), ${ }^{94}$ afirma que Mitre y Sarmiento sólo quieren reemplazar a estos "caudillos de poncho, por los caudillos de frac". 95

En el tomo IX critica las apreciaciones de Eduardo Laboulaye ${ }^{96}$ cuando hace el retrato de Sarmiento de acuerdo con la información que el mismo protagonista le aporta, lo que lo induce al error de alegar en su favor en relación con la muerte del Chacho. Alberdi se queja de que se intervenga con esta irresponsabilidad en cuestiones tan graves, ya que Laboulaye expresa sin empacho que Peñaloza fue ajusticiado "según el uso de las pampas".

Recuerda, además, los antecedentes del Chacho, cuyos títulos militares "son de la misma tinta y pluma que los de Mitre", y vuelve sobre lo que considera que "toda la República Argentina sabe": que el Chacho no fue ajusticiado en regla sino "lanceado en el acto de rendirse". Y una vez más, mediante el uso de los destacados, Alberdi refuerza su mensaje: busca recuperar el conflicto sobre las "formas legales", que es lo que pone en discusión todo el episodio de Peñaloza; es el tema sobre lo que Alberdi quiere insistir y el que Sarmiento desea silenciar. El jurista no podía dejar de recalcar que "el partido de la civilización" ha preconizado un manejo de la formalidad que en realidad oculta una manipulación alevosa. ${ }^{97}$

${ }^{93}$ En uno de sus típicos razonamientos silogísticos, concluye: "Luego los caudillos son los representantes más naturales de la democracia de Sud América, como ella es pobre, atrasada, indigente" (ibidem, p. 203).

94 "Su remedio era éste: Belgrano quería salvar la democracia independiente de América, monarquizándola, es decir, dándole una personificación americana noble, alta, digna de ella, en un jefe irrevocable de su elección, con el título de soberano, en lugar de tener por personificación y símbolo encarnado a los Artigas, a los Quiroga, a los Chacho, y a toda esa larga dinastía de reyes de poncho, sin corona pero sin ley, y armados de un cuchillo en lugar de un cetro" (ibidem, p. 204).

${ }_{95}$ El destacado es de Alberdi.

${ }^{96}$ El jurista, publicista, y político francés de la Tercera República, Edouard Laboulaye (18111883) fue un observador atento y un admirador de la política de los Estados Unidos.

${ }^{97}$ Consigna Alberdi: "M. Laboulaye hace el retrato de la vida de Sarmiento sobre el testimonio mismo de su héroe (los Recuerdos de Provincia son su fuente, que él cita). He aquí otro rasgo de esa vida: "En 1862, nombrado gobernador de San Juan, fue obligado a tomar la espada. La ciudad estaba amenazada por una banda de gauchos, conducida por un jefe célebre, el Chacho; pero el coronel sabía cómo se hace la guerra de las pampas: en poco tiempo la banda estaba anonadada y su jefe fusilado. "Así, el ilustre Laboulaye aplaude implícitamente que, según el uso de las pampas, se hubiese mandado asesinar al Chacho (pues toda la República Argentina sabe que el Chacho no fue fusilado en regla, sino asesinado, lanceado en el acto de 
En el apartado LIII del tomo X, se publican otros apuntes sobre Sarmiento y el fenómeno del caudillismo. ${ }^{98}$ Principian con una referencia a las biografías de Aldao y Quiroga para establecer un contrapunto permanente entre éstos y su biógrafo, comparando con fina ironía sus servicios para el país de pedagogo y de escritor liberal, “que no le impedirán incurrir en el odio" (como le sucedió “a sus héroes favoritos”) y le permiten convertirse en "el peor déspota" mientras que todos los caudillos como Rosas, Quiroga, Peñaloza, etc. representaban la barbarie "a título de guerreros, de militares".

Luego la escritura hace una referencia en presente (lo que la ubica en una temporalidad anterior a la de los apuntes publicados en el tomo V) a una guerra fratricida, que para "lavarse del cargo de barbarie, se justifica con el título de guerra de policía", haciendo franca alusión a cómo se justificó el asesinato de Peñaloza. ${ }^{99}$ Una vez más, se insiste en el contrapunto entre las "montoneras" y los caudillos de las ciudades que reúnen gente en "clubs, cafés, meetings, logias, pronunciamientos, motines, revoluciones". 100

rendirse - y el que lo lanceó no tardó en recibir un ascenso en premio de su noble acción. Su biógrafo de Los Debates es quien hace hoy a Sarmiento el honor de esa hazaña, no nosotros. ¿Quién era el Chacho? El mismo Debates colocó en los anales cronológicos de 1862, a la cabeza de los militares célebres, muertos en 1861, el nombre del general Peñaloza. Ese general era el Chacho. ¿Era digno de ese honor? Mejor que de su muerte al uso de las pampas. Había militado por la libertad contra el Dictador de Buenos Aires en 1841, a las órdenes del general Lavalle, como aliado de los franceses. Vencido en esa noble campaña, se refugió en Chile, como Mitre y Sarmiento; pero no vivió como éstos, mezclado a la política del país que le hospedaba; ni salió de Chile desterrado como Mitre, para volver a su país después de caído Rosas. Como gobernador de La Rioja, asistió al congreso de gobernadores tenido en San Nicolás y firmó el pacto que suprimió las aduanas interiores, abrió los ríos a la libre navegación y convocó al congreso que sancionó la constitución célebre de 1853. -Sarmiento no hizo igual papel: Mitre, lejos de asistir, resistió a esos trabajos, más nobles que la victoria dolorosa de Caseros. Los títulos militares del general Peñaloza son de la misma tinta y pluma que los títulos del general Mitre. Mientras éstos luchaban contra él, disponiendo de todo el tesoro y los recursos de la República sin poder vencerlo, el Chacho no tenía más tesoro para defender la causa defendida por una mitad de la Nación, que el amor de su pueblo, que lo seguía, sin sueldo ni estipendio pecuniario. Y el representante literario de la democracia francesa encuentra bien que Sarmiento hubiese fusilado al Garibaldi de La Rioja, como se hace la guerra de las pampas, es decir, sin juicio y de un modo salvaje, no fusilado, sino lanceado y degollado" (Alberdi, 1895-1901, IX, pp. 556-558).

${ }_{98}$ Nunca debe olvidarse, cuando se consultan los Escritos póstumos de Alberdi, que se trata de borradores jamás considerados por su autor "listos para ser publicados". Sus editores los disfrazaron de "textos" alterando la secuencia cronológica primigenia, que sólo puede reconstruirse mediante los manuscritos que se conservan (Lois, 2007, pp. 14-16).

${ }^{99}$ Alberdi, 1895-1901, X, p. 349.

${ }^{100}$ Ibidem, p. 350. 
Por otra parte, en el apartado XI, titulado "El asesinato político", había comparado el asesinato de Peñaloza con la suerte de otros personajes destacados de la historia europea y americana, como el Príncipe d'Orange, a quien Felipe II hizo matar prometiendo una recompensa monetaria a su asesino. Y había comentado, con sarcasmo: “¡Cuántos imitadores ha tenido, más tarde, Felipe II en la América del Sud!” e incluye en la lista a los asesinos de Florencio Varela, Sucre, Bolívar, ${ }^{101}$ y el Chacho: "El asesino del general Peñaloza recibió un grado militar en el ejército argentino". ${ }^{102}$

En el tomo XI, en tanto se dedica a criticar el centralismo económico de la aduana y el puerto porteños como los causantes de la concentración de poder político que da lugar a figuras como Rosas, vuelve a apuntar a la labor de Sarmiento como publicista, criticándolo porque, en lugar de difundir obras que sirvan para ilustrar al pueblo argentino sobre estas cuestiones tan necesarias como la Historia de Felipe II, se empecinó en traducir "su vida de Facundo Quiroga y en escribir la Vida del Chacho, tiranos aldeanos de su país, héroes oscuros de guerra civil” y continuó el modelo económico de Felipe II, es decir, la concentración del poder en Buenos Aires. Este comentario pone de relieve con qué atención sigue Alberdi a todas las publicaciones de Sarmiento y cómo analiza con minuciosidad su contexto de producción. Desde esta mirada, a Alberdi le resulta desconcertante que Sarmiento haya escrito "esas vidas de Quiroga y del Chacho" que sólo tuvieron "un sentido general en la historia de las resistencias con que lucha en todas partes el desarrollo de la civilización”, mientras reprodujo como gobernante, el régimen económico de origen colonial. ${ }^{103}$

\subsubsection{Alberdi, precursor del análisis del discurso y de la crítica genética}

Alberdi es conocido por su condición de Redactor de la Ley y por la profundidad de sus tratados jurídicos tanto en nuestro país como en el exterior; pero la historia del pensamiento argentino lo ha señalado, además, como uno de los precursores de los estudios económicos y sociológicos, en tanto que quienes examinan los procesos culturales y la producción literaria se han detenido en su desempeño en el periodismo costumbrista y en su producción satírica (tanto narrativa como teatral). Ahora bien, el modo en que Alberdi analiza el conflicto que nos ocupa lo revela, a su vez también,

\footnotetext{
${ }^{101}$ Alberdi acepta la postura de quienes sostienen que Bolívar ha sido asesinado.

${ }^{102}$ Alberdi, 1895-1901, X, p. 497.

${ }^{103}$ Ibidem, XI, p. 213.
} 
como "precursor" en otros dos campos disciplinares: el análisis del discurso y la crítica genética.

Cuando Alberdi emprende un minucioso examen de la Campaña en el Ejército Grande en la primera de sus Cartas quillotanas, declara:

[...] nada tengo que hacer con su persona, sino tributarle respeto. Voy a estudiarlo en sus escritos, en lo que es del dominio de todos. ${ }^{104}$

Y a continuación se dedica a relevar en el discurso de Sarmiento indicadores (tanto lingüísticos -como el predominio de la $1^{\text {a }}$ persona del singular-como conceptuales) que le permiten elaborar un sistema explicativo que da cuenta tanto de lo que se dice y del modo en que se lo dice, como de lo que no se expresa directamente y configura un subtexto.

El arsenal de estrategias discursivas de las Quillotanas se vale también de herramientas geneticistas. ${ }^{105}$ En una dimensión universal, el análisis genético de textos se había venido realizando toda vez que un lector crítico advertía la existencia de reescrituras del autor en dos o más versiones (manuscritas o éditas) de un texto y leía en esas reformulaciones significados dignos de ser tomados en cuenta. ${ }^{106}$ Pero Alberdi se transformó en un precursor inesperado de los estudios de genética textual en Hispanoamérica cuando en medio de su polémica de 1853 interpretó la significación de las reformulaciones de la $2^{\text {a }}$ edición del Facundo en estos términos:

Facundo es no solamente la historia de la barbarie y el proceso de los caudillos argentinos, sino también la historia y el proceso de los errores de la civilización argentina representada por el partido unitario. ${ }^{107}$

La primera edición de Facundo ${ }^{108}$ tenía una introducción en que se daba la teoría del caudillaje presentándolo como expresión normal de la vida argentina; y dos capítulos finales sobre el gobierno unitario y el presente y provenir argentino, en que

\footnotetext{
${ }^{104}$ Alberdi, 1957, p. 12.

${ }^{105}$ Ver Lois, 2011, pp. 149-156.

${ }^{106}$ Lois cita un ejemplo de 1501 (ibidem, p. 149).

${ }^{107}$ Todos los destacados son de Alberdi.

${ }^{108}$ Civilización y barbarie. Vida de Facundo Quiroga, y aspecto físico, costumbres y hábitos de la República Argentina (Sarmiento, 1845).
} 
hacía Vd. justa acusación al liberalismo destituido de sentido práctico, que hoy reaparece en la lucha.

Esa introducción y esos dos últimos capítulos han desaparecido en la segunda edición de Facundo, ${ }^{109}$ por consejo del doctor Alsina, representante actual del antiguo partido unitario. [...] Esa supresión cambió el sistema y el carácter del libro, despojándole de su imparcialidad en gran parte, no del todo. ${ }^{110}$

Una atenta lectura de ediciones sucesivas le permitió a Alberdi valerse de un análisis genético para denunciar un acto de camaleonismo político, a la vez que su aguda percepción metalingüística construía a partir del análisis del discurso de la Campaña en el Ejército Grande la implacable máquina argumentativa de su polémica.

Esas aptitudes se observan también en la lectura crítica a la que sometió el célebre ensayo acerca de la identidad nacional que instaló a Sarmiento como el más destacado prosista del siglo XIX. Facundo y su biógrafo se publicó en el tomo V de sus Escritos Póstumos, ${ }^{111}$ pero se trata de anotaciones que habrían sido escritas durante 1874. ${ }^{112}$ Ya el título de esos apuntes es un indicador de que, durante toda su vida, Alberdi seguirá polemizando con su adversario: la coordinación no oculta que sus reflexiones apuntan contra dos objetivos: la propuesta del texto y su autor.

El estudio comprende 27 capítulos en los que Alberdi -retomando la línea inaugurada por las Quillotanas - intenta destruir el texto de Sarmiento cuestionando su enfoque histórico, su pertinencia literaria y, por último, el núcleo de su tesis: la antinomia misma. No se priva de acusar a Sarmiento de mendaz, de especulador político y de caudillo de la pluma. Pero agrega, ahora, la imputación de que el Facundo ha resultado un texto "peligroso", "pernicioso", por haber instalado la "teoría del crimen político y social como medio de gobierno". Así, redefine la obra como "manual del caudillo y del caudillaje", como el "catecismo del caudillaje urbano". ${ }^{113}$

A partir del capítulo XIX hasta el XXVII, se concentrará en el análisis de $E l$ Chacho, último caudillo de la montonera de los llanos, y otra vez desde una perspectiva

\footnotetext{
${ }^{109}$ Sarmiento, 1851.

${ }^{110}$ Alberdi, 1957, pp. 79-80.

${ }_{111}^{11}$ Alberdi, 1897, V, pp. 273-383.

${ }^{112}$ Jorge M. Mayer y Alberto Octavio Córdoba intentaron fechar todos los borradores incluidos en los Escritos póstumos (Mayer, 1963; Córdoba, 1968); posteriormente, Lois (2005, 2007, 2010, 2011b) estableció algunas correcciones a partir del examen de manuscritos.

${ }^{113}$ Alberdi, 1895-1901, V, pp. 287 y 318.
} 
genética del proceso editorial, registrará que una nueva edición del Facundo que incluye biografías de varios "personajes", como Aldao, el Chacho y "el Sarmiento", "transformado de historiador y biógrafo, en caudillo y actor":

El Chacho-Sarmiento. El Chacho podría titularse con igual motivo el Sarmiento, como libro que se ocupa de Sarmiento más que del Chacho. No es un libro con visos de historia, como los otros. Es un alegato de bien probado, la relación de un pleito; un proceso en que Sarmiento no puede ser historiador y juez, porque es parte beligerante. Es, a la vez, un ataque contra el enemigo muerto, hecho en defensa propia por el enemigo vivo: un escrito de guerra, un acto de hostilidad, pasada ya la guerra, pues el vencido está en la tumba sepultado por el autor del libro. Se necesita no respetar al público para darle a leer tal escrito digno de él. La sola excusa del autor es que su obra es su vindicación de un hecho que la opinión del país le imputa como un crimen de asesinato político. El que es acusado de haber hecho matar a Peñaloza alevosamente y en guerra desleal, no puede ser su historiador, es decir, su juez. El libro titulado el Chacho, es la prosecución de la guerra civil, un acto de guerra civil contra un cadáver, contra una tumba. Lo que inquieta al cronista es que la razón y la moral tienden a proteger a su víctima. ${ }^{114}$

Por otra parte, antes no había prescindido de compararlo con Rosas:

El hecho es que la misma causa que quebró la vida de Rosas en dos partes, haciendo de un buen ciudadano campesino un terrible tirano de Buenos Aires, es lo que ha dividido en dos mitades la vida de Sarmiento, haciendo de un buen provinciano liberal, un aciago restaurador de la tiranía económica que tuvo a Rosas por instrumento. ${ }^{115}$

El objetivo manifiesto de Alberdi es impedir que el texto funcione como justificativo de una acción política "bárbara" y machaca el concepto de que el que escribe el libro es protagonista de los hechos, por lo que no puede ser "juez y parte", no se puede ser "acusador y detractor póstumo y de ultratumba".

${ }^{114}$ Ibidem, p. 305.

${ }^{115}$ Alberdi, 1895-1901, V, p. 304. 
Introduce, además, una semblanza conmovedora del caudillo riojano que "pobre y desnudo de recursos, arrastraba la mitad de la República, que le seguía por simpatía", mientras del lado opuesto, describe a un adversario político que, con todos los recursos de la República, "temblaba de miedo y de impotencia ante la popularidad del Chacho; y de miedo, como es visible en su libro, lo hizo matar alevosamente". ${ }^{116}$ Frente al heroísmo desinteresado del Chacho, la cobardía alevosa de los poderosos, que además se dan el lujo de escribir una obra justificativa cuya caracterización se compendia así:

Es una pesada y desesperada vindicación sin éxito. No es la vida del Chacho. Es la acusación del Chacho por motivos compuestos para justificar su muerte, de que es responsable en la historia de su país su mismo acusador. ${ }^{117}$

Desde la mirada de Alberdi, la publicación de ese libro se convierte en un acto de agresión, en un hecho de violencia: "es la prosecución de la guerra civil, un acto de guerra civil contra un cadáver, contra una tumba", "un crimen de asesinato político".

Alberdi examina el texto remitiéndolo a los moldes clásicos de la autobiografía defensiva y considera que, si Sarmiento hubiera encarado el tema abiertamente desde esta perspectiva, su crítica debería limitarse a cuestiones de fondo; sin embargo, se demora en analizar el discurso del texto porque reconoce en sus estrategias una maniobra astuta para desviar la atención hacia otro tema y desfocalizar su persona y su responsabilidad directa en los hechos. ${ }^{118}$

Por ello, los intentos de Alberdi van en el sentido opuesto; busca vincular al texto con las necesidades vitales del sanjuanino en el momento que lo compuso y destaca la construcción de un "su antagonista" de la Civilización. Aunque el Chacho "era un ángel de bondad" al lado de Quiroga, toda su vida descripta por Sarmiento se convierte en un tejido de asesinatos y robos:

\footnotetext{
${ }^{116}$ Alberdi devuelve así la estocada que Sarmiento le asestó a él repetidas veces: la acusación de cobardía.

${ }^{117}$ Ibidem, p. 325.

${ }^{118}$ En 3.2.3. se analizarán los modos de enunciación del texto de Sarmiento, que se incorpora a la narración desde la tercera persona evitando ese uso permanente de la $1^{a}$ persona del singular que tanto le han censurado.
} 
El libro de El Chacho ha sido otra refutación del Facundo, pues después de excusar los crímenes de este caudillo por la manera peculiar de ser de la sociedad argentina en las campañas pastoras, que tenían en Quiroga su personificación y su símbolo, hace matar al Chacho como un mero salteador, por actos cien veces menos enormes que los de Facundo Quiroga, en la opinión de todos, incluso Sarmiento mismo, que confiesa la humanidad y benignidad del Chacho. Nativo de esa misma Rioja que produjo a Quiroga, y mil veces más popular que éste, pues Sarmiento confiesa que no forzaba a los paisanos a seguirlo, ni usó jamás del terror, ¿por qué ha sido inexcusable a los ojos de Sarmiento? Porque era su beligerante, su rival, su antagonista en poder. Si durante treinta años las masas democráticas de la Rioja no dejaron de seguirlo a pesar de sus desastres, es claro que lo querían como su representante. Siendo La Rioja un estado soberano, como Buenos Aires, ¿con qué derecho tratar como salteador común a un jefe suyo, porque imitaba la actitud de Buenos Aires en 1853, ante el Gobierno nacional argentino? ${ }^{119}$

La manipulación semántica de Sarmiento se denuncia también en sus opiniones sobre la montonera, en donde Alberdi demuestra este alevoso corrimiento: mientras que la montonera en el Facundo es la "forma natural de la guerra en las democracias rurales", en la Vida del Chacho es "mero bandalaje [sic] de salteadores".

Como conclusión, Alberdi sentencia que luego del Chacho vendrán los caudillos de la ciudad, recuperando su tesis de las Cartas quillotanas:

Al caudillo de las campañas sigue el caudillo de las ciudades, que se eterniza en el poder, que vive sin trabajar, del tesoro del país, que fusila y persigue a sus opositores, que hace guerras de negocios, pero todo en forma y en nombre de la ley que, en sus manos, es la lanza perfeccionada del salvaje. ${ }^{120}$

En el entramado intertextual que el polemismo habilita, los adversarios de Sarmiento vuelven a retomar sus obras y a refuncionalizarlas dentro de un contexto político en permanente crisis, indagando en la simbología social para resemantizar lexemas que ya se han impuesto y señalando la otredad en Sarmiento, cuya divisa Alberdi acababa de definir en estos términos:

${ }^{119}$ Alberdi, 1895-1901, V, p. 325.

${ }^{120}$ Ibidem, p. 374. 
[...] Civilización y barbarie, es decir, las dos cosas unidas, formando un solo todo: una civilización bárbara, una barbarie civilizada. ${ }^{121}$

Como en un último duelo, así como Rawson en su discusión parlamentaria con Sarmiento lo compara con Rosas, Alberdi lo confronta con el Chacho:

No fue el Chacho el que acabó de arrasar al Paraguay, [...] arrasó al Entre Ríos [...], ha endeudado a la nación [...], arrancó de las manos de Wheelwright las empresas [...], el que privó a Buenos Aires y a la nación del puerto de la Ensenada ni el autor de la espantosa crisis de pobreza por que pasa la República Argentina. ${ }^{122}$

De este modo, Alberdi colabora en el juego de "álter egos" ferozmente irónico que construyen los polemistas que enfrentan a Sarmiento y lo hace con otra analogía, aún más audaz, mediante la cual se parangona la multifacética personalidad del ex presidente de la República con otra imagen de la "barbarie".

\subsection{Hernández periodista}

La actividad de José Hernández como publicista se desarrolló en un contexto de tácitas alianzas políticas que se definieron, principalmente, por su oposición a la figura de Sarmiento y se expresaron con frecuencia por medio de polémicas públicas a lo largo de una etapa histórica signada por acontecimientos que representaron puntos de inflexión (Caseros, la escisión de Buenos Aires, Pavón); pero finalmente, se encarriló (aunque con idas y vueltas) por el inicio de un proceso de conciliación de los partidos. Por consiguiente, referirse ahora a su trayectoria periodística individual nos obligará a recorrer nuevamente la temporalidad de la producción examinada en 2.1. y 2.2.

\subsubsection{Resemantización de la antinomia "civilización versus barbarie" en el periodismo de Hernández}

\footnotetext{
${ }^{121}$ Alberdi, 1895-1901, V, p. 317 (apartado "El Chacho-Sarmiento").

${ }^{122}$ Ibidem, p. 380.
} 
Como se ha dicho, Rasgos biográficos del General D. Angel V. Peñaloza también puede abordarse desde la perspectiva del género ensayístico como una operación dialógica mediante la cual Hernández, un periodista novel, se decide a acometer la refutación de los principios sociológicos postulados en el Facundo y se lanza de este modo a desafiar un esquema de interpretación sobre la argentinidad ya ampliamente legitimado, aunque también puesto en cuestión por las Quillotanas.

Hernández recorta este texto de su producción periodística y compone un folleto ordenando un conjunto de artículos que habían sido publicados en forma sucesiva. Con la reunión de esas piezas conforma su primer opúsculo independiente dentro de lo que hasta entonces ha sido una producción escritural exclusivamente periodística, ${ }^{123}$ y lo seguirá siendo hasta que en 1872 produzca con El gaucho Martín Fierro un éxito que, por transformarse en un fenómeno editorial jamás visto en el incipiente campo literario de la época, tiene que haber impresionado hasta a los letrados que jamás lo mencionaron.

Al seguir el itinerario de Hernández como diarista, se aprecian, simultáneamente, tanto la singularidad de esos Rasgos biográficos del General D. Angel V. Peñaloza -la única de sus construcciones periodísticas que ofreció una mirada detallada y pormenorizada acerca de un caudillo de provincias-, como los hilos que vinculan al opúsculo con su actividad de publicista.

Hernández revista durante más de una década en el bando urquicista (es el urquicismo el que financia El Argentino de Paraná, al menos hasta la publicación de esa semblanza del Chacho que conlleva un subtexto admonitorio dedicado al General). Sin embargo, durante su desempeño en las filas del periodismo partidario, en todas sus menciones de Urquiza, predomina el registro informativo (por ejemplo, en referencias puntuales a su desempeño como vencedor de Caseros y como presidente de la Confederación), a pesar de la evidente intención propagandística. Así, salvo la cuota de ficcionalización que conlleva el subgénero "propaganda política”, Hernández no hace de la figura del General Urquiza un objeto de elaboración literaria. ${ }^{124}$ Tampoco se

\footnotetext{
${ }^{123}$ Incluso los dos poemas gauchescos firmados con el seudónimo "Juan Barriales", cuya autoría le atribuye Fermín Chávez, habían sido publicados en El Nacional Argentino de Paraná. Ver 2.1.2.2.

${ }^{124}$ El único contraejemplo es la mencionada advertencia a Urquiza, que -como se ha vistotoma la forma de una enfática alocución profética, lo que en 1875 dará pie para que -en $L a$
} 
encuentran descripciones extensas de ningún otro caudillo del interior, ninguna reminiscencia anecdótica ni evocativa de Benavídez, Virasoro, ni de otro defensor de la causa de la Confederación, mencionados al pasar en su biografía del Chacho, y que son incorporados sólo esporádicamente en su discurrir periodístico. Tampoco escribió Hernández sobre Ricardo López Jordán, caudillo al que conocía personalmente desde su llegada a Paraná y al que acompañó más tarde en su primer levantamiento y en el posterior exilio. $^{125}$

En ese tratamiento detenido que sólo le merece la figura del Chacho parece haber algo más, además del homenaje a una figura patriarcal y la condena de un atropello en consonancia con la reacción de su bando político: a lo largo de la escritura va creciendo el cuestionamiento de una construcción maniquea de la identidad nacional. Es la visión de dos polos inconciliables lo que Hernández intenta resquebrajar y su versión sobre la vida del Chacho vehiculiza esta tensión.

Con la proyección de su propia subjetividad y la apelación violenta a la figura de Sarmiento, identifica a un adversario y se erige en su acusador. Así, ambos escritores se integran en un complejo esquema referencial que densifica el universo de sentidos y construye un nuevo relato en el que intervienen Hernández y Sarmiento. A partir del folleto sobre el Chacho, Hernández se autopostula como el principal detractor de Sarmiento en el presente histórico y el recorrido por su producción periodística permite apreciar un proceso de construcción en el que el impugnador personifica en algunos casos la libertad y la justicia, pero en otros la rebelión y la "barbarie", en un itinerario que se articula en relación con una red de polémicas que lo tienen a Sarmiento como antagonista (fundamentalmente en la proximidad de su presidencia y en su cierre).

La resemantización de la dicotomía que había iniciado el propio Sarmiento cuando en su Campaña en el Ejército Grande incluyó a Urquiza en el campo de la barbarie, se había transformado en una desviación-boomerang en las Quillotanas de Alberdi, que convierte al autor del Facundo en un "gaucho de la pluma". Hernández profundizará esa desviación presentándolo en su biografía de Peñaloza como un "bárbaro de la política” frente a un Chacho patriarcal que es, a la vez, héroe y mártir, y

Tribuna de Buenos Aires- se acuse maliciosamente a Hernández de "anunciar" la muerte de Urquiza. Ver 5.3.

${ }^{125}$ López Jordán era yerno de Ramón Puig, en cuya casa trabajó Hernández como tenedor de libros ni bien llegó a Paraná en 1858. 
que encuentra la muerte asesinado a manos de los que supuestamente representaban la “civilización”. A partir de aquí, no habrá órgano del partido federal que omita referencias a Sarmiento o a su célebre antinomia contribuyendo a la multiplicación de los desvíos referenciales.

\subsubsection{Sarmiento y la antinomia "civilización versus barbarie" en el periodismo de Hernández}

El enfrentamiento conflictivo de los dos modos antagónicos de ver la realidad nacional, desde la perspectiva de Sarmiento o desde la perspectiva de Hernández, puede rastrearse a lo largo de toda la labor periodística del futuro autor del Martín Fierro. Desde su tarea inicial en sus colaboraciones para La Reforma Pacífica de Buenos Aires (1860-1861), seguida por los editoriales de El Nacional Argentino (1860), su colaboración en el periódico de Evaristo Carriego, El Litoral (1862) y los artículos de su propio órgano El Argentino (1863) - estos últimos todos de la ciudad de Paraná-, puede seguirse un proceso en el que Hernández va profundizando su confrontación con Sarmiento.

Este conflicto se agudiza en sus colaboraciones para El Eco de Corrientes (1868) y La Capital de Rosario (1868-1869) en las que se observa la recuperación perentoria del conflicto en el momento en que se define la candidatura presidencial de Sarmiento.

Los editoriales de El Río de la Plata (1869-1870), el diario que publica durante la presidencia de Sarmiento, tampoco soslayan esta mirada que se retoma de manera definitiva en su participación periodística al finalizar la gestión, cuando se vuelve al conflicto en los artículos que Hernández escribe para La Patria de Montevideo (1874) y La Libertad de Buenos Aires (1875) y que se analizarán en el apartado 5.

La investigación pormenorizada de todos estos escritos periodísticos permite trazar una línea de continuidad coherente en la polémica que Hernández establece con los postulados del Facundo y con la figura política y literaria de Sarmiento. Se demuestra a partir de ellos, que Hernández es el contrincante más fervoroso y atento del sanjuanino, no perdiendo ninguna oportunidad para censurarlo.

En el estado de Buenos Aires desfilan en veredas opuestas, Hernández con los reformistas y Sarmiento con los separatistas. Luego, desde su exilio en Paraná, la lucha prosigue con el asesinato del Chacho que hace irreductible el enfrentamiento que 
pervivirá en las opiniones que volcará Hernández respecto de la candidatura presidencial del sanjuanino. Luego viene un período en el que Hernández se muestra más benévolo y dispuesto a ejercer la oposición "legítima" en la presidencia de Sarmiento. Pero esta pretensión es fugaz y Hernández termina exiliado en Brasil, acompañando a un caudillo en la última rebelión provincial de Entre Ríos, lo que hace notorio, una vez más, que sus posiciones son inconciliables y que la manipulación proteica de los términos de la antinomia es permanente en el discurso periodístico de ambos escritores.

Se pueden distinguir al menos dos ciclos semánticos sobre la reformulación de la tesis sarmientina, claramente escindidos en la labor periodística inicial de Hernández. Por un lado los artículos comprendidos en La Reforma Pacífica de Buenos Aires (18601861)y en El Nacional Argentino de Paraná (1860). En estos primeros escritos Hernández emplea el término “civilización” en el sentido más común, como sinónimo del progreso al que la joven Nación aspira. El hincapié está hecho en la idea de unidad y comunidad, como los fines últimos a alcanzar para lograr la entrada en la nueva era de promisión y adelanto para el país, con un cierto tono de advertencia frente a la posibilidad de que los intereses sectarios de Buenos Aires impidan la concreción de los hechos.

En un segundo lugar se pueden incluir a sus colaboraciones en El Litoral de Paraná (1862), de Evaristo Carriego, que funciona como un claro antecedente para sus editoriales de El Argentino de Paraná (1863), el periódico urquicista en el que Hernández se manifiesta profundamente desilusionado por la política nacional. Podemos apreciar que aquí otorga un nuevo significado al término positivo de la antinomia, que ahora se carga de contenido religioso: "civilización cristiana" mientras que el polo negativo se ahonda con referencias al mundo animal: la fiereza de los tigres, colas, garras, la curiosa figura del “tiburón” en el sillón de Rivadavia.

$\mathrm{Su}$ discurso se polariza e incorpora un tinte irónico que esgrime los mismos ideologemas en contra de la oposición. Hernández ataca con marcado acento de combate, con una prosa cargada de polemicidad que recupera el empleo insistente del polo negativo de la antítesis, y, en algunas oportunidades, de lexemas mazorqueros.

Significativamente este ánimo polémico, con el que dio a luz el folleto del Chacho, intentará moderarse en algunas oportunidades pero volverá a resurgir, 
inevitablemente, en muchas de las colaboraciones que Hernández hace en los periódicos El Eco de Corrientes (1868), La Capital de Rosario (1868-69) y La Patria de Montevideo (1874) que, como se puede entender por las fechas de publicación, salen en el inicio y en el cierre de la gestión presidencial de Sarmiento. En un desembozado y definitivo ataque personal se retomará este mismo tono periodístico de los editoriales paranaenses, en las cartas que Hernández publicará en La Libertad de Buenos Aires (1875).

La exploración de esta labor periodística permite distinguir entonces dos líneas discursivas claramente escindidas y que acompañan el ánimo político de Hernández. Para Hernández habría dos únicas luchas legítimas: una por la libertad, que vendría a estar simbolizada en la batalla de Caseros, y otra por la unión, en la de Pavón. La sorpresiva respuesta de Urquiza frente a la posición de los porteños y las consecuencias que este hecho tuvo para la vida de la Nación signaron de manera indeleble el juicio de Hernández que eligió a la figura del Chacho como emblema de lo que él consideró su gran desilusión política; el descubrimiento de que la "barbarie" podía encontrarse en el seno de la "civilización". Con esta lógica alberdiana, a partir del asesinato de Peñaloza Hernández explica, para adelante y para atrás, toda una lista de excesos y violencias ejercidas por el liberalismo. Si bien, como se verá luego, Hernández republica el folleto del Chacho, en 1875, con enormes variantes moderadoras, sus últimos escritos en $L a$ Libertad retroceden el conflicto al mismo punto de oposiciones maniqueas que originalmente postuló Sarmiento con su antinomia. ${ }^{126}$

\subsubsection{La Reforma Pacífica de Buenos Aires (1860-1861) ${ }^{127}$}

Hernández colabora para La Reforma Pacífica con varios artículos en la sección "Correspondencia de las Provincias" firmadas con el seudónimo "Vincha", que fueron escritos desde Paraná. ${ }^{128}$ Sus comentarios se refieren a aspectos políticos generales que atañen a la Confederación: el deseo de que se logre la unidad nacional definitiva, la

\footnotetext{
${ }^{126}$ Según se analizará en el apartado 5.

${ }^{127}$ Las colaboraciones de Hernández se registran a partir del 18 de enero de 1860 hasta el 12 de enero de 1861. Valeria Tetti consultó la colección microfilmada de la Biblioteca del Congreso de la Nación y obtuvo impresiones de todo el material que, generosamente, nos permitió consultar para nuestra investigación.

${ }^{128}$ El peculiar uso de seudónimos que hace Hernández se examina en 2.3.2.
} 
condición legítima del gobierno de Urquiza, el aprecio popular que recibe Derqui del interior del país, la crisis rentística de Paraná. ${ }^{129}$

Las notas son extensas e insisten en denostar el ánimo separatista de los porteños, pero asoma la terminología sarmientina cuando Hernández se lamenta por el estado de ruina y el clima de violencia en que está sumido el país. Se observa, además, cómo Hernández se entromete en las polémicas que Sarmiento viene sosteniendo con antiguos detractores, como es el caso de Nicolás A. Calvo (redactor fundador del periódico en el que él ha comenzado a colaborar). Así, la exhibición de su adhesión al programa federal reformista se complementa con sus primeras consideraciones públicas sobre Sarmiento, para las que se remonta a la "Gran polémica nacional”, y de acuerdo con la norma del diarismo de las provincias federales confederadas, se adscribe en la línea abierta por las Quillotanas.

A lo largo de las muestras de adscripción a una programática, la escritura del joven Hernández va afianzando soltura y seguridad. Un mes después de haber iniciado sus colaboraciones subraya su alianza con colegas de Paraná, terciando en discusiones ajenas en las que se polemiza con Sarmiento.

En ese marco, Hernández lanza su primer ataque público al sanjuanino (en el que no faltan las citas del poema satírico "Sarmienticidio" que, como hemos visto, Juan Martínez Villergas había compuesto contra Sarmiento y se había convertido en un leit motiv de los adversarios de Sarmiento):

¡Llamarse "Nacional" el periódico más separatista de la prensa Argentina!!! Esta sí que es una verdadera anomalía. No fue Villergas más feliz en la pintura de su "D. Pascual Fandango que andaba con dos maletas" y sólo se explica esta contradicción con la palpitante contradicción que se nota frecuentemente entre unos y otros de los

\footnotetext{
${ }^{129}$ La primera nota que aparece firmada con este seudónimo está marcada por el tono general de las que fueron asumidas con su nombre y apellido: "Estas son las tres grandes épocas de la República Argentina. Nuestra historia de medio siglo, puede resumirse en estas tres palabras: sangre, sangre y sangre. La Nación entera tiene muy fijas sus miradas en esa parte preciosa de su territorio y espera con ansiedad el instante de que esa hermana querida se una definitivamente a ella, que con ella disfrute de las ventajas de esta unión y que con ella también comparta las fatigas de la grande obra de la organización. Ese día será el del triunfo de las buenas ideas, de las sanas doctrinas sobre las teorías absurdas y perniciosas de los exclusivistas. Será el triunfo de la Patria" (La Reforma Pacífica, Buenos Aires, 18 de Enero de 1860, 2da. Época, año 3, p. 2, cols. 1 y 2).
} 
artículos que en ese diario se registran y con la inconsecuencia natural de alguno de sus escritores.

Decimos esto porque creemos que Sarmiento es uno de sus redactores y no se encuentran en El Nacional, ideas que concuerden con las que ese escritor manifestó en varios artículos en noviembre y enero próximo pasado. Él sostenía entonces la necesidad y conveniencia que había en que Buenos Aires aceptara la Constitución de Mayo sin reserva alguna, y se mostraba tan decidido defensor de esta idea, que según su juicio de entonces, no debía perderse tiempo alguno ni aun en el examen y discusión del código.

Estos eran los principios sostenidos por Sarmiento en sus artículos de hace dos meses; entonces él no pensaba que la dignidad de Buenos Aires se comprometía con esa aceptación, que su decoro de virgen se mancillaba y que se exponían las instituciones y hasta el porvenir de esa provincia. Sarmiento llevó entonces su impavidez hasta decir que todo debería hacerse a fin de que no triunfara en las elecciones para presidente una candidatura que a él le desagradaba.

Hoy Sarmiento es todo lo contrario de lo que era hace dos meses, hoy es verdaderamente Sarmiento contra Sarmiento, hoy sostiene a voz en cuello lo contrario de lo que entonces, y en su despecho se conforma con dirigir al ciudadano que dentro de muy poco será el magistrado de la República, una manada de injurias y dicterios que hace extensivos a cuantos trabajaron por su candidatura. ${ }^{130}$

En esta extensa nota, Hernández asume su lugar en el esquema de enfrentamiento que queda planteado en el diarismo ya a partir de la batalla de Caseros, y que se expresará fundamentalmente a través de sus dos periódicos cuasi oficiales: $E l$ Nacional de Buenos Aires, fundado antes del 11 de septiembre de 1852, y el Nacional Argentino, que vio la luz en Paraná inmediatamente después de esa fecha. Hernández asume aquí la defensa de Nicolás Antonio Calvo y también la de Juan Francisco Seguí, redactor de El Nacional Argentino, atacados con saña por Sarmiento.

Al acusar a la facción política que domina el gobierno de Buenos Aires de impedir la unión nacional, Hernández polariza su opinión de acuerdo con las categorías críticas sarmientinas con un tono rotundo que no le va a la zaga, como cuando acusa a los separatistas de ser los "dulcamaras" que impiden el progreso de la patria porque

130 "Correspondencia de La Reforma Pacífica", La Reforma Pacífica, Buenos Aires, 29 de febrero de 1860, 2da. Época, año 3, p. 2, cols. 3, 4, 5 y 6. El destacado es del autor. 
sostienen la discordia y dificultan el acceso a una etapa de "civilización" (en cinco oportunidades empleará este vocablo con ese mismo sentido, acentuando que el acceso a ella es un derecho de todo país). ${ }^{131}$

El primer empleo se registra en la nota del 7 de febrero de 1860 y apunta al hecho de que la administración porteña funcionó como una "valla a la civilización, a la libertad y al progreso" y en el presente amenaza con continuar los "proyectos de aislamiento y por consiguiente de desquiciamiento y de ruina". ${ }^{132}$

A fin de este mismo mes persiste en sus críticas a los porteños que antepusieron los intereses de Buenos Aires a los de la totalidad del país, "los que evitaron todo arreglo pacífico cual era digno de la civilización y dignidad de los argentinos”, y caracteriza en estos términos el encuadre que a su juicio hubiera tenido la instauración nacional del polo positivo después de Caseros: "La solemnidad del acto que en seguida tuvo lugar, la altura, a que en esos momentos aparecía el gobierno nacional, y las ideas de libertad, de orden y de civilización que naturalmente surgían". 133

El 24 de marzo sigue enfrentándose a la actitud de los hombres de Buenos Aires que impiden que esta provincia se coloque "a la cabeza de todas ellas para ayudarlas en su marcha de civilización y de progreso". ${ }^{134}$ Y por último, el 28 de abril del mismo año se muestra temeroso por la suerte de la patria debido a las pasiones individuales y al espíritu faccioso que hacen imposible la realización de la pacificación definitiva y arrebatan "ese triunfo de las sanas ideas de la civilización" precipitando al país a la guerra civil. ${ }^{135}$

En cambio, se registra únicamente un empleo del término "bárbaro" en la nota del 14 de junio de 1860, que aparece explícitamente ligado a su precursor. Hernández menciona a Sarmiento en su segunda crítica pública. Se trate de lo que un joven, que ni

\footnotetext{
${ }^{131}$ Por su parte, mientras Hernández denuncia a los "dulcamaras", la prensa porteña fatiga los diarios con la denuncia de que es el "caudillismo" el que impide la entrada en la senda de la "civilización" y del progreso (un caballito de batalla que se reiterará en la mayoría de los diarios porteños cuando anuncien en 1863 la muerte del Chacho).

132“"Correspondencia de las provincias", La Reforma Pacífica, Buenos Aires, 7 de febrero de 1860, 2da. Época, año 3, p. 2, cols. 3 y 4.

133“"Correspondencia de La Reforma Pacífica", La Reforma Pacífica, Buenos Aires, 29 de febrero de 1860, 2da. Época, año 3, p. 2, cols. 3, 4, 5 y 6.

134" Correspondencia de La Reforma Pacífica", La Reforma Pacífica, Buenos Aires, 24 de marzo de 1860, 2da. Época, año 3, p. 2, cols. 1, 2 y 3.

135“"Correspondencia de La Reforma Pacífica”, La Reforma Pacífica, Buenos Aires, 28 de abril de 1860, 2da. Época, año 3, p. 2, cols. 1, 2 y 3.
} 
siquiera firma con su propio nombre, le reprocha a "un tal Sarmiento" el haber calificado a Buenos Aires de pueblo "bárbaro". También destaca las características contradicciones de su discurso avaladas por abundantes datos biográficos acerca del sanjuanino. Entre estos detalles de la vida de Sarmiento, Hernández recupera con ironía su vínculo inicial con Urquiza al mismo tiempo que alude a las estrategias discursivas de la Campaña en el Ejército Grande que fueron analizadas en las Quillotanas.

Esta correspondencia de Paraná comienza con la mención a la polémica que sostiene Nicolás Calvo con el señor Kaiser, que a decir de Hernández: "es el faldero del Ministro Sarmiento". Kaiser y Calvo se acusan mutuamente de haberse robado unos francos, y Hernández se adentra en el conflicto dando cifras precisas como prueba de la inocencia de Calvo y denunciando la avidez de Sarmiento:

El Nacional dice que "los comunicados pagarán a razón de $100 \$$ por columna”. Él ha publicado ya como once columnas, lo que importa tres veces más de lo que necesitaría para venir al Paraná. Resulta pues que, o tiene dinero y no quiere venir, o no lo tiene y las publicaciones se hacen gratis, lo que prueba la parte muy principal que en este negocio tiene D. Domingo Faustino \& Co. ${ }^{136}$

Más adelante profundiza la estocada con un recorrido bastante pormenorizado de la actuación política de Sarmiento en el que le recuerda que calificó de "bárbaro" al pueblo de Buenos Aires y, repitiendo las acusaciones de Alberdi, le recrimina haber actuado con doblez frente a Urquiza; lo acusa, además, de ser un falso patriota por haber aceptado la condecoración brasileña sin contar con la autorización del gobierno. Por añadidura, recupera entre datos ciertos la alevosía de un subtexto con el que Alberdi pone sombras en el discurso enjundioso de las Quillotanas al reprochar a Sarmiento no haber hecho los estudios que el sanjuanino hubiera deseado ardientemente hacer:

Es muy probable que si no estuviéramos como estamos seguros de la parte muy principal que un tal Sarmiento tiene en este asunto, no nos ocuparíamos en nada de él, pero se nos ha asegurado que es uno de los hombres que hoy gobierna Buenos Aires, después de haberlo calificado del "pueblo más bárbaro que existe en América", un hijo

136“Correspondencia del Paraná”, La Reforma Pacífica, Buenos Aires, 14 de junio de 1860, 2da. Época, año 3, p. 2, cols. 1 y 2. 
de San Juan que debió estudiar en el seminario de Córdoba en 1821, que debió hacerlo en el colegio de Buenos Aires en 1826, que se alistó en Chile al servicio de un partido, defendiendo su causa personal, como que fue enviado a Europa para liberarse de él, que volvió para ensalzar al general Urquiza y después se ocupó de deprimirlo, que ha perdido hasta el derecho de ciudadano argentino, aceptando una condecoración de Brasil, sin previo permiso, que adquirió esta condecoración alterando el parte de la batalla de Monte Caseros, dando al Brasil parte de las glorias argentinas, que ha escuchado tranquilo cuanto el Sr. Calvo le ha dicho, y dice todavía, y que actualmente es ministro de Buenos Aires, es el instigador principal, el locomotiva de esa máquina de infamias y calumnias que se titula Kaiser. ${ }^{137}$

Esta es la segunda embestida de Hernández, pero no será la última. ${ }^{138}$ Ya firmando con su nombre y su apellido, dirigiendo medios propios o colaborando en periódicos de terceros, acompañará con gran perseverancia todos los movimientos de Sarmiento; retratará y sopesará con constancia inalterable su actuación: colaborando con Mitre como publicista, desempeñándose en cargos públicos en Buenos Aires, actuando como director de la guerra y como gobernador de San Juan, y finalmente, como presidente de la República.

\subsubsection{El Nacional Argentino de Paraná (1860) ${ }^{139}$}

Este periódico se inaugura el 3 de octubre de 1852 (menos de un mes después de la escisión de Buenos Aires), con el objetivo de difundir los actos y la política del Director Provisorio de la Confederación. En su redacción actúan personalidades como Eusebio Ocampo, Alfredo M. du Graty, Emilio de Alvear, Benjamín Victorica, Lucio V. Mansilla, Francisco Bilbao, Juan Francisco Seguí y José Hernández.

Cuando Hernández toma la dirección, ocho años después, el país se está preparando para una nueva guerra civil, la Confederación se aproxima a su fin y el

\footnotetext{
137،"Correspondencia del Paraná”, La Reforma Pacífica, Buenos Aires, 14 de junio de 1860, 2da. Época, año 3, p. 2, col. 1 y 2.

${ }^{138}$ Incluye también unos versos burlescos de su cosecha: "No es raro / Porque es claro / Que el creyente que de ciento / Noventa y nueve chupó / Le quede algún sentimiento / Por el uno que dejó".

${ }^{139}$ Hernández tendrá a su cargo la dirección de este periódico desde el 4 hasta el 25 de octubre de 1860.
} 
órgano que le responde va en camino de su cierre. ${ }^{140}$ El anterior director, Juan Francisco Seguí, había renunciado al cargo por diferencias irreconciliables con Urquiza. A continuación, se dedicará desde El Correo Argentino a polemizar con ese mismo diario para cuestionar a Urquiza. Hernández se afanará entonces por sostener, en contra del embate del poderío porteño, un estado de cosas que está a punto de desmoronarse: el gobierno de Paraná, el poder del federalismo, la fuerza de la unión entre Urquiza y las provincias.

Con esta ilusión elegirá emplear un discurso prospectivo de exaltación y de utopía. Resigna su partidismo para embarcarse en una celebración acrítica de la recién lograda unidad nacional, para presentarla como la posibilidad de conseguir todos los anhelos. Los editoriales de este periódico están teñidos de la euforia patriótica que despierta la incorporación de Buenos Aires a la definitiva unidad nacional, sin detenerse a examinar dificultades ni matices. En medio de esta exaltación oficialista, Hernández sólo se referirá al polo positivo de la antinomia sarmientina, presentada como un bien al alcance de la mano.

Se pueden encontrar nueve empleos de términos pertenecientes al campo lexemático de la "civilización" que celebran el acceso al progreso, a la modernidad, la paz, la fraternidad, la organización, la cultura y la comunicación con los primeros pueblos del mundo. Los títulos son perfectamente ilustrativos del discurso de un Hernández que sueña con un futuro promisorio.

Su primera colaboración se titula "La nueva época" y festeja el hecho supuesto ahora de que el país está preparado "para recibir los beneficios de la civilización moderna", la "marcha de la civilización y progreso". ${ }^{141}$

En su segunda nota: "Los viejos partidos y los partidos nuevos", contrapone partidos caducos de épocas sangrientas que han muerto frente a los nuevos partidos de dignidad y cultura, sanas ideas, inteligencias jóvenes, "civilización y progreso". ${ }^{142}$

En "Hasta cuándo" festeja eufórico la unidad nacional:

\footnotetext{
${ }^{140}$ Néstor Tomás Auza observa que esta participación de Hernández, a los veintiséis años, "acrecienta su experiencia política, múltiple y variada"; aquí se pone en contacto con figuras importantes con las que seguirá en contacto a lo largo de su vida. (Auza, 1978, p. 121). En este ámbito se documenta, también, su vinculación con Federico de la Barra, pues Hernández transcribe algunas notas suyas en el periódico.

${ }^{141}$ El Nacional Argentino, Paraná, 4 de octubre de 1860. Tomamos las transcripciones que hizo Beatriz Bosch (Bosch, 1963, pp. 27-29).

${ }^{142}$ Ibidem, pp. 29-31.
} 
La República Argentina ha presenciado el más grandioso espectáculo que puede tener lugar en una nación civilizada: el sacrificio de pasiones arraigadas, la unión y fraternidad de dos partidos, a impulsos de un sentimiento patriótico.

Y considera que ha aportado una definición clara de lo que para él significa “civilización” en términos políticos. Sin embargo, esta nota, en la que se esboza un giro ensayístico, deja deducir que el optimismo puede ser efímero y que siempre puede reiniciarse una nueva lucha de la "civilización" contra la ignorancia, las pretensiones retrógradas, las tentativas de desquicio, y acompaña este desplazamiento con un tono más combativo. ${ }^{143}$ Pero pocos días después, en "El pueblo y el escritor", vuelve a congratular al país por la concordia obtenida: "Por primera vez podemos decir con propiedad, que los Pueblos Argentinos con el sello puesto a su organización nacen a la vida de las naciones civilizadas y progresistas". ${ }^{144}$

En "El estilo es el hombre", discurre sobre cuestiones que rápidamente desechará, como la moderación estilística: "queremos razones contra razones, no injurias contra razones". Esta mitigación del tono periodístico que tan encarecidamente encomia ahora (será olvidada muy pronto en su siguiente proyecto editorial) busca contener la actitud de su beligerante circunstancial, El Correo Argentino. En un último intento por sostener la unidad de la decadente Confederación no desea que dos periódicos de Paraná contiendan abiertamente: "nos abstendremos de entrar en polémica con él [El Correo Argentino], hasta que se haya civilizado [...] hasta que adquiera la civilidad y cultura de que hoy carece". ${ }^{145}$ Con el periodismo porteño no será tan contemplativo.

Ni el polo negativo de la antinomia ni el nombre de Sarmiento son mencionados en esta actuación periodística.

\subsubsection{El Litoral de Paraná (1862) ${ }^{146}$}

\footnotetext{
${ }^{143}$ Ibidem, pp. 31-33.

${ }^{144}$ Ibidem, pp. 51-53.

${ }^{145}$ Ibidem, pp. 53-55.

${ }^{146}$ El Litoral de Paraná fue fundado por Evaristo Carriego el 16 de enero de 1862. Los ejemplares de este periódico fueron consultados en la Hemeroteca de la Biblioteca de la Universidad Nacional de La Plata (periódico n ${ }^{\circ} 187$ ).
} 
Fue Fermín Chávez el primer crítico que señaló esta participación periodística de Hernández:

En 1962, su amigo el doctor Evaristo Carriego le ofrece las columnas de $E l$ Litoral, diario antimitrista y por momentos antiurquicista, federal disidente. Hernández ha visto cómo pelearon en Pavón sus amigos Juan Saá y Ricardo López Jordán, acepta y colabora. ${ }^{147}$

La lectura atenta del órgano de Evaristo Carriego ratifica esta opinión; ${ }^{148}$ se encuentran varios artículos con la firma de José Hernández, además de una sección titulada "Laberinto" a cargo de su hermano Rafael. Aunque esta documentación no es muy extensa confirma la coincidencia político-ideológica entre los hermanos Hernández y Carriego. $^{149}$

\subsection{Colaboración de los hermanos José y Rafael Hernández}

Hernández hace su primera aparición en el periódico de Carriego el 18 de marzo de 1862 con una publicación solicitada al Sr. Editor de El Litoral con el objeto de desmentir afirmaciones vertidas en un artículo titulado "Presente marzorquero", que se había publicado en La Patria de Montevideo. ${ }^{150}$ Aquí se le adjudicaba a Hernández, a Manuel Fontes y a Guillermo Puig la supuesta elaboración de unas tarjetas de carnaval con versos burlescos. A Hernández se le atribuían estas dos:

Rivadavia! Vaya un chaucha:

¡Quién no le conoce la hebra!

\footnotetext{
${ }^{147}$ Chávez, 1973, p. 50.

${ }^{148}$ Una sucesión de padres e hijos compartieron el nombre y apellido "Evaristo Carriego" en la provincia de Entre Ríos. El fundador de El Litoral es Evaristo Federico Carriego de la Torre (1828-1908) que fue abogado y periodista polémico. Era hijo del Coronel Evaristo Carriego (1791-1836) -que fue colaborador de Francisco Ramírez- y a su vez abuelo de Evaristo Federico Carriego (1883-1912) el poeta autor de Misas herejes (1908) y La canción del barrio (1913).

${ }^{149}$ Aunque en el índice del Archivo Losada, sobre cuya base Tulio Halperín Donghi elaboró su José Hernández y sus mundos (Halperín Donghi, 1985), se incluyen "dos artículos publicados en El Litoral" que demuestran su afinidad con Carriego, Losada no alcanzó a transcribirlos. Halperín Donghi, sin embargo, sugiere la existencia de un enfrentamiento entre Hernández y Carriego para el que no encontramos confirmación en la documentación que hemos reunido.

150 "Publicación solicitada", El Litoral, Paraná, 18 de marzo de 1862, año I, n 26, p. 2, cols. 1, 2,3 y 4 .
} 
Que con cognac y ginebra

Murió ahogado como un laucha.

De veras? Vive Dios! Mitre?

Dime simpática chica

Y ese tísico belitre

Es el que tanto te pica?

En razón de estos obsequios, que según La Patria fueron ofrecidos a unas señoritas de Paraná, se los acusaba de "villanos, mazorqueros y cobardes". Hernández hace su descargo lamentando que no haya un editor o redactor que se haga responsable de la denuncia y firma la nota con su verdadero nombre. Luego, en una nueva solicitada, vuelve a reclamar que el tal Aramís que los acusa desde La Patria se dé a conocer. ${ }^{151}$

Una semana después de esta publicación se crea una nueva sección del periódico llamada "Laberinto", que está a cargo de Rafael Hernández. Es una sección de variedades con comentarios breves, en general de orden social y de tono festivo, aunque en casos excepcionales se traten temas políticos. Entre estos últimos, el 17 de abril Rafael acusa al "loco Sarmiento" de "diezmar a la población de San Juan”, coincidiendo con los juicios de su hermano y de Carriego. ${ }^{152}$

Del 17 de julio al 12 de agosto se publican numerosos avisos de José Hernández (casi una docena), en calidad de síndico en las quiebras de Juan Poitevin, José D’Espuy, Facundo Leguizamón y Carlos D’Halwyn. Luego, el 14 de agosto de 1862, salen dos artículos firmados “J. H.", ambos en una posición central y destacada, a continuación de la columna editorial firmada por Carriego.

El primero se titula "Muy notable" y se trata de un episodio de robo en un vapor paraguayo, en el que Hernández expresa la esperanza de que no se repita. ${ }^{153}$ El segundo, "Revista de periódicos", comenta críticamente las noticias que trae el vapor "Dolorcitas": la federalización de Buenos Aires y el desplazamiento de Gelly y Obes y

\footnotetext{
151 "Publicación solicitada", El Litoral, Paraná, 5 de abril de 1862, año I, n 34, p. 3, cols. 4 y 5.

${ }^{152}$ La sección de Rafael, "Laberinto", continuará apareciendo en El Argentino del año siguiente (y años después, José Hernández la incorporará en su periódico de Buenos Aires, El Río de La Plata). Después de varios números, el diario publica una despedida a Rafael Hernández -que acaba de emprender un viaje-; se lo califica de amigo y se lamenta que el periódico haya perdido un "colaborador inteligente".

${ }^{153}$ El Litoral, Paraná, 14 de agosto de 1862, año I, n ${ }^{\circ}$ 33, p. 2, cols. 4 y 5.
} 
de Rivas para reprimir la revolución en Catamarca y la amenaza de Mendoza. Cierra con esta síntesis:

Los elementos de orden no imperan en ninguna parte y el malestar y la agitación general, reaparecen aunque lentamente. La reorganización nacional, tan decantada es problemática aún. El restablecimiento del orden, de la paz, de la armonía, parece alejarse por instantes. El arte de reedificar no se aprende demoliendo. ${ }^{154}$

Hernández se aleja cada vez más de las esperanzas de cambio con que había soñado en El Nacional Argentino. El 26 de agosto publica una nota titulada “Corrientes", en la que se explaya sobre el desorden social y político de esta provincia para concluir: "Se espera con fundamento un cambio de política del Gobierno en atención a los funestos resultados que está dando la política seguida hasta hoy". ${ }^{155} \mathrm{El} 28$ del mismo mes publica dos notas: "Capital" y "Una medida justa". La primera, sobre la capitalización de la provincia de Buenos Aires, alerta sobre los posibles disturbios que esta medida puede suscitar en el ánimo porteño; la segunda se refiere a la deuda de los sueldos de los empleados provinciales (que habrá de solventarse finalmente con las rentas de la Aduana). ${ }^{156}$

El 6 de septiembre, en la sección "Noticias generales", vuelve a escribir sobre la situación del interior y la federalización de Buenos Aires, y discurre sobre la extensión del código de comercio y los nuevos nombramientos de generales para premiar “servicios prestados en la organización del país". También hace referencia a candidaturas políticas -entre las cuales se menciona a Sarmiento- y cierra la nota denunciando el malestar por la situación en la que se encuentra el país. ${ }^{157}$

El 25 de ese mes, escribe una necrológica sobre el Coronel Palao, ${ }^{158}$ y el 30, "La actividad del Congreso", una nota donde continúa la línea del comentario que lo precede: el editorial de Carriego titulado "La apatía del Congreso". Hernández ironiza

\footnotetext{
${ }^{154}$ El Litoral, Paraná, 14 de agosto de 1862, año I, n ${ }^{\circ}$ 33, p. 3, cols. 1 y 2.

${ }^{155}$ El Litoral, Paraná, 26 de agosto de 1862, año I, n ${ }^{\circ} 87$, p. 2 , col. 2.

${ }^{156}$ El Litoral, Paraná, 28 de agosto de 1862, año I, no 88 , p. 2, cols. 2 y 3.

${ }^{157}$ El Litoral, Paraná, 6 de septiembre de 1862, año I, n ${ }^{\circ}$, p. 2, cols. 3 y 4.

158 "El Coronel Palao", El Litoral, Paraná, 25 de septiembre de 1862, año I, nº 99, p. 2, col. 5 y p. 3, col. 1 .
} 
acerca de la falta de operatividad de los legisladores de la Nación y vuelve a manifestar un marcado escepticismo político. ${ }^{159}$

El 4 de octubre, en una nota titulada "Acusación de El Litoral", hace cuestionamientos a Domingo Cullen, hermano del gobernador de Santa Fe, y a su vez se defiende apoyándose en la ley sobre la libertad de imprenta de $1811 .^{160}$ Luego publica "Renuncia" sobre la supuesta dimisión de Cullen, el gobernador de Santa Fe; ${ }^{161}$ y el 7 del mismo mes transcribe el testamento de Bolívar de El Comercio de Lima. ${ }^{162}$ Luego, en una breve nota sin comentarios informa sobre la composición del gabinete ministerial de Mitre. ${ }^{163}$

Sus dos últimas colaboraciones son un artículo sobre la elección del Gobernador del Obispado ${ }^{164}$ y otro sobre La Rioja en el que ya se refiere al Chacho mostrándose atento a los movimientos del caudillo al que acompañará en sus notas de El Argentino durante todo el año siguiente:

Por nuestra correspondencia particular en La Rioja sabemos que esta provincia seguía tranquila [...]. El general Peñaloza continuaba tranquilo y sometido al gobierno de la provincia y reparando de varios modos los desastres causados por la guerra que sostuvo con tanto brío, y que concluyó por el pacto de paz, celebrado con los comisionados del general Mitre. ${ }^{165}$

\subsection{El Litoral como antecedente y como paralelo de El Argentino}

La reunificación nacional lograda luego de la batalla de Pavón deja a la ciudad de Paraná en una situación desventajosa. Su condición de capital de la Confederación ya es historia y el programa político de Mitre no es visto desde sus periódicos como el de la "organización nacional", sino como un verdadero plan de "exterminio del interior".

\footnotetext{
${ }^{159}$ Distingue dos etapas, la de la "admiración" en la que los congresales son mirados como "héroes de la antigüedad" y la de las "compensaciones", en la que se asignan los sueldos, pero que en el intervalo entre ambas no hicieron nada (El Litoral, Paraná, 30 de septiembre de 1862, año I, $\mathrm{n}^{\circ} 101$, p. 2 , col. 5 , p. 3, cols. 1 y 2 ).

${ }^{160}$ El Litoral, Paraná, 4 de octubre de 1862, año I, nº 103, p. 2, cols. 2, 3 y 4.

${ }^{161}$ El Litoral, Paraná, 4 de octubre de 1862, año I, n 103 , p. 2, col. 4.

162 "Testamento de Bolívar", El Litoral, Paraná, 7 de octubre de 1862, año I, n 104, p. 2, cols. 2 y 3 .

163 "Buenos Aires", El Litoral, Paraná, 18 de octubre de 1862, año I, n 109, p. 2, cols. 3 y 4.

164 "Elección de gobernador del obispado", El Litoral, Paraná, 21 de octubre de 1862, año I, n ${ }^{\circ}$ 110 , p. 2, col. 3 .

165 "La Rioja”, El Litoral, Paraná, 21 de octubre de 1862, año I, n ${ }^{\circ} 110$, p. 2, col. 3.
} 
En este marco general, el periódico de Carriego, como El Argentino (1863) de Hernández, encarnan la lucha federal en oposición al poderío porteño y en este sentido Hernández se suma a su prédica. Efectivamente, se observan en El Litoral numerosos antecedentes para muchos de los planteos políticos que proseguirá Hernández desde $E l$ Argentino, y en el plano de las modalidades y estrategias discursivas, ambos compartirán la descarga panfletaria, las sátiras burlonas y la manipulación irónica de la antinomia "civilización versus barbarie" como fórmula rectora de la política imperante frente al rol del caudillo; ambos periódicos retratan la situación política del interior del país en términos de conflicto con la autoridad central, personalizada en la figura presidencial de Mitre, y coinciden en el tratamiento casi obsesivo del papel que desempeña Sarmiento como director de guerra contra los caudillos y gobernador de San Juan, y como creador del modelo que da forma a esa política.

Carriego se anticipará a Hernández en la reformulación irónica de la antítesis sarmientina haciendo permanentes paralelos entre "bárbaros y civilizados" y también seguirá con fidelidad los pasos de Peñaloza en La Rioja en numerosas notas que describen la progresión del enfrentamiento con el gobierno central. Esta mirada reconcentrada en Peñaloza es demostrativa de la expectativa que generaba ya el caudillo riojano en la órbita del partido federal, mirada que será recuperada con virulencia cuando se conozca la noticia de su muerte en 1863, no sólo en las páginas de El Argentino de Paraná, de Hernández, sino también en las de la segunda época de La Reforma Pacífica de Montevideo, de Nicolás A. Calvo. ${ }^{166}$

En este órgano Carriego lanza furibundas invectivas al gobierno central en relación con la campaña contra los caudillos y hace un detallado seguimiento de la figura de Peñaloza, se muestra atento a la reaparición de La Reforma Pacífica en Montevideo, elogia a Nicolás A. Calvo y se queja de los "bárbaros atentados" del partido liberal.

Ya desde el 8 de mayo de 1862 elogia a Peñaloza, a quien califica como "la mano de Dios", "un caudillo, pero no porque represente la barbarie, sino porque representa el prestigio personal que se adquiere con una serie de acciones heroicas". ${ }^{167}$

\footnotetext{
${ }^{166}$ Cuando Calvo se exilia a Montevideo perseguido por la censura de la mitrista, retoma allí La Reforma Pacífica (Segunda época) desde donde seguirá con mirada atenta la suerte del federalismo.

${ }^{167}$ El Litoral, Paraná, 8 de mayo de 1862.
} 
A lo largo de todo este año le dedicará varias notas en las que se puede apreciar el detallado seguimiento que Carriego hace de los movimientos del 1lanista: "Peñaloza negociando", "Peñaloza imponiendo", y la opinión enaltecedora que de él tiene: "bendito caudillo que se olvida de s'́. Además incorpora la biografía escrita por Federico de la Barra para La discusión de Montevideo, ${ }^{168}$ que publica en tapa y que, según ya hemos visto, ocupa casi tres columnas con ideas del mismo tenor como: "El general Peñaloza no es un bárbaro, es un patriota". 169

Al año siguiente, el 5 de mayo de 1863, en un artículo titulado "La mordaza y el puñal" que ocupa dos páginas completas, Carriego define su posición sobre el gobierno de Mitre, claramente coincidente con la de Hernández y se anticipa al conflicto:

El Gobierno Nacional está metiéndose en lo que no debe meterse. Así son regularmente los gobiernos como ese, ejecutores del crimen y hechura de las facciones que suelen ensangrentar los pueblos. ${ }^{170}$

Días después, incorpora transcripciones de distintas notas de Peñaloza: al gobernador de Córdoba, D. Justiniano Posse, y a Sarmiento como gobernador de San Juan. $^{171}$

El hincapié en la figura de Sarmiento está estrechamente vinculado con la preocupación con que sigue la campaña contra los caudillos federales. Una nota del 21 de julio se titula "Sarmiento y Sandes" y allí Carriego incluye un juicio lapidario sobre Sarmiento en el que invierte tácitamente el campo designativo de la antinomia del Facundo:

El deslenguado Sarmiento, líctor de Mitre, ha desatado su haz de varas para azotar a los indefensos habitantes de la desgraciada provincia que oprime [...]

\footnotetext{
${ }^{168}$ Ver 1.3.

${ }^{169}$ El Litoral, Paraná, 15 de mayo de 1862.

${ }^{170}$ El Litoral, Paraná, 5 de mayo de 1863.

${ }^{171}$ Las dos notas son del mismo tenor. Peñaloza les ofrece alianza para evitar recurrir a la fuerza. En la que dirige a Sarmiento explica la razón de su ofrecimiento: para "reivindicar los sagrados derechos de nuestra patria hollados por la planta de algunos perjuros" y para "economizar la efusión de sangre argentina". Carriego toma la información de los partes del 7 de mayo de 1863 de El Zonda de San Juan.
} 
¿Éste es el hombre "liberal” que tanto ha gritado contra el despotismo; éste es el hombre "civilizado" que tanto ha clamado contra la barbarie $[\ldots] ? ?^{172}$

E1 8 de septiembre, en "Noticias Importantes", con un lenguaje cada vez más agresivo que repone anatemas del discurso rosista, Carriego se burla de los "siempre salvajes y siempre embusteros unitarios" que tratan de falsear los datos sobre la campaña de Peñaloza. En el apartado titulado "La Nación Argentina" firmado por F. Z., ${ }^{173}$ se critica al periódico de Mitre y se defiende apasionadamente al Chacho:

[Mitre] Dice que Peñaloza no puede ser el representante de una causa justa y legítima porque no sabe leer [...]. ¿Con que porque un hombre como Peñaloza sea ignorante no puede de ningún modo representar los sentimientos de la mayoría del país? $[\ldots]$

Peñaloza puesto del lado de los débiles, de los pobres desheredados, es la encarnación viva del derecho, es más, es la justicia que se levanta amenazante [...]. Peñaloza como defensor de los pueblos oprimidos, tiene un valor intrínseco que no le puede ser disputado por nadie [...].

¿Qué vale si no Mitre, usurpador de una autoridad legalmente constituida, en comparación de Peñaloza, incansable sostenedor de una causa santa [...]? Peñaloza es ignorante, está bien; pero en cambio su corazón no se halla mancillado por la traición.

El 10 de septiembre, en "Correspondencia de El Litoral" se comenta con sorna la campaña de Sarmiento:

El Gral. Peñaloza tiene sitiado a Arredondo [...] El loco de Sarmiento, que ve que su directura de la guerra se le va a poner fruncida marchando el Gral. Peñaloza adelante, como lo hará, ha mandado llamar precipitadamente al asesino Sandes [...]. ${ }^{174}$

El $1^{\circ}$ de octubre, una nota titulada "Apuros de Sarmiento" transcribe burlonamente pasajes de un artículo de su pluma publicado en El Zonda en donde se

\footnotetext{
${ }^{172}$ El Litoral, 21 de julio de 1863.

${ }^{173}$ Presumiblemente Floriano Zapata, sobrino de Carriego y condiscípulo de Olegario V. Andrade y de Evaristo Carriego hijo, y posteriormente maestro de Manuel Gálvez.

${ }^{174}$ El destacado de Carriego subraya el neologismo que funde "dirección" con "dictadura" y el empleo irónico de la expresión.
} 
queja de las correrías de las montoneras. Sarmiento se muestra temeroso de que luego de la muerte de Sandes los montoneros ataquen con nuevo vigor y pide la ocupación militar. Luego Carriego va registrando el recorrido de Peñaloza y lo describe en paralelo con los movimientos de las fuerzas de Sarmiento. ${ }^{175} \mathrm{Y}$ en un artículo sobre la conducta de Rivas en La Rioja titulado "Salvajes y cobardes", apunta refiriéndose al recurso despiadado de apoderarse de los hijos y las esposas de los montoneros para obligarlos a rendirse: "Lo que los bárbaros respetan no han respetado ya los hombres civilizados". 176

El 15 de octubre publica "El momento se acerca":

San Juan se ha puesto en estado de guerra. El general Peñaloza pisa victorioso el suelo de San Juan [...] El general Urquiza se pone de pie [...], la paz es un crimen $[\ldots]$, los pueblos argentinos claman venganza $[\ldots]$.

No vuelve a mencionar a Peñaloza hasta el 19 de noviembre de 1863, cuando Peñaloza ya ha sido asesinado, pero Carriego habla de Peñaloza como si todavía siguiera con vida, ${ }^{177}$ hasta que el 12 de diciembre se encuentra un artículo titulado "El Viriato argentino" 178 en donde expresa su dolor por la muerte del caudillo y predice la condición mítica que asumirá su figura:

La vida del General Peñaloza dará materia a cien romances, como las hazañas fabulosa de los paladines de la Edad Media [...]. Cayó tronchada por el hacha de los verdugos, esa figura gigantesca y majestuosa [...]. Pero su alma ha pasado al alma del pueblo [...]. Peñaloza no ha muerto! ${ }^{179}$

\subsubsection{El Argentino de Paraná (1863)}

\footnotetext{
${ }^{175}$ El Litoral, 10 de octubre de 1863 (Sección “Interior").

${ }^{176}$ Esta cursiva también es del autor, lo que nos indica la conciencia que tiene de la connotación de los términos de la antinomia.

177 “Al fin nos halla la razón”, El Litoral, Paraná, 19 de noviembre de 1863. La nota es copia de El Uruguay.

${ }^{178}$ Por la fecha, es evidente que Carriego hace una cita explícita de Hernández, que comparó al Chacho con el jefe lusitano muerto a traición en una de sus notas publicadas en noviembre en $E l$ Argentino.

${ }^{179}$ Tomado de El Pueblo Entrerriano.
} 
Hernández no tarda en fundar en Paraná su primer periódico, El Argentino, desde donde sigue los acontecimientos nacionales proyectando en su discurso una profunda desilusión que sólo cede el paso a denuncias virulentas. ${ }^{180}$

Se trata de un órgano de prensa del urquicismo y seguirá con atención el desplazamiento de las tropas gubernamentales por el interior de las provincias; como se ha visto, el levantamiento del Chacho pronto se transforma en un tema predominante, hasta el punto de que la serie de artículos que Hernández le dedica -vistos en retrospectiva- pueden ser considerados como la fase pre-textual de la biografía de Peñaloza, que empezará a publicar a fines de noviembre, en cuanto llega la noticia de su muerte.

Ya desde los primeros números de febrero se suceden las referencias a Sarmiento y las alusiones a su modelo de identidad nacional. Se computan cinco ocurrencias lexemáticas que se refieren al polo positivo de su antinomia. La primera, en la nota inaugural celebratoria del aniversario de Caseros: "Allí, vivo todavía el entusiasmo del triunfo, después de 40 años de sangrientos combates, se oyó la voz del generoso vencedor; proclamando un principio sublime de civilización cristiana [...]”. ${ }^{181}$ Dos semanas después, en "Siempre los mismos" se apoya en una cita de un periódico adicto al poder de Buenos Aires (La Democracia) para denunciar la hipocresía de quienes atribuyen sólo a los proscriptos el derrocamiento de Rosas y dice de estos presuntos gestores que en ellos "estaban encarnadas las ideas de la civilización, de progreso y de moral". Puede advertirse aquí cómo, en el campo semántico de la civilización que va configurando el discurso de Hernández, se integran no sólo conceptos como "progreso" -como en Sarmiento-, sino otros provenientes del orden del culto ("cristianismo") y de la conducta pública y privada ("moral").

En esta misma nota, se registra la primera referencia peyorativa a Sarmiento en irónica contigüidad con su lexema-estandarte. De este modo se aporta un testimonio de

\footnotetext{
${ }^{180}$ Salía los martes, jueves y sábados. Se consultó la colección (incompleta) que se encuentra en la Hemeroteca de la Biblioteca de la Universidad Nacional de La Plata (periódico ${ }^{\circ} 148$ ). Ver 1.2.1

${ }^{181}$ El Argentino, Paraná, 3 de febrero de 1863, año 1, no 1, p. 2, cols. 1 y 2. Como se ha señalado en 1.2.1., llama la atención la concurrencia de lexemas del campo semántico de la santidad no sólo en la biografía del Chacho, sino también en la crónica periodística acerca de su campaña.
} 
la atención con la que Hernández viene siguiendo su actuación como director de la guerra:

La ausencia perpetua de Sarmiento no habría detenido la civilización de nuestros pueblos, no habría influido en su marcha, y se habría excusado quizás algunas lágrimas y alguna sangre. Sus panfletos de Chile habrían sido siempre tan inmorales pero menos funestos que su Nacional de Buenos Aires. ${ }^{182}$

El ánimo de Hernández ya se había mostrado dominado por el pesimismo días antes: "Todo ha ido a estrellarse contra la obcecación y la tenacidad de un partido político [...] Todo se ha desvanecido como el humo, arrebatado por el huracán violento de una revolución que no trajo contingente para su civilización y su progreso". ${ }^{183}$

El tono agresivo de sus notas se va incrementado y la última ocurrencia del lexema que se ha podido registrar ${ }^{184}$ se inserta en una enfática interrogación retórica que, con ironía amarga, acomete una enumeración de epítetos que emblematizan los actos de barbarie cometidos en nombre de la civilización:

¿No tienen otro instrumento que el puñal para escribir sus nombres en el catálogo de esa pléyade de hombres ilustres, compuesta de libertadores, regeneradores, apóstoles de la civilización, sectarios del progreso y adeptos de la libertad, que hoy nos invaden, amenazando por todas partes con el exterminio y con la muerte? ${ }^{185}$

Pero además, se suceden varias ocurrencias lexemáticas que designan al polo negativo de la antinomia, nominación que hasta ahora se había registrado una sola vez en la práctica periodística de Hernández.

En nota del 26 de marzo, denuncia la "bárbara ley" que autoriza fusilamientos y penas de muerte, ${ }^{186}$ en tanto que en un comentario acerca de la invasión de tribus

\footnotetext{
182 "Siempre los mismos", El Argentino, Paraná, 17 de febrero de 1863, año I, n 7, p. 1, cols. 5 y 6.

183 “Los tres roles", El Argentino, Paraná, 14 de febrero de 1863, año I, nº 6, p. 1, cols. 3 y 4.

${ }^{184}$ Como El Argentino de Paraná no se conserva completo en ningún repositorio público, la compulsa no pudo ser exhaustiva.

185 "Otro más", El Argentino, Paraná, 24 de marzo de 1863, año I, n 22, p. 2, cols. 2, 3 y 4 . El destacado es de Hernández.

186 “Más muertes”, El Argentino, Paraná, 26 de marzo de 1863, año I, nº 23, p. 2, col. 3.
} 
indígenas que asolaron la población de Río Cuarto, el uso del lexema muestra la capacidad de disociar a sus referentes cuando Hernández habla de la "barbarie" de un gobierno que no protege al pueblo de los "bárbaros" salvajes, y denuncia los métodos violentos con que los generales mitristas pretenden imponer la autoridad en el interior del país:

Y mientras los indios arrasan poblaciones enteras, llevándose infinidad de desgraciados cautivos, el Gobierno Nacional dispone la ocupación militar de una Provincia Soberana, mantiene inútilmente batallones de línea en los pueblos, y la prensa liberal [...] se ocupa solo de fulminar anatemas de muerte contra el partido federal, de execrar a todos cuantos hacen un esfuerzo por la patria, y de aplaudir los actos bárbaros de Sandes y sus secuaces. ${ }^{187}$

En la sección "Interior” reflexiona desengañado:

Sangre, siempre sangre, los hechos que se refieren pueden no valer nada, no significar nada, pero parece que es una fatalidad de nuestro suelo, que han de llevar siempre la sanción de la sangre, el sello de la barbarie. ${ }^{188}$

En ese clima signado por una barbarie ejercida por quienes se autocaracterizan como representantes de una cruzada civilizatoria, se suceden las referencias a Sarmiento. Hernández lo considera uno de los responsables de las prácticas ilegales, como cuando en la sección titulada "Interior" describía un mes antes su desempeño como gobernador:

En San Juan, Sarmiento ha hecho ya del exclusivismo una condición esencial de Gobierno, ha normalizado la arbitrariedad, si es posible decirse así, y ha hecho de la confiscación de bienes, abolida por nuestro código, una pena legal. Continuaban las persecuciones, y en suspenso las garantías constitucionales para cuantos no pertenecen al círculo exclusivo del Gobierno. ${ }^{189}$

\footnotetext{
187 "Invasión del Río 4”, El Argentino, Paraná, 18 de abril de 1863, año I, n 32, p. 1, cols. 4 y 5 ; p. 2 , cols. 1 y 2.

${ }^{188}$ El Argentino, Paraná, 28 de abril de 1863, año I, nº 36, p. 2, col. 2.

${ }^{189}$ El Argentino, Paraná, 17 de marzo de 1863, año I, n 19 , p. 2, cols. 4 y 5.
} 
El 24 de marzo -en "Última hora"-, informa acerca de cómo Sarmiento le sigue los pasos al Chacho, ${ }^{190}$ y para fines de abril -en "Documento"-, promete publicar una proclama de Sarmiento sobre el conflicto; ${ }^{191}$ en este mismo número se refiere con ácida ironía a las prácticas de votación fraudulenta propias de la época:

He aquí los siguientes curiosos datos que tomamos de La Nación Argentina, y que dan una idea de la legalidad de las elecciones. [...] Siguen votando los Gobernadores y los caudillos de Provincia, vivos y muertos y quedan convertidos en electores en 1863: Ángel Peñaloza, Justiniano Posse, Domingo Sarmiento, Félix Aldao, Facundo Quiroga [...]. ${ }^{192}$

Esta serie de crónicas periodísticas culmina con la publicación de Rasgos biográficos del General D. Angel V. Peñaloza, que Hernández empieza a publicar por entregas en cuanto llega a Paraná la noticia de su muerte. Allí redoblará su artillería sobre sus contrincantes políticos, y puntualmente contra Sarmiento. Pero la voz de alarma que había venido levantando en la serie de artículos reseñada se convertirá ahora en un exacerbado lamento por el asesinato del Chacho y se traducirá en violentos antatemas. Se acumularán las descripciones de los excesos de los generales mitristas y se insistirá en subvertir la valoración de los polos de la antinomia sarmientina.

Si bien el opúsculo de Hernández tenía un antecedente (los apuntes biográficos de Federico de la Barra difundidos el año anterior) y un amplio sector de la sociedad nacional compartía la percepción de Hernández acerca de la imagen del caudillo y

190 "Pasajeros venidos del Rosario nos aseguran que había llegado allí un comisionado de Sarmiento con la noticia del Gobierno Nacional de que el General Peñaloza había invadido la Provincia de San Juan y se hallaba ya cerca de la ciudad. No podemos garantir la exactitud de esta noticia, pero no nos sorprende el hecho, que no es más sino el resultado de las amenazas constantes de Sarmiento al General Peñaloza y de sus trabajos bien conocidos para acabar de un golpe con la influencia de éste en La Rioja" (El Argentino, Paraná, 26 de marzo de 1863, año I, $\mathrm{n}^{\circ} 23$, p. 2, col. 4).

191 "Los diarios que hemos recibido publican una nota del Coronel Clavero datada en San Carlos y dirigida al Gobierno de Mendoza intimándole que entregue inmediatamente el mando de la Provincia; registran además dos proclamas, una de Clavero y otra de Sarmiento, que publicaremos en nuestro próximo número" (El Argentino, Paraná, 30 de abril de 1863, año I, n ${ }^{\circ}$ 37, p. 2, col. 5).

192 "La escuela del Fraude", El Argentino, Paraná, 30 de abril de 1863, año I, nº 37, p. 1, cols. 4 y 5 . 
acerca de la campaña del ejército gubernamental, será la semblanza del Chacho publicada en El Argentino de Paraná, y recogida en un folleto a fines de ese mismo año 63, la que persistirá en la memoria escritural de otros autores argentinos: Eduardo Gutiérrez (con su tetralogía, de 1886), Pedro Delheye (con la Muerte del Chacho, de 1890) y otros autores (Martiniano Leguizamón, Salvador de la Colina y César Reyes). ${ }^{193}$

\subsubsection{El Eco de Corrientes (1867-1868)}

Aunque Hernández se desempeña desde comienzos de 1867 como redactor de $E l$ Eco de Corrientes -órgano oficial del gobierno de Evaristo López- su nombre se menciona a partir del mes de junio, cuando en la sección oficial y en calidad de secretario de la cámara de diputados, se ocupa de la transcripción de las sesiones legislativas. ${ }^{194}$

El 10 de marzo de 1868 se descubre su nombre en la sección editorial, donde opina acerca de la cuestión electoral que mantiene en vilo al país y que tiene como antagonistas - por última vez- a Urquiza y a Sarmiento. Hernández declara que tomó la decisión de ocuparse públicamente de este tema al enterarse de esta nueva incursión de Sarmiento en la arena política. Así, sale al ruedo decidido a combatir su candidatura, por medio de una serie de notas editoriales que tratarán sobre las desventajas y los peligros que según su punto de vista significaría la presencia de Sarmiento en la primera magistratura. Aunque manifestarse a favor del vencedor de Caseros es una actitud consecuente con su militancia, se empeña en subrayar que él es el único responsable de todo cuanto dice, una insistencia que -según Halperín Donghi- estaría motivada por la conveniencia política de las autoridades provinciales. Sus intervenciones representan, entonces, un nuevo escalón en la línea del enfrentamiento personal que ha establecido con el sanjuanino (que continuará en colaboraciones para La Capital de Rosario). ${ }^{195}$

\footnotetext{
${ }^{193}$ Chávez, 1962.

${ }^{194}$ Los números de 1867 en los que aparece la firma de Hernández son: 7, 11, 18 y 21 de junio; $2,5,9,12,23$ y 26 de julio; 2,27 y 30 de agosto; $3,6,10,13,17,20,24$ y 27 de septiembre; 1 , $4,15,18,22,25$ y 29 de octubre; $1,5,8,12,15,19,22,26$ y 29 de noviembre; 13, 17, 24, 27 y 31 de diciembre. Además, suscribe cinco colaboraciones a comienzos de 1868: 3, 7, 10, 14 y 17 de enero. Se ha consultado la colección que se encuentra en la Hemeroteca de la Biblioteca de la Universidad Nacional de La Plata (periódico ${ }^{\circ} 74$ ).

${ }^{195}$ Tulio Halperín Donghi ya había analizado los pormenores sobre la redacción anónima de Hernández en $E l E c o$, que respondería a los cuestionamientos que debió enfrentar en relación
} 
Consecuentemente, también, en las notas que se suceden (con títulos como “Candidaturas”, “Candidaturas y caudillos”, “¿Hasta cuándo?”, “La combinación que han formado los sucesos es la única posible. Urquiza-Elizalde", "Urquiza-Elizalde”, "El error debe desaparecer" y "Tiempo al tiempo"), retoma la línea argumentativa inaugurada en 1853 por Alberdi. ${ }^{196}$

En el primer artículo se concentra en criticar una carta que Sarmiento ha enviado a Mansilla para agradecerle el gesto de promover su nombre como sucesor de Mitre. Hernández, después de transcribirla, emite su juicio sobre ella. Califica su enfoque como frívolo, superficial y vulgar, y su estilo como incoherente e impropio de un candidato que va a enfrentar las graves complicaciones que dejará como herencia la gestión mitrista. Sus comentarios recuperan anécdotas:

Sarmiento, siempre Sarmiento! En la convención de Santa Fe en plena sesión, se sacó un zapato por que le dolía un pie. ${ }^{197}$ En las cámaras de Buenos Aires dirigió a uno de sus colegas, como apóstrofe, este dicho tan vulgar, como poco parlamentario: "No eche pelos en la leche". 198

Pero es la opinión que Sarmiento vierte sobre Urquiza retomando las acusaciones de su Campaña en el Ejército Grande lo que impulsa a Hernández a recuperar el conflicto que signó su ruptura definitiva con Alberdi:

Pero, más grave que todo esto, más trascendental y nebuloso para el porvenir es el juicio que se vierte en esa carta respecto del general Urquiza, parangonándolo con Calfulcurá, con el cacique de una tribu de indios pampas, y presentándolo como la

con su múltiple labor como secretario legislativo, como fiscal y como redactor del periódico (tampoco serían ajenos a esos cuestionamientos, los rencores que habría despertado en la elite correntina el protagonismo del clan González del Solar-Hernández); pero en esta nueva etapa destaca también que, para Hernández, su combate con Sarmiento responde, evidentemente, a una fuerza superior (Halperín Donghi, 1985, pp. 36-40).

${ }^{196}$ El Eco, Corrientes, 1868: 10, 17 y 31 de marzo; 17 y 24 de abril; 5 y 8 de mayo.

${ }^{197}$ Esta imagen de su primera visión de Sarmiento se verá ampliada en la primera nota de réplica a La Tribuna, el 23 de septiembre de 1875.

${ }^{198}$ En esa línea burlesca, Hernández vuelve a mencionar aquí a Juan Martínez Villergas cuando cita la frase en la que Sarmiento expresó que se sabía de memoria los Estados Unidos: "Razón tenía Villergas al decir que Sarmiento no sabía el castellano, pero sin duda que debe ser fuerte en geografía" ("Candidaturas", El Eco, Corrientes, 10 de marzo de 1868, año VIII, n 158, p. 2, cols. 2,3 y 4$)$. 
carencia de toda idea buena, como la negociación de toda verdad útil. ¡Mal principio de semana cuando ahorcan el lunes!

La palabra del candidato es una palabra de guerra. ${ }^{199}$

Y a continuación, un comentario irónico toma la forma de una imagen vívida:

Podríamos sentar más bien un tiburón en la silla presidencial. ${ }^{200}$

Hernández se empeña en combatir esa candidatura porque considera que se traducirá en la imposición de una política exclusivista y de facción, que descuidará la situación del pueblo en aras de sus propios intereses sectarios y significará la supervivencia de las prerrogativas del círculo porteño. A su vez olvida por un momento esas declaraciones iniciales en las que destacó su individualidad enunciativa y pasa a emplear la $1^{a}$ persona del plural: "Somos opositores a la candidatura de Sarmiento", y la mantiene en una enumeración de razones para rechazarla: "porque la reputamos funesta para el país"; "porque es una candidatura de amenaza". ${ }^{201}$

El siguiente escrito ("Candidaturas y caudillos!"), exhibe el discurso de las Quillotanas; desde la acusación de "caudillo de la pluma" hasta la exaltación de los aportes concretos hechos por Urquiza (el dictado de la constitución, la apertura de los ríos, y lamentando que se le endilgue el título de caudillo). Algunas formulaciones reproducen el discurso alberdiano ("Pasó la época de los caudillos en la República Argentina y hablar de caudillos hoy es un anacronismo y una falsedad histórica"). Más adelante afina la puntería y discrimina: los caudillos eran Artigas, Ramírez, Güemes, López y Quiroga que extendían su poder "hasta donde alcanzaban a clavar su lanza"; pero Urquiza es presentado como un conductor de naturaleza diferente. En esta oportunidad Hernández se cuida de nombrar a Peñaloza, pero deja asentado con claridad

\footnotetext{
199 “Candidaturas”, El Eco, Corrientes, 10 de marzo de 1868, año VIII, n ${ }^{\circ}$ 158, p. 2, cols. 2,3 y 4.

${ }^{200}$ Ibidem, p. 2, col. 3 .

${ }^{201}$ Cierra con la propuesta de: "Combatir esa candidatura que representa la reavivación de los odios, la recrudescencia de los rencores de partido, la división de los argentinos, el estigma de una fracción, el sacrificio de los principios federales consignados en nuestra carta fundamental, la preponderancia de un círculo exagerado y por la tanto la anarquía en permanencia" ( $E l$ Eco, Corrientes, 10 de marzo de 1868, p. 2, cols. 2, 3 y 4).
} 
que frente a estos jefes populares, se alza el verdadero peligro, el que confiere el poder de la palabra:

Hoy los caudillos temibles son esos caudillos de pluma, que se hacen el eco de los círculos apasionados para sofocar los impulsos de la conciencia nacional. ${ }^{202}$

En "Hasta cuándo" sigue dedicado a definir los peligros que ve en la candidatura de Sarmiento "cuyos antecedentes políticos y cuyo carácter personal son una amenaza viva para la paz y la quietud de sus habitantes". Lo retrata como un hombre capaz de convertir al país en un "vasto cementerio", ${ }^{203}$ y retomando su tajante antinomia la revierte al presentar a los pueblos retrasados culturalmente como masas sacrificadas "bárbaramente" por las ambiciones de unos pocos. El editorial se cierra con un tono apocalíptico que actualiza los artículos de El Argentino de Paraná:

¿No se sienten conmovidos los autores de la anarquía en presencia de esas multitudes sacrificadas bárbaramente en holocausto de sus ambiciones bastardas, a la vista de esas hermosas campiñas donde blanquean los huesos de tantos millares de hijos de esta desgraciada República, al contemplar esos pueblos empobrecidos, aniquilados por la guerra civil y sentadas sobre sus escombros las viudas, las madres, los huérfanos como la imagen de la desilusión? ${ }^{204}$

Los dos editoriales siguientes - del 17 de abril ("La combinación que han formado los sucesos es la única posible. Urquiza-Elizalde") y del 24 del mismo mes (“Urquiza-Elizalde")- muestran un corrimiento ideológico importante en relación con la valoración de las montoneras, que ahora son claramente cuestionadas. Ambas notas exhiben un examen objetivo y una mirada prospectiva que examina las combinaciones posibles y más acertadas para el desarrollo armónico de la Nación. Trazando como objetivo la búsqueda de una fusión prudente y patriótica de los partidismos en pro de una consolidación pacífica de la organización nacional, se emplea un discurso más

\footnotetext{
${ }^{202}$ El Eco, Corrientes, 17 de marzo de 1868, año VIII, n ${ }^{\circ} 160$, p. 2, cols. 3, 4 y 5.

203 "¿Ha escrito acaso en su bandera la palabra de muerte para toda la Nación e intenta convertirla en un vasto cementerio" (El Eco, Corrientes, 31 de marzo de 1868, año VIII, $\mathrm{n}^{\circ} 165$, p. 2 , cols. 1 y 2 ).

${ }^{204}$ Ibidem, p. 2, col. 2.
} 
neutro y un tono moderado, que pareciera retener las proyecciones emocionales y se esfuerza por emitir un juicio imparcial sobre las realidades problemáticas del país.

En otra vuelta de tuerca sobre la antinomia sarmientina, Hernández juzga ahora negativamente a los dos bandos enfrentados: opina que las dos grandes amenazas que se ciernen sobre el país son las montoneras y la oligarquía; el desafío de la futura gestión será conjurar ambos males.

La montonera, esa amenaza siempre viva del interior, dispuesta en todo momento a caer como un azote fatal sobre los pueblos indefensos y que brota espontánea como las yerbas del desierto. La oligarquía, esa especie de montonera de frac y [?] que batalla en el litoral por superar a todos los elementos de orden y suplantar con su imperio caprichoso el imperio santo y benéfico de la ley. ${ }^{205}$

Así fundamenta Hernández la conveniencia de optar por Urquiza como el único jefe capacitado tanto para dominar las extralimitaciones de las masas riojanas como para contener los atropellos de los porteños "crudos". La fórmula Urquiza-Elizalde proporcionaría el equilibrio político necesario para garantizar la paz del interior y la unión de Buenos Aires, dominar a la montonera ("esa amenaza siempre viva del interior") y también a la oligarquía ("esa especie de montonera de frac").

En "El error debe desaparecer" insiste en sus opiniones adversas a la candidatura de Sarmiento sobre la base de su trayectoria y repite: "Somos opositores a la candidatura de Sarmiento" que "envolvería a la Nación en sangre", y actuaría como una "espada desnuda" sobre el partido federal. Y aunque en un alarde de objetividad acepta reconocer algunos méritos en él, sostiene que no alcanzan para convertirlo en presidente de la República, y explayándose en apreciaciones acerca de su índole personal, insiste en el tema de "su locura" y en el pronóstico de las calamidades a las que podría arrastrar al país:

Ayer, hoy y siempre, mientras Sarmiento sea Sarmiento, lo reputaremos como un distinguido pedagogo, como un escritor lleno de novedad y de brío, como un partidista, si se quiere, lleno de méritos para los suyos, pero su elevación al rango de primer magistrado de la República, la reputaremos también como una grandísima

${ }^{205}$ El Eco, Corrientes, 24 de abril de 1868, año VIII, n ${ }^{\circ} 172$, p. 2, cols. 1 y 2. 
calamidad, como un resultado cruento y amargo de nuestras disensiones y nuestros extravíos, porque solo una república de locos, puede sacar un presidente de la residencia. $^{206}$

Su último editorial firmado, "Tiempo al tiempo", ${ }^{207}$ es una vindicación de su nombre frente al ataque desembozado que ha recibido desde La Tribuna de Buenos Aires de parte de Luis Baibiene. Este enfrentamiento es una suerte de preludio de la polémica que sostendrá con ese medio en 1875, a propósito de la republicación de su biografía (que titulará Vida del Chacho ). ${ }^{208}$

Luis Baibiene pertenece a una familia de hacendados correntinos de raigambre unitaria, rivales al gobierno de Evaristo López, quien -según denuncia-impide la libre expresión de las ideas en su provincia. Puede suponerse que es pariente de Santiago Baibiene ${ }^{209}$ uno de los organizadores de la revolución que en mayo de ese año derroca a López, determinando la partida de Hernández en dirección a Santa Fe, desde donde persistirá con sus ataques en La Capital de Rosario. ${ }^{210}$

En este entredicho con Luis Baibiene, ${ }^{211}$ Hernández modera sus exabruptos; pero este enfrentamiento establece conexiones con la polémica troncal que se analiza aquí.

${ }^{206}$ El Eco, Corrientes, 5 de mayo de 1868, año VIII, n ${ }^{\circ} 175$, p. 2, cols. 1, 2, 3 y 4.

${ }^{207}$ El Eco, Corrientes, 8 de mayo de 1868, año VIII, n 176 , p. 2, cols. 1 y 2.

${ }^{208}$ Ver más adelante 5.2.

${ }^{209}$ En tanto ninguno de los diccionarios biográficos citados en la Bibliografía general registra a Luis Baibiene, sí proporcionan abundantes datos sobre Santiago Baibiene Molinari (18381895), quien participará activamente de la revolución que derrocará al gobierno de Evaristo López; a fines de 1868 será electo vicegobernador de Corrientes y poco después asumirá como gobernador. Sarmiento le encomendará liderar las fuerzas provinciales que, junto con las tropas nacionales, llevan adelante la lucha contra Ricardo López Jordán, quien será vencido en la batalla de Naembé.

${ }^{210}$ En este periódico denunciará el atropello al gobierno de López, sostendrá que ese levantamiento tiene que ser considerado ilegal y reclamará tanto la intervención armada del gobierno nacional como algún tipo de reacción de Urquiza. Como nada de esto sucede, Hernández augura nuevos problemas. Esa derivación se producirá con el alzamiento de López Jordán y la decisión de Hernández de acompañarlo se enhebra en esas convicciones políticas.

${ }^{211}$ En la nota titulada "La provincia de Corrientes, al redactor de El Eco y los niños colegiales", Luis Baibiene comienza quejándose de la situación de Corrientes: "hace mucho tiempo que no nos permiten hablar con independencia". Luego añade que López es "ignorante, apto más bien para capataz de peones". Critica el "lenguaje exagerado" de Hernández, a quien considera "adulador", "novelesco", "licencioso". La nota se cierra con una implícita alusión al programa "civilizador" de Sarmiento cuando afirma: "[El Redactor de El Eco de Corrientes] nos llama pobres niñitos colegiales y a fe que no se equivoca. Somos cincuenta niñitos [...] trabajando por la extinción completa del caudillaje" (La Tribuna, Buenos Aires, 26 de abril de 1860, año XV, $\mathrm{n}^{\circ} 4269$, p. 1, cols. 4, 5, y 6). 
Por una parte, la conocida posición de La Tribuna que en ese momento funciona como el órgano propagandístico de la campaña presidencial de Sarmiento (desde 1868 promociona su nombre en la primera página del periódico, se dedica a denostar a Urquiza y a Elizalde igual que a los opositores políticos de Sarmiento, y ofrece sus columnas -como en este caso- para atacar a sus contrincantes periodísticos) se define ya como el órgano adecuado para lanzar la polémica que clausurará la expresión pública del conflicto entre Hernández y Sarmiento, en 1875. Evidentemente Héctor Varela ya ha venido siguiendo con desagrado, desde 1868, las invectivas de Hernández y volverá a brindar las columnas de su periódico para que lo batallen.

Pero por otra parte, los planteos de Baibiene se muestran en consonancia con la versión de la vida del Chacho que Sarmiento publicará a fines de ese año. Allí imprimirá un desplazamiento en su valoración de los caudillos (de la insistencia en sus rasgos violentos y sanguinarios, se pasará a enfatizar su condición de seres fundamentalmente ignorantes), y en su interpretación de la "barbarie" (que se irá acotando como un territorio que debe ser educado). Las críticas de Baibiene se pliegan a la impronta educativa de la campaña presidencial de Sarmiento desde donde son vistos los caudillos, como nunca antes, más que como individuos violentos, como hombres incultos. Baibiene acusa a López de caudillo "bárbaro" porque no ha fundado "ni una escuela"; pero además, también retorna a la postura inicial, la del Facundo, reponiendo el discurso sarmientino acerca de la sociedad que engendra la vida rural: “¿Qué otra escuela ha tenido que la escuela del gaucho metido casi toda su vida en el campo detrás de sus vacas?"212

Estas valoraciones que Hernández considera irónicamente "anteojeras pedagógicas" determinará que tilde a sus sostenedores de "escueleros". ${ }^{213}$ No obstante, en las colaboraciones que publicará en La Capital de Rosario, Hernández volverá a ocuparse del tema educativo con más seriedad sin dejar de criticar lo que considera un enfoque limitado de Sarmiento

\subsubsection{La Capital de Rosario (1868-1869)}

${ }^{212}$ Ibidem, p. 1, col. 4.

${ }^{213}$ Luis Baibiene figura como celador y bibliotecario del Colegio Nacional de Buenos Aires en la memoria que el rector, D. Alfredo Cosson, presentó al Congreso de la Nación el 25 de julio de 1868. Por esta razón, evidentemente, Hernández lo ha tildado de "escuelero". www.genealogiafamiliar.net 
Una vez establecido en Rosario, Hernández escribe colaboraciones para su diario más importante -La Capital- durante junio y julio de $1868 .{ }^{214}$ Aquí se aboca, sobre todo y como modo de combatir la preeminencia porteña sobre el resto del país, a la tarea de promover a Rosario como potencial capital de la Nación. Pero también se servirá de esas columnas para continuar analizando la candidatura de Sarmiento a presidente de la República. Hernández recuperará sus opiniones adversas, repetirá las razones por las que rechaza su candidatura presidencial y retomará el hilo de sus advertencias a Urquiza acerca de los supuestos peligros a los que se expone al dialogar con el poder político porteño. También publica allí una nota recordatoria sobre el asesinato de Peñaloza en la se que rescata polémica original y la mención de la tesis "civilización y barbarie".

Los primeros artículos están destinados exclusivamente a promocionar la capitalización de la ciudad, y hasta el 2 de julio no hay ninguna mención de Sarmiento. Sin embargo, en una nota titulada "Los cantos de las sirenas" reaparece el tono encendido de sus editoriales de El Argentino (y más puntualmente, el de la dramática advertencia a Urquiza acerca de los peligros de la inacción política con la que había rubricado su semblanza del Chacho):

Mitre es el enemigo de su poder. Sarmiento es el rival de su gloria. Déjese adormecer por los cantos armoniosos de esas sirenas que trabajan por su perdición, y pronto lo habrán arrastrado hasta el fondo del mar de su ruina, y de la ruina de todos. ${ }^{215}$

Discurre aquí sobre la idea de que el poder gubernamental ha iniciado una política de falsas conciliaciones que esconde el propósito de adormecer toda reacción de del general entrerriano para destruir la figura política del que considera que es "la única gloria que todavía queda en pie”. Continúa más adelante:

${ }^{214}$ La Capital de Rosario fue fundado el 15 de noviembre de 1867 y su editor responsable era Ovidio Lagos. La primera colaboración que lleva la firma Hernández es del 20 de junio de 1868 y la última de ese año es del 21 de julio. La colección que hemos podido consultar llega hasta el 25 de octubre de 1868 (Biblioteca de la Universidad Nacional de La Plata, Sección Hemeroteca, periódico $\mathrm{n}^{\circ}$ 265), el resto de los artículos los tomamos del Archivo Losada. El material transcripto por Alejandro Losada Guido se encuentra en el Instituto Iberoamericano de Berlín y obtuvimos copias gracias a la generosidad del Prof. Ángel Núñez.

${ }^{215}$ La Capital, Rosario, 2 de julio de 1868, año I, n 173 , p. 2, cols. 1 y 2. 
Mitre siempre su grande y buen amigo. Sarmiento ha de ser para él un escudo y un compañero. Veremos hasta qué extremo es densa la venda con que sus artificiosos enemigos han cubierto los ojos del General Urquiza, hasta qué extremos son impenetrables para él los vapores que en torno suyo levantan la mentira y el disimulo. La marea crece. El agua llega al cuello $[\ldots]^{216}$

En la nota titulada "Lecciones para los pueblos" Hernández traza un panorama histórico de la evolución política nacional y vuelve a referirse a Sarmiento como una amenaza funesta para Urquiza:

Sarmiento, que ha aspirado desde su juventud a ser el héroe de la organización nacional, no ha de dejar esta gloria al General Urquiza, y pronto se consagrará a cambiar esa Constitución para que el nombre de aquel sea borrado de ella para siempre.

Y agrega luego:

Los EE. UU. habrían proporcionado a Sarmiento ideas y conocimientos suficientes para hacer fácil y realizable su obra, para dar al país una constitución nueva, para borrar así el nombre del general Urquiza del código de Mayo, y para ligar el suyo a la época de la nueva organización que se pretende inaugurar. ${ }^{217}$

El artículo concluye con una reflexión pesimista sobre el "martirio de los pueblos" y el "sacrificio de sangre generosa" frente a las promesas halagüeñas de los "falsos liberales",218 y la ingratitud del "círculo explotador".

En "De mal en peor" desecha el tono sombrío para recuperar un tópico típicamente panfletario: la difamación y se dedica a fustigar con cargo recurrente en el discurso de los adversarios de Sarmiento: la excentricidad del sanjuanino. Asevera que el país "ha metido la mano en las urnas electorales y ha sacado de ellas el nombre de un

${ }^{216}$ La Capital, Rosario, 2 de julio de 1868, año I, $n^{\circ} 173$, p. 2, cols. 1 y 2 . El destacado es de Hernández.

${ }^{217}$ La Capital, Rosario, 18 de julio de 1868, año I, n 186 , p. 2, cols. 3 y 4.

${ }^{218}$ Este sintagma, que circula en el diarismo del partido federal, reaparece en Peregrinación de Luz del Día de Juan Bautista Alberdi (que comenzó a escribir este texto a fines de 1870 y lo editó en 1874): un testimonio de que en el lazo que los vincula hay un movimiento de ida y vuelta. 
loco", y después de calificarlo de "Presidente maniático", se descontrola con esta explosión:

¿Pero consentirá el Congreso, consentirán los hombres influyentes de la República, consentirá el país en que un loco, que ya ha fulminado sus anatemas contra el Credo y contra la Religión, que ha dicho que va a nombrar una mujer para ministra de Culto, que es un furioso desatado, venga a sentarse en la silla Presidencial, para precipitar al país a la ruina y al desquicio?

Se despeña también cuando persiste en la idea de que la programática educativa de Sarmiento es una limitación para su desempeño como gobernante (un motivo que había emergido en su polémica con Luis Baibiene):

Es un destino amargo el de esta pobre república. Esto se llama ir de mal en peor. Mitre ha hecho de la República un campamento. Sarmiento va a hacer de ella una escuela. Con Mitre ha tenido la República que andar con el sable en la mano. Con Sarmiento va a verse obligada a aprender de memoria la anagnosia, el método gradual y los anales de Doña Juana Manso. ${ }^{219}$

Por último, se registra la aparición de dos notas de noviembre del año siguiente. Una -titulada “Asesinato del General Peñaloza" - es un recordatorio del Chacho en el aniversario de su muerte el 12 de noviembre de 1869, que comienza con un incomprensible error de datación:

Hoy hacen cinco años que la daga de la mazorca del general Mitre, trozaba la cabeza del honrado y patriota general Peñaloza, exhibiéndola en una pica en la plaza del pueblecito de Olta en presencia de su esposa que era escarnecida por la turba salvaje de asesinos. Este hecho horroroso que se registra en las páginas sangrientas de la administración de Mitre, no se puede recordar, sin que el sentimiento menos noble se subleve contra los bárbaros autores de aquel fúnebre episodio, premiados por el general Mitre con el grado de coronel. ${ }^{220}$

${ }^{219}$ La Capital, Rosario, 20 y 21 de julio de 1868, año I, n ${ }^{\circ} 188$, p. 2, cols. 2 y 3.

${ }^{220}$ La Capital, Rosario, 12 de noviembre de 1869, año II, $\mathrm{n}^{\circ} 605$, p. 2, cols. 1 y 2 (la transcripción es de Alejandro Losada Guido). 
Es cierto que los ajetreos de sus reinstalaciones sucesivas y la envergadura de la empresa periodística y política que ha emprendido en Buenos Aires podrían justificar una desubicación temporal -ya que se cumplen seis años de la muerte del caudillo-, pero tomando en cuenta la prodigiosa memoria de Hernández ${ }^{221}$ y la atención que dispensó a la trayectoria del Chacho, este error llama demasiado la atención. Hasta se podría pensar en una redacción de 1868 que, por alguna razón, Ovidio Lagos hubiera decidido postergar; de todas maneras, no hemos podido fundamentar esta hipótesis.

Resurge aquí la reversión designativa de los lexemas de la barbarie y con ella la denuncia de los "bárbaros autores de aquel fúnebre episodio" y se reponen las modalidades discursivas desenfrenadas del folleto de 1863. Hay incluso desvíos apreciables hacia una intensificación del conflicto, ya que se acentúa la incriminación explícita de Mitre. ${ }^{222}$ Recupera también la crudeza del lenguaje para pintar la escena de la muerte del Chacho, insiste nuevamente en la pintura del "viejo patriota" cuya cabeza "fuera colgada en una plaza pública" y se detiene en "la figura ensangrentada de aquel mártir de su fe". Incluso, hace una transcripción exacta de un pasaje de su folleto de 1863, sin alterar nada de su contenido y lamentándose de no tener más espacio para poder describir la vida de Peñaloza:

La pequeñez de nuestro diario no nos permite delinear los grandes perfiles biográficos de aquel valiente soldado, cuya vida militar es un caudal de hechos magnánimos. $^{223}$

A continuación reedita el apartado subtitulado "Revelación de un crimen" de Rasgos biográficos del General D. Angel V. Peñaloza a partir de la trascripción del

\footnotetext{
${ }^{221}$ La memoria de Hernández era proverbial. Además de ser un requerimiento sine qua non para la práctica de la poética del contrapunto -que está atestiguado que él cultivaba (Fernández Saldaña, 1940)-, su hermano Rafael ha recogido anécdotas confirmatorias (R. J. Hernández, 1896, pp. 79-90).

${ }^{222}$ Mitre es mencionado tres veces sólo en el primer párrafo. En tanto que en Rasgos biográficos del General D. Angel V. Peñaloza las acusaciones se concentraban en la figura de Sarmiento, puede decirse que a partir de 1863 se incrementará el antimitrismo de Hernández, una posición que comparte con sus colegas del diarismo federal y que culminará en 1874 en sus publicaciones en La Patria de Montevideo. Ver 5.1.

${ }^{223}$ La Capital, Rosario, 12 de noviembre de 1868, año II, $n^{\circ}$ 605, p. 2, cols. 1 y 2 (transcripción de Alejandro Losada Guido).
} 
parte de Irrazábal que da la noticia del asesinato de Peñaloza, y llega hasta dramática descripción de los "unitarios" como tigres cebados en sangre humana. Así, hayan sido escritas en 1868 o en 1869, estas recuperaciones alteran tanto la línea de moderación que había empezado a cultivar Hernández en sus editoriales de El Eco (en los que había criticado en paralelo a las montoneras y a la oligarquía), como la tónica periodística más analítica y reflexiva que signará su más relevante emprendimiento periodístico: El Río de la Plata.

Por otra parte, esa desestabilización discursiva se relaciona con el capital simbólico que ha adquirido la figura del Chacho a partir de su desgraciada muerte. Ese fenómeno social determinará no sólo recuperaciones de Hernández, sino una construcción inversa que polemiza con la que él ha instalado en 1863: la réplica de Sarmiento en El Chacho, último caudillo de la montonera de los años, publicada a fines de 1868. A partir de allí, serán dos construcciones simbólicas las que se enfrentarán tanto en el diarismo como en los cuerpos legislativos y volverán a imbricarse a partir del cierre de la gestión presidencial del sanjuanino, entre 1874 y 1875.

En contraposición, en "La paz se consolida" - una nota que se publica yuxtapuesta con la anterior, reinstala la tónica de los editoriales contemporáneos de $E l$ Río de la Plata, y habla de la tendencia hacia una concordia generalizada que promete la superación de una época turbulenta y sangrienta que impide el avance del progreso. Sin embargo, aunque predomina un tono optimista y conciliador que avizora la superación de las pasiones políticas y los vastos horizontes del progreso ("La época que atravesamos pertenece a la industria, a las artes, a la inmigración, teniendo por vanguardia el telegrama y la locomotora"), también afloran ecos de sus denuncias inflamadas:

Pasó la época de los Sandes, y desaparecieron con las risotadas del ridículo y la silbatina de la muchedumbre, la de los falsos profetas, que prometían redimir pueblos en tres meses. $^{224}$

\subsubsection{El Río de la Plata de Buenos Aires (1869-1870) 225}

${ }^{224}$ La Capital, Rosario, 12 de noviembre de 1868, año 2, n 605, p. 2, cols. 1 y 2 (transcripción de Alejandro Losada Guido). 
José Hernández regresa a su provincia natal en el año en que comienza la presidencia de Sarmiento, ${ }^{226}$ y en agosto de 1869 inicia una nueva etapa en su desempeño como publicista y editor. Sin abandonar su actitud crítica pero con voluntad de conciliación, funda El Río de la Plata, un periódico de tirada diaria en el que colaboran numerosos periodistas y políticos de reconocida jerarquía. Entre ellos aparece la firma de Vicente G. Quesada, Carlos Guido y Spano, Carlos Pellegrini, José A. Ferry, Eusebio Ocampo, quienes junto con los restantes colaboradores se unirán con la intención de conformar una tercera fuerza política en la provincia. ${ }^{227}$

El primer número sale el 6 de agosto de 1869, dispuesto a conquistar el favor de un público independiente con vocación progresista y con el objetivo explícito de sostener la paz social tan duramente conquistada. Desde la presentación, Hernández deja asentada su intención de diferenciarse de una "oposición por sistema" pero también de la elite exclusivista porteña:

El Río de La Plata se ha fundado para ser el guardián de los intereses permanentes del progreso [...] y considerando las cuestiones desde esa altura, no reconoce círculos, ni entidades personales, que puedan levantarse sobre el nivel de los intereses generales. $^{228}$

En el editorial del 7 de agosto -dedicado a la Guerra del Paraguay- Hernández agrega precisiones acerca de su nuevo enfoque: se autoproclama como "opositor

${ }^{225}$ El Río de la Plata, Buenos Aires, Redactor José Hernández- Redacción y Administración, Calle Victoria 202. Fue consultado en la Biblioteca de la Universidad Nacional de la Plata (Microfilms, rollo n ${ }^{\circ} 1528$-año 1869- y nº 1529 -año 1870-).

${ }^{226}$ Según Horacio Zorraquín Becú Hernández llega a Buenos Aires con el antecedente que significan las notas de junio y julio publicadas en La Capital en las que ataca a Sarmiento: "Con ese pasaporte desembarca Hernández en la ciudad del puerto en noviembre de 1868" (Zorraquín Becú, 1972, p. 135).

${ }^{227}$ El grupo declara su intención de actuar en "homenaje a la independencia del ciudadano" y batallar contra la política de círculo. Encabezando la lista para elecciones a diputados estarán Mariano Acosta, Manuel Argerich y Emilio de Alvear (Guido y Spano, 1879, II, p. 64).

${ }^{228}$ El Río de La Plata, 12 de agosto de 1869 . Se observa, también, una notoria dedicación hacia aspectos culturales. En los primeros números se incluye la publicación, en folletín, de Los hijos del Capitán Grant, de Julio Verne, y se irán incorporando artículos sobre literatura, traducciones de obras literarias, reproducción de poesías, y una sección titulada "Laberinto" semejante a la que su hermano Rafael publicaba en El Litoral de Evaristo Carriego de 1862-, en la que se alternan notas de crítica artística con comentarios sociales y referencias al mundo femenino de Buenos Aires. 
legítimo" de la administración de Sarmiento. Se categoriza de esta manera en contraposición a lo que denominó el día anterior la "oposición por sistema" que, a su juicio, no puede aportar nada constructivo a la sociedad porque sólo busca la confrontación por la confrontación misma sin reconocer ningún aporte positivo en sus adversarios. Propone, por consiguiente, ejercer una crítica constructiva por medio del análisis objetivo de los acontecimientos políticos. ${ }^{229}$

Pero a su vez, Hernández hace oir nuevamente su voz, consciente de haber ganado ya un lugar en el periodismo nacional: se siente autorizado para tomar ahora la palabra en la ciudad-puerto. Según la opinión de Tulio Halperín Donghi, sus esfuerzos resultan "considerablemente exitosos" porque ha encontrado el momento más apropiado para ser "aceptado como interlocutor legítimo en el complejo diálogo de órganos y corrientes que caracteriza a un momento de laboriosa transición política". ${ }^{230}$

Esta nota es también un testimonio de su actitud contemporizadora: en el tratamiento del conflicto evita incluir a Sarmiento en sus críticas destacando que se ha encontrado con una gravosa herencia del gobierno anterior y con la pesada tarea de tener que resolver este enorme problema. Así, deja caer en Mitre todo el peso de la responsabilidad de lo que considera -dentro de la más ortodoxa línea alberdiana- un conflicto oprobioso. ${ }^{231}$ Esta reconsideración de actitudes llevará aparejados movimientos de resemantización de la antinomia “civilización versus barbarie".

La declinación política de Urquiza -expresada en su negativa a asumir nuevamente un rol capital para la organización del país- redefine el ocaso del partido federal e impone la reubicación de sus sostenedores. Para remontar esa desilusión, Hernández regresa su provincia en las nuevas circunstancias políticas que han llevado a Sarmiento a la presidencia y ensaya otra metodología de construcción. Pero por otro lado, la redistribución de fuerzas que se ha producido dentro del partido liberal lo impulsa momentáneamente a definir, en primer lugar, otro adversario: Bartolomé Mitre. El presidente actual se encuentra en una situación de desventaja política, acosado por

\footnotetext{
${ }^{229}$ El Río de la Plata, Buenos Aires, 7 de agosto de 1869.

${ }^{230}$ Halperín Donghi, 1985, p. 68.

${ }^{231}$ Define así una firme posición antimitrista que culminará con sus notas de 1874 publicadas en La Patria de Montevideo, en las que retornando al género decididamente panfletario y el tono apasionado de su diarismo más combativo, califica a Mitre de "funesto" y de "bolilla negra", responsable de ensangrentar al país y de arrasar a un país hermano. Este análisis se detalla en el apartado 5 .
} 
esas facciones de círculo cerrado que Hernández ha venido denunciando y por la agresiva batalla periodística y política que encabeza Mitre. A esa nueva oposición enfrentará, principalmente, el diario de Hernández, más que para hacer una defensa explícita de Sarmiento, con la ilusión de ofrecer una visión crítica en su término justo (pero en este nuevo contexto, ya no se lo calificará de "tiburón" ni de "maniático").

La llegada del nuevo órgano a la arena porteña fue celebrada con una exhibición de fuegos artificiales, y en la reseña humorística acerca de la inauguración que luego publica Hernández, un comentario irónico introduce uno de los principales temas políticos que planteará el diario para esa coyuntura:

Unos creían que los cohetes eran por la conclusión de la guerra del Paraguay; otros porque se creyó que el emperador del Brasil había muerto, pero ninguna cosa sucedió sobre el particular- recibiendo el curioso público un chasco espantoso. ${ }^{232}$

Se anticipa así la corrosiva crítica contra la Guerra del Paraguay que sostendrá el diario, pero si bien se entronca con la serie de tratados que Alberdi dedicó al tema, ${ }^{233}$ se intenta, como se ha dicho, exhibir una actitud contemporizadora con la administración de Sarmiento al presentarla como la heredera del funesto obsequio de la presidencia anterior. $^{234}$

Mientras que varios apartados van siguiendo las novedades del frente, los editoriales de Hernández desarrollarán temas directa o indirectamente conectados con la necesidad de poner fin a esa situación bélica: la crisis económica, la necesidad de abolir los derechos de exportación, el puerto y los ferrocarriles, las relaciones con las provincias, la inauguración de revistas para lectores extranjeros para tenerlos al corriente de lo que sucede en estas regiones, la división de tierras y el exclusivismo político. También se incluyen documentos oficiales, como por ejemplo, la carta del presidente Sarmiento al gobernador Taboada, de Santiago del Estero.

\footnotetext{
${ }^{232}$ El Río de la Plata, Buenos Aires, 7 de agosto de 1869.

${ }^{233}$ El último trabajo que Alberdi acaba de publicar -El Imperio del Brasil ante las democracias de América (en el que compendia todos sus trabajos anteriores dedicados al tema)- está circulando ampliamente por el Plata (Alberdi, 1869).

${ }^{234}$ El 24 de agosto, en un editorial titulado "La guerra del Paraguay", Hernández declara: "Nosotros no queremos desempeñar el rol de los declamadores vulgares [...] Nos hemos constituido en órganos de la opinión legítima y queremos proclamar siempre la verdad". El jueves 26 otro editorial -titulado "La nueva faz"- continúa desarrollando el mismo tema.
} 
Pero simultáneamente, los editoriales destacan la presentación de una nueva línea política. En "Nuestra misión" se destaca la importancia de defender la independencia de criterios, de superar el partidismo de bandas y de abandonar personalismos en aras de la paz:

Hemos abjurado los odios y la venganza y hemos cerrado la antigua liza de irreconciliables bandos, para apelar a la lucha vivificante de las ideas [...]. Nosotros no aspiramos al efímero triunfo de prepotencias personales. ${ }^{235}$

En el editorial titulado "La idea nueva", Hernández retoma un deseo que ya había esbozado en El Nacional Argentino de Paraná: la búsqueda de renovación política mediante la creación de nuevos partidos. Entonces había hablado de "partidos viejos y partidos nuevos", ahora se refiere a la oposición entre "los partidos de principios" -que representan ideas, reformas, progresos-y "los partidos personales", que no representan otra cosa que "los intereses raquíticos y las ambiciones bastardas de los caudillos que los dirigen". 236

El viernes 20 de agosto, defiende en "El peligro de la oposición" a la prensa independiente, saludable, que no es lisonjera, que se expresa respetando los derechos republicanos, libre del peso de los errores y que "debe prevenir el desborde de una oposición que quiere envolver al país de nuevo en las tenebrosas complicaciones de otra época infausta", promoviendo a su periódico como un órgano orientado en busca de la paz, la libertad y las garantías sociales. En la vereda opuesta sitúa a los círculos de poder del mitrismo que amenazan con anarquizar al país o demorar su progreso con críticas estériles. $^{237}$

La renovación propugnada permitiría la reorganización política tan ansiada, el camino hacia la fraternidad y la paz de la sociedad, que sólo sería posible a partir de la fundación de un partido alternativo a las fuerzas tradicionales. Con este fin se presentó

\footnotetext{
${ }^{235}$ El Río de la Plata, Buenos Aires, 17 de agosto de 1869.

${ }^{236}$ Dice Hernández: "Los partidos de principio son la garantía de la libertad [...] Los unos marchan hacia la fraternidad, los otros hacia la guerra. [...] Respetemos la libertad del ciudadano, porque sólo ella arrancará la base de una situación estable, porque solo así habremos iniciado la grande obra de nuestra reorganización política" (El Río de la Plata, Buenos Aires, 14 de agosto de 1869).

${ }^{237}$ Ver editoriales del 28 de agosto ("La oposición y la anarquía") y del 4 de septiembre ("La gran dificultad").
} 
un acta de fundación, con la firma de sus adherentes, en la que se invitaba a una "Gran Reunión Popular". ${ }^{238}$ Pero estos sueños tuvieron un final abrupto cuando Hernández abandonó el diario de manera intempestiva para seguir los pasos revolucionarios de Ricardo López Jordán, con quien había estrechado relaciones desde su llegada a Paraná.

\subsection{El caudillismo y las intervenciones del gobierno nacional}

También respecto del fenómeno del caudillismo - tan vigilado por Hernández y por todos los políticos y periodistas de la época-, Hernández desplaza el blanco de sus críticas de Sarmiento a Mitre: el ex presidente pasa a ser ahora la encarnación del conflicto. Mitre es presentado como el nuevo caudillo, y por lo tanto, una etapa que es necesario superar, el escollo que impide la renovación del país, la rémora del personalismo que impone el temor a la dictadura, la amenaza del caos y de la revolución permanente.

Por otro lado, cuando Hernández encara temas de orden nacional -como el supuesto alzamiento de Taboada en Santiago del Estero-, retoma el conflicto sobre el caudillismo, pero mostrando un ánimo conciliador. En "La conflagración desaparece" habla de "la actitud pacífica de los caudillos del interior" como una razón decisiva para finalizar las campañas militares centrales y comenta que las intervenciones armadas que Mitre lanzó sobre las provincias sólo lograron convulsionar aún más a la sociedad. ${ }^{239}$ La

\footnotetext{
${ }^{238}$ El Río de la Plata, Buenos Aires, 23 de noviembre de 1869.

239 "Determinada la actitud pacífica de los caudillos del interior, fuerza es que el gobierno se preocupe cuanto antes de restablecer sus relaciones con los gobiernos de provincia, ligándolos, menos por el imperio de su fuerza, que por el aliciente de su política circunspecta, imparcial, equitativa. La República necesita de paz y disfruta de ella materialmente. Pero la paz no es un hecho arraigado, inconmovible, en donde subsiste la amenaza continua de los ejércitos permanentes. Los ejércitos permanentes son un contrasentido en la República, son el alimento de la inmoralidad y la corrupción, son una amenaza. [...] No nos personalizamos, pero no podemos considerar sino como un peligro, la fuerza que se coloca en manos de un jefe militar, en una situación tranquila y regular.[...] Por ese camino vamos retrogradando y llegaremos a hacer indispensable el régimen de la militarización del país. En todo caso, las intervenciones militares en el interior, en una situación normal, son perjudiciales al orden público, a la marcha independiente de los gobiernos, y afectan profundamente los derechos políticos de los pueblos. Es imposible que los jefes interventores se mantengan en una absoluta neutralidad en las cuestiones locales [...] Hoy que la situación del interior se aclara, debemos esperar que el gobierno nacional [deje de hacer intervenciones]. Si el gobierno nacional no tiene esa aspiración, es que aspira a convertir en triunfos sus derrotas y quiere seguir rutinariamente la estrecha senda que le ha trazado el sable de los caudillos" (El Río de la Plata, Buenos Aires, 3 de septiembre).
} 
nota finaliza expresando esta esperanza: que Sarmiento no se extravíe por la senda que los caudillos "han trazado con el sable".

Este reposicionamiento es muy evidente en el editorial del 5 de septiembre, en el que transcribe el mensaje del poder ejecutivo nacional respecto de las intervenciones en las provincias. Cuando revisa el tema que había motivado sus explosivas denuncias en Rasgos biográficos de D. Angel $V$. Peñaloza, desplaza el acento de la critica hacia la inoperancia de la "prensa opositora por sistema" y se manifiesta dispuesto a apoyar al gobierno cuando actúa correctamente. Pero tampoco claudica totalmente y advierte en el PEN el defecto del personalismo:

Habríamos deseado que se hubiese prescindido hasta el fin de las alusiones personales que quitan al mensaje, el sello de la alta gravedad y circunspección que lo distinguirían y que no le imprimen, en cambio, ni más energía ni más fuerza de razón. Esa propensión a levantar en medio de las grandes cuestiones, la figura más o menos expectable del jefe de estado, se comprende cuando el mandatario aspira al incienso y al prestigio personal, que los caudillos conquistan con el sable, pero es ajena, sin duda, del magistrado que aspira solo al triunfo de la ley, confundiendo su personalidad, entre los pliegues de esa bandera majestuosa. Lamentamos esa desviación del terreno firme en que se ha colocado el gobierno. ${ }^{240}$

No obstante, el desplazamiento de sus juicios en busca de posiciones menos apasionadas con respecto al caudillismo del interior es un camino que será retomado después de su último arresto de rebeldía en su reformulación de su biografía del Chacho, y luego de responder al polemismo que despierte, terminará reconcentrándose en los conflictos de su provincia natal.

En este sentido, es ilustrativa la línea que trazan los dos periódicos fundados por Hernández en relación con la trama histórica nacional: en Paraná, El Argentino es la respuesta de un porteño exiliado de Buenos Aires en un país que no acierta a lograr una convivencia entre sus facciones. Luego, una vez que la Argentina se ha reunificado, y Hernández vuelto a Buenos Aires, abandona la mirada general para reconcentrarse en

240 "Documento del Poder Ejecutivo Nacional", El Río de la Plata, Buenos Aires, 5 de septiembre de 1869. 
los conflictos de su provincia natal: y en este punto no abandona la denuncia de injusticias sociales.

De este modo, en El Río de la Plata aparecen desde los inicios los temas que se vinculan estrechamente con el universo del discurso de Martín Fierro: la puja entre el campo y la ciudad, los atropellos y los gravámenes que pesan sobre el hombre de campo, y muy particularmente, los decretos injustos del gobierno de la provincia sobre el servicio de fronteras. ${ }^{241}$

\subsection{La propuesta partidaria de El Río de la Plata}

El 11 de septiembre - día del significativo aniversario del separatismo porteño-, Hernández publica un extenso editorial (titulado "El pasado y el presente"); pero su tono cauto es representativo de la voluntad de respetar el tácito pacto de no agresión que ha establecido con la administración de Sarmiento. Hace un repaso de la historia de la organización nacional, y al mencionar a Urquiza como un caudillo, deja traslucir un decidido alejamiento del entrerriano, que anticipa su apoyo a la causa de López Jordán luego de que su revolución sea enfrentada por Sarmiento:

El caudillo vencedor solo se preocupó de girar en el círculo de estrechas y menguadas ambiciones, esterilizando los frutos de una victoria que no supo apreciar ni comprender. La lluvia de proyectos con que pretendió halagar las imaginaciones sobre excitadas de la época hizo creer en la posibilidad de un edén, pero bien pronto se vio que eran fuegos fatuos [...]. ${ }^{242}$

\footnotetext{
${ }^{241}$ Numerosos editoriales tratan este tema. En el del 19 de agosto ("La seguridad de las fronteras"), Hernández se pregunta: "¿Qué se consigue con el sistema actual de los contingentes? Empieza por producirse una perturbación profunda en el hogar del habitante de campaña. Arrebatado a los labores, a su familia, quitáis un miembro útil a la sociedad que lo reclama, para convertirlo en un vago, en un elemento de desquicio y de inmoralidad [...] Qué tributo espantoso es ese que se obliga a pagar al poblador del desierto? Parece que lo menos que se quisiera fomentar es la población laboriosa de la campaña, o que nuestros gobiernos quisieran hacer pagar, como un delito oprobioso, el hecho de nacer en el territorio argentino y de levantar en la campaña la humilde choza del gaucho. ¿Qué privilegio monstruoso es el que así se quiere acordar a las capitales? [...] ¡Qué! ¿No es hogar tan respetable el del gaucho?” Y este tema será tratado en editoriales sucesivas. Continúa en "La seguridad en las fronteras II, III y IV", del 21, 22 y 23 de agosto, respectivamente. En ellos se detallan las penurias y se subrayan, también, las necesidades: "La frontera debe ser guarnecida por tropas de línea [...]. Este es el medio legítimo de custodiarlas. Los ejércitos de frontera no solo deben tener armas, deben estar además munidos de instrumentos de trabajo".

${ }^{242}$ El Río de la Plata, Buenos Aires, 11 de septiembre de 1869.
} 
También vuelve sobre el período en que "vinieron enseguida las convulsiones del interior que anegaron en sangre las provincias, vino la tiranía de los Procónsules a los cuales se ensalzaba entonces y hubo escenas repugnantes que deseáramos ver cubiertas con el sudario del eterno olvido [...]". Se refiere sin duda al asesinato de Peñaloza, y aunque no deja de acentuar que se trata de un recuerdo muy doloroso, persiste en el propósito de sostener un espíritu avenido con la "necesidad de la paz", ahora más pronunciada por los estragos que sigue produciendo la guerra exterior.

Durante todo el mes de septiembre el diario se ocupa de cuestiones diversas; se discurre sobre proyectos relacionados con la vida rural, sobre la prolongación de la contienda con el Paraguay y otras cuestiones políticas y administrativas. En octubre, predominan dos temas concomitantes: el lanzamiento de la campaña política que el diario ha decidido promocionar y las críticas al círculo mitrista. ${ }^{243}$ De este modo, en sucesivas editoriales tituladas "La cuestión electoral" y "Las próximas elecciones" se ofrecerá, a partir de los primeros días de noviembre, la lista de los candidatos que se presentarán como diputados (El Río de la Plata conforma un acta de fundación de un nuevo partido ${ }^{244}$ y un "Club de los Libres", que intenta convocar a una juventud independiente). Hernández se aplica con verdadero entusiasmo a promover ideas "a favor del hombre de a pie" e insiste en que se trata de una alternativa renovadora de los anquilosados partidos personalistas. ${ }^{245} \mathrm{Y}$ ya sobre el último mes del año, recuperando las críticas a la Guerra del Paraguay (finalizada de hecho), acumula nuevos dicterios

\footnotetext{
${ }^{243}$ Éstos son los títulos de los editoriales de octubre: "Gobiernos empresarios" (con una crítica contundente a Mitre), "Reforma de la ley electoral", "La descentralización administrativa, (trascripción de un discurso del Gral. Guido firmada por su hijo -"Guido y Spano"-), "La regeneración de la campaña", "Contestación a La República", "La ciudad y la campaña I y II", "Proyectos sobre tierras I y II", "Los ejidos de los pueblos", "El Paraguay", "Triunfos que son derrotas, "Las dos exposiciones" (referiéndose a la "Exposición Universal" del Río de la Plata y a la que fue organizada en Córdoba por Sarmiento, Hernández enfatiza que no desea polemizar sobre ellas porque ambas ayudan al progreso), "Los enemigos del progreso", "La situación" (donde reconoce la "empeñosa constancia en la obra del progreso" del gobierno nacional), "El gobierno y la situación I y II", "Ministerio Nacional de Hacienda" "Un buen proyecto, "La lucha de vida" (para no volver al período de guerras civiles o la del Paraguay), "La discusión es siempre oportuna".

${ }^{244}$ Tulio Halperín Donghi caracteriza esa propuesta política con estos términos: "la formulación de una ideología ruralista en la Argentina" (Halperín Donghi, 1985, pp. 223-279).

${ }^{245}$ Aunque está inmerso en el fragor electoral, Hernández no descuida sus predilecciones literarias: después de que el 19 de noviembre concluyan las entregas de Los hijos del Capitán Grant, vuelve a elegir una obra de Verne y empieza a publicar en folletín Cinco semanas en globo (en traducción española de D. A. Ribot y Fontseré).
} 
contra Mitre a medida que realiza un examen pormenorizado de su emprendimiento político-militar. $^{246}$

En el editorial del 4 de diciembre, titulado "El triunfo de los principios", retorna su espíritu crítico al análisis del fenómeno del caudillismo:

Los pueblos tienen siempre los gobiernos que merecen, porque si un hombre impone su despotismo a la sociedad, es porque esa sociedad está bastante desquiciada y corrompida para ser el pedestal de la tiranía. Si el caudillaje ha surgido del pueblo, es porque ha sido engendrado por la ignorancia y la anarquía que extraviaron su actividad, en la aurora de su emancipación política [...]. Por eso rodamos en la noche de la anarquía, en el infortunio de las guerras civiles, a cuyo calor se incuban esos monstruos del caudillaje, que según una enérgica expresión, se enroscan al árbol de nuestros derechos para quebrantarlos. Esa es la historia del caudillaje que los pueblos van ya sacudiendo de sus espaldas. La lección ha sido dura. Los caudillos han perdido ya su fuerza [...]. A cada momento tenemos pruebas importantes del aislamiento en que se hallan los reaccionarios. ${ }^{247}$

${ }^{246}$ Éstos son los títulos de los editoriales de de noviembre y diciembre: "La cuestión electoral", "Las próximas elecciones I, II, III, IV, V, VI, VII, VIII, IX, X, XI" (sobre la lista del partido de El Río de la Plata, que postula como diputados a Mariano Acosta, Vicente G. Quesada, Manuel Argerich, Emilio de Alvear, Octavio Garrigós y Rufino Varela), "Política internacional, Nuestras aspiraciones" (se extiende sobre lo que considera "la verdadera democracia"), "Política internacional - Falsas teorías", "Los jueces de paz", "Las próximas elecciones XII", "La lucha electoral-Las malas influencias", "La lucha electoral-El vacío", "La lucha electoral-Unificación y fuerza", "La lucha electoral- La lista secreta" (otra enfática nota contra Mitre), "Los candidatos independientes", "El último recurso" (acerca de los "reaccionarios" que se refugian en los viejos partidos para seguir polarizando a la sociedad), "El Club de los Libres" (programa de libertad a favor del hombre de la campaña y del pueblo), "Las estocadas al viento", "El último recurso", "La protesta de los reaccionarios", "El sofisma de los partidos", "La representación del pueblo", "El Dr. Quesada y el general Mitre-Correspondencia inédita", "El triunfo de los principios", "Programa y hechos-El sistema de la calumnia", "Elementos en acción-La lucha electoral", "El falso programa", "La bandera de la oligarquía", "La libre opinión", "El peligro de la división", "Las causas de la guerra-La luz se hace" (sobre la guerra del Paraguay), "La guerra y la alianza-El velo se descorre", "La guerra y la alianza-Los sofismas del general Mitre", "La fuerza de la verdad", "La guerra y la alianza-El general Mitre en derrota", "Al general D. Bartolomé Mitre", "La neutralidad de Mitre-Las municiones del parque", "La política oriental", "La verdadera cuestión", "Nuestro credo republicano", "El carácter de la guerra", "Política internacional-Las repúblicas del Pacífico", "El pueblo y los gobiernos-La guardia nacional".

${ }^{247}$ El Río de la Plata, Buenos Aires, 4 de diciembre de 1869. 
Pero el blanco de sus críticas sigue siendo Mitre y su intento por perpetuar el poder de su círculo personal. Hernández sigue insistiendo en la necesidad de superar ese personalismo que lo muestra como un "caudillo" más y este enfoque dominará la mayor parte de los artículos del año siguiente.

El 4 de enero de 1870, en "La nueva política", pasa revista de los acontecimientos de año anterior, y aunque la Guerra del Paraguay no se considera formalmente finalizada hasta el $1^{\circ}$ de marzo (con la muerte de Solano López), habla ya de su "feliz conclusión" y analiza la alianza con el Brasil, que considera "inmoral y subversiva" y la responsabilidad de Mitre. La valoración del período analizado se completa en "La nueva política II" en donde insiste en la necesidad de una política renovadora:

Vendrá a hacer estéril el trabajo de los demagogos y a cerrar para siempre en el libro de nuestra historia la página consagrada a los caudillos, azote de los pueblos del Plata, que es tiempo ya de dejar abandonados a la miseria de su impotencia. ${ }^{248}$

\subsection{La despedida de El Río de la Plata: de la oposición crítica a la revolución}

${ }^{248}$ El Río de la Plata, Buenos Aires, 6 de enero de 1870.

Los restantes editoriales de enero y los de febrero tratan los siguientes temas: "La política trascendental" (una semblanza irónica del desempeño de Mitre como gerente de La Nación argentina), Las grandes reformas", "Los jueces de paz", "La política trascendental-El inventario del general Mitre" (Mitre propone desde su periódico hacer inventarios en el Palacio gubernamental para demostrar que él fue austero, y Hernández comenta que al pueblo no le afectan detalles triviales), "Un presidente-Un ex presidente", "Reformas necesarias" (en contra del gobernador Castro que no ha hecho nada por la provincia de Buenos Aires), "Revista para el exterior", "Las grandes reformas", "Partidos electorales-La ciudad y la campaña", "Los gobiernos electores-La verdadera reforma", "Política internacional-América y España", "La república y la monarquía", "Las elecciones de marzo", "Las reformas" (se trata de noticias provinciales sobre la renovación administrativa, judicial, etc), "La bandera de las reformas", "La emancipación de Cuba", "Al comercio del litoral" (sobre las aduanas), "Nuestro comercio con los Estados Unidos I, II, III, IV, V", "Abolición del servicio de fronteras", "Revista política para el exterior", "Los argentinos en la República Oriental", "Estadísticas de aduanas", "La lucha de marzo", "La necesidad de la unión" (artículo en procura de combatir el círculo personal de Mitre), "La elección de los jueces de paz", "La unión es la fuerza" (propuesta de una estrategia para vencer a Mitre en la próxima elección), "La República en el exterior", "La reforma de la Administración Justicia", "Los paños calientes del tribunal de Justicia", "La República Argentina y los Estados Unidos", "La Administración de Justicia", "Caducidad legal y notoria del personal de nuestros tribunales", "Segundo acto del drama judiciario-Castro y Malaver en la picota", "Las reformas reclamadas-El gobernador Castro", "Prédica peligrosa", "Las reformas y el gobernador Castro", "La Convención ad hoc", "Injurias graves" (reacción ante opiniones publicadas en el Standard y en Le Courrier), "Insultos nacionales". 
En los dos últimos dos meses del diario -marzo y abril de 1870-, se persiste en las críticas a Mitre y en las propuestas del proyecto alternativo con el que El Río de la Plata intenta desactivar la política de círculo. Hay también referencias a la muerte de Solano López en Cerro Corá y un significativo artículo sobre Alberdi firmado por Eusebio Ocampo. ${ }^{249}$ La nota "El Dr. Juan Bautista Alberdi”, además de trazar una semblanza elogiosa y comentar la posibilidad de que sea elegido senador por Tucumán (cuyo pueblo debiera recibirlo "a tambor batiente"), aporta un nuevo testimonio de la actitud conciliatoria con Sarmiento que viene exhibiendo el diario. Ocampo opina que el Presidente debería recibir y aceptar a Alberdi -aunque haya hecho apreciaciones sobre la Guerra del Paraguay (que el articulista asume no conocer exhaustivamente) que le hayan disgustado-, porque "el publicista argentino" que escribió "on ne tue point les idées en las paredes del calabozo que dejaba" [...], "debe dar una lección de tolerancia" y aceptar el nombramiento. También continúa discurriendo sobre el problema de la seguridad de la frontera. ${ }^{250}$

En abril, el diario comienza haciendo un significativo agradecimiento al pueblo porteño que lo ha venido acompañando en sus preocupaciones sobre la frontera, los jueces de paz y los demás temas que Hernández encaró repetidas veces y que tomaron forma en las listas de su partido político. ${ }^{251}$ A continuación, se dedica a promover a los candidatos para integrar la Convención Reformadora que se reuniría ese año en Santa Fe (entre los cuales figura el propio Hernández).

El 17 de abril, llega la noticia del asesinato de Urquiza: ha llegado con ella el principio del fin para El Río de la Plata. Hernández se manifiesta sobre la "horrible noticia" en términos condenatorios, y sostiene que López Jordán -a quien conoce bienno pudo haber sido el instigador del crimen ("nos resistimos a creer en su participación") y asegura que, por el contrario, él se encargará de juzgar a los asesinos.

${ }^{249}$ El Río de la Plata, Buenos Aires, 27 de febrero de 1870.

${ }^{250}$ Éstos son los títulos de los editoriales de marzo: "Una palabra a Le Courrier", "La Convención", "Convocatoria de la Convención", "Del Uruguay al Paraná", "López", "La prensa y la muerte de López", "La muerte de López", "La política brasilera", "La Convención I, II, III", "El pueblo redimido", "Acuerdo de opiniones", "Seguridad de la frontera I, II, III", "La Convención y la prensa", "La reforma y el gobernador Castro", "Vida nueva" (acerca de la importancia de consagrarse al bien público: reformas administrativas necesarias en el ámbito de la justicia, la educación, la industria y el comercio), "Reforma económica".

${ }^{251}$ Éstos son los títulos de los editoriales de abril: "Una palabra de agradecimiento al pueblo", "Reforma económica II, III, IV, V, VI y VII", "Al pueblo de la Provincia I, II y III", "Lista de convencionales", "Los sucesos de Entre Ríos-El gobierno nacional". 
Insiste en que ésta es "una crisis peligrosa para la nación" y que espera del gobierno nacional "toda la prudencia, todo el tino, circunspección y mesura necesarias para disipar esos mismos peligros". Reclama sobriedad, patriotismo sano y prudencia porque la política estrecha "será la ruina de todos".

El 19 de abril, consagra un editorial al análisis de los detalles que enmarcan la muerte de Urquiza (en el que transcribirá documentos oficiales y correspondencia esclarecedora), cuyo título -esta vez, en letras mayúsculas-, destaca el asesinato de los hijos del general:

\section{SUCESOS DE ENTRE RIOS. MUERTE DE WALDINO Y JUSTO C. DE URQUIZA. DETALLES IMPORTANTES SOBRE TODO EL MOVIMIENTO REVOLUCIONARIO}

Pero, la suerte ya estaba echada, y al día siguiente, 20 de abril, Hernández declara en su editorial (titulado "La intervención en Entre Ríos-El pequeño Paraguay") que deplora la decisión de invadir Entre Ríos tomada por Sarmiento. El 21 de abril publica "El Comité Electoral" - la lista de candidatos a convencionales-; pero a continuación, insiste en su posición: subraya que ya se pronunció públicamente en contra de la muerte de Urquiza, pero que también rechaza la intervención armada nacional porque provocará un nuevo derramamiento de sangre para la República y volverá a polarizar el conflicto entre los dos partidos de dominantes. Sostiene, a su vez, que en definitiva sólo servirá a los intereses del Brasil.

El 22 de abril, en un suelto titulado "Última palabra de El Río de la Plata", comunica la drástica decisión de clausurar su redacción (que se extendió hasta el número 207):

Hijos de Buenos Aires, de este pueblo de donde fructifican todas las inspiraciones generosas, hemos estudiado con calma, en una peregrinación de muchos años, las ideas, los sentimientos, y los intereses de los demás pueblos argentinos, y ellos como Buenos Aires se inspiran en el deseo ardiente de la paz, del orden, del progreso, de la libertad, del derecho, de la justicia y del trabajo.

No hemos aprendido a cortejar en sus extravíos, ni a los partidos, ni a los gobiernos, y antes que hacernos una violencia a que no se somete la independencia y 
rectitud de nuestro carácter preferimos dejar de la mano la pluma que hemos consagrado exclusivamente al servicio de las legítimas conveniencias de la patria. Dejamos de escribir el día en que no podemos servirla. ${ }^{252}$

Para iniciar un nuevo período de rebelión: se incorporará a las filas jordanistas, participará en la batalla de Ñaembé y acompañará a Ricardo López Jordán al destierro, corolado por la llamativa decisión de Sarmiento de poner precio a las cabezas de los revolucionarios, de acuerdo con las costumbres de los Estados Unidos.

El opositor crítico empeñado en contemporizar con los adversarios termina por tomar el camino de la revolución. Pero regresará del exilio en Rio Grande do Sul en 1872, en virtud de un pacto político no documentado, y privado de la posibilidad de expresarse por medio del diarismo, se valdrá de otras armas: en el Hotel Argentino de Buenos Aires comenzará a escribir El gaucho Martín Fierro.

Entre tanto, el proceso de resemantización de la antinomia "civilización versus barbarie" -comenzado en el exilio paranaense y continuado en su provincia natal- ha recorrido en la escritura de José Hernández un camino con idas y vueltas agitado por las tensiones que conmocionaron su vida política.

\subsubsection{El nacimiento de la firma en el periodismo de José Hernández}

Hemos apartado una cuestión puntual en el examen de la práctica periodística de Hernández porque la firma del autor garantiza una ligazón con la "fuente de enunciación" y es, de ese modo, presencia y escritura. ${ }^{253}$ En la vida de un escritor, significa ante todo investirse a sí mismo como el autor de lo escrito y de la propia

${ }^{252}$ Continúa "Última palabra de El Río de la Plata": "No queremos asistir en la prensa al espectáculo de sangre que va a darse a la República. Partidarios ardientes de la paz y del progreso, hemos pedido al gobierno nacional, en nombre de los más altos intereses públicos, una política que teniendo por base la ley, salvara a los pueblos del cataclismo que los amenaza. En presencia del cadáver ensangrentado del general Urquiza que crea para la república una situación peligrosa y difícil, pusimos decididamente nuestros esfuerzos al servicio de la paz, para que una provincia abundante, fuerte y rica, que es para la República la vanguardia contra el imperio, no se viera convertida en teatro de guerra y desolación. Nuestra palabra cayó en el vacío. El primer paso ha sido dado y hoy no hay brazo suficientemente robusto que pueda contener el curso de los acontecimientos que van a sacudir a la República [...]. Nuestra última palabra al pueblo, es la expresión sincera de nuestro agradecimiento por la cooperación con que nos ha ayudado de una manera que obligará para siempre nuestra gratitud" (El Río de la Plata, Buenos Aires, 22 de abril de 1870).

${ }^{253}$ Jacques Derrida ha reflexionado agudamente sobre la relación de los actos de habla con la escritura (Derrida, 1971). 
firma, una zona de la escritura que se acerca más que ninguna otra a los "actos de habla". ${ }^{254}$ Por otra parte, también esta cuestión se vertebra -al igual que 2.3.1. y 2.3.2.en torno de un eje temático: la resemantización de la antinomia "civilización versus barbarie".

Varios investigadores han atribuido la autoría de Hernández a artículos periodísticos y a versos gauchipolíticos ${ }^{255}$ que no están firmados con las iniciales "J. H." sino por una serie de seudónimos: "Juan Barriales", 256 "Polilla", 257 "el payador José Pepe", 258 "Un Patagón",259 (todos ellos, registrados por los diccionarios de seudónimos argentinos), 260 "Vincha", 261 "Fulgencio". 262

Esta serie de seudónimos se ubica en una etapa de su vida signada por la lucha política. No incluimos en esta consideración seudónimos utilizados fuera del período histórico que contextualiza nuestro estudio (1852-1875). Después de esta época, sólo puede hablarse de seudónimos festivos; uno de ellos -registrado por la mayoría de sus biógrafos- fue "Martín Fierro"; así firmó, el 20 de agosto de 1878, una carta de tono humorístico dirigida a Juan Manuel Blanes cuando su cuadro "El juramento de los treinta y tres orientales" fue exhibido en Buenos Aires. ${ }^{263}$

\footnotetext{
${ }^{254}$ Austin, 1971.

255 Las composiciones gauchipolíticas firmadas con seudónimos también circularon en periódicos.

${ }^{256}$ Seudónimo que -según argumenta Fermín Chávez- emplea José Hernández para firmar dos cielitos que se publican en El Nacional Argentino de Paraná, el 20 y 28 de abril de 1859 (Chávez, 1859, pp. 27-56). Ver 2.1.2.2.

${ }^{257}$ Vicente Osvaldo Cutolo -en su Diccionario de alfónimos y seudónimos- asegura que con este seudónimo Hernández publicó artículos en La Patria de Montevideo (1873), desde cuyas columnas continuó con sus ataques a la política de Mitre y Sarmiento; afirma, también, que lo empleó en la prensa bonaerense (Cutolo, 1962). No obstante, no hemos podido constatar ningún ejemplo (por otra parte, no hemos podido acceder a la colección completa de La Patria de Montevideo).

${ }^{258}$ Los diccionarios consultados lo incluyen en la serie de seudónimos de Hernández, pero no citan fuentes ni identifican los medios en los que habría circulado. Podría ser una deformación de "Pepe Lata", uno de los motes que sus amigos habían adjudicado a José Hernández a causa de su locuacidad, pero tampoco en este caso hemos podido constatar su empleo.

${ }^{259}$ Hernández firma así las nueve cartas que escribe en La Patria de Montevideo, en 1874. Ver 5.1 .

${ }^{260}$ Los diccionarios de seudónimos consultados se citan en la Bibliografía general (ver 8.3.).

${ }^{261}$ Auza, 1978.

${ }^{262}$ Chávez, 1973.

${ }^{263}$ Para determinar los restantes seudónimos, habría que rastrear las colaboraciones que se le atribuyen en el periódico satírico, político y literario El Bicho Colorado, para el cual colaboró en 1876.
} 
Hemos podido observar entonces, que todos los seudónimos que se atribuyen a Hernández en este período (unos documentados, otros apenas postulados como posibles) pertenecen al campo semántico de la "barbarie". Esta adscripción es muy evidente en "Vincha" - el potente emblema de la vida salvaje con el que firma incursiones primigenias en el diarismo- y “Un Patagón”, que emergen desde el llano en momentos de debilidad política, pero paralelamente, concentran su voluntad combativa. Y con respecto a dos seudónimos para los que no hemos encontrado documentación probatoria, como "Polilla" y "José Pepe", podría decirse que tanto el poder destructivo de esa larva como el anonimato de una suerte de "Juan Pérez" (cuya ausencia de señales de "distinción" es lo opuesto a "elite") son términos que de algún modo se sitúan también en las antípodas del polo positivo "civilización", tal como lo emblematiza Sarmiento (frac, conocimientos, educación). ${ }^{264}$

En cuanto a "Fulgencio", el seudónimo con que se firma una composición gauchipolítica en El Río de la Plata, ${ }^{265}$ podría evocar a Fulgencio Yegros (1780-1821), considerado el Padre de la Patria en el Paraguay. En un medio periodístico que ha asumido desde su aparición una abierta crítica a la Guerra de la Triple Alianza, esta alusión se ubicaría también dentro del campo de la "barbarie": en el clima enfervorizado que el poder gubernamental había logrado crear en Buenos Aires para acompañar la contienda (al menos, durante los primeros años), el panteón de los próceres del Paraguay se ubicaba automáticamente en ese lugar.

\subsubsection{1. "Vincha", un seudónimo significativo}

José Hernández se inició en el diarismo valiéndose del seudónimo "Vincha" cuando, ya emigrado a Paraná, colaboraba desde allí en el último período en que pudo seguir publicándose en Buenos Aires La Reforma Pacífica. Ese lapso fue breve pero

\footnotetext{
${ }^{264}$ Por otra parte, contrastan con la opción "bárbara" de Hernández gran parte de los seudónimos ya empleados por Sarmiento: "El Director de la Escuela Normal" (1842), "El autor de Civilización y Barbarie" (1850), "El autor de Argirópolis" (1851); todos ellos se inscriben, ostensiblemente, en el campo semántico de la "civilización" (Cutolo, 1962).

265 El $1^{\circ}$ de septiembre de 1869, El Río de la Plata publica una epístola en versos gauchipolíticos (firmada "Fulgencio") contra el caudillo santiagueño Manuel Taboada, y según Fermín Chávez, Hernández sería el autor de esos versos (Chávez, 1973, p. 17).
} 
suficiente como para instalar su lugar de enunciación en la escena política y en el ámbito periodístico. ${ }^{266}$

Néstor Tomás Auza fue el primer investigador que sostuvo que José Hernández había usado el seudónimo "Vincha" para firmar colaboraciones en La Reforma Pacífica -en calidad de "corresponsal” en Paraná- desde el 13 de febrero de 1860, y que volvió a emplearlo en El Nacional Argentino, desde el 22 de septiembre de ese año -en el interregno que se produce luego de la renuncia de su anterior editor, Juan Francisco Seguí- hasta que aparece su firma completa el 11 de octubre de ese año cuando se hace cargo formalmente de la redacción del periódico orgánico de la Confederación. ${ }^{267}$ Posteriormente, Valeria Tetti descubrió artículos firmados por Vincha intercalados entre los que relevó Auza; este hallazgo adelanta la aparición de esa firma de Hernández en La Reforma Pacífica al 18 de enero de $1860 .{ }^{268}$ Dice Auza:

Algunos autores han señalado la iniciación periodística de José Hernández en las páginas de La Reforma Pacífica, pero ninguno, que sepamos, ha llegado a identificar los artículos que le pertenecían. [...] Nuestra compulsa al diario nos ha permitido arrojar un poco de luz sobre los pasos iniciales de Hernández en el periódico chupandino de Buenos Aires.

[...] Las colaboraciones de Hernández fueron enviadas en calidad de corresponsal, y con ese enfoque redactaba sus escritos, que se publicaron firmados con el seudónimo de Vincha. [...] Precisamente, la mayor parte de sus escritos como corresponsal están datados en esa ciudad litoral, cuyos sucesos y acontecimientos políticos describe para el diario porteño. ${ }^{269}$

\footnotetext{
${ }^{266}$ Ver 2.3.2.1.

${ }^{267}$ Auza, 1978. Sin descartar una posible colaboración en la Reforma Pacífica ni participaciones anteriores sin su firma en El Nacional Argentino, tanto Beatriz Bosch (1950, pp. 16-18; 1963, pp. 12-13) como Zorraquín Becú (1972, pp. 48 y 71, nota al pie ${ }^{\circ} 3$ ) sólo habían considerado documentada la iniciación de Hernández en el diarismo en el momento en que asume la dirección de ese periódico de Paraná en octubre de 1860 (para Bosch esa fecha está atestiguada por la primera nota con su firma, el 11 de octubre, en tanto que Zorraquín considera que su incorporación se produce el 19 de septiembre, a partir de la renuncia de Seguí a la dirección del diario).

${ }^{268}$ Valeria Tetti -integrante del equipo de la Fundación Hernandarias que prepara las Obras Completas de Hernández bajo la dirección de Ángel Núñez- descubrió la presencia de otros nueve artículos firmados por Vincha intercalados entre los quince que relevó Auza.

${ }^{269}$ Auza, 1978, pp. 168-169.
} 
Rastreando la participación de Hernández en El Nacional Argentino de Paraná, descubre que la aparición del seudónimo se produce unos días después de la irrupción de una redacción anónima a partir de la intempestiva renuncia de Juan Francisco Seguí. Considera que, a partir del 19 de septiembre, se advierte la presencia de "una mano firme y segura" al frente El Nacional Argentino, hasta que el 22 de septiembre, en el lugar destinado al editorial se publica un "Comunicado" firmado por Vincha. Y Auza concluye:

Sin dudas aquellos artículos oficiaban de editoriales y retomaban la tradición del periódico de adoptar su propia posición ante los sucesos, mas incluían una novedad, cual era el uso del seudónimo para amparar la verdadera personalidad del redactor. ¿Quién era, en este caso, ese anónimo redactor? [...] Este artículo, como otros, llevaba el seudónimo de "Vincha" y quien lo usaba era nada menos que el luego célebre poeta y escritor José Hernández. [...] No cabía duda de que "Vincha" no era otro que el futuro autor del Martín Fierro, haciendo entonces su experiencia de ministerial y periodista. ${ }^{270}$

Esta aseveración se funda en palabras del propio Hernández en dos artículos en los que reconoce que ha estado usando un seudónimo pero que dejará de hacerlo. Antes de presentarse con nombre y apellido el 11 de octubre, una nota del 30 de septiembre, firmada por Vincha anuncia:

Concluiremos por hoy asegurando a "alguien" que no es con la mira poco digna de eludir la responsabilidad de nuestras propias opiniones que usamos de un seudónimo, sino porque él nos pertenece desde mucho tiempo y no tenemos por qué dejarlo; y porque las verdades tienen siempre su valor, lleven o no al pie la firma de quien las dice. $^{271}$

La referencia a un uso reiterado del seudónimo ("nos pertenece hace mucho tiempo") remite a sus colaboraciones para La Reforma Pacífica desde comienzos de 1860. Auza destaca la escasa vinculación con los sucesos del interior nacional que había venido poniendo de manifiesto el diario de Calvo y Soto desde el momento de su

${ }^{270}$ Auza, 1978, pp. 120-121.

${ }^{271}$ El Nacional Argentino, Paraná, 30 de septiembre de 1860. 
creación. El aporte de Hernández vendría a marcar, entonces, el ensanchamiento de una óptica exclusivamente porteña; de allí que la sección "Correspondencia de las provincias", firmada con el seudónimo "Vincha" -aunque no muy extensa- resultaría significativa por incorporar la mirada del interior.

Después de transcribir el primer artículo firmado con su propio nombre el $11 \mathrm{de}$ octubre en La Reforma Pacífica -en donde comunica el abandono de la firma con seudónimo-, Auza reseña quince notas de la La Reforma Pacífica del mismo año firmadas por Vincha: la primera del 13 de febrero, y la última, del 12 de enero de 1861 (es decir, que el uso del seudónimo intersecta durante unos meses estas colaboraciones con artículos publicados en la El Nacional Argentino). ${ }^{272}$

Por otra parte, Auza cree que una investigación que atendiera a rasgos temáticos y discursivos podría rastrear en ese diario colaboraciones de Hernández publicadas sin firma, en las que con el mismo tono apasionado se apunta siempre implacablemente contra el círculo porteño concentrando las críticas en las figuras de Mitre y Sarmiento. ${ }^{273}$ Por otra parte, así lo confirma este suelto insertado en "Correspondencia de las provincias":

VINCHA. Tal es el seudónimo de uno de los nuestros más activos, laboriosos e ilustrados corresponsales de las provincias. Ya hemos publicado antes correspondencias del Sr. Vincha que lo han hecho conocer ventajosamente, en adelante bastará ver su nombre al pie de un escrito para que los lectores se detengan con gusto a recorrer las páginas trazadas por su pluma. Estamos ciertos que ninguno de nuestros colegas podrá presentar un extracto tan fiel y tan minucioso de la sesión del 6 como el que publicamos a continuación debido a la infatigable laboriosidad de Vincha. ${ }^{274}$

El seudónimo "Vincha" -que los responsables de La Reforma Pacífica se sintieron obligados a justificar con razones- es la exhibición de un símbolo de la barbarie, y como gesto escritural, es tan potente como ese vibrante comienzo del alegato

\footnotetext{
${ }^{272}$ Auza incorpora en el Apéndice de su libro los quince textos firmados por Vincha que relevó en La Reforma Pacífica.

${ }^{273}$ Incluso, Hernández podría haber comenzado a colaborar sin firma con el diario chupandino en Buenos Aires -antes de emigrar a Paraná y transformarse en "corresponsal"-, ya que se incorporó al partido federal reformista en 1856, año de la fundación de La Reforma Pacífica. ${ }^{274}$ La Reforma Pacífica, Buenos Aires, 18 de febrero de 1860 (citado por Auza, 1978, p. 169).
} 
de Hernández ante la muerte del Chacho en 1863: "Los salvajes unitarios están de fiesta" (un acto de habla de la "barbarie" que el propio Hernández suprimió en su reformulación de la biografía en 1875, pero cuya recuperación por parte de adversarios políticos seguía lastimando doce años después). ${ }^{275}$

\subsubsection{El presente de la firma}

Después de haber puesto en práctica una estrategia eficaz para construir un proyecto de firma que remitiera a un sujeto ajeno al campo de la "civilización", el propio José Hernández anuncia el 11 de octubre de 1860, en El Nacional Argentino de Paraná, que ha decidido desechar el empleo de un seudónimo y que en adelante firmará con las iniciales de su nombre y su apellido (“J. H."):

Dicho esto, nos importa hacer conocer también que por una condición propia de nuestro carácter, no hemos firmado nuestros artículos, pero no porque hayamos pretendido esquivar la responsabilidad de nuestra opiniones; porque si bien tenemos la conciencia de la pureza de nuestro patriotismo y de la elevación de nuestros sentimientos, la tenemos también de la humildad de nuestros conocimientos y, más que todo, de nuestra posición; y aun cuando la tenemos y muy grande de que el afianzamiento de la ley importa la salvación del país, no hemos querido poner nuestro humilde nombre al pie de nuestros artículos, porque él no iba a dar prestigio alguno a nuestras palabras. Pero de hoy en más lo haremos para probar así que somos personalmente responsables de cuanto escribimos. ${ }^{276}$

En este significativo artículo José Hernández redefine su comienzo escritural y su archivo, estableciendo un corte con su pasado; a partir de este momento, entonces, se irá gestando su condición de sujeto de procesos de escritura, de "autor". ${ }^{277} \mathrm{Se}$ autocaracteriza como "pluma política" y lo rubrica con una firma autorizada, legítima y legitimante de la oposición al proyecto liberal tal como se lo está gestando en Buenos

\footnotetext{
${ }^{275}$ Ver 5.2.

${ }^{276}$ El Nacional Argentino, Paraná, 11 de octubre de 1860. $6^{\circ}$ época, año IX, n ${ }^{\circ} 1343$, p. 3, cols. 1, 2 y 3. Se cita la trascripción de Beatriz Bosch (1963, pp. 53-58).

${ }^{277}$ Dice Roland Barthes: "Cuando se cree en el Autor, éste se concibe siempre como el pasado de su propio libro: el libro y el autor se sitúan por sí mismos en una misma línea, distribuida en un antes y un después: se supone que el Autor es el que nutre al libro, es decir, que existe antes que él, que piensa, sufre y vive para él, mantiene con su obra la misma relación de antecedente que un padre respecto a su hijo" (Barthes, 1987, p. 48).
} 
Aires. Su firma nace de la pulsión de "probar así que somos personalmente responsables de cuanto escribimos", ${ }^{278}$ y aunque afecte un tono de modestia (una "débil voz"), exhibe la fuerza de una "manifestación franca" de "la juventud de hoy" que viene a superar a los "partidos que murieron" para pelear por la integridad nacional. En suma, "J. H." va a suscribir una programática que propugna la superación de las antinomias irreductibles y la regeneración de la política nacional, y esa programática coincide con la de los federales reformistas ("Por eso es que, hablando con nosotros mismos y emitiendo nuestro propio juicio, dijimos y decimos que La Reforma Pacífica era la expresión de una grande idea"), y afirma del vehículo de difusión de las propuestas de ese partido (en el que continúa escribiendo colaboraciones) que es "el órgano más resuelto de la nacionalidad argentina". 279

A su vez, con un gesto típico del romanticismo social, prefigura la futura alianza con la voz del gaucho cuando fundamenta la autoridad de su firma en el apoyo del "Pueblo" a quien dice representar. Se ha erigido así como un portavoz escritural del vulgo, y el día anterior (cuando ya había anunciado que abandonaría su seudónimo), había manifestado en un artículo titulado "El pueblo y el escritor":

Hemos creído siempre, y nos ratificamos en ello, que el Pueblo es la fuente más pura, y en la que únicamente deben inspirarse los periodistas. ${ }^{280}$

De este modo, el nacimiento de la firma del joven periodista de 26 años se funda en un pasado anónimo que, sin embargo, se ofrece ya como una garantía de experiencia que comenzará a construir, paulatinamente, la figura de "el Autor José Hernández", que se caracteriza por ser un "publicista popular", una imagen que resemantiza la antinomia “civilización versus barbarie", ya que sus adversarios juzgan el "publicismo" como una actividad privativa del campo positivo de la oposición irreductible.

${ }^{278}$ Cuando dos años más tarde polemice en El Litoral de Paraná con un tal Aramís que lo difama desde La Patria de Montevideo, le exige la "responsabilidad" de la identificación: le reclama que firme con su nombre y su apellido (ver 2.3.2.3.1.).

${ }^{279}$ Manuel Gálvez opinaba que, en caso de probarse la colaboración de Hernández en La Reforma Pacífica, allí "habría entonces comenzado la enemistad política entre los dos más grandes escritores argentinos" (Gálvez, 1945, p. 82). Y sin duda, desde sus comienzos en el periodismo, Hernández se manifestó como contrincante acérrimo de Sarmiento y de su interpretación de la realidad nacional.

${ }^{280}$ El Nacional Argentino, Paraná, 10 de octubre de 1860. $6^{\circ}$ época, año IX, n ${ }^{\circ}$ 1342, p. 2, cols. 2 y 3 . 
La Reforma Pacífica -opuesta a la secesión de Buenos Aires sin dejar de ser porteña- se había erigido en busca de una solución que conciliara los intereses de las dos grandes facciones enfrentadas; no obstante, el análisis de la trayectoria de Hernández en el diarismo -que culmina en con la fundación de El Río de la Plata-, lo mostrará debatiéndose constantemente entre la pasión combativa de Vincha y la recurrencia del tema de la necesidad de buscar una "conciliación". Sin embargo, en 1870 todavía no había llegado la hora de resolver esa contradicción fundamental, y el periodista moderado que escribe los editoriales de El Río de la Plata cerrará su diario para sumarse a las filas rebeldes de López Jordán.

El objeto de esta tesis es una producción escritural que sólo desde 1872 hasta 1875 se intersecta con la del autor de El gaucho Martín Fierro, y se está trabajando aquí -fundamentalmente- con un corpus de escritura del Hernández político y publicista (cuya obra escrita permanece, sin embargo, en gran parte inédita y en parte sin haber sido objeto de una edición crítica). No obstante, puede afirmarse que no sólo en el recorrido escritural del período estudiado (desde el debut periodístico hasta El Río de la Plata) y en el itinerario textual de las biografías del Chacho que encara Hernández, ${ }^{281}$ sino también en el proceso creativo de El gaucho Martín Fierro y La vuelta de Martín Fierro, ${ }^{282}$ palpita esa suerte de tensión fundamental entre la pulsión de rebelión y el deseo de conciliar posiciones enfrentadas.

\footnotetext{
${ }^{281}$ Ver Ortale, 2005, y en este estudio, 4.3.

${ }^{282}$ Ver Lois, 2001a, pp. XXXIII-CXVI.
} 


\section{SARMIENTO CONTRAATACA CON SU VIDA DEL CHACHO}

\subsection{La actuación de Sarmiento en la "nueva atmósfera" de Buenos Aires}

Con la revolución del 11 de septiembre de 1852, la escisión de Buenos Aires marca el comienzo de una nueva etapa en la historia política del país. Los antiguos exiliados pasarán ahora a ejercer el gobierno, pero lo harán sobre la base de una alianza con el poder económico de la etapa rosista: los enemigos de ayer confluyen para defender los privilegios de la provincia más rica del país. Se vuelve a los enfrentamientos polarizados y se crea un clima que José Luis Romero describe en estos términos:

La revolución porteñista sacudió a la ciudad en septiembre, y el sitio de Lagos acentuó la inquietud: fue una época vibrante, en la que los porteños sintieron reverdecer su viejo jacobinismo y se sintieron los defensores de la ciudadela liberal contra el país bárbaro. En Buenos Aires, la rivalidad entre porteños y provincianos creó unos enconos que durarían largo tiempo, y que todavía en la década del sesenta descubriría Miguel Cané entre los alumnos del Colegio Nacional, tal como lo refirió en Juvenilia. ${ }^{1}$

Buenos Aires se aísla, se reconcentra, está segura de que es imperioso para el país que una reorganización contundente haga tabla rasa del arraigado régimen caudillista y que esto sólo se podrá lograr en razón de asumir medidas ejemplarizadoras. Importantes cambios sociales son acompañados por un clima de fanatismo que conlleva numerosas injusticias y una vez más se genera la persecución de los contrarios -tildados ahora de mazorqueros- imponiéndoseles el exilio a conocidas y respetadas familias porteñas, clausurándose órganos periodísticos, dominando las cámaras legislativas por medio de elecciones fraudulentas; se consolida así el predominio de una facción que mantendrá a la provincia alejada de la Confederación desde el 11 de septiembre de 1852 hasta que la batalla de Pavón imponga en 1861 la unificación del país bajo la hegemonía de Buenos Aires.

\footnotetext{
${ }^{1}$ Romero, 1983, I, p. 309.
} 
Este recrudecimiento de la polarización política y social se ve reflejado en una reposición lingüística de lemas y anatemas como el de "mazorqueros y mártires", "unitarios y federales", “civilizados y bárbaros", “caudillos y políticos liberales". La sociedad intenta dar cuenta de una nueva realidad reactualizando un lenguaje impregnado de una fuerza connotativa tan intensa, que todavía se siente apropiado para una coyuntura en la que aún subsisten las guerras civiles y no se ve la solución de sus conflictos ni la posibilidad de un Estado consolidado. Como sostiene Maristella Svampa, la propuesta que se desprende del Facundo de Sarmiento se convierte en una “ideología de legitimación". 2

En este contexto, el discurso que acompaña este proceso encontrará fórmulas acordes con las líneas políticas e ideológicas que defiende cada bando. Urquiza había intentado prescribir de las polarizaciones ("Ni vencedores ni vencidos", "partidos nuevos"); pero los secesionistas, suscribiendo la conceptualización antinómica, actualizarán en diversas manifestaciones lingüísticas una posición intransigente que sólo ofrece optar entre la imposición absoluta de su propuesta o la guerra. En esta línea, frente a la figura del "caudillo", el poder político de Buenos Aires propone otro modelo social: un político culto y progresista, amigo de las leyes, de la educación, del orden, de la administración y de la paz, ambición que también se refleja en el discurso propagandístico que encara un proceso de "pacificación del interior" y de "organización nacional".

En esta nueva atmósfera renace el periodismo, que a la vez constituye una vía de acceso para reconstruirla. La nueva etapa histórica abierta por la batalla de Caseros

\footnotetext{
2 Aquí explica: "La importancia del momento que atravesaba la república no puede ser subestimada. En efecto, luego de 1852, aún más después de 1861, un actor de la sociedad argentina se apodera de la Historia. Toda clase social que gobierna sin concurso de la providencia requiere legitimar su poder, y la fórmula más usada para ello ha sido la de arrogarse la gestión del progreso en nombre de ciertos valores de Civilización cuyo monopolio ella detentaría. Obviamente que aquella ideología de legitimación que se esgrimirá como fundamento del poder debe imponer una creencia, si no compartida por todos, al menos expandida en gran parte del cuerpo social. Tal era la creencia en el progreso, y su encarnación conflictiva en la realidad social argentina era el dilema expuesto por Sarmiento. En líneas generales, es posible afirmar que en todas partes el Estado fue construido en función de un discurso del orden y orientado por una voluntad de transformación social y de progreso general. Hasta aquí el Facundo no tiene nada de especial. Pero a eso hay que agregar que la fórmula del Facundo fue una de las temáticas fundadoras en la Argentina. Más aún lo que otorga un lugar importante al Facundo es que la fórmula no sólo legitima el poder sino que es a la vez (a partir de 1845) el principio por el cual se lo va a tomar" (Svampa, 1994, p. 43).
} 
marca un hito en el desarrollo del periodismo nacional, ya que el ansia de disfrutar de la libertad de prensa se proyectó en la aparición de una enorme cantidad de órganos de opinión. Este fenómeno es verdaderamente llamativo en la ciudad de Buenos Aires, donde se descubre que desde 1852 a 1861 se fundaron (con distintas situaciones de intersección) de entre 30 y 60 publicaciones nuevas por año, lo que demuestra que la prensa era considerada un medio de civilización y el periodista un nuevo poder en el proceso de interpretación y circulación de ideas en la sociedad. ${ }^{3}$ Desde su triste autoexilio en Chile, Sarmiento estaba ansioso por participar en esta suerte de paraíso del periodismo de opinión y es fácil comprender que en su correspondencia con Mitre de 1854 describa una situación de "angustia". 4

Por otro lado, la tarea de hacer un diario se había transformado en una "empresa fácil" porque coexistían periodistas políticos que podían prescindir de un salario junto con mano de obra (a veces, muy calificada) que las diferentes facciones políticas estaban dispuestas a subvencionar. ${ }^{5}$ En este marco, inmediatamente después de Caseros proliferaron nuevos órganos de prensa en todo el país.

En abril de 1852 comenzó a editarse en Buenos Aires El Progreso, periódico oficial que se proponía difundir las actividades del Director Provisorio de la Confederación. Poco después, Mitre fundó Los Debates, con el fin de fijar su postura en defensa de los intereses porteños frente al proyecto de Urquiza y desde allí comenzó a replicar irónicamente a El Progreso. ${ }^{6}$ Luego del 11 de septiembre, el diario reaparece en las filas separatistas, con José M. Saborido como redactor, empezando por polemizar con Federico de la Barra, que en El Federal Argentino escribía a favor del sitio de Buenos Aires.

Entre las nuevas publicaciones, se destacaron periódicos de gran tirada y algunos de prolongada permanencia, como El Nacional, de Vélez Sarsfield -que, fundado en 1852, habría de durar medio siglo-, La Tribuna, de los Varela -editado desde 1853 y también de larga vida-, y El Orden, creado en 1855 por Félix Frías. Todos eran

\footnotetext{
${ }^{3}$ Luna, 1983, I, p. 362. Luna toma este dato de la Historia de la Nación Argentina de Guillermo Furlong.

${ }^{4}$ Campobassi, 1975, I, p. 422.

${ }^{5}$ Luna, 1983, I, p. 368.

${ }^{6}$ Esto le valió el cierre del periódico en julio y un breve exilio en Montevideo. Retornó el 14 de septiembre y fue designado Ministro de Gobierno.
} 
portavoces y megáfonos de los “oradores" que pugnaban por representar -con matices diversos- los intereses de la provincia convertida en Estado autónomo. ${ }^{7}$

Mientras tanto, también en la Confederación se procuraba combatir contra ese poderío periodístico. En Paraná, su flamante capital, se crea La Voz del Pueblo (1852), como continuador de El Iris Argentino (1851-1852), que tiene como programa trabajar para la unidad nacional e "ilustrar al pueblo en sus derechos y marcarle sus deberes" aunque sin redactores conocidos. ${ }^{8}$ También El Nacional Argentino (1852) pretende servir a la política organizativa de Urquiza con el lema: "Alrededor del Director Provisorio está el pensamiento argentino". Este periódico, fundado por Juan María Gutiérrez, contará entre sus redactores a Eusebio Ocampo (1855), Alfredo M. Du Graty (1855), E. de Alvear, Benjamín Victorica y L. Cáceres (1856), Lucio V. Mansilla (1857-1858), Francisco Bilbao (1859) y Juan Francisco Seguí (1859); en 1860, año de su cierre definitivo, se había incorporado como redactor José Hernández.

Desde fines del siglo XVIII, el desarrollo del periodismo político irá instituyendo la consolidación de "un nuevo poder". 9 En una etapa compleja de la historia de nuestro país, ante una profunda crisis social, política, institucional y económica que conoció dos gobiernos paralelos, dos constituciones, dos legislaturas, dos sistemas judiciales, todos estos órganos creados a partir de la caída de Rosas se disputarán -como dice Barthes- "el lenguaje de la nación". ${ }^{10}$ Los medios gráficos funcionaron como conductores y aglutinadores de ideas, y las polémicas entre ellos emblematizan esta lucha de lenguajes en la que todos se disputan el poder de la palabra porque comprenden que detrás de ella se esconde el poder político que logrará la unión definitiva del país.

\subsubsection{Matices dentro del periodismo porteño}

\footnotetext{
${ }^{7}$ Ibidem, p. 368.

${ }^{8}$ Auza, 1978, p. 29.

9 José Acosta Montoro desarrolla el concepto del periodismo como nuevo poder: "Durante toda la era capitalista clásica, del siglo XVI al XIX, los propietarios indiscutibles del idioma fueron los escritores. Poco a poco fue produciéndose la llegada de otros hombres a la posesión del lenguaje, gracias precisamente a la comunicación. En Francia, a partir de la revolución, el escritor no es el único que habla. Surgen hombres que se apropian del lenguaje del escritor con fines políticos. Después, en todas partes, cunde el ejemplo" (Montoro, 1973, p. 78).

${ }^{10}$ Barthes, 1967, p. 63.
} 
La retórica de la mayor parte de los periódicos de Buenos Aires coincidía en la presentación de una imagen: la ciudad ofreciéndose en calidad de mártir en sacrificio a la nacionalidad: "libre o mártir". Es ilustrativa, a este respecto, la descripción de estos órganos que da B.Vicuña Mackenna en su viaje por el Buenos Aires de 1855, en donde se ve al abanico ideológico que va, desde órganos que propugnan la ruptura definitiva hasta los que se acercarán a la visión mesiánica de la provincia. Así detalla $\mathrm{V}$. Mackenna:

Los principales diarios de la prensa de Buenos Aires son: La Tribuna, El Nacional, La Crónica y El Orden. No cuentan menos de 4.500 suscriptores (de los que 3.000 pertenecen a los dos primeros y 1.500 a los últimos) y cada uno representa, en graduación sucesiva, los diferentes matices de la opinión liberal que hoy impera absoluta en Buenos Aires. Todo lo que no es liberal es mazorquero y, por consiguiente, prohibido, lo que no puede ser de otro modo en los tiempos de celosa rehabilitación que corren sobre el país. Así, La Tribuna, redactada por los hijos de Florencio Varela, es el diario ultra-liberal de Buenos Aires y estaba por eso en oposición al gobierno, el que poco antes había tenido la imprudencia de cerrar la imprenta, que una masa de indignado pueblo vino luego a abrir a despecho de la autoridad. El Nacional es liberal puramente. La Crónica, que es el diario oficial, redactado por el señor Tejedor, es liberal moderado, y El Orden es todavía liberal, pero eminentemente religioso. ${ }^{11}$

A pesar, sin embargo, del abanico de matices que describe el chileno, ninguno de estos periódicos reconocerá el gran logro de Urquiza, sino que se despreciará la Constitución del 53 como una "constitución de caudillaje" y se considerará a todo lo que se vincula con la vida y los hombres de Paraná como el símbolo del atraso y la rusticidad colonial, mirando con soberbia a las provincias, que desde este enfoque no son más que "trece ranchos" frente a una urbe en acelerada renovación modernista y europea. $^{12}$

Pero este rompimiento rotundo con el interior amenazaba seriamente la integridad nacional. Los porteños que percibieron esta amenaza se movilizaron para

\footnotetext{
${ }^{11}$ Vicuña Mackenna, 1936, p. 49.

${ }^{12}$ Se trata de una expresión de Nicolás Anchorena citada en Mayer, 1963, p. 471.
} 
propugnar la incorporación de la provincia al resto del país y se creó una nueva fuerza: el Partido Reformista de Nicolás Antonio Calvo y Juan José Soto.

\subsubsection{Sarmiento llega a Buenos Aires}

Sarmiento sigue atentamente los movimientos de Buenos Aires desde su autoexilio en Chile luego de su rompimiento con Urquiza, pero desea fervientemente incorporarse a la lucha encarnizada de ideas que se vive entre Buenos Aires y la Confederación. A pesar de que no es partidario de la separación propugnada por Adolfo Alsina, toma la decisión de incorporarse a la vida porteña que lo recibe el 4 de agosto de 1855, no sin cierta suspicacia.

En su correspondencia con su amigo de toda la vida, José Posse - con quien se escribe desde 1845 hasta el año de su muerte en 1888-, describe Sarmiento su delicada posición frente al ofrecimiento que se le hace de la diputación nacional por Tucumán; Sarmiento sopesa sus posibilidades: o "embarcarse en el cascarón de la Confederación”, en donde Benavídez, Lucero y demás "son restablecidos en sus situaciones antiguas de caudillos", o incorporarse a Buenos Aires y proyectar allí su programática acerca de la educación. Esta decisión le merece "mucha meditación” y siente la necesidad de hablar con sus "amigos de Buenos Aires". ${ }^{13}$

${ }^{13}$ Carta de Sarmiento a Posse, Rosario, 30 de abril de 1855:

Dire algo sobre mi diputacion que aun no acepto, hasta mas adelante. Ya habia pasado la Cordillera cuando he recibido el bienvenido nombramiento, lo que te probará que traya propósitos anteriores i estraños a este incidente. Era mi animo propender a la reincorporación de Buenos Aires, por una transacción en que quedase garantida la libertad de aquel pueblo, que es la nuestra. Verdad es que los ministros, en cuanto ministros se ríen de la palabra libertad que huele a demagojia pura. Con tu perdon pues, yo creo en la libertad. Tengo todo motivo para creer que en nada se piensa por ahora, i un reciente escrito de tu paisano Alberdi te lo probará. Ahora pues yo vacilo embarcarme en el cascaron de la Confederacion, i aceptar voluntariamente las obligaciones personales que impone la constitución, sin esponerme a ser llamado al orden espulsado como Ferré, declarado traidor anulado i pisoteado por mayorías oficiales. En el camino hablé con Frías, mi concolega, i ya puede juzgar de lo que puedo prometerme. Por otra parte, San Juan permanece tiranizada, i a pretestos de Jefes de departamentos militares, Benavídez, Lucero son restablecidos en sus situaciones antiguas de caudillos. De estas razones i de otras que tu sagacidad descubrirá queda de manifiesto que al aceptar la Diputacion de Tucuman acepto todos los vinculos que ligan al gobierno i a la constitucion, entrando lisa y llanamente en el gremio de los que reconocen i sostienen tales instituciones. Semejante paso requiere mucha meditación, i no lo daré sino después de haber hablado con mis amigos de Buenos Aires, pues no quiero abandonar su causa sin motivo, i sin justificacion.

Añadase esto, que terminadas las sesiones del Congreso no me queda un palmo de terreno en donde pararme en la Confederacion, pues no puedo volver a San Juan, que está en manos del enemigo. Añadase también que la cuestion de San Juan no ha recibido solucion todavía i necesito defenderla con toda la libertad que me da mi actual situación independiente. Si en Buenos Aires puedo hacer algo por la educación pública tendré un terreno neutro en que 
Una vez decidido por la capital portuaria, Sarmiento viajará a Buenos Aires, donde quien se ocupa de hacerle una recepción pública es Mitre, a través del periódico El Nacional. A pesar de este apoyo, se le hace difícil al sanjuanino labrarse una posición en esa ciudad tan hostil al interior, tan reconcentrada en sí misma. El círculo porteño sospecha sus ambiciones políticas y teme poner en riesgo sus intereses. Como hombre de provincias no despierta interés y el sanjuanino pasará un duro trance en la convulsionada ciudad. Su famoso lema describe esta situación: "Porteño en las provincias, provinciano en Buenos Aires, argentino en todas partes"; pero en esta coyuntura histórica no es prudente publicitarlo. ${ }^{14} \mathrm{Su}$ desafío mayor consiste en que, por un lado, para ganarse su entrada en la política del círculo del poder deberá probar su porteñismo, entendido como la lucha con el "bárbaro", el caudillo y el atraso cifrados en el interior del país, de donde justamente proviene. Y, por otro, proyectar su figura hacia el resto del país, consciente de que la nacionalidad no puede pensarse sin Buenos Aires y viceversa.

Sarmiento no sólo no apoya el separatismo a ultranza, sino que en su correspondencia con Mitre lo alerta sobre el temor de la disolución nacional. Sin embargo, ve en Buenos Aires la posibilidad de cumplir todos sus sueños, de ejecutar todas sus ideas, liberado el camino de "la rémora de los caudillos"; así inicia en 1855 un proceso de inserción política en el pequeño mundo porteño para luego candidatearse a nivel nacional desde su gobernación en San Juan y contar con el apoyo de su importante poder político. Ya tiene claros los pasos inmediatos y los siguientes: actuar en el periodismo político y actuar como mediador entre Buenos Aires y los hombres de pensamiento afín que habitan las provincias. En carta a Posse del 14 de julio del 55, expone su estrategia inmediata: ante la posibilidad de incorporarse a la redacción de $E l$

asilarme, siendo tan util a la Confederacion como a B.A. i siguiendo una de las empresas a que he consagrado mi vida. Quiero desprenderme del todo de Chile, i traer a mi familia, i para hacerlo tu comprendes que no debo dejar mi porvenir librado a los azares de una posicion fluctuante, sin base, sin país especial, i tu sabes que he huido de aceptar situaciones tales. Edición en línea: www.proyectosarmiento.com.ar Se respetan las grafías originales.

14 En carta a Mitre del 23 de octubre de 1852 ya aparecía este lema. También en carta a Modestito Pizarro del 15 de noviembre de 1852, en una especie de epígrafe en verso: "La paz y el libre congreso / Provinciano en Buenos Aires / En las provincias porteño / argentino en todas partes". Edición en línea: www.proyectosarmiento.com.ar 
Nacional, ya piensa en dedicarse a incrementar la cantidad de suscriptores en las provincias para extender la prédica política que comparte con figuras del poder. ${ }^{15}$

\subsubsection{Sarmiento, nuevo redactor de El Nacional}

Es su biógrafo más destacado, José Campobassi, quien explica en detalle cómo se le da esta oportunidad única a Sarmiento:

Más importante para su carrera política fue la designación con que se lo favoreció a mediados de 1855, el 14 de julio de ese año, para que dirigiera el diario $E l$ Nacional, que era el más importante de la ciudad de Buenos Aires y de la República. El nombramiento se hizo para cubrir la vacante dejada por Mitre, nombrado entonces ministro bonaerense de guerra y marina. Sarmiento recibió el cargo de manos de éste, como una antorcha encendida, según dijo en ocasión de asumir su puesto, que conservó durante varios años. [..] De tal modo, el sanjuanino desplegó en El Nacional una actividad extraordinaria, sea como director o como autor de centenares de artículos. Muchos incluyeron su firma; los más fueron anónimos; y algunos, del año 1855, llevaron al pie el seudónimo "Plubius". Desde ese año hasta 1861, en que se alejó de Buenos Aires, no hubo asunto de interés público, general o local, que no considerara desde las columnas del diario. ${ }^{16}$

Desde estas columnas, el Sarmiento periodista intentará persuadir a los porteños duros de que él apoya la causa de Buenos Aires y a su vez buscará consolidar su proyección nacional, para lo cual se ocupará con singular dedicación de las actividades de los caudillos del interior, particularmente de los que se vinculan con la zona de Cuyo y de los llanos riojanos: Benavídez, Virasoro, el Chacho. Apoyará a los candidatos liberales de San Juan, en artículos para los que contará con la amistad decidida de Aberastain, y combatirá a sus enemigos políticos, los caudillos federales.

\footnotetext{
${ }^{15}$ (Carta de Sarmiento a Posse: www.proyectosarmiento.com.ar)

Buenos Aires, 14 de julio de 1855:

Estan en el gobierno Alsina y Mitre, y puedo yo estar en la prensa luego, si encuentro en las provincias un contrapeso con que equilibrar la tiranía que la opinión ejerce aquí sobre todo diario que se atreva a ver con otros ojos que los suyos las cuestiones arjentinas. Para poder intentarlo el Nacional, necesitaríase una fuerte suscripcion en las Provincias, y esto es lo que solicito en esta, y en la adjunta que tu rotularás a quien convenga. Espero que Tucuman, la culta Tucuman, comprenda sus intereses.

${ }^{16}$ Campobassi, 1975, p. 437.
} 
No obstante, el sanjuanino aprecia que su situación en la capital portuaria es crítica y que no es sencillo hacerse un lugar allí. Al respecto también le escribirá a su amigo Posse dos cartas más: una del 7 de enero de 1856, en la que le habla de su aún precaria situación como redactor del periódico ("No represento nada. No estoy en la opinión"), y la segunda, del 15 de junio del mismo año, que profundiza la mirada ya desencantada de Sarmiento: descubre la frialdad de los porteños enceguecidos por la fabulosa prosperidad de su ciudad, y la miseria de los entrerrianos, a los que describe viviendo en medio de la anarquía y la expoliación.

Esta carta es un documento que no sólo permite trazar un paralelo entre las dos ciudades desde la óptica de Sarmiento, sino que permite apreciar hasta qué punto él se autoconsideraba el portador de la mirada más perspicaz a la hora de justipreciar la conjunción de estos dos mundos que conformaban la totalidad del país. Se autodescribe como una excepción: un personaje buscado como el portavoz del conflicto que se convierte luego, inevitablemente, "en el pato de la boda" por tener la virtud "de ver un poco más claro". Sin embargo, esta excepcionalidad no es apreciada en su verdadero valor en Buenos Aires, donde siente con humillación que lo estiman como a cualquier otro, que nadie le presta especial atención ni se preocupa por sus opiniones:

Estoi bien, saludo a todos, me saludan, me agazajan se complacen de que venga a habitar en este país. Si les digo que son unos malvados hallan mucha razon i me ofrecen un habano. En seguida se habla de la Biscachianti, de Portela, del precio de las onzas. $^{17}$

\footnotetext{
${ }^{17}$ (Cartas de Sarmiento a Posse: www.proyectosarmiento.com.ar . Se respeta la grafìa original) Buenos Aires, 7 de enero del 56:

Mi situacion es la mas precaria. No represento nada. No estoy con la opinion ni me atrevo a contrariarla porque al día siguiente no tendría un suscriptor. Diez de Tucuman el pueblo amigo, te daran la medida del apoyo que la prensa encuentra alla para hacer frente a la impopularidad aquí. Otra vez te escribiré mas.

Buenos Aires, 15 de junio de 1856:

Desencantado de todo, de Buenos Aires, como del Parana, cada uno quisiera tenerme de su lado para maldecir al otro, siendo yo en todo ello el pato de la boda, por tener la desgracia de ver un poco mas claro. Aquí hai egoístas ignorantes; allá malvados sapientísimos; aqui anarquía i desgobierno, alla miseria, i espoliacion. Unos cuantos hombres candorosos, i algunos pueblos bisoños, creen que las fuerzas de un hombre, que la palabra lanzada en una Camara sin ecos pueden enderezar, situacion que está montada en un abismo de contradicciones inconciliables. No hablemos de Buenos Ayes. Nada hai que esperar de él, precisamente porque todo lo tiene, sino es intelijencia, i prevision. Que podéis esperar de un pueblo que sin gobierno, sin prensa util, sin administracion, sin ejercito casi, emprende a la vez la construccion de un muelle, un camino de hierro, un alumbrado de gas, una aduana, varios templos, diez leguas de empedrado;
} 
Sarmiento se muestra aquí como un agudo observador de la transformación profunda que empieza a darse en la ciudad colonial que será retratada con maestría por Lucio V. López ${ }^{18}$ en el momento en que se aprecie ya su rumbo hacia la modernización cosmopolita.

Por otro lado, la complejidad política de Buenos Aires (separada de la Confederación pero a la vez subdividida entre separatistas acérrimos los - "pandilleros" - y los que deseaban integrar las provincias a una República cuya cabeza debería ser Buenos Aires -los chupandinos-) obliga a Sarmiento a extremar su esquema, a polarizarlo aún más, y a su vez a ampliar sus categorizaciones haciendo entrar en ellas a actores impensados; así, llega a enfrentarse con casi todos, valiéndose de una eficacia lingüística que impacta por lo excesiva. Es también Vicuña Mackenna quien da una opinión personal muy ilustrativa:

El señor Sarmiento redacta El Nacional, y el excelente y timorato don Félix Frías dirige El Orden, y ya por supuesto cada uno de estos diarios tienen su calificación aparte y su bandera hostil, y El Orden llama demagoga a La Tribuna, y ésta ultramontano al "Padre Frías". El Nacional se mide con todos, porque ¿con quién no estará en perpetua lucha el gran guerrero argentino, teniente coronel del Ejército

1500 edificios particulares; i que dobla las entradas de aduana; tiene doce millones de depositos de particulares en el banco; i recibe tres mil emigrantes por mes que ganan 12 reales plata diarios, i los trabajos se suspenden por falta de brazos? Qué vas a decirle de provincias, nacion, Urquiza, i puterías, a quien tiene a la Ida i a la Biscachianti en la Opera luchando, con dobles entradas, a la compañía española i a la Hispano americana en el drama, i a mas de dos clubs una filarmonica, i exhibiciones de la Sociedad de Beneficencia, i comunion de los enfermos del Hospital a donde concurren por millares las señoras a derramar lágrimas de contento i de entusiasmo? Qué contarle de miserias a un pueblo que amenazado por los indios, que le arrebatan cien mil cabezas de ganado de un golpe, i deja que un complot de ajiotistas compre doscientas mil onzas de oro, las sustraiga del mercado i las haga subir de 335 a 367 en quince días i bajar a 350 de ayer a hoi? Que lucha por voltear a Portela1 que vale tanto como . . como vos . . . i se burla de la opinion amotinada i las cosas marchan bien, mal, peor, pero marchan? Vas a hablarle a este pueblo de Urquiza, el Congreso; i todas esas majaderías? Yo estoi aquí como en mi casa en Chile; estimado de todos como estiman a cualquier otro. Mas sensacion hizo mi presencia en el Morro i en el Rio IV que aqui. Estoi bien, saludo a todos, me saludan, me agazajan se complacen de que venga a habitar en este país. Si les digo que son unos malvados hallan mucha razon i me ofrecen un habano. En seguida se habla de la Biscachianti, de Portela, del precio de las onzas. Hasta de los indios se habla algunas veces; pero de Urquiza, de vos, i de la Confederacion nunca, o pocas veces; pues la conversacion cae, con este comienzo: "Con Urquiza nada puede hacerse". Hablo con Gorostiaga, con Huerguito, con todos los confederales, i arribamos a esto "Con Buenos Aires nada puede arreglarse; es de balde" - i aquí me tienes a todos 1os políticos parados, empeñados en hallar siempre la razon de su lado.

${ }^{18}$ Lucio V. López publicará La gran aldea en 1884. 
Grande, caballero de la orden militar de la Rosa del Brasil, Don Domingo Faustino Sarmiento ${ }^{19}$

La crítica ha coincidido en considerar esta etapa de la vida de Sarmiento su flanco más débil. Aquí discute con muchos porteños que gozan de estima; su conocido exabrupto con Cané (padre) y todos los excesos que distinguirán sus escritos en este caldeado período de la política nacional le permitirán ganarse el mote de "el loco Sarmiento". Con el correr de los años, se arrepentirá de sus excesos y logrará obtener algún perdón, pero muchos enfrentamientos no serán superados jamás.

Si bien la correspondencia íntima -tanto la que mantiene con su amigo Posse y la que intercambia con Mitre- marca una importante diferencia entre lo que opina verdaderamente cuando propone estrategias para enfrentar al reducto caudillista y lo que publica en sus editoriales de El Nacional, abandona ese pudor cuando celebra públicamente la muerte del Chacho (1863). Ya entre los contemporáneos despertará los repudios que conservará la posteridad, pero en esa coyuntura histórica, más que su posición misma, lo que se censura es la enunciación: es el haberlo dicho públicamente, lo que se le critica.

En la guerra periodística del momento, se enfrentan dos medios antagónicos y complementarios a la vez: desde Buenos Aires El Nacional. Órgano de la Política, Comercio y Lliteratura de la República Argentina, que dirige Sarmiento, y desde Paraná, el confederado El Nacional Argentino. Ambos se yerguen desde su parcialidad facciosa con la ilusión de ser la Nación y representarla en su conjunto.

Dentro de la provincia de Buenos Aires, Sarmiento combatirá también, sucesivamente, con otros frentes de batalla: con La Reforma Pacífica de Nicolás A. Calvo, con El Orden de Féliz Frías y Luis L. Domínguez, con La Revista del Nuevo Mundo de Francisco Bilbao, y se enfrentará en torno a la causa del caudillismo, haciendo blanco en Urquiza, y en torno al proceso de reorganización nacional que propone el nuevo partido liberal, que empieza a abrirse un camino que culminará cuando Mitre -un protector inicial que no tardará en mirarlo con recelo- se imponga en Pavón y llegue a la presidencia al año siguiente; después, ya llegará el turno de la suya propia.

${ }^{19}$ Vicuña Mackenna, 1936, p. 50. 


\subsubsection{Polémicas periodísticas en torno al tema del caudillismo}

En este profuso marco de innumerables periódicos e innumerables facciones en que la sociedad argentina se encuentra dividida, todos coinciden en elegir al caudillismo como el fenómeno sobre el cual discutir y pelearse. Ésta sigue siendo la piedra angular: para los liberales porque aún el país no se ha despojado de esa rémora, ese atraso. Los detractores, porque ven en Sarmiento y en Mitre nuevos caudillos, y siguiendo a Alberdi, una "barbarie ilustrada", el triunfo del personalismo y de la facción. De este modo, la suerte de los caudillos del interior que quedaban afectos a Rosas y los que se habían acercado a Urquiza mantiene los ánimos pendientes de toda la sociedad, unos para defenderlos del atropello y otros para intentar superarlos definitivamente.

Sarmiento entiende que esto es así y empleará su periódico para, una vez más, dominar el terreno a través de la imposición de su lenguaje y hará una clara selección para jerarquizar la información que le interesa ofrecer. Además de usar el órgano para diseminar sus planes de progreso material y educativo y para describir el paulatino crecimiento de la ciudad, elegirá narrar todos los hechos que se vinculen con el fenómeno del caudillismo, organizando con efectividad su discurso como un punto orientador. Para ello dará preferencia a los sucesos que atañen a Benavídez, Virasoro y el Chacho, rubricándolos con su firma, como si ésta actuara como un sello de garantía, de marca de propiedad. De este modo, cuando describe a los caudillos, los vuelve a significar en los términos de su antigua dicotomía, sólo que ya como protagonistas de un modelo perimido, en franca extinción, en lucha desigual con el progreso que se impone al final de la historia nacional. ${ }^{20}$ Por otro lado, conservará el interés de establecerse como modelo contrincante. En sus aartìculos, el "otro" sigue siendo el caudillo, y él, el civilizador, en un propósito político cada vez más claro y palpable. ${ }^{21}$

\footnotetext{
${ }^{20}$ En este sentido es ilustrativo el cierre de la biografía del Chacho de Sarmiento que se analizará más adelante en donde Sarmiento compara a los caudillos con los dinosaurios, figura retomada a su vez en los artículos de La Tribuna de 1875.

${ }^{21}$ Esto ya se hacía claramente personal y expreso en su Campaña en el Ejército Grande, donde Sarmiento se plantea como el civilizador que arrastra la imprenta aún cuando Urquiza decide no cargarla más, que se viste con todos los detalles del uniforme europeo y que lleva mapa cartográfico. Este periodista que escribía desde el exilio en contra de Rosas, hablará ahora en persona con Urquiza, aunque éste no le permita formar parte de su cuartel general, y luego de constatar su barbarie se autoexiliará para refugiarse más tarde en Buenos Aires desde donde iniciará su plan de acción contra los caudillos que quedan, contra los últimos, plan del que participará, ahora sí, como "Director de guerra". Podría analizarse incluso en una graduación en
} 
Sarmiento comprende que con "civilización" puede ahora recortar a los protagonistas porteños que quieren imponer su poder, sus normas de vida y de cultura al resto del país, porque ha llegado el momento de obtener frutos de su tesis, tiene el dominio político para hacerlo y lo aprovecha. Sabe que se encuentra en una nueva instancia de su carrera pública que la sociedad portuaria le ha ofrecido y sacará ventajas de ello.

Por su lado, la oposición se tomará el trabajo de señalar las contradicciones de los liberales que propugnan un modelo teórico, pero que en su metodología actúan del mismo modo que el más violento de los caudillos federales. Como ya se ha analizado en el apartado 2, Calvo, Bilbao, Carriego y Hernández denunciarán los métodos de la "barbarie ilustrada" y a los "caudillos de la oligarquía", siguiendo la línea trazada por Alberdi desde su polémica chilena con Sarmiento y señalando la otredad en el propio Sarmiento.

\subsubsection{El discurso de Sarmiento en El Nacional de Buenos Aires}

En la tapa del periódico consultado a partir del $1^{\circ}$ de enero de 1855 , no aparece el nombre de ningún redactor, de lo que se entiende que todavía es Mitre quien sigue a cargo, siendo que más adelante se hallará un suelto que felicita con profusión la llegada de Sarmiento a Buenos Aires. No obstante, antes de que Sarmiento se vincule concretamente con el periódico se observa una línea común de enfrentamiento con las figuras del interior. El 5 de mayo se encuentra una nota referida a Aldao que demuestra el tenor del periódico que expresa con ironía: "Ni bien vuelvan los Quirogas... le daremos nuestro voto para que se ponga a la cabeza de todos los pillos". ${ }^{2}$

En este marco, la aparición de Sarmiento no se hará esperar. El 8 de mayo sale un apartado titulado "El Sr. Sarmiento" que le da una cálida recibida a este "distinguido publicista, que tantos servicios ha prestado a la causa de la civilización" y Mitre propone al gobierno provincial que lo nombre en la administración general de correos, a pesar de las suspicacias que despierta su llegada para los hombres del círculo porteño. ${ }^{23}$

aumento del modo en que Sarmiento involucra hasta su propio cuerpo en la pelea contra la "barbarie", hasta el episodio del Chacho.

${ }^{22}$ El Nacional, Buenos Aires, 5 de mayo de 1855.

23 "El Sr. Sarmiento", El Nacional, Buenos Aires, 8 de mayo de 1855, año IV, n 905.

Este distinguido publicista argentino que tantos servicios ha prestado a la causa de la civilización, ha venido a hospedarse entre nosotros, y aún cuando antes de ahora hemos tenido el 
Mientras tanto el órgano se ocupa en señalar los avances de la educación popular en Buenos Aires y de quejarse por la inoperancia de Obligado, sin olvidarse de fustigar contra la facción de los reformistas; se presentan con ironía las leyes "hermosas y atrevidas [...] casi es decir que son quimeras" propuestas en el congreso por Nicolás A. Calvo a quien se lo define con sorna como "el socialista, el Prudhom del Senado". Sin embargo, hasta el fin de junio no se halla ninguna firma de Sarmiento. ${ }^{24}$

Hasta este mes la tapa del periódico, como ya se explicó, no contiene ninguna información respecto de directores o redactores. Tampoco en la sección editorial se aprecia ninguna firma que la encabece, por lo que queda sujeto a la posibilidad de análisis e interpretación de los temas, la autoría de las mismas. De hecho, el problema de la firma y de la adjudicación de los artículos es bastante compleja, incluso para el propio Sarmiento quien se quejará repetidas veces, durante toda su gestión al frente del periódico, del personalismo de sus polemistas cuando insisten en referirse al "Sr. Sarmiento", en lugar de referirse a El Nacional como sería de su agrado. Estas evasivas resultan verdaderamente curiosas dentro del espíritu combativo frontal que ha ostentado siempre Sarmiento, pero se volverán a observar en la polémica de La Tribuna y La Libertad de 1875, en donde será Hernández quien insistirá en apelar a su nombre, según veremos en el apartado 5.

Sin embargo, algunos meses más adelante Sarmiento sí se decide a estampar sus iniciales o su nombre completo. La primera firma que se encuentra y esto no es de extrañar, corona un artículo titulado “Acusación del general Benavídez”, del 9 de septiembre. Allí se dedica a describir la historia de las vicisitudes de San Juan y el heroísmo cívico de la mayoría de sus vecinos, denunciando que la política del gobierno

honor de dirigirle nuestra bienvenida, queremos llamar la atención pública sobre el partido que la autoridad puede sacar de la venida accidental de una persona utilísima en la administración bajo tantos respectos. No se inquieten los ministros vitalicios [...] que no tenemos la pretensión de presentarles un candidato para Ministro de Gobierno [...]. Pero en la falta casi absoluta que tenemos de hombres para encomendarles [...] y en la obligación de no desaprovechar esos hombres, [...] creemos que el Gobierno está en el deber imprescindible de atraerse una persona conspicua y altamente necesaria que pueda dar un impulso vigoroso a una de las tantas ruedas de la administración [...] Por ejemplo la administración general de correos.

${ }^{24}$ La colección que se ha consultado en la hemeroteca de la Biblioteca de la Universidad Nacional de La Plata, lleva en este segundo tomo de 1855 (julio-diciembre) una hoja inicial en blanco, que tiene escrito en tipografía grande, en mitad de la hoja: El Nacional. Redactores D. Domingo F. Sarmiento D. Palemón Huergo. Julio a Diciembre 1855. Es una hoja suelta, del mismo tamaño que el periódico y parecería que de la misma calidad de papel. La tapa del periódico, como ya se explicó, no contiene ninguna información respecto de directores o redactores y tampoco la sección editorial tiene alguna firma que la encabece. 
de la Confederación ha contribuido a mantener el estado de malestar que "persiste en creer que los antiguos caudillos ejercen influencia sobre los pueblos, y pueden prestar apoyo a la Constitución". Según Sarmiento, debido a esta ilusión han impuesto a Benavídez, al que los ciudadanos honestos de San Juan desaprueban. ${ }^{25}$ Con esta firma, Sarmiento ofrece un importante sostén a su provincia.

Luego se continúan las editoriales sin firmar, de diversos temas, pero la atención sobre San Juan se sostiene. El 17 de octubre aparece: "Situación actual de la provincia de San Juan", el 18 de octubre la editorial se ocupa nuevamente de Benavídez y el 25 del mismo mes se editorializa sobre las "Nuevas tentativas del sistema de caudillos". También hay editoriales que versan sobre otros aspectos claves para la cultura de círculo como los conceptos de "nacionalidad” y "provincialismo". El 28 de noviembre, concretamente se tratará sobre la "nacionalidad argentina" polemizando explícitamente con su gemelo de Paraná. ${ }^{26}$

Para el año siguiente, las temáticas preferidas de Sarmiento se multiplican. Continuarán las referencias a San Juan comentando que "Benavídez está caído, anulado, por los coroneles que él creó por docenas" y en nota titulada "La Revolución de Santa Fe y los caudillos" se destaca de nuevo la bella prosa del sanjuanino que expresa ahora poéticamente su viejo dilema:

La triste experiencia de 4 años ha mostrado [...] la imposibilidad de esa monstruosa amalgama entre la libertad y el arbitrario, entre la responsabilidad administrativa y la explotación del gobierno como negocio, que es la cualidad distintiva del caudillo. [...] es imposible la liga del caudillo y la constitución. Tres años han luchado por incorporar elementos que se rechazan. El caudillo ha quedado caudillo, y la constitución hojarasca que no cubre ya el feo tronco del árbol. ${ }^{27}$

El 16 de agosto de 1856, por primera vez, Sarmiento asume públicamente su función de redactor de El Nacional y firma la editorial con sus iniciales, D.F.S. Aquí se exculpa de las acusaciones que se le dirigen al diario a propósito del folletín inserto

\footnotetext{
${ }^{25}$ El Nacional, Buenos Aires, 9 de septiembre de 1855, año IV, $\mathrm{n}^{\circ} 1008$.

${ }^{26}$ El Nacional, Buenos Aires, 28 de noviembre de 1855, año IV, $\mathrm{n}^{\circ} 1070$.

${ }^{27}$ El Nacional, Buenos Aires, 9 de agosto de 1856, año V, n ${ }^{\circ} 1267$.
} 
porque éste pudiese afectar su reputación; se está ya en un plano más personal, más íntimo:

La persona que escribe en este diario como redactor, lo hace desde su casa, no va a la imprenta sino rara vez, no se mezcla en sus asuntos, ni ve el diario sino en la noche cuando se recoge a su casa, o por accidente en casa de sus amigos. ${ }^{28}$

Esto muestra un grado mayor de vinculación con su público lector, a quien puede referirle cuestiones más domésticas, puesto que, evidentemente, los lectores tienen la posibilidad de verificarlo en la vida ya más conocida que lleva Sarmiento en la capital portuaria, y esta familiaridad es casi como un guiño de complicidad para los porteños.

También se conoce a través de las editoriales que Sarmiento recibe de los vecinos de Chivilcoy una quinta cultivada que acepta públicamente mediante el periódico, el 20 de agosto. Claramente este hecho funcionará como una prueba de proyección política hacia el Interior; en Chivilcoy Sarmiento hace los primeros ensayos de su carrera presidencial y con este mismo propósito irá incorporando a El Nacional muchos otros artículos que le servirán para difundir su popularidad, "las muestras de consideración" y "otros actos de distinción con que ha sido públicamente favorecido en estos días". También salen notas que se refieren a la calurosa defensa que le hace B. Vicuña Mackenna en Chile frente a los ataques opositores, como una manera de mostrarle a los porteños que goza de buena fama.

Se analiza también en este período el estado de La Rioja en razón de los problemas subsistentes con Peñaloza y lo "pinta con colores bien oscuros" transcribiendo que hay "entumecimiento a la par de los vicios [...] y en su alrededor el servilismo, el idiotismo y la inercia". También varias editoriales se dedican a analizar la convivencia entre Buenos Aires y la Confederación: "Cómo se cultiva la paz entre hermanos" y "Paraná y Buenos Aires" muestran los problemas de ambas ciudades y sobre cuál es la situación oficial de Buenos Aires en la Confederación, si es Estado independiente o es provincia rebelde. Y para el 11 de septiembre, como es de esperar,

28 "Acusación de El Nacional", El Nacional, Buenos Aires, 16 de agosto de 1856, año V, n ${ }^{\circ}$ 1271. 
sale la conmemoración de la separación porteña como un renacimiento a la vida civilizada, liberada del caudillismo:

Mañana es el aniversario de las libertades públicas conquistadas por el pueblo y para el pueblo. Desde el once de Septiembre empieza nuestra regeneración política, y el gobierno republicano sin tutores, sin caudillos. ${ }^{29}$

Luego se encuentran dos extensísimas notas que también llevan las iniciales del sanjuanino. Están dirigidas al diputado Esteves Sagui, y se titulan: "Escuelas y Papas”; versan sobre la promesa de transformación social que puede originar la escuela moderna "tal como puede ser en Buenos Aires", que va a civilizar a la población y va a beneficiar a los trabajadores garantizando la superación de los "restos de barbarie, estas apariencias semi-salvajes que son fatales a la sociedad en general y embarazan el progreso". Sarmiento despliega su programa: "La agricultura necesita libros, la guerra necesita de libros, la cría de ganados necesita de libros, la escuela necesita de libros" y se refiere también a la labor "sublime pero humilde" del maestro como "instrumento de producir a la larga maravillosas transformaciones". 30

Estas editoriales se continúan el 26 de septiembre con "Papas y Escuelas" en donde Sarmiento se dedica a contabilizar el ganado del país y transcribe una parte de su Campaña en el Ejército Grande de donde retoma sus viejas ideas:

He aquí las graves cuestiones que quería elucidar durante mi residencia en Buenos Aires, pues que a estas simples bases, que no hago más que extractar, se refieren muchas cuestiones económicas, sociales y políticas que quería elucidar. Políticas nada menos! Las vacas dirigen la política argentina! Qué son Rosas, Quiroga y Urquiza, apacentadores de vacas, nada más. ${ }^{31}$

La nota continúa, pero introduce aquí una llamada al pie de página en donde dice “Campaña en el Ejército Grande, página 187”. Este empleo de la intertextualidad que hace Sarmiento es una estrategia discursiva muy efectiva que permite darle cohesión a

${ }^{29}$ El Nacional, Buenos Aires, 17 de septiembre de 1856, año V, $\mathrm{n}^{\circ} 1295$.

${ }^{30}$ El Nacional de Buenos Aires, 22, 24 y 26 de septiembre de 1856, año V, n ${ }^{\circ} 1310$.

${ }^{31}$ Las últimas dos frases son transcripciones literales de la Campaña en el Ejército Grande. 
su prédica, continuidad y verosimilitud a sus afirmaciones. Sarmiento maneja este recurso con habilidad, cuando además ya había también explicado en su diario sobre Caseros que todos sus textos son capítulos de un mismo libro, ${ }^{32}$ y a su vez son constitutivos de su esencia personal e "indivisible". ${ }^{33}$

Por otro lado, se observa con claridad la vista aguzada de Sarmiento, que como ya se mostró, inicialmente había pensado acercarse a Buenos Aires para realizar tareas en educación, según le confiesa a su amigo Posse "como una de las empresas a que ha dedicado su vida". Este anhelo, si bien no es cumplido aún, en el sentido de que Sarmiento no se encarga todavía de tareas concretas en un ministerio del área, se verá reflejado en muchas notas que recogen el tema de la educación popular, de la modernización de la ortografía, propagandas de gramáticas, y difusión de proyectos pedagógicos para la enseñanza primaria.

\subsubsection{Los últimos caudillos}

La tolerancia de Urquiza con los caudillos que habían apoyado a Rosas, ${ }^{34}$ exasperó particularmente el espíritu de Sarmiento, según se aprecia de la carta a Posse ya citada. Este statu quo que Sarmiento denuncia se tornó insostenible al finalizar la presidencia del entrerriano y empiezan a producirse enfrentamientos que se centran casi exclusivamente en la zona de Cuyo, donde, como se sabe, había nacido y pasado su primera juventud.

El General Benavídez es asesinado el 23 de octubre de 1858; El Nacional y La Tribuna de los Varela, aplauden su muerte, en La Reforma Pacífica Nicolás A. Calvo y Francisco Bilbao protestan de la ironía de que se aplaudan estos hechos "en nombre de la civilización" y que "a los momentos de barbarie" se les otorgue legitimidad. Calvo

\footnotetext{
32 "Si la libertad argentina sucumbe, es decir: si el caudillaje triunfa de nuevo, habré sucumbido yo también con los míos y el mismo polvo cubrirá Civilización y Barbarie, Crónica, Argirópolis, Sud América y Campaña del Ejército Grande, que son sólo capítulos de un mismo libro" (Sarmiento, 1997, p. 306).

${ }^{33}$ Eduardo Mallea opina sobre la vinculación estrecha entre la labor periodística y los libros de Sarmiento: "Sarmiento fue el hombre más indivisible del mundo. El periodista Sarmiento forma tan íntima parte del maestro Sarmiento y del escritor Sarmiento que solo los podemos aislar para estudiarlos [...] Entre sus cuadros periodísticos y sus libros autónomos no hay más que una diferencia de previsión y enfoque. Los elementos capitales de su caudal, los rasgos distintivos de su originalidad y de su poder están tanto en los unos como en los otros" (Mallea, 1988, p. 303).

${ }^{34}$ Manuel Taboada en Santiago del Estero, Celedonio Gutiérrez en Tucumán, Pablo Lucero en San Luis, Nazario Benavídez en San Juan y Manuel Vicente Bustos en La Rioja.
} 
saca un artículo titulado "El álbum sangriento" en el que denuncia los asesinatos como un programa del partido liberal. ${ }^{35}$ Sarmiento, a su vez, publica una carta en $E l$ Nacional, pidiendo cautela hasta que se confirme el hecho, aunque en apoyo de los sanjuaninos lo califica de "notorio malvado". Después de confirmado el hecho, se refiere al asesinato como una "acción santa", publica las ejecuciones que Benavídez autorizó en San Juan y le adjudica la responsabilidad a Del Carril, por no impedir las actividades subversivas del caudillo.

En carta a Mitre del 23 de octubre de 1852 en que Sarmiento festejaba con euforia el triunfo de Caseros, ya mencionaba a Benavídez como el problema más serio que quedaba en el país:

No olviden a San Juan, está preso. Irigoyen ha sido electo diputado, después de haberlo yo sido por aclamación. Benavídez es el único caudillo de Rosas restaurado. Su existencia en el gobierno será el más grave obstáculo a la organización del país. ${ }^{36}$

José Antonio Virasoro, coronel correntino impuesto por Urquiza, es el caudillo que asume luego la gobernación de San Juan. Los liberales lo consideran un gobernador autoritario, sanguinario y cruel y a él se enfrenta el amigo personal de Sarmiento, el Dr. Aberastain. Sus partidarios asesinarán a Virasoro el 20 de noviembre de 1860, durante la presidencia de Derqui y mientras Mitre firma el acuerdo que sella la unión nacional. El 29 de noviembre La Reforma Pacífica, que todavía no tiene la noticia, dice que la muerte de Virasoro ha sido anunciada por El Nacional, y una vez confirmado el suceso, Nicolás A. Calvo publicará una carta de Virasoro que incrimina a Sarmiento como uno

\footnotetext{
${ }^{35}$ La estrategia de la oposición tiene que ver con los conceptos que Larrosa trabaja de Bajtín cuando éste habla de "la transmisión y análisis de los discursos ajenos y de la palabra ajena". Se trata de ver cómo se utiliza el discurso de los otros en el habla propia sometiéndolo a "distintos procesos de modelación y de encuadramiento interpretativo" (Larrosa, 2005, p. 116). Calvo y Bilbao usan el discurso de Sarmiento y lo reponen en un contexto opuesto para reforzar la ironía de lo que intentan denunciar.

${ }^{36}$ En esta carta Sarmiento continúa diciéndole:

Pidan ustedes, pues, que no existan en las ciudades argentinas tropas asalariadas mientras se discute la constitución, que se organice la guardia nacional -que se revoque como írrito, atentatorio, peregrino el restablecimiento de Benavídez en el poder- que todos los otros gobiernos emanados de la elección popular y reconocidos legítimos por Urquiza, lo desconozcan como gobernador, dando por legítimas las autoridades que él derrocó. No se vuelva porteño amigo. Seamos argentinos siempre. Porteños en las provincias, provincianos en Buenos Aires.
} (Carta de Sarmiento a Mitre: www.proyectosarmiento.com.ar) 
de los responsables. Sarmiento lo denuncia en los tribunales y escribe a Posse sobre ello mientras lanza su pequeña y poco conocida biografía El tirano José Virasoro que ha sido analizada en el apartado 1.3.1.1.

\subsubsection{Asesinato del Chacho Peñaloza}

El asesinato de estos dos caudillos, Benavídez y Virasoro, fue tomado por el decaído partido federal como un precedente nefasto del período presidencial que inicia Mitre en 1862. Ya se ha visto cómo se encaró este proceso de la reorganización nacional, entendido desde la óptica liberal como una renovación exclusivista que fue dejando a un lado a los antiguos líderes populares. A este respecto se muestra sin tapujos Sarmiento cuando le recomienda con pasión a Mitre: "Defiendan a cada ciudad, la libertad en todas partes. Matemos el caudillaje; hagámoslo imposible".37

Aunque para 1862 casi todas las provincias estaban ya dominadas por la facción liberal, aún permanecía en La Rioja el caudillo Ángel V. Peñaloza, último reducto del castigado bastión federal que se mostraba rebelde al programa mitrista. Numerosa correspondencia demuestra cómo este general de la Nación pretendía entenderse y recibir órdenes únicamente de Urquiza, que nunca le respondió. No obstante, en un esquivo sistema de montoneras mantenía al ejército nacional en estado de alerta permanente, resistiendo a su autoridad y a la del mismo gobernador de La Rioja, Domingo A. Villafañe, que se había pronunciado por la causa de Mitre. De esta manera, los seguidores de Peñaloza andaban libremente por los Llanos y realizaban invasiones a las provincias vecinas, Catamarca, Tucumán, San Luis y San Juan, generando verdadera alarma entre sus gobernantes, sobre todo en Sarmiento, que se había hecho cargo del ejecutivo de su provincia natal el 9 de enero de 1862.

Desde la perspectiva de Sarmiento, este resabio del caudillismo significaba la más absoluta frustración e impotencia, pues las montoneras dificultaban la concreción de sus planes políticos. Sarmiento acusaba a las huestes del Chacho de todos los impedimentos que debía enfrentar y que retardaban los logros de su ansiada gestión. Como ejemplo patente se encuentra uno de los primeros decretos que emite en su provincia en la que establece la obligatoriedad de asistencia a la escuela de todos los niños sanjuaninos, en el que luego de imponer este nuevo deber a los padres bajo

${ }^{37}$ Carta de Sarmiento a Mitre con motivo de la batalla de Caseros, ya citada. 
supervisión policial, advierte en su documento que "las escuelas se hallaban abandonadas so pretexto de que Peñaloza había invadido la provincia" y que por ello el gobierno debía atacar esta "tendencia a propagar la barbarie" en los campos de batalla. ${ }^{38}$

Toda la correspondencia entre Mitre y Sarmiento, muy copiosa en este período, sirve para ilustrar que sufre a Peñaloza como una permanente amenaza para sus planes civilizadores, puesto que lo que él consigue con enormes esfuerzos, la montonera lo deshace en un día; por ello las invasiones de Peñaloza se convierten en una verdadera obsesión para él. ${ }^{39}$

No obstante los eufemismos estilísticos que maniobrara el mitrismo para justificar el asesinato de Peñaloza, este desafortunado suceso fue señalado por la oposición como uno de los atropellos más flagrantes de la política liberal. El Chacho era casi un patriarca en La Rioja, un afable caudillo de más de sesenta años, a quien la montonera seguía sin coacción alguna y que vivía en los Llanos, entre la paisanada. El violento modo en que fue ajusticiado sin la posibilidad de un juicio militar significó una mancha para la facción mitrista que preconizaba la llegada del orden y de la paz a la Nación; el Chacho estaba en su rancho de Guaja cuando lo rodearon y se había entregado voluntariamente a las autoridades. A pesar de ello, lo lancearon frente a su esposa, desarmado y sin oponer resistencia. Luego lo degollaron y expusieron su cabeza en un palo, en la plaza principal de Olta.

Los medios de opinión reflejaron el rechazo que sentía la sociedad en relaciòn con estas reminiscencias de prácticas violentas desde el poder. Los principales antagonistas de Sarmiento se llamaron a opinar y señalaron la contradicción en la que había incurrido la facción liberal y proliferaron de este modo las biografías favorables al Chacho.

Mitre, al comprender que el excedido episodio podía traerle alguna consecuencia política indeseada, se aparta públicamente del hecho, e incluso en su correspondencia

\footnotetext{
${ }^{38}$ José Campobassi transcribe tres artículos del decreto (Campobassi, 1975, I, p. 523).

39 En carta a Mitre del 3 de septiembre de 1863, luego de reseñar los enormes gastos que ha tenido que dedicar para combatir a Peñaloza y el retardo que esto implica en la ejecución de sus proyectos en educación y en minería, le confía con desánimo al Presidente: "Mi presencia aquí se hace ya redundante. Mi bella obra de civilización ha sido inutilizada por la insurrección del Chacho" (Carta de Sarmiento a Mitre: www.proyectosarmiento.com.ar).
} 
con él se aprecia su corrimiento respecto del exabrupto de Sarmiento, que había felicitado el hecho en su provincia "precisamente por su forma". ${ }^{40}$

También debe enfrentar Sarmiento los ataques de Calvo y Bilbao, sus antiguos polemistas, y de su co provinciano Guillermo Rawson, en ese entonces ministro del interior, con quien tendrá que discutir la decisión de declarar el estado de sitio que supuestamente motiva la supresión de las garantías personales y que desemboca en la ejecución del Chacho. Esto ocasiona una ardua polémica entre el ministro y el gobernador que debilita peligrosamente la posición de Sarmiento y que ya ha sido analizada en el apartado 2. Así las cosas, Mitre se decide a interrumpir su gestión provincial para enviarlo a E.E.U.U. en misión diplomática.

\subsubsection{La barbarie y la educación popular}

Junto con su incansable actividad periodística, política y literaria, Sarmiento va desarrollando a lo largo de toda su vida una intensa labor educativa que inicia de muy joven con el ejercicio de la docencia: se desempeña como maestro, primero en San Juan (1826) y en sucesivos exilios en Chile. Exiliado nuevamente en Chile desde 1841 hasta

${ }^{40}$ Sarmiento le explica a Mitre la actitud que ha asumido y revela la diferencia de criterios que comenzará a apartar a ambos políticos:

San Juan, 18 de noviembre de 1863

[...] No sé lo qué pensarán de la ejecución del Chacho. Yo, inspirado por el sentimiento de los hombres pacíficos y honrados aquí he aplaudido la medida, precisamente por su forma. Sin cortarle la cabeza a aquel inveterado pícaro y ponerla a la expectación, las chusmas no se habrían aquietado en seis meses. [...]

San Juan, 3 de diciembre de 1863

[...] Con aquello y con esto terminé la guerra, castigando como lo había dejado traslucir en mi carta al Chacho. ¿Creerá usted creer que el general Paunero se empeña en negarme que la invasión del Chacho en San Juan era de mi parte una preocupación exclusiva, razonada, y en quitarme toda influencia en el desenlace de la guerra? Cuando tal sostenía era ridículo miedo; cuando el hecho lo confirmó, él había tomado todas las disposiciones para parar el golpe, iy ni me menta a mí para nada! ¿No le han escrito a usted que yo había detenido a Irrazábal? ¡Mudo! Lo que me hace gracia es que el que mueve el regimiento entero después de concluida la guerra, por valor, y al general Rojo por valor, y trata con el Chacho por valor, me trate de miedoso a mí que nunca tuve sino de paso un soldado de línea a mi lado, pues a Méndez lo he hecho salir tres veces para La Rioja, que cerré a Peñaloza toda puerta a transacción al día siguiente de la retirada de Furque, y lo batí con ciento treinta hombres, todo ello conforme con las ideas que he emitido, y lo que es más con mi carácter, cuyo rasgo histórico diré así es obrar decididamente y sin vacilación en los medios. Sin la muerte del Chacho, tal como ha ocurrido, no estaba bien expresado mi pensamiento. Ahora lo está. Perdóneme que me afecten estas cosas, usted sabe que era mi misión creerme capaz como cualquiera otro de hacer la guerra; y me ha lastimado que cuando la ocasión se me presentó de justificarlo, y lográndolo, se me hayan creado obstáculos, levantado sombras para oscurecer los hechos. Hasta otra vez su afectísimo amigo, D. F. Sarmiento.

(Cartas de Sarmiento a Mitre: www.proyectosarmiento.com.ar) 
1851, realizó una importante prédica a favor de la educación popular y de todo tema vinculado con la enseñanza en columnas periodísticas, apoyado por Manuel Montt que para esa época era ministro de instrucción pública. Los acontecimientos políticos de su país en 1851 lo llevan a Entre Ríos para participar en la campaña militar que logrará derrocar a Rosas en 1852. Pero después de su rompimiento con Urquiza, vuelve otra vez a refugiarse en el país vecino en el que retoma su tarea educacionista, apoyado como siempre por Montt, que ahora es presidente de Chile. Publicará trabajos sobre Lectura gradual y editará la revista Monitor de las Escuelas Primarias, en la que incorporará todas sus propuestas y completará minuciosas investigaciones consagradas a conocer el estado del sistema educativo chileno con el fin de preparar material pedagógico destinado a la enseñanza de la lectura y la escritura.

Fue en el momento en que estaba abocado a estas tarea, como dijimos antes, cuando recibe la invitación de participar como diputado de la legislatura porteña (1854), invitación que rechaza, al igual la de ser diputado nacional por Tucumán (1855).

Sarmiento se ha fogueado en Chile en dos actividades: el periodismo de combate y la elaboración de políticas educativas, y es consciente de que en ambos terrenos es una figura descollante; ${ }^{41}$ antes de que se cumpliera el año de asumir la redacción del diario, se le presentará también la oportunidad de desempeñarse como primer Jefe del Departamento de Escuelas, cargo creado virtualmente para él, durante la gobernación de Obligado y siendo ministro Vélez Sarsfield, el 7 de junio de 1856. En febrero de 1855 se había gestado el Consejo de Instrucción Pública con el propósito declarado de retomar los principios de Mayo: la educación general de la sociedad y la institución de la enseñanza gratuita para los niños pobres. ${ }^{42}$ En este contexto, Sarmiento se dedica a reorganizar el sistema pedagógico de la provincia.

La opinión pública conoce así su proyecto pedagógico y los logros de su gestión a través de sus notas periodísticas y de sus publicaciones específicas sobre educación popular. Paralelamente, la información acerca de las instituciones educativas que inaugura va instalando en la sociedad la figura de un hombre de palabra y de acción: un pensador y un realizador. Así, entre 1855 y 1861, mientras ejerce la dirección de uno de los periódicos más leídos de la provincia, Sarmiento va revirtiendo en el pueblo porteño

\footnotetext{
${ }^{41}$ También en esa carta a Posse ya citada, demuestra especial interés por desarrollar tareas educativas en Buenos Aires.

${ }^{42}$ Levene, 1939.
} 
la desconfianza generada por su desenfrenado polemismo político al exhibir otra faceta de su personalidad: sus éxitos en materia educativa permiten difuminar la imagen del "gaucho de la pluma" contraponiendo la del "civilizador". Ahora que está en la ciudad más poderosa del país, la concreción de la meta de la "civilización" lleva al primer plano de su discurso la instrucción pública, en lugar de del combate contra el desierto y la vida que genera. La lucha contra la barbarie le cederá la preponderancia a la lucha contra la ignorancia. Y la ciudad que se autoconsidera el centro irradiador de la cultura y la educación empieza a mirar al gestor de una "épica pedagógica" con otros ojos.

En el campo de sus consideraciones pedagógicas, incluye la cuestión de la lengua del pueblo argentino, la lengua nacional, que -como sostiene Graciela Salto- ya "había sido ubicada, según la impronta de Johann G. Herder, como fundamento político de los nuevos imaginarios nacionales". ${ }^{43}$ En esta línea le preocupa la elección de un modelo lingüístico que pueda ser tomado como vehículo de la instrucción pública nacional, y consciente del papel que cumple el lenguaje como factor integrador de una Nación, elige la norma de Buenos Aires porque considera a esta ciudad el faro iluminador de la cultura nacional. De este modo, la estructura pedagógica que monta en estos años, al institucionalizar una lengua nacional estandarizada sobre la base del dialecto porteño, implementa una política lingüística que contribuye a consolidar un poder hegemónico.

La preocupación por afirmar una lengua y una literatura nacional fue un tema recurrente en la Generación del 37. Tanto Alberdi como Sarmiento enfatizan que el proceso revolucionario no puede limitarse a la independencia política y que ésta debe ser necesariamente complementada por una independencia cultural y lingüística. Como ha destacado Ennis, la percepción del cambio lingüístico adquiere a partir de este momento un carácter eminentemente político. Sarmiento nunca pierde esta visión política de la lengua, y cuando ya ha abandonado la lucha contra la tradición española (por considerarla un vehículo de la opresión), la reencauza en otra discriminación dentro del orbe social nacional-criollo. ${ }^{44}$

Puede observarse, además, que este enfoque signa la "última" biografía de caudillos que Sarmiento escribe, la vida de Peñaloza, y que conforma la trilogía de la

\footnotetext{
${ }^{43}$ Salto, 2007, p. 31.

${ }^{44}$ Ennis, 2008, p. 114.
} 
barbarie. Esta nueva obra publicada en EEUU como un alegato de su acción política en el desgraciado episodio del Chacho, y que tiene numerosos pasajes que pueden leerse desde el género de la autobiografía (como autojustificación y propaganda), posee una marcada inclinación hacia los aspectos educativos y lingüísticos expuestos. ${ }^{45}$ Escrita en 1866, veinte años después que las vidas de Facundo y Aldao, Sarmiento desplazará el acento narrativo de la antigua tensión colorista entre la naturaleza y el hombre americano, al problema pedagógico social y también étnico. El texto se encamina más bien a la tesis sociológica que presentará en Conflicto y armonía de las razas en América, de 1883.

\subsubsection{Viaje a EEUU y publicación de su biografía del Chacho}

Los sinsabores que le deparó la gobernación de San Juan fueron mitigados por el viaje a Norteamérica propuesto por Mitre en 1865. Aquí Sarmiento se encontrará con Mary Mann que será una de las más entusiastas colaboradoras en la tarea educativa de Sarmiento. Horace Mann fue uno de los pedagogos más destacados de la posguerra norteamericana y rápidamente Sarmiento supo ver un paralelo interesante entre su situación y la de Argentina, usando su experiencia como modelo a imitar. Se enhebrará su viaje con la tarea educativa que ya venía realizando para el Estado de Buenos Aires.

Sarmiento había conocido a Horace Mann en su primer viaje a los Estados Unidos en 1847, pasando dos días en su casa de West Newton, Massachussets, cuando regresaba desilusionado de su viaje por Europa y pudo observar en Mann la pujanza del imperio norteamericano y la importancia que le daban a la enseñanza como modo de asegurar el progreso de la Nación. Esta visita fue la semilla de una fructífera amistad con Mary Mann, retomada fundamentalmente luego de la muerte de Horace (1859) en este segundo viaje. ${ }^{46}$ En esta oportunidad Sarmiento reanuda su vínculo con la viuda del pedagogo y dedica casi toda su visita a empaparse de las teorías del gran educador.

\footnotetext{
${ }^{45}$ Estas anteojeras pedagógicas de Sarmiento son bien detectadas por Alberdi: "Por rústico no entiendo bárbaro, sino rural. La rusticidad no es la barbarie. Son rústicos los campesinos de las naciones más civilizadas de la Europa, pero no bárbaros. Decir que las campañas argentinas, pobladas de gentes originarias de Europa, hablando un idioma europeo y profesando la religión cristiana que la Europa culta profesa, representan la barbarie, es una torpe exageración de un escuelero" (Alberdi, 1897, V, p. 94).

${ }^{46}$ La correspondencia entre Sarmiento y Mary Mann se sostendrá durante veinte años funcionando como un verdadero canal de comunicación para estrechar vínculos con educadores, maestras y escritores de ambos países. Personalmente se vieron solo en cuatro oportunidades.
} 
Una serie de coincidencias le sirven a Sarmiento para fijar a la educación como la última lucha contra la barbarie. Estado Unidos venía de terminar su guerra de secesión, guerra civil que parangonaba con las de Argentina. El norte se imponía sobre la barbarie sureña, como en Argentina, Buenos Aires sobre el resto del país. Estados Unidos había decidido elegir a la educación como el arma para la reconstrucción de su país y Sarmiento la elegiría como el arma para la "reorganización nacional", para “civilizar" a los "bárbaros", a la clase popular. ${ }^{47}$

Desde otro punto de vista, su relación con Mary Mann también le sirvió para candidatearse como presidente pues lo conectó con todos los hombres de la política y la cultura norteamericanas y con maestras para traer a Argentina, incluso le facilitó la posibilidad de dar conferencias sobre la creación de escuelas públicas en nuestro país, tradujo sus textos fundamentales e hizo toda la propaganda que estaba a su alcance para difundir su personalidad política.

En este viaje también sintió Sarmiento que podía reforzar los principios de Mayo que establecían a la escuela como primer eslabón hacia la república y a la constitución de las escuelas como la constitución de la patria. Allí asistiría a congresos y conferencias que planteaban esta idea y también la de que la guerra civil había sido un problema de educación: "una educación difundida y universal en el Norte y una educación muy limitada en el Sur". ${ }^{48}$ Estos criterios lo ayudaron a pensar en la problemática local y desde esta mirada compondrá el texto sobre la vida de Peñaloza: $E l$ Chacho, último caudillo de la montonera de los Llanos (1868), ${ }^{49}$ tomando el problema educativo como eje principal de reflexión. Este enfoque es empleado estratégicamente en la composición de su biografía, como respuesta a las denuncias en su contra y a su vez, como programa político.

\footnotetext{
${ }^{47}$ En este sentido, los biógrafos de Sarmiento insisten en mencionar que también aprendió de Norteamérica la preocupación social de sus pedagogos, desvelados por educar a los pobres negros libertos del sur, preocupación que Mann planteaba en sus numerosas conferencias. Cabe destacar que en concordancia con lo dicho, Sarmiento compone en 1866, el mismo año que dedica a escribir su versión biográfica sobre el Chacho, un informe en el que enfoca el vínculo entre la educación y la conformación de la república norteamericana titulada "Las escuelas: base de la prosperidad y la República en los Estado Unidos".

${ }^{48}$ Citado en Parkinson, 1977, p. 13.

${ }^{49}$ Sarmiento, D. F. El Chacho, último caudillo de la montonera de los llanos-Episodio de 1863, en Facundo ó; civilización i barbarie en Las Pampas Arjentinas. Nueva York, D. Appleton y compañía, 1868, pp. 217-318.
} 
Cuando escribe las primeras biografías de caudillos de 1845 la "barbarie" está estigmatizada en la violencia física. La crueldad de los hombres que describe, Quiroga y Aldao, son la manifestación más patente de la agresividad. En este texto, por el contrario, el Chacho no está representado como cruel o violento -los hechos biográficos se prestarían mal a ello-, sino como un ignorante que no sabe leer y escribir y que entonces está dominado por sus amanuenses o por cualquier oportunista que se aprovecha de ello.

Desde esta etapa de su vida dedicada a la educación como programa político, Sarmiento denuncia la ignorancia como el peor hecho de barbarie que hay que erradicar, y Peñaloza será entonces el "último" caudillo, como titula sugerentemente su obra, ${ }^{50}$ símbolo del último ignorante de la Argentina. Sarmiento propone a la educación como fuerza igualadora de todas las condiciones sociales, por lo tanto, una vez que él sea presidente, porque no se debe olvidar que el texto se escribe para reforzar su campaña a la presidencia que llegará a asumir directamente desde los Estados Unidos, ya no habría más ignorantes analfabetos como el Chacho.

El otro gran eje discursivo son los indios. Como un nuevo paralelo con los Estados Unidos, Sarmiento centra ahora en la cuestión indígena la desgracia del país. El problema es educativo y racial porque la Argentina, como colonia española, ha permitido el mestizaje, cosa que no ha sucedido en Norteamérica. Su biografía sobre Peñaloza articula estos dos males, el de la ignorancia en el Chacho y el racial en los montoneros que lo siguen, identificados como de origen indígena.

Además Sarmiento querrá aprovechar el apoyo que le ofrece su amistad con Mitre, hecho que legitima su discurso pues en ese entonces es el presidente y, por lo tanto posee el lenguaje de la Nación. ${ }^{51}$ Así como logró imponer una visión polarizada de la sociedad argentina explicando su esencia en términos antagónicos irreconciliables,

\footnotetext{
${ }^{50}$ José Campobassi destina dos capítulos completos de Sarmiento y su época a este lamentable episodio (op. cit., I, cap. XIX; II, cap. XX) y consagra el cap. XXII, del tomo II a la publicación de El Chacho, último caudillo de la montonera de los Llanos; también en el capítulo IV de Sarmiento y Mitre, hombres de Mayo y Caseros (Buenos Aires, Losada, 1962) trata específicamente este tema. De todos modos, dentro del vastísimo corpus bibliográfico dedicado a la obra de Sarmiento, abundan las referencias a la ejecución del Chacho: Castro, 1937; Rodríguez, A., 1955; Palcos, 1938; Gálvez, 1957.

${ }^{51}$ Roland Barthes en Ensayos críticos analiza esta problemática y se pregunta: “¿Quién habla? ¿Quién escribe? Nos falta aún una sociología de la palabra. Lo que sabemos es que la palabra es un poder y que entre la corporación y la clase social, un grupo de hombres se define bastante bien, por eso, por poseer en grados diversos el lenguaje de la nación" (Barthes, 1967, p. 177).
} 
Sarmiento se arriesga nuevamente a exponer los postulados del Facundo pero desde un enfoque alternativo y menos visceral, que permitirá que los hombres de Buenos Aires puedan aceptar su versión de la muerte del Chacho asumiendo su tesis desde el enfoque lingüístico y educativo. Con esta confianza avanza entonces en este sentido y presenta un cariz moderado de su antiguo esquema de interpretación. ${ }^{52}$

\subsubsection{El sociolecto del Chacho}

Después de las guerras independentistas y definida la voluntad de constituir una Nación (aunque su consolidación insumiría largo tiempo), los pensadores de la nueva realidad postcolonial se consagraron con celo a construir las marcas diferenciales que la distinguirían de la Metrópoli. En este afán, se volcaron a subrayar el carácter de los usos regionales del castellano y postularon la existencia de una "lengua criolla". Consecuentemente, defendieron esas "diferencias" instituyéndolas como el vehículo necesario para la expresión de un mundo de cambios sociales, políticos y estéticos que se pronosticaron con cierto vértigo. En esta línea, Sarmiento acometió una vez más otra de sus sonadas polémicas - en este caso con el venezolano Andrés Bello-, a propósito de la reforma ortográfica que él proponía adoptar: una normativa de escritura americana, que reproducía, por ejemplo, el seseo del español de América. ${ }^{53}$

Esta proyección del arrebato inicial antipeninsular se diluyó rápidamente, pero no se desecharon las cavilaciones sobre la "lengua nacional", sino que se reorientaron. La oposición norma peninsular-norma americana fue sustituida por otra: la norma del centro urbano que se consideraba más prestigioso (la ciudad de Buenos Aires) fue propuesta como patrón de un proceso de estandarización. Paralelamente, los dialectos rurales y ciertos usos propios del interior del país fueron estigmatizados. De este modo

\footnotetext{
${ }^{52}$ Pierre Bourdieu explica la conformación del campo literario como un lugar en el que se disputa la dominación lingüística y la dominación simbólica. Desde esta perspectiva se ha pensado en toda una geografía de textos que surgieron para cuestionar o adherir a los postulados establecidos en el Facundo por Sarmiento. También desarrolla Bourdieu en este texto la idea de lengua estándar, como la lengua autorizada-legítima-verdadera y propone revisar el concepto saussuriano de lengua como "tesoro" ya que esto tiene que ver con su distribución en la sociedad. Puede pensarse que éste es también el enfoque de Sarmiento que se considera el que posee la lengua autorizada, la doxa y desde esta perspectiva, el Chacho y los caudillos no poseen el "tesoro" de la lengua, lo que les va a impedir el éxito social, la inserción en la "civilización" (Bourdieu, 1985, cap. I, p. 31).

${ }^{53}$ Sobre la polémica reforma ortográfica de Sarmiento y su discusión con Bello: Caballero Wanguemert, 1992, 500, pp. 177-187; Carilla, 1964; Varela, 1999, pp. 18-35; Di Tulio, 1988, 4, pp. 17-22; Velleman, 2004; Ennis, 2008, pp. 117-143.
} 
se reconfiguró el mapa de operaciones educativas, asumiendo que el centro urbano porteño encarnaba una norma lingüística legítima que debía imponerse y uniformar las características del país, para asegurar la conformación del nuevo ciudadano argentino. Con este propósito absorbido en los planes pedagógicos de Sarmiento, se organiza una estandarización exhaustiva en todo el territorio que impone las variantes "oficiales" de la lengua nacional y proscribe las otras.

Tanto Sarmiento como Hernández se comportan como agudos "dialectólogos", ya que distinguen con claridad los "lectos" y "registros" del uso lingüístico local. Como en tantos otros aspectos, vuelven a enfrentarse en el terreno de la lucha por la dominación lingüística: uno desencadenará, desde el poder político, una reforma educativa que dará sustento a la consolidación de un proceso de estandarización lingüística que impondrá una preceptiva centrada en el dialecto de la ciudad-puerto; el otro logrará desde el esplendor literario que un dialecto rural se asocie a otro modelo de identidad nacional. ${ }^{54}$

La biografía del Chacho que escribe Sarmiento revela estas tensiones de una manera bastante explícita. ${ }^{55}$ En 1845, Sarmiento se encargaba de señalar en el Facundo que Quiroga sabía leer y escribir y centraba la crítica de sus dos primeras biografías de caudillos - la de Aldao y la de Quiroga- en la barbarie de la violencia. Sin embargo, en

\footnotetext{
${ }^{54}$ Rodolfo Borello ve en el surgimiento del género gauchesco una búsqueda de diferenciación de lo peninsular que se encarna en el personaje y en la voz del gaucho: "El único tipo social que mostraba esa diferenciación, que era 'otro' aún dentro del mosaico americano, fue el gaucho. Ello explica la elección de su figura y las evidentes intenciones de intensificar sus rasgos lingüísticos distintivos" (Borello, 1974, p. 20).

${ }^{55}$ A primera vista, puede creerse que, en una etapa posterior a la de su polémica con Bello, hubo un corrimiento en la concepción de la política lingüística sostenida por Sarmiento. En 1847, Andrés Bello censuraba lo que consideraba "vicios" americanos en la pronunciación y la ortografía chilena y sus desvelos puristas lo impulsaban a identificar la normativa lingüística con el uso culto de Madrid; pero, paradójicamente, con las descripciones de su Gramática de la lengua castellana destinada al uso de los americanos, preparaba el terreno para la llegada a Chile de Rodolfo Lenz, autor del primer estudio riguroso sobre una variedad del español en América, y el primero que estudió la influencia de un sustrato vernáculo (el del mapuche) en su fonética. Podría pensarse que Sarmiento, que en Chile había polemizado con Bello a favor de modernizar y regionalizar la ortografía según la pronunciación americana y en contra del casticismo, era un antipurista que posteriormente revisó su posición; pero Sarmiento tiene un proyecto pedagógico y eso implica imponer normas. Además, en todo momento sostuvo la superioridad de lo hispánico sobre las culturas originarias y de lo urbano sobre lo rural.
} 
1866, veinte años más tarde, Sarmiento desplaza el eje y se encarga de denunciar la barbarie de la ignorancia, centrándose en el problema cultural y lingüístico. ${ }^{56}$

En una operación igualmente maniquea, Sarmiento ha redireccionado su ataque y elige condenar el analfabetismo del Chacho, describiendo hiperbólicamente las consecuencias que presuntamente activaría: el caos, el desorden, la anarquía, la ventaja de los pícaros, y en consecuencia, la imposibilidad de acceder al mundo de la civilización. Atribuía así a la ignorancia todo el orbe de matices sobre el horror, que antes encarnaba en la violencia.

Por todo esto, considera que el Chacho, aunque hubiera sido popularmente mitificado como un caudillo amable y pacífico, conduciría igualmente con su irregularidad, su desorden y su ignorancia, al mismo retraso y a la misma ligadura con el pasado colonial que significaron los caudillos de particularidades casi antagónicas. Desde esta mirada, como símbolo del caudillismo también sostiene que deberá condenarse, y que es legítimo que se lo condene del mismo modo en que también es legítimo que la norma lingüística urbana y porteña se imponga y que se proscriban los dialectos rurales.

Hay un pasaje que ilustra con claridad esta operación discursiva de Sarmiento. En el capítulo III del Facundo, cuando describe la vida del gaucho y las pulperías, Sarmiento reproducía una anécdota popular del Chacho, cuando se lamentaba de estar en Chile y no tener caballo. En este caso Sarmiento transcribía la supuesta expresión del Chacho que habría de pervivir en la tradición oral:

¡Cómo me ha de ir! [...] ¡en Chile i a pie! $!^{57}$

Curiosamente, este pasaje funciona casi como un pre-texto de El Chacho, último caudillo de la montonera de los Llanos, donde al compaginar los detalles biográficos del caudillo en 1866, Sarmiento retoma esta misma escena, sólo que en este caso, al citar la frase tan conocida del riojano, registrará su sociolecto:

\footnotetext{
${ }^{56}$ Cuando en El Chacho, último caudillo de la montonera de los Llanos Sarmiento evoca los Andes con la sugestiva imagen de "un libro que hasta los niños saben leer", despoja a la naturaleza agreste de todo potencial educativo (Sarmiento, 1868, p. 219).

${ }^{57}$ Nuestras citas del Facundo pertenecen a una edición moderna (Sarmiento, 1967, p. 55); pero si nos apartamos de la ortografía impuesta en las ediciones chilenas de su época ("i" en lugar de “y”), falseamos el cotejo que estamos realizando.
} 
¡Cómo me a de dir amigo! En Chile! i a pié!! ${ }^{58}$

Este detalle no es poco significativo, si se analiza en el marco de una política lingüística. ${ }^{59}$

Unas páginas más adelante Sarmiento opera nuevamente como un dialectólogo cuando registra el uso rural del Chacho, su habla gaucha. Se ficcionaliza una escena de diálogo en que el Chacho, refiriéndose al propio Sarmiento como gobernador de San Juan, expresa:

Si es tan guapo, vaya pues a San Juan donde gobierna un dotor. Por qué no va pues? Qué ha dir amigo! $!^{60}$

Este sociolecto del Chacho, este "golpeado acento" -como se lo describe peyorativamente-, distancia su habla de la norma culta porteña y Sarmiento intenta instalar, por todos los medios imaginables, la presencia de un abismo entre dos mundos, y consecuentemente, la imposibilidad de conciliarlos:

Llamaba la atención de todos en Chile la importancia que sus compañeros generalmente cultos daban a este paisano semi-bárbaro, con su acento riojano tan golpeado, con su chiripá y atavíos de gaucho. ${ }^{61}$

La curiosa metáfora - reiterada por Sarmiento- en la que la imagen de un "golpe" reproduce el desagrado de un hablante culto ante los sociolectos estigmatizados, le permite asociar marcadores lingüísticos con la violencia de la barbarie. De allí que, en medio de la descripción de una disputa, el sociolecto sea percibido como un ingrediente que intensifica la agresión (ya no es, meramente, un rasgo que se asocia a la violencia:

\footnotetext{
${ }^{58}$ Sarmiento, 1868, p. 220. El destacado es nuestro.

${ }^{59}$ Los conceptos de "sociolecto", "dialecto" y "registro" se toman de Halliday, 1982 y de López Morales, 1986. Estos conceptos sirven para pensar cómo circulan los sentidos sociales en los distintos discursos emitidos por distintos secteros: los caudillos por un lado, Sarmiento y los políticos porteños liberales por otro.

${ }^{60}$ Ibidem, p. 296. El destacado en cursiva es de Sarmiento.

${ }^{61}$ Ibidem, p. 220.
} 
es en sí mismo un arma, un agente de violencia): "Un rasgo de ironía del Chacho, con su golpeado acento, daba sabor acre a la disputa". ${ }^{2}$

Como ya se ha señalado, Sarmiento acompaña la reorganización del sistema educativo (el rosismo había desarticulado las instituciones rivadavianas, pero el tiempo transcurrido imponía una etapa fundacional), y cuando logra desempeñarse como autoridad en ese campo -inicialmente en Buenos Aires, luego en todo el país-, acomete una serie de transformaciones normativas en la enseñanza de la lecto-escritura, que entre otras innovaciones- encara la cuestión de la estandarización lingüística. En esta línea, Sarmiento propiciará la consolidación de una norma culta en el ámbito escolar porteño -en donde ocupa posiciones de gestión entre 1855 y 1861- y luego expandirá esta política lingüística hacia el interior del país a partir del comienzo de su presidencia en 1868.

Tomando en cuenta que la composición de esta biografía se integra en una campaña electoral que ha puesto énfasis en la programática pedagógica del candidato, no es casual que una visión glotopolítica se cuele por los intersticios del texto. No es casual, entonces, la insistencia en inventariar marcas lingüísticas y culturales de un ámbito que se propone "regenerar": el Chacho "no sabía leer" aunque "era de esperarse de un familiar de convento", 63 "firmaba, sin embargo, con una rúbrica los papeles que le escribía un amanuense o tinterillo cualquiera, que le inspiraba el contenido también". ${ }^{64}$

Sarmiento no sólo se esmera en registrar los rasgos de atraso cultural del caudillo o su incapacidad para valerse de otros "lectos" que no pertenezcan al mundo rural, denuncia la voluntad de no abandonarlos (e incluso de intensificarlos) para establecer una comunicación que le permita afianzar su poder:

${ }^{62}$ Ibidem, p. 296.

${ }^{63}$ Ibidem, p. 220.

${ }^{64}$ En su inteligente análisis de dos sugestivos pasajes del Martín Fierro donde el universo letrado se aleja en una transcripción icónica (la referencia al "facón con S" de la Ida) o irrumpe con su grafemática para desestabilizar la cultura de la oralidad ("los meses que train erre", arma mortal para derrotar al Moreno en la payada de la Vuelta), Julio Schvartzman ha concentrado la significación de la llaga del analfabetismo en el mundo rural: "En todo caso, la $\mathrm{S}$ de la Ida y la erre de la Vuelta nos ponen en presencia de una fobia de Fierro hacia el otro, cuando se corporiza en un negro, hasta el punto de sacar a relucir el letrado que había dicho, desde el principio, que no era. Complementariamente, el paso del icono a la letra como tal emblematiza, junto con otros trazos más gruesos y más finos, el tránsito problemático entre el texto de 1872 y el de 1879" (Schvartzman, 2003, p. 244). 
Su lenguaje era rudo más de lo que se ha alterado el idioma entre aquellos campesinos con dos siglos de ignorancia, diseminados en los llanos donde él vivía; pero en esa rudeza ponía exageración y estudio, aspirando a dar a sus frases, a fuerza de grotescas, la fama ridícula que las hacía recordar, mostrándose así cándido y al igual del último de sus muchachos. ${ }^{65}$

Así, Sarmiento lanza una gravísima acusación: los caudillos contribuyen conscientemente a impedir la llegada de la civilización.

De esta manera se observa cómo se refuerza la mirada sobre la cultura del interior del país en esta última biografía, buscando distinguir a los caudillos y a las montoneras "bárbaras" por su ignorancia, en contraposición con los porteños “civilizados" por su cultura en el marco de modernización y refinamiento que Buenos Aires había empezado a experimentar durante su aislamiento de la Confederación, cuando comienza a disfrutar de sus teatros, clubes, escuelas y colegios. ${ }^{66}$ Sarmiento usará este texto desde esta perspectiva política para ofrecerse nuevamente como la solución del problema que deberá enfrentar actualmente el país: la alfabetización. ${ }^{67}$

En este marco, y retrotrayendo al lector a los hechos de 1863, el texto incorpora pasajes en los que Sarmiento se presenta como el encargado de luchar contra el atraso riojano desde su gestión como gobernador de San Juan, como si hubiese sido comisionado ad hoc por Mitre para encargarse de cuestiones pedagógicas:

Ya se habia espuesto en términos jenerales al Gobierno nacional la situacion precaria de aquella parte del territorio arjentino, i en correspondencia íntima indicádosele con insistencia al Gobernador de San Juan la necesidad de hacer de esta ciudad la única existente en más de diez mil leguas cuadradas un centro de poder material i de educacion a fin de contener los progresos de la barbarie $[\ldots]^{68}$

Esta reducción de la "barbarie" a la carencia de una educación "formal" será especialmente cuestionada por su antagonista Alberdi, que relativizará el proyecto de

\footnotetext{
${ }^{65}$ Sarmiento, 1868, p. 221.

${ }^{66}$ Carta de Posse citada, del 15 de junio de 1856.

${ }^{67}$ Sarmiento se refiere al pueblo riojano como "estólidas muchedumbres embrutecidas por el aislamiento i la ignorancia" (ibidem, p. 223).

${ }^{68}$ Ibidem, p. 243.
} 
educación popular como fundamental para el progreso de la Nación discurriendo (desde una perspectiva utilitaria que merecerá futuros cuestionamientos) sobre la importancia de una educación práctica que mejore la mano de obra tanto en el ámbito rural como en el urbano. ${ }^{69}$

Sarmiento, al mismo tiempo que no escatima halagar al público elector porteño distanciándolo de las inscripciones de la barbarie en el habla, expone su política lingüística: el proceso de estandarización que su programa educativo implementará en todo el país tomará como modelo la norma culta porteña. El proyecto político con el que se pretende consolidar definitivamente una nación necesita una lengua que funcione como factor de identidad y cohesión: el sociolecto culto de la ciudad-puerto está destinado a convertirse en la "lengua" del ciudadano argentino y la "lengua" hegemónica del Estado. Esta preocupación no se limitará a una preceptiva escolar que destierre formas estigmatizadas (prosódicas, fonéticas, morfosintácticas, gramaticales, lexemáticas), se entremezclará también con normativas jurídicas; por eso no es extraño que esta temática se cuele en la polémica que sostiene en 1868 con Rawson acerca del estado de sitio y el habeas corpus:

Podría objetarse a la generalidad de esa doctrina que los Estados Unidos al darse una constitución insertaron en ella el privilegio con la restricción, tan inseparable es la una del otro, sin imaginarse ingleses y norteamericanos que había luego de presentarse en la tierra un pueblo que tiene en su lengua las palabras chiripá $i$ guardamontes, caudillo, masorca, montonera que pretendería hacer dar un paso mas a la humanidad en cuanto a las garantías de la libertad personal, reclamándola aún

\footnotetext{
${ }^{69}$ Este tema será retomado por Alberdi en muchos de sus escritos, en los que polemiza con Sarmiento y su esquema sociológico. Y ya en las Cartas quillotanas, Alberdi denuncia que la barbarie puede encontrarse también entre gente instruida. En "Facundo y su biógrafo", vuelve a recriminar a Sarmiento su intento por imponer la creencia de que el hombre de campo no tiene educación porque es rústico y recupera la desestabilización de la célebre antinomia refiriéndose a la "barbarie ilustrada" (Escritos Póstumos, op. cit., V). También en XII, p. 231, se detiene a analizar la relación entre "la barbarie y la instrucción" y avanza un paso más al deslegitimar la labor pedagógica del sanjuanino; sostiene que en la República Argentina "se cuentan hoy más de dos mil sesenta establecimientos, entre escuelas, colegios, liceos, universidades, en que sus alumnos se instruyen, sin educarse. Esos establecimientos han costado millones a la nación, han hecho reputaciones inmensas a sus fundadores, elevando a más de uno de ellos a los rangos supremos del gobierno del país".
} 
en caso de insurreccion para Chacho, Potrillo, el Flaco de los Berros, Chumbita, el Rubio de las Toscas $[\ldots]^{70}$

Las investigaciones sociolingüísticas de María Beatriz Fontanella de Weinbeg han demostrado cómo - entre 1800 y 1880, pero muy particularmente a partir de 1852la reactivación sociocultural que fue experimentando la ciudad de Buenos Aires (proliferación de periódicos, teatros, clubes, escuelas primarias y secundarias, la recuperación de la Universidad) se proyectó en un proceso de estandarización. ${ }^{71}$

Según testimonian documentos oficiales y privados, en el habla bonaerense se reduce la frecuencia de vacilaciones vocálicas en sílabas átonas, las omisiones y ultracorrecciones de la /-s/ en final de palabra, en tanto desaparece de la norma urbana la confusión de las líquidas /-1/ y /-r/ y el uso del refuerzo velar del diptongo /ue-/, también se impone la restitución de los grupos cultos (el paulatino retroceso en la escritura de grafías como "otubre", “concetos", "susisten", etc., testimonia las reposiciones que se impusieron en el habla). ${ }^{72}$

No obstante, la presión normalizadora nunca logró desterrar dos rasgos fonológicos del español de América impuestos por la pronunciación de los primeros colonizadores: el seseo y el yeísmo. Pero las otras transformaciones fonológicas inventariadas subsistieron en la campaña bonaerense, alejada de los centros educativos que imponen la norma.

El género gauchesco se apropiará de esas marcas del dialecto rural para construir la voz del gaucho, y son estas marcas justamente las que Sarmiento elige para estigmatizar a Peñaloza como un "bárbaro". El menospreció se extiende a los pobladores rurales de La Rioja que sólo conservan un "idioma adulterado". 73

Esa actitud de menosprecio de la cultura rural (que Sarmiento comparte con la mayor parte de la elite letrada) se proyecta sobre la gauchesca. Las escasas menciones del género que pueden rastrearse en sus Obras Completas van acompañadas de comentarios adversos, como cuando se refiere a un autor como Hilario Ascasubi, que milita en su mismo bando político. A diferencia de las burlas amables de Estanislao del

\footnotetext{
${ }^{70}$ Sarmiento, 1868, pp. 273-274. Las cursivas son de Sarmiento.

${ }^{71}$ Fontanella de Weinberg, 1987.

${ }^{72}$ Fontanella de Weinberg, 1987, pp. 95-129.

${ }^{73}$ Sarmiento, 1868, p. 256.
} 
Campo, ${ }^{74}$ las de Sarmiento entrañan un rechazo visceral, ya que las asocia a esa "barbarie" que considera imperioso suprimir. La estandarización que propone su política lingüística es, entonces, un arma más en la lucha contra la barbarie.

Como señala Fontanella de Weinberg, los procesos de estandarización son lentos y acompañan la historia política de la Nación. Como ya se ha visto, en el período postindependentista surgieron conceptualizaciones acerca de la identidad nacional acompañadas de propuestas de "independencia lingüística". Pero en una etapa posterior, la modernización, el progreso urbano y el desarrollo de la vida cultural impusieron otros patrones de estandarización.

El concepto de educación popular característico del romanticismo desemboca en el proceso de alfabetización masiva -cuya figura más preclara es Domingo F. Sarmiento-, que tiene como consecuencia directa la extensión de normas estándar a un porcentaje cada vez más amplio de la población. ${ }^{75}$

Es desde la perspectiva de una política lingüística, que, para Sarmiento, el registro del sociolecto rural del Chacho -en tanto manifestación de la barbarie- es también el señalamiento del campo que la educación deberá transformar. Así, la imposición de un proceso de estandarización linguiística -que conlleva la imposición de la norma del lugar del poder- se integra en una programática educativa que promete garantizar la igualdad social que suprima la distinción entre "civilizados" y "bárbaros".

Durante el siglo XIX, se impone un concepto de Nación que presupone la existencia de homogeneidades cohesivas (religión, cultura, lengua). Desde la concepción cultural monoglósica de Sarmiento, el Chacho es un "otro" lingüístico que, si no puede manejar el sociolecto culto, tampoco podrá comprender la función de las leyes ni el significado de las instituciones, es decir, no podrá integrarse nunca a una

\footnotetext{
${ }^{74}$ Los gauchipolíticos, por su parte, se valieron de esas formas estigmatizadas conscientes de la fuerza agresiva del sociolecto rural. Hernández, incluso, no recibe con agrado las burlas amables del Fausto y le dice a José Zoilo Miguens: "Quizás la empresa habría sido para mí más fácil y de mejor éxito, si solo me hubiera propuesto hacer reír a costa de su ignorancia, como se halla autorizado por el uso, en este género de composiciones" (Hernández, 2001, p. 5).

${ }^{75}$ Fontanella de Weinberg, 1987, p. 129.
} 
sociedad organizada. ${ }^{76}$ De este modo, identifica sociolectos estigmatizados con deficiencia cognitiva e inadaptación social, aludiendo a que el analfabetismo del Chacho lo convierte en un marginal social, un incapaz, que no puede ni siquiera manejar un código de comunicación, que no tiene una mínima estrategia lingüística porque incluso sus amanuenses le escriben lo que quieren ya que él ni siquiera puede asegurarse ni verificar sus notas o cartas. ${ }^{77}$ En última instancia lo que intenta deslizar Sarmiento es que el Chacho ni siquiera puede pensar, porque el amanuense piensa por él, no tiene identidad porque no tiene lengua, porque no posee este "tesoro" que le garantiza su inserción social. Al respecto observa con desconfianza y fina ironía después de transcribir un parte militar del Chacho: "No sería fácil decir si estos conceptos de la cancillería de Guaja (el rancho del Chacho) eran suyos o del amanuense", 78

Más avanzado el texto, continúa con el análisis lingüístico del discurso del caudillo al que denomina "común parlanza de la jente llana" para desestimar la posibilidad de que el Chacho hubiera usado el adjetivo "venturoso" que es propio de la gente culta. ${ }^{79}$ Sarmiento contrapone ahora el habla del Chacho con el de Rivadavia que "en sus conversaciones, se estasiaba al arrullo de la esperanza en el venturoso porvenir que aguardaba al país". ${ }^{80}$ Con este comentario Sarmiento se lamenta de la ironía de que esta expresión refinada haya sido ridiculizada por sus detractores políticos y de que estos términos, propios de un lenguaje elevado, sean bastardeados por un hablante no calificado para tal uso, cuando dice a continuación:

[...] i el que esto escribe lo oyó en 1830 andando de boca en boca entre los parciales de Quiroga. ¡Triste cosa! Despues de treinta años de desastres, en lugar del

\footnotetext{
${ }^{76}$ En un apartado titulado "La cultura monoglósica y el dogma del homogeneísmo", José del Valle y Gabriel Stheeman analizan detalladamente las características de este tipo de procesos (del Valle y Stheeman, 2004).

${ }^{77}$ M.A.K. Halliday (1982, p. 124) ha analizado detenidamente la relación entre "lectos" y socialización.

${ }^{78}$ Sarmiento, 1868, p. 245.

79 "Hay, sin embargo, una palabra cuyo origen es curioso recordar. El adjetivo venturoso no entra en la común parlanza de la jente llana. Rivadavia, en sus conversaciones, se estasiaba al arrullo de la esperanza en el venturoso porvenir que aguardaba al país. Sus enemigos hicieron de esta frase un apodo de ridículo" (ibidem, p. 245).

${ }^{80}$ Ibidem, p. 246. El destacado es de Sarmiento.
} 
venturoso porvenir anunciado, encuéntrase la frase en el fondo de los Llanos, en boca de uno de los bárbaros que alejaron ese porvenir $[\ldots]^{81}$

Sarmiento intenta distinguir los que poseen la doxa, el lenguaje de la Nación, ejemplificados en Rivadavia, de los que lo usan sin poseerlo. ${ }^{82}$ Aprovecha también para presentarse él también como un interlocutor culto y políglota que maneja además de su lengua natal, la lengua francesa e inglesa incorporando expresiones en estos idiomas, gesto característico de sus textos pero que aquí adquiere otra connotación por efecto del contraste con las limitaciones que se describen en la expresión del Chacho.

Como otra marca de la ignorancia del caudillo describe el episodio que muestra el maltrato que reciben los turistas franceses en La Rioja al ser asaltados por montoneros. El Chacho perdona el exceso de sus partidarios y no ejerce ningún tipo de castigo, despreocupándose por la situación de los desvalidos extranjeros. Esto puede verse también en paralelo el pasaje del Facundo en que narra las circunstancias en que escribe la famosa máxima que sus perseguidores no podrán traducir. Sarmiento elige una vez más a la lengua francesa como símbolo de la cultura que los caudillos no comprenden y desprecian en contraposición con su lengua vulgar, llena de incorrecciones, que la norma culta porteña ha decidido condenar.

Por otro lado, Sarmiento deduce que el habla está ligada a roles sociales: si no se maneja un lenguaje determinado no se puede cumplir un determinado rol, e intenta contrastar el hecho de que un general de la Nación no emplee un registro adecuado para dirigirse a sus subalternos. Manuel Alvar, en Lengua nacional y sociolingüística: las constituciones de América describe la relación que se establece en el siglo XIX en América, entre los ciudadanos y el analfabetismo y concluye que a quienes carecían de esta mínima formación les resultaba dificultoso aspirar a la carta de ciudadanía. ${ }^{83}$

En concordancia con estas apreciaciones, en la biografía de Peñaloza Sarmiento persiste significativamente en que el Chacho necesita los servicios de un amanuense, repitiéndolo una y otra vez:

${ }^{81}$ Ibidem, p. 246.

${ }^{82}$ Eric Hobsbawm desarrolla la relación entre el surgimiento de los nacionalismos y la gestación de la lengua como símbolo de lo nacional (Hobsbawm, 1998).

${ }^{83}$ Alvar, 2006. 
Como este estilo y estas ideas embrionarias son comunes a todas las notas del Chacho, deben atribuirse a la rudeza e ignorancia de los tinterillos que escribían con él. $^{84}$

La ausencia de estas mínimas condiciones culturales no sólo lo convierte en un "bárbaro", lo deja en manos de la rapacidad de sus escribientes y lo excluye de una sociedad civilizada. ${ }^{.85}$ Desde la perspectiva de Sarmiento, la ignorancia del Chacho le impide ser un ciudadano de la Nación. ${ }^{86}$ Hacer hincapié en ella también le sirve, desde un criterio clasista, para seguir distinguiendo a las masas montoneras populares de la elite cultural porteña, y no pierde oportunidad de insistir en el tema:

Sin embargo, si no es un señor Gil Navarro que tomó cartas en este movimiento, en todas las provincias a donde se estendió, no hubo manifestaciones escritas ni más racionales ni mas intelijibles que esta, por no haber tomado parte ningun hombre de cierta educacion. Es el movimiento mas plebeyo, mas bárbaro que haya tenido lugar en aquellos paises. $^{87}$

Finalmente, Sarmiento sentencia en el cierre del texto:

Así se ha visto como un bárbaro que no sabe leer, un salteador de caminos, basta para poner en peligro nuestra frágil organización, incapaz por lo mal ajustada de resistir al menor choque. ${ }^{88}$

\subsubsection{El control de los discursos}

\footnotetext{
${ }^{84}$ Sarmiento, 1868, p. 253. Se lee en la p. 220: "Firmaba sin embargo con una rúbrica los papeles que le escribia un amanuense, o tinterillo cualquiera, que le inspiraba el contenido tambien" (ibidem).

${ }^{85}$ En el apartado "Nacionalidad y ciudadanía", destaca Manuel Alvar: "De una u otra forma, nacional es cualquier persona nacida en el territorio del Estado, pero no todos los que poseen la nacionalidad son ciudadanos. Y en esta valoración surgen ya, de nuevo, los problemas lingüísticos. Porque para ser ciudadano es necesario saber leer y escribir" (Alvar M. y B. Pottier, 2006).

${ }^{86}$ Esta aseveración es una respuesta elíptica a los cuestionamientos que se han hecho acerca de la responsabilidad de Sarmiento en el asesinato del Chacho. La estrategia defensiva del discurso de Sarmiento consiste en construir la figura de un "bandido".

${ }^{87}$ Sarmiento, 1868, p. 253.

${ }^{88}$ Ibidem, pp. 317-318.
} 
En la versión que ofrecerá Sarmiento sobre el Chacho se percibe, por otra parte, el cuidado que tiene al reponer su esquema de polarizaciones. Aunque Sarmiento comprende que debe básicamente desviar las miradas sobre su persona y que para ello es imperioso moderar su discurso, no se resiste a desechar su efectiva antinomia e intenta reencauzar la significación original que los términos adquieren en el Facundo, acentuando elementos que antes eran aleatorios en la concepción integral del "bárbaro". Si bien Peñaloza no encarna la crueldad sanguinaria que tan bien construyó en el Facundo, o incluso en la figura de Aldao, no puede permitir que se lo asocie a las cualidades positivas que se le señalan popularmente; el de ser afable, honesto, patriarcal. ${ }^{89}$ Sarmiento no consiente en que estos semas estén del lado del enemigo político y para ello recupera los términos de su tesis, aunque deba forzar sus propias teorías; ahora el Chacho es "bárbaro" porque no sabe leer y porque mantiene vínculos con los indígenas de los Llanos.

Por otro lado, como se ha señalado, todo el abanico de opositores políticos de Sarmiento desde su ruptura con Urquiza, intentará correr el significado de "caudillo" y "barbarie" para enfrentarlo con los creadores, se refieren a la "barbarie ilustrada", a los “caudillos de la pluma" y al "caudillismo oligárquico" para estigmatizar el sesgo caudillista que aprecian en la figura de Mitre y en la del propio sanjuanino. ${ }^{90}$

La producción de sentidos siempre es social y se verifica en los discursos. Esto se detecta con claridad en el modo en que se disputaban los conceptos en la prensa de este belicoso período de la organización nacional. El Chacho no es más que un nuevo capítulo de esta batalla discursiva en la que se muestra que el lenguaje incluye determinaciones poderosas que conducen la interpretación de los sentidos. Sarmiento entiende que aunque el Chacho no comporte todos los semas que conforman el significado de caudillo, al nombrarlo como tal se activarán una serie de determinaciones

\footnotetext{
${ }^{89}$ Por esta misma razón, una vez que Héctor Varela encuentre el poema de Andrade, en 1870, suprimirá las dos primeras estrofas y lo publicará como su hubiese sido compuesto en honor al general Lavalle, según ya se analizó en el apartado 1.3.

${ }^{90}$ Luego Hernández va a querer decir que Mitre también es un caudillo y va a criticar su personalismo. Mariquita Sánchez escribe a Alberdi sobre esto, refiriéndose a Mitre con ironía, como el "caudillo Napoleón".
} 
que sujetarán la interpretación de Peñaloza en el ánimo del público porteño y se aprovecha de esta comprensión para retomar su fórmula tan eficaz. ${ }^{91}$

No obstante, Sarmiento asume que el Chacho tiene alguna excepcionalidad, no es como todos los caudillos porque no es violento, la gente pobre lo aprecia, vive con los suyos y por eso describe un acto de Peñaloza sentenciando con espíritu condescendiente: "algo bueno tendrá este caudillo". Pero entonces, inmediatamente construye para el lector porteño los defectos imperdonables del Chacho; la dejadez en que vive, su inconstancia política, su falta de educación y su ligazón con la tradición indígena de la zona. Le cuenta esto a los orgullosos e intransigentes porteños que lo deben elegir como presidente, porque Sarmiento entiende que los mundos construidos en el lenguaje legítimo son los mundos legítimos y que cuanto más autorizado sea el locutor, mayor capacidad tiene de nominalizar y categorizar el mundo. Sabe que sus palabras crean el mundo social porque se encuentra de la mano del poder, a un paso de su propia presidencia.

\subsubsection{La cuestión del indio}

El posicionamiento de Sarmiento como "civilizado", dueño del "yo civilizador" se sostiene sobre la base de un permanente contrapunto en un texto en el que es, como lo denuncia Alberdi, juez y parte. ${ }^{92}$ Sin embargo, esto no impide que se garantice la recepción afortunada del texto para sus ambiciones políticas. En ese sentido, en El Chacho, último caudillo de la montonera de los Llanos se establece un vínculo muy estrecho entre el antiguo programa anti rosista del Facundo y su actual afición por la educación, en el que nuevamente él es el protagonista. Por un lado, porque con el fin de “organizar la república” hay que suprimir el desorden y la anarquía que significan los

91 Pierre Bourdieu explica que: "Los discursos no son únicamente (o lo son solo excepcionalmente) signos destinados a ser comprendidos, descifrados; son también signos de riqueza destinados a ser valorados, apreciados y signos de autoridad destinados a ser creídos y obedecidos" (Bourdieu, 1985, p. 40). Es evidentemente que Sarmiento, a pocos pasos de la presidencia de la Nación, comprende que su discurso ya es un discurso de autoridad.

${ }_{92}$ En carta a Mitre, en la que se refiere a su tarea como gobernador de San Juan, explicita este esquema personalista:

San Juan, 13 de agosto de 1862

Le agradezco que me haga una política y un papel para mí, que estoy cojo, como se hacen dramas a la talla del actor. La misión providencial que desempeño yo será traer un rayo de civilización al interior, la que preveo es, si todo fuese desquiciado allá, mantener este pedazo de tierra en paz: por aquí no habrá sino bandalaje y destrucción o yo.

(Carta de Sarmiento a Mitre: www.proyectosarmiento.com.ar) 
caudillos del interior y las montoneras mayormente "indígenas". Por otro lado, porque para imponer el proyecto de educación masiva y de estandarización de la lengua también debe enfrentarse con estas figuras que representan el atraso cultural más absoluto; el Chacho no sabe leer ni escribir y habla mal. Sarmiento manipula una estrategia de planificación lingüística que conlleva un criterio de discriminación, de supresión de lo otro, de lo que "no habla como yo", del caudillo inculto y del indígena que tiene otra lengua. ${ }^{93}$

Entonces, para conseguir sus fines políticos, en esta biografía de Peñaloza Sarmiento se encargará de decir que todos los montoneros riojanos son de origen indígena y se tomará el trabajo de detallar las tribus que habitaban la zona, señalándolas una por una, dando sus características y su localización precisa. ${ }^{94}$ El relato comienza señalando que el teatro del último levantamiento del Chacho tiene fisonomía indígena y que los territorios están poblados por "descendientes de la antigua tribu indígena de los huarpes". Luego de puntualizar la existencia de distintas tribus errantes, apunta concretamente a la provincia aclarando: "Pero es en La Rioja misma donde se encuentran rastros más frescos de la antigua reducción de indios", para después analizar los topónimos de pueblos como Nonogasta, Vichigasta, Sañogasta y de otros nombres de origen quichua, además de registrar la presencia de numerosos vestigios de las poblaciones indígenas en Calingasta, así como también de ruinas de cementerios de antiguas y numerosas poblaciones indígenas que habitaron el valle. Este examen minucioso, digno de un antropólogo, ocupa varias páginas del texto e incluye menciones del arte indígena, de construcciones de canales de riego y de muros para la defensa de numerosas ruinas que atestiguan el pasado aborigen del territorio.

Cuando vuelve a concentrar su mirada en La Rioja lo hace para remarcar que era "lo mismo y peor" que ha descrito, ya que allí "los indígenas vivían a la margen de las escasas corrientes y fueron reducidos en lo que hoy se llaman los Pueblos". Y esta

${ }_{93}^{93}$ Calvet, 1997.

${ }^{94}$ Daniel Zalazar presenta otra opinión: "En su biografía de El Chacho muestra interés por los poblados indígenas o mestizos que se encontraban diseminados todavía en la década del 60 en las zonas rurales de La Rioja y noreste de San Juan. Aunque piensa que estos poblados, que eran villas miserables sin tierras aptas para el cultivo, formados a la fuerza por los propietarios de tierras, han desempeñado una función importante en apoyo de los levantamientos montoneros de El Chacho Peñaloza, es decir, en el rebrote de la barbarie y las luchas civiles después de la caída de Rosas, afirma que los verdaderos culpables son los blancos dueños de las tierras, porque han vaciado los campos de seres humanos para poblarlos de animales" (Zalazar, 1986, p. $58)$. 
referencia se relaciona directamente con los sucesos del Chacho, puesto que el relato continúa describiendo:

El coronel Arredondo, que recorrió los Pueblos para someterlos, los encontró siempre en poder de mujeres medio desnudas y solo amenazando quemarlos consiguió que los montaraces varones volviesen a sus hogares. ${ }^{95}$

Es llamativo este enfoque que no se aprecia en el Facundo, siendo que describe la misma provincia. También es extraño si se considera que previamente caracterizó la fisonomía caucásica del Chacho, que era rubio de ojos azules, para luego referirse a él, sin ningún pudor, como un "cacique". ${ }^{96}$ No obstante es categórico cuando explica al respecto:

De estos resabios salió la montonera, pronunciándose al espirar en el movimiento final del Chacho, bajo las formas de un alzamiento de campañas, que bien examinado en sus localidades i propósitos, era casi indíjena, como se verá por los hechos que vamos a referir. Por eso, siempre que usemos la palabra caudillo para designar un jefe militar i gobernante civil, ha de entenderse uno de esos patriarcales i permanentes jefes que los jinetes de las campañas se dan, obedeciendo a sus tradiciones indíjenas, e impusieron a las ciudades, embarazando hasta 1862 la reconstrucción de la República argentina, bajo las formas de los gobiernos regulares que conoce el mundo civilizado $[\ldots] .{ }^{97}$

Este prejuicio racista se enlaza con una de las últimas obras de Sarmiento, Conflicto y armonías de las razas en América, y tiene que ver con los graves inconvenientes que todavía, en 1866, tenían las poblaciones urbanas, fundamentalmente de Buenos Aires y Córdoba, con las invasiones indias. ${ }^{98}$ Lo que propone la lectura del texto es asociar los montoneros a los indios riojanos y los indios riojanos a los indios pampeanos que continuaban flagelando a los porteños. Y el propósito nuevamente es

\footnotetext{
${ }^{95}$ Toda esta descripción étnica ocupa desde la página 224 a la 231, que comprende el apartado titulado "Las travesias".

${ }^{96}$ Sarmiento, 1868, p. 243.

${ }^{97}$ Sarmiento, 1868, p. 224. La cursiva es de Sarmiento.

${ }^{98}$ Sarmiento, D.F. Conflicto y armonías de las razas en América. Buenos Aires, Imprenta de D.Tuñez, 1883, primera edición. Versión digital en: www.proyectosarmiento.com.ar.
} 
político: de este modo Sarmiento señala al indio como el otro gran conflicto irresuelto del país. Es interesante observar, en este sentido, el corrimiento ideológico que se ha efectuado del Facundo hasta El Chacho: en 1845 La Rioja estaba constituida, según Sarmiento, por pueblos esencialmente pastores y los caudillos eran descendientes de familias criollas.

En Conflicto, por otro lado, presentará una estrecha relación entre la situación socio-cultural de los países de Hispanoamérica y su origen racial. Este libro, que publica en 1883, se lo dedica a Mary Mann, la educadora que tanto lo ayudara en sus afanes pedagógicos, e incluye una recomendación a la viuda de Horace Mann en la que habla de su biografía de Peñaloza como antecedente del texto. Dice:

Lea Ud. Vida del Chacho que corre impresa en la edición Appleton de Nueva York al fin de Civilización y Barbarie, y encontrará Ud. los primeros barruntos de la idea que he desenvuelto en este libro, generalizando a toda la América lo que aquí transcribo. ${ }^{99}$

Incorpora seguidamente unas líneas de la obra en la que comenta los ascendentes aborígenes de la zona, muchos deducidos de los topónimos y de los “apellidos Chiñinca, Juaquinchai, Chapanai [que] están acusando el origen de la lengua primitiva de los habitantes". ${ }^{100}$ De este modo se hace muy clara la impronta racista que su última biografía sobre caudillos estaría presentando.

En Hablar y callar, Peter Burke trabaja lo que él llama su última tesis:

La de que hablar constituye una forma de hacer, que la lengua es una fuerza activa dentro de la sociedad, un medio que tienen individuos y grupos para controlar a

\footnotetext{
${ }^{99}$ Conflicto y armonías de las razas en América, versión digital, p. 8.

${ }^{100}$ En Conflicto y armonías de las razas en América Sarmiento explica: "Pero fue en San Juan, como lo anuncia la Vida del Chacho, donde empecé a fijarme en la influencia de las razas en la América del Sur, y en el espíritu distinto que las caracteriza; y tomando cada días más cuerpo e intensidad esta preocupación, me ocurrió que debía releer la historia y aún la redacción verbal de los sucesos, para ver las sustituciones y cambios, esclarecimientos y reflejos que ofrecería, mirándola a la luz de esta nueva antorcha" (Versión digital en www.proyectosarmiento.com.ar, p.12).
} 
los demás o para resistir a tal control, un medio para modificar la sociedad o para impedir el cambio, un medio para afirmar o suprimir identidades culturales. ${ }^{101}$

Estas apreciaciones pueden aplicarse a El Chacho y a su proceso de producción. Al señalar como "bárbaro" a un tipo social, al caudillo, al hombre de campo, al montonero, al indígena, Sarmiento y el programa liberal que se encarna en su tesis binaria y que va a signar el período de "organización nacional”, intentan suprimir esas identidades culturales, que en el caso del Chacho se resignifican en el ignorante que no sabe leer, escribir, ni hablar correctamente, y en el indígena que tiene una lengua primitiva.

En una preocupación que se registra desde los primeros años del Salón Literario de Marcos Sastre de 1837, la generación de intelectuales patriotas, entre los que se encuentra Sarmiento, ha pensado ya en la configuración de un idioma nacional que deseche el lenguaje anacrónico español para adquirir los conceptos modernos de las lenguas francesa e inglesa. Este anhelo, que es el que seguirá persiguiendo Sarmiento, es en definitiva el de una:

[...] lengua (y no lenguaje, o habla o idioma) abstracta y homogénea, objeto de acción política (de perfeccionamiento, tarea reservada a la elite intelectual) construido según el patrón de la lengua escrita, que por lo demás, constituye la variedad de uso exclusivo de la clase ilustrada. ${ }^{102}$

Por ello se deduce que el proyecto linguiístico de Sarmiento será forzosamente exclusivista. Se desprecia al sociolecto rural con el deseo de regir el habla de "sociedad civilizada" que se intenta forjar desde principios liberales para definir quiénes, cuánto y cómo pueden hablar estos agentes sociales y mostrar cómo se pretende determinar, con evaluaciones y prejuicios, una actitud lingüística diferente. ${ }^{103}$ Sarmiento propone en $E l$

\footnotetext{
${ }^{101}$ Peter Burke continúa desarrollando esta tesis: "Lo que hay que afirmar es que la historia social del lenguaje, lo mismo que otras formas de historia social, no puede divorciarse de las cuestiones de poder" (Burke, 1996, p. 38).

${ }^{102}$ Varela, 1999, p. 39.

${ }^{103}$ Otra referencia al sociolecto del paisano argentino que trasluce el prejuicio puede verse en la página 107 de El Chacho en donde Sarmiento dice que éste "habla" con la "compostura y calma imperturbable del indio".
} 
Chacho que estas variedades pertenecen a lenguas primitivas de identidades primitivas que deben superarse en nombre del progreso.

Sin embargo, la proscripción de los dialectos del interior del país vehiculizada por un programa de estandarización exclusivista no se interrumpió con la entrada masiva de otras lenguas como la de los inmigrantes italianos, ingleses o franceses, porque estas otras lenguas eran las lenguas de prestigio para la política liberal. Muriel Saville Troike en La etnografía de la comunicación plantea la relación entre la lengua y la identidad y sostiene que la lengua sirve frecuentemente para mantener identidades diferentes. ${ }^{104}$ Puede deducirse que Sarmiento tuvo en cuenta estos criterios en la composición de El Chacho y que los empleó a favor de su causa ante la necesidad de ofrecer un discurso proselitista efectivo.

\subsection{Respuesta de Sarmiento a sus acusadores}

En una época de enconados enfrentamientos políticos internos en la que subsisten guerras civiles de consecuencias sangrientas, se descuenta la atenta lectura de "todas" las publicaciones de contenido político editadas por "el enemigo"; particularmente, la lectura por parte del bando que ejercía el poder político y podía disponer de un mayor número de "informantes" en las principales ciudades del país y de la Banda Oriental; casi todos los epistolarios de ese violento período de nuestra historia que se han editado recogen pruebas acerca de ese tipo de circulación informativa. ${ }^{105}$ Consecuentemente, los alegatos a favor del Chacho publicados por diarios de Montevideo y Paraná no podían ser desconocidos por un hombre que vivía pendiente de todo tipo de información; ${ }^{106}$ por otra parte, Sarmiento ya era probado antagonista de Calvo y de Federico de la Barra, seguramente conocía a Olegario V. Andrade -al menos como secretario privado de Derqui-, y hasta es posible que su memoria privilegiada hubiera retenido ya el nombre de un novel redactor llamado José Hernández que en 1860 había debutado en el periodismo político desde las páginas de El Nacional

\footnotetext{
${ }^{104}$ Saville Troike, 2005, p. 31.

${ }^{105}$ En los epistolarios citados en 7.1.1. y 8.2. se registran numerosos ejemplos.

${ }^{106}$ La copiosa correspondencia privada (édita e inédita) de Sarmiento testimonia su avidez por obtener información.
} 
Argentino. A pesar de que no hemos podido corroborar menciones expresas de las notas de El Argentino en los medios periodísticos porteños que tocaron el tema de la reacción del diarismo del Interior ante la muerte del Chacho, Sarmiento tuvo que saber de la existencia de esos furibundos ataques a su actuación, en los que se lo acusaba, como se dijo, de haber sido el instigador e incluso el máximo responsable del asesinato del Chacho; ${ }^{107}$ por otra parte, el folleto de Paraná ha tenido repercusión en los periódicos del interior y ha contribuido a gestar una actitud crítica más generalizada. Pero fundamentalmente, es su decisión de publicar otra biografía del Chacho y las formulaciones que -en el marco del intertexto examinado- se convierten en reconocibles "respuestas", lo que nos permite afirmar la existencia de una auténtica “interacción polémica" vehiculizada en una práctica altamente politizada del discurso biográfico. $^{108}$

Sin embargo, la decisión de escribir esa biografía se inscribe, como se señaló a propósito de Sarmiento, en un contexto de situación tan complejo, que es imposible establecer un único factor desencadenante para su redacción. Y justamente, los principales teóricos de la corriente denominada "crítica genética" insisten en destacar, frente a la multiplicidad de datos con los que suelen enfrentarse quienes analizan archivos escriturales, que el proyecto mental que ha precedido un proceso creativo resultará siempre inaccesible para el investigador: sólo es posible reunir testimonios, analizarlos, y a partir de ese examen formular hipótesis lo más consistentes que sea posible pero siempre probabilísticas.

Un nutrido epistolario de la época testimonia que Sarmiento vivió el episodio del Chacho casi como una "apuesta personal", como un enfrentamiento entre sus ambiciones políticas y la posibilidad concreta de llevarlas a cabo, que él consideraba demoradas por los alzamientos del Chacho. ${ }^{109}$ Todos los sectores políticos del país

${ }^{107}$ En esta línea acusatoria, la biografía de Hernández es la única absolutamente explícita. Cuando Barra escribe su nota biográfica, el Chacho aún vive, y en el poema de Andrade, la responsabilidad sobre su asesinato se difumina en una referencia anónima al "déspota porteño" (que incluso pareciera, más bien, aludir a Mitre).

${ }^{108}$ La continuación de esta interacción polémica después de la republicación de la biografía del Chacho que emprende José Hernández en 1875 confirma esta línea interpretativa.

${ }^{109}$ La importancia que Sarmiento le adjudicaba a la lucha contra Peñaloza y los demás caudillos del interior se advierte en su correspondencia con Mitre y su ofrecimiento de ser en San Juan el representante del gobierno nacional no está desconectado de ese propósito. En la carta del 18 de noviembre plantea con lucidez política el esquema de poderes que se medirán en la zona: "Mi idea política es que alguien de buena estampa pasee el nombre de Mitre por el interior, que 
conocían esta situación y se mantuvieron expectantes ante este "duelo" entre Sarmiento y el plan civilizatorio liberal y el movimiento sedicioso de los llanistas. ${ }^{110}$

\subsubsection{Repercusiones porteñas}

No solamente el interior se conmociona, en la capital portuaria la noticia del asesinato se desparrama con rapidez. Según lo describe Carlos Heras, los tres órganos más importantes de la ciudad - El Nacional, La Nación Argentina y La Tribunareproducen la novedad en varias notas a lo largo de muchos días. ${ }^{111}$ Los tres periódicos liberales aprueban la muerte del caudillo. No obstante, Heras registra que El Nacional no deja de publicar una "solicitada" sin firma en la que se hace un análisis bastante objetivo de la actuación del Chacho y de las montoneras llanistas. Heras sugiere la posibilidad de que el autor de la solicitada sea Félix Frías, José Mármol o Norberto de la Riestra considerando el tenor de las cartas que cada uno de ellos dirigió a Mitre, en las que se vislumbra cierto cuestionamiento al modo en que el nuevo presidente está encauzando su proyecto de organización.

Pero en contraposición con el tono de esta solicitada, la mayoría de los diarios de la provincia celebra la muerte del caudillo "bárbaro" que mantenía al país en estado de alerta retrasándolo en el camino de la civilización. Se insiste en la idea de que la desaparición de Peñaloza garantiza la entrada a una era de progreso, educación, cultura y que la extinción de la montonera permitiría alcanzar la paz definitiva de la Nación. El Nacional -que ahora dirige Carlos D’Amico, futuro gobernador de Buenos Airesaplaude la noticia de su muerte. La Nación Argentina -de hecho, el periódico oficial de

alguna fuerza de Buenos Aires se mezcle en las cosas de las provincias: que los gobiernos liberales, puedan escoger oficiales amigos, y unos pueblos se pongan en contacto con otros en estos negocios. Mi presencia sería sólo para dar dirección constitucional al negocio, darle a mi San Juan libertad, y organizar tocando las cosas de cerca, el gobierno y las minas. Las minas, hacer producirse diez, quince millones de duros de ellas en cuatro años, he aquí la grande empresa que empieza a preocuparme desde ahora. Hay paño en los minerales, para fundar una industria inmensa".

${ }^{110}$ En su correspondencia con Mitre, son numerosas las cartas en las que Sarmiento se refiere al papel que adjudica al Chacho. Desde el 22 de junio de 1861 hasta la pieza del 3 de diciembre de 1863, precedida por una de noviembre (aunque sin fechar) en la que le da la noticia de la ejecución y otra del 23 del mismo mes, le habla sobre el tema en numerosas cartas: en 1862, el 3 y 4 de abril, los días 10, 22 y 28 de mayo, 3 y 20 de junio, 19 y 31 de julio, 13 de agosto, 11 de noviembre y 28 de diciembre; en 1863, los días 22 y 24 de enero, 29 de marzo, 7 y 22 de mayo, 5,11 y 25 de junio, 18 y 27 de agosto, 3,11 y 24 de septiembre, 8 de octubre.

${ }^{111}$ Heras, 1958, pp. 106-126. 
Mitre- se encarga de dar detalles militares del suceso, y La Tribuna-que tiene al frente a los hermanos Varela- se suma al coro celebratorio.

Heras registra más de una veintena de artículos en estos tres órganos, que se suceden desde el 25 de noviembre hasta el 10 de diciembre, enfocando diferentes aspectos de la noticia. El 25 de noviembre, la primera información sobre la muerte del Chacho aparece simultáneamente en los tres periódicos como cable de último momento. Los recursos gráficos (mayúsculas y negrita) resaltan la importancia que se le dio a la noticia:

\section{IMPORTANTÍSIMO. DERROTA Y MUERTE DEL CHACHO ${ }^{112}$}

\section{IMPORTANTÍSIMO!! DERROTA Y MUERTE DE PEÑALOZA (a) CHACHO ${ }^{113}$}

Por su parte, El Nacional editorializó sobre la novedad bajo un título inequívoco:

\section{LA PAZ DE LA REPÚBLICA.}

Los distintos medios relatan la sorprendente captura y muerte del escurridizo caudillo, pero se distinguen matices discursivos: La Nación Argentina comenta con serenidad que "la montonera ha desaparecido. La paz de la República está afianzada" mientras transcribe a continuación 11 documentos en los que predominan los partes oficiales que intercambiaron Irrazábal, Vera, Sarmiento, etc. En La Tribuna, con más exaltación, se refieren al Chacho como un "célebre montonero", un "caudillejo", que “pagó con la vida la tenaz resistencia y los saqueos y crímenes”. En El Nacional parece escucharse la voz de Sarmiento cuando, en una nota más extensa, se define al Chacho como: "un hombre semisalvaje y sin genio y hasta sin valor personal", "de los tipos fantásticos del desierto", "último vestigio del gaucho bárbaro", y "vínculo vergonzoso [con] nuestro triste pasado".

Ante lo sorpresivo de la noticia, la euforia es la primera reacción de la mayoría de los porteños al ver superado el escollo de La Rioja y los periódicos la reflejan con

\footnotetext{
${ }^{112}$ La Nación Argentina, Buenos Aires, 25 de noviembre de 1863.

${ }^{113}$ La Tribuna, Buenos Aires, 25 de noviembre de 1863.
} 
exclamaciones de júbilo ("hurrah pues, al general Paunero y a los demás bravos”), las reiteradas felicitaciones al gobierno por "esta nueva feliz", las propuestas de ofrecer "un buen regalo al chasque y al mismo tiempo se le dé un grado militar o un ascenso" por la "feliz noticia" haciendo extensivo el agradecimiento a los militares que participaron de la captura -Irrazábal y Vera-, que "se han hecho acreedores de la gratitud del país". En El Nacional, siempre más pasional, se repite la noticia al día siguiente "con el corazón latiendo de esperanza".

No obstante, a pesar del clima general de celebración, el 26 de noviembre $L a$ Tribuna y La Nación Argentina comienzan a manifestar sus reservas respecto de la forma en la que se terminó con la vida del caudillo. La Tribuna deja caer una tímida objeción: "si como se nos dice, él ha sido pasado por las armas sin forma de proceso, [el Gobierno Nacional] no aprobará el hecho". Y en los días subsiguientes irá siendo más explícita al respecto: “el gobierno de la República, que es un gobierno de principios, no podía aprobar la muerte del caudillo que implicaba una violación a las leyes”, y al observar que los partes son un poco confusos, pide "que se levanten instrucciones". En otra nota manifiesta la necesidad de que el gobierno se exprese con urgencia en contra "del derramamiento de sangre", y luego de que esto sucede, aplaude el decreto de Mitre en el que se "ha condenado ese fusilamiento" y se desaprueba el hecho que "importa la violación de todo principio y arroja una sombra sobre el gran triunfo que ha alcanzado la República". La Nación Argentina también reprueba el asesinato ("hemos debido guardar los principios") y reproduce con satisfacción el decreto de Mitre que sentencia que "nadie ha debido ni podido ejercer sobre él atribuciones y prerrogativas exclusivas de los Tribunales".

Pero El Nacional, a diferencia de los otros dos periódicos que no están dispuestos a aprobar públicamente un asesinato, ya se había manifestado en la orilla opuesta el mismo 25 de noviembre, al sentenciar que "no puede haber inmoralidad en quitarle la vida" a Peñaloza,. Esta posición no se atenuará con el correr de los días, como se observa en los otros dos periódicos que se muestran sensibles al asesinato, y sin hacer ningún tipo de revisión, El Nacional mantendrá su opinión y el 30 de noviembre reiterará su dureza al referirse a ese "bandido denodado" después de transcribir unas líneas de La Reforma Pacífica de Montevideo. Continúa, entonces, oyéndose aquí la voz de Sarmiento, ya que además de recuperar su valoración del 
caudillismo se retoman los conflictos que mantuvo con Nicolás A. Calvo -el mentor del partido de La Reforma Pacífica-, que ha defendido la causa del Chacho: "Sólo Calvo podía llamar a ese bandido denodado, campeón de la igualdad, bravo soldado de la libertad".

A pesar de los reparos esbozados, La Tribuna de los Varela coincide en la “determinación de opositores" y lleva a cabo una minuciosa indagación sobre las reacciones exaltadas que el acontecimiento suscita en el resto del país y en el país hermano. Individualizan y describen a quiénes se preocuparon por la muerte del Chacho. Denuncian que El Litoral de Paraná, de Evaristo Carriego, "viene de luto y lanzando diatribas". Censuran que se haya realizado en Montevideo un funeral en homenaje al caudillo encabezado por Derqui, Federico de la Barra y Nicolás A. Calvo. Después de transcribir la crónica del funeral que Federico de la Barra publica en $E l$ Comercio de Montevideo en la que se enumera a las personalidades que participaron, Héctor Varela cierra la nota preguntándose con ironía: “¿Qué otra cosa que un mártir ha de ser para esos personajes el malvado caudillo?"114

En otras secciones de los órganos porteños dedicadas al resto del país -como “Opinión de las provincias" e "Interior"- se recoge la información de los periódicos El Zonda de San Juan (cuyo autor podría ser el propio Sarmiento) y de El Riojano de La Rioja, ambos defensores de la posición centralista. ${ }^{115}$

Pero haciendo un balance del panorama periodístico, se advierte que la sociedad porteña no lamentó la muerte del caudillo pero rechazó el proceder violento de sus matadores; por eso Mitre debió intervenir con rapidez para distanciar la participación de su gobierno de los excesos violentos que terminaron en el asesinato del Chacho. ${ }^{116} \mathrm{El}$

\footnotetext{
${ }^{114}$ En el corpus periodístico que hemos podido revisar, no se menciona a El Argentino de Paraná

${ }^{115}$ Para completar el panorama acerca del abanico periodístico porteño y la atmósfera general de su recepción, se puede agregar que el "periódico satírico-burlesco" El Mosquito (que desde el 24 de mayo de 1863 retrataba con perspicacia y humor los principales acontecimientos del país y cuyos retratos caricaturescos se hicieron muy famosos) tocó el tema de la actuación del Chacho en los números 6 y 20 (28 de junio y 4 de octubre de 1863); pero posteriormente, no se registraron recriminaciones de la actuación de Sarmiento. Al respecto, este medio fue consecuente con la predilección que mostró más tarde por él, a quien tuvo como personaje principal de sus tapas durante toda su presidencia y a quien jamás dejó de lado. Ver $E l$ cumpleaños de El Mosquito, 1964.

${ }^{116}$ Puede observarse ese proceso en la correspondencia entre Sarmiento y Mitre. A partir del 23 de diciembre de 1863 comienza Mitre a reprochar la forma en que se produjo la muerte del Chacho, aunque valiéndose de ambigüedades políticas:
} 
hecho provocó, además, una serie de polémicas sobre temas institucionales, y en relación con ellas, una cuestión que se consideraba crucial para mantener el equilibrio de la recién obtenida integridad nacional, como lo fue la ley de estado de sitio. Sobre este punto discutieron con especial denuedo Guillermo Rawson -ministro del Interior de Mitre- y Sarmiento, ambos oriundos de la provincia de San Juan. Es evidente que estas revisiones de la actuación del ejército nacional se originan y responden a un cuestionamiento generalizado.

En suma, la opinión pública obliga a Mitre a adoptar medidas políticas y además de emitir su decreto condenatorio, encomienda a Sarmiento un viaje diplomático a los Estados Unidos con el fin de alejarlo temporariamente de la provincia de Buenos Aires y del país. ${ }^{117}$

\subsubsection{Sarmiento "candidateándose" en 1866}

Sarmiento parte para Chile en 1864 y, de allí viaja a los Estados Unidos. Como se ha analizado en el apartado anterior, se pone inmediatamente en contacto con la viuda del educador Horace Mann y estrecha un vínculo que le asegurará su inserción en ese país mediante el conocimiento de sus grandes personalidades políticas y culturales y su proyección política personal, pues Mary Mann actuó, a su vez, como relacionista

Buenos Aires, 23 de diciembre de 1863. Señor gobernador don Domingo F. Sarmiento. Mi querido amigo:

Recibí su apreciable carta fecha 18 del próximo pasado, de la que me impuse con mucho placer, por las interesantes noticias que me transmitía acerca del lisonjero estado en que entraba esa provincia, después de la destrucción de los restos de las montoneras de La Rioja y muerte del Chacho, sucesos en los que me es agradable declarar para su satisfacción, corresponde a usted una parte por sus acertadas medidas militares que contribuyeron a preparar y producir tan satisfactorios resultados. Por lo que respecta a sus apreciaciones sobre la muerte del Chacho, bajo las circunstancias en que tuvo lugar, aun cuando comprendo la exactitud de sus vistas, y todo el bien que ella ha de traer para la conservación del orden y la paz, puesto que esas masas tan poco civilizadas de La Rioja han visto con sus propios ojos postrado y muerto a su caudillo, sin embargo no he podido prestar mi aprobación a tal hecho, nuestro partido ha hecho siempre ostentación de su amor y respeto a las leyes y a las formas que ellas prescriben, y no hay a mi juicio un solo caso en que nos sea permitido faltar a ellas, sin claudicar de nuestros principios. Pero habiendo entrado éste en la categoría de los hechos consumados, y salvada como ha quedado la responsabilidad moral del gobierno, no hay más remedio que recoger las ventajas que él nos ofrece para la completa pacificación de La Rioja, y para la tranquilidad de las provincias colindantes, que pueden entregarse ya libres de toda zozobra a su adelanto y prosperidad.

Ver www.proyectosarmiento.com.ar

${ }^{117}$ Ya en razón de los disgustos que le deparaban los alzamientos y demás dificultades del gobierno de San Juan, Sarmiento había considerado con bastante anticipación la posibilidad de irse en comisión al exterior y su correspondencia con Mitre lo confirma (Campobassi, 1972, II, p. 19). 
pública y promotora de Sarmiento: tradujo sus libros al inglés, lo hizo invitar a dar conferencias y lo conectó con las universidades más prestigiosas.

Con este nuevo impulso Sarmiento se fortalece y revitaliza sus postulados para encauzarlos definitivamente en su campaña presidencial. El viaje a Estados Unidos "lo confirma en su propósito colonizador dentro de la Argentina: la lucha debe darse no sólo con la guerra; debe darse con la letra, se hará contra el saber nativo y contra su voz". ${ }^{118}$ Y con esta idea retoma las penurias vividas en San Juan, que lo enfrentaron de modo contundente con las limitaciones prácticas que ofrecía el país para la consecución de sus objetivos, pero ahora lo hace desde una mira proselitista.

Desde esta perspectiva redacta, en 1866, la biografía que le permitirá insertar su análisis del episodio de Peñaloza, que simboliza - para él- el "último" obstáculo que se interponía en sus planes civilizatorios, y desde un punto de vista personal, el "último" opositor a su candidatura presidencial. Pareciera que éste es el fondo en el que diseña su texto; busca convertirlo, así, en el epílogo de su propia epopeya, la coda de una vida dedicada al país, a la lucha obsesiva contra la barbarie, contra el atraso y la ignorancia. Esta mirada de Sarmiento se reconoce en la correspondencia que mantiene en estos momentos con Mitre, en la que enlaza sus textos con su proyecto pedagógico; y en conexión con este tema, no se priva de criticar el reconcentramiento en sí mismos de los porteños, que sólo salen de su entorno para mirar la producción de los grandes polos culturales: desconocen su obra pedagógica y sólo se interesan en ella cuando se enteran de que se está difundiendo en el exterior. ${ }^{119}$

\footnotetext{
${ }^{118}$ Montaldo, 2004, p. 74.

${ }^{119}$ En carta a Mitre del 28 de junio, desde el Lago Oscawana (Nueva York) anuncia que está componiendo El Chacho, último caudillo de la montonera de los llanos (aunque desconocemos si ya ha elegido este título):

Escribo una sucinta biografía del Chacho, para engrosar y completar la de Quiroga que hago reimprimir. La de Lincoln va por la tercera edición que se hará luego, para proveer a la demanda que de ella hacen de Habana, Centro América, Curaçao, etc. De Buenos Aires me escriben que hay poca esperanza de colocar doscientos ejemplares, en pueblo tan audaz para sostener doctrinas de su invención, y que sin embargo no tiene el pobre niño precoz el hábito de leer nada ni bueno ni malo. Mi país en los presupuestos de distribución de los libreros para colocar sus ediciones, figurará como Santiago en Chile, que tenía número inferior a Copiapó y Valparaíso; por la misma causa, la propia suficiencia, por lo que no supieron que se había publicado en Chile el Facundo sino cuando se lo avisaron de Francia. Veo que en Buenos Aires están leyendo recién mis Viajes de 1847, y que yo releo ahora, y me enorgullezco de haberlos escrito. Hasta la hora del apogeo norteamericano pude señalar entonces, ¡veinte años con previsión astronómica! Esto resarce con usura de muchos desencantos, en la difícil tarea de aleccionar pueblos mal educados.
} 
El 27 de junio de 1866, Mary Mann le envía una carta donde confirma la recepción del manuscrito de la biografía del Chacho, de la que se deduce que, además de su opinión, espera que le consiga un editor. ${ }^{120}$ De hecho así sucede porque la primera publicación de esa biografía se imprime en los Estados Unidos en el mismo volumen que una nueva edición del Facundo, que Mrs. Mann ayuda a corregir. ${ }^{121}$ Barry Velleman, el compilador de las cartas de Mann, anota entre corchetes, al referirse a esta misiva, que Sarmiento "le había enviado a Mary Mann los dos primeros capítulos", la biografía de Aberastain y "algunas notas biográficas de sí mismo", lo que ratifica el vínculo indisoluble que existe en estos textos entre obra literaria y actividad política autopropagandística. $^{122}$

\subsubsection{El Chacho, último caudillo de la montonera de los llanos como respuesta}

\section{recontextualizada a las acusaciones de José Hernández}

Si bien este texto aporta una respuesta implícita a las acusaciones de Hernández, resulta evidente que Sarmiento -en esta etapa de su trayectoria vital- no sólo se ha propuesto rebatir al autor del folleto de Paraná, sino también atemperar el rechazo de la opinión pública ante los excesos cometidos en la represión de las montoneras; pero sobre todo, su autodefensa deberá sumarse a la exhibición implícita de una programática y de una capacidad para ponerla en práctica dignas de un futuro presidente de la República.

En un momento histórico en que la mayoría de los porteños ha visto en Peñaloza el "último" obstáculo para el inicio de la nueva etapa que comienza con la Nación reunificada, que sea justamente el autor del Facundo quien decida componer su

\footnotetext{
${ }^{120}$ La breve misiva de Mrs. Mann dice "Le envié una carta a Peeksill \& Lake Oscawana. Tal vez no sea la manera correcta, por lo tanto envío ésta a Nueva York. Estoy aguardando para enviarle el manuscrito sobre Chacho y las travesías pero temo correr riesgos con ellos. Por favor envíeme instrucciones" (Citada en Velleman, 2005, p. 124).

${ }^{121}$ Sarmiento, D. F. Facundo; civilización i barbarie en Las Pampas Arjentinas. Nueva York, D. Appleton y compañía, 1868. Se la identifica como "cuarta edición en castellano" (lo que hace evidente que Sarmiento está considerando como edición príncipe la publicación por entregas en el diario El Progreso de Santiago de Chile); además, introduce un cambio en el título que llevaban las ediciones de 1845 y 1851 (Civilizacion i barbarie. Vida de Facundo Quiroga, $i$ aspecto físico, costumbres $i$ hábitos de la República Argentina). El Chacho, último caudillo de la montonera de los llanos-Episodio de 1863 ocupa las páginas 217-318. En adelante tomamos las citas de esta $1^{\text {a }}$. edición. Respetamos la puntuación y ortografía original.

${ }^{122}$ Velleman, 2005, p. 123
} 
biografía, anticipa una voluntad de coincidencia con esa "opinión pública". La imagen del Chacho que construya en ella se opondrá ostensiblemente a la de José Hernández.

Pero Sarmiento no sólo está adscribiendo al género: el subgénero autodefensivo, que él había inaugurado brillantemente en Mi defensa, está presente en el subtexto. De todas maneras, evitará con astucia las marcas del discurso autobiográfico (como el uso de la $1^{a}$ persona), y al diluirse como contrincante político, su texto se convierte en un compuesto híbrido, de difícil catalogación, en el que se enfrentan amagos autobiográficos con el denodado esfuerzo por reprimirlos.

Como se ha dicho, es la elección del género autobiográfico uno de los rasgos que permiten deducir que esta nueva versión de la vida del Chacho interactúa polémicamente con el folleto de Paraná, esa pieza apasionada que no encubre su naturaleza panfletaria; sin embargo, cuidándose de replicar con exaltación, también toma distancia de esa mirada con una sutileza que se reiterará en el manejo de diferentes estrategias discursivas. Así, lejos de exhibir una postura confrontativa, el autor, construye una escenografía como marco de un relato en el que habla de sí mismo como “el coronel Sarmiento" o mediante el empleo de elipsis que atenúan el conflicto y logran desviar la trama para evitar un choque frontal entre un "yo" civilizatorio y un "tú" bárbaro -puja a la que Sarmiento nos tenía acostumbrados-; el relato intenta crear apariencia de objetividad y va encadenando hechos y describiendo circunstancias paralelas que atenúan la responsabilidad única del que se había jactado de ser el garante impar del operativo y el político más idóneo para enfrentar a todos los caudillos del país. $^{123}$

A partir de esta treta bien identificada por Alberdi, ${ }^{124}$ la estrategia narrativa busca distanciarse de los hechos violentos concretos y Sarmiento pretende mostrarse como un personaje más de este trozo de historia del país, que en medio de la barbarie puede incluir episodios heroicos y grandiosos, como el de la descripción del cruce de la

\footnotetext{
${ }^{123}$ En este sentido es muy ilustrativa una carta de Sarmiento a Mitre (San Juan, 13 de agosto de 1862) en la que le agradece la posibilidad que éste le ofrece de intervenir en los desórdenes que suscita Peñaloza: "Le agradezco que me haga una política y un papel para mí, que estoy cojo, como se hacen dramas a la talla del actor. La misión providencial que desempeño ya, será traer un rayo de civilización al interior, la que preveo es, si todo fuese desquiciado allá, mantener este pedazo de tierra en paz: por aquí no habrá sino bandalaje y destrucción o yo".

${ }^{124}$ Alberdi define al texto como "un alegato de bien probado, la relación de un pleito", y luego agrega: "Se necesita no respetar al público para darle a leer tal escrito como digno de él" (Alberdi, 1897, V, p. 307).
} 
cordillera. En este momento Sarmiento da vuelo a su maestría literaria; la majestuosidad de los Andes enmarca el paso obligado para todos los exiliados políticos de esa región, entre los que él también se cuenta. De este modo, el texto vuelve a cruzar de manera sesgada el relato autobiográfico, pues Sarmiento narra el paso desde su propia experiencia, no desde la mirada del Chacho. Esa descripción cumple la función de desviar la atención desde el personaje del Chacho hacia un sujeto plural; Sarmiento y todos los exiliados que debieron huir a Chile y a otros países vecinos en busca de refugio durante la tiranía rosista. Así, el heroísmo que Sarmiento parece reconocerle al Chacho no es tal, sino una excusa para aludir a su propia hazaña, a su sacrificio personal por el país y a su denodada lucha en contra de la tiranía; sus estrategias discursivas buscan difuminar su responsabilidad en los hechos violentos que terminan con la vida del caudillo.

\subsubsection{Interacción polémica con Rasgos biográficos del General D. Angel V. Peñaloza}

La interacción polémica que El Chacho, último caudillo de la montonera de los llanos de Sarmiento entabla con Rasgos biográficos del General D. Angel V. Peñaloza de José Hernández se vertebra en dos parejas de opuestos: se contraponen ahora sendos núcleos narrativos destinados al ataque de un personaje político en ascenso, dos formaciones discursivas destinadas a su autodefensa.

Recordemos que la agresión de Hernández se había valido de fuertes impactos emocionales: la construcción de la figura idealizada de la víctima de un asesinato político (un patriarca venerable, generoso y justo) y la determinación de un culpable que se revela como "un bárbaro de la política" en una argumentación que se vale de la misma estrategia discursiva que había utilizando Alberdi en las Quillotanas (una reversión argumentativa, a partir de la tesis del Facundo, para acusarlo de ser "un gaucho de la pluma").

A su vez, la defensa de Sarmiento se fundamenta en la construcción de otra figura del Chacho (que se identifica con otra "barbarie") y en su autorrepresentación como "civilizador" (con alusiones a su trayectoria y a su condición de autor de propuestas que le dan el estatuto de "pensador y constructor de la Nación"); pero además, para esgrimir su autodefensa, busca apartarse ostensiblemente del discurso 
panfletario de la Campaña y de Las ciento y una (y también del folleto de Hernández), lo que permite advertir que -a la par que polemiza y "guarda rencores"- sabe asimilar las críticas a una conducta y un desenfado expresivo que provoca, ciertamente, varios rechazos. También reprimirá ostensiblemente esa omnipresencia del yo ridiculizada en las Quillotanas.

Por otra parte, la tensión que se deduce del empleo del texto como promoción de su candidatura presidencial (mediante un discurso proselitista dirigido exclusivamente a los porteños en el que combina reflexiones sobre el desarrollo industrial del país, la actividad solidaria en Mendoza, etc.) y a su vez como autodefensa de acusaciones (debe responder a Hernández, a Alberdi, a Rawson, etc) conduce a la desarticulación narrativa. La obra no presenta una estructura orgánica, hay permanentes puntos de fuga que tienen que ver con la policausalidad de este proceso escritural que alterna, en una sucesión caótica, las intenciones proselitistas, luego justificativas, a veces polémicas. Sin embargo el cierre está logrado con una imagen que recupera el sentido y lo relaciona con el Facundo estrechando sus vínculos indisolubles.

El principal contrapunto que establece con los Rasgos biográficos de Hernández se sostiene sobre la demolición de la estatura heroica del Chacho. Este Chacho es un antihéroe: "Ni aún la simple curiosidad merece hablar de su origen". ${ }^{125}$ No tiene calidad militar: "fue derrotado siempre que alguien lo combatió, sin que se sepa en qué encuentro fue feliz; pues de encuentros no pasan nunca sus batallas"126 y tal es su insignificancia y mediocridad que "la mente se abisma buscando la atracción que ofrecía sobre sus secuaces". ${ }^{127}$ No aspira a la gloria: "A pocos hombres ha hecho morir, [...] pero millares han perecido en sus desórdenes". No tiene tampoco virtudes morales; sirve a cualquier poder sin lealtad política, va con quien lo llama: "Su papel, su modo de ganar la vida, digámoslo así, era intervenir en las cuestiones y conflictos de los partidos, cualquiera que fuesen, en las ciudades vecinas". ${ }^{128}$ Para Hernández era un caudillo que estaba atento a la construcción de la nacionalidad, para Sarmiento sólo es un confuso montonero acomodaticio. El episodio en el que Hernández destaca que Urquiza lo nombra general de la Nación, Sarmiento lo recupera pero lo enmarca en un gesto de

\footnotetext{
${ }^{125}$ Sarmiento, 1868, p. 220.

${ }^{126}$ Ibidem, p. 222.

${ }^{127}$ Ibidem, p. 222.

${ }^{128}$ Ibidem, p. 222. La cursiva es de Sarmiento.
} 
desprecio de Urquiza que sólo lo hace "para dejarlo tranquilo en su casa" y luego señala "la poca importancia que se daba a este caudillejo en el Litoral". ${ }^{29}$

La imagen del Chacho que construye se ajustará a otra perspectiva: analfabeto, bandido, vándalo montonero que demora la organización definitiva de la Nación; una rémora de la rusticidad política colonial que perturba la entrada del país en una etapa de revolución social y política modernizadora. Al despojarlo de la talla épica que le había otorgado Hernández, el Chacho pasa a ser sólo un "perturbador", un cobarde que "huye, huye, huye", un "depredador" que molesta con sus "correrías", un "oscuro cabecilla sin ideas, sin periódicos" y cuyas batallas no tienen "brillo", un "plebeyo" y en una escalada de agresividad: "un ebrio estólido". 130

Sin embargo, con un evidente fin proselitista, Sarmiento asume una mirada condescendiente novedosa. Debió entender que la defensa de Hernández y la reacción periodística que suscitó la muerte del Chacho le imponían un esfuerzo de moderación, no muy común en su prosa, y se avino a aceptar cierta singularidad en la figura del Chacho, pero con la reticencia suficiente como para desactivar un efecto que pudiera perjudicarlo:

Desde ese día principia el acto más heroico, más romanesco que las crónicas de la montonera tan intanjible, tan rápida i fugaz recuerdan. Alguna cualidad verdaderamente grande debia de haber en el carácter de aquel viejo gaucho, si no era nativa estolidez, como la terquedad brutal que a veces pasa plaza de constancia heroica. $^{131}$

El Chacho de Sarmiento también le disputará al de Hernández la incriminación drástica de su persona en los hechos que determinan la muerte violenta del caudillo. Sarmiento se opone a esta estrategia de Hernández que lo apostrofa de "bárbaro matador" construyendo su propia imagen como "civilizador", gesto que implica la difuminación de su participación política en los hechos militares: de ningún modo puede ser un "bárbaro asesino" el "gobernador de San Juan que ya no dirijía la

\footnotetext{
${ }^{129}$ Sarmiento, 1868, p. 240.

${ }^{130}$ Ibidem, p. 264.

${ }^{131}$ Ibidem, p. 276.
} 
guerra", ${ }^{132}$ que pedía auxilio legal al gobierno nacional, que se intercambiaba partes respetuosos con el Chacho, que estaba asegurando el progreso industrial, educativo e institucional de San Juan.

Con este objeto, Sarmiento se dedica a refutar las denuncias de "Revelación de un crimen", en donde Hernández, como vimos, describía con lujo de detalles la supuesta manipulación fraudulenta de las fechas, partes y circunstancias en que el asesinato de Peñaloza había sido fraguado. En el capítulo "Las cosas como son" Sarmiento está respondiendo claramente a estas acusaciones, desvinculándose de los hechos y apuntando a los responsables. En relación con la datación del asesinato, se cuida bien de fijarla según los partes que recibió de Irrazábal y de Arredondo, para demostrar que no ha mentido sino que sólo se ha limitado a reproducirlos. Y en cuanto al hecho concreto de cortarle la cabeza al Chacho y exponerla en la plaza de Olta, cuando ya no puede evitarlo, Sarmiento hace una descripción sucinta:

Llegado el mayor Irrazábal, mandó ejecutarlo en el acto y clavar su cabeza en un poste, como es de forma la ejecución de salteadores, puesto en el medio de la plaza de Olta, donde quedó ocho días. ${ }^{133}$

Pero Sarmiento entiende que esta explicación es insuficiente y dedica varios párrafos a analizar el hecho desde el punto de vista político. Distingue los matices semánticos entre guerrilla y montonera, militar y bandido para reforzar la posición que sabe débil, retomando la escena que finalmente justifica:

Chacho, como jefe notorio de banda de salteadores, i como guerrilla, haciendo la guerra por su propia cuenta, murió en guerra de policia, en donde fué aprehendido, i su cabeza puesta en un poste en el teatro de sus fechorias. Esta es la lei, i la forma tradicional de la ejecucion del salteador. Algo mas justificaba aquel acto. Que no habia justicia en el país que tales cosas sucedían $[\ldots]^{134}$

\footnotetext{
${ }^{132}$ Sarmiento, 1868, p. 279.

${ }^{133}$ Ibidem, p. 302.

${ }^{134}$ Ibidem, p. 310. El énfasis, muy significativo, es de Sarmiento.
} 
Antes había tomado la precaución de seleccionar un antagonista que desviara la atención del lector. Sarmiento elige a Sandes, un denodado jefe mitrista fallecido recientemente, delegando en su mítica calidad como militar la responsabilidad del asesinato del Chacho. A pesar de que Sandes muere antes que el Chacho, Sarmiento se las arregla para trasladar toda la culpa a su leyenda hercúlea y llega al paroxismo de sostener que el Chacho "murió en sus manos, aún después de muerto él”. Así Sarmiento desaparece como contrincante y a su vez intenta evitar futuros conflictos con militares que aún viven y que pueden contradecirlo. Los problemas vendrán indefectiblemente de parte de Irrazábal y Arredondo, quienes al finalizar su presidencia le reclaman a Sarmiento su responsabilidad en los acontecimientos.

Por otra parte este esfuerzo de moderación de Sarmiento se trasluce en la propia manipulación de las categorías del Facundo. Una vez más volverá a recuperar la antinomia, pero no para dirigirla con saña a Peñaloza. Intentará disimular las categorías antagónicas en una estructura que tampoco las contiene con la claridad programática del Facundo. En El Chacho los capítulos no conforman una unidad articulada y el discurso de "civilización o barbarie" no se capitaliza contra el caudillo enemigo en una progresión clara, ni siquiera subliminal, como la de la Campaña en el Ejército Grande. ${ }^{135}$

Esto es quizás la prueba más contundente de que la oposición, liderada como ya se ha visto por Alberdi y Hernández, se ha apropiado del discurso de Sarmiento. Preocupado por garantizar su proyección política, Sarmiento comprende con aguda perspicacia que no debe reponerlo impunemente pues este objetivo no admite los excesos de una prosa panfletaria.

De este modo, no se atreverá a fustigar con la "barbarie" ni a esgrimir un lenguaje expresivo desmedido en contra de Peñaloza. La recuperación de este tópico será menos vertebral en este texto que abandona el molde ajustado y adquiere más amplitud. Con este fin, Sarmiento encuentra que Sandes, un jefe mitrista, era "un montonero de origen". ${ }^{136}$ Luego, para fundar un nuevo argumento de justificación, en

135 Tanto el Facundo como la Campaña en el Ejército Grande describen mediante un increscendo de la tensión narrativa, el camino de barbarización (de Quiroga y Rosas en el primer caso, de Urquiza en el segundo) que culmina a su vez en Barranca Yaco y Palermo. Sarmiento no justifica el asesinato del Chacho con este recurso porque lo considera riesgoso. Sería interpretado ahora como un gesto faccioso que es imperioso suprimir.

${ }^{136}$ Sarmiento, 1868, p. 280. 
"La guerra en los Llanos", cita la opinión de un mariscal de Francia que recomienda cuestionables estrategias de guerras: "El Mariscal Bugeaud decía con este motivo que para vencer a los bárbaros con sus medios era preciso hacerse más bárbaro que ellos". ${ }^{137}$

En cambio, las referencias a la barbarie de Peñaloza se orientarán, como se observó en 3.1., a denunciar un aspecto menor, la ignorancia del caudillo. En el primer capítulo define a Peñaloza como: "un paisano semi-bárbaro", ${ }^{138}$ que "conservóse bárbaro toda su vida", ${ }^{139}$ y cuya vestimenta de gaucho era un modo "de burlarse de los pueblos civilizados". ${ }^{140}$ Luego recupera el tópico del desierto asiático para continuar ahora refiriéndose en términos teóricos a "el bárbaro". Ya no se refiere puntualmente Peñaloza, sino que emplea una referencia de sentido general que va enfocando el conflicto. El "bárbaro" es un individuo rústico e inculto, pero no por ello violento; es “insensible de cuerpo, como es poco impresionable por la refleccion, que es la facultad que domina en el hombre culto". 141

En el segundo capítulo se registran tres empleos del término pero ahora están referidos a los indios de la zona, en una digresión narrativa importante que incluye premisas electorales que desvían la atención del lector. Sarmiento se refiere a sí mismo usando un circunloquio que despista; ¿cómo podría encargarse de perseguir al Chacho por los Llanos cuando se estaba dedicando a los cultivos de San Juan? ${ }^{142}$

En el apartado siguiente la tesis se emplea para describir a Mendoza como un baluarte de la "civilización", cuya acción "civilizadora" se perdió luego del devastador terremoto que la dejó en ruinas. En consecuencia San Juan se entroniza como único centro de civilización y educación para contener "los progresos de la barbarie". ${ }^{143}$ Ahora sí la tesis del Facundo opera con claridad; Sarmiento ha redireccionado su ataque mediante un corrimiento ideológico importante. El texto testimonia esta resignificación

\footnotetext{
${ }^{137}$ Sarmiento, 1868 , p. 276. Es curiosa la coincidencia con la biografía del Chacho de Federico de la Barra, en 1.3., que también incorpora referencias a los mariscales de Francia.

${ }^{138}$ Sarmiento, 1868, p. 220.

${ }^{139}$ Ibidem, p. 221.

${ }^{140}$ Ibidem, p. 221.

${ }^{141}$ Ibidem, p. 223.

${ }^{142}$ Sarmiento viene describiendo la actividad agrícola de las poblaciones originarias que se manifiesta en vestigios de antiguos canales de irrigación: "Aquellas indicaciones de canales, sirvieron al Gobernador de San Juan en 1863, para fijar el lugar donde habrían de erigírselas fundiciones de Hilario, que empiezan a dar nueva vida y riqueza mayor que las labranzas de Soria a aquellos lugares despoblados por la conquista" (ibidem, p. 228).

${ }^{143}$ Ibidem, p. 243.
} 
de las categorías y les da rienda suelta. Sarmiento encarna a partir de aquí al “civilizador", al educador, que desprecia la rusticidad del Chacho que no sabe leer ni escribir, cuyos partes son inventados por los amanuenses, que se atreve a emplear un lenguaje culto que no le pertenece, que no sabe ni siquiera pronunciar como corresponde.

Pero las referencias se han limitado a un matiz menor, vinculado, como ya dijimos, a su aspecto educativo. Peñaloza es bárbaro porque no fue alfabetizado y en este terreno la oposición maniquea sí se admite como indiscutible, porque se esgrime en el campo en el que Sarmiento se mueve con más naturalidad. Con esta autoridad legítima puede ahora incorporar una de sus proclamas al pueblo riojano en la que se aprecia el uso desembozado de los términos de la tesis. En el capítulo "El alzamiento del Chacho" se retoman sin maquillaje las expresiones más típicas de Sarmiento, de lenguaje más desmedido y pasional pero que excluye la violencia, sin descuidar a su vez el enfoque pedagógico que ha preferido para la composición de su texto:

Peñalosa se ha quitado la máscara. Desde la estancia de Guaja, secundado por media docena de bárbaros oscuros, que han hecho su aprendizaje político en las encrucijadas de los caminos [...] No es un sistema político lo que estos bárbaros amenazan destruir. Es todo orden social [...] [La Rioja] es hoy un desierto poblado de muchedumbres que solo el idioma adulterado conservan de pueblos cristianos. ${ }^{144}$

Finalmente los últimos capítulos no incorporan ninguna mención de la antinomia. Sarmiento no puede contenerse y se desboca polemizando con Rawson y el estado de sitio, la explicación del habeas corpus y las garantías constitucionales de "constitucionalistas de nuevo cuño". ${ }^{145}$ Se burla con sorna de las imposiciones formalistas que no tienen en cuenta las circunstancias de aplicación práctica, pero se cuida de demostrar que aceptó la decisión superior y se "tragó sus razones". No obstante deja en claro que se hace cargo de la polémica, pues parece que además escribió a los gobiernos de provincias vecinas que también estaban amenazados por los alzamientos,

\footnotetext{
${ }^{144}$ Sarmiento, 1868, p. 256.

${ }^{145}$ Ibidem, p. 291.
} 
diciendo que daba "grima ver al gobierno nacional, como unos chiquillos, metiendo bulla con el estado de sitio". ${ }^{146}$

El cierre, a pesar de esta desviación extensa, es muy logrado. Sarmiento ilustra con una metáfora de gran efecto el sentido de la muerte del Chacho y anuda el vínculo con el Facundo:

Hemos por esto dado grande importancia al drama al parecer humilde que terminó en Olta en 1863. Era como las goteras del tejado, después que la lluvia cesa, la última manifestacion del fermento que introdujeron Artigas a la márjen de los rios, Quiroga a las faldas de los Andes. El uno desmembró el Virreinato, el otro inutilizó el esfuerzo de Ituisango [sic], con treinta años de convulsiones internas. Civilización i barbarie era a mas de un libro un antagonismo social. ${ }^{147}$

\subsection{Organización del relato}

El texto se divide en once capítulos que van urdiendo, de modo un tanto inconexo, la trama vital de Peñaloza. Como se ha dicho, dos objetivos inmediatos se entrecruzan en el designio escritural que Sarmiento emprende con esta nueva biografía de un caudillo: contrarrestar los rechazos que ha concitado su responsabilidad ideológica en la represión de las montoneras y promover su candidatura presidencial consolidando su imagen de "civilizador", imagen que tiene interés en presentar como una "sumatoria" debido a diversos factores: su contribución al esclarecimiento de una identidad nacional, su apoyo a una programática política que ha sido liderada por Buenos Aires y sus propuestas concretas en materia de educación, que postula como el instrumento fundamental para emprender el camino definitivo hacia el Progreso. Esos dos objetivos se implican mutuamente, pero imponen de todas maneras diferentes estrategias discursivas; de estos entrecruzamientos (y de la velocidad con que, seguramente, fue redactado el texto), surge esa cierta falta de conexión que sólo es restablecida por un subtexto que aporta claves interpretativas (un fenómeno textual que ya fue señalado en el análisis de Campaña en el Ejército Grande).

Como venimos observando, con estos fines, la figura del Chacho se convierte en emblema de dos cuestiones claves para la vida política nacional que el gobierno de

\footnotetext{
146 Ibidem, p. 302.

${ }^{147}$ Sarmiento, 1868, p. 318.
} 
Mitre ha dejado sin solución y que a Sarmiento le interesan sobremanera: la educación y la cuestión de los indios. ${ }^{148}$

Para concentrar la mirada sobre estos tópicos, Sarmiento redefinirá el fenómeno del caudillismo en este último trabajo sobre el tema, del que se deduce, de modo explícito, que el gauchaje es un producto del mestizaje indígena. ${ }^{149}$ Este último ataque al gaucho se materializará luego, durante su presidencia, en la decisión de incrementar las cuestionadas levas compulsivas de pobladores de la campaña para enviarlos a los fortines de a la frontera con el fin de resistir las frecuentes invasiones. En un contexto de alarma creciente ante la intensificación de los malones, el político que se está autoproponiendo como candidato a la presidencia de la República decide dar otra vuelta de tuerca en su concepción antinómica de la problemática nacional: la oposición civilización-barbarie debe sumar y reinstalar enfáticamente al indio en ell polo negativo. El determinismo natural y social al que adscribe Sarmiento los considera como el producto humano del mismo ámbito: el desierto, el espacio salvaje que los cobija. ${ }^{150}$

\subsection{Sucesión de capítulos}

Los capítulos de El Chacho, último caudillo de la montonera de los llanos van desarrollando esos tópicos de manera gradual, intentando desactivar esa crítica

\footnotetext{
${ }^{148}$ A lo largo de la historia argentina del s. XIX se fueron entrecruzando propuestas políticas diversas frente a los pobladores originarios que habitaban el llamado "desierto": van desde escasas mociones de programas de asimilación cultural e incorporación paulatina hasta las campañas militares contra las tolderías y pasan por la metodología de las dádivas a cambio de convivencia pacífica o -durante las guerras civiles- de colaboración con los ejércitos que se enfrentaban. En este momento histórico, la frecuencia de los malones determina en la sociedad una actitud que se va alejando progresivamente de una posición humanitaria, de allí que fijar una posición beligerante frente al indio forme parte de la plataforma política de alguien que, como Sarmiento, aspiraba a ocupar la presidencia de la República.

${ }^{149}$ Con suspicacia le dice Sarmiento al lector, casi sobre el final de El Chacho, último caudillo de la montonera de los llanos: "Habránse notado durante toda la lucha estas concomitancias de la montonera con los indios salvajes del desierto" (op. cit., p. 311).

${ }^{150}$ Sarmiento es explícito al reunir al gaucho y al indio en el paisaje salvaje americano: "La causa de estas relaciones es que entre el gaucho de a caballo i el indio de la pampa, la línea divisoria en fisonomia, hábitos e ideas es tan vaga, que no acertaria cualquiera a fijarla (ibidem, p. 311). Insiste también sobre este tópico en el apartado donde se refiere a Clavero, donde narra que el caudillo se refugia entre la indiada un tiempo para escapar de la persecución del Estado. El gaucho, el indio, el desierto, la frontera: una vez más, el tratamiento de estos tópicos divide (a la par que revela alguna afinidad subterránea) en los discursos de Sarmiento y José Hernández; pero los ataques que Hernández dirige en forma directa contra su adversario por medio de El gaucho Martín Fierro comportan una confrontación que esta fuera de los límites de este trabajo, centrado en la interacción polémica entre dos textos biográficos.
} 
devastadora que había sido iniciada por Hernández tres años antes y que -en forma directa, mediatizada o acompañada de reacciones con la misma orientación- fue asumida no sólo por los opositores políticos -que condenaron de inmediato la ingerencia de Sarmiento en el ejercicio de la violencia desproporcionada-, sino por un abanico más amplio de la opinión pública, que reclamó por el acatamiento de la normativa legal.

\section{"EN CHILE I A PIÉ!"}

El primer capítulo describe poéticamente el marco geográfico majestuoso de la cordillera. Es aquí donde Sarmiento entrecruza con la vida del biografiado una experiencia de su propio exilio (cuando debió atravesar los Andes en busca del refugio chileno). Pero con un cambio drástico de modalidad discursiva, irrumpe la anécdota que da título al capítulo desentonando con el tono épico del relato inicial. Sarmiento describe al Chacho como un bárbaro ignorante, que por ello pierde todas las batallas, se entromete imprudentemente en los asuntos ajenos y carece de convicciones firmes: ha servido a todos los jefes, desde Rosas hasta Mitre. Ya desde el comienzo, se discurre además sobre la relación entre las montoneras y los pobladores originarios de la zona.

\section{"LAS TRAVESÍAS"}

Desde la perspectiva determinista del Facundo, se describe aquí "la fisonomía del teatro del último levantamiento del Chacho"-los Llanos riojanos-como un desierto que se extiende entre las ciudades de La Rioja, San Luis, San Juan y Mendoza: este desierto impide el avance de la civilización y amenaza con su destrucción definitiva. Se discurre sobre los pobladores originarios (tribus huarpes) y sobre los quichuas que se enseñorearon del valle; se insiste así en remarcar una afinidad de esencias entre lo indígena y la idiosincrasia del gaucho.

\section{"RECONSTRUCCION"}

Este apartado analiza el desgraciado episodio del terremoto de Mendoza. Luego de un claro intento proselitista por captar al publico porteño en el que ensalza su labor solidaria con los afectados por la catástrofe, el texto pone de relieve que ya sólo quedaba la provincia de San Juan para encarar la tarea de frenar "el salvajismo de la 
travesía" (“el desierto pesaba sobre San Juan”). Así, se presenta la reacción de esta provincia como la única que puede enfrentar la barbarie de los seguidores del Chacho, e implícitamente, a su gobernador (en esa etapa, Sarmiento) como el hombre destinado a hacerse cargo de esa empresa.

\section{"SAN JUAN"}

Sarmiento inicia este capítulo con una sentida lamentación por la muerte de su amigo Aberastain a manos de los "bárbaros" (denominación que aquí engloba a todos los opositores políticos del programa liberal que se propone implantar en San Juan). Sarmiento critica a Juan Sáa, el interventor de la provincia enviado por Derqui -y a Derqui por ser incapaz de resolver el conflicto-, y aquí aparece la primera mención de sí mismo, aunque en $3^{\mathrm{a}}$ persona.

\section{"REACCION"}

Para entrar en el tema que más le interesa crea una atmósfera digna de las novelas de suspenso: "Bajo los más siniestros auspicios se abría el año 1863 en la región que hemos descrito". En ese clima localiza un planteo dramático (el "drama de Olta") y presenta a los personajes principales que van a actuar con ese fondo escenográfico: el Chacho, Sandes, Irrazábal y Arredondo. Para sí, prefiere reservarse un papel breve y secundario. Este capítulo incluye la transcripción de comunicaciones oficiales entre él y el Chacho para resaltar el hecho de que éstas son escritas por amanuenses ya que su rival es analfabeto.

\section{"ALZAMIENTO DEL CHACHO"}

El recurso retórico de la oposición paralelística y una alusión al apoyo institucional que tuvo su misión política (el día en que "todas las provincias se pusieron en armas para luchar en contra del Chacho") aportan intensidad y solidez a su principal argumento defensivo: la invasión de estas hordas hambreadas, desorganizadas, incivilizadas, que constituyen una amenaza para el nuevo orden social que se aspira a imponer (tienen una acentuada tendencia al ocio, no respetan la propiedad privada), se 
contrapone a los logros progresistas de su gobernación: la llegada del ferrocarril, la fundación de escuelas, los inicios de la explotación minera. ${ }^{151}$

\section{"EL CHACHO EN CÓRDOVA"}

Como las huestes de Peñaloza se mueven con rapidez y avanzan después de haber logrado dejar a la ciudad de San Juan sitiada, Sarmiento debe ir describiendo a la vez las posiciones de Sandes y de Arredondo. Y no se olvida de registrar las opiniones “autorizadas" en contra del caudillo: las del gobierno nacional, las de los distintos ministros de Mitre, y la del "gobernador de San Juan" (en otra referencia a sí mismo en tercera persona).

\section{"LA GUERRA EN LOS LLANOS"}

El talento literario de Sarmiento logra dar aliento de epopeya a la campaña militar que va a culminar con la muerte del Chacho. Empieza describiendo la denodada personalidad del comandante Arredondo. Después se detiene en la del brioso coronel Sandes, que finalmente morirá de sus muchas heridas y en un pasaje memorable, describe cada una de las cincuenta y tres heridas que sufrió Sandes a lo largo de su carrera militar. Y después de describirlo como un "Orlando Furioso", la muerte del Chacho -a la que se llegará por la intervención de "héroes" como él- es presentada como el producto de una "cólera homérica". Así, la literatura sustituye a la historia: el discurso épico con que se describe la batalla, la mitificación de sus paladines y la maestría en el manejo de la hipérbole aspiran a opacar objeciones legalistas y humanitarias. ${ }^{152}$ También se transcriben los partes oficiales con el Chacho en los que Sarmiento busca mostrar un dominio de la situación (supuestamente verificable en la lectura del registro respetuoso y moderado que impone su comunicación oficial con el caudillo) que se desmiente al conocer su correspondencia personal con Mitre.

\footnotetext{
${ }^{151}$ Se trata del capítulo más coherente con el tenor de su correspondencia con Mitre; pero en las cartas es explícito y no oculta su inveterado egocentrismo: el Chacho le arruina su "bella obra de civilización".

${ }^{152}$ Emilio Carilla se ha referido a esta descripción hiperbólica de Sandes: "Retrato e hipérbole confluyeron en este párrafo sobre el sanguinario (en todo sentido) Sandes. Naturalmente Sarmiento no lo ve como lo vieron, por ejemplo, Hernández y otros. Lo que me interesa destacar aquí es el acierto expresivo logrado" (Carilla, 1964, p. 54).
} 


\section{"EL CHACHO EN SAN JUAN"}

Sarmiento establece un vínculo intertextual con el Facundo, "de que es complemento este último episodio de la montonera" y transcribe algunos pasajes donde nuevamente se menciona a sí mismo en tercera persona. ${ }^{153}$ Sigue los derroteros de Irrazábal y Arredondo, ambos demorados en trámites legales para la obtención de caballadas y mulas mientras el Chacho se traslada con libertad por los Llanos.

\section{"LAS COSAS COMO SON"}

Describe con prosa despojada el momento en que rodean al Chacho y lo baten en Olta, y se pormenorizan los últimos movimientos antes de prenderlo.

\section{"LA JUSTICIA DEL ESTADO"}

Analiza el indulto a Clavero, sedicioso que volvió a convocar a la sedición al pueblo riojano y luego se refugió entre los indios. El ejemplo de Clavero le sirve a Sarmiento para introducir la discusión sobre el derecho del Estado a declarar una ley marcial tal como se acostumbraba en los países anglosajones como Estados Unidos e Inglaterra. En el contexto de una autodefensa, esa digresión funciona como un recurso para aludir a la funcionalidad del juicio militar sumario para disponer la ejecución de un jefe sedicioso que pueda poner en peligro la paz de la Nación (condición que él atribuye a Peñaloza).

Por último, el texto remonta vuelo en la cuerda ensayística, donde un "pensador americano" interpreta el pasado caudillista como una "prehistoria" argentina, donde los caudillos son presentados como "dinosaurios" que los futuros estudiosos del país considerarán como "monstruos inexplicables pero reales". Con una lógica que anuda este texto con todos sus escritos sobre la barbarie, los reúne con maestría argumentativa para cumplir el objetivo que nunca relegaron: promover su personalidad política. De este modo, un texto un tanto errático y desparejo reinstala a un "constructor de la Nación” y confirma la dominación simbólica que había logrado con el Facundo (la obra consagratoria que, por otra parte, tiene una presencia palpable como paratexto de las dos primeras ediciones de El Chacho).

153 "El lector necesita otro antecedente para comprender este cargo de unitario. En la vida de Quiroga de que es complemento este último episodio de la montonera [...]" (Sarmiento, 1868, p. 291). 
Esta construcción discursiva dispara sentidos múltiples: para Sarmiento, es él quien empieza a escribir la historia del país cuando extingue a los caudillos y a la ignorancia que ellos representan. Y hay un doble juego con el tópico de la escritura: por un lado, su construcción literaria es identificada con la tarea de construir una Nación; por otro lado, es el vehículo de su propuesta política inmediata. Si se le brinda la posibilidad de acceder a la presidencia de la República, se concretará su proyecto alfabetizador y el país pasará de la "prehistoria" - definida en función de la ausencia de "escritura"- y entrará en el mundo moderno, donde los hombres ya no necesitarán ser héroes cavernarios para poder sobrevivir, donde la inteligencia tendrá más valor que la fuerza física.

Pero la construcción literaria también deja flotando una imagen gótica de lo monstruoso que ofrece lugar al misterio, a lo "inexplicable", y abre la puerta a las interpretaciones del lector para que pueda aportar sus propias conclusiones, una opinión más sobre el fenómeno del caudillismo y sobre la polisémica figura del Chacho Peñaloza.

Pero como ya se ha apuntado, no todos los que defendieron al Chacho acusaron a Sarmiento. Algunos eligieron un responsable colectivo en la política porteña, otros se circunscribieron al nivel del mayor Irrazábal y otros excusaron su conducta por las intemperancias propias de las guerras irregulares. Fue José Hernández quien, redactando en El Argentino de Paraná las notas que luego se difundieron en un folleto, inauguró una línea acusatoria focalizada en la figura de Sarmiento y quien lo anatemizó con un epíteto que reforzaba la agresión alberdiana: el "gaucho de la pluma" pasó a ser "el bárbaro de la política”.

\subsection{El encubrimiento del yo}

Paradójicamente, un texto que encubre la doble intención de autodefenderse y de candidatearse políticamente evita sistemáticamente el uso de la primera persona del singular, uso del que Sarmiento fue un cultor inveterado. Ya las Quillotanas habían emprendido el análisis del discurso de Campaña en el Ejército Grande destacando su exasperante egocentrismo; pero la crítica posterior continuó insistiendo en censurar ese exacerbado narcisimo que le valió el mote popular de "Don yo". 
En el interior de un texto que responde a múltiples factores desencadenantes, también persigue más de un objetivo este subterfugio para desestabilizar la autorreferencialidad. El más importante: desdibujarse en la escena del crimen entremezclándose en un abigarrado colectivo de militares, funcionarios y caudillos; pero quien ha emprendido su promoción como candidato presidencial también se concentra en impedir toda manifestación susceptible de generar rechazo, y la perspicacia de Sarmiento no podía ignorar reprobaciones de larga data. Esta estrategia discursiva de difuminación del yo tiene que haber sorprendido a lectores acostumbrados al estilo desembozado de sus escritos, pero también puede haber mitigado rechazos.

Si bien su omnipresencia no se despega del subtexto, prefiere nombrarse a sí mismo en tercera persona ("el coronel Sarmiento"), ${ }^{154}$ o acude a circunloquios: "el autor que había hecho el retrato político del antiguo unitario", "el gobernador de San Juan", 155 "el autor de la vida de Facundo Quiroga".

\subsubsection{Primeras ediciones de El Chacho, último caudillo de la montonera de los llanos}

La primera edición de esta biografía de Peñaloza acompaña una nueva edición del Facundo publicada en Nueva York, en $1868 .{ }^{156}$ En esta reedición, Sarmiento incluye el prefacio de Mrs. Mann, los capítulos I al XIII de Civilización i barbarie y un Apéndice en el que transcribe las proclamas de Quiroga. Luego vienen las dos biografías que completan la trilogía: El general D. Fray Félix Aldao, que había sido

\footnotetext{
${ }^{154}$ Los ejemplos son numerosos: "El coronel Sarmiento, hasta entonces Auditor de guerra del 1er. Cuerpo de Ejército, aceptó así el gobierno que sus compatriotas le imponian, como un deber y un honor que estimaba en mucho" (Sarmiento, 1868, p. 238). Sus esfuerzos por desparecer del escenario de violencia se extienden también hacia Mitre y el texto describe con morosa referencia el intercambio comunicativo entre ambos. Sarmiento habla de que comunicó al "Gobierno nacional" la situación precaria de su provincia y que a su vez éste le había indicado con "insistencia al Gobernador de San Juan la necesidad de hacer de la ciudad la única existente [...]" (Ibidem, p. 243).

${ }^{155}$ En numerosas oportunidades alude de este modo a su persona y al resto de los integrantes del gobierno de Mitre. Se citan algunos ejemplos: "Esta carta había sido precedida, meses antes, por otra dirigida al gobernador de San Juan en que recordaba con arte los servicios" (Ibidem, p. 243); "uno de los ministros del gobierno nacional escribía al gobernador de San Juan" (Ibidem, p. 264). También hace un uso más impersonal, incluso, refiriéndose a sí mismo como "el gobierno de San Juan" (Ibidem, p. 249).

${ }^{156}$ Sarmiento, D. F. El Chacho, último caudillo de la montonera de los llanos-Episodio de 1863, en Facundo; ó civilizacion i barbarie en Las Pampas Arjentinas. Nueva York, D. Appleton y compañía, 1868, pp. 217-318. Ejemplar consultado en la Biblioteca de la Universidad Nacional de La Plata. Colección Farini 8093.
} 
añadida en la versión de 1851, y El Chacho, último caudillo de la montonera de los Llanos. Esta estructura tripartita en la que el Chacho se introduce en la posición final, contribuye a su vez al sentido plurisémico del título.

Como se detalló, el conjunto de estos textos va precedido por el "Prefacio de la traducción inglesa de Mrs. Horace Mann” de expreso contenido proselitista. Mrs. Mann repasa en trazos gruesos la historia del país y refiere la participación de Sarmiento en la lucha contra Rosas, menciona a Quiroga y a Urquiza pero apenas alude al conflicto de La Rioja como un conflicto en el que "se le opusieron sus amigos unitarios [que] Hoi le llaman al gobierno".

La segunda edición, que se publicó en París seis años después, ${ }^{157}$ también acompañó al Facundo; en realidad, se trató de una reimpresión de El Chacho publicado en Nueva York, ${ }^{158}$ con el ajuste correlativo del número de páginas. ${ }^{159}$ Sin embargo, en esta nueva versión del Facundo sí incorporó importantes modificaciones -además de los aspectos menores referidos al título-, agregando, luego del prefacio de Mrs. Mann, la famosa anécdota de su exilio en que escribe On ne tue point les idées, la vehemente Introducción ("Sombra terrible de Facundo"), la carta a Valentín Alsina de la edición de 1851 y los dos capítulos finales "Gobierno Unitario" y "Presente y porvenir".

Con estas anexiones Sarmiento recupera su "teoría sobre el caudillaje" en el cierre de su presidencia, al publicar su visión completa de la realidad nacional y su propuesta fundamental para la construcción del Estado. Sin embargo, se observa que esta decisión se impuso (seguramente no sin tensiones) aun a riesgo de incluir

${ }^{157}$ El Chacho, último caudillo de la montonera de los llanos-Episodio de 1863, en Facundo ó civilizacion i barbarie en Las Pampas Argentinas. París, Librería Hachette y Cía., 1874, pp. 267-370. Ejemplar consultado en la Biblioteca de la Universidad Nacional de La Plata. Colección Farini 6409.

${ }^{158}$ Aunque se registran modificaciones en la portada (la edición de 1868 lleva punto y coma luego del nombre del caudillo: Facundo; ó civilizacion i barbarie, y registra la escritura Arjentinas; en la edición de 1874 se suprime ese signo de puntuación y se sustituye la j por la $\mathbf{g}$ en Argentinas), y se produce una importante recuperación textual (la restitución de las tres secciones del Facundo cuya eliminación en 1851 había sido acremente censurada en las Quillotanas), el texto de El Chacho es, efectivamente, una reimpresión. Debo este dato a Javier Fernández, quien aseguró que las planchas de Appleton habían sido enviadas desde Nueva York a París. Aunque no citó documentación precisa, el dato se confirma sencillamente con la confrontación de las páginas (ver "Apéndice Documental"). Javier Fernández se desempeñó como Director de la Biblioteca de la Universidad Nacional de La Plata desde diciembre de 1996 hasta mayo de 2001.

${ }^{159}$ Oscar Tacca sólo menciona la incorporación de una introducción y de la biografía de Aldao (Tacca, 2000). 
contradicciones, como la que se observa contrastando la carta a Alsina de 1851 -en la que Sarmiento le explicaba que había decidido suprimir la Introducción-, con la reincorporación de esa célebre pieza en esta nueva edición de 1874. 


\section{VIDA DEL CHACHO Y EL GAUCHO MARTÍN FIERRO: REESCRITURAS EN 1875}

\subsection{El discurso panfletario}

De acuerdo con la tipología de Marc Angenot, ${ }^{1}$ tanto en las biografías de Peñaloza que escribe Hernández como en el Martín Fierro, se actualiza un discurso panfletario, es decir, el uso del lenguaje como arma propio de una "literatura de combate". Tanto la vida del caudillo Peñaloza como las desventuras del gaucho Fierro son historias de víctimas de los abusos del poder en un contexto de aguda confrontación entre dos parejas de opuestos: el poder de la ciudad-puerto versus los derechos de las provincias, y los intereses de los núcleos urbanos contrapuestos con los del mundo rural.

La biografía del Chacho, como ya se ha expuesto, se publica como un alegato en defensa de la memoria de un caudillo histórico que se ha convertido en una víctima del poder político de Buenos Aires (que Hernández encarna en la figura de Sarmiento). En cuanto al poema, su universo ficcional tiene un sustrato real que lo convierte en el emblema de una problemática candente: la situación de injusticia social que sufren las capas inferiores del mundo rural (tanto el proletariado como los pequeños pastores y labradores), que se ha venido profundizando a partir de $1952{ }^{2}$ por lo tanto, se convierte también en un alegato. De acuerdo con una tradición oral, por intercesión de Benito Magnasco $^{3}$ ante el presidente Sarmiento y con el compromiso de no ejercer el periodismo, se le permite a Hernández el regreso a Buenos Aires, y en marzo de 1872, alojado en el Hotel Argentino, se dedica a la redacción de El gaucho Martín Fierro. ${ }^{4}$ Así, si bien ambas obras fueron gestadas en épocas diferentes, se observa que el itinerario textual acompaña un ritmo político; por ello, no es de extrañar que Hernández

\footnotetext{
${ }^{1}$ Angenot, 1982.

${ }^{2}$ Garavaglia, 2001, pp. 654-690.

${ }^{3}$ Miembro destacado de la Masonería, asociación a la que pertenecían tanto Sarmiento como Hernández al igual que un gran número de políticos de la época.

${ }^{4}$ Así lo manifiesta en la carta-prólogo: "Al fin me he decidido a que mi pobre Martín Fierro, que me ha ayudado algunos momentos a alejar el fastidio de la vida del Hotel, salga a conocer el mundo".
} 
republique ambos textos en 1875: la convocatoria a la conciliación de los partidos iniciada en la presidencia de Avellaneda no es ajena a esta confluencia.

Desde enfoques geneticistas (poco transitados entre nosotros) se pueden relevar nuevos datos acerca de los vaivenes de la interacción polémica que venimos analizando, pues al examinar la génesis editorial de los dos textos se descubre que Hernández fue introduciendo muchas reformulaciones atento a la evolución política y cultural del país.

Hernández publicó en vida 12 ediciones de El gaucho Martín Fierro y en todas ellas hubo reescrituras significativas; su examen permite adentrarse en el proceso creativo del poema y en su interacción con un contexto de situación en movimiento, proceso que ha sido reconstruido y analizado por Élida Lois. ${ }^{5}$ Desde un punto de partida basado también en la metodología geneticista, se intenta ahora interrelacionar dos procesos bien significativos de reformulación textual que se producen durante el año de la reinserción de José Hernández en la ciudad-puerto y desembocan en Vida del Chacho (nueva versión de la biografía publicada en 1863) y la 9a edición de El gaucho Martín Fierro. ${ }^{6}$

El discurso panfletario va modulando "tonos": normalmente grita, pero puede reclamar, denunciar, amenazar, llorar. Rasgos biográficos del General D. Angel V. Peñaloza y El gaucho Martín Fierro lloran y amenazan; por eso los dos "tonos" del género gauchesco señalados por Josefina Ludmer (el "lamento" y el "desafío") ${ }^{7}$ están presentes en dos obras que la crítica ha disociado. Y justamente, la reformulación en 1875 de ambos procesos textuales trabajará sobre esos "tonos".

\subsection{Biografías de gauchos}

Los dos textos, Vida del Chacho y El gaucho Martín Fierro refieren la vida del hombre del mundo rural en los que se tensan los pares de oposiciones tradicionales que Sarmiento había puntualizado en el Facundo: hombre de campo-hombre de ciudad, barbarie-civilización, códigos orales-leyes escritas. Son textos que involucran al gaucho: en su biografía, Hernández convierte a un caudillo en un "gaucho" (aunque en

\footnotetext{
${ }^{5}$ Lois, 2001b, pp. XXXIII-CXVI, 1-541.

${ }^{6}$ Esta reedición - publicada en Rosario- es la versión del poema que ha sido reformulada con mayor intensidad (es la única edición de El gaucho Martín Fierro publicada en vida de Hernández en la que se registran más de 130 modificaciones).

${ }^{7}$ Ludmer, 1988.
} 
su enunciación no signifique lo mismo que cuando el enunciador es Sarmiento); en su poema, le presta su voz. ${ }^{8}$ A grandes rasgos, el contexto histórico es el mismo (el predominio político de los intereses urbanos sobre los rurales ejercido de modo creciente a partir de 1852 y la prepotencia con la que se ejerce el poder gubernamental), aunque las coyunturas políticas precisas sean diferentes en 1863 (cuando operaciones militares contra levantamientos del interior impulsadas por el gobierno nacional han quebrantado las normas de la ley) y en 1872 (cuando arrecian las críticas contra los abusos que se cometen en el mundo rural). ${ }^{9}$

En 1863, en el momento de conocer la noticia de la muerte injusta del Chacho, Hernández reacciona violentamente y lo exalta con ardor como un gaucho-patriota que entrega su vida al servicio de la Nación y es traicionado. Todo el texto del 63 se articula sobre este postulado y Hernández revierte con contundencia la antinomia del Facundo para denunciar y lamentar el mismo estado de cosas contra el cual también reacciona el género gauchipolítico: un "sistema diferencial y dislocado de leyes y de universos militares y económicos". ${ }^{10}$ Así, el discurso de este alegato se modula con los mismos tonos de la gauchesca: como explosión de subjetividad, puede leerse como un "lamento" exacerbado; pero la violencia del discurso panfletario constituye, por sí misma, un "desafío".

En 1872, desde El gaucho Martín Fierro, también se denuncia la injusticia social y la responsabilidad del poder político. El poema enhebra un relato que lo demuestra palmariamente modulándolo en esos mismos tonos: lamento por la felicidad perdida y actitud desafiante ante la sucesión de atropellos que sufre el protagonista. Pero aquí hay un tono predominante: el "desafío".

Tres años después, Hernández retorna definitivamente a Buenos Aires después de que el llamado a la conciliación nacional del presidente Avellaneda permitiera el regreso de los interdictos. Intenta sumarse al nuevo orden político del país y su primer

\footnotetext{
${ }^{8}$ El Chacho de Hernández, en cambio, no habla con su voz. Tanto en Rasgos biográficos de D. Angel V. Peñaloza como en Vida del Chacho, discursos directos que completan la imagen patriarcal del Chacho se canalizan por la retórica de la narrativa romántica. Por contraste, la figura diseñada por la biografía de Sarmiento insistirá en su rudeza y en su condición de analfabeto.

${ }^{9}$ En este sentido, son muy significativos los dos documentos de denuncias contemporáneas que inserta Hernández como epígrafes de El gaucho Martín Fierro: fragmentos de un discurso del senador Nicasio Oroño y de un artículo del diario La Nación de Buenos Aires (Hernández, 2001, p. 83).

${ }^{10}$ Ludmer, 1988, p. 30.
} 
gesto explícito como escritor político es la publicación de Vida del Chacho, una nueva versión de su biografía sensiblemente moderada por una postura más cautelosa y política: narra los mismos hechos acerca de la vida y la muerte del caudillo riojano, pero con una modalidad discursiva que evita la exaltación (suprime incluso los estallidos más violentos). Pero en su condición de autor exitoso de El gaucho Martín Fierro, ya ha previsto un procedimiento más sutil: una nueva modelización de la "clave lingüística" con la que ha creado el fenómeno editorial más impresionante de la literatura argentina del siglo XIX. La reelaboración desemboca en la $9^{a}$ edición de El Gaucho Martín Fierro, que se publicó también en $1875,{ }^{11}$ pero que no fue considerada por la investigación literaria hasta $2001^{12}$ debido a que el itinerario editorial pergeñado por el autor la dejó de lado a partir de la $10^{\mathrm{a}}$. Hernández reelabora en ella la prosodia del dialecto rural en forma taxativa, pero a pesar de tratarse de la versión que incorpora mayor cantidad de modificaciones, renegó de ese esfuerzo reescriturario cuando publicó, al año siguiente, la $10^{\text {a }}$ edición. Se trata, sin duda, de una etapa de cambios, tanto en la vida como en la escritura de Hernández.

\subsection{La segunda versión de la biografía de Peñaloza: Vida del Chacho ${ }^{13}$}

El folleto de 1875 se estructura así: 1) "Advertencia": texto firmado por el editor; ${ }^{14}$ 2) "Rasgos Biográficos del General D. Angel V. Peñaloza": capítulos I-X sobre la vida del Chacho; 3 ) "Apéndice”, que incluye una carta de Ricardo Vera a Sarmiento donde le reprocha haber festejado el asesinato del caudillo-, el parte de Irrazábal a Sarmiento con la noticia de la muerte del Chacho y un texto final sin firma. ${ }^{15}$

En 1863, se advertía desde el material pre-redaccional ${ }^{16}$ la intencionalidad polémica que marcará la primera versión de la biografía de Peñaloza de Hernández.

\footnotetext{
${ }^{11}$ Hernández, 1875 b.

${ }^{12}$ Lois, 2001b, pp. XXXIII-CVI.

${ }^{13}$ Hernández, 1875a. Esta edición de 1875, impresa en cuarenta páginas, puede consultarse en la sección "Tesoro" de la Biblioteca Nacional (con la identificación topográfica TE 3 A 0651 06). ${ }^{14}$ Esta "Advertencia" está transcripta en la edición crítico-genética que hemos publicado (Hernández, 2005, pp. 56-57).

${ }^{15}$ Ibidem, pp. 57-58.

${ }^{16}$ Ver 1.2.1.2. El enfoque genético aplicado en un sentido amplio-que excede el campo del dossier de una obra en particular- nos ha llevado a considerar a las publicaciones periodísticas en las que Hernández fue siguiendo las campañas de Peñaloza en El Argentino de Paraná como "pre-textos" de su biografía.
} 
Pero el exacerbado tono agónico que la desencadena será sensiblemente atenuado en la reformulación de 1875 .

El autor había empezando dando la noticia de la muerte del Chacho y acompañándola con una maldición a sus matadores, había sumado una denuncia acerca de la tergiversación de los hechos y había sumado dos explosivos alegatos, para luego presentar la biografía de un caudillo que era elevado a la categoría de héroe mítico. En la reelaboración posterior del texto, suprimirá esos alegatos y morigerará las explosiones emocionales, procurará dotar a sus opiniones personales de una apariencia de objetividad y ejercerá una intensa operación de borrado sobre las marcas de ostensible combate partidista. Pero si bien se mantuvo el respeto por la figura del biografiado, se produjeron algunos desplazamientos ideológicos ligados a su recontextualización: las reescrituras van despojando sutilmente al biografiado de su categoría de "héroe", de su condición mítica, aunque no de su condición de ciudadano respetable. De esta manera, se irá modelando una nueva realidad, despojada de desbordes pasionales, que se encauzará en un discurso más meditado, más analítico. Se volverá más evocativo y menos visceral. Se mostrará también muy atento frente a la manifestación de simpatías personales, eliminará varias de sus opiniones sobre el partido unitario, sobre el asesinato de Dorrego, sobre las trayectorias de Lavalle, de La Madrid.

\subsubsection{Las reformulaciones estructurales registradas en la edición de 1863}

Cuatro de los componentes del folleto del 63 fueron suprimidos y no dejaron siquiera huella en la segunda versión. Se eliminó el primer apartado (“Asesinato atroz”), que ya llevaba un título connotativo e incluía acusaciones directas al partido unitario; se hablaba aquí de la "maldad del partido unitario" como una condición intrínseca y se recuperaba el epíteto "los salvajes unitarios". Corrió la misma suerte el segundo ("El General Peñaloza ha sido degollado"), que contenía dos cartas anónimas reveladoras del aprecio de la gente por el Chacho y del efecto que había producido la muerte de este "patriota defensor de la causa de los Pueblos"; también se recogía aquí la acusación popular a Sarmiento como responsable del crimen, ya que decía de su asesino: "y después lo degolló cortándole completamente la cabeza y huyendo con ella para San Juan a llevarle sin duda al asesino Sarmiento el testimonio de haber consumado su 
horrendo crimen". Además, fueron desterrados los dos textos que introducían el tono violento y exaltado que atravesaría el discurso panfletario de la biografía, que llevaban la firma de Hernández: el tercer apartado (“La política del puñal”) y el cuarto ("Revelación de un crimen”), dos alegatos impregnados de inflamada indignación. ${ }^{17}$

En su lugar se incluye una "Advertencia" firmada por el editor que habla de rasgos "escritos con imparcialidad" y de que "su lectura es tan amena por la novedad de alguna de las escenas [...] y por la verdad que se descubre en todas". Se justificaba además la republicación de la obra por el desconocimiento general que se tenía de la figura del caudillo, a quien en este nuevo momento del pensamiento nacional se consideraba "menos brillante que muchos, pero más humano que todos". Pero se declaraba, también, que se sumaba a la recuperación de esta figura que acababa de iniciarse en el Senado ("Por primera vez acaba de oírse en el Congreso la voz de un elocuente orador, el Dr. Rawson, recordando con elogio al Patriarca de La Rioja"). ${ }^{18}$

El comienzo mismo de esta "Advertencia" cambia el planteo del folleto del 63; ya no son "los salvajes unitarios" los culpables denunciados, es una época de guerras encarnizadas que enfrentó a dos facciones enconadas: "Peñaloza fue arrebatado hacen [sic] doce años por el oleaje sangriento de un torbellino revolucionario". ${ }^{19}$ Se diluyeron los partidismos, el objetivo político inmediato del folleto de 1863, las acusaciones violentas y las invectivas. Los doce años que pasaron habían limado las aristas y Hernández buscó ser "imparcial”, "claro", "correcto".

Por último, incorporó a esta edición un "Apéndice” final que incluía una carta del Coronel D. Ricardo Vera, un parte de Pablo Irrazábal (ambas dirigidas a Sarmiento) y un texto de cierre en el que recuperaba modalidades enunciativas de la primera versión. La carta de Vera describía la actitud festiva de Sarmiento frente a la noticia de la muerte del Chacho: “Cuando le referí, a su pedido, las circunstancias de su captura y las formas horribles de su muerte, él, Gobernador de San Juan entonces, Presidente de la

\footnotetext{
${ }^{17}$ En cuanto a la presencia de la firma de Hernández (“J. H.”) al pie de estos dos textos suprimidos, no estaba al servicio de un fin expresivo particular, es una marca más del ritmo acelerado que el diarismo imponía a la producción de esta época. Como ya se ha comentado, la inmediatez de la edición del folleto después del cierre de El Argentino permite deducir que Hernández debe de haberse limitado a la reproducción de las notas periodísticas. Mientras los dos primeros apartados eran "sueltos" del diario (la noticia infausta y un documento), los dos siguientes eran "editoriales", y consecuentemente, llevaban su firma.

${ }^{18}$ Hernández, 2005, p. 57.

${ }^{19}$ Ibidem, p. 56.
} 
República después, y Senador ahora entusiasmado con el suceso, me dio un fuerte abrazo, mostrando verdadero gozo en el fin de aquel desgraciado". ${ }^{20}$ Y aquí, Hernández no pudo abandonar las marcas de la pesquisa del cronista de El Argentino de Paraná: "Hay suficiente luz para juzgar el hecho".

Como cierre -luego de los dos documentos que acusaban a Sarmiento-, Hernández comentaba la situación de la esposa del Chacho, que había sido:

[...] conducida a la cárcel de San Juan, engrillada y obligada a salir con sus cadenas, mezclada con otros presos a barrer las calles públicas. [...] El uno muerto como bandido, sólo obtuvo como galardón de sus generosos esfuerzos, un palo en que fue colocada su cabeza! La otra, por su parte viendo prolongarse su martirio, alcanzó por toda recompensa la oprobiosa cadena del presidio. ${ }^{21}$

Así, en el “Apéndice”, y a pesar de que la referencia a los "Amargos frutos de la guerra civil!" intenta diluir acusaciones puntuales, Hernández no pudo evitar una última mención a Sarmiento, responsabilizándolo ahora, y por primera vez, del destino de la viuda del caudillo. Por eso es sintomático que la frase final del folleto retome un lexema del campo semántico de la antinomia irreductible con cuya cita se encadena la nueva versión de su biografía al hipertexto que venimos analizando: "Escenas de barbarie: pasad para siempre del suelo de la República".

La notoria intención de la reescritura del 75 ha sido ofrecer garantías de ecuanimidad. Sin embargo, el "Apéndice" recupera la modalidad enunciativa de la primera versión, aunque esa calidad de "apéndice final" lo transforme en un documento de la barbarie del pasado con cuya referencia se ha abierto la reedición. No obstante, su presencia pone de manifiesto que difícilmente un texto es el resultado de una aplicación de reglas sistemáticas: las tensiones del proceso escritural siempre dejan en él alguna huella.

\footnotetext{
${ }^{20}$ Ariel de la Fuente explica con minuciosidad la participación de Vera en el episodio del Chacho: "Ricardo y Gregorio Vera, hijos de José María, estaban entre los pocos aliado que el gobierno nacional tenía en los Llanos en la década de 1860. Más aún, fue Ricardo quien, en noviembre de 1863, capturó a Chacho y lo entregó al comandante Pablo Irrazábal, que luego asesinó a Peñaloza" (De la Fuente, 2007, p. 47).

${ }^{21}$ Hernández, 2005, p. 58.
} 


\subsubsection{Otras reformulaciones}

No se ha producido, en cambio, ninguna reformulación estructural en la secuencia de diez capítulos que narran la vida del caudillo. Pero en el cotejo textual de las dos versiones se registra alrededor de 60 reescrituras en las que Hernández se esfuerza por eliminar toda marca de furor panfletario. Si atendemos a una operatoria escrituraria formal en la cadena enunciativa, las reformulaciones son de tres tipos: a) supresiones, b) reemplazos, c) interpolaciones. ${ }^{22}$

a) Las supresiones se asocian a la búsqueda de otros borramientos: el del encono claramente asociable con las luchas facciosas de una etapa histórica y el de la furia panfletaria del discurso político que las expresaba. La supresión del adjetivo "perversos" 23 con la que se calificaba a los adversarios del Chacho es un claro ejemplo. También se eliminan sistemáticamente las referencias peyorativas al partido que llama "unitario", en las que se había proyectado una fuerte carga de agresividad, como cuando se acusaba al grupo gobernante de manchar "con sangre las páginas de nuestra historia" ${ }^{24}$ y de ser "un partido de asesinos" 25.

b) Los reemplazos conllevan la misma intención moderadora en busca de formulaciones menos apasionadas y menos violentas. En lugar de "enemigos" del Chacho, ahora hablará de "adversarios" 26 (una identificación más neutra del oponente). Con el fin de atenuar marcas ostensibles de agresividad, en vez de "bárbaros asesinos", los matadores del caudillo serán "crueles asesinos"27 (una calificación que sólo dentro de un intertexto preciso conlleva ese efecto expresivo).

c) Gran parte de las interpolaciones responden a un propósito documental: aportan datos sobre las campañas de Peñaloza, detalles militares que Hernández no habría podido incorporar en las apresuradas primeras ediciones (la de las entregas de $E l$ Argentino de Paraná y el folleto publicado a su término); sobre todo, amplían las descripciones de los sucesos en los que intervino el Chacho. Un agregado le permite subrayar la proverbial generosidad del caudillo: "distribuyendo entre ellos un poco de

\footnotetext{
${ }^{22}$ Este cotejo editorial fue incluido en nuestra edición crítico-genética (Hernández, 2005, pp. 59-66).

${ }^{23}$ Hernández, 2005, p. 27.

${ }^{24}$ Ibidem, 2005, p. 30 ,

${ }^{25}$ Ibidem, p. 47.

${ }^{26}$ Ibidem, p. 27.

${ }^{27}$ Ibidem, p. 29.
} 
dinero del muy escaso que llevaba consigo, y aconsejándoles que abandonaran para siempre ese vergonzoso oficio". ${ }^{28}$

A lo largo de esta campaña de reescrituras, la enunciación se modaliza con otra orientación: a la par que se busca desterrar los actos de habla desafiantes y atenuar el tono exacerbado del lamento, se procura la objetividad narrativa. Ya no se trata -como se ha ejemplificado- de diseñar enfrentamientos maniqueos entre buenos y malos, y en la misma línea, se borra o se desdibuja la contundencia de las descalificaciones. Así, sólo desde la perspectiva de un hipertexto que contiene a la antinomia "civilización versus barbarie", puede entenderse que sustituir "bárbaros" por "crueles" es una atenuación que elude sobredeterminar el polo negativo del modelo. En otro contexto, la interpolación de este mismo adjetivo incorpora una actitud condenatoria inexistente en la primera versión: se trata de la suma del adjetivo "cruel" a una calificación de Facundo Quiroga (a quien la versión de 1863 describía como "prestigioso caudillo"): "prestigioso y cruel caudillo"29; pero el resultado es un sugestivo oxímoron que da cuenta de los debates internos que agitaban el pensamiento de Hernández en el año de su regreso definitivo a Buenos Aires. Pero en relación con Quiroga, se registra también un corrimiento muy significativo con el que Hernández toma distancia del campo de la "barbarie": en el texto del 75, Facundo Quiroga hará una cruzada "rápida y sangrienta", en lugar de "rápida y feliz" ${ }^{30}$, como se consignaba en la primera versión.

Así como se eliden las descalificaciones del partido gubernamental (los "salvajes unitarios" de la primera versión) se difuminan las referencias agresivas a Sarmiento. De la reiteración del apóstrofe "bárbaro asesino" se ha pasado a menciones neutras y a una crítica (tomada de las Quillotanas) que configura un registro anecdótico marginal -y aun así, convenientemente atenuado-: en la edición del 63 se dictaminaba que Sarmiento escribía su Facundo "haciéndose remunerar con largueza", pero en 1875 se consigna con más discreción: “aseguran que se hizo remunerar". ${ }^{31}$ A la vez, apartándose de las líneas acusatorias que -a través del conjunto de anónimos soldados del ejército nacional- confluían en Sarmiento, ahora se individualiza a un ejecutor para el principal

\footnotetext{
${ }^{28}$ Ibidem, p. 42.

${ }^{29}$ Hernández, 2005, p. 32.

${ }^{30}$ Ibidem, p. 33.

${ }^{31}$ Ibidem, p. 27.
} 
delito: Arredondo ${ }^{32}$. Se diluye así hasta ese enfrentamiento encarnizado entre facciones que tanto el comienzo de la "Advertencia" incorporada en la nueva versión, como sus reflexiones finales, señalaban como la principal causa de los males que conmocionaron un largo período de la vida nacional.

También en la visión del pasado se busca mayor objetividad al evocar la actuación del ejército unitario, como cuando suprime una opinión demoledora de las aptitudes profesionales de Lavalle; ${ }^{33}$ y atenúa ciertas descalificaciones: prefiere escudarse en un "según se cree" con el que sustituye la secuencia "por no dar a sus amigos parte en una gloria que él quería sólo para sí” "34. En la misma línea, se esfuman apreciaciones críticas acerca de la actuación de La Madrid, que de receptor de una acusación de traidor se transforma en un agente intermediario en un campo gobernado por "la fuerza de los sucesos". 35

A su vez, borra las marcas de exaltación de lo que se presentaba como una gesta heroica del Chacho, con una orientación reescrituraria que va despojando al caudillo de su categoría mítica: no lo privará totalmente de la denominación de "héroe", pero lo describe como un "héroe sencillo y modesto". ${ }^{36}$ Sin embargo, en otro pasaje sustituye el lexema "héroe" por "hombre" 37 para referirse a él; pero si Hernández desdibuja la dimensión heroica del personaje, no deja de destacar paralelamente su condición humana ejemplar. Así, el furibundo discurso panfletario que pretendía, desafiante, narrar una epopeya, y la acompañaba con un lamento exacerbado, se esfuerza por construir un relato biográfico objetivo atravesado por un tenue tono elegíaco.

En el final, en lugar de canalizar la responsabilidad última en los "unitarios", definidos como un "partido de asesinos", vuelve a identificar lo que la "Advertencia" había determinado como "causa fundamental": el encono de la lucha facciosa. ${ }^{38}$ Ya no hay "salvajes unitarios" y bárbaros de la política enfrentados con

\footnotetext{
${ }^{32}$ Ibidem, p. 47.

${ }^{33}$ En la versión de 1863 Hernández criticaba con dureza a Lavalle "que había asumido una empresa muy superior a sus fuerzas y a su genio [...]"; esta última descalificación es suprimida en la reedición del 75 (Hernández, 2005, p. 36).

${ }^{34}$ Ibidem, p. 37. En este mismo párrafo se elide también una subordinada en la que Hernández descalificaba violentamente a Lavalle: "cuya impericia militar era solo comparable con su petulante arrogancia".

${ }^{35}$ Ibidem, p. 37.

${ }^{36}$ Ibidem, p. 27.

${ }^{37}$ Ibidem, p. 45.

${ }^{38}$ Ibidem, p. 47.
} 
figuras patriarcales que encabezan gestas heroicas: hay sólo hombres en manos de un destino "ciego" que los maneja. El subtexto comunica que ha llegado la hora de la conciliación.

\subsection{Las reescrituras registradas en la $9^{\text {a }}$ edición de El gaucho Martín Fierro}

Esta extraña edición -analizada por primera vez en el volumen 51 de la Colección Archivos- ${ }^{39}$ continúa planteando interrogantes y la confrontación de las reescrituras que se registran en ella con el proceso textual de la biografía de Peñaloza puede acercar nuevas respuestas. En las modificaciones introducidas se ha reelaborado con especial atención el sociolecto del poema, no obstante lo cual se han producido también otras reformulaciones sugestivas. Aparentemente a contrapelo del itinerario reformulativo de la biografía de Peñaloza, El gaucho Martín Fierro retorna a la primera etapa escritural registrada. Sin embargo, las orientaciones reescriturarias de 1875 son coincidentes: para el poema, Hernández busca recuperar un registro expresivo del primer manuscrito que fue siendo progresivamente anulado en versiones sucesivas (desde la que se lee en la edición príncipe hasta la $8^{\mathrm{a}}$ edición); aunque en el caso de Rasgos biográficos del General D. Angel V. Peñaloza, se trata de imponerle al texto una modalidad discursiva que se aparta de la de 1863.

Si bien en esa $9^{a}$ edición, Hernández revierte en forma intempestiva la orientación reformulativa registrada, curiosamente también, esta reposición será desechada tajantemente en 1876 , en la $10^{\text {a }}$ edición. ${ }^{40}$ Así, paradójicamente, la $9^{\text {a }}$ es la edición de El gaucho Martín Fierro más intensamente reelaborada (se descubre en ella más de un centenar de modificaciones), pero Hernández rechaza esas reescrituras al año siguiente. Además, hay un detalle que se asocia a ese curioso proceso de ida y vuelta: Hernández publicaba una nueva edición de su poema cada vez que se había agotado la anterior, sin embargo publica la $9^{\text {a }}$ sin que se haya agotado la $8^{\text {a }}{ }^{41}$ Por otra parte, cuando en 1876 se reedite el poema, en una nota firmada por "Los Editores de la 10 Edición" (donde parece escucharse "la voz de Hernández") se hace una referencia

\footnotetext{
${ }^{39}$ Lois, 2001b, pp. LXII-LXVI y XCIV-XCVI.

${ }^{40} \mathrm{La} 10^{\mathrm{a}}$ edición retoma el texto de la $8^{\mathrm{a}}$, cuya línea reelaboradora será mantenida con escasas reescrituras en esa misma versión y la de las otras ediciones publicadas en vida del autor $\left(11^{\mathrm{a}} \mathrm{y}\right.$ $\left.12^{\mathrm{a}}\right)$.

${ }^{41}$ Zorraquín Becú , p. 238.
} 
expresa de esa "recuperación". ${ }^{42}$ Por lo tanto, el proceso reformulativo de la 9 a se asocia indisolublemente a conflictos personales y políticos que lo agitan en el año de su regreso definitivo a Buenos Aires.

Como en Rasgos biográficos del General D. Angel V. Peñaloza, Hernández también denunciaba la prepotencia del poder gubernamental cuando a fines de 1872 edita el folleto El gaucho Martín Fierro, que se enmarcaba en una prolongada situación de injusticia social cuyos efectos tuvieron consecuencias aún más devastadoras que las que se habían venido señalando (a pesar de estar claramente expuestas en el poema). ${ }^{43}$ En ambos textos, además, Hernández demostraba que la injusticia social provoca más rebeldía y más violencia: en el de 1863, la de su pluma; en el de 1872, la de un personaje gaucho creado por su pluma.

En el caso de El gaucho Martín Fierro, se han documentado numerosas etapas escriturales: un pre-texto manuscrito y varias ediciones supervisadas por Hernández. En ellas se descubren cambios muy significativos, que remiten a tensiones políticas y literarias; nos detendremos en las registradas en la edición de 1875.

Desde la óptica geneticista, los objetos de estudio que condensan indicios privilegiables son aquellos lugares de la enunciación donde las conceptualizaciones que regulan las prácticas discursivas se resquebrajan; y siendo la recursividad uno de los principios que gobiernan las conceptualizaciones -así como los procesos de socialización y de producción cultural-, es indudable que su incremento en los puntos de tensión es siempre significativo. Por eso, recortar los lugares de conflictos discursivos permite recopilar testimonios reveladores de sentidos ocultos o pruebas confirmatorias de hipótesis preexistentes.

Particularmente, en un contexto de situación agitado por tensiones sociales, una de las marcas que los enfrentamientos grupales imprimen en la escritura latinoamericana suele ser la elaboración del sociolecto. Y en este campo nos detendremos en un rasgo prosódico que a lo largo del proceso textual de El gaucho Martín Fierro entró en pronunciados vaivenes escriturales. Desde la variación libre propia del uso lingüístico real (registrada en el único manuscrito conservado), hasta su reelaboración en un proceso no

\footnotetext{
42 "Su autor, el señor Hernández, no ha querido hacer las mejoras que en su concepto reclama el plan orgánico de su producción" (Hernández, 2001, p. 93 -el destacado es nuestro-).

43 Esas consecuencias, que han sido puestas de relieve en las últimas décadas por los especialistas en historia agraria, instalaron nuevas lecturas del Martín Fierro (Garavaglia, 2001).
} 
documentado que desemboca en la $1^{\mathrm{a}}$ edición, pasando por un ajuste de cabos sueltos hasta la $8^{\mathrm{a}}$, siendo objeto de una reversión absoluta en la $9^{\mathrm{a}}$ pero repuesto totalmente en las siguientes, este rasgo marginal entra en un proceso de ida y vuelta que lo convierte, sin duda alguna, en un "lugar de conflictos discursivos".

La $1^{\mathrm{a}}$ edición del poema instaura una norma general para el encuentro de vocales que en la prosodia culta se pronunciaba invariablemente marcando un hiato: sinéresis al comienzo o en el interior del verso (aunque nunca en posición final porque se ha buscado destacar la fonética rural pero sin llegar al extremo de desnaturalizarla). ${ }^{44}$ Pero justamente, el género literario es "gauchesco" y no "gaucho" porque desde la etiqueta que lo rotula toma distancia de una realidad sociocultural, por más que sus autores se sientan consustanciados con sus penurias. La norma lingüística que vehiculiza el género da cuenta de una alianza de diferencias: "léxico y morfonética del dialecto rural pero con prosodia culta" (de allí que en las piezas más celebradas de la gauchesca anterior al poema de Hernández, "peleo" y "tenía" sean normalmente trisílabos en el interior del verso -muy particularmente, en el Fausto de Estanislao de Campo-). ${ }^{45}$

Ésta es una muestra del tipo de reescrituras que prevalece en la $9^{\mathrm{a}}$ ed.:

v. 105

ms.

[Qu]e no peleo ni mato

$1^{\mathrm{a}}, 2^{\mathrm{a}}, 8^{\mathrm{a}}$

Que nunca péleo ni mato

$9^{a}$

Que no peleo ni mato

$10^{\mathrm{a}}, 11^{\mathrm{a}} \mathrm{y} 12^{\mathrm{a}}$

Que nunca péleo ni mato

\footnotetext{
${ }^{44}$ La métrica panhispánica del siglo XIX demuestra que no se había generalizado la variación contextual del castellano actual: "María" es trisílabo en la pronunciación de "Ana María" pero bisílabo en la de "María Luisa".

${ }^{45}$ Aunque para la recepción letrada del siglo XIX el género gauchesco fue siempre considerado como una especie de "subliteratura", esta pieza fue ampliamente celebrada. Josefina Ludmer considera que, con ella, por primera vez se produce en el género una "autonomización de lo literario" (Ludmer, 1988, p. 242).
} 
ms.

$1^{\mathrm{a}}, 2^{\mathrm{a}}, 8^{\mathrm{a}}$

$9^{\mathrm{a}}$

$10^{\mathrm{a}}, 11^{\mathrm{a}}$ y $12^{\mathrm{a}}$

vs. $647-648$

ms.

$1^{\mathrm{a}}, 2^{\mathrm{a}}, 8^{\mathrm{a}}$

$9^{\mathrm{a}}$

$10^{\mathrm{a}}, 11^{\mathrm{a}}$ y $12^{\mathrm{a}}$
Con lo que habían tomao.

Con lo que habian manotiao.

Con lo que habían tomao.

Con lo que habian manotiao.
Me tenían medio loco

La pobreza y los ratones.

Ya nos tenian medio loco

La pobreza y los ratones.

Me tenían medio loco

La pobreza y los ratones. ${ }^{46}$

Ya nos tenian medio loco

La pobreza y los ratones. ${ }^{47}$

En el peritexto crítico que Hernández anexó a la $8^{\text {a }}$ edición de El gaucho Martín Fierro (y que salvo en la $9^{a}$-que lo suprimió- fue ampliándose notablemente) ${ }^{48}$ se reitera

\footnotetext{
${ }^{46}$ Esta orientación reformulativa se reitera en los versos 326, 456, 528, 538, 552, 575, 593, 652, 797, 900, 1003, 1025, 1056, 1682.

${ }^{47}$ Ver la génesis de los vs. 326, 456, 528, 538, 552, 575, 593, 652, 797, 900, 1003, 1025, 1056 y 1682 de El gaucho Martín Fierro (Hernández, 2001).

${ }^{48}$ Hernández tituló esa sección "Juicios críticos" y la sucesión de ediciones va documentando cómo, en forma progresiva, figuras del campo político-cultural cada vez más prominentes comentaban el poema y su formidable éxito editorial (Hernández, 2001, pp. 11-97).
} 
una y otra vez la mención de "versos mal medidos" (juzgados siempre como una falta que empaña grandes méritos). ${ }^{49}$ No obstante, todos los versos registrados en manuscritos tienen una invariable medida octosilábica. ${ }^{50}$ La sociedad letrada se niega a "oír" la voz del dialecto gaucho en una zona en que hasta el código del género gauchesco la había enmudecido: son los hiatos de la prosodia culta y la lectura de la sociedad letrada los que crean "versos rengos". 51

Sin duda, un rasgo prosódico que tiene su disparador en derivas panhispánicas, y cuyo carácter de marcador sociolingüístico no depende de su naturaleza sino del índice de frecuencia, debería tener una circulación mayor en la campaña. Es muy probable también que, después de haber vivido en los campos del Sur desde los 11 a los 18 años, éstas y otras marcas distinguiesen el habla de Hernández de la de la elite urbana. ${ }^{52}$ Llama la atención, por ejemplo, que las practique en su poesía culta. ${ }^{53}$

A veces es posible hallar en los márgenes indicios reveladores de lo que se agita en el centro; en este sentido, Élida Lois ha interpretado ese rasgo prosódico como un schibboleth $^{54}$ hernandiano, una marca lingüística que genera discriminación social y un emblema de sus debates ideológicos. La hegemonía lingüística que impone una cultura dominante nunca es absoluta, tiene resquicios por los que penetran -a través del mismo lenguaje- concepciones del mundo que entrañan ideas disímiles y contradictorias. Así, registros, dialectos sociales, temas y géneros discursivos heterogéneos -como en este caso, el híbrido de la literatura gauchesca- constituyen un soporte apropiado para la construcción de un discurso contrahegemónico. ${ }^{55}$

\footnotetext{
${ }^{49}$ Ibidem, pp. 8, 14, 34.

${ }^{50}$ En este sentido, tienen mayor valor probatorio los manuscritos de la Vuelta porque en ellos se registran apuntes veloces y primeras textualizaciones.

${ }^{51}$ En cuanto a los eneasílabos reiterados de los vs. 3036 y 3042 de la Vuelta ("Artículos de Santa Fe", en lugar de "Artículos de la Fe"), disuenan a sabiendas para destacar la presunta confusión de Picardía atraído por una bella mulata.

${ }^{52}$ En cuanto a su prosa periodística y su oratoria parlamentaria, puede decirse que no comete más incorrecciones gramaticales que Sarmiento, por ejemplo.

${ }^{53}$ Son citados por Lois (2001b, p. XCV, n. 159).

${ }^{54}$ Jacques Derrida denomina así "toute marque insignifiante, arbitraire, par exemple la différence phonématique entre schi et si quand elle devient discriminante, décisive et coupante"; juzga que el vocablo conserva la tensión del episodio bíblico donde se la utiliza (la pronunciación de ese vocablo permitía identificar la nacionalidad de guerreros vencidos que intentaban ponerse a salvo transponiendo la frontera): "Son origine suppose elle-même l'appartenance à une communauté culturelle et linguistique, à un milieu d'apprentissage, une alliance en somme" (Derrida, 1986, pp. 44-45, 50-51).

${ }^{55}$ Lois, 2001b, pp. XCIV-XCVI.
} 
Es probable que, desde 1872 hasta 1874, la intensificación de ese marcador social haya estado asociada a un gesto de rebeldía desafiante y que los vaivenes subsiguientes acompañaran su proceso de reinserción en la ciudad letrada. Así, como en el mismo año 1875 busca mediante variados recursos borrar el tono de desafío de Rasgos biográficos del General D. Angel V. Peñaloza, esta esforzada reelaboración de la "clave lingüística" parece orientarse en la misma dirección.

Pero también se registran otras reelaboraciones de la "clave lingüística" en la $9^{a}$ edición. Aunque no de modo sistemático, Hernández elimina a veces vacilaciones de timbre vocálico del dialecto rural que se proyectaron en todas las piezas de género gauchesco: formas como avirigüé, dispierto, sepoltura, plaito, son reemplazadas por averigüé, despierto, sepultura, pleito. Hay también alguna sustitución aislada de la velarización de labiales (güeno) por la forma estandarizada (bueno) y alguna reposición esporádica de la - $d$ - intervocálica en la terminación -ao (marcas linguiísticas inseparables del género). Se podría pensar que, justamente porque Hernández domina el habla rural, intenta recrear la variación libre de las lenguas vivas, o que se empeña en evitar la caricaturización del gaucho suprimiendo la acumulación de ocurrencias que nunca han sido sistemáticas en la oralidad; pero también podría ser que busque moderar la rebeldía propia del género gauchipolítico atenuando la rusticidad de un lenguaje que todavía muchos perciben como un latigazo de la barbarie. No obstante estas posibilidades deductivas, lo concreto es que estas reescrituras también serán abandonadas definitivamente por Hernández al año siguiente.

Los teóricos de la crítica genética destacan la imposibilidad de reconstruir el mundo de asociaciones que motivan cada reformulación de un autor, por eso se proponen recortar tendencias, conflictos discursivos y explosiones discordantes para proponer sobre esa base interpretaciones posibles. Recortando tendencias, vinimos analizando en dos textos de 1875 procesos reformulativos en los que Hernández busca modelar un discurso menos violento reprimiendo actitudes desafiantes y borrando gestos de aceptación o de conmiseración frente a la barbarie; pero como ningún texto es el resultado inevitable de la aplicación de un sistema de reglas, una reescritura aislada marcha en otra dirección (la del v. 1468):

vs. $1463-1468$ 


\section{$1^{\mathrm{a}}, 2^{\mathrm{a}} \quad$ Es triste en medio del campo \\ Pasarse noches enteras \\ Contemplando en sus carreras \\ Las estrellas que Dios cría, \\ Sin tener más compañía \\ Que su soledá y las fieras.}

vs. $1467-1468$

$8^{\mathrm{a}}$

Sin tener más compañía

Que su delito y las fieras.

$9^{a}$

Sin tener más compañía

Que la soledá y las fieras.

$10^{\mathrm{a}}, 11^{\mathrm{a}}, 12^{\mathrm{a}} \quad$ Sin tener más compañía

Que su delito y las fieras.

En 1874, la $8^{\text {a }}$ edición había introducido la carga de la culpa en la conciencia de una víctima de la injusticia social, apenas insinuada antes en los versos 1237-1238 ("Nunca me puedo olvidar / De la agonia de aquel negro"); pero en 1875, el mismo autor que está atenuando el tono desafiante del discurso del poema no se decide, sin embargo, a culpar a su criatura, que aparece en medio de una soledad que ya no es la de la situación individual del matrero que vive fuera de la ley sino la de un hombre desamparado frente a la inmensidad de la naturaleza americana. ${ }^{56}$ No obstante, un año después, la $10^{\mathrm{a}}$ edición repondrá el verso 1468 de la $8^{\mathrm{a}}$ : el anticipo de una vertiente que se acentuará en la escritura de la Vuelta.

\subsection{Las reformulaciones escriturales de 1875 en contexto}

La unificación nacional no podía poner fin a los enfrentamientos facciosos; tras la batalla de Pavón, cuyo desenlace fue atribuido por los federales del interior a una defección de su jefe político-militar, se incubaron rencores que no estallaron hasta el

${ }^{56}$ Ibidem, p. LXVI. 
levantamiento de López Jordán. Pero con el correr de los años se fue produciendo el progresivo regreso de los exiliados porteños.

En la práctica periodística que se desarrolló intensamente en el interior, se había engendrado el anatema de "falsos liberales" para calificar a los actores del poder gubernamental de Buenos Aires, una designación que ponía de manifiesto una adscripción esencial a la ideología que prevalece en el campo político de la época ("libertad", "progreso", "escuelas", los típicos lexemas del campo de la "civilización" delineado por el liberalismo, hasta pueden rastrearse en proclamas de caudillos regionales). ${ }^{57}$ Por otra parte, ya El Río de la Plata había expuesto una programática de reinserción (que Halperín Donghi interpreta como la formulación de una ideología ruralista). ${ }^{58}$

El contexto de situación del regreso de Hernández muestra acercamientos multidireccionales: el año anterior, la unión del Partido Autonomista y el Partido Nacional había llevado a la presidencia de la República a Nicolás Avellaneda, quien -en el marco de esa alianza- inaugurará una política de "conciliación nacional". Progresivamente, tanto militantes del Partido Federal del interior como los antiguos “chupandinos" que se habían exiliado de Buenos Aires se irán incorporando a la que se convertirá en la fuerza dominante hasta comienzos del siglo XX: el Partido Autonomista Nacional. Hernández ya estará militando en el autonomismo en 1876, pero en 1875, fuerzas contrapuestas se agitan en sus reescrituras.

Los adversarios a los que se había enfrentado en su producción como publicista ya no tienen la significación que tuvieron en la vida nacional. Sarmiento ocupará cargos públicos después de su presidencia, pero ya no será un "nombre del poder"; en cuanto a Mitre, si bien no desaparecerá de la escena porteña, ha dejado de ser el hombre que manejó hilos políticos en Buenos Aires desde 1852 y que dirigió los destinos del país desde 1861 hasta 1868.

En este marco, la resemantización de la antinomia "civilización versus barbarie" tomará otra orientación. Ya no es funcional redireccionarla en un discurso-boomerang contra su autor y contra el engranaje político donde Sarmiento se incorporará una década después de haberla creado; ha llegado el momento de apoderarse de ella para

\footnotetext{
${ }^{57}$ Jitrik , 1971b.

${ }^{58}$ Halperín Donghi, 1985, pp. 223-279.
} 
proponer otra programática que intente convertir la "barbarie" en "civilización", y paulatinamente, temas concretos irán ocupando el centro de la escena. Pero en 1875, aunque Hernández ha decidido responder al llamado a la "conciliación nacional", todavía se debate entre impulsos contrapuestos (faltan cuatro años para que puedan ser leídos los versos 4827-4828 de la Vuelta: "Debe el gaucho tener casa, / Escuela, Iglesia y derechos").

Como hemos visto, el biógrafo de Vida del Chacho toma distancia de la epopeya y del planctus. Se esfuerza por conferir a su relato apariencias de objetividad. Para ello elimina el maniqueísmo de las mitificaciones y la actitud desafiante del enfervorizado discurso panfletario de 1863: el héroe de epopeya es un hombre digno que ha sido víctima del abuso del poder, y la enunciación apenas se permite un suave tono elegíaco para sustituir el grito desgarrador con que se había recibido la noticia de su muerte. Abre y cierra la historia con referencias a la violencia de una época superada, en la que radica la responsabilidad de las desmesuras bárbaras, pero en medio de un "Apéndice" que parecería responder al afán de un documentalista ecuánime, afloran las proyecciones emocionales refrenadas en el texto. De allí que puedan estallar nuevamente en otro género: la polémica que se desencadena después de la publicación entre "la voz de Sarmiento" que lo enfrenta desde La Tribuna y la recuperada voz del diarista Hernández que le responde desde La Libertad. ${ }^{59}$

Pero en su condición de autor exitoso de El gaucho Martín Fierro, ha ensayado un procedimiento más sutil (aunque más condescendiente de lo que él mismo debe de haber imaginado en un principio) para hacer una ofrenda en el altar de la conciliación: la atenuación del tono de desafío de su poema mediante la reelaboración del sociolecto en el que se canaliza, entre nosotros, el fenómeno editorial más llamativo del siglo XIX. El número de ediciones, el hecho de que se agotaran velozmente, ${ }^{60}$ los inicios de una recepción crítica que el propio autor empieza a compilar y publicar como paratexto a partir de la $8^{a}$ edición $^{61}$ y la veloz oralización del poema (registrada ya en la campaña

\footnotetext{
${ }^{59}$ Ver 5.2. y 5.3.

${ }^{60}$ Empiezan a circular, incluso, ediciones piratas. Hernández es el primer escritor argentino que entabla pleitos por piratería editorial.

${ }^{61}$ Hernández, 2001, pp. 86-91.
} 
rioplatense en 1874), ${ }^{62}$ todos esos datos configuran un fenómeno jamás visto en el incipiente campo literario de la ciudad que pronto dejará de ser la Gran Aldea.

En las obsesivas reescrituras que alteran ostensiblemente el discurso de un poema que en poco tiempo ya se ha vuelto famoso, Hernández suprime marcadores lingüísticos que podrían ser percibidos como una "agresión" tan fuerte como aquel virulento "Los salvajes unitarios están de fiesta" de los Rasgos biográficos del General D. Angel V. Peñaloza. Pero Hernández está ofrendando algo que ya no le pertenece: la voz de Fierro ya está circulando por vía de la transmisión oral. ${ }^{63}$

Al examinar la interrelación entre ambos procesos editoriales, se advierte la existencia de una nueva etapa de la producción de Hernández cuyo análisis no había sido encarado antes. El año 75 es un punto de inflexión en su vida y conlleva una reconsideración de su posición política y de su escritura: la reformulación de estos dos textos lo atestigua con claridad. Sus reescrituras dan cuenta de múltiples reflexiones que a veces se acompañan pero otras veces parecieran contradecirse, deslindando la vertiente de dos actitudes contrapuestas; esta tensión es tan intensa, que las dos líneas reformulativas serán rápidamente alteradas por el escritor: la moderación enunciativa de Vida del Chacho será sustituida por la recuperación del ardor panfletario en la polémica periodística que siguió a su publicación, y la vibrante voz del gaucho Fierro volverá a escucharse en 1876 (y no será totalmente borrada de la Vuelta). ${ }^{64}$

\footnotetext{
${ }^{62}$ Ibidem, pp. 65-66.

${ }^{63}$ El propio Hernández lo está reconociendo cuando dice por medio de los "Editores de la $10^{\mathrm{a}}$ edición": "Su autor, el señor Hernández, no ha querido hacer las mejoras que en su concepto reclama el plan orgánico de su producción. Él ha caído en cuenta que se expondría a desvirtuar una de sus principales condiciones de popularidad, la sencillez, la incorrección misma con que se aproxima muchas veces al sentimiento estético del gaucho" (Hernández, 2001, p. 93 -el destacado es nuestro-).

${ }^{64}$ La vuelta de Martín Fierro, versos 3617-3656, 3689-3724, 3835-3842.
} 


\section{EL ÚLTIMO ESLABÓN DE UNA POLÉMICA. SARMIENTO VS. HERNÁNDEZ}

\subsection{Hernández reafirma su postura. Recuperación de la polémica en La Patria de Montevideo (1874)}

Hernández vuelve a polemizar con Sarmiento sobre el cierre de su presidencia en 1874, aunque desde 1870 no se registraba ninguna participación periodística suya. Entre tanto se gestó la elaboración de El gaucho Martín Fierro (1872) y se produjo su formidable éxito editorial, lo que seguramente desvió su encono político. Antes de ello, además, Hernández se había marchado en rebeldía tras de las huestes de López Jordán, luego del asesinato de Urquiza en 1870, y Sarmiento había puesto precio a su cabeza. Entre estas mudanzas y la plena satisfacción de disfrutar del triunfo que su poema significa, hacia el final de la administración sarmientina Hernández desplazaba el eje de sus críticas periodísticas a Mitre, aunque no puede evitar que algunas notas de desprecio alcancen al sanjuanino.

En 1874 Hernández prolongaba su exilio en Montevideo, y en La Patria, periódico de Héctor S. Soto -hijo de Juan José Soto, el co-redactor de La Reforma Pacífica-, ${ }^{1}$ publicó siete cartas -firmadas “Un Patagón”- dirigidas a Benjamín Vicuña Mackenna, en las que denostaba duramente el personalismo de Mitre. ${ }^{2}$ Sin embargo, deslizaba también algunas referencias a Sarmiento en la segunda carta, la quinta y la séptima. En esta última mencionaba las Cartas quillotanas de Alberdi como una de las “obras notables de esclarecidos ingenios".

También en las notas agrupadas bajo el título "La bolilla negra", en las que daba rienda suelta a las más severas críticas a Mitre, se refería a Sarmiento. En esta etapa de un crecido furor antimitrista, Hernández parece atenuar su encono con el sanjuanino disculpando sus excesos a los que "lo empujaba el hombre más funesto", de la misma manera que lo había hecho en sus editoriales de El Río de la Plata, como se ha observado ya.

\footnotetext{
${ }^{1}$ Jorge Rivera señala que, en La Patria de Montevideo, aparece una de las primeras críticas elogiosas de El gaucho Martín Fierro (Rivera, 2001, pp. 545-575).

${ }^{2}$ Las transcripciones de los artículos se toman de Walter Rela (1967).
} 
De este modo, las desviadas menciones a Sarmiento, siempre en estrecha relación con el ataque rabioso a Mitre (la mención inicial recuerda que Sarmiento se presentó al último Congreso Americano "sin autorización y sin poderes" porque Mitre no se dignó enviar representantes), quedaban perdidas en un fárrago de objeciones a la política mitrista.

Más adelante, sí será corrosivo al recordar la relación de ambos políticos liberales con el Imperio brasileño. Hernández demostraba que seguía con atención la lectura de los textos sarmientinos diciéndole a Vicuña Mackenna: "Permítame Ud. que ayude su memoria al respecto con un antecedente publicado en uno de los libros de Sarmiento" y transcribe textualmente el segundo párrafo de una carta que desde Río de Janeiro le dirige a Mitre para recordarle el momento en que ambos compartieron el puente del navío brasileño en el combate naval del Tonelero y que les valió la condecoración de la Orden Militar de la Rosa. Esta referencia es muy significativa en varios aspectos. Primero, porque el texto citado está incluido en la Campaña en el Ejército Grande, que como ya se ha visto, es el gran disparador de los futuros obstáculos en el recorrido político de Sarmiento; ${ }^{3}$ con la publicación de este texto con una irónica dedicatoria a Alberdi, Sarmiento se gana al gran adversario de toda su vida, y abre la ancha vía de una oposición que se extenderá hasta el final de sus días. Segundo, porque permite evidenciar una vez más que Hernández es un concienzudo lector de Sarmiento. Y en tercer lugar, sirve para determinar nuevamente que en este punto sus posiciones son terminantes, pues este episodio es duramente interpretado por Hernández como una traición a la patria.

La quinta carta firmada por "Un Patagón” estaba dedicada a estudiar la cuestión del personalismo en América y evaluaba la sucesión presidencial de Sarmiento, que se disputaba entre Avellaneda y Mitre. Hernández le explicaba al chileno que existía también la posibilidad de "ocurrencia Sarmentezca [sic] de dejar a los dos mirando" al "hacerse prorrogar sus poderes, por dos o tres años más, pues el ejemplo de Mac-Mahon le encanta y hay Congreso para todo". ${ }^{4}$ Esta apreciación se vincula con todo el orbe polémico que se ha venido analizando, al igual que una intercalación en medio de la

\footnotetext{
${ }^{3}$ El extracto que copia Hernández pertenece a la misiva enviada a Mitre desde Río de Janeiro el 3 de abril de 1852, que Sarmiento incluye en su Campaña, en el Complemento. Puede leerse completa en la edición de la Universidad de Quilmes ya citada, pp. 108 a 115.

${ }^{4}$ Rela, 1967, p. 54.
} 
despedida de la séptima misiva en la que Hernández se refiere a antecesores gloriosos del género epistolar entre los que incluye las Cartas quillotanas "del Dr. Alberdi dirigidas al actual presidente argentino" (lo que refuerza nuestro convencimiento de que Hernández ha seguido con particular interés la desavenencia suscitada entre Alberdi y Sarmiento luego de Caseros).

En 1875, finalizada ya la gestión presidencial de Sarmiento, Hernández retorna del exilio para radicarse definitivamente en su provincia natal, bajo la protección del gobierno de Avellaneda, pero no tardará en verse involucrado en nuevas confrontaciones. Entre agosto y septiembre decide publicar una vez más su folleto sobre el Chacho Peñaloza con la intención de ofrecer su versión de los hechos, pero como se ha analizado en el capítulo anterior- se moderan los desbordes pasionales, se mitigan las adhesiones facciosas y se atenúa la visión épica del caudillismo. Sin embargo, la republicación se enmarca en un proceso complejo de recriminaciones políticas dirigidas al ex presidente Sarmiento, y actual senador, en pleno recinto legislativo mientras se discute su posición frente a hechos políticos muy significativos para la vida nacional. La Tribuna -el diario de los hermanos Varela- se sumará a ese coro de voces con una airada respuesta en defensa de la posición del sanjuanino. ${ }^{5}$

\subsection{La reacción del diario La Tribuna}

Como señala Claudia Román, ${ }^{6}$ los hijos de Florencio Varela -Héctor y Marianoheredan de su padre un capital simbólico tan importante, que esto les permite fundar inmediatamente después de la caída de Rosas su propio periódico: La Tribuna (18531884) -conocida popularmente como "La Tribuna de los Varela"-, y posicionarse con holgura entre los órganos más destacados de Buenos Aires durante treinta años. ${ }^{7}$ Como legatarios de la raigambre unitaria de su padre, los Varela sostendrán un fuerte apoyo a la política del nuevo partido liberal -que se manifestará claramente en el ataque a los caudillos del interior-, y luego del 11 de septiembre de 1852, abrazarán la causa

\footnotetext{
${ }^{5}$ Horacio J. Becco señala la existencia de esta polémica en su "Bibliografía hernandiana", asiento 302 (Becco, 1972a).

${ }^{6}$ Esta autora analiza, especialmente, el periodismo combativo de Héctor Varela (Román, 2003, pp. 439-467).

${ }^{7}$ Florencio Varela había sido asesinado el 22 de mayo de 1848, en Montevideo, donde había fundado su periódico El Comercio del Plata, desde el cual se disponía a batallar contra Rosas.
} 
porteña. ${ }^{8}$ Además de la veta política signada por el ícono en que se convierte Florencio Varela luego de su asesinato a manos de la mazorca, Héctor y Mariano y sus demás colaboradores -todos jóvenes menores de 30 años- le dan a La Tribuna una impronta “zumbona”, que se singulariza por el tono cáustico de sus notas; lidera esta línea la sección del propio Héctor, que en esta época hace famoso su seudónimo: "Orión".9

Ya se ha visto cómo refleja La Tribuna, en 1863, la "feliz" noticia de la muerte del Chacho, que se aprecia como la puerta de entrada a una nueva era de progreso para la Nación. Esta lectura es coherente con el espacio que se le dedicará ahora a la defensa de Sarmiento en relación con su participación en los hechos que terminaron con el asesinato del Chacho. El vínculo de los Varela con Sarmiento se había estrechado en los últimos años: el periódico funcionó como un declarado promotor de su candidatura, y durante su presidencia, Mariano se desempeñó como ministro de relaciones exteriores y Luis V. como ministro del interior. Esta múltiple relación con los Varela obliga a pensar que su periódico funcionó como agente propagandístico de la personalidad de Sarmiento y de la gestión en la cual habían participado activamente y en cargos relevantes dos miembros de la familia.

En la correspondencia privada de Sarmiento con José Posse -fundamentalmente durante 1870- se encuentran numerosas menciones a Héctor Varela a propósito del viaje que hace Sarmiento al litoral, cuya comitiva integra. Este viaje, que significa un paso importante para su administración pues supone el acercamiento a una zona de resistencia política, es pormenorizado en notas que Orión publica en La Tribuna y que dan cuenta del espíritu ilusionado que acompañó a este significativo período de la administración sarmientina, iniciado con el histórico encuentro entre Sarmiento y Urquiza, pero que culminó con el funesto asesinato del caudillo entrerriano. ${ }^{10}$ En sus

\footnotetext{
${ }^{8}$ Héctor Florencio y Mariano se alternan la dirección del periódico, pero también participan de la redacción los hermanos menores: Horacio, Luis V., Juan Cruz y Rufino.

${ }^{9}$ En carta a Alberdi de 1856, Mariquita Sánchez de Mendeville discurre sobre los "excesos" del periodismo de Buenos Aires y se detiene en Héctor Varela, "que quiere especular siempre con la memoria y el cadáver de su padre" y critica a La Tribuna por sus artículos desmedidos que tienen "popularidad porque los llena de cuentos, de bromas, de mentiras y tan grandes que al día siguiente se desdicen ellos mismos" (citado en Sierra, 1980, p. 295).

${ }^{10}$ Sarmiento llegó a Concepción del Uruguay el 2 de febrero de 1870 y al día siguiente aniversario de la batalla de Caseros- se entrevistó con Urquiza. Acompañaba a Sarmiento una nutrida comitiva: además de su edecán -Pantaleón Gómez-, su ministro Gorostiaga, el gobernador de Santa Fe Mariano Cabal, el Coronel Luis María Campos, los Generales Conesa y Arredondo, el Canónigo Martín Piñeiro, Héctor F. Varela, Miguel Cané, el redactor de The
} 
cartas se observa que Sarmiento siente una simpatía particular por Héctor, a quien llama

“el león y el niño mimado del pueblo", aun a sabiendas de que la opinión de Posse es diferente y bastante crítica del "orionismo"; ${ }^{11}$ incluso, ha intentado sin éxito convencer a Posse para que modifique su juicio negativo sobre el enjundioso periodista. ${ }^{12}$

Standard, los ministros de Estados Unidos, de Rusia, de Francia y los Condes de España y de Italia, además de otras altas autoridades civiles y militares. Urquiza fue asesinado el 11 de abril de 1870.

${ }^{11}$ Son numerosas las referencias a Orión en la correspondencia de Sarmiento con José Posse. El 24 de enero de 1870 Sarmiento viaja a Rosario exultante de optimismo por la pujanza del campo argentino, por los estancieros y el arranque promisorio de su administración y le comenta a Posse:

Gorostiaga que me acompaña ha brillado por su cultura con los ministros, por su decisión y robustez de palabra en los banquetes, en que ha sido todo mi desempeño. Hector Varela es el león y el niño mimado del pueblo. Tengo una deuda inmensa contraída con Villafañe a quien leeras esta carta como dirijida a él. El nacionalista lleno el proposito de su titulo aunque la impresion es perversa. A nuestro amigo Frias mis mas calorosos recuerdos; y si tu no vinieras en su lugar nunca me consolaria de su ausencia en el Congreso.

Buenos Aires, 7 de abril de 1870:

No por afinidad líbreme Dios del caso, sino porque estaras tambien dando al traste con mi silencio me acuerdo de la rabieta quondam amigo. Ah $i$ me he acordado cien veces y a cada hora de ti! Pero que se hace con quinientas leguas de por medio para recibir una contestacion! Ha muerto Piñero, paladium que tenia en el Senado, y te han cerrado a ti la puerta. En materia de amigos he sido desgraciado! Ambos Peñas, Aberastain, Dominguito, Belin, Piñero todos los que me querían me han faltado en la hora en que necesitaba de su concurso, y tu tambien atado con las tela arañas de Provincia no has podido en dos años darme la mano. Queda un asiento vacio en el Senado, y una pluma sin tinta en la prensa. Esta podrias mojarla tu, y poner un poco de talento y gracia del lado del gobierno, que está en mano de Orion y un inepto en el $\mathrm{N}$.

Buenos Aires, 17 de septiembre de 1870:

Aqui tiene sus secuaces la Republica - Orion. Ayer hubo un meeting para festejarla y felicitarla. Hector, Mitre, su hijo, J. C. Gomez. Guido, etc. etc . Hai cordiales simpatias por la Republica, aun por la esperanza de ella. Si triunfase en Francia tendriamos imitaciones de desorden popular. [...] Hemos tenido al fin una victoria en el Entre Rios que ira completandose con nuevos triunfos. Esto nos dejara respirar, durante los seis meses de interregno de Oroño y demas. Empiezan a ajitarse trabajos para la Presidencia futura y aunque creo que seran mui anticipados sino tienen atingencia con la presente, no dejaran de ejercer influencia en los movimientos sino de la prensa de la oposicion. La prensa aqui son los hombres que estan en barbecho. Cada diario es un personaje, a quien pertenece la empresa. Asi no hai esperanza de convencerlos de error. Cómo convencerá V. a Quintana, Mitre, Oroño, Rawson de que no son ellos R., Oroño, Mitre o Quintana Todos contra el G. N. o el Ejecutivo o yo (pobre individualidad como dice Orion) pero cada uno de ellos contra todos los demas. He hablado con Avellaneda quien me asegura tiene puesto para tu protegido para el $1^{\circ}$ de Enero. Recordaras que te dije que era mas facil hacerte Emperador que proveer para un escribiente. Deseo oirte en tus cartas si has abandonado tu idea del Orionismo has hecho bien. Esas cosas se tratan de cerca. De lejos fiambre y debil pon los incidentes nuevos.

Ver www.proyectosarmiento.com.ar

${ }^{12}$ Respuestas de Posse a Sarmiento:

12 de mayo de 1870 :

La muerte de Piñero me ha causado tanta pena como a ti pensando en la falta que te hace en el Senado $\mathrm{p}^{\mathrm{a}}$ mantener la disciplina del partido, y para tener a raya la osadía de la oposicion. Y lo peor es que no veo quien lo reemplaze en el papel especial que desempeñaba. Ha muerto sin desmoralizarse lo que ya es mucho decir en un pais cuya administracion de justicia acaba de descubrirnos la lepra qe devora a esa sociedad; allá donde Orión pasa por el primer hombre del 
Por otro lado, se observa que Orión actúa como una suerte de asesor de imagen de Sarmiento, según se deduce de lo que éste le cuenta a Posse en la misiva del 17 de septiembre de 1870 , en la que se queja de su aislamiento político y se define -citando las palabras de Héctor Varela- como una "pobre individualidad". La influencia de Orión es tal, que Sarmiento le otorga el crédito, poco común en él, de definir su propio “yo". También se descubre en su correspondencia con Posse que el órgano de los Varela y La Unión se muestran dispuestos a ofrecer sus columnas a Sarmiento para colocar sus artículos y así llegar a la opinión pública. ${ }^{13}$

Estos antecedentes permiten conjeturar que Sarmiento, durante su presidencia, se dirigía con absoluta naturalidad a la redacción de La Tribuna tanto para acercar sus notas-como para orientar la redacción; práctica ya ejercitada por él, según demostró Ana María Barrenechea. ${ }^{14}$ El testimonio que ella analiza en su artículo sobre la carta que

Río de la Plata, dando música con su organito en todos los banquetes, y banquetes inventados $\mathrm{p}^{\mathrm{a}}$ oir la música.

2 de noviembre de 1870:

Estoi aturdido con el trájico fin del Imperio Frances y mas aturdido de la aparicion de la República, como idea y como forma de Gobno. por el mismo pueblo y por la misma opinión que dio el plebiscito de ahora ocho meses. Con mil diablos qe todo el mundo se vá volviendo Oriones?

10 de diciembre de 1870 :

La aparicion del Comité de la Paz en Buenos Ayres me hace creer que la rebelion entrerriana saca por alla las uñas, no solo por hipócrita revelacion de sus fines, sino por el personal que compone el Comité. Me parece que allí estan la flor de la canela de caudillejos y anarquistas de levita, de esos que toda su vida se han llevado jugando con trampas en la política. Ecepto de entre ellos a Orion que debe estar ahí con entrada gratis, a pedido suyo, por satisfacer la fiebre qe tiene su pobre personalidad de estar presente donde se queman cohetes o somete cualquier otro jénero de bulla, y por fin donde haya que vaciar discursos a los vivos o a los muertos. Sin Orion no hai vida porteña.

11 de enero de 1871:

A la vejez me he puesto del lado de las antiguas preocupaciones contra Bs Ays, no encontrando exajerado cuanto Alberdi ha escrito en ese sentido. De alla ha soplado siempre el viento de la anarquia, de alla el modelo de los tiranos, de alla el desorden moral y las descomposiciones sociales. iQue hormiguero aquel de hombres inquietos! Tiendo la vista buscando uno de buen sentido y hallo que todos son Oriones.

Ver www.proyectosarmiento.com.ar

${ }^{13}$ Sarmiento se refiere también a su vínculo con otros periódicos de la época. Carta a Posse del 8 de junio de 1873:

Aun se arrastra la guerra en preparativos de uno y otro lado; pero tengo ya siete batallones (medios) de linea en acción, tres buenos, rejtos, toda la artillería necesaria, y milicia hasta siete mil hombres. El movimiento es salvaje, y parece intensa la revuelta, aunque no sepan decir con que fin. Faltabanos esta pata por desollar el Entre Rios y ya veras por mi mensaje sobre la materia como tomo las cosas. El Congreso me apoya, y la opinion publica también. Oroño mui abollado, no obstante su insolencia; y ya veras por algunos artículos en la Tribuna o en la Union donde quiera que me permiten disponerlos, que no los dejo tranquilos.

Ver www.proyectosarmiento.com.ar

${ }^{14}$ Barrenechea, 1988, pp. 45-62. 
Sarmiento envía a Félix Frías para solicitarle que promocione sus méritos en su periódico da sustento firme a la hipótesis de que Sarmiento haya pedido una intermediación del mismo tipo a los Varela en numerosas ocasiones. Sin lugar a dudas, Sarmiento tuvo cabal comprensión del valor de la propaganda política y vivía “autopropagandeándose" y pidiendo este tipo de favores, como se conoce que hacía, también, con el periódico El Mosquito. ${ }^{15}$

Por otra parte, un examen minucioso del periódico de los Varela permite observar que, luego de finalizada su gestión presidencial, el vínculo con el diario sigue siendo muy estrecho. Campobassi registra que Sarmiento "trabajó como periodista para La Tribuna" inmediatamente después de finalizada su administración, ${ }^{16} \mathrm{y}-\mathrm{al}$ menos durante varios meses de $1875-$, numerosos artículos con su firma pueden atestiguarlo. ${ }^{17}$

Durante todo este primer año de la presidencia de Avellaneda en que se reorganiza el esquema político nacional, el periódico se esfuerza en contestar los ataques que recibe Sarmiento con notas ad hoc que advierten sobre la "lógica de los detractores de Sarmiento". ${ }^{18}$ Este gesto se pronuncia a partir del mes de junio, en que arrecian las críticas a su gestión a propósito de la recuperación del conflicto con Peñaloza que se inicia en el congreso de la Nación por parte de un correligionario y coprovinciano: Guillermo Rawson. ${ }^{19}$ La Tribuna sigue de cerca los debates parlamentarios con ánimo exaltado y acusa al senado de "mazorquear" a los liberales y de convertir el congreso en una "plaza de toros"; sostiene, además, que se está propiciando "el comienzo de la reacción federal”.

\footnotetext{
${ }^{15}$ En el prólogo de El cumpleaños de El Mosquito, Danero cuenta que "Sarmiento le exigía [a H. Stein, el editor-propietario] que se ocupara de él, "aunque fuera para desagradarlo" (El cumpleaños de El Mosquito, 1964).

${ }^{16}$ Campobassi, 1975, II, p. 306.

${ }^{17}$ La Tribuna, Buenos Aires, 1875 (consultado en la Sala de Documentación de la Biblioteca de la Universidad de La Plata, en microfilm: Diario ${ }^{\circ} 306$, rollos 45 y 46). Sólo en noviembre y en diciembre de 1875 no se halla ninguna firma de Sarmiento.

${ }^{18}$ Fundamentalmente la prensa opositora a Sarmiento era liderada por el diario La Nación, que Mitre funda el 4 de enero de 1870. Desde este periódico se lanzarán los mayores ataques a Sarmiento hasta que es clausurado en septiembre de 1874 con motivo del acto revolucionario que Mitre encabeza. Sin embargo, la prédica antisarmientina se retoma con la reapertura del diario, el $1^{\circ}$ de marzo de 1875 .

${ }^{19}$ La Tribuna, Buenos Aires, 24 de junio de 1875, año XXII, n 7405 , p. 1, col. 2.
} 
Mientras Sarmiento saborea su vida de ex presidente escribiendo extensas notas de tono ensayístico sobre "El alma de la historia" de la Nación, ${ }^{20}$ los editoriales de La Tribuna revitalizan el conflicto con el Chacho y recuperan la virulencia de los antiguos enfrentamientos polémicos que Sarmiento sostuvo con sus rivales políticos una vez instalado en Buenos Aires en 1855, e incluso de episodios de su vida anterior en Chile. De este modo arrecian los insultos y apreciaciones irónicas en contra de Peñaloza, de Rawson, de los Bilbao y de Hernández, que aunque no llevan su firma y salen en la sección editorial - es decir, se asumen como la opinión de los Varela-, están teñidos de un inconfundible acento sarmientino. ${ }^{21}$

El 17 de julio se editorializa sobre "El Chacho ante el Senado", en respuesta irónica a la reposición del conflicto que ha hecho Rawson, y que se ha analizado en el apartado 2.1.2.3. Es evidente que esta nota (que será acompañada por otras que sí llevan la firma de Sarmiento) funciona como apoyatura para la delicada situación de Sarmiento, que es gravemente acometido -como ya se ha visto- en un extendido discurso orquestado con alevosía para establecer un paralelo entre su recién finalizada administración y la de Rosas. ${ }^{22}$ Sobre esta cuestión el periódico asume una posición tan rotunda, que olvidando que en sus páginas, si bien se había celebrado la derrota del caudillo también se había esbozado una tímida objeción de las metodologías ilegales, ${ }^{23}$ no vacila ahora en justificar la decapitación del Chacho:

\footnotetext{
${ }^{20}$ Se trata de cinco cartas extensas dirigidas a Roca y publicadas a continuación de la sección editorial, del 24 al 30 de julio, en las que Sarmiento repasa la historia nacional desde sus orígenes.

${ }^{21}$ Mientras otras notas de La Tribuna advierten con alarma sobre la reinserción de "Los hombres de Rosas en el poder", en la prosa editorial se acentúa una recuperación modelar: la tesis del Facundo.

${ }^{22}$ El periódico acompaña el discurso legislativo de Rawson en varios editoriales en los que se dedica a reprobarlo. Pero los editoriales también acotan que, en todo caso, se debería acusar conjuntamente a Sarmiento y a Mitre como responsables de la represión ilegal sufrida por el Chacho, ya que acontecieron durante la presidencia mitrista y cuando Rawson se desempeñaba como ministro del interior. También se censura que Rawson dedique sesiones enteras a discutir sobre el estado de sitio en "La semana", nota del 29 de agosto en la que se sostiene que "o hay garantías o hay estado de sitio" y se califica a las intervenciones de Rawson como "interpretaciones inútiles".

${ }^{23}$ Ver referencia a la nota del 24 de noviembre 1863, citada en 3.2.1. Pero -como se verá al final de 5.2.- los vaivenes de La Tribuna serán más notorios en 1876.
} 
Irrazábal lo ejecutó en el acto, le cortó la cabeza y la clavó en un poste en Olta, como se hace con los salteadores de camino a quienes las leyes de la guerra han negado su protección. ${ }^{24}$

La Tribuna se anticipa así a los cuestionamientos que volverán a renovarse con motivo de la decisión de republicar su biografía del Chacho que toma Hernández entre agosto y septiembre de este mismo año. La redacción, con la misma ironía que empleará poco después para criticar la republicación de Hernández subraya que algunos diarios: "sentían verdadero orgullo al recordar los méritos del Chacho, a quien se llamaba el honrado general y virtuoso paisano Angel V. Peñaloza". También se encarga de criticar a Rawson, de quien se afirma que "tiró un tontísimo decreto", así como a la cámara alta del congreso nacional:

El senado argentino ocupa sesiones enteras en discutir la ejecución de Peñaloza, a quien no nos extrañaría oír llamar el SR. CHACHO en el curso del debate. ${ }^{25}$

Luego de esta editorial se suceden varios artículos de Sarmiento que llevan su firma y que están en posición central, en los que se ofrece documentación probatoria de su inocencia. La primera nota lleva un título que conduce la lectura: "HISTORIA DOCUMENTADA" e incluye la revelación de consejos de Sarmiento a Sandes en los que aparece un Sarmiento conciliador, que ahora le recomienda, a quien en su versión biográfica del Chacho de 1868 había elogiado como un Orlando Furioso, cumplir los cometidos "sin salirse de las reglas". ${ }^{26}$ También se incorporan pequeñas notas de queja de los maltratos que recibe desde la redacción de La Nación, desde donde indudablemente, entra a terciar Mitre. En la nota “iCómo tratan al sordo!!", Sarmiento destaca que se ensañan con él porque ha cambiado su posición en el gobierno: “Ahora no soy Presidente ni cosa que valga". ${ }^{27}$

\footnotetext{
${ }^{24}$ La Tribuna, Buenos Aires, 17 de julio de 1875, año XXII, n ${ }^{\circ}$ 7425, p. 1, cols. 1,2 y 3.

${ }^{25}$ Ibidem, p. 1, col. 2. Las mayúsculas son de la redacción del periódico.

${ }^{26}$ La Tribuna, Buenos Aires, 19 de julio de 1875, año XXII, n ${ }^{\circ 427}$, p. 1, cols. 2 y 3. Notar nuevamente en este punto cómo Sarmiento y Hernández, dos adversarios que en otra etapa histórica han coincidido en utilizar el discurso panfletario en su modulación más virulenta, ahora coinciden en la exhibición de actitudes más moderadas sin renunciar por ello a la defensa de sus respectivas posturas políticas.

${ }^{27}$ La Tribuna, Buenos Aires, 21 de julio de 1875, año XXII, $\mathrm{n}^{\circ} 7429$, p. 1, cols. 2 y 3.
} 
El 7 de agosto continúa el conflicto. Sarmiento publica con su firma la nota "POLÍTICA RETROSPECTIVA - LEGISLACIÓN DE SANGRE”, en la que transcribe cartas de Mitre, de Sandes y de Irrazábal para fortalecer su causa, probar su inocencia e incriminar a Mitre. Y en otra nota demostrativa de la consonancia entre Sarmiento y la redacción editorial de La Tribuna se describe con sarcasmo la escena parlamentaria:

\section{¿Y en dónde están los Macabeos?}

Oh! No hay para qué pensar en ellos. Están allí en el Congreso muy bien sentados en aquellos asientos cómodos que el pueblo les dio en un día de reparto de premios [...]. Ellos discuten de algo más útil que una medida económica tendente [sic] a detener los progresos de la ruina general -discuten si fue Pedro, o Juan o Diego quien mató al Chacho, o si fue Ruperto o Bonifacio quien recibió un premio del Gobierno por haberlo matado [...].

Nota: El Dr. Rawson ha pedido que se llame al Ejecutivo a la Sala de Sesiones para que dé explicaciones sobre algunos detalles del último o del penúltimo estado de sitio.

Otra: Se dice que prepara largos, brillantes y luminosos discursos, y que la barra también se prepara para hacerle una digna manifestación.

Otra: replicará el Sr. Sarmiento defendiendo los procederes del Ejecutivo y la barra lo silbará como merecen ser silbados todos los defensores del despotismo.

Última nota: La crisis arrecia. El comercio y el pueblo amedrentados esperan ansiosos el resultado de aquella eficaz interpretación del Dr. Rawson. ${ }^{28}$

Por último, el apoyo a la situación particular que está viviendo Sarmiento como ex presidente neófito, también se verifica en las pullas que dirigirá La Tribuna contra La Libertad y contra su redactor, Manuel Bilbao, ${ }^{29}$ que hará lugar a las réplicas de Hernández que se analizarán en 5.3. Por otra parte, numerosos artículos de La Tribuna dan cuenta de las acusaciones que recibe Sarmiento sobre su desempeño respecto de los intereses chilenos sobre la Patagonia y la redacción declara que no perderá su tiempo en denunciar a La Libertad y a Bilbao que "odia a Sarmiento porque Sarmiento lo

28 "En dónde están los Macabeos", La Tribuna, Buenos Aires, 10 de agosto de 1875, Año XXII, n 7449 , p. 1 , cols. 1 y 2 .

${ }^{29}$ Manuel Bilbao es hermano del fallecido Francisco, el antiguo contrincante de Sarmiento en Chile, cuyos enfrentamientos han sido analizados en 2.1.2.2. 
conoce". ${ }^{30}$ Y con el afán defensivo que ha asumido el periódico en esta etapa, se denuesta la publicación de las Cartas de Bilbao a Sarmiento, recopiladas por unos amigos de la verdad (ya analizadas en 2.1.2.2.), que incluyen la reproducción de una epístola que Sarmiento dirige a Mariano Varela, actual redactor de La Tribuna: una constatación más del estrecho vínculo que los unía. ${ }^{31}$

\subsubsection{El primer análisis genético de la biografía hernandiana}

Aunque la nueva versión de la vida del Chacho que ofreció Hernández presenta, según hemos analizado, una visión atenuada de los hechos, la reacción que suscita su republicación no lo fue. La Tribuna se lanza a intervenir con pasión y revela sobre todo una atentísima lectura de la obra. Y precisamente, Sarmiento había puesto de relieve esa calidad lectora en la redacción de su propia versión biográfica; por lo tanto, en su verosímil intervención en La Tribuna (haya sido directa o indirecta), se tomaría una doble revancha pública: contra José Hernández y contra Juan Bautista Alberdi (cuya voz no pudo dejar de reconocer detrás de las argumentaciones de Hernández). Por otra parte, que se utilice el mismo método (el análisis de génesis escritural) y la misma acusación de camaleonismo político que Alberdi había utilizado contra Sarmiento en las Quillotanas ("Tercera carta", a partir del párrafo 23) es también muy sintomático; ${ }^{32}$ pero uno de los puntales de esta hipótesis es la obstinación con que José Hernández se dirige al "Sr. Sarmiento" aun después de la desmentida de autoría que hace La Tribuna sin atreverse a revelar el nombre de otro autor; Hernández dice que tiene pruebas para no aceptar la negativa de La Tribuna y además denuncia explícitamente la intención evasiva de Sarmiento, que según Hernández busca quedar oculto y confundido en una redacción anónima.

También se puede traer a colación aquí lo que se ha dicho en 1.3.2. con respecto a la divulgación tramposa del poema de Olegario V. Andrade dedicado a Peñaloza, porque actualiza la actitud celebratoria que compartieron Sarmiento y Héctor Varela ante la muerte del Chacho. Ese encarnizamiento contextualiza el fraude alevoso de los Varela, calificado como "infamia" por Barcia y como "superchería” por Tiscornia.

\footnotetext{
30 “También es propio de la época”, La Tribuna, Buenos Aires, 22 de agosto de 1875, año XXII, p. 1 , cols. 2 y 3.

${ }^{31}$ Los Varela dan detalles acerca de las cartas de Bilbao y hasta apuntan que "están recopiladas en un cuaderno que se encuentra en las oficinas de La Libertad".

${ }^{32}$ Ver 2.2.2.
} 
Según demuestran los críticos, Héctor Varela toma el texto del periódico El Entrerriano de Gualeguaychú en 1870, mientras está de viaje con Sarmiento. Luego, ya en Buenos Aires unos meses más tarde, se atreverá a suprimir las estrofas iniciales del poema de Andrade, a mutilarle el título y a sustituirlo por el del antagónico "Al general Lavalle" y publicarlo falseado y amputado de este modo en su periódico porteño, para desviar descaradamente un sentido homenaje a un caudillo patriarcal. Esta audacia, y esta "comunidad de pasiones", se vuelve evidente en la correspondencia citada de Sarmiento a Posse, en donde además de describir la popularidad de Orión como "un niño mimado por el pueblo" se demuestra el grado de cercanía que existió durante todo 1870 entre Sarmiento y la labor periodística de Héctor Varela (afinidad que, evidentemente, se prolongará); y en lo que atañe a la actitud frente a Peñaloza, no es de extrañar que perdure cinco años después. Es muy sintomático, también, que el canibalismo practicado con el texto de Andrade haya tenido lugar en el mismo periódico en que se iniciará la polémica que se analiza a continuación.

Por otra parte, es necesario acotar que, si bien Tulio Halperín Donghi parece aportar más precisiones respecto de la relación entre Sarmiento y La Tribuna a propósito de la disputa que el diario entabla con Hernández, ${ }^{33}$ las fechas de los ataques no corroboran su atribución de responsabilidad exclusiva a Mariano Varela. Halperín Donghi comenta que en 1875 ese órgano está dejando de ser "el diario de los Varela" (ya que la divergencia de opiniones entre Héctor y Mariano conduce a la disolución de la sociedad) y atribuye a Mariano Varela la responsabilidad exclusiva de los ataques contra Hernández. No obstante, si bien la posición política que hemos venido remarcando se acentuará a partir de la fecha en que Mariano se hace cargo, ${ }^{34}$ la mayoría de las piezas polémicas se suceden antes del cambio de dirección del diario, que el mismo historiador fecha el 26 de septiembre. ${ }^{35}$

La primera carta de La Tribuna es del 18 de septiembre, cuando aún los dos hermanos están a cargo del diario, sólo la última carta - del 28 de septiembre- fue publicada cuando Mariano era ya el propietario exclusivo. De cualquier modo, la

\footnotetext{
${ }^{33}$ Halperín Donghi, 1985, pp. 133-143.

${ }^{34}$ Halperín Donghi (1985, p. 134) registra que a partir del momento en que se hace cargo con exclusividad de La Tribuna, Mariano se dedicará a pronunciar la polarización política en contra de los ex federales y a denunciar la interna del partido liberal que se perjudica con el enfrentamiento entre Sarmiento y Rawson, e incluso con los mitristas.

${ }^{35}$ Halperín Donghi, 1985, p. 143, nota al pie ${ }^{\circ} 18$.
} 
participación expresa de Sarmiento en ese medio y el contenido de sus colaboraciones (como ya se ha consignado) es argumento suficiente para sostener que él es o el agente mismo o un copartícipe responsable de la polémica con Hernández; por ese motivo, identificamos en esa impugnación anónima "la voz de Sarmiento".

Las notas críticas que salieron desde la redacción de La Tribuna fueron cuatro. ${ }^{36}$ La primera, la que desencadenó la tormenta, se publicó el 18 de septiembre de 1875 con el título "Bibliografía". ${ }^{37}$ Aquí la voz de Sarmiento ironiza sobre las reformulaciones del folleto de Hernández para acusarlo de oportunista. ${ }^{38}$ El segundo artículo, "La reacción”, salió el 21 de septiembre e incluye las supresiones que Hernández había hecho en su republicación.

Hernández, a su vez, respondió el 23 de septiembre en La Libertad (periódico de Manuel Bilbao) con un enérgico artículo titulado "Sr. Sarmiento: ¿por qué mataron?”; se actualiza de esta manera un hondo conflicto, que retrotrajo la cuestión a los años de la muerte del Chacho.

El 24 de septiembre La Tribuna sale al cruce de la identificación de autoría encarada por Hernández negando la injerencia de Sarmiento, pero se vale de un argumento endeble (declara que Sarmiento no integra el cuerpo estable de redactores del diario), que se refuta fácilmente con la visualización de su firma en artículos que han venido sucediéndose a continuación de la sección editorial.

Finalmente, la última pieza de la polémica entablada en La Tribuna -del 28 mismo mes- se tituló "El biógrafo y admirador del Chacho". Aquí (cuando ya se puede considerar esa aprobación expresa de Mariano Varela a la que alude Halperín Donghi), se califica a Hernández en estos términos:

Federalote ultra, entusiasta admirador y humilde eco de los actos del Chacho y servidor del virtuoso General D. Ricardo López Jordán. ${ }^{39}$

\footnotetext{
${ }^{36}$ La polémica completa fue publicada en Hernández, 2005, pp. 73-94. De esta edición se toman las transcripciones.

${ }^{37}$ Con este título, solía identificarse en los periódicos de la época la sección dedicada a reseñas bibliográficas.

${ }^{38}$ En 5.3. se analizan las respuestas de Hernández.

${ }^{39}$ Hernández, 2005, p. 91.
} 
El primer artículo de La Tribuna promete con cinismo la transcripción de las partes suprimidas de la nueva versión de la Vida del Chacho a la que califica como un "eco de la reacción" federal propia de un gesto oportunista. Luego se hace un comentario mordaz sobre la génesis del texto publicado "allá por el año 1863 ” y con igual sorna se subraya el reposicionamiento del texto nuevo como una obra notable por las "bellezas" con las que se describe la "moderna vida del honrado General y virtuoso paisano D. Ángel V. Peñaloza". 40

Tres días después, La Tribuna ofrece lo prometido divulgando las supresiones hechas por Hernández, pero glosadas con una serie de apreciaciones socarronas como las que ya han iniciado la polémica. Se califica al texto de Hernández como "muy de actualidad" en días de "plena reacción federal" y se incluye la transcripción de la “Advertencia del editor” apelando a la intervención de Guillermo Rawson, cuyas firmas aparecen en los partes que anuncian la muerte de Peñaloza. Una vez más, los textos cruzan polémicas y anudan vínculos. ${ }^{41}$

Cuando se publican los dos textos más ardorosos del folleto de Hernández -los que habían sido titulados "Asesinato atroz" y "La política del puñal"-, en los que Hernández daba rienda suelta a una desaforada pasión partidista, La Tribuna denuncia el gesto de un político que aprovecha las circunstancias: uno de los "decididos amigos de la situación, y que desempeña más de un puesto público".

Luego, en la transcripción de "La política del puñal", el texto de Hernández va siendo interrumpido por permanentes acotaciones incisivas. En un primer caso se lee un cartel que indica en mayúsculas: “ATENCIÓN”. Más adelante, en el pasaje del texto donde Hernández alerta a Urquiza sobre el peligro que corre su vida, se acota: “Advierta el lector que fue asesinado más tarde por D. Ricardo López Jordán, de la talla de D. José Hernández. Más atención!’. Y avanzada la lectura, cuando el texto predice la futura muerte del general entrerriano, se lee: "Tremenda profecía-. Así fue, en San José, en medio de los halagos de su familia; pero no por el partido unitario sino por la reacción

\footnotetext{
${ }^{40}$ Ibidem, p. 73. Se repite la misma expresión irónica de la nota del 17 de julio de 1875 mencionada anteriormente.

${ }^{41}$ Ibidem, p. 74.
} 
roja". Por último se recomienda al gobierno de Avellaneda que compre algunos ejemplares. $^{42}$

En la siguiente nota -"Una Carta"- continúan las referencias despectivas a Hernández:

[...] el entusiasta admirador de los méritos del virtuoso general y honrado paisano D. Angel Vicente Peñaloza bandido más bandido que Chumbita y más bárbaramente cruel que el Tata Dios del Tandil, ante cuya grandeza de alma su biografía se pone de rodillas. ${ }^{43}$

Esta apreciación muestra que un sector político reconoce claramente el reposicionamiento y el ánimo moderador de la nueva edición de Hernández, pero exhibe su intransigencia para aceptarla porque la juzgan altamente riesgosa para el momento político que atraviesa el país. De este modo, persisten con los ataques a Hernández y reponen la visión maniquea del Chacho para tomar distancia de las "hipócritamente federales, o federalmente hipócritas sonrisas" que presentan a "los famosos salteadores de caminos y montoneros, asesinos e incendiarios" como el tipo del "virtuoso General y honrado paisano D. Angel Vicente Peñaloza". ${ }^{44}$

Finalmente, el artículo se concentra en denostar a Hernández como "situacionista" político, que se "ha vengado" de tres presidentes "con refinada crueldad", sirviendo "al matador de Urquiza", haciendo pedazos "el alma" y la reputación de Sarmiento y abandonando "la pluma para servir con las armas en las filas del virtuoso General D. Ricardo López Jordán, asesino del General Urquiza" ${ }^{4}$

En la última nota (titulada "El biógrafo y admirador del Chacho" y finalizada con una declaración de cierre de la polémica: "Es nuestra última palabra"), el redactor anónimo que habla con la voz de Sarmiento hace un repaso de la polémica insistiendo en el comentario de los pasajes suprimidos y fingiendo sorpresa por la réplica airada de

\footnotetext{
${ }^{42}$ La nota también se demora en pormenores: "Hasta aquí las transcripciones que habíamos prometido a nuestros lectores. Es la introducción que tiene la vieja edición de la Vida del Chacho y que ha sido suprimida en la nueva" (ibidem, p. 75).

${ }^{43}$ Ibidem, p. 80.

${ }^{44}$ Ibidem, p. 81.

${ }^{45}$ Ibidem, p. 83.
} 
Hernández. ${ }^{46}$ Esta introducción en el tema da lugar a una nueva invectiva contra Hernández a quien se califica de "admirador e idólatra de ese gran salteador de caminos". Se lleva a cabo, así, una defensa ardorosa de Sarmiento al mismo tiempo que se busca desplazar el enfoque de la discusión mediante un último ataque, cuyo subtexto busca reverdecer el recuerdo de la participación de Hernández en el levantamiento de López Jordán. ${ }^{47}$

\subsection{Las cartas de Hernández en La Libertad de Buenos Aires (1875)}

Hernández responde en tres cartas sucesivas que publica en La Libertad de Buenos Aires, el periódico de Manuel Bilbao -hermano de Francisco-, reconocido antagonista de Sarmiento. ${ }^{48}$ En esas cartas abiertas se obstina en seguir dirigiéndose a Sarmiento (“es la abeja que me picó”) a pesar de la enérgica desmentida de su autoría por parte de los Varela (aunque desde la segunda identifique a su destinatario con el periódico desde cual se lo agrede: “A La Tribuna -o al señor Sarmiento").

La citada réplica del 23 de septiembre de 1875, “Sr. Sarmiento, ¿por qué mataron?", comienza con la famosa descripción de la primera vez que Hernández vio a Sarmiento, en la Convención Nacional de Santa Fe, donde volvía a cargar las tintas

\footnotetext{
46 "Al dar la noticia de la publicación de un libro o de un folleto cualquiera, debe decirse en pocas palabras su significado, si no se hace un estudio más o menos prolijo de su contenido. Con esta idea, toconos ensayar con La vida del Chacho escrita por D. José Hernández en el Paraná en 1863 y reproducida en Buenos Aires en 1875. En dos líneas, dijimos lo que es ese folleto, lo que vale; mencionamos lo favorable del momento en que aparecía, y lo recomendamos al público y al Gobierno Nacional. Hicimos más: transcribimos la introducción de la vieja edición, que había sido suprimida en la nueva. En nuestra opinión, no se podía hacer más por un libro de pocas páginas, en cambio de la injuria que se le infería al no elogiarlo. Sin embargo, nuestro proceder disgustó sobremanera a su autor" (ibidem, p. 89).

47 "No defiende su libro, ni la santa federación de su libro, ni su federal personalidad cuando le hacemos algún cargo, sino que sostiene que el Sr. Sarmiento se quitó los zapatos en la Convención de Santa Fe, y se asombra de que La Tribuna no haya levantado este grave cargo, o convincente argumento, como si los pies calzados o descalzos del Sr. Sarmiento, o sus zapatos puestos o sacados, fuesen cosas dignas de mencionarse cuando se trata del movimiento reaccionario de un elemento impío vencido en los campos de batalla a fuerza de sacrificios gigantescos. Observando otras cosas más serias, mientras D. José Hernández se ocupaba de los zapatos del Sr. Sarmiento, supusimos hombre de principios al autor de la Vida del Chacho y admirador e idólatra de ese gran salteador de caminos" (ibidem, p. 90). El énfasis es de La Tribuna.

${ }^{48}$ Así como en 1874 Hernández escribe en La Patria, periódico fundado por el hijo de Juan José Soto, ya en el país y al año siguiente se observa que continúa manteniendo, coherentemente, su vinculación con la línea de opositores de Sarmiento que se examinó en el apartado 2.1.; por eso apela al auxilio de Bilbao para defenderse de ataques sarmientinos.
} 
sobre la figura del entonces ex presidente de la Nación. El 26 de septiembre continuó la discusión con “A La Tribuna o al Sr. Sarmiento". Y finalmente, la respuesta del 29 de septiembre: “A la última palabra, las últimas palabras”. La polémica se cerró con esta carta en la que Hernández refutó una por una las acusaciones de La Tribuna.

Hernández, de esta manera, defendió las modificaciones realizadas en la republicación de su texto adjudicándolas a la evolución en su manera de pensar y reflexionar sobre la patria, que sus críticos no quisieron aceptar. Sugestivamente, la reedición disparaba en el entorno social un nuevo conflicto, donde las antiguas diferencias de partido salían otra vez a la luz en contraposición con el espíritu que, aparentemente, había guiado las reescrituras. La intención contemporizadora de Hernández -que buscaba reinsertarse en Buenos Aires al amparo del llamado a la conciliación de los partidos propiciada por el gobierno de Avellaneda- se diluyó inmediatamente después de la reacción difundida por el diario de los Varela, y volvió a disparar en sus artículos contra la política de facción y a favor de los desposeídos. ${ }^{49}$

Se debe sumar también al contexto polémico reinaugurado por Rawson en el Senado otra reacción periodística. Manuel Bilbao, el editor del periódico que permite la réplica de Hernández, había a su vez compuesto unas sonadas cartas contra Sarmiento unos meses antes, entre abril y mayo, que luego se difundirán compiladas en forma de folleto, y que como se ha visto, los Varela se encargan de criticar. Ya se ha examinado cómo se enhebra la polémica de Bilbao con la serie de enfrentamientos que había tenido su hermano Francisco, y cómo en este momento se reflotan antiguas disensiones alrededor del tema del caudillismo; Bilbao también recuperaba en estas cartas el conflicto con Peñaloza.

En este contexto sale la primera nota de Hernández, titulada "Sr. Sarmiento, ¿por qué mataron?", que comienza con la descripción de Sarmiento en la Convención Constituyente de Santa Fe. Se lo presenta como un desaforado irrespetuoso que se "agitaba continuamente en su silla" y que no vacila en quitarse los zapatos a pesar de tratarse de una situación tan formal. ${ }^{50}$ Luego, apelando a la complicidad del lector,

\footnotetext{
${ }^{49}$ Ver Zorraquín Becú, 1972, cap. XXXIII; Halperín Donghi, 1985, cap. III

50 "En la fila de la derecha, en el primer asiento, se encontraba un convencional que se revolvía agitándose continuamente en su silla. Miraba a todas partes como un desaforado, manifestando en todos sus movimientos una agitación, y algo de un malestar que no le permitía permanecer tranquilo. De pronto hace un movimiento rápido, y se saca un botín, a pocos minutos el otro, coloca los pies cubiertos solo con las medias sobre aquellos zapatos que tanto le habían
} 
Hernández pasa a contar las persecuciones que recibió durante su gobierno y los pedidos de encarcelamiento que Sarmiento libró contra él:

Ese hombre era el Sr. Sarmiento, y ese fue el día y las circunstancias en que lo conocí, bajo la impresión que cada uno de los lectores puede calcular que produciría en el observador aquel hecho de intimidad y confianza con la Convención y con el público. De allí parten mis relaciones de vista con el Sr. Sarmiento, por quien después he sido perseguido sin tregua. ${ }^{51}$

Después, en la tradición abierta por las Cartas quillotanas, se dedica a criticar la actitud violenta del sanjuanino comparándola con la violencia de la palabra escrita de su panfleto, ya que se le había recriminado que sus textos eran el "eco de la reacción federal”. En cambio, Hernández siente que él sí puede excusar su tono exaltado, porque "ni viudas ni huérfanos han de maldecirme". Devuelve también las preguntas irónicas: "Y Ud. Sr. Sarmiento, ¿podría decir lo mismo?” Toda la carta establece una comparación entre los excesos de la pluma y los excesos de la espada, y Hernández se siente como vencedor por ser el hombre de la palabra que puede arrepentirse de algunos de sus escritos pero que no será maldecido por nadie. Recupera con habilidad estratégica el tópico del degüello, denostado hasta el cansancio por Sarmiento en su trilogía de los caudillos y en la Campaña en el Ejército Grande, ${ }^{52}$ para denunciar que este horror -epítome de la barbarie caudillista- se constató también en el campo de la política liberal:

Ni se escribirán más en la prensa argentina, artículos como el que yo escribí el año 63, ni se causará daño alguno con su reproducción como Ud. pretende hacerlo el 75. Esos tiempos se fueron -llórelos Ud. Aquellos tiempos se pasaron, y lo bueno es, que se pasaron para todos. Se pasaron no solo para mi artículo y los de su tono, sino también para aquellos que creían granjearse los favores de la opinión, y abrirse las puertas del cielo de la política, degollando federales. Aquellos tiempos se pasaron; ya no se arrojará

mortificado, y respirando fuertemente como quien se libra de una gran incomodidad, permanece muy tranquilo, como en el retiro de su casa, delante de la respetable Asamblea" (Hernández, 2005 , p. 76). Téngase en cuenta que, así como las diatribas contra el caudillismo tenían su público, la pintura de Sarmiento como un personaje desorbitado también tenía el suyo.

${ }^{51}$ Hernández, 2005, p. 76.

${ }^{52}$ Analizado en 1.1.2.3. y 1.1.2.4. 
a los adversarios por el balcón como a Benavídez; ni se les matará con sus hijos en los brazos, como a Virasoro; ni se colocará la cabeza en un palo como a Peñaloza. Aquellos tiempos se pasaron; ya no habrá más hecatombes sangrientas a nombre de la libertad. Esos tiempos no volverán, porque no volverán las pasiones que los agitaron, ni los hombres que los produjeron. De esos hombres, uno de los últimos es el Sr. Sarmiento, que siente que se va, y al despedirse quiere hacer a la generación actual heredera de los odios que han agitado su vida, que sus ingénitos a su naturaleza, y de que no puede ni quiere desprenderse. $^{53}$

La siguiente se titula "A La Tribuna o al Sr. Sarmiento" y se trata inicialmente de adjudicar la autoría de la polémica. Hernández no está dispuesto a hacer concesiones porque "tiene antecedentes" que lo prueban y deja en claro la responsabilidad exclusiva de Sarmiento; es su único interlocutor en este duelo final:

Niega sea el Sr. Sarmiento el autor de la transcripción y del artículo que la había precedido dos días antes; pero aparte de tener antecedentes para no dar crédito a semejante negativa, diré que el Sr. Sarmiento pertenece a esa colmena, y que esa es la abeja que me picó, aun cuando ahora busque quedar oculta y confundida entre las demás. 54

También aquí vuelve a desarrollar la idea de que la violencia fue el sello que caracterizó a la administración sarmientina:

El nombre de Chumbita recordará siempre aquel rasgo de la administración del Sr. Sarmiento, en que fueron cruel y bárbaramente fusilados por equivocación, ciudadanos que ningún crimen habían cometido, sin que sus matadores se tomaran ni el tiempo ni la molestia de asegurarse de la identidad de las personas a quienes fusilaban. ¿Hay nada más elocuente y más terrible que eso, y la impunidad en que se dejó el hecho, para juzgar de un hombre, de una época y de un gobierno ${ }^{55}$

${ }^{53}$ Ibidem, pp. 77-78. Estas referencias deben relacionarse con el artículo ya analizado sobre "Los exaltados y los indiferentes", donde Hernández no renuncia a destacar que no se ha roto la coherencia con sus ideas de 1860.

${ }^{54}$ Hernández, 2005, p. 84-85.

${ }^{55}$ Ibidem, p. 85. 
Concluye la diatriba con la publicación de "A la última palabra, las últimas palabras". Hernández habla ya con ánimo más reposado y se dispone a cerrar el conflicto mediante una revisión pausada de la polémica. Primero declara que no podría esperar nunca un gesto amable de Sarmiento:

A quién ha elegido La Tribuna que no haya pertenecido a su comunidad política, ni a quien ha elogiado en su vida el Sr. Sarmiento?

Recuérdese cómo acaba de tratar a respetables ciudadanos entre los que se comprendía el Sr. Albarracín, pariente suyo, de quienes dijo que había tenido que arrojarlos de la casa de gobierno, y calcúlese cómo podrá tratarme a mí. ${ }^{56}$

Luego inserta su nueva versión del Chacho en el contexto político inmediato:

Eco de los actos del Chacho: hagan el mismo cargo al Dr. Rawson que ayer nomás hacía su elogio en el Congreso [...]

Y con la intención de subrayar la vigencia de su tesis, vuelve a contrastar las posiciones:

Entre la conducta de un ciudadano que se mezcla en una revolución, sin mancharse en ella, y la del primer magistrado que dio ante la República y ante el mundo el escándalo de ofrecer cien mil patacones por la cabeza del jefe revolucionario, hay una diferencia fácil de medir. El primero comprometió su individualidad; el segundo escarneció la moral pública, vilipendió la autoridad que investía, escandalizó a la República, infirió un ultraje a la civilización.

Yo no inauguré el período de las revoluciones. Y él pretendió inaugurar en el Río de la Plata, un período aciago, la costumbre inmoral, impía, de poner a precio las cabezas.

Finalmente Hernández se despide con el aplomo del autor del Martín Fierro que ya se dispone a pergeñar la segunda parte del poema:

Ciérrese la polémica.

\footnotetext{
${ }^{56}$ Ibidem, p. 92.
} 
Continúen ellos en su agitado afán de demolición contra la actualidad que contribuyeron a fundar.

Yo vuelvo a las tareas tranquilas de mi trabajo honrado. ${ }^{57}$

Con esta serie de manifestaciones públicas en la que termina proyectándose una “escritura del yo", se abre una nueva etapa en la obra de Hernández. Los artículos han tomado un notorio giro autobiográfico y el lector puede compartir algunos secretos que hablarían de una supuesta relación entre dos autores que se debaten en un último duelo polémico, más personal e íntimo. En este gesto vuelve a coincidir Hernández con Alberdi, que hacia el final de la presidencia de Sarmiento envía su autobiografía Palabras de un ausente a Buenos Aires.

Hernández se venía expresando de diversos modos pero siempre en contra de la figura del adversario, pero una vez que la gestión administrativa de Sarmiento ha finalizado, el conflicto se focaliza. La perspectiva se acorta en su mirada en la imagen de un exaltado a quien él mismo vio quitarse los zapatos y vociferar en plena Convención Constituyente y a veces se reduce a una relación "personal" con el recuerdo de las últimas persecuciones sufridas en carne propia. Pero se intenta paralelamente una reinstalación pública: es también un hombre que pertenece al pasado sangriento en que "se fusilaba por equivocación".

Sin embargo, la dimensión popular que asumió Hernández por la difusión masiva de El gaucho Martín Fierro, junto con el atardecer político que experimenta su contrincante histórico, le permite ofrecer ahora otra mirada de Sarmiento que ya no es parangonado con un tigre o un tiburón, individualidades salvajes de agresividad fatal, sino con un insecto comunitario, una abeja, que cuenta con el amparo de una colmena (La Tribuna), pero que apenas ataca con una picadura.

Los tiempos traen muchos cambios: por lo pronto, al año siguiente y después del ingreso de Hernández al Partido Autonomista Nacional, será este mismo diario La Tribuna el que lance esta primicia en su edición del 18 de abril: “[José Hernández] está escribiendo el segundo tomo de su bella composición con el título de La vuelta de Martín Fierro". 58

\footnotetext{
${ }^{57}$ Ibidem, pp. 93-94.

${ }^{58}$ La Tribuna, Buenos Aires, 18 de abril de 1876.
} 


\section{CONCLUSIONES}

La investigación que se propuso rescatar dos procesos de textualización para demostrar que interactuaban polémicamente partió de su inserción en una genealogía que arrancaba del Facundo, continuaba con Campaña en el Ejército Grande y conocía un punto de inflexión en la línea político-ideológica abierta por las Quillotanas. Posteriormente, observamos que todas estas obras se interrelacionan en una compleja red intertextual en la que se integran otras piezas cuyo estudio nadie ha agotado (y que en algunos casos, nadie ha emprendido); entonces, intentamos rastrear el mayor número de sus componentes con la certeza de que encontraríamos nueva información en esa compleja trama de interrelaciones. Ese relevamiento anudó en esa red intertextual otros documentos (muchos inéditos y de difícil acceso, algunos nunca explorados o interrogados desde otras perspectivas), y el análisis de cada componente descubrió nuevas problemáticas; inclusive, la reconexión a la que obliga cada nuevo hallazgo impuso relecturas dentro del territorio que ya habíamos recorrido. ${ }^{1}$

Nuestra primera "relectura" empezó por el encuadramiento intertextual primario del núcleo del corpus: "la gran polémica nacional". Adolfo Prieto ha manifestado que juntamente "con la respuesta del propio Sarmiento, contenida en el opúsculo conocido con el título de Las ciento y una, las Cartas quillotanas marcan uno de los momentos auténticamente memorables de la literatura política del siglo XIX". ${ }^{2}$ Así, Prieto sigue una línea de recepción iniciada por los lectores contemporáneos de la polémica -y continuada

${ }^{1}$ En el "Apéndice documental" incluido en el apartado 10, se registran algunas de las piezas inéditas de la producción periodística de José Hernández que hemos relevado. Para nuestra investigación hemos compulsado la colaboración de Hernández para La Reforma Pacífica de Buenos Aires (1860-1861), El Litoral de Paraná (1862), El Eco de Corrientes (1867-1868) y La Capital de Rosario (1868-1869); y los editoriales de sus propios órganos: El Argentino de Paraná (1863) y El Río de La Plata de Buenos Aires (1869-1870); se trata de un interesante acopio testimonial que no ha sido editado aún. En el caso de El Litoral hemos incorporado material desconocido hasta ahora por la crítica. Respecto de la labor periodística de Sarmiento, examinamos su participación en la redacción de La Tribuna de Buenos Aires durante 1875 y hemos hallado artículos que nunca habían sido publicados ni reseñados.

${ }^{2}$ Prieto, 1968, p. 36. 
por los historiadores y por la mayor parte de la crítica-, que llega hasta nuestros días. ${ }^{3}$ A partir de 1853 se viene reiterando un enfoque reductor de esa polémica focalizando el análisis en las dos piezas que se canalizaron en un mismo género textual: la publicación por parte de dos adversarios políticos de sendas series de cartas abiertas (es decir, un formato) impuso una lectura.

No obstante, no está en esas dos piezas el meollo de la polémica: está en Campaña en el Ejército Grande (1852) y en la rápida respuesta de Alberdi en Cartas sobre la prensa y la política militante en la República Argentina (1853); ni se cierra tampoco con los textos que ambos autores intercambiaron (implícitamente) en ese mismo año 1853 después de la publicación de Las ciento y una. ${ }^{4}$ El 11 de septiembre de 1852, la fecha que instaló la secesión de Buenos Aires, fue un punto de inflexión en el largo y trabajoso período de construcción nacional de la Argentina, y dividió nuevamente en dos facciones el mapa político. En esa nueva coyuntura histórica, el autor de Campaña en el Ejército Grande (entonces residente en Chile), a la par que declaraba públicamente su adhesión al poder que comenzó a gobernar en Buenos Aires, en su "Dedicatoria" definía, agraviándolo, a un adversario de reconocida trayectoria intelectual: el autor de la palabra simbólica de la declaración de principios de la Asociación de Mayo que funcionaría como embrión textual de las Bases. Así, el autor del Facundo - poco antes de emprender una brillante carrera política en Buenos Aires- se mide con quien en pocos meses se convertiría, de hecho, en "el Redactor de la Ley". 5

La complejidad de la red hipertextual analizada reinstaló, también, el Facundo: una obra de 1845 en donde la prosa potente del proscripto Sarmiento había impuesto un modelo de identidad nacional que obtuvo de inmediato aceptación calurosa, y había propuesto una programática para una futura organización estable del país. Pero mientras su autor reacomodaba en Campaña en el Ejército Grande su célebre antítesis para ubicar a Urquiza y a sus seguidores en el polo de la "barbarie", Alberdi inauguraba con las Quillotanas una

\footnotetext{
${ }^{3}$ Ver, por ejemplo, Alberdi-Sarmiento, 2005. Altamirano (2012) constituye una excepción reciente; pero analiza el polemismo de Alberdi con otro enfoque.

${ }^{4}$ Ver 1.1.

${ }^{5}$ En plena polémica con Nicolás Calvo, Sarmiento -para denigrar a su contrincante- le recuerda que él debatió con figuras de muy superior prestigio en Chile y menciona explícitamente a Alberdi, a quien califica como un detractor "mucho más alto". Ver 2.1.2.1.
} 
línea cuestionadora, tanto del diagnóstico de Sarmiento como de la terapéutica propuesta, a la par que proporcionaba un molde retórico para resquebrajar la antinomia irreductible: la reversión del sentido del discurso del adversario haciendo que se volviera contra él como un boomerang. Así, en el meduloso discurso del jurista que bombardea un texto y un subtexto con conceptualización rigurosa y pretendida objetividad se cuela una de las marcas inherentes del discurso panfletario ${ }^{6}$ cuando acusa a Sarmiento de ser un "gaucho de la pluma" y manifiesta el temor de que la barbarie de la escritura se proyecte sobre sus proyectos políticos. Pero sobre todo, Alberdi desestabiliza la identificación precisa de cada polo de la antinomia "civilización versus barbarie".

A partir de esa confrontación, la antinomia irreductible se pondría al servicio de la política del poder gubernamental de Buenos Aires, y en el nuevo período histórico que comenzaría después de la batalla de Pavón, regiría casi dos décadas los intentos de imponer a todo el país su modelo de organización nacional. En el bando opuesto, suscribieron la posición de Alberdi, primero, las provincias confederadas, y después de la unificación del país, los adversarios del poder de la ciudad-puerto.

El enfoque genético, que pudo aplicarse estrictamente para dar cuenta del proceso textual de la biografía del Chacho escrita por Hernández, se aplicó también a un intertexto privativo de su reformulación de 1875. Durante ese año se editó la 9a edición de El gaucho Martín Fierro en la que Hernández se abocó, con un considerable esfuerzo, a reelaborar el sociolecto del ya exitoso poema. Las idas y vueltas de ambos procesos de reescritura no están desvinculadas, por eso fueron abordadas en paralelo. ${ }^{7}$ Pero el mismo impulso moderador del tono desafiante que guió ambos procesos reformulativos viró repentinamente: el que desembocó en Vida del Chacho, recobró la furia panfletaria a partir de los ataques que recibió su autor desde el diario La Tribuna; no sabemos en qué momento preciso Hernández abjuró de las concesiones que subordinaban su poema a una normativa más "urbana", pero al año siguiente volvió a vibrar en la $10^{\mathrm{a}}$ edición la voz de ese gaucho Martín Fierro que en unos pocos años ya se había incorporado a la memoria oral.

\footnotetext{
${ }^{6}$ Angenot, 1985, p. 293

${ }^{7}$ Ver 4.3. y 4.4.
} 
La crítica genética ha demostrado que la linealidad inherente de la cadena significante se quiebra en la marcha de la escritura in progress porque en los papeles privados del escritor "escritura" es "reescritura" (la tensión y su consecuente recursividad está en su esencia); por eso no puede interpretarse un proceso de producción de sentido como una marcha que, inevitablemente, debe desembocar en un fin predeterminado (la crítica genética ha demostrado que el "texto" no lo es). Las tendencias que gobiernan la reformulación que culminó en Vida del Chacho no se cumplen mecánicamente obedeciendo a una regla sin excepciones.

La huidiza direccionalidad de la escritura impide interpretar sus pasos en términos de reglas que, obedeciendo las pautas de un "modelo", desemboquen en un final previsible. En cambio, sí es posible hablar de un conjunto indeterminado de "estrategias" variables para cada situación. Las estrategias tienen una "orientación”, pero no pueden interpretarse en términos ortodoxamente teleológicos porque pueden no estar conscientemente dirigidas hacia un fin y no están necesariamente determinadas por él. Ahora bien, es cierto que aun cuando el objetivo no esté nítidamente recortado, la marcha de la escritura dibuja un recorrido "hacia alguna parte": la textualización está dotada de una suerte de direccionalidad, pero en el camino puede detenerse, vacilar, cambiar de rumbo, diversificarse, y hasta explotar: se trata de una direccionalidad "virtual". 8

El abordaje genético tuvo que salir de sus límites estrictos para enfocar todas las piezas de la constelación intertextual generada por "la gran polémica nacional". Pero los hilos que las vinculan muestran también idas y vueltas.

Hemos postulado que la antinomia irreductible "civilización versus barbarie", como modelo de identidad nacional y como base para el diseño de una programática para la organización estable del país, es el eje de la interacción polémica que atraviesa la totalidad de la red hipertextual construida: un bando pretende afianzarla y sus oponentes resquebrajarla (a la par que individualizan a un contrincante: el autor del modelo). No obstante, al examinar cada pieza en su individualidad no se constata la aplicación mecánica de esta regla.

En los Rasgos biográficos del General D. Angel V. Peñaloza, Hernández toma la senda abierta por Alberdi y la profundiza: Sarmiento ya es más que "un gaucho de la

${ }^{8}$ Lois, 2001a, pp. 39-45. 
pluma", es un "bárbaro de la política". También sostiene, como Alberdi, que el gaucho es funcional al progreso del país; no obstante, no faltan las tensiones: el Chacho biografiado simboliza todos los valores del gaucho argentino que está siendo perseguido en nombre de la civilización, pero su biógrafo reclama por él con una iracundia que a veces, aunque recupere epítetos mazorqueros ("Los salvajes unitarios están de fiesta”), recuerda más a la retórica desenfrenada de Las ciento y una que a la prosa reflexiva de su mentor ideológico. Además, como había ocurrido con Sarmiento, su discurso polémico se encara con un escritor y un político consagrado para definir un adversario: la estatura del joven diarista crece al medirse con él. ${ }^{9}$

El encadenamiento temporal de las piezas analizadas va mostrando también cómo tanto las posturas políticas puntuales y las modalidades con las que el discurso las expresa interactúan con el contexto de situación; y esto se manifiesta tanto en la evolución del diarismo nacional como en la interacción de las dos biografías confrontadas. En El Chacho, último caudillo de la montonera de los Llanos, Sarmiento refrena la violencia de su discurso anti-barbarie. Aquí la polémica con Hernández está presente en el tramado argumentativo, pero no es el objetivo fundamental: cuando Sarmiento escribe este opúsculo está en plena campaña presidencial y rebatir a Hernández es un medio para demostrar que él es un "civilizador". A su vez, cuando siete años después Hernández reformule su biografía del Chacho en otra coyuntura política, pondrá en práctica la misma estrategia discursiva de Sarmiento: no sólo moderará la exaltación del caudillismo sino también el tono con que el que se teje una trama que sigue demostrando que hubo un delito y hay "culpables".

También las piezas del diarismo de diferentes épocas que fuimos relevando están agitadas por tensiones aunque se adviertan rasgos coincidentes en cada corte temporal (el que comienza con la escisión de Buenos Aires y termina con Pavón, y a partir de allí el todavía dificultoso camino hacia una búsqueda más decidida de una auténtica "conciliación nacional"). Muy particularmente, impulsos contrapuestos contienden desde el principio al fin en el diarismo de Hernández: desde su militancia en el Partido Federal Reformista, cuando adscribía a la convicción de que sólo un acuerdo entre las facciones podía orientar

\footnotetext{
${ }^{9}$ Ver 1.2.
} 
el país en el camino del progreso (pero su intervención en La Reforma Pacífica se canaliza en el ardoroso polemismo de "Vincha"), hasta la programática reflexiva de El Río de la Plata, que busca el mismo objetivo por la vía de la creación de un tercer partido y se esfuerza por argumentar con serena objetividad (pero un día termina abruptamente porque su editor ha decidido sumarse a la rebelión de López Jordán). ${ }^{10}$ Las idas y las vueltas de su famoso poema reproducirán este conflicto sin resolverlo tajantemente.

Pero el recorrido de las polémicas canalizadas en periódicos o por medio de folletos culminará en 1875 con un discurso en el recinto del Senado: Guillermo Rawson -un liberal reconocido y ex ministro durante la presidencia de Mitre que no ha abjurado de su credo político-ideológico- rebate con palabras calcadas de Rasgos biográficos del General D. Angel V. Peñaloza el proyecto de "Ley de amnistía" que Sarmiento ha redactado para liberar a los sediciosos que se han levantado en 1874 contra el presidente electo. ${ }^{11}$ Es en ese marco que Hernández decide seguir diciendo su palabra de otro modo y reformula su biografía del Chacho.

Los tiempos están cambiando, una reconfiguración de los partidos está en germen, pero continuarán los vaivenes. Los últimos testimonios analizados constituirán otra vuelta de tuerca. Las piezas principales no fueron halladas por nosotros, pero no habían sido interpretadas antes con exactitud; sí, en cambio, relevamos su intertexto inmediato y así pudimos adjudicarles su sentido más probable.

Cuando Horacio J. Becco registra en su "Bibliografía hernandiana" la edición de Vida del Chacho, agrega una información complementaria: la existencia de una polémica periodística entre el diario La Tribuna y el propio Hernández-que replica desde La Libertad- y aporta las fechas correspondientes; pero no hace ningún comentario acerca de sus características. ${ }^{12}$ Como se ha visto, un ataque anónimo marca el comienzo de una guerra verbal, y en su respuesta, Hernández se dirige directamente al "Sr. Sarmiento". Tulio Halperín Donghi -que en José Hernández y sus mundos realizó un sutil análisis de la

\footnotetext{
${ }^{10}$ Ver 2.3.

${ }^{11}$ Ver 2.1.2.3.

${ }^{12}$ Becco, 1972a, asiento n ${ }^{\circ}$ 303. Por su parte, Horacio Zorraquín Becú se refiere también a esta polémica, pero no intenta confirmar la identidad del atacante mismo (Zorraquín Becú, 1972, pp. 239-241).
} 
producción periodística de Hernández tomando como principal fuente documental el Archivo Losada (resultado del relevamiento de la producción del autor que Alejandro Losada pudo hallar)- ${ }^{13}$ interpreta con la lógica rigurosa que siempre ha gobernado sus trabajos que Sarmiento no puede estar interesado en reavivar el tema reflotado por Rawson (algo absolutamente inconveniente para su prestigio) y conjetura que Hernández quizá no está convencido de haber identificando al verdadero autor del ataque, pero quiere instalar su propio nombre invocando a su alocutario como el "Sr. Sarmiento", una figura de renombre y un ex presidente de la República. ${ }^{14}$ Sin embargo, nuestra lectura de La Tribuna-desde el fin de la presidencia de Sarmiento hasta los números anteriores al que inicia la polémicacomprueba que no sólo colaboraba en el diario con su firma sino que él en persona había vuelto a retomar el tema (aunque insistiendo, al mismo tiempo, en su falta de responsabilidad en los cargos que se le hacen).

Por otra parte, se ha atestiguado que Sarmiento se dirigía con naturalidad a la redacción de La Tribuna (práctica largamente ejercitada por él tanto en Chile como en Buenos Aires). ${ }^{15} \mathrm{Y}$ de cualquier modo, la participación expresa de Sarmiento en ese medio y el contenido de sus colaboraciones es argumento suficiente para sostener que, si él no es el agente mismo, es copartícipe obligado de la polémica con Hernández: por ese motivo, y considerando también las razones que el propio Hernández esgrime, identificamos en esa impugnación anónima "la voz de Sarmiento". 16

De todas maneras, el proceso de reubicación política propiciado por el gobierno de Avellaneda continúa: al año siguiente Hernández ingresa al Partido Autonomista Nacional, y desde La Tribuna - como hemos visto- se lanza la gran primicia de que José Hernández está escribiendo el segundo tomo de su "bella composición con el título de La vuelta de Martín Fierro". ${ }^{17}$ Así, en el hipertexto conformado por todas las polémicas que se ramifican a partir de "la gran polémica nacional" también hay idas y vueltas porque las

\footnotetext{
${ }^{13}$ Halperín Donghi, 1985, pp. 7-19.

${ }^{14}$ Ibidem, pp. 133-143.

${ }^{15}$ Ver 5.2. Allí se documenta, también, cómo La Tribuna acompaña belicosamente el debate sobre la Ley de Amnistía que Rawson encabeza en el Senado.

${ }^{16}$ Ver 5.2.1.

${ }^{17}$ La Tribuna, Buenos Aires, 18 de abril de 1876.
} 
piezas que lo componen están atravesadas por tensiones y penetradas de desbordes pasionales.

Hoy, la epistemología ha instalado la certeza de que todo conocimiento es provisional. En ese marco, el objetivo último de nuestro trabajo es que, a partir de la documentación relevada (que nos propusimos describir y analizar en una lectura crítica), puedan generarse nuevas investigaciones. 


\section{CORPUS}

\subsection{Textos analizados}

HERNÁNDEZ, José

1863 Rasgos biográficos del General D. Angel V. Peñaloza; colección de artículos publicados en El Argentino, Paraná, 20 pp. [Publicado por entregas, en noviembre de 1863]

1875a Vida del Chacho; rasgos biográficos del General D. Angel V. Peñaloza, Buenos Aires, Angel da Ponte editor, 40 pp.

SARMIENTO, Domingo F.

1868 El Chacho, último caudillo de la montonera de los Llanos, en Facundo; ó civilizacion i barbarie en Las Pampas Arjentinas. Nueva York, D. Appleton y compañía, pp. 217-318. [Se cita por esta edición]

1874 El Chacho, último caudillo de la montonera de los Llanos, en Facundo ó civilizacion i barbarie en Las Pampas Argentinas. París, Librería Hachette y Cía., pp. 267370.

\subsubsection{Otras ediciones}

HERNÁNDEZ, José

1939 La vida de "El Chacho" (En: "Reconquista", Buenos Aires, 19 y 22 de noviembre). Reproducción del folleto existente en la Biblioteca Nacional.

1943 Vida de "El Chacho". Palabras aclaratorias de Francesco J. Capelli, Mar del Plata. Reproducción del folleto citado anteriormente en Biblioteca Nacional, Edición de FORJA.

1947 Vida del Chacho, rasgos biográficos del General Ángel Vicente Peñaloza. Precedida por Estudio preliminar sobre el Chacho y su época, por Santos López y Canto al general Ángel Vicente Peñaloza, por Olegario V. Andrade. Buenos Aires, A. Dos Santos (Moderna biblioteca Argentina, 2 volúmenes).

1962 Vida del Chacho. Buenos Aires, Ediciones Coyoacán. Estudio preliminar titulado: José Hernández y los dos federalismos, por Juan Carlos Trejo, pp. 7-11.

1967 "Vida del Chacho" y otros escritos en prosa. Selección por Noé Jitrik. Buenos Aires, Centro Editor de América Latina, Colección "Biblioteca argentina fundamental".

HERNÁNDEZ, José y SARMIENTO, Domingo F.

1967 Proceso al Chacho. Estudio preliminar de León Pomer. Buenos Aires, Ediciones Caldén.

SARMIENTO, Domingo F. 
1925 El Chacho. $2^{\mathrm{a}}$ ed., Buenos Aires, La Cultura Argentina.

\subsection{Intertexto analizado}

ALBERDI Juan Bautista

1853a Cartas sobre la prensa y la política militante en la República Argentina. Valparaíso, Imprenta El Mercurio. [Se las conoce como Cartas Quillotanas por haber sido escritas en la localidad chilena de Quillota.]

1853b Complicidad de la prensa en las guerras civiles de la República Argentina, continuación de las cartas escritas por Alberdi. Valparaíso, Imprenta del diario El Mercurio.

1853c Estudios de la Constitución de 1853 en que se restablece su mente alterada por comentarios hostiles y se designan los antecedentes nacionales que han sido base de su formación y deben serlo de su jurisprudencia, Valparaíso, Imprenta del diario El Mercurio.

1862 De la anarquía y sus dos causas principales, del gobierno y sus dos elementos necesarios en la República Argentina, con motivo de su reorganización por Buenos Aires. Besançon, Imprenta de José Jacquin.

1869 El Imperio del Brasil ante las democracias de América. Colección de los últimos escritos dados a luz por don J. B. Alberdi, ex Ministro de la República Argentina en París y Londres. París, Imprenta A. E. Rochette.

1895 "Facundo y su biógrafo" en Escritos Póstumos. Buenos Aires, Imprenta Europea, t. V, pp. 273-283.

1895-1901 Escritos póstumos. Buenos Aires, 1895-1901, 16 tomos: Imprenta Europea, 1895-1897, I-V; Imprenta Alberto Monkes, 1898-1900, VI-XI; Imprenta Juan Bautista Alberdi, 1900-1901, XII-XVI. [Fueron reeditados en 2003 por la Universidad Nacional de Quilmes.]

1953 La Revolución de Mayo. Buenos Aires, Editorial Luz del Día.

1957 Cartas Quillotanas. Buenos Aires, Ediciones Estrada. [Se cita por esta edición.]

1967 Epistolario 1855-1881. Edición al cuidado de Alfonso Bulnes, Santiago de Chile, Editorial Andrés Bello, 784 p.

1986 "Emancipación de la lengua" en Escritos satíricos y de crítica literaria. Buenos Aires, Academia Argentina de Letras. [1 ${ }^{\mathrm{a}}$. ed. El Iniciador, Montevideo, $1^{\circ} \mathrm{de}$ septiembre de 1838.]

2007a Juan Bautista Alberdi-Gregorio Benites. Epistolario inédito (1864-1883). Edición crítica de Élida Lois y Lucila Pagliai. Asunción-San Martín, Fondec, Coedición de la Academia Paraguaya de la Historia, la fundación Furt y la Universidad Nacional de San Martín, 3 volúmenes.

2007b El crimen de la guerra. Edición crítico-genética y "Estudio preliminar" de Élida Lois. San Martín, UNSAM EDITA, Buenos Aires.

ALBERDI, J. B. -SARMIENTO, D. F. 
2005 La gran polémica nacional: Cartas quillotanas-Las ciento y una. Prólogo de L. Pagliai. Buenos Aires, Leviatán.

HERNÁNDEZ, José

1872 El gaucho Martín Fierro. $1^{\mathrm{a}}$ ed. Buenos Aires, Imprenta La Pampa.

1873 El gaucho Martín Fierro. En El Correo de Ultramar, año 32, números, números 1069, 1070, 1072, 1073, 1074, 1075, 1077, 1078, 1080, 1082, 1083 y 1085 (París, 1873).

1874 El gaucho Martín Fierro, $8^{\mathrm{a}}$ ed., Buenos Aires. No he podido consultarla; se recogen los testimonios de J. Gil (1968), tomo I, pp. 490, 494-517.

1875b El gaucho Martín Fierro, 9a ed., Rosario, Imprenta de "El Mercurio".

1876 El gaucho Martín Fierro, $10^{\mathrm{a}}$ ed., Buenos Aires, editor Ángel da Ponte, Librería "Martín Fierro".

1878 El gaucho Martín Fierro, 11ª ed., Buenos Aires, Librería "Nueva Maravilla".

1883 El gaucho Martín Fierro, 12a ed., San Martín (Provincia de Buenos Aires), Escuela de Artes y Oficios.

1879 La vuelta de Martín Fierro, Buenos Aires, Depósito Central: Librería del Plata, Imprenta de Pablo E. Coni. Se reimprimieron en vida del autor -y también en la Imprenta de Pablo E. Coni- cuatro ediciones más: $2^{\mathrm{a}}$ (1879), $3^{\mathrm{a}}, 4^{\mathrm{a}}$ y $5^{\mathrm{a}}$ (1880).

s/f Obra Parlamentaria de José Hernández. Investigación y coordinación Prof. María Celina Ortale, La Plata, Ediciones de la pluma para la Honorable Cámara de Diputados, 3 tomos.

1967 "Vida del Chacho" y otros escritos en prosa. Selección por Noé Jitrik. Buenos Aires, Centro Editor de América Latina, Colección "Biblioteca argentina fundamental".

2005 Vida del Chacho. Estudio filológico, edición y notas de María Celina Ortale, Buenos Aires, Ediciones del Dock. (Incluye la transcripción de la polémica periodística entre La Tribuna y La Libertad de 1875). [Se cita por esta edición.]

\section{SARMIENTO, Domingo F.}

1845 Civilizacion $i$ barbarie. Vida de Facundo Quiroga, $i$ aspecto físico, costumbres i hábitos de la República Argentina, Santiago de Chile, diario El Progreso. [De mayo a junio se había publicado como folletín, con el título Facundo, en el mismo diario El Progreso.]

1860 El Tirano José Virasoro. Buenos Aires, Imprenta Argentina de El Nacional, pp. 22.

1862 Itinerario del primer cuerpo de ejército de Buenos Aires a las órdenes del general D. Wenceslao Paunero, 1861. Buenos Aires, Imprenta Comercio del Plata, pp. 74.

1883 Conflicto y armonías de las razas en América. Buenos Aires, Imprenta de D.Tuñez, primera edición. Edición digital en Internet: www.proyectosarmiento.com.ar.

1925 El Chacho. Buenos Aires, La Cultura Argentina.

1950a Obras Completas. Buenos Aires. Editorial Luz del Día, 53 tomos. [1 a . ed. Santiago de Chile, Editor Julio Belin, 1887.] 
1950b Las ciento y una, en Obras Completas. Buenos Aires, Editorial Luz del Día, Tomo XV. [1 $1^{\mathrm{a}}$ ed. Valparaíso, 18 de octubre de 1853, publicadas en Buenos Aires, $E l$ Nacional, 19 de noviembre de 1853.]

1967 Facundo. Buenos Aires, Losada. [Se cita por esta edición.]

1975 "Carta prólogo de la 2da. edición” en Facundo, Buenos Aires, Stockcero, pp. 12-14. Edición en línea: www.stockcero.com .

1993 Viajes. Javier Fernández, coordinador. Edición crítica y "Estudio filológico preliminar” de Elena M. Rojas. París-Madrid, Colección Archivos (UNESCO-CNRS), [1ª. ed. Santiago de Chile, Impr. de Julio Belín, 1849-1851]

1997 Campaña en el Ejército Grande. Quilmes, Universidad Nacional de Quilmes. [1 ${ }^{\mathrm{a} e d .}$ Río de Janeiro, imprenta de J. Villeneuve y Comp., 1852]. [Se cita por esta edición.]

2001a Obras Completas. Buenos Aires, Universidad Nacional de La Matanza, 52 tomos.

2001b "El Doctor Antonino Aberastain y la revolución de San Juan” (incluye "El tirano José Virasoro", "Protesta del Doctor Aberastain y de más víctimas de la tiranía de Don José Antonio Virasoro en San Juan" y "El Doctor Antonino Aberastain"), en Obras Completas, Buenos Aires, Universidad Nacional de La Matanza, XLV, pp. 9-128.

2001c Itinerario del primer cuerpo de ejército de Buenos Aires a las órdenes del general D. Wenceslao Paunero, 1861, en Obras Completas, Buenos Aires, Universidad Nacional de La Matanza, XLV, pp. 130-202.

\subsubsection{Correspondencia de Sarmiento}

1911 Sarmiento-Mitre. Correspondencia 1846-1868. Buenos Aires, Imprenta de Coni Hermanos. www.proyectosarmiento.com.ar.

1946 Epistolario entre Sarmiento y Posse. Buenos Aires, Museo Histórico Sarmiento, T. 1 y 2. www.proyectosarmiento.com.ar.

Cartas de Santiago Arcos a Domingo F. Sarmiento y a B. Mitre. Buenos Aires, Museo Histórico Sarmiento, Carpeta 10. www.proyectosarmiento.com.ar.

Correspondencia entre Manuel Montt y D.F.Sarmiento. Museo Histórico Sarmiento y Archivo Central de la Universidad de Chile. www.proyectosarmiento.com.ar.

\subsubsection{Intertexto periodístico}

BILBAO, Francisco

1857 Revista del Nuevo Mundo, Buenos Aires, Imp. y Lit. J. A. Bernheim.

BILBAO, Manuel

1875 Cartas de Bilbao a Sarmiento, recopiladas por unos amigos de la verdad Buenos Aires, Imprenta Rural.

CALVO, Nicolás Antonio 
1879 Interesantes cartas publicadas en El Siglo (1878-1879). Córdoba, Biblioteca Mayor, pp. 236.

\subsubsection{Artículos inéditos de José Hernández consultados en la Biblioteca de la Universidad Nacional de La Plata y en la Biblioteca del Congreso de la Nación}

\section{LA REFORMA PACÍFICA , BUENOS AIRES (1860-1861)}

"Correspondencia de las Provincias", La Reforma Pacífica, Buenos Aires, 18 de enero de 1860, 2da. época, año III, p. 2, cols. 1 y 2.

"Correspondencia de las Provincias", La Reforma Pacífica, Buenos Aires, 7 de febrero de 1860, 2da. época, año III, p. 2, cols. 2 y 3.

"Correspondencia de las Provincias", La Reforma Pacífica, Buenos Aires, 8 de febrero de 1860, 2da. época, año III, p. 1, cols. 6 y 7; p. 2, cols. 1 y 2.

"Correspondencia de las Provincias", La Reforma Pacífica, Buenos Aires, 18 de febrero de 1860, 2da. época, año III, p. 2, cols. 2, 3, 4, 5 y 6.

"Correspondencia de La Reforma Pacífica", La Reforma Pacífica, Buenos Aires, 29 de febrero de 1860, 2da. época, año III, p. 2, cols. 3, 4, 5 y 6.

"Muy señores míos", La Reforma Pacífica, Buenos Aires, 14 de marzo de 1860, 2 da. época, año III, n ${ }^{\circ} 798$, p. 1, cols. 5 y 6.

"Correspondencia de La Reforma Pacífica", La Reforma Pacífica, Buenos Aires, 24 de marzo de 1860, 2da. época, año III, p. 2, cols. 1, 2 y 3.

"Correspondencia de La Reforma Pacífica", La Reforma Pacífica, Buenos Aires, 6 de abril de 1860, 2da. época, año III, n 818, p. 1, cols. 1, 2, 3, 4, 5, 6 y 7.

"Correspondencia de La Reforma Pacífica", La Reforma Pacífica, Buenos Aires, 28 de abril de 1860, 2da. época, año III, p. 2, cols. 1, 2 y 3.

"Correspondencia de La Reforma Pacífica", La Reforma Pacífica, Buenos Aires, 4 de mayo de 1860, 2da. época, año III, p. 2, cols. 3, 4 y 5.

"Correspondencia de La Reforma Pacífica", La Reforma Pacífica, Buenos Aires, 5 de mayo de 1860, 2da. época, año III, p. 2, cols. 4, 5 y 6.

"Correspondencia para La Reforma Pacífica", La Reforma Pacífica, Buenos Aires, 29 de mayo de 1860, 2da. época, año III, p. 2, cols. 3, 4 y 5.

"Correspondencia del Paraná", La Reforma Pacífica, Buenos Aires, 14 de junio de 1860, 2da. época, año III, p. 2, cols. 1 y 2.

"Correspondencia del Paraná", La Reforma Pacífica, Buenos Aires, 12 de agosto de 1860, 2da. época, año IV, p. 2, cols. 3 y 4.

"Silencio inexplicable", La Reforma Pacífica, Buenos Aires, 18 de agosto de 1860, 2 da. época, año IV, p. 2, cols. 5 y 6.

"Correspondencia para La Reforma Pacífica", La Reforma Pacífica, Buenos Aires, 22 de septiembre de 1860, 2da. época, año IV, p. 1, col. 7 y p. 2, col. 1.

"Muy señores míos", 4 de octubre de 1860, 2da. época, año IV, p. 2, cols. 5 y 6.

"La reincorporación de Buenos Aires y su influencia en la Confederación", La Reforma Pacífica, Buenos Aires, 23 de octubre de 1860, 2da. época, año IV, p. 2, cols. 3 y 4.

"Correspondencia para La Reforma Pacífica", La Reforma Pacífica, Buenos Aires, 8 de enero de 1861, 2da. época, año IV, p. 2, cols. 1, 2 y 3. 
"Correspondencia para La Reforma Pacífica", La Reforma Pacífica, Buenos Aires, 12 de enero de 1861, 2da. época, año IV, n 1042 , p. 2, cols. 1 y 2.

EL LITORAL, PARANÁ (1862)

"Publicación solicitada", El Litoral, Paraná, 18 de marzo de 1862, año I, n 26, p. 2, cols. 1, 2,3 y 4.

“Publicación solicitada", El Litoral, Paraná, 5 de abril de 1862, año I, n 34, p. 3, cols. 4 y 5.

"Memoria presentada al juzgado de comercio por el síndico del concurso de D. Carlos D’Halwyn”, El Litoral, Paraná, 12 de agosto de 1862, año I, nº 82, p. 1, cols. 3 y 4.

"Muy notable", El Litoral, Paraná, 14 de agosto de 1862, año I, n 83, p. 2, cols. 4 y 5.

"Revista de periódicos", El Litoral, Paraná, 14 de agosto de 1862, año I, n ${ }^{\circ}$ 3, p. 3, cols. 1 y 2 .

"Corrientes”, El Litoral, Paraná, 26 de agosto de 1862, año I, n 87, p. 2, col. 2.

“Capital”, El Litoral, Paraná, 28 de agosto de 1862, año I, n 88, p. 2, cols. 2 y 3.

"Una medida justa”, El Litoral, Paraná, 28 de agosto de 1862, año I, n 88, p. 2, col. 3.

"Noticias generales", El Litoral, Paraná, 6 de septiembre de 1862, año I, n 91, p. 2, cols. 3 y 4.

“El coronel Palao", El Litoral, Paraná, 25 de septiembre de 1862, año I, nº 99, p. 2, col. 5 y p. 3, col. 1.

"La actividad del Congreso", El Litoral, Paraná, 30 de septiembre de 1862, año I, n 101, p. 2 , col.5 y p.3, cols. 1 y 2 .

“Acusación de El Litoral", El Litoral, Paraná, 4 de octubre de 1862, año I, n 103, p. 2, cols. 2,3 y 4.

"Renuncia", El Litoral, Paraná, 4 de octubre de 1862, año I, n 103, p. 2, col. 4.

“Testamento de Bolívar", El Litoral, Paraná, 7 de octubre de 1862, año I, n 104, p. 2, cols. 2 y 3.

"Buenos Aires", El Litoral, Paraná, 18 de octubre de 1862, año I, nº 109, p. 2, cols. 3 y 4.

“Elección de gobernador del obispado", El Litoral, Paraná, 21 de octubre de 1862, año I, n ${ }^{\circ}$ 110 , p. 2, col. 3.

"Rioja", El Litoral, Paraná, 21 de octubre de 1862, año I, n 110, p. 2, col. 3.

“Aviso”, El Litoral, Paraná, 23 de octubre de 1862, año I, n 111, p. 3, col. 5.

EL ARGENTINO, PARANÁ (1863)

"3 de febrero", El Argentino, Paraná, 3 de febrero de 1863, año I, n 1, p. 1, cols. 1 y 2.

"Hoy”, El Argentino, Paraná, 3 de febrero de 1863, año I, n 1, p. 1, cols. 3 y 4.

"La Catedral Paranaense", El Argentino, Paraná, 3 de febrero de 1863, año I, n 1, p. 1, cols. 4 y 5.

“Antagonismo", El Argentino, Paraná, 3 de febrero de 1863, año I, n 1, p. 2, col. 5.

"De Herodes a Pilatos", El Argentino, Paraná, 5 de febrero de 1863, año I, n 2, p. 1, cols. 3 y 4.

“Mala política”, El Argentino, Paraná, 5 de febrero de 1863, año I, n 2, p. 2, cols. 1, 2 y 3.

"Buenos Aires", El Argentino, Paraná, 5 de febrero de 1863, año I, n 2, p. 2, col. 5.

"Garantía del presupuesto", El Argentino, Paraná, 7 de febrero de 1863, año I, n 3, p. 2, cols. 3,4 y 5 . 
“¿Qué quieren?”, El Argentino, Paraná, 10 de febrero de 1863, año I, n 4, p. 1, cols. 3 y 4. "Presente y porvenir", El Argentino, Paraná, 12 de febrero de 1863, año I, n 5, p. 2, cols. 1 y 2 .

"Siguen las destituciones", El Argentino, Paraná, 12 de febrero de 1863, año I, n 5, p. 2, cols. 4 y 5 ; p. 3, col. 1.

"Vapor Dolorcitas", El Argentino, Paraná, 12 de febrero de 1863, año I, n 5, p. 2, col. 5. "Los tres roles", El Argentino, Paraná, 14 de febrero de 1863, año I, n 6, p. 1, cols. 3 y 4.

"Los sucesos de La Paz", El Argentino, Paraná, 14 de febrero de 1863, año I, n 6, p. 1, cols. 4 y 5 .

“Siempre los mismos", El Argentino, Paraná, 17 de febrero de 1863, año I, n 7, p. 1, cols. 5 y 6.

"Nuevo jefe político", El Argentino, Paraná, 17 de febrero de 1863, año I, n 7, p. 3, cols. 1 y 2 .

"La Paz”, El Argentino, Paraná, 17 de febrero de 1863, año I, n 7, p. 3, col. 2.

“Garantía del presupuesto", El Argentino, Paraná, 19 de febrero de 1863, año I, n 8, p. 2, cols. 1 y 2.

"Vapor Dolorcitas", El Argentino, Paraná, 19 de febrero de 1863, año I, n 8, p. 2, cols. 3 y 4.

"Vapor Gran Chacho", El Argentino, Paraná, 19 de febrero de 1863, año I, n 8, p. 2, col. 4. "La reacción”, El Argentino, Paraná, 7 de marzo de 1863, año I, n 15, p. 1, cols. 2 y 3.

"Viaje alarmante", El Argentino, Paraná, 7 de marzo de 1863, año I, n 15, p. 1, cols. 4 y 5. "La fusión”, El Argentino, Paraná, 7 de marzo de 1863, año I, n 15, p. 2, cols. 2 y 3.

“La Paz”, El Argentino, Paraná, 7 de marzo de 1863, año I, n 15, p. 2, col. 5; p. 3, col. 1. "La Concordia", El Argentino, Paraná, 7 de marzo de 1863, año I, n 15, p. 3, col. 1. "El general Pedernera", El Argentino, Paraná, 7 de marzo de 1863, año I, n 15, p. 3, cols. 1 y 2 .

"Garantía del presupuesto - Derecho constitucional", El Argentino, Paraná, 10 de marzo de 1863, año I, $\mathrm{n}^{\circ} 16$, p. 2, cols. 2, 3 y 4.

“La Paz”, El Argentino, Paraná, 10 de marzo de 1863, año I, n 16, p. 2, col. 4.

"Uruguay", El Argentino, Paraná, 10 de marzo de 1863, año I, n 16, p. 2, cols. 4 y 5.

"Rosario", El Argentino, Paraná, 10 de marzo de 1863, año I, n 16, p. 2, col. 5.

“Dos perspectivas", El Argentino, Paraná, 12 de marzo de 1863, año I, n 17, p. 2, cols. 3 y 4.

"De la provincia", El Argentino, Paraná, 12 de marzo de 1863, año I, n 17, p. 2, col. 5.

"Revista de periódicos", El Argentino, Paraná, 12 de marzo de 1863, año I, n 17, p. 2, col. 5; p. 3, col. 1.

"El coronel Cordero", El Argentino, Paraná, 12 de marzo de 1863, año I, n 17, p. 3, col. 6. "Despedida”, El Argentino, Paraná, 12 de marzo de 1863, año I, n 17, p. 3, col. 6.

“Juicio imparcial”, El Argentino, Paraná, 14 de marzo de 1863, año I, n 18, p. 1, cols. 4 y 5.

"Situación”, El Argentino, Paraná, 14 de marzo de 1863, año I, n 18, p. 2, cols. 2 y 3.

“Garantía del presupuesto", El Argentino, Paraná, 14 de marzo de 1863, año I, n 18, p. 2, col. 5 .

“Ley de contribución”, El Argentino, Paraná, 14 de marzo de 1863, año I, n 18, p. 2, col. 5. 
“Cuasi siniestro en el Dolorcitas", El Argentino, Paraná, 14 de marzo de 1863, año I, n 18, p. 3, col. 1.

"Compromiso olvidado", El Argentino, Paraná, 17 de marzo de 1863, año I, n 19, p. 2, cols. 3 y 4.

“Interior”, El Argentino, Paraná, 17 de marzo de 1863, año I, n 19, p. 2, cols. 4 y 5.

“Córdoba", El Argentino, Paraná, 17 de marzo de 1863, año I, n 19, p. 2, col. 5; p. 3, col.

1.

“Anuncio cumplido", El Argentino, Paraná, 19 de marzo de 1863, año I, n 20, p. 1, cols. 3, 4 y 5.

"20 de marzo", El Argentino, Paraná, 19 de marzo de 1863, año I, n 20, p. 1, col. 5.

"Buenos Aires", El Argentino, Paraná, 19 de marzo de 1863, año I, n 20, p. 21, col. 1.

"Justicia”, El Argentino, Paraná, 19 de marzo de 1863, año I, n 20, p. 2, col. 2.

“Garantía del presupuesto", El Argentino, Paraná, 21 de marzo de 1863, año I, n 21, p. 1, cols. 4 y 5.

"La Paz", El Argentino, Paraná, 21 de marzo de 1863, año I, n 21, p. 2, col. 1.

"El Vapor Dolorcitas", El Argentino, Paraná, 21 de marzo de 1863, año I, n² 21, p. 2, cols. 1 y 2.

“Otro más”, El Argentino, Paraná, 24 de marzo de 1863, año I, n 22, p. 2, cols. 2,3 y 4.

“Acusación a La Democracia”, El Argentino, Paraná, 24 de marzo de 1863, año I, n 22, p. 2, col. 4.

“Uruguay”, El Argentino, Paraná, 24 de marzo de 1863, año I, n² 22, p. 2, col. 5.

“Jefatura política”, El Argentino, Paraná, 24 de marzo de 1863, año I, n 22, p. 2, col. 5.

“Interior”, El Argentino, Paraná, 24 de marzo de 1863, año I, n 22, p. 2, col. 5.

"Última palabra", El Argentino, Paraná, 26 de marzo de 1863, año I, n 23, p. 1, cols. 2 y 3.

"Buenos Aires", El Argentino, Paraná, 26 de marzo de 1863, año I, n 23, p. 2, col. 1.

"Mendoza", El Argentino, Paraná, 26 de marzo de 1863, año I, n 23, p. 2, cols. 1 y 2.

"Más muertes", El Argentino, Paraná, 26 de marzo de 1863, año I, n 23, p. 2, col. 3.

“Gobierno Nacional”, El Argentino, Paraná, 26 de marzo de 1863, año I, n 23, p. 2, col. 4.

"Última hora", El Argentino, Paraná, 26 de marzo de 1863, año I, n 23, p. 2, col. 4.

"Más muertes", El Argentino, Paraná, 26 de marzo de 1863, año I, n 23, p. 2, col. 5.

"Invasión del Río 4", El Argentino, Paraná, 18 de abril de 1863, año I, n 32, p. 1, cols. 4 y 5 ; p. 2 , cols. 1 y 2.

"Una medida anárquica", El Argentino, Paraná, 18 de abril de 1863, año I, n 32, p. 2, cols. 4 y 5.

"Proclama", El Argentino, Paraná, 21 de abril de 1863, año I, n 33, p. 1, cols. 4 y 5.

"Vapor Paraná", El Argentino, Paraná, 21 de abril de 1863, año I, n 33, p. 2, cols. 1 y 2.

"Entre Ríos", El Argentino, Paraná, 21 de abril de 1863, año I, n 33, p. 2, cols. 2 y 3.

“Interior”, El Argentino, Paraná, 21 de abril de 1863, año I, n 33, p. 2, cols. 4 y 5.

“El Sr. Dr. Ocampo", El Argentino, Paraná, 21 de abril de 1863, año I, n 33, p. 2, col. 5.

“El único camino", El Argentino, Paraná, 23 de abril de 1863, año I, n 34, p. 2, cols. 2, 3, 4 y 5 .

“Tribunal de alzada", El Argentino, Paraná, 23 de abril de 1863, año I, n 34, p. 2, col. 5.

“Artículo dictado por mi reloj”, El Argentino, Paraná, 23 de abril de 1863, año I, n 34, p. 2, col. 5 .

"Fiasco", El Argentino, Paraná, 23 de abril de 1863, año I, n 34, p. 2, col. 5. 
"Viaje del Presidente y su comitiva", El Argentino, Paraná, 25 de abril de 1863, año I, n 35 , p. 1 , cols. 2 y 3.

"Reconocimiento de la deuda pública", El Argentino, Paraná, 25 de abril de 1863, año I, n 35 , p. 1, cols. 3 y 4.

“Interior", El Argentino, Paraná, 25 de abril de 1863, año I, n 35, p. 2, col. 3.

"Estado Oriental", El Argentino, Paraná, 25 de abril de 1863, año I, n 35, p. 2, cols. 1 y 2.

"Impuesto arbitrario", El Argentino, Paraná, 28 de abril de 1863, año I, n 36, p. 1, cols. 4 y 5 .

"Paraná y Victoria", El Argentino, Paraná, 28 de abril de 1863, año I, n 36, p. 2, col. 1.

"Elecciones", El Argentino, Paraná, 28 de abril de 1863, año I, n 36, p. 2, col. 1.

"Victoria", El Argentino, Paraná, 28 de abril de 1863, año I, n 36, p. 2, col. 2.

"Interior", El Argentino, Paraná, 28 de abril de 1863, año I, nº 36, p. 2, col. 2.

"La Comisión Clasificadora", El Argentino, Paraná, 30 de abril de 1863, año I, n 37, p. 1, cols. 2 y 3.

"La escuela del fraude”, El Argentino, Paraná, 30 de abril de 1863, año I, n 37, p. 1, cols. 4 y 5 .

“Otro remitido de La Paz", El Argentino, Paraná, 30 de abril de 1863, año I, n 37, p. 2, cols. 1 y 2.

"Un diputado por Entre Ríos", El Argentino, Paraná, 30 de abril de 1863, año I, n 37, p. 2, col. 3.

"Medio sencillísimo de pagar toda la deuda inmediatamente", 30 de abril de 1863, año I, n 37, p. 2, col. 3.

"La legión Charloni se ha disuelto", El Argentino, Paraná, 30 de abril de 1863, año I, n 37 , p. 2, col. 4.

"Documento", El Argentino, Paraná, 30 de abril de 1863, año I, n 37, p. 2, col. 5.

"Los militares y el ferrocarril", El Argentino, Paraná, 2 de mayo de 1863, año I, n 38, p. 2, col. 2.

"Prepararse", El Argentino, Paraná, 2 de mayo de 1863, año I, n 38, p. 1, col. 5.

“Complicaciones”, El Argentino, Paraná, 2 de mayo de 1863, año I, n 38, p. 2, col. 1.

"Deuda Pública”, El Argentino, Paraná, 2 de mayo de 1863, año I, n 38, p. 2, col. 2.

"Documento importante", El Argentino, Paraná, 2 de mayo de 1863, año I, n 39, p. 2, cols. 3 y 4.

"Carta del Presidente de la República al Gobernador de San Juan”, El Argentino, Paraná, 7 de mayo de 1863, año I, n ${ }^{\circ}$ 40, p. 1, cols. 1, 2, 3, 4 y 5.

“Qué dirá el dueño?”, El Argentino, Paraná, 7 de mayo de 1863, año I, n 40, p. 2, cols. 1, 2 y 3 .

"Buenos Aires", El Argentino, Paraná, 7 de mayo de 1863, año I, n 40, p. 2, col. 4.

"Rosario", El Argentino, Paraná, 7 de mayo de 1863, año I, n 40, p. 2, col. 4.

"Le tomamos la palabra", El Argentino, Paraná, 7 de mayo de 1863, año I, n 40, p. 2, col. 5.

"Estado Oriental”, El Argentino, Paraná, 7 de mayo de 1863, año I, n 40, p. 2, col. 5.

“¿Cuáles son?”, El Argentino, Paraná, 30 de mayo de 1863, año I, n 50, p. 1, cols. 4 y 5.

EL ECO, CORRIENTES (1868)

"Candidaturas", El Eco, Corrientes, 10 de marzo de 1868, año II, p. 2, cols. 2, 3 y 4. 
“Candidaturas y caudillos!", El Eco, Corrientes, 17 de marzo de 1868, año II, n 162 , p. 2, cols. 3,4 y 5 .

“¿Hasta cuándo?”, El Eco, Corrientes, 31 de marzo de 1868, año II, p. 2, cols. 1 y 2.

"La combinación que han formado los sucesos es la única posible: Urquiza-Elizalde", $E l$ Eco, Corrientes, 17 de abril de 1868, año II, ${ }^{\circ} 170$, p. 2, cols. 2, 3, 4 y 5.

"Urquiza-Elizalde. Esta combinación no sólo es la única posible, sino también la más conveniente", El Eco, Corrientes, 24 de abril de 1868, año II, p. 2, cols. 1 y 2.

"El error debe desaparecer", El Eco, Corrientes, 5 de mayo de 1868, año II, p. 2, cols. 1, 2, 3 y 4.

"Tiempo al tiempo", El Eco, Corrientes, 8 de mayo de 1868, año II, p. 2, cols. 1 y 2.

LA CAPITAL, ROSARIO (1868-1869)

"Los cantos de las sirenas", La Capital, Rosario, 2 de julio de 1868, año I, n 173, p. 2, cols. 1 y 2.

"Lecciones para los pueblos", La Capital, Rosario, 18 de julio de 1868, año I, n 186, p. 2, cols. 3 y 4.

"De mal en peor", La Capital, Rosario, 20 y 21 de julio de 1868, año I, n 188 , p. 2, cols. 2 y 3 .

"Asesinato del General Peñaloza", La Capital, Rosario, 12 de noviembre de 1869, año II, $\mathrm{n}^{\circ} 605$, p. 2 , cols. 1 y 2 .

"La paz se consolida", La Capital, Rosario, 12 de noviembre de 1869, año II, n 605, p. 2, cols. 1 y 2 . 


\section{BIBLIOGRAFÍA GENERAL}

\subsection{Marco teórico general}

\subsubsection{Crítica textual y crítica genética}

\section{AAVV}

2010 “Théorie: état des lieux”, Genesis (Paris, ITEM-CNRS), n 30, 2010, pp. $1-295$.

BARRENECHEA, Ana María

1982 Cuaderno de Bitácora de "Rayuela". Buenos Aires, Sudamericana.

BELLEMIN-NOËL, Jean

1972 Le texte et l'avant-texte. Les brouillons d'un poème de Milosz. Paris, Larousse.

BIASI, Pierre-Marc de

2000 La génétique des textes. Paris, Nathan Université.

CONTAT, Michel et Daniel FERRER (edits.)

Éditions.

1998 Pourquoi la critique génétique? Méthodes, Théories. Paris, CNRS

ESPAGNE, Michel

1998 De l'archive au texte. Recherches d'histoire génétique. Paris, PUF.

FALCONER, Graham

1993 “Genetic criticism", Comparativa literature 45, 1, pp. 1-21.

FERRER, Daniel

2007 "Le matériel et le virtual: du paradigme indiciaire a la logique de mondes posibles", Item [En ligne], Puesto en línea el: 19 de enero de 2007. Disponible en: http://www.item.ens.fr/index.php?id=14091.

GRÉSILLON, Almuth

1994 Eléments de critique génétique. Lire les manuscrits modernes. Paris, PUF.

HAY, Louis

1981 "Genèse du texte et études comparées", Revue de littérature comparée 55,1, pp. 5-10.

1985 “Le texte n'existe pas", en Poétique 62 (1985), pp. 146-158.

1986 "Nouvelles notes de critique génétique: la troisième dimension de la littérature", Texte, 5-6, pp. 313-328.

1993a "L'écriture vive", en HAY, L., editor (1993, pp. 10-33). 
137).

$1993 b$ "Les manuscrits au laboratoire", en HAY, L., editor (1993, pp. 122-

1995 “La memoire des signes”, en AAVV (1995, pp. 105-113).

HAY, Louis (editor)

1993 Les manuscrits des écrivains. Paris, CNRS-Éditions Hachette.

LEBRAVE, Jean-Louis

1992 "La critique génétique: une discipline nouvelle ou un avatar moderne de la philologie?", Genesis, 1, pp. 33-72.

LOIS, Élida

1986 "La reelaboración del capítulo XI de Don Segundo Sombra: la mitificación de la sociedad paternalista", Filología, XXI, 2, pp. 213-226.

1995a "Orillas movedizas: la génesis del paratexto", en Gênese e Memória. IV Encontro internacional de pesquisadores do manuscrito e de edicões (USP, 1994), Sao Paulo, Anna Blume, pp. 555-562.

1995 b "Louis Hay y la memoria de los signos. El movimiento de la escritura y las tensiones del proceso cultural", Manuscrítica (São Paulo), 5, pp. 17-20.

2001a Génesis de escritura y estudios culturales. Introducción a la crítica genética. Buenos Aires, Edicial.

2001b Edición crítico-genética de El gaucho Martín Fierro y La vuelta de Martín Fierro y "Estudio filológico preliminar", en Hernández, José. Martín Fierro. París-Madrid, Colección Archivos, (volumen 51 coordinado por É. Lois y Á. Núñez).

2007 "Estudio preliminar" en Alberdi, J. B. El crimen de la guerra. San Martín, UNSAM EDITA, Buenos Aires.

2008 Edición crítico-genética anotada, "Estudio preliminar" y "Apéndice documental" de El crimen de la guerra de J. B. Alberdi. San Martín, UNSAM Edita, 2008.

2010 "Autobiografía y autoficción en la escritura del último Alberdi", Aletria.

Revista de Estudos de Literatura (Programa de Pós-Graduação em Letras: Estudos Literários da Universidade de Minas Gerais), 20, v. 2, 2010, pp. 13-26.

2011 "La critique génétique en Argentine: précurseurs, irruption et état actuel", Genesis (ITEM / CNRS), 33, pp. 149-156.

\subsubsection{Lingüística, análisis del discurso y sociología del lenguaje}

ABEILLE, Lucien

1900 El idioma nacional de los argentinos, Paris, Emile Buillon.

ALARCOS LLORACH, Emilio

1991 Fonología española. Madrid, Gredos.

ALONSO, Amado

1935 El problema de la lengua en América, Madrid, Espasa Calpe.

1937-1938 "Rodolfo Lenz y la fonética del castellano", Anales de la Facultad de Filosofía y Educación (Sección de Filología, Universidad de Chile), II, 1. Homenaje a la memoria del Dr. Rodolfo Lenz, pp. 11-17. 
1939 "Examen de la teoría indigenista de Rodolfo Lenz", Revista de Filología Hispánica, I, 4, 313-350.

1946 Castellano, español, idioma nacional, Buenos Aires, Losada.

1951 "Substratum y superstratum", en Estudios lingüísticos. Temas españoles, Madrid, Gredos.

1969 De la pronunciación medieval a la moderna en español. Madrid, Gredos.

ALVAR, Manuel y Bernard POTTIER

1977 Morfología histórica del español. Madrid, Gredos.

2006 Lengua nacional y sociolingüística: las constituciones de América.

Edición digital: Alicante, Biblioteca Virtual Miguel de Cervantes.

BALLY, Charles

1971 "La presión social del lenguaje" en El lenguaje y la vida. Buenos Aires, Losada.

BERNSTEIN, Basil

1993 La estructura del discurso pedagógico. Madrid, Morata.

BIXIO, Beatriz y Luis HEREDIA

2000 "Algunos lugares de articulación disciplinaria: la vulnerabilidad de las fronteras", Interdisciplina (publicación del CIFFyH), I, 1, pp. 83-95.

BLANCO, Mercedes

1991 Lenguaje e identidad. Actitudes lingüísticas en la Argentina, 1800-1960. Bahía Blanca, Universidad Nacional del Sur.

BLECUA, José M. y Juan GUTIÉRREZ

1998 Estudios de grafemática en el dominio hispano. Bogotá, Universidad de Salamanca e Insituto Caro y Cuervo.

BORDELOIS, Ivonne y Ángela DI TULIO

2002 "El idioma de los argentinos: cultura y discriminación", Ciberletras, 6, http: // www.lehman-cuny.edu/ciberletras

BORELLO, Rodolfo

1974 Habla y literatura en la Argentina. Tucumán, Universidad Nacional del Tucumán.

BORGES, José Luis

1960 "Las alarmas del Dr. Américo Castro" y "El idioma de los argentinos" en Otras Inquisiciones. Buenos Aires, Emecé.

BRIONES, Claudia y Lucía GOLLUSCIO

1995 "Discurso y metadiscurso como procesos de construcción cultural", en Actas de las Segundas Jornadas de Lingüística Aborigen, Buenos Aires, UBA, pp. 498517. 
BOURDIEU, Pierre

1985 ¿Qué significa hablar? España, Akal Universitaria.

BURKE, Peter

1996 Hablar y callar. Funciones sociales del lenguaje a través de la historia. Madrid, Gedisa.

BYNON, Theodora

1981 "La motivación social del cambio lingüístico", en Lingüística histórica. Madrid, Gredos.

CABALLERO WANGUEMERT, María M.

1992 "Las polémicas lingüísticas durante el siglo XIX", Cuadernos Hispanoamericanos, 500, pp. 177-187.

CABRERA, Carmen

1998 "Reflexiones sobre el sistema gráfico avulgarado de los textos primitivos leoneses", en Blecua, J.M., Gutiérrez, J. y Sala, L. Estudios de grafemática en el dominio hispano. Bogotá, Universidad de Salamanca e Instituto Caro y Cuervo.

CALVET, Luis-Jean

1997 Las políticas lingüísticas. Buenos Aires, Edicial.

CARBONELL, María C.

1994 La polémica en torno a las cartas americanas de Juan Valera (1889), Actas del XXIX Congreso del Instituto Internacional de Literatura Iberoamericana, Barcelona, P.P.U., pp. 157-173. Edición digital.

CARDONA, Giorgio Raimondo

1994 Los lenguajes del saber. Madrid, Gedisa.

CASTRO, Américo

1941 La peculiaridad lingüística rioplatense y su sentido histórico. Buenos Aires, Losada.

COSTA ÁlVAREZ, Arturo

1928 El castellano en la Argentina. La Plata, Talleres de la Escuela San Vicente de Paul.

CUERVO, Rufino José

2004 El castellano en América. Polémica con Juan Valera. Bogotá, Instituto Caro y Cuervo.

DEL VALLE, José y Luis Gabriel STHEEMAN

2004 "La cultura monoglósica y el dogma del homogeneísmo", en La batalla del idioma. La intelectualidad hispánica ante la lengua. Madrid, Editorial Iberoamericana, pp. 15-33. 
DURANTI, A.

1992 "La etnografía del habla. Hacia una lingüística de la praxis", en Newmeyer F. (comp.) Panorama de la lingüística moderna de la Universidad de Cambridge. Tomo IV. "El lenguaje en su contexto sociocultural". Madrid, Visor.

ENNIS, Juan Antonio

2008 Decir la lengua. Debates ideológico-lingüísticos en Argentina desde 1853. Frankfurt, Peter Lang.

ESPÓSITO, Fabio

1997 "El problema del idioma nacional: del Santos Vega a La guerra gaucha", Orbis Tertius, II, 4, pp. 59-75.

FONTANELLA DE WEINBERG, María Beatriz.

1987 El español bonaerense. Buenos Aires, Hachette.

1992 El español de América. Madrid, Editorial MAPFRE, 1992.

GUITARTE, Guillermo

1983 Siete estudios sobre el español de América. Mexico, UNAM.

1989 "Del español de España al español de veinte naciones: la integración de América al concepto de lengua española" en Hernández C. et al. El español de América. Actas del III Congreso Internacional de el español de América, Valladolid, 3 al 9 de julio de 1989. Juan de Castilla y León: Consejería de Cultura y Turismo, 1991, pp. 6589.

GUMPERZ, Jenny

1988 "La sociolingüística interaccional en el estudio de la escolarización”, en Cook-Gumperz, Jenny (edit.) La construcción social de la alfabetización. Madrid, Paidós.

HALLIDAY, M.A.K.

1982 El lenguaje como semiótica social. La interpretación social del lenguaje y del significado. México, FCE.

HENRÍQUEZ UREÑA, Pedro

1977 Observaciones sobre el español de América y otros estudios filológicos. Buenos Aires, Academia Argentina de Letras, Editorial Coni.

HUDSON, R.A.

1981 La sociolingüística. Barcelona, Anagrama, 1981.

KERBRAT-ORECCHIONI, Catherine

1983 La connotation. Paris, Hachette.

2005 Le discours en interaction. Paris, Armand Colin.

2009 L'énonciation: De la subjectivité dans le langage. Paris, Armand Colin, $4^{\mathrm{a}}$ ed. $\left[1^{\mathrm{a}}\right.$ ed., 1980]

LABOV, William 
1983 Modelos sociolingüísticos. Madrid, Cátedra.

LAVANDERA, Beatriz

1984 Variación y significado. Buenos Aires, Hachette, 1984.

LAPESA, Rafael

1980 Historia de la lengua española. Madrid, Gredos.

LARROSA, Jorge

2005 Entre las lenguas. Lenguaje y educación después de Babel. Madrid, Alertes.

LAUSBERG, Heinrich

1965 Lingüística románica. Madrid, Gredos.

LENZ, Rodolfo, Andrés BELLO y Rodolfo OROZ

1940 El español en Chile, traducción, notas y apéndices de Amado Alonso y Raimundo Lida, Instituto de Filología (Biblioteca de Dialectología Hispanoamericana, VI), Facultad de Filosofía y Letras, Universidad de Buenos Aires.

LIPSKI, John M.

1994 El español de América. Madrid, Cátedra.

LOIS, Élida

1987 "Modelos de cambio lingüístico". Buenos Aires, (Materiales de la cátedra de "Filología Hispánica", FAHCE-UNLP).

1998 "La dialéctica cambio-permanencia en la reescritura de poemas del primer Borges" en AAVV, Borges, Buenos Aires, Biblioteca del Congreso de la Nación.

LÓPEZ MORALES, Humberto

1986 Sociolingüística. Madrid, Gredos.

MALMBERG, Bertil

1967 Los nuevos caminos de la lingüística. Mexico, S. XXI.

MARTINET, A.

1974 Economía de los cambios fonéticos. Madrid, Gredos.

MORENO FERNÁNDEZ, Francisco

1993 La división dialectal del español de América. Alcalá de Henares, Imprenta de Alcalá.

MOURE, José Luis

2004 "Un temprano proyecto colombiano de creación de una Academia Americana de la lengua y su recepción en la Argentina". Boletín de la Academia Argentina de Letras, LXIX, 275-276, pp. 467-483. 
2005 El joven Alberdi y la creación filosófica del español de América. La Biblioteca $\mathrm{N}^{\circ} 2$ y 3 http: // www.labiblioteca.edu.ar/index.htm.

NARVAJA DE ARNOUX, Elvira y Rodolfo BEIN (compiladores)

1999 Prácticas y representaciones del lenguaje. Buenos Aires, Eudeba.

PENSADO, Carmen

1998 "Sobre los límites de la mala ortografía en romance" en Blecua, J.M., Gutiérrez, J. y Sala, L. Estudios de grafemática en el dominio hispano. Bogotá, Universidad de Salamanca e Instituto Caro y Cuervo, 1998.

POTTIER, Bernard

1992 "La variación lingüística y el español de América” en RFE, LXXII, pp. $29-41$.

RAGUCCI, Rodolfo

1947 Palabras enfermas y bárbaras. Buenos Aires, Sociedad Editora Internacional.

RIVAROLA, José Luis

1990 La formación lingüística de Hispanoamérica. Lima, Universidad Católica del Perú.

ROMAINE, Susanne

1974 El lenguaje en la sociedad. Barcelona, Ediciones Ariel.

ROSEMBLAT, Ángel

1961 Las generaciones argentinas del siglo XIX ante el problema de la lengua. Buenos Aires, UBA.

1971 Nuestra lengua en ambos mundos. Madrid, Salvat-Alianza.

1973 Bases del español de América: nivel social y cultural de los conquistadores y pobladores. Bogotá, Instituto Caro y Cuervo.

SAVILLE TROIKE, Muriel

2005 Etnografía de la comunicación. Buenos Aires, Prometeo.

VERÓN, Eliseo

1987 La semiosis social. Fragmentos de una teoría de la discursividad. Buenos Aires, Gedisa.

TOBIN, Yishai

1997 Phonology as human behavior. Theoretical Implications ans clinical applications. Durham, NC, Duke University Press.

\subsubsection{Otras líneas críticas}

ADORNO, Theodor 
36.

1962 "El ensayo como forma" en Notas de literatura. Barcelona, Ariel, pp. 11-

ANDERSON, Benedict

1991 Imagined Communities. Reflections on the Origin and Spread of Nationalism. Londres, N. York, Verso.

ANGENOT, Marc

1982 La parole pamphlétaire: contribution à la typologie des discours modernes. Paris, Payot.

ALTAMIRANO, Carlos y Beatriz SARLO

1982 Literatura y Sociedad. Buenos Airtes, Hachette.

AUGÉ, Marc

1995 Los "no lugares” espacios del anonimato. Barcelona, Gedisa.

AUSTIN, John L.

1971 Palabras y acciones. Buenos Aires, Paidós.

BACZKO, Bronislaw

1991 Los imaginarios sociales. Buenos Aires, Beatriz Viterbo Editora.

\section{BAJTÍN, Mijail}

1986 "La biografía y la autobiografía antiguas" en Problemas literarios y estéticos. La Habana, Arte y literatura.

BARRENECHEA, Ana María pp. $35-50$.

1981 "Los actos de lenguaje en la teoría y en la crítica literaria", Lexis, V, 2,

BARTHES, Roland

1966 Critique et vérité. Paris, Editions du Seuil.

1967 Ensayos críticos. Barcelona, Seix Barral.

105-205).

1969a "El efecto de lo real" (trad. esp. de N. Finetti), en Piglia, R. (1969, pp.

1969b S/Z. Paris, Éditions du Seuil.

1987 El susurro del lenguaje. Barcelona, Paidós Comunicación.

BHABHA, Homi (edit.)

1995 Nation and Narration. Londres, N.York, Routledge.

BENJAMIN, Walter

1999 “Tesis de la filosofía de la historia”, en Ensayos escogidos. México, Ediciones Coyoacán, pp. 43-52.

BLOOM, Harold

1991 La angustia de las influencias. Caracas, Monte Avila Latinoamericana. 
BORRAT, Héctor

1989 El periódico, actor político. Barcelona, Gustavo Pili.

BOURDIEU, Pierre

1967 "Campo intelectual y proyecto creador", en Pouillon, J. y otros, Problemas del estructuralismo. México, Siglo XXI.

1979 La distinction. Paris, Minuit.

1985 ¿Qué significa hablar? España, Akal Universitaria.

1995 Las reglas del arte. Génesis y estructura del campo literario. Barcelona, Anagrama.

CATELLI, Nora

2000 Testimonios tangibles. Barcelona, Anagrama.

CAVALLO, Guglielmo y Roger CHARTIER

1998 Historia de la lectura en el mundo occidental. Madrid, Taurus.

CERTEAU, Michel de

1990 L'invention du quotidien. Paris, Gallimard.

CHARTIER, Roger

1991 El mundo como representación. Barcelona, Gedisa.

1994 El orden de los libros. Barcelona, Gedisa.

2000 Entre poder y placer. Madrid, Cátedra.

2001 "Las paradojas de lo escrito: placer y verdad en el discurso historiográfico. Conversaciones con Patricia Flier y María Minellono", Sociohistórica, 8, pp. 155-174.

CHARTIER, Roger (compilador)

1993 Practiques de la lectura. Paris, Rivales.

CHARTIER, Anne-Marie y Jean HEBRARD

2002 La lectura de un siglo a otro. Barcelona, Gedisa.

DERRIDA, Jacques

1967 L'Écriture et la différence. Paris, Éditions du Seuil.

1968 De la Grammatologie. Paris, Minuit.

1986 Schibboleth. Pour Paul Celan. Paris, Galilée.

1996a La Diseminación. Madrid, Editorial Fundamentos.

1996b El monolingüismo del otro. Buenos Aires, Ediciones Manantial.

1997 Mal de archivo. Una impresión freudiana. Madrid, Editorial Trotta. [Conferencia dictada en Londres el 5 de junio de 1994 en el Coloquio internacional Memory: The Question of Archives.]

DIJK, Teun A. van

1980 Text and context. London, Longman.

1999 Manual de análisis del discurso. Barcelona, Ariel. 
FOUCAULT, Michel

1990 Vida de los hombres infames. Madrid, Ediciones La Piqueta.

1992 Dits et écrits. II/1970-1975. Paris, Gallimard.

1998 La arqueología del saber. Madrid, Siglo XXI. [1 ${ }^{\text {a }}$ ed. francesa, 1969]

GARGANI, A., edit.

1979 Crisi de la ragione. Torino, Einaudi.

GEERTZ, Clifford

1991 La interpretación de las culturas. Barcelona, Gedisa.

GENETTE, Gérard

1982 Palimpsestes. La littérature au seconde degré. Paris, Éditions du Seuil

1986 Seuils. Paris, Éditions du Seuil.

GINZBURG, Carlo

1979 “Spie. Radici di un paradigma indiziario", en Gargani, 1979, pp. 59-106.

1994 "Indicios. Raíces de un paradigma de inferencias indiciales", en Mitos, emblemas, indicios. Morfología e historia. Trad. esp. de C. Catroppi. Barcelona, Gedisa, 1994, pp. 138-175. [Se cita por esta edición.]

HALL, Stuart y Paul DU GAY (compiladores)

1996 Questions of Cultural Identity. Londres, Verso.

HALLIDAY, M. A. K.

1978 Language as social semiotic. The social interpretation of lenguage and meaning. London, Edward Arnold (trad. esp. de J. Ferreiro Santana. México, FCE, 1982)

HOBSBAWM, Eric J.

1998 Naciones y nacionalismo. Madrid, Crítica.

2002 La invención de la tradición. Madrid, Crítica.

JAKOBSON, Roman

1963 Essais de linguistique générale (trad. franc. de N. Ruwet). Paris, Éditions de Minuit.

JAMESON, Frederic

1989 Documentos de cultura. Documentos de barbarie. Madrid, Visor.

JAUSS, Hans Robert

1976 La literatura como provocación. Barcelona, Península.

1979 Estética de la recepción. Warning, Rainer, ed.

1986 Experiencia estética y hermenéutica literaria (trad. esp.) Madrid, Taurus.

LEJEUNE, Philippe 
1975 Le pacte autobiographique. París, du Seuil.

LOUREIRO, Ángel

1993 "Direcciones en la teoría de la autobiografía", en Romera Castillo, J. (comp.), Escritura autobiográfica. Actas del II Seminario Internacional del Instituto de Semiótica Literaria y Teatral. Madrid, Visor Libros, pp. 36-45.

LUKÁCS, Georg

1975 "Esencia y forma del ensayo", en El alma y las formas. Barcelona, Grijalbo, pp. 13-39.

1977 “Narrar o describir?”, en Goldmann, Escarpit, Hauser y otros, Literatura y sociedad. Buenos Aires, CEAL.

LUDMER, Josefina

1977 Los procesos de construcción del relato. Buenos Aires, Sudamericana.

MAINGUENEAU, Dominique

1980 Introducción a los métodos del discurso. Buenos Aires, Hachette. [ $1^{\mathrm{a}} \mathrm{ed}$. francesa, 1976]

MATTONI, Silvio

2003 Las formas del ensayo en la Argentina de los años '50. Córdoba, Universitas.

MIGNOLO, Walter

1978 Elementos para una teoría del texto literario. Barcelona, Editorial Crítica.

1986 Teoría del texto e interpretación de textos. México, UNAM.

MIRAUX, Jean Philippe Visión.

2005 La autobiografía: las escrituras del yo. Buenos Aires, Ediciones Nueva

MONTAIGNE, Michel

1962 Essais. Paris, Editions Garnier Fréres, Tome I.

PRATT, Mary Louis

1997 Ojos imperiales. Literatura de viajes y transculturación. Bernal, Universidad Nacional de Quilmes.

REBOUL, Olivier

1986 Lenguaje e ideología. México, Fondo de Cultura Económica.

REST, Jaime

1994 El cuarto en el recoveco. Buenos Aires, Centro Editor de América Latina.

RIVERA, Jorge 
1998 El escritor y la industria cultural. Buenos Aires, Atuel.

ROBBINS, Derek

2000 Bourdieu \& Culture. Londres, Sage Publications.

ROMERA CASTILLO, José (comp.)

1993 Escritura autobiográfica. Actas del II Seminario Internacional del Instituto de Semiótica Literaria y Teatral. Madrid, Visor Libros (UNED, 1-3 julio 1992).

SAID, Edward

1990 Orientalismo. Madrid, Libertarias.

1993 Cultura e imperialismo. Barcelona, Anagrama.

SILVESTRI, Graciela y Fernando ALIATA

2001 El paisaje como cifra de armonía. Buenos Aires, Nueva Visión.

STAROBINSKI, Jean

1998 "Es posible definir el ensayo", Cuadernos Hispanoamericanos, 575, pp. $31-40$.

TODOROV, Tzvetan

1981 Mikhail Bakhtine, le principe dialogique. Suivi de "Écrits du Cercle de Bakhtine”. Paris, Éditions du Seuil.

VOLOSHINOV, Vladimir N.

1976 El signo ideológico y la filosofía del lenguaje (trad. esp. de R. Rússovich). Buenos Aires, Nueva Visión [1 ${ }^{\mathrm{a}}$ ed. rusa, 1930]

WEINBERG, Liliana

2001 El ensayo, entre el paraíso y el infierno. México, FCE.

WHITE, Hayden

1992a El contenido de la forma. Madrid, Paidós.

1992b Metahistoria. Buenos Aires, Fondo de Cultura Económica.

WILLIAMS, Raymond

1980 Marxismo y literatura. Barcelona, Ediciones Península.

1982 Cultura. Sociología de la comunicación y el arte. Barcelona, Paidós.

2001 El campo y la ciudad. Buenos Aires, Paidós.

\subsection{Historia y literatura latinoamericana}

ACADEMIA NACIONAL DE LA HISTORIA

1966 Historia Argentina contemporánea (1862-1930). Vol II, Buenos Aires, Editorial "El Ateneo" 
ACOSTA MONTORO, José.

1973 Periodismo y literatura. Madrid, Ediciones Guadarrama.

ALTAMIRANO, Carlos

2012 “Alberdi polemista”, en Diana Quattrocchi-Woisson (coordinadora), Juan Bautista Alberdi y la independencia argentina. La fuerza del pensamiento y de la escritura. Bernal, UNQ, pp. 179-916.

AMANTE, Adriana

2003 "La crítica como proyecto. Juan María Gutiérrez", en Historia crítica de la literatura argentina dirigida por Noé Jitrik. Buenos Aires, Emecé editores, volumen 2, pp. 161-190.

ANDRADE, Olegario V.

1953 Obras Poéticas. Buenos Aires, Academia Argentina de Letras, Coni Hermanos.

1957 Las dos políticas. Buenos Aires, Editorial Devenir.

1998 Obras poéticas. Buenos Aires, Confluencia.

ARRIETA, Rafael

1955 La ciudad y los libros. Excursión bibliográfica al pasado porteño. Buenos Aires, Librería del Colegio.

AUZA, Néstor Tomás

1978 El periodismo de la Confederación 1852-1861. Buenos Aires, Eudeba.

BATTICUORE, Graciela, Loreley EL JABER y Alejandra LAERA (comps.)

2008 Fronteras escritas. Cruces, desvíos y pasajes en la literatura argentina.

Rosario, Beatriz Viterbo Editora.

BARCIA, Pedro Luis

1998 "Prólogo" a las Obras poéticas de Olegario V. Andrade. Buenos Aires, Confluencia.

BAZÁN, Armando

1979 Historia de La Rioja. Buenos Aires, Editorial Plus Ultra.

1983 La Rioja y sus historiadores. Buenos Aires, Editorial Platero.

BOSCH, Beatriz

1968 "Urquiza y el último levantamiento del general Peñaloza", en Angel Vicente Peñaloza, Comisión Central de Homenaje. Buenos Aires, Hachette.

CAMPOBASSI, José S.

1962 Sarmiento y Mitre. Hombres de Mayo y Caseros. Buenos Aires, Losada.

CARILLA, Emilio

1975 El romanticismo en la América Hispánica. Madrid, Gredos. 
CELLA, Susana

1999 "Panorama de la crítica", en La irrupción de la crítica (volumen 10 de Historia crítica de la literatura argentina. Buenos Aires, Emecé Editores.

CHÁVEZ, Fermín

1963 Alberdi y el mitrismo. Buenos Aires, Editorial Peña Lillo.

1988 Civilización y barbarie en la historia de la cultura argentina. Buenos Aires, Los Coihues, $2^{\mathrm{a}}$ ed.

2004 Historia y antología de la literatura gauchesca, Buenos Aires, Ediciones Margus.

CHICOTE, Gloria y Miguel DALMARONI (edits.)

2007 El vendaval de lo nuevo. Rosario, Beatriz Viterbo Editora.

CHIARAMONTE, José Carlos

1971 Nacionalismo y liberalismo 1860-1880. Buenos Aires, Solar-Hachette.

COLOMBI, Beatriz

1994 Viaje intelectual. Migraciones y desplazamientos en América Latina (1880-1915). Rosario, Beatriz Viterbo Editora.

CONI, Emilio, A.

1945 El gaucho; Argentina, Brasil, Uruguay. Buenos Aires, Solar-Hachette.

CÓRDOBA, Alberto Octavio

1966 Los Escritos Póstumos de Alberdi. Buenos Aires, Ediciones Theoría.

1968 Bibliografía de Juan Bautista Alberdi. Buenos Aires, Academia Nacional de Derecho y Ciencias Sociales-Distribuidor Abeledo-Perrot.

DE LA FUENTE, Ariel

2007 Los hijos de Facundo. Buenos Aires, Prometeo.

DE LA VEGA DÍAZ, Dardo

1976 Mitre y el Chacho. Buenos Aires, FCE.

DE MARCO, Miguel Ángel

1961 El periodismo en Rosario. Rosario, Anuario de Investigaciones históricas, Universidad Nacional del Litoral.

DUNCAN, Tim

1980 "La prensa política: Sud-América, 1884-1892" en Ferrari y Gallo, La Argentina del 80 al centenario. Buenos Aires, Sudamericana.

EL MOSQUITO

1964 El cumpleaños de El Mosquito. Presentación, selección y notas explicativas por E.M.S. Danero. Buenos Aires, Eudeba. 
FEINMANN, José Pablo

1984 Filosofía y Nación. Estudios sobre el pensamiento argentino. Buenos Aires, Legasa.

FERNÁNDEZ MORENO, César (coordinador)

1972 América Latina en su literatura. México, Siglo XXI-UNESCO.

FERNÁNDEZ RETAMAR, Roberto

1984 Algunos usos de civilización y barbarie. Buenos Aires, Editorial Contrapunto.

FERNÁNDEZ ZÁRATE, Luis

1952 Ángel Vicente Peñaloza. El señor de Guaja. Buenos Aires, Talleres Gráficos Cervantes.

GALVÁN MORENO, Carlos

1944 El periodismo argentino. Buenos Aires, Editorial Claridad.

GIORDANO, Alberto

1993 Modos del ensayo. Jorge Luis Borges-Oscar Masotta. Rosario, Beatriz Viterbo Editora.

GRAMUGLIO, María Teresa

1992 "La construcción de la imagen", en Tizón y otros, La escritura argentina. Santa Fe, UNL y Ed. de la Cortada.

GUIDO Y SPANO, Carlos

1879 Ráfagas. Buenos Aires, Igor Hermanos, 2 t.

GUTIÉRREZ, Bartolomé

1937 Montoneros y caudillos. Paraná, Anales del Instituto popular de la Confederación, t. XXII.

GUTIÉRREZ, Juan María

1941 Los poetas de la revolución. Buenos Aires, Academia Argentina de Letras.

1942 Cartas de un porteño. Buenos Aires, Editorial Americana.

\section{HALPERÍN DONGHI, Tulio}

1978 Proyecto y construcción de una Nación (Argentina 1846-1880). Selección, Prólogo y Cronología. Caracas, Biblioteca Ayacucho.

JITRIK, Noé

1969 Ensayos y estudios de literatura argentina. Buenos Aires, Galerna.

KUSCH, Rodolfo 
1954 Lo superficial y lo profundo en Martínez Estrada", Contorno, (Número especial dedicado a Martínez Estrada), dic., 4, pp. 5-8.

LAFFORGUE, Jorge

2009 Explicar la Argentina. Ensayos fundamentales. Buenos Aires, Editorial Taurus.

LUNA, Félix

1983 "Nacionalistas y autonomistas", en Romero, José Luis y Romero Luis Alberto, Buenos Aires. Historia de cuatro siglos, Op. cit. Apartado "El diarismo", t. I, p. 362. [Luna toma este dato de la Historia de la Nación Argentina de Guillermo Furlong.]

MANSILLA, Lucio V.

2010 Mis memorias y otros escritos. Buenos Aires, Secretaría de Cultura de la Nación y Lugar Editorial.

MASIELLO, Francine

1997 Entre civilización y barbarie. Rosario, Beatriz Viterbo Editora.

MATAMORO, Blas

1975 Oligarquía y literatura. Buenos Aires, Del Sol.

MAYER, Jorge M.

1963 Alberdi y su tiempo. Buenos Aires, Eudeba.

MINELLONO, María (comp.)

2008 La distorsión del espejo: estrategias de representación en textos de literatura argentina y comparada. La Plata, Ediciones al Margen.

MOLINA, Hebe Beatriz

1999 La narrativa dialógica de Juana Manuela Gorriti. Mendoza, Editorial de la Facultad de Filosofía y Letras de la U.N.de Cuyo.

MONTALDO, Graciela

1993 De pronto, el campo. Rosario, Beatriz Viterbo Editora.

MYERS, Jorge

2003 "Aquí nadie vive de las Bellas Letras. Literatura e ideas desde el Salón Literario a la Organización Nacional", en Historia crítica de la literatura argentina, Buenos Aires, Emecé editores, dirigida por Noé Jitrik, volumen 2 (dirigido por Julio Schvartzman), pp. 305-333.

NEWTON, Jorge

1973 El Chacho. Ángel Vicente Peñaloza. Buenos Aires, Editorial Plus Ultra.

OBLIGADO, Rafael

1967 Santos Vega y otros poemas. Buenos Aires, Editorial Huemul. 
PARKINSON, Henry J.

1977 The imperfect panacea: American Faith in Education, 1865-1979. Nueva York, Random House.

PAS, Hernán

2008 Ficciones de extranjería. Literatura argentina, ciudadanía y tradición (1830-1850). Buenos Aires, Katatay.

PASTORMERLO, Sergio

1996 "Borges crítico", en Cuadernos Angers-La Plata. UNLP/Université d'Angers, La Plata, I, 1, pp. 93-108.

PERUS, Francoise

2001 "Aportes de la crítica literaria al estudio de la cultura latinoamericana", en la Revista Chilena de Humanidades del 01-enero-01, n 21.

POMER, León

1967 "Estudio preliminar", en Proceso al Chacho. Buenos Aires, Ediciones Caldén, pp. 4-11.

QUESADA, Vicente G.

1911 La vida intelectual en las provincias argentinas. Buenos Aires, Atlántida.

1948 Memorias de un viejo. Buenos Aires, Editorial Solar.

RAMA, Ángel

1976 Los gauchipolíticos rioplatenses. Buenos Aires, Calicanto.

1984 La ciudad letrada. Montevideo, Fundación Ángel Rama.

1985 Literatura y clase social. México, Folios Ediciones.

RAMOS, Julio

1992 Desencuentros de la modernidad en América Latina. Literatura y política en el siglo XIX. México, FCE.

RODRÍGUEZ, Rafael

1951 "Introducción” a La poesía gauchesca en lengua culta. Buenos Aires, Ciorda y Rodríguez.

RODRÍGUEZ, Ricardo (catalogador)

2004 Archivo epistolar de Juan Bautista Alberdi. San Martín, UNSAMFundación "Biblioteca y archivo de Jorge M. Furt" (CD-Rom).

RODRÍGUEZ MOLAS, Ricardo E.

1982 Historia social de gaucho. Buenos Aires, CEAL.

RODRÍGUEZ PÉRSICO, Adriana 
2003 "Juan Bautista Alberdi: nación y razón", en Historia crítica de la literatura argentina. Buenos Aires, Emecé editores, dirigida por Noé Jitrik, volumen 2 (dirigido por Julio Schvartzman), pp. 279-303.

ROMÁN, Claudia

2003 "La prensa periódica. De La Moda (1837-1838) a La Patria Argentina (1879-1885)" y "Tipos de imprenta. Linajes y trayectorias periodísticas" en Historia crítica de la literatura argentina, Buenos Aires, Emecé editores, dirigida por Noé Jitrik, volumen 2 (dirigido por Julio Schvartzman), pp. 439-467, 469-484.

ROMANO, Eduardo Latina.

1983 Sobre poesía popular argentina. Buenos Aires, Centro Editor de América

1991 El nativismo como ideología en Santos Vega. Buenos Aires, Biblos.

ROMERO, José Luis

1975 Las ideas políticas en Argentina. Buenos Aires, FCE.

1983 "La ciudad patricia", en Romero, José Luis y Romero, Luis Alberto (Directores), Buenos Aires, historia de cuatro siglos. Buenos Aires, Editorial Abril, t. I, p. 309.

ROSA, José María

1965 La guerra del Paraguay y las montoneras argentinas. Buenos Aires, Peña Lillo.

1969 Historia Argentina. Buenos Aires, Editorial Juan Carlos Granda, 7 vols.

RUIZ MORENO, Martín

1913 La presidencia del Dr. S. Derqui y la batalla de Pavón. Buenos Aires, Imprenta de la Facultad de Buenos Aires.

SALDÍAS, Adolfo

1977 Historia de la Confederación Argentina. Buenos Aires, Eudeba, 2 vols.

SARLO, Beatriz

1978 "En el origen de la cultura argentina: Europa y el desierto. Búsqueda de un fundamento", en Seminario Latino-Americano de Literatura comparada. Porto Alegre, Universidade Federal do Rio Grande do Sul, 8-10 de setembro de 1986.

1988 Una modernidad periférica: Buenos Aires 1920-1930. Buenos Aires, Nueva Visión.

SVAMPA, Maristella

1994 El dilema argentino: civilización o barbarie. De Sarmiento al revisionismo peronista. Buenos Aires, El cielo por asalto.

SHUMWAY, Nicolás

2005 La invención de la Argentina. Buenos Aires, Emecé.

SIERRA, Vicente D. 
10 vols.

1980 Historia de la Argentina. Buenos Aires, Editorial Científica Argentina,

TERÁN, Oscar

1996 Escritos de Juan Bautista Alberdi. El redactor de la ley. Buenos Aires, Universidad Nacional de Quilmes.

TISCORNIA, Eleuterio

1953 "Prólogo" a las Obras Poéticas de Olegario V. Andrade, Buenos Aires, Academia Argentina de Letras, Coni Hermanos, pp. VII-LVVII.

VARELA, Lía

1999 "Ideas sobre el lenguaje y proyectos de país. Posiciones en el debate de 1837" en Narvaja de Arnoux y Bein (compiladores), Prácticas y representaciones del lenguaje. Buenos Aires, Eudeba, pp. 18-39.

VÁZQUEZ, María Celia

1998 "Beatriz Sarlo: una crítica moderna", en Giordano y Vázquez (compiladores), Las operaciones de la crítica. Rosario, Beatriz Viterbo Editora.

VICUÑA MACKENNA, Benjamín

1936 La Argentina en el año 1855. Buenos Aires, Editorial de la Revista Americana.

VIÑAS, David

1954 "La historia excluida: ubicación de Martínez Estrada", Contorno, (Número especial dedicado a Martínez Estrada), dic., 4, pp. 10-16.

1982 Literatura argentina y realidad política. Buenos Aires, Centro Editor de América Latina.

2003 Indios, ejército y frontera. Buenos Aires, Santiago Arcos Editor.

WEINBERG, Félix

1958 El salón literario, Buenos Aires, Hachette.

1992 'La antítesis sarmientina 'civilización y barbarie' y su percepción coetánea en el Río de La Plata”, en Cuadernos Americanos (México), 13, pp. 97-118.

YUNQUE, Álvaro

1941 La literatura social en la Argentina. Buenos Aires, Claridad.

ZANETTI, Susana

2002 La dorada garra de la lectura. Lectoras y lectores de novela en América Latina. Rosario, Beatriz Viterbo.

\subsection{Diccionarios, glosarios y otros repertorios especializados}

ACADEMIA ARGENTINA DE LETRAS

2003 Diccionario del habla de los argentinos. Buenos Aires, Espasa-Calpe. 
ABAD DE SANTILLÁN, Diego

1956 Gran Enciclopedia Argentina. Buenos Aires, Ediar, 8 vols.

1976 Diccionario de argentinismos de ayer y de hoy. Buenos Aires, TEA.

BELLO, Andrés

1958 Gramática de la lengua castellana. Buenos Aires, Sopena.

CARRIZO, Juan Alfonso.

1937 Cancionero Popular de Tucumán. Buenos Aires, Espasa Calpe.

1941 Cancionero Popular de Catamarca. Buenos Aires, Espasa Calpe.

1942 Cancionero Popular de La Rioja. Buenos Aires, Espasa Calpe.

CELLA, Susana

1988 Diccionario de literatura latinoamericana. Buenos Aires, El Ateneo.

COROMINAS, Joan

2010 Diccionario etimológico de la lengua castellana. Madrid, Gredos, 4 vols.

CUTOLO, V. O.

1962 Diccionario de alfónimos y seudónimos de la Argentina (1800-1930).

Buenos Aires, Editorial Elche.

1968 Nuevo diccionario biográfico argentino (1750-1930). Buenos Aires, Editorial Elche.

1972 Apodos y denominativos en la historia argentina. Buenos Aires, Editorial Elche.

DE LUCA, Rubén

2008 Diccionario argentino de seudónimos. Buenos Aires, Editorial Dunken.

DURÁN, Leopoldo

1961 Diccionario de seudónimos en la Argentina. Buenos Aires, Huemul.

LEVENE, Ricardo

1939 "Advertencia", en Fundación de escuelas públicas en la provincia de Buenos Aires durante el gobierno escolar de Sarmiento. La Plata, Taller de impresiones oficiales del Archivo Histórico de la Provincia de Buenos Aires.

PICCIRILLI, Ricardo

1953 Diccionario Histórico Argentino. Buenos Aires, Editorial Hispanoamericana, 6 vols.

PRIETO, Adolfo

1968 Diccionario básico de literatura argentina. Buenos Aires, Centro Editor de América Latina.

SEGOVIA, Lisandro 
1911 Diccionario de argentinismos, neologismos y barbarismos. Buenos Aires, Coni.

TESLER, Mario

1992 Diccionario argentino de seudónimos. Buenos Aires, Editorial Galerna.

2007 Autores y seudónimos porteños. Buenos Aires, Durken.

VIDAL DE BATTINI, Berta

1980-1995 Cuentos y leyendas populares de la Argentina. Buenos Aires, Ediciones Culturales Argentinas, Secretaría de Cultura, 10 tomos.

YABÉN, Jacinto

1938 Biografías Argentinas y sudamericanas. Buenos Aires, Editorial Metrópolis, 6 vols.

Diccionario Inédito de Argentinismos 1875-1877.

2006 Edición de Pedro Luis Barcia, Buenos Aires, Academia Argentina de Letras.

\subsection{Bibliografía general sobre vida y obra de Sarmiento y Hernández}

ACEVES, Ángel, Héctor

1949 Contribución al estudio del Martín Fierro. El moreno de la payada. La Plata, Anotaciones marginales.

ALBARRACÍN SARMIENTO, Carlos

1978 Estructura del Martín Fierro. Amsterdam, Benjamins, XIX.

ALSINA, Valentín

1909 "Notas al libro Civilización y barbarie", Revista de derecho, historia y letras (1898-1923), t. X y XI de Estanislao Zeballos, Buenos Aires, J. Peuser, www.salvador.edu.ar/juri.

ALTAMIRANO, Carlos

1997 "La fundación de la literatura argentina", en Ensayos Argentinos. De Sarmiento a la vanguardia. Buenos Aires, Ariel, pp. 201-209.

ALTAMIRANO, Carlos y Beatriz SARLO

1997 Ensayos Argentinos. De Sarmiento a la vanguardia. Buenos Aires, Ariel.

AMÍCOLA, José

2007 Autobiografía como autoconfiguración. Rosario, Beatriz Viterbo.

ANDERSON IMBERT, Enrique

1954 "El historicismo de Sarmiento", en Estudios sobre escritores de América, Editorial Raigal, Buenos Aires.

1967 Genio y figura de Sarmiento. Buenos Aires, Eudeba. 
ARA, Guillermo

1972 "Hernández en su tiempo", Cuadernos de cultura de Santiago del Estero (Argentina), a. 3, $\mathrm{n}^{\circ}$ 6, oct., pp. 44-53.

1974 "Sarmiento y Hernández; divergencia y conciliación”, Revista Iberoamericana, 40, 87-88, abr.-sept., pp. 245-257.

ARIAS, Aberlardo

1972 "Martín Fierro, hoy y para nosotros", en Martín Fierro/72, homenaje a José Hernández, al cumplirse el centenario de "El gaucho Martín Fierro". Buenos Aires, Instituto Salesiano de Artes Gráficas, pp. 168-169.

ARRIETA, Rafael Alberto

1988 "Sarmiento y la poesía" en Sarmiento. Centenario de su muerte. Buenos Aires, Academia Argentina de Letras.

ASTESANO, Eduardo B.

1973 Bases históricas de la doctrina nacional; San Martín, Rosas y el Martín Fierro. Buenos Aires, Eudeba.

ASTRADA, Carlos

1972 El mito gaucho. Buenos Aires, Ediciones Kairós.

AUZA, Néstor Tomás

1978 “El Nacional Argentino. La redacción de José Hernández” y “La Reforma Pacífica (José Hernández corresponsal)", en $\mathrm{El}$ periodismo de la Confederación 1852-1861. Buenos Aires, Eudeba, pp. 107-128, 168-187.

AYALA GAUNA, Velmiro

1971 "Ubicación social del Martín Fierro", en ¿Existe una literatura nacional? Santa Fe, Colmegna, pp. 39-41.

AZEVES, Ángel Héctor

1972a "Escribir para el pueblo", en Martín Fierro/72,homenaje a José Hernández, al cumplirse el centenario de El gaucho Martín Fierro. Buenos Aires, Instituto Salesiano de Artes Gráficas, pp. 130-131.

1972b "José Hernández periodista", en Martín Fierro un siglo. Buenos Aires, Editorial Xerox Argentina, pp. 105-108.

1986 José Hernández, el civilizador. La Plata, UNLP, Facultad de Humanidades y Ciencias de la Educación.

BARCIA, Pedro Luis

1992 “José Hernández y la cultura popular”, Cuadernos del milenio, 3, pp. 8599.

BARRENECHEA, Ana María

1956 "Notas al estilo de Sarmiento", Revista Iberoamericana, XXI, 41-42, enero-dic., pp. 275-294. 
1959 "Las ideas de Sarmiento antes de la publicación del Facundo", Filología, V, 3, sept-dic., pp. 193.

1980 "Sobre la modalidad autobiográfica en Sarmiento", Nueva Revista de Filología Hispánica (México), XXIX, pp. 509-519.

1988 "Autobiografía y epistolario: a propósito de una carta de Sarmiento a Frías”, Filología, XXIII, 2, pp. 45-62.

BARSKI, León

1977 Vigencia del Martín Fierro. Buenos Aires, Editorial Boedo.

BATTISTESSA, Ángel José

1972a "Unamuno y Menéndez y Pelayo; sus juicios en torno a Martín Fierro", en Martín Fierro un siglo. Buenos Aires, Editorial Xerox Argentina, pp. 21-28.

1972b "Eleuterio Tiscornia y su edición de Martín Fierro", en Martín Fierro un siglo. Buenos Aires, Editorial Xerox Argentina, pp. 67-71.

1972c “José Hernández y Martín Fierro en la perspectiva del tiempo", Boletín de la Academia Argentina de Letras, 37, 145-146, jul-dic., pp. 297-320.

BECCO, Horacio Jorge

1972a "Bibliografía hernandiana", en Martín Fierro, un siglo. Buenos Aires, Xerox, pp. 261-389.

1972b Antología de la poesía gauchesca. Madrid, Aguilar.

1973 Hernández: poesía y política. Buenos Aires, Plus Ultra.

BECCO, Horacio, Rodolfo BORELLO, Adolfo PRIETO y Félix WEINBERG

1977 Trayectoria de la poesía gauchesca, Buenos Aires, Editorial Plus Ultra.

BENARÓS, León

1972 "El Martín Fierro en 1972”, en Martín Fierro/72, homenaje a José Hernández, al cumplirse el centenario de "El gaucho Martín Fierro". Buenos Aires, Instituto Salesiano de Artes Gráficas, pp. 24-25.

BENÍTEZ, Rubén Ángel

1974 "La condición humana en el Martín Fierro", Revista Iberoamericana, XL, 87-88, abr-sept., pp. 47-71.

\section{BERENGUER CARISOMO, Arturo}

1973 "La poesía en lengua gaucha", en Las corrientes estéticas en la literatura argentina. La poesía lírica; los postrománticos. Buenos Aires, Librería Huemul, t. 3, segunda parte, pp. 127-180.

BISCHOFF, Efraín

1982 “José Hernández, periodista", Historia; revista-libro trimestral, II, 2, 5, marzo-mayo, pp. 74-86.

BLANCO AMORES DE PAGELLA, Ángela

1996 Un manuscrito desconocido del Martín Fierro. Buenos Aires, PPC/Fraterna. 
BOLLO CABRIOS, Palmira

1989 "Política institucional y educativa de Sarmiento. Influencia de los Estados Unidos”, Boletín de la Biblioteca del Congreso de la Nación, 1156, pp. 54-69.

BORELLO, Rodolfo

1972 El poema Martín Fierro. Mendoza, Instituto Cuyano de Cultura Hispánica.

1973 Hernández: poesía y política. Buenos Aires, Plus Ultra.

BORGES, Jorge Luis

1953 El "Martín Fierro" (en colaboración con Margarita Guerrero). Buenos Aires, Editorial Columbia.

1955 "El escritor argentino y la tradición", Sur, 232, ene-feb, pp. 1-8.

1972 "Sobre el culto de Hernández", en Martín Fierro/72, homenaje a José Hernández, al cumplirse el centenario de "El gaucho Martín Fierro". Buenos Aires, Instituto Salesiano de Artes Gráficas, pp. 42-43.

1974 Prólogo de Facundo de D.F. Sarmiento. Buenos Aires, El Ateneo

1979 “Borges y el libro", La Nación, Buenos Aires, 4 sección, 19 de agosto, p. 1.

BOSCH, Beatriz

1950 “Labor periodística inicial de José Hernández”, El Hogar, XLVI, 2112, p.16.

1963 Labor periodística inicial de José Hernández. Santa Fe, Universidad Nacional del Litoral.

1972 “José Hernández y la sociabilidad paranaense”, Palabra hernandista, 2, abr-jun., pp. 6-10.

BOTANA, Natalio

1984 La tradición republicana. Buenos Aires, Editorial Sudamericana.

BOTHWELL TRAVIESO, Luis C.

1980 "Coincidencias ideológicas entre Facundo y Martín Fierro", Casa de las Américas, 21, 122, pp. 35-47.

BUCICH, Antonio J.

1951 Sarmiento periodista. Buenos Aires, Museo Histórico Sarmiento.

BUENO, Mónica

2001 "Borges, lector de Martín Fierro", en Hernández, José. Martín Fierro, Edición crítico-genética Élida Lois y Ángel Núñez (coordinadores), París-Madrid, Colección Archivos (UNESCO-CNRS), pp. 635-653.

BUNKLEY, Allison Williams

1966 Vida de Sarmiento. Buenos Aires, Eudeba.

CAILLET-BOIS, Julio 
1972 "El payador de Leopoldo Lugones", en Martín Fierro, un siglo. Buenos Aires, Xerox, pp. 45-46.

\section{CALVETTI, Jorge}

1972 "El gaucho Martín Fierro y el habla de los argentinos", en Martín Fierro/72, homenaje a José Hernández, al cumplirse el centenario de "El gaucho Martín Fierro”. Buenos Aires, Instituto Salesiano de Artes Gráficas, pp. 180-181.

CAMPOBASSI, José S.

1962 "Mitre, Sarmiento y Peñaloza: luchas y divergencias", en Sarmiento y Mitre, hombres de mayo y Caseros. Buenos Aires, Losada, pp. 130-155.

1975 Sarmiento y su época. Buenos Aires, Losada, 2 vols.

CAMPRA, Rosalba

1995 “Martín Fierro. Entre otros”, en Hernández, José, Martín Fierro. Élida Lois y Ángel Núñez (coordinadores). París-Madrid, Colección Archivos (UNESCOCNRS), pp. 768-782.

\section{CANAL FEIJÓO, Bernardo}

1972 "El Martín Fierro y sus comentadores, de la perennidad del poema", en Martín Fierro/72, homenaje a José Hernández, al cumplirse el centenario de "El gaucho Martín Fierro”. Buenos Aires, Instituto Salesiano de Artes Gráficas, pp. 4-5.

1988 "La polémica inconclusa", en Sarmiento. Centenario de su muerte. Buenos Aires, Academia Argentina de Letras, p. 77. [Tomado de la revista Sur, 341, juldic., 1977.]

\section{CARRETERO, Andrés}

1972 Ida y vuelta de José Hernández. Buenos Aires, Corregidor.

\section{CARILLA, Emilio}

1953 Cartas de Sarmiento a María Mann. Buenos Aires, Academia Argentina de Letras.

1958 “José Hernández”, en El romanticismo en la América Hispánica. Madrid, Gredos, pp. 243-248

1961 El embajador Sarmiento. Rosario, Facultad de Filosofía y Letras.

1964 Lengua y estilo en Sarmiento. La Plata, Facultad de Humanidades, UNLP.

\section{CARRICABURO, Norma y MARTÍNEZ CUITIÑO, Luis}

1969 "El Martín Fierro en España", Anales de literatura hispanoamericana, Madrid, Universidad Complutense, 2-3, pp. 255-309.

\section{CARRIZO, Juan Alfonso}

1988 "Sarmiento y el cantar tradicional a la muerte del general Juan Facundo Quiroga", en Sarmiento. Centenario de su muerte. Buenos Aires, Academia Argentina de Letras, pp. 133-144.

\section{CASASBELLAS, Ramiro}


1972 “Los biógrafos de Hernández”, en Martín Fierro, un siglo. Buenos Aires, Xerox, pp. 131-137.

CASTAGNINO, Raúl Héctor

1972 "Para una lectura estructural del Martín Fierro". La Prensa, Buenos Aires, $1^{\text {a }}$ sección, 12 de noviembre, p. 3.

1973 "Referencialidad y grado oral de la escritura en Martín Fierro", en José Hernández; estudios reunidos en conmemoración del centenario de El gaucho Martín Fierro, 1872-1972. La Plata, Universidad Nacional de La Plata, Instituto de Literatura Argentina e Iberoamericana, pp. 71-111.

1998 "Martín Fierro y el teatro gauchesco", en Misceláneas de lo literario. Buenos Aires, Academia Argentina de Letras, pp. 201-215.

CASTRO, Isaac E.

1937 Sarmiento ante la montonera. Corrientes, Imprenta del Estado, Museo Colonial Histórico y de Bellas Artes de la Provincia de Corrientes.

CHÁVEZ, Fermín

1959 José Hernández. Periodista, político y poeta. Buenos Aires, Ediciones culturales argentinas.

1962 Vida del Chacho de José Hernández. Buenos Aires, Ediciones Theoría.

1973 La vuelta de José Hernández. Del Federalismo a la República liberal. Buenos Aires, Ediciones Theoría.

1999 Otra vuelta con Martín Fierro. Buenos Aires, Ediciones Theoría.

CHIAPPINI, Ligia

2001 “Martín Fierro e a cultura gaúcha do Brasil”, en Hernández, José, Martín Fierro. Élida Lois y Ángel Núñez (coordinadores). París-Madrid, Colección Archivos (UNESCO-CNRS), pp. 691-730.

CLEMENTE, José Edmundo

1972 “Martín Fierro", en Martín Fierro un siglo, Buenos Aires, Editorial Xerox Argentina, pp. 11-17.

1983 "El tema de José Hernández", en Obras Completas 1. Buenos Aires, Corregidor, pp. 144-156.

COBAS CARRAL, A.

2003 "Sarmiento/Alberdi: Apuntes para una polémica posible (o de cómo construir los esquivos destinos de la patria)", $V^{\circ}$ Congreso Internacional Orbis Tertius de Teoría y Crítica Literaria, 13 al 16 de agosto de 2003, La Plata. Polémicas literarias, críticas y culturales.

http: // www.fuentesmemoria.fahce.unlp.ar/trab_eventos/ev.8/ev.8.pdf

CORTAZAR, Augusto Raúl

1960 José Hernández, "Martín Fierro" y su crítica: aportes para una bibliografía. Buenos Aires, Fondo Nacional de las Artes.

1972 “Martín Fierro a la luz de la ciencia folklórica", Logos, 12, pp. 63-78. 
CORVALÁN, Octavio

1972 "El gaucho Martín Fierro en su contexto histórico", Cuadernos de Cultura de Santiago del Estero, III, 6, oct., pp. 24-37.

CÚNEO, Dardo

1972 "El clásico", en Martín Fierro/72,homenaje a José Hernández, al cumplirse el centenario de "El gaucho Martín Fierro". Buenos Aires, Instituto Salesiano de Artes Gráficas, pp. 94-95.

CUTOLO, Vicente Osvaldo

1981 "José Hernández librero, editor y trampeado", Todo es historia, XIV, 168, mayo, pp. 69-72.

\section{DELLEPIANE, Ángela}

1974 "José Hernández un siglo. Nota biográfica a dos recientes publicaciones", Revista Iberoamericana, XL, 87-88, abr-set., pp. 509-548.

1992 "Trayectoria del personaje gaucho en la literatura gauchesca", en Le gaucho dans la littérature argentine. Paris, Presses de la Sorbonne Nouvelle, Université de la Sorbonne Nouvelle, pp. 21-31.

DALMARONI, Miguel

2001 "Lugones y el Martín Fierro: la doble consagración", en Hernández, José, Martín Fierro. Élida Lois y Ángel Núñez (coordinadores), París-Madrid, Colección Archivos (UNESCO-CNRS), pp. 576-601.

DEL PINO DE CARBONE, M.L.

1954 Correspondencia entre Sarmiento y Lastarria, Buenos Aires. www.proyectosarmiento.com.ar.

DÍAZ ARAUJO, Enrique

1972 La política de Fierro; José Hernández ida y vuelta. Buenos Aires, La Bastilla.

DI TULIO, Ángela

1988 "Precisiones acerca de la actitud de Sarmiento frente a la lengua", Revista de lengua y literatura, Universidad Nacional de Comahue, 4, pp. 17-22.

DOALLO, Beatriz Celina

1995 Las vidas de José Hernández; ensayo. Buenos Aires, Faro Editorial.

DONOSO, Ricardo

1942 Sarmiento Director de la Escuela Normal 1842-1845. Santiago de Chile, Imprenta Universitaria.

DORRA, Raúl

1990 "Martín Fierro; la voz como forma del destino nacional", Dispositio, revista americana de estudios semióticos y culturales, University of Michigan, XV, 40, pp. 95105. 
2003 "El libro y el rancho. Lecturas del Martín Fierro", en Historia crítica de la literatura argentina. Buenos Aires, Emecé editores, dirigida por Noé Jitrik, volumen 2 (coordinado por Julio Schvartzman), pp. 251-275.

FAYO, Néstor

1972 Contenido histórico social del Martín Fierro. Buenos Aires, Casa Pardo.

FERNÁNDEZ LATOUR DE BOTAS, Olga

1972 "Aportes del folklore a la crítica del Martín Fierro", Logos, 12, pp. 177220.

1977 Prehistoria de Martín Fierro. Buenos Aires, Platero.

FERNÁNDEZ SALDAÑA, José

1940 José Hernández emigrado en Brasil, en La Prensa, Buenos Aires, 6 de octubre.

FLORIO, Rubén

1972 Los ritos de iniciación en el Martín Fierro. Bueno Aires, Ediciones de Mandala.

FONTANA, Patricio y Claudia ROMÁN

2008 "Estatuas para amarrar caballos. Frontera y peripecia en la literatura argentina (1837-1852)", en Batticuore, El Jaber y Laera (comps.), Fronteras escritas, Rosario, Beatriz Viterbo Editora, pp. 53-96.

FONTANELLA DE WEINBERG, M. Beatriz

1988 “Las ideas lingüísticas de Sarmiento”, Filología, XXIII, 2, pp. 63-76.

GÁLVEZ, Manuel

1945 José Hernández. Buenos Aires, Editorial La Universidad.

1957 Vida de Sarmiento. El hombre de autoridad. Buenos Aires, Editorial Tor.

GAMMALSON, Hialmar Edmundo

1972 José Hernández; ubicación histórica, trayectoria, motivaciones ideológicas. Buenos Aires, Plus Ultra.

GANDÍA, Enrique

1985 José Hernández, sus ideas políticas. Buenos Aires, Depalma.

GARAVAGLIA, Juan Carlos

2001 "El Martín Fierro y la vida rural en la campaña de Buenos Aires", en

Hérnández, José. Martín Fierro. Élida Lois y Ángel Núñez (coordinadores). París-Madrid, Colección Archivos (UNESCO-CNRS), pp. 654-690.

GARCÍA, Néstor Eduardo

1972 Análisis socio-estructural de la obra de José Hernández. Buenos Aires, UBA, Facultad de Filosofía y Letras, Instituto de Literatura Argentina "Ricardo Rojas". 
GARCÍA MANSILLA, M. R.

1917 Cartas confidenciales de Sarmiento a Manuel R. García. Buenos Aires, Imprenta de Coni Hermanos.

GARCÍA SARAVÍ, Gustavo

1992 Le gaucho dans la littérature argentine. Paris, Presses de la Sorbonne Nouvelle, Université de la Sorbonne Nouvelle.

GHIANO, Juan Carlos

1972 "El Martín Fierro hoy", en Martín Fierro/72,homenaje a José Hernández, al cumplirse el centenario de "El gaucho Martín Fierro". Buenos Aires, Instituto Salesiano de Artes Gráficas, pp. 32-34.

1978 Relecturas argentinas: de José Hernández a Alberto Girri. Buenos Aires, Ediciones del Mar de Solís.

GIMÉNEZ VEGA, Elías y GONZÁLEZ, Julio César

1975 Hernandismo y martinfierrismo (geopolítica del Martín Fierro). Buenos Aires, Plus Ultra.

GIUSTI, Roberto

1965 "Sarmiento y los Estados Unidos", Revista Interamericana de Bibliografía, XV, 2, abril-junio, pp. 111-126.

GONZÁLEZ LANUZA, Eduardo

1981 Temas del Martín Fierro. Buenos Aires, Academia Argentina de Letras.

GONZÁLEZ TUÑÓN, Raúl

1972 "Martín Fierro el gran poema gauchesco comprometido", en Martín Fierro/72, homenaje a José Hernández, al cumplirse el centenario de "El gaucho Martín Fierro”. Buenos Aires, Instituto Salesiano de Artes Gráficas, pp. 142-143.

GORI, Gastón

1993 Vagos y malentretenidos. Eduardo Wilde. Santa Fe, Universidad Nacional del Litoral, Centro de Publicaciones.

GRAMUGLIO, María Teresa y Beatriz SARLO

1979 Martín Fierro, Buenos Aires, Centro Editor de América Latina.

1981 "Martín Fierro", en La Historia de la Literatura Argentina, Buenos Aires, Centro Editor de América Latina, Capítulo 24.

GUGLIELMINO, Osvaldo

1954 Rafael Hernández, el hermano de Martín Fierro. Buenos Aires, Librería Perlado S.R.L Editores.

\section{HALPERÍN DONGHI, Tulio}

1985 José Hernández y sus mundos. Buenos Aires, Editorial Sudamericana, Instituto Torcuato Di Tella. 
1995 Proyecto y construcción de una nación (Argentina 1846-1880). Buenos Aires, Ariel.

1997 "Prólogo" a la Campaña en el Ejército Grande. Bernal, Universidad Nacional de Quilmes, pp. 9-53.

HERAS, Carlos

1958 "La noticia de la muerte del Chacho", Trabajos y comunicaciones, 7, pp. 106-126.

HERNÁNDEZ, Rafael J.

1896 “José Hernández", en Pehuajó; nomenclatura de las calles. Breve noticia sobre los poetas que en ellas se conmemoran. Buenos Aires, Impr. J. A. Berra, pp. 7990.

IGLESIAS, Cristina

2008 "Secretarios de la pampa. Apuntes sobre la figura del secretario letrado del caudillo gaucho" en Batticuore, El Jaber y Laera (comps.), Fronteras escritas. Rosario, Beatriz Viterbo Editora, pp. 117-162.

ISAACSON, José

1986 Encuentro político con José Hernández, notas y digresiones. Buenos Aires, Marymar.

ISAACSON, José (comp)

1986 Martín Fierro, cien años de crítica. Buenos Aires, Plus Ultra.

JAURETCHE, Arturo

1972 "Nueva visión del Martín Fierro", en Martín Fierro/72, homenaje a José Hernández, al cumplirse el centenario de "El gaucho Martín Fierro". Buenos Aires, Instituto Salesiano de Artes Gráficas, pp. 20-21.

JITRIK, Noé

1971a "El tema del canto en el Martín Fierro", en El fuego de la especie. Madrid, Siglo XXI, pp. 23-46.

1971b José Hernández. Buenos Aires, CEAL.

1993 "Prólogo" a Facundo. Caracas, Biblioteca Ayacucho, pp. I-LIV. [1ª ed. 1977]. Edición en línea: www.bibliotecayacucho.gob.ve.

JOFRÉ BARROSO, Haydée Mercedes

1998 José Hernández, el senador Martín Fierro. Buenos Aires, Círculo de Legisladores de la Nación Argentina, Ediciones Los Laureles.

KATRA, William $\mathrm{H}$.

1993 "Sarmiento en los Estados Unidos", en Sarmiento, Domingo F. Viajes. Javier Fernández, coordinador. París-Madrid, Colección Archivos (UNESCO-CNRS), pp. 853-911.

LANDA, Augusto 
1951 Sarmiento y el general Benavídez. Buenos Aires, Museo Histórico Sarmiento, serie II, $\mathrm{n}^{\circ} 21$.

LEPRO, Alfredo

1972 Vida y obra de José Hernández y su amigo Martín Fierro. Montevideo (Uruguay), Barreiro y Ramos.

1980 Leumann, Borges, Martínez Estrada; Martín Fierro y su crítica; antología. Buenos Aires, Centro Editor de América Latina.

LEVENE, Ricardo

1938 "Sarmiento sociólogo de la realidad americana y argentina", Humanidades, XXVI, pp. 73-105.

LIDA, María Rosa

1988 "Una anécdota de Facundo Quiroga", en Sarmiento. Centenario de su muerte. Buenos Aires, Academia Argentina de Letras, pp. 259-264.

LOIS, Élida

2003 "Cómo se escribió el Martín Fierro", en Historia crítica de la literatura argentina dirigida por Noé Jitrik, volumen 2 (dirigido por Julio Schvartzman). Buenos Aires, Emecé, pp. 193-224.

LÓPEZ AGNETTI, Elías

1974 Bases del Martín Fierro. Buenos Aires, Talleres Gráficos Mundial.

LOSADA GUIDO, Alejandro

1985 “Cómo puede un europeo estudiar la literatura latinoamericana?", Caravelle, Cahiers du Monde Hispanique et Luso Brésilien, Toulouse, 45, pp. 37-46.

LUDMER, Josefina

1988 El género gauchesco. Un tratado sobre la patria. Buenos Aires, Editorial Sudamericana.

LUGONES, Leopoldo

1979 El payador y antología de poesía y prosa. Caracas, Biblioteca Ayacucho.

LUISETTO, Raúl

1973 “José Hernández y la interpretación de la biografía del General Ángel Vicente Peñaloza”, en José Hernández: estudios reunidos en conmemoración de El gaucho Martín Fierro, 1872-1972. La Plata, Universidad Nacional de La Plata, Facultad de Humanidades, pp. 51-70.

MAFUD, Julio

1986 Contenido social del Martín Fierro; análisis e interpretación. Buenos Aires, Distal.

MALLEA, Eduardo 
1988 “Aseveración sobre Sarmiento”, en Sarmiento. Centenario de su muerte. Buenos Aires, Academia Argentina de Letras, p. 303.

MARTÍNEZ ESTRADA, Ezequiel

1958 Muerte y transfiguración de Martín Fierro. Ensayo de interpretación de la vida argentina, $2^{\mathrm{a}}$ ed. corregida, México, FCE, 2 vols.

1967 Sarmiento. Buenos Aires, Editorial Sudamericana.

MARTÍNEZ SARASOLA, Carlos

1992 Nuestros paisanos los indios. Buenos Aires, Emecé.

MARTÍNEZ VILLERGAS, Juan

1853 Sarmienticido o a mal sarmiento buena podadera. Refutación, comentario, réplica, folleto o como quiera llamarse esta quisicosa que, en respuesta a los Viajes publicados sin ton ni son por un tal Sarmiento ha escrito a ratos perdidos un tal J. M. Villergas. París, Agencia General de Librería Español y Extranjera.

MATELO, Gabriel

2008 "Aplicación continental del modelo 'Civilización \& Barbarie'. Configuración y funcionamiento de la edición en inglés del Facundo" publicado en: Minellono, María (compiladora), La distorsión del espejo: estrategias de representación en textos de literatura argentina y comparada. La Plata, Ediciones Al Margen, pp. 45-61.

MAYOCCHI, Enrique Mario

1998 Presencia de José Hernández en el periodismo argentino. Buenos Aires, Academia Nacional de Periodismo.

MOLLOY, Sylvia

1996 Acto de presencia. La escritura autobiográfica en Hispanoamérica. México, Fondo de Cultura Económica.

MONTALDO, Graciela

2004 Ficciones culturales y fábulas de identidad en América Latina. Rosario, Beatriz Viterbo Editora.

MONTELEONE, Jorge

1998 El relato de viaje. De Sarmiento a Humberto Eco. Buenos Aires, El Ateneo.

MONTSERRAT, Marcelo

1993 "Hacia las fuentes del entusiasmo político" en SARMIENTO, Domingo F. Viajes. Javier Fernández, coordinador. París-Madrid, Colección Archivos (UNESCOCNRS), pp. 1027-1032.

MORÍNIGO, Mariano 
1984 "Color local y marginamiento en el Martín Fierro", en su Temas cervantinos y otros ensayos. Asunción (Paraguay), Universidad Católica Nuestra Señora de la Asunción.

NELSON, Ernesto

1945 Sarmiento y los Estados Unidos de Norteamérica, Buenos Aires, Museo Histórico Sarmiento, serie II, $\mathrm{n}^{\circ} 12$.

NÚÑEZ, Ángel

1992 "El canto nacional", en Chávez, Fermín, director, 500 años de la Lengua en Tierra Argentina, Buenos Aires, Secretaría de Cultura de la Nación, capítulo XVI.

2001 "La heroicidad de Martín Fierro y del pueblo gaucho", en Hernández, José. Martín Fierro. Élida Lois y Ángel Núñez (coordinadores). París-Madrid, Colección Archivos (UNESCO-CNRS), pp. 783-822.

OCAMPO, Victoria

1972 "Las mujeres y el Martín Fierro", en Martín Fierro/72, homenaje a José Hernández, al cumplirse el centenario de "El gaucho Martín Fierro". Buenos Aires, Instituto Salesiano de Artes Gráficas, pp. 16-17.

ONIS, Federico de

1968 "Sarmiento y los Estados Unidos", en España en América. Puerto Rico, Editorial Universitaria, pp. 140-150.

ORDÓÑEZ, Antonio

1991 Análisis de Martín Fierro, José Hernández. Bogotá, Editorial Voluntad.

ORTALE, María Celina

s/f "Investigación y coordinación" de la Obra Parlamentaria de José Hernández. La Plata, Edición de la Honorable Cámara de Diputados de la Provincia de Buenos Aires.

2005 "Estudio filológico, edición y notas" en Hernández, José. Vida del Chacho. Buenos Aires, Ediciones del Dock.

2008 "Vida del Chacho y Martín Fierro: reescrituras de la obra", en Minellono, María (compiladora), La distorsión del espejo: estrategias de representación en textos de literatura argentina y comparada. La Plata, Ediciones Al Margen, pp. 151-163.

PADULA PERKINS, Jorge Eduardo

1996 El periodista José Hernández, La Plata, Tall. Gráf. De la Dirección de Impresiones del Estado y Boletín Oficial, Ministerio de Gobierno y Justicia de la Provincia de Buenos Aires.

PAGÉS LARRAYA, Antonio

1987 Prosas del Martín Fierro, Buenos Aires, Hyspamérica.

1980 "El Martín Fierro a los cien años", Cuadernos Hispanoamericanos, 357, mar., pp. 497-524. 
1988 "La recepción de un texto sarmientino: Facundo", en Sarmiento. Centenario de su muerte. Buenos Aires, Academia Argentina de Letras, p. 343. [Tomado del Boletín de la Academia, XLIX, 193-194, jul-dic, 1984.]

PAGLIAI, Lucila

2005 "Prólogo" de La gran polémica nacional: Cartas quillotanas-Las ciento y una. Buenos Aires, Leviatán.

PALCOS, Alberto

1938 Sarmiento, la vida, la obra, las ideas, el genio. Buenos Aires, Edición El Ateneo.

1941 El panamericanismo de Sarmiento. Buenos Aires, Museo Histórico Sarmiento, serie II, $\mathrm{n}^{\circ} 6$.

PAZ, Carlos

1974 Hernández y Fierro contra la oligarquía. Buenos Aires, Ediciones del Mirador.

PELLICER, Jaime O.

1990 El Facundo: significante y significado, Buenos Aires, Editorial Trilce.

1993 "Los Estados Unidos en Sarmiento", en SARMIENTO, Domingo F. Viajes. Javier Fernández, coordinador. Edición crítica y "Estudio filológico preliminar" de Elena M. Rojas. París-Madrid, Colección Archivos (UNESCO-CNRS), pp. 913-952.

PEREZ GILHOU, Dardo

1993 "Ideas y sistemas políticos en los Viajes de Sarmiento", en Sarmiento, Domingo F. Viajes. Javier Fernández, coordinador. París-Madrid, Colección Archivos (UNESCO-CNRS), pp. 1033-1051.

PETIT DE MURAT, Ulyses

1972 "El amor de un rescoldo" (prólogo) en Martín Fierro/72, homenaje a José Hernández, al cumplirse el centenario de "El gaucho Martín Fierro", Buenos Aires, Instituto Salesiano de Artes Gráficas, pp. XI-XII.

POLLMANN, Leo

1988 “José Hernández y analogía entis”, Argentina en su literatura; cuaderno de la Sección de Literatura Argentina del Instituto de Investigaciones Lingüísticas y Literaturas Hispanoamericanas, Tucumán, Facultad de Filosofía y Letras, Universidad Nacional del Tucumán, ${ }^{\circ}$ 3, abr.-oct., pp. 57-71.

PRIETO, Adolfo

1977 "La culminación de la poesía gauchesca", en Becco, Borello, Prieto y Weinberg, Trayectoria de la poesía gauchesca, Buenos Aires, Editorial Plus Ultra, pp. 81102.

1982 La literatura autobiográfica argentina. Buenos Aires, Centro Editor de América Latina.

1988 "El escritor como mito político", Revista Iberoamericana, 143, abril-junio, pp. $477-489$. 
1992 Prosa y oratoria parlamentaria (edición y prólogo). Rosario, Editorial Biblioteca.

2006 El discurso criollista en la formación de la Argentina moderna. Buenos Aires, Siglo XXI editores.

RAGUCCI, Rodolfo

1973 "Noticias sobre una creación nacional afortunada", en Voces de Hispanoamérica. Buenos Aires, Academia Argentina de Letras, pp. 141-156.

RAMA, Ángel

1976 "Fundación de la poesía social" en su Los gauchipolíticos rioplatenses. Literatura y sociedad. Buenos Aires, Calicanto, pp. 115-143.

1992 "El sistema literario de la poesía gauchesca", en Poesía gauchesca, Caracas, Biblioteca Ayacucho, pp. IX-LXVI.

RAWSON, Guillermo

s/f Polémicas con Sarmiento. Buenos Aires, W. M. Jackson Inc. editores.

RELA, Walter

1967 Artículos periodísticos de José Hernández en La Patria de Montevideo (1874). Montevideo, Editorial el Libro Argentino.

1975 Poesía guachesca; [José Hernández]. Montevideo, Técnica, 39, 3 p.

1979 De Martín Fierro a D. José Hernández. Montevideo, Ciencias.

REYES, Alfonso

1988 "Sarmiento, Alberdi, Mitre", en Sarmiento. Centenario de su muerte. Buenos Aires, Academia Argentina de Letras, pp. 375-376.

RIVERA, Jorge B.

1984 "Martín Fierro, la herida abierta", Clarín, cultura y nación, nov. 8, p.1.

2001 "Ingreso, difusión e instalación modelar del Martín Fierro en el contexto de la cultura argentina", en Hernández, José, Martín Fierro. Élida Lois y Ángel Núñez (coordinadores). París-Madrid, Colección Archivos (UNESCO-CNRS), pp. 545-575.

RODRÍGUEZ, Augusto

1955 Sarmiento militar. Buenos Aires, Peuser.

RODRÍGUEZ MONEGAL, Emir

1969 "El Martín Fierro en Borges y Martínez Estrada", Revista Iberoamericana, 40, 87-88, abr-set., pp. 287-302.

RODRÍGUEZ PÉRSICO, Adriana

1988 "La teoría estético-política de los Viajes", Actas de las Jornadas Internacionales Domingo Faustino Sarmiento, Neuquén, Universidad Nacional del Comahue, Facultad de Humanidades, pp. 89-111.

1993 Un huracán llamado progreso. Utopía y autobiografía en Sarmiento y Alberdi, Washington, Colección INTERAMER, OEA/OAS. 
ROJAS, Elena M.

1993 "Texto, texturas y formas", en Sarmiento, D. F., Viajes. Edición crítica Javier Fernández, coordinador. París-Madrid, Colección Archivos (UNESCO-CNRS), pp. 955-1004.

ROJAS, Ricardo

1945 El profeta de la pampa. Vida de Sarmiento, Buenos Aires, Losada.

\section{ROMANOS DE TIRATEL, Susana}

2001 “José Hernández y Martín Fierro: Bibliografía 1972-2000” en Hernández, José, Martín Fierro. Élida Lois y Ángel Núñez (coordinadores). París-Madrid, Colección Archivos (UNESCO-CNRS), pp. 1327-1421.

ROSEMBLAT, Ángel

1988 "Sarmiento y Unamuno ante el problema de la lengua", en Sarmiento. Centenario de su muerte. Buenos Aires, Academia Argentina de Letras, pp. 385-392.

ROSALES, César

1999 Tres arquetipos argentinos; Sarmiento, Hernández, Lugones. San Luis, Fondo Editorial Sanluiseño.

SÁBATO, Ernesto

1972 "Los atributos del Martín Fierro", en Martín Fierro/72, homenaje a José Hernández, al cumplirse el centenario de "El gaucho Martín Fierro". Buenos Aires, Instituto Salesiano de Artes Gráficas, pp. 12-13.

SAER, Juan José

1993 "Liminar" , en Sarmiento, D. F., Viajes. Javier Fernández, coordinador. París-Madrid, Colarección Archivos (UNESCO-CNRS), pp. XIII-XVI.

1997 "Martín Fierro, problemas de género", en Concepto de ficción. Buenos Aires, Ariel, pp. 58-65.

\section{SALOMON, Noël}

1980 Realidad, ideología y literatura en el Facundo de D. F. Sarmiento. Amsterdam, Rodopi.

SALTO, Graciela

2006 "La lengua literaria americana en la crítica de entresiglos", en Orbis Tertius, 11 (12):/ www.orbistertius.unlp.edu.ar/numeros/numero-12/sumario.

2007 "Entre Bogotá y Buenos Aires: debates sobre los usos literarios de la lengua popular", en Chicote y Dalmaroni (editores), El vendaval de lo nuevo. Rosario, Beatriz Viterbo Editora, pp. 23-37.

SANSONE DE MARTÍNEZ, Eneida

1981 La poesía gauchesca en Martín Fierro. Montevideo, Ediciones de la Casa del Estudiante. 
SANTOVENIA, Emeterio

1949 Sarmiento y su americanismo. Buenos Aires, Americalee.

SARLO, Beatriz

1979 "Razones de la aflicción y el desorden en Martín Fierro", Punto de vista, 7, pp. 7-9.

2007 "El voluntarismo biográfico" y "La invención de Sarmiento", en Escritos sobre literatura argentina. Buenos Aires, Siglo XXI, pp. 15-17, pp. 18-19.

\section{SCHVARTZMAN, Julio}

1996 "Pólvora y tinta. La estrategia polémica de Las ciento y una", en Microcrítica. Lecturas argentinas (cuestiones de detalle). Buenos Aires, Editorial Biblos, pp. 45-60.

1996 "El gaucho letrado", en Microcrítica, op. cit., pp. 155-175.

2001 "Levas y arriadas del lenguaje. El mecanismo proverbial del Martín Fierro", en Hernández, José. Martín Fierro. Élida Lois y Ángel Núñez (coordinadores). París-Madrid, Colección Archivos (UNESCO-CNRS), pp. 823-835.

2003 "Las letras del Martín Fierro", en Jitrik, Noé (director), Historia Crítica de la Literatura Argentina, vol. 2 (La lucha de los lenguajes, coordinado por Julio Schvartzman). Buenos Aires, Emecé, pp. 225-250.

SIMMONS, Merle E.

1953 "Los Estados Unidos en el pensamiento de Domingo F. Sarmiento antes de su primera visita a Norteamérica", Revista de Historia de América (México), 35-36, enerodiciembre, pp. 59-95.

\section{SORENSEN, Diana}

1998a "La construcción de los mitos nacionales en la Argentina del centenario", Revista de crítica literaria latinoamericana, 24, 47, pp. 147-166.

1998b El Facundo y la construcción de la cultura argentina. Rosario, Beatriz Viterbo Editora.

\section{TACCA, Oscar}

2000 Los umbrales de Facundo y otros textos sarmientinos. Buenos Aires, Academia Argentina de Letras.

VÁSQUEZ, Aníbal S.

1953 José Hernández en los entreveros jordanistas. Paraná, Editorial "Nueva Impresora".

VEDOYA, Juan Carlos 95.

1974 “El campo rosista y Hernández", Todo es historia, $1^{a}$ parte, 81, feb.: 76-

\section{VELLEMAN, Barry}

2005 Mi estimado Señor. Cartas de Mary Mann a Sarmiento (1865-1881). Buenos Aires, Ediciones Fundación Victoria Ocampo. 
VERBITSKY, Bernardo

1975 "José Hernández, trascendencia de su creación", en Literatura y conciencia nacional. Buenos Aires, Paidós.

VERDEVOYE, Paul

1981 "Don Andrés Bello y Domingo Faustino Sarmiento: una polémica y una colaboración", Bello y Chile. Caracas, La Casa de Bello, Tercer Congreso del Biecentenario, t. 1, pp. 103-124.

1978 Domingo Faustino Sarmiento, educar y escribir opinando (1839-1852). Buenos Aires, Editorial Plus Ultra.

1988 "Costumbrismo y americanismo en la obra de Domingo Faustino Sarmiento", en Sarmiento. Centenario de su muerte. Buenos Aires, Academia Argentina de Letras, pp. 435-450.

2001 "La identidad nacional y el Martín Fierro", en Hernández, José. Martín Fierro. Élida Lois y Ángel Núñez (coordinadores). París-Madrid, Colección Archivos (UNESCO-CNRS), pp. 733-765.

VIDAL DE BATTINI, Berta

1972 "Una nota sobre la lengua del Martín Fierro", Logos, 12, pp. 239-242.

VIÑAS, David

1978 "José Hernández, del indio al trabajo y a la conversión (1872-1879)", en Indios, ejército y frontera, Buenos Aires, Siglo XXI Editores, pp. 159-170.

1983 "José Hernández de la heterodoxia a la conversión, 1872-1879”, Plural (México), 12, 137, feb., pp. 39-42.

WEINBERG, Félix

1993 "Sarmiento, Alberdi, Varela: viajeros argentinos por Europa", en Sarmiento, Domingo F. Viajes. Javier Fernández, coordinador. París-Madrid, Colección Archivos (UNESCO-CNRS), pp. 1005-1026.

WEINBERG, Gregorio

1949 "Estudio preliminar" a Educación común. Buenos Aires, Lautaro.

1999 Sarmiento, Bello, Mariátegui y otros ensayos. Buenos Aires, Academia Nacional de Educación.

WEINBERG DE MAGIS, Liliana

2001 "El Martín Fierro y la gauchesca en la interpretación de Ezequiel Martínez Estrada, en Hernández, José, Martín Fierro. Élida Lois y Ángel Núñez (coordinadores). París-Madrid, Colección Archivos (UNESCO-CNRS), pp. 602-634.

ZALAZAR, Daniel E.

1986 La evolución de las ideas de Domingo F. Sarmiento. New Jersey, SLUSA.

ZORRAQUÍN BECÚ, Horacio

1972 Tiempo y vida de José Hernández (1834-1886). Buenos Aires, Emecé. 


\section{SIGNOS, ABREVIATURAS Y SIGLAS}

$\begin{array}{ll}\text { [ ] } & \begin{array}{l}\text { Encierran reposiciones textuales necesarias para la comprensión. Insertos en una } \\ \text { transcripción de manuscritos o de materiales documentales, los corchetes } \\ \text { señalan las intervenciones de la autora de esta tesis. }\end{array} \\ \text { [?] } & \text { Lección ilegible. } \\ \text { / } & \text { Final de verso o final de párrafo. } \\ \text { // } & \text { Final de estrofa. } \\ \text { BF } & \text { Biblioteca Furt. Estancia Los Talas, Luján, Provincia de Buenos Aires. } \\ \text { col. / cols. } & \text { Columna / Columnas (columna de los artículos periodísticos). } \\ \text { ed. cit. } & \text { Edición citada. } \\ \text { Ibidem } & \text { 'En la misma obra que acaba de ser citada'. } \\ \text { ms. } & \text { Manuscrito. } \\ \text { op. cit. } & \text { Opere citato, 'en la obra ya citada'. } \\ \text { p. / pp. } & \text { Página / páginas. } \\ \text { passim } & \text { 'Por todas partes', 'a lo largo de todo el texto'. } \\ \text { s. a. } & \text { Sin autor ('sin especificación del nombre del autor'). } \\ \text { s. f. } & \text { Sin fecha ('sin especificación de la fecha'). } \\ \text { [sic }] & \text { Se inserta esta aclaración cuando algún desmañamiento textual pueda hacer } \\ \text { pensar al lector que se trata de una transcripción errónea. }\end{array}$ 


\section{APÉNDICE DOCUMENTAL (listado de reproducciones)}

10.1. Página 2 de La Reforma Pacífica, Buenos Aires, 18 de febrero de 1860. Explicación del seudónimo "Vincha”.

10.2. Primera plana de La Reforma Pacífica, Buenos Aires, 14 de marzo de 1860. Carta firmada por Vincha.

10.3. Página 2 de El Litoral, Paraná, 18 de marzo de 1862. "Publicación solicitada" dirigida al editor del periódico y firmada "J.H.".

10.4. Primera plana de El Litoral, Paraná, 13 de mayo de 1862. "El Chacho", artículo biográfico de Federico de la Barra.

10.5. Primera plana de El Litoral, Paraná, 8 de agosto de 1862. Avisos de José Hernández como síndico.

10.6. Página 2 de El Litoral, Paraná, 26 de agosto de 1862. “Corrientes”, artículo firmado "J.H." a continuación del editorial de Evaristo Carriego.

10.7. Página 2 de El Argentino, Paraná, 3 de febrero de 1863. Primer editorial del periódico de José Hernández.

10.8. Primera plana de El Argentino, Paraná, 17 de febrero de 1863. Firma de Hernández como redactor del periódico.

10.9. Página 2 de El Eco, Corrientes, 17 de abril de 1868. Editorial con la firma "José Hernández".

10.10. Página 2 de El Eco, Corrientes, 8 de mayo de 1868. Editorial con la firma "José Hernández". 
10.11. Página 2 de La Capital, Rosario, 12 de junio de 1868. Editorial con la firma "J.H.".

10.12. Página 2 de La Capital, Rosario, 18 de junio de 1868. Editorial con la firma "J.H.".

10.13. Portada del Facundo de Sarmiento, edición de 1868.

10.14. Primera página de El Chacho, último caudillo de la montonera de los Llanos de Sarmiento, primera edición (1868).

10.15. Portada del Facundo de Sarmiento, edición de 1874.

10.16. Primera página de El Chacho, último caudillo de la montonera de los Llanos de Sarmiento, segunda edición (1874).

10.17. Primera plana de La Libertad, Buenos Aires, 23 de septiembre de 1875. Primera carta a Sarmiento: “Sr. Sarmiento, ¿Por qué mataron?”, firmada “José Hernández”.

10.18. Detalle de la carta citada.

10.19. Primera plana de La Libertad, Buenos Aires, 26 de septiembre de 1875. Segunda carta a Sarmiento: “A La Tribuna o al Sr. Sarmiento" firmada "José Hernández". 
BIOGRAFÍAS DEL CHACHO. GÉNESIS DE UNA INTERACCIÓN POLÉMICA ENTRE JOSÉ HERNÁNDEZ Y DOMINGO F. SARMIENTO

0. INTRODUCCIÓN

1. LA GRAN POLÉMICA NACIONAL DEL SIGLO XIX COMO INTERTEXTO DE LAS BIOGRAFÍAS DEL CHACHO

2. EL ALINEAMIENTO DE LA OPOSICIÓN A SARMIENTO

3. SARMIENTO CONTRAATACA CON SU VIDA DEL CHACHO

4. VIDA DEL CHACHO Y EL GAUCHO MARTÍN FIERRO:

REESCRITURAS EN 1875

5. EL ÚLTIMO ESLABÓN DE UNA POLÉMICA. SARMIENTO VS. HERNÁNDEZ

6. CONCLUSIONES

7. CORPUS

8. BIBLIOGRAFÍA GENERAL

9. SIGNOS, ABREVIATURAS Y SIGLAS

10. APÉNDICE DOCUMENTAL 
BIOGRAFÍAS DEL CHACHO. GÉNESIS DE UNA INTERACCIÓN POLÉMICA ENTRE JOSÉ HERNÁNDEZ Y DOMINGO F. SARMIENTO

0. INTRODUCCIÓN

1. LA GRAN POLÉMICA NACIONAL DEL SIGLO XIX COMO INTERTEXTO DE LAS BIOGRAFÍAS DEL CHACHO

2. EL ALINEAMIENTO DE LA OPOSICIÓN A SARMIENTO

3. SARMIENTO CONTRAATACA CON SU VIDA DEL CHACHO

4. VIDA DEL CHACHO Y EL GAUCHO MARTÍN FIERRO:

REESCRITURAS EN 1875

5. EL ÚLTIMO ESLABÓN DE UNA POLÉMICA. SARMIENTO VS. HERNÁNDEZ

6. CONCLUSIONES

7. CORPUS

8. BIBLIOGRAFÍA GENERAL

9. SIGNOS, ABREVIATURAS Y SIGLAS

10. APÉNDICE DOCUMENTAL 